
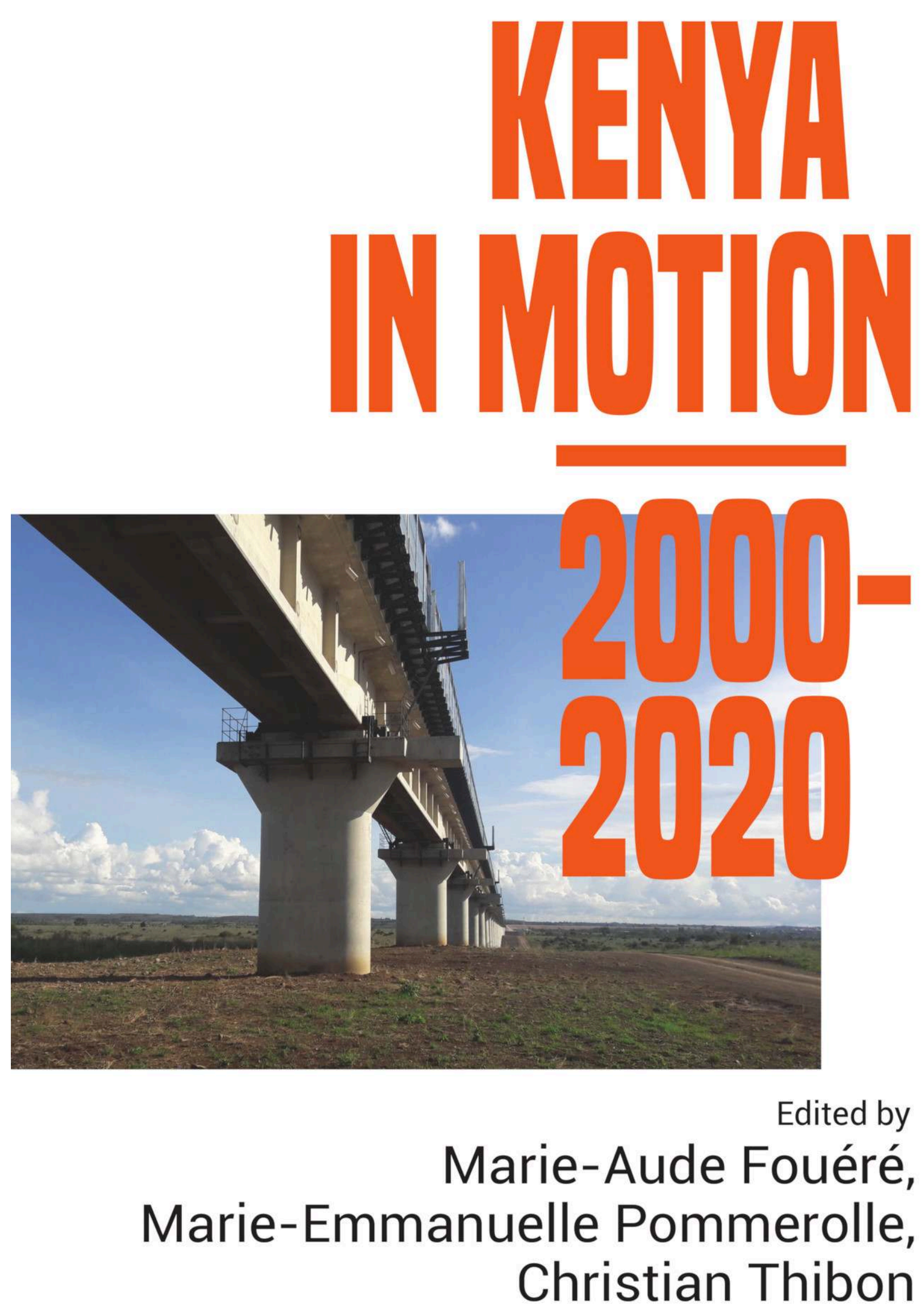

Africae 


\section{Africae Africae}

\section{Kenya in Motion 2000-2020}

Marie-Aude Fouéré, Marie-Emmanuelle Pommerolle and Christian Thibon (dir.)

DOI: 10.4000/books.africae.2390

Publisher: Africae

Place of publication: Nairobi

Year of publication: 2021

Published on OpenEdition Books: 8 June 2021

Series: Africae Studies

Electronic EAN: 9782957305889

\section{Q OpenEdition}

Books

https://books.openedition.org

Printed version

EAN (Print version): 9782957305896

Number of pages: $x$ ii-414

\section{Electronic reference}

FOUÉRÉ, Marie-Aude (ed.) ; POMMEROLLE, Marie-Emmanuelle (ed.) ; and THIBON, Christian (ed.)

Kenya in Motion 2000-2020. New edition [online]. Paris \& Nairobi: Africae, 2021 (generated 28 juin

2022). Available on the Internet: <http://books.openedition.org/africae/2390>. ISBN: 9782957305889

DOI: https://doi.org/10.4000/books.africae.2390. 


\section{ABSTRACTS}

This edited volume offers a broad understanding and particular visions of Kenya in the first quarter of the twenty-first century. By bringing together rigorous yet accessible contributions, it shows how, since the 2002 transition, Kenya has been striving for change through economic modernisation and political liberalisation. The planned transformations are coming to fruition, even if the legacies of the past and political habits are slowing down the process. The various chapters take us from developmental capitalism to extreme poverty and enduring inequalities, from reforms on paper to mixed results in multiple sectors: decentralised governance, natural resources, land, and education. They also explore Kenya's ancient and colonial history and the diversity of its population. Thus, the book helps understand contemporary political, religious and community cleavages, the asymmetries between towns and the countryside, between Nairobi and the coast, in a country open to the world, as much through trade and finance as through art networks.

Cet ouvrage offre une saisie synthétique et des visions particulières du Kenya en ce premier quart $\mathrm{du} \mathrm{XXI}^{\mathrm{e}}$ siècle. Il rassemble des contributions rigoureuses et accessibles pour montrer comment, depuis l'alternance de 2002, le Kenya s'efforce de changer par la modernisation économique et la libéralisation politique. Les transformations annoncées voient le jour, même si les legs du passé et les habitus politiques en ralentissent la marche. Les différents chapitres nous mènent du capitalisme développemental kényan à la grande pauvreté et aux inégalités vivaces, des réformes sur le papier aux mises en œuvre en demi-teinte dans de multiples secteurs: gouvernance décentralisée, ressources naturelles, foncier, éducation. L'histoire ancienne et coloniale, la diversité du peuplement au Kenya permettent de mieux comprendre les clivages politiques, religieux et communautaires, les asymétries entre villes et campagnes, entre Nairobi et la côte, dans un Kenya ouvert sur le monde, autant par le commerce et la finance que par les réseaux de l'art.

\section{MARIE-AUDE FOUÉRÉ (DIR.)}

Institut français de recherche à Nairobi (IFRA-Nairobi), USR Afrique au sud du Sahara. Nairobi, Kenya ; Institut des mondes africains (IMAF), École des hautes études en sciences sociales. Paris, France.

\section{MARIE-EMMANUELLE POMMEROLLE (DIR.)}

Institut des mondes africains (IMAF), Université Paris 1 Panthéon-Sorbonne. Paris, France.

\section{CHRISTIAN THIBON (DIR.)}

Les Afriques dans le monde, Université de Pau et des Pays de l'Adour. Pau, France. 
Kenya in Motion 2000-2020 
Africae Studies

Series editors: Sophie Dulucq, Marie-Aude Fouéré \& Marc Maillot 


\title{
Kenya in Motion 2000-2020
}

\author{
Edited by Marie-Aude Fouéré, \\ Marie-Emmanuelle Pommerolle \\ and Christian Thibon
}

\section{Africaze}


IFRA-Nairobi

Laikipia Road, Kileleshwa

5848002200 Nairobi

KENYA
USR Afrique au sud du Sahara - CNRS

3 rue Michel-Ange

75794 Paris Cedex 16

FRANCE

Africae Books online: https://books.openedition.org/africae

Fouéré, Marie-Aude, Marie-Emmanuelle Pommerolle, and Christian Thibon (eds). 2021. Kenya in Motion 2000-2020. Africae Studies. Nairobi \& Paris: Africae. DOI : 10.4000/books.africae.2390.

Tous les textes de ce livre sont publiés avec la Licence Creative Commons CC-BY-SA 3.0 :

«Attribution - Partage dans les mêmes conditions non transposé».

See: https://creativecommons.org/licenses/by-sa/3.0/deed.en

"You are free to:

- Share - copy and redistribute the material in any medium or format

- Adapt - remix, transform, and build upon the material for any purpose, even commercially. Under the following terms:

- Attribution - You must give appropriate credit, provide a link to the license, and indicate if changes were made. You may do so in any reasonable manner, but not in any way that suggests the licensor endorses you or your use.

- ShareAlike - If you remix, transform, or build upon the material, you must distribute your contributions under the same license as the original.

No additional restrictions - You may not apply legal terms or technological measures that legally restrict others from doing anything the license permits."

Archiving of web pages: The mention "[archive]" in notes and bibliographies indicates an archived version of the web document in the Wayback Machine (https://web.archive.org).

ISBN (printed version): 978-2-9573058-9-6

ISBN (digital version): 978-2-9573058-8-9

Open Access HTML version : https://doi.org/10.4000/books.africae.2390

Cover design: Valérie Alfaurt (Les Afriques dans le monde, CNRS).

Cover image: Madaraka Express railway viaduct between Nairobi and Mombasa, passing Nairobi National Park. Author: Marie-Aude Fouéré, 2020.

Printed in Belgium (Louvain-la-Neuve) by Ciaco. 


\section{Table of Contents}

Acronyms .. $\mathrm{V}$

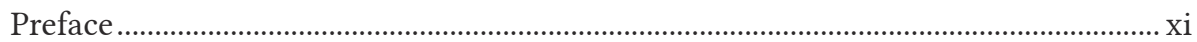

Marie-Aude Fouéré

Introduction. To the Test of Social and Political Violence:

From the Kenya of Millionaires and Millions of Beggars

to the Three Kenyas of the Twenty-First Century

Christian Thibon

Chapter 1. State, Economy and Development in Kenya

Hervé Maupeu

Focus no. 1. The World of Banks and Finance in Kenya Adeline Pelletier

Chapter 2. The Large Gaps in Development in Kenya Bernard Calas

Chapter 3. Emerging Elites, Oligarchy, and the Kenyan Middle Classes Christian Thibon

Chapter 4. Between Hopes and Disillusionment:

Constitutional Reforms and Decentralisation in Kenya, 2000-2020

Chloé fosse-Durand

Chapter 5. Low-Cost Business in Kenya from the City to the Countryside Sylvain Racaud

Chapter 6. The Politicisation of Land Policy Reform in Contemporary Kenya Francesca Di Matteo

Chapter 7. Natural Resources Management in Kenya (Water and Forest): Centralised Policies, Between Exclusion and Participation of the Local Population 223 Gaële Rouillé-Kielo

Chapter 8. Securing the Everyday Nairobi: Challenges and Tactics of Private Security Guards in the Fragmented City Jean-Baptiste Lanne

Chapter 9. What Education for All in Kenya? The School of Inequalities 261 Hélène Charton

Focus no. 2. The Regionalisation of University Systems: An Empty Shell? 281

Olivier Provini 
Chapter 10. Christian Forms of Religion in Kenya

Yvan Droz \& Yonatan N. Gez

Focus no. 3. The Church as a Provider of Material Support:

An Inner/Outer Circles Perspective

Yonatan N. Gez

Chapter 11. Minorities of Indo-Pakistani Origin Michel Adam

Chapter 12. Kenya's Coast: Religion, Race, Ethnicity and the Elusive Nature of Political Community Justin Willis \& Hassan Mwakimako

Focus no. 4. History, Memory, and the Heritage of Slavery on the Kenyan Coast:

The Witu and Shimoni Cases

Patrick O. Abungu \& Clélia Coret

Chapter 13. Beyond its Whitewashed Past, the Unique Peoples of Precolonial Kenya

Anne-Marie Peatrik

Focus no. 5. The Aravai Peoples,

the Site of Rabai and its Sacred Forests on the Kenyan Coast

Marie Pierre Ballarin

Chapter 14. Stage Dynamics:

Presentation and Representation in the Nairobi Art Market.

Danielle de Lame

Focus no. 6. Into a "Global Encounter" from the Art Scene in Nairobi.

Olivier Marcel

The Authors 


\section{Acronyms}

ADB African Development Bank

AFD Agence française pour le développement

AIC African Inland Church

BBI Building Bridges Initiative

BIFA Buruburu Institute of Fine Arts

BWRC Basin Water Resources Committee

CAAC Catchment Area Advisory Committee

CBD Central Business District

CDF Constituency Development Fund

CDTF Community Development Trust Fund

CEC County Executive Committee Members

CFA Communauté financière en Afrique

(Financial Community of Africa)

CHE Commission for Higher Education (Kenya)

CIPK Council of Imams and Preachers of Kenya

CKRC Constitution of Kenya Review Commission

CNRS Centre national de la recherche scientifique

(French National Centre for Scientific Research)

CPK Church of the Province of Kenya

CRA Commission on Revenue Allocation

CSM Church of Scotland Mission

CSRP Civil Service Reform Program

DAAD Deutscher Akademischer Austauschdienst

(German Academic Exchange Service)

DHS Demographic and Health Surveys

EAC East African Community

EACC Ethics and Anti-corruption Authority

ECK Electoral Commission of Kenya

EDCG Education Donor Coordination Group

EPZ Export Processing Zone 
ERS Economic Recovery Strategy for Wealth and Employment Creation

EUR Euro (ISO 4217 Currency Codes:

https://www.iso.org/iso-4217-currency-codes.html)

FAO Food and Agriculture Organization

FDSE Free Day Secondary Education

FIDA Federation of Women Lawyers

FMI International Monetary Fund

FPE Free Primary Education

GDP Gross Domestic Product

GDP Gross Domestic Product

GEMA Gikuyu, Embu, Meru Association

GNI Gross National Income

GNP Gross National Product

GROK Government of Republic of Kenya

HDI Human Development Index

HELB Higher Education Loans Board

ICUEA Inter-University Council of East Africa

IDE Integrated Development Environment

IDP Internally Displaced Persons

IEA Institute of Economic Affairs

IEBC Independent Electoral and Boundaries Commission

IFRA Institut français de recherche en Afrique

(French Research Institute in Africa

IGO Intergovernmental Organization

ILO International Labour Organization

IMF International Monetary Fund

INRA Institut national de la recherche agronomique

(National Institute of Agricultural Research)

IPCC Intergovernmental Panel on Climate Change

IPK Islamic Party of Kenya

IRD Institut de recherche pour le développement (Research Institute for Development)

IUCEA Inter-University Council for East Africa 
IUCN International Union for Conservation of Nature

IWRM Integrated Water Resource Management

KADU Kenya African Democratic Union

KANU Kenya African National Union

KAS Kenya Art Society

KASVIT Kisumu Alliance of Street Vendors and Informa Traders

KAULI Kenya Assembly of Ulama and Imam

KBS Kenyan Bureau of Statistics

KCPE Kenya Certificate of Primary Education

KCSE Kenya Certificate of Secondary Education

KEFRI Kenya Forestry Research Institute

KEPSA Kenya Private Sector Alliance

KES Kenyan Shilling (ISO 4217 Currency Codes :

https://www.iso.org/iso-4217-currency-codes.html)

KESSP Kenya Education Sector Support Programme

KFS Kenya Forest Service

KFWG Kenya Forests Working Group

KHCR Kenya Human Rights Commission

KIEMS Kenya Integrated Election Management System

KIHBS Kenya Integrated Household Budget Survey

KISTA Kisumu Informal Traders Association

KITES Kisumu Informal Traders Economic Support

KLA Kenya Land Alliance

KLR Kenya Law Reports

KNBS Kenya National Bureau of Statistics

KPC Kenya Pipeline Company

KWS Kenya Wildlife Service

KWTA Kenya Water Towers Agency

LAM Les Afriques dans le monde

LNC Local Native Councils

MCA Members of County Assemblies

MDG Millennium Development Goals 


\begin{tabular}{|c|c|}
\hline MEST & Ministry of Education, Science and Technology \\
\hline MP & Member of Parliament \\
\hline MRC & Mombasa Republican Council \\
\hline NARC & National Rainbow Coalition \\
\hline NCCK & National Council of Churches of Kenya \\
\hline $\mathrm{NCIC}$ & National Cohesion and Integration Commission \\
\hline NCLR & National Council for Law Reporting \\
\hline NEMA & National Environment Management Authority \\
\hline NGO & Non-governmental Organization \\
\hline NHIF & National Hospital Insurance Fund \\
\hline NLC & National Land Commission \\
\hline NLP & National Land Policy \\
\hline NLPFP & National Land Policy Formulation Process \\
\hline NPC & Nairobi Pentecostal Church \\
\hline NSSF & National Social Security Fund \\
\hline ODM & Orange Democratic Movement \\
\hline OVC & Orphans and Vulnerable Children \\
\hline PCEA & Presbyterian Church of East Africa \\
\hline PELIS & Plantation Establishment and Livelihood Improvement Schemes \\
\hline PES & Payment for Environmental Services \\
\hline PPP & Public-Private Partnership \\
\hline PSCU & President's Strategic Communications Unit \\
\hline REDD & Reduced Emissions from Deforestation and Forest Degradation \\
\hline SAP & Structural Adjustment Plan \\
\hline SEIA & Socio-Economic Impact Assessment \\
\hline SGR & Standard Gauge Railway \\
\hline SID & Society for International Development \\
\hline SME & Small and Medium-sized Enterprisess \\
\hline TEU & Twenty-foot equivalent unit \\
\hline TJRC & Truth, Justice, and Reconciliation Commission \\
\hline UN & United Nations \\
\hline UNEP & United Nations Environment Programme \\
\hline
\end{tabular}


UNEP United Nations Environment Programme

UNICEF United Nations Children's Fund

USA United States of America

USAID United States Agency for International Development

USD Unites States Dollar (ISO 4217 Currency Codes: https://www.iso.org/iso-4217-currency-codes.html)

WHO World Health Organization

WRMA Water Resource Management Authority

WRUA Water Resource Users Association

WSTF Water Service Trust Fund

WWF World Wildlife Fund

YMCA Young Men's Christian Association 



\section{Preface}

\section{Marie-Aude Fouéré}

This edited volume was initiated in 2013. At that time, Christian Thibon (2010-2014) was the director of the French Institute for Research in Africa (IFRA) in Nairobi and I was myself its resident researcher (2011-2014). The responsibility for this editorial project was shared with the new director in 2014, Marie-Emmanuelle Pommerolle (2014-2018), and handed over to me when I succeeded her in 2018. With Kenya in Motion, the three directors aim to provide a panorama of the first two decades of the 2000s in Kenya that can be useful to students and researchers, but also accessible to the general public. It is modelled on Le Kenya contemporain-a book by Karthala publishers and edited by François Grignon and Gérard Prunier-that came out in 1998 but dealt mainly with the late 1980s and early 1990s.

However, since the changeover in 2002, Kenya has been striving for change. On the one hand, throughout the 2000s, the Kenyan economy modernised and there has been a strong and steady growth rate which, by 2015, moved Kenya into the lower middle-income bracket. In June 2008, former President Mwai Kibaki's Kenya Vision 2030 national development programme announced its ambitions: it was "a roadmap for accelerating transformation of (the) country into a rapidly industrialising middleincome nation by the year 2030." This strategy notably took the form of developmental capitalism with massive investments in infrastructure mega-projects (railway, airport, port, dams, etc.). This policy of megaprojects continued after 2017 with President Uhuru Kenyatta's national development programme, the "Big Four Agenda," which more firmly asserts redistribution and democratisation as a goal. At the political level, the adoption of a new Constitution in 2010 and the implementation of decentralisation from 2013, which was strongly supported by Kenyans, propelled the country towards democratisation; it encompasses the fight against the injustices of the past that are still present and are producing blatant inequalities. But the path towards the proclaimed transformations has been chaotic: the 2007 elections were marred with violence, caused too many victims, traumatised Kenya, and weighed in on the next two elections. Recent assessments of Vision 2030 are mixed while the effects of the Big Four Agenda remain tenuous. Criticism resonates in a country where civil society, one of the most dynamic in Africa, acts as a pressure force on a political class still locked in its patron-client and ethnic logic. 
In view of such changes-be they expected or planned, but also hindered or even disordered-, it was imperative for a research centre based in Nairobi to document and analyse the last twenty years of Kenyan political, economic and social life, from 2000 to 2020, in a book accessible to the greatest number of people. Kenya in motion, which is published both online and in print and available in both French and English-thus making it possible to discuss with all our English-speaking colleagues and to enter in a dialogue with the recent and ambitious Oxford Handbook of Kenyan Politics edited by Nic Cheeseman, Karuti Kanyinga and Gabrielle Lynch (2020)-brings together the contributions of specialists from Kenya. Some contributions cover a broad spectrum (political economy, social history, development, decentralisation) while others address more specific themes (arts, school, religion, land, water, security, trade, etc.). Six short texts called "Focus" are added to the fourteen chapters that make up this volume. They enrich certain chapters with their close focus on banking, higher education, slavery, sacred forests, religious adherence and the globalised art scene. Together, these texts provide both a synthetic grasp and particular visions of Kenya in the first quarter of the twenty-first century.

We wish to thank several institutions and individuals. First of all, our deepest gratitude goes to the colleagues who contributed to the bookdoctoral students, newly graduated doctors, and experienced researchersfor their sustained commitment to IFRA projects and for their unfailing patience. Secondly, this project would not have been possible without IFRA's financial and human resources support, nor without the OpenEdition Books platform, which hosts the publisher's brand "Africae" and its "Studies" collection in which this book is being published. Within IFRA, our special thanks go to Chloé Josse-Durand and Marion Asego, respectively for the proofreading of some texts and for the administrative and financial support. We are also very grateful to our colleague Claire Médard from IRD (French National Research Institute for Sustainable Development) for her involvement and rigorous peer reviewing. Our warmest thanks also go to Antoine Kauffer for his efficient editorial work, and to Bastien Miraucourt, in charge of editing at the CNRS based at the Les Afriques dans le monde (LAM) laboratory in Bordeaux and in charge of the publications of the French research institutes of sub-Saharan Africa, without whom this book could not have existed. Finally, our gratitude goes to all the translators of the English-language version of Le Kenya en marche, that is, Kenya in motion, who have enthusiastically and professionally put their language skills at the service of IFRA through the "UN Volunteers" online platform. 


\section{Introduction \\ To the Test of Social \\ and Political Violence \\ From the Kenya of Millionaires \\ and Millions of Beggars to the Three Kenyas \\ of the Twenty-First Century}

\section{Christian Thibon}

Translated by Catriona Bell

"The eyes of a starving child," "Kenya has become a nation of ten millionaires and ten million beggars": these lines from Josiah Mwangi Kariuki's most often-quoted speeches are fitting anecdotal hooks to begin this chapter. Such critical views concern two historical periods: firstly in 1962 when Kenya was assessing its colonial era, and then at the beginning of the 1970s during the first decade of independence with its many people "left out in the cold," that is, beggars as well as reliant vulnerable people. Such words-both critical and provocative, sensitive and political-reflect the life and political trajectory of Kariuki, a nationalist, progressive and populist leader, incidentally a millionaire, who was assassinated on 2 March 1975. His position was brilliantly taken up by a generation of intellectuals and especially in the novels from the new Kenyan school, also known as the Postcolonial Kenyan novels, which include amongst others Meja Mwangi, Ngugi wa Thiong'o, Charles Mangua, and Grace Ogot. These literary works embrace critical social realism and target the ruling elite. They do not simply resound with post-independence disappointment, but reflect a deeper dissonance, both urban and rural, against the backdrop of a culture clash, of a tension between tradition and modernity, as well as of the political deadlock (Kabayi 1998; Kurtz 1998). In this way these works are as lucid about the first two decades of independence as they are foreboding of the subsequent changes that Kenyan society is presently experiencing-a premonitory mode of thinking which only artists have the gift of.

In 2020, nearly half a century later, how relevant are these observations? And to what extent have social changes over the last thirty years confirmed or changed such social polarisation? Do these changes weigh on the identity crises and dilemmas which Kenyans are experiencing, as well as on the national political pact? 
At first glance these images and discourses are still relevant today. Various elements appear to confirm this idea in spite today's natureoriented and tourist-aimed marketing with its stereotyped ethnic categories (including the archetypal serene "Masai Warrior") as well as more distant and cautious photo reportages, somewhat blur the picture. ${ }^{1}$ Media buzz perpetuates these images with titles such as "Kibera-Africa's largest slum" (Desgroppes \& Taupin 2011) or "Dabaab, the world's largest refugee camp," for example. Reports also abound about the daily life and suffering of many, which are usually intertwined if we pay close attention. Take for instance the chokoras (street children) "who rummage through waste," or "the stone breakers" who work by the roadside. And last, fear prevails because of the violence of gangs and urban ghettos' militias as well as, in pastoral areas, of livestock thieves. Conversely, other images offer an optimistic vision, and hopes of success, even if only in their beginning stage. They shed light on the proliferation of malls, the digital revolution, and the housing bubble and urban growth, which a political communication that promotes national success emphasises even further... And minor news items back up these major successes as well, such as the broadcasting of the import of mechanical crushers-crushers that should bring an end to the slave-labour conditions of stone breakers! Yet such emergent modernity brings in offensive situations exemplified by the ostentatious and mediatised lifestyle of some millionaire tycoons which urban and rural legends tell about. Recent opinion polls ${ }^{2}$ have recently revealed a divide in public opinion between the confidently hopeful and the despairingly suspicious in the face of the unknown, between Saint Valentine's Day-a rose business success story as well as a reflection of a new individualised lifestyle-and recurring fears generated by the rising cost of living, corruption and violence, and the risk of famine in the pastoral North of the country.

The social question and the condemnation of injustices remain as prevalent in political speeches as in some clerics' sermons, intellectuals' accounts, journalists' reports and in the sharp satire of caricaturists. ${ }^{3}$ Even if these messages have lost their original radical nationalist ideology or Marxist leanings and its political spokesmen, their capacity to mobilise,

1. These photographic works, which are both exhibited and published, have been on the rise in recent years. They aim to visually capture social issues, the rise of the middle class, etc., by adopting an aesthetics of the everyday that aligns with a strong commitment to fight human suffering.

2. Opinion polls from Ipsos Synovate are available on their website: http://www. ipsos.com/fr-fr/toutes-les-publications.

3. Among others, the works of cartoonist Gado in The Daily Nation. 
young people in particular, through the new mass culture ${ }^{4}$ remains intact. At the same time, the arguments have changed. We find many more moralistic denunciations of deviances from televangelists or elders. We also find ethnic recriminations which focus on access to land and spoliation, that is, on the "land question"-whether it concerns rural or urban dwellers. Categorial and sectorial claims have arisen to defend certain professions. And millenarian revolts have reappeared and are taking roundabout routes. ${ }^{5}$ In a society deeply marked by political debates and becoming more and more a show-society-due to the importance taken by the media and social networks-, these images and speeches are of tremendous importance, even more because they feed in people's conscious and unconscious attitudes: indeed, they bring to light a division within Kenyan society, and in the urban world in particular, that would increasingly become rigid and could potentially result in explosive fractures. It is noteworthy that, in contrast to the independence years when the modern-urban world and the traditional-rural world were split and distinct, nowadays this halfworld where wealth is neighbouring poverty increases frustrations among those who cannot access the enrichment they see but from which they are banned, as much in the cities as in the countryside.

Whatever comments are made about them, these imaginaries, sometimes overstated, get revitalised through real-life experience: they relate to objective realities. In order to capture them, it is possible to use statistics, maps and sociological data based upon social and economic monitoring and observations. From the 1990s, multiple sources offer information that is global and national, but also sectoral and regional or even local. ${ }^{6}$ These series are mapped-and thus somewhat dramatised. They raise questions regarding the permanence as well as the dynamics and causes of the changes observed.

4. Songs and music such as benga or reggae, theatre, and the urban language of the ghettos, Sheng.

5. This includes the great increase in urban and rural militias, vigilantes, and urban gangs, some of which spread millenarian claims and expectations, in particular the Mungiki, in the 1990s-2000s.

6. The data provided here are extracted from international and national agencies reports, public or accessible online, such as: census data, data from KNBS (annual statistics and Basic report on well-being in Kenya), from KIBHS and from KPHC, financial, demographic and health surveys from DHS, economic surveys from $\mathrm{BM}, \mathrm{WHO}$, Unicef; finally, from SID, the Society for International Development, and from some NGOs such as Oxfam; see KNBS-SID (2013). 


\section{The Poverty-Growth-Inequalities Triangle}

An initial macroeconomic social response, supplemented by a more birdeye-view observation, confirms finding and brings further nuance it to it at the same time. On the one hand, Kenya remains a nation of millionaires, some of whom have become billionaires, and the land of a politico-economic monopoly which, for some of its actors, is entering its third generation. This is evidenced by the consolidation of politico-economic dynasties successively put in place by each new governmental team, the saga of political entrepreneurs as well as the family trajectories of industrial or agribusiness entrepreneurs, and the trajectories of individuals-who can be called "tycoons"-who are hard-working or lucky magnates. More recently the success of wealthy urbanites in real estate, services and finance has been as rapid as urban legends would have it and sometimes the financial scandals that come up with them. Incidentally, these individuals now exceed the 200 families of the politico-economic clique - listed ${ }^{7}$ in a register that the media and social networks regularly update. They were said to be about 9,400 individuals in 2016, which represents a 95\% increase between 2006 and 2016, according to African Wealth Report, pulling consumption and investment upwards... according to a consumerist trend which supposedly attract "up-market" tourists and rich foreign residents to the Indian Ocean coast followed by celebrity magazines and national tabloids.

On the other hand, "the beggars" are still there, yet perhaps less visible than in the past. However, the poverty and structural vulnerabilities remain prevalent, so much so that the last great famines of a recent past, like those from 1984-85, still resonated in the 2010s as shown by the increasing price of ugali flour and food shortages. Furthermore, climate change and its local variations stress the structural constraints, clearly evident in the arid or semi-arid northern part of the country and continue to impact communities with a high population growth. Knowledge about these destitute populations has increased as well the categorisation they are subject to. As early as 1999, the National Poverty Eradication Plan ${ }^{8}$ targeted the following groups: farmers without land, disabled people, female headed households, farming communities in semi-arid regions, AIDS orphans, street children, and beggars. In 2015, there were 3.6 million orphans and vulnerable children (OVC), 0.41 million internally displaced people owing

7. See Verdier (2013), Kenya Private Sector Alliance (2013), "Kenya, les cercles d'affaires des décideurs." 2012. La Lettre de l'océan Indien - Insiders, 16 November.

8. This 15-year plan was presented in February 1999 under Daniel arap Moi's presidency. It followed on from the World Congress in Copenhagen, right after the Structural Adjustment Plans (1993) that announced the adoption of povertyreduction policies. 
to "political or natural reasons" (IDP), 0.48 million registered refugees, and $3.6 \%$ to $4.6 \%$ of the national population living with a disability (2008 survey and 2009 national census). The undernourished population is estimated at 9.6 million, out of a population of 46 million, while the numbers of farmers without land-more difficult to discern as figures does not take into account young people without unemployment who are often moving around, if not migrants-made up $10 \%$ of the farm workers in $2004 .{ }^{9}$ Finally one third of households are headed by women, but this measure refers to various situations of dependency or vulnerability as well as autonomy, notably in the cities, thus not exclusively a measure of heads of poor households.

On a regular basis, large national surveys progressively follow one after the other, even more with the launch of national plans to eradicate poverty. ${ }^{10}$ They provide quantitative data that records and follows the evolutions, allowing us to reconstruct historical trends, to classify the chronic nature of poverty, to identify populations below the poverty line, and to assess the persistence of extreme poverty and the levels of prevalence of hunger. General trends come out from these datasets. Beginning in the 1990s, but starting earlier in the 1980 s, a general deterioration of key indications is visible (poverty levels, hunger, demographic indicators) with regional and cyclical patterns revealing the impact of droughts, prices and sociopolitical conflicts. The concurrence of an economic depression, structural adjustment programs, an AIDS epidemic followed by political crises in time of transition reduced the number of public jobs, thus doubling the number of poor people that rose from $25 \%$ to $56.8 \%$ ( $44 \%$ in the cities) as well as of people living below the poverty line between 1972 and 2000. Life expectancy went downward from 59 to 54 years and the average income per resident reduced from 360 USD to 306 USD between 1989 and 2000.

A key fact, these curves reversed from 2002-2004. The changes to the trends are slow but lasting whilst at the same time macroeconomic indicators (growth rate and GDP) are returning to growth. This general improvement includes vital indicators, such as life expectancy and the prevalence of hunger which has gone from $30 \%$ of the population on average in the 1990 s to $21 \%$ in 2015 . The same is true for the number of poor people that has slightly fallen from $56.8 \%$ in 2000 to $46 \%$ in 2006, followed by $45 \%$ in 2009 and $32 \%$ in $2015-2016$. Yet this remains a high number: nearly 16 to 17 million people, of which 1.5 to 2 million Nairobi dwellers out of 3.5 million. It is also the case for extreme poverty which has fall off from $19.5 \%$ to $8.5 \%$ between 2005 and $2015-16$.

9. The land data are a special case in Kenya's statistics as it is always approximate.

10. They target the OVC, disabled groups, populations living in arid and semiarid zones, and more recently dependent elderly populations. 
This new course is linked to the return of economic growth and a sustained increase in the average per capita income, despite the high population growth, which rose from less than 500 USD to 743 USD in 2006, 1,000 USD in 2010 and 1,432 USD in 2015 (World Bank data). The improvement is more modest when calculated and compared in Kenyan currency and current exchange rates, taking into consideration inflation: this is the case between 2004 and 2011, from 37,000 to 76,500 KES per year, from 35,000 to 39,000 KES per year ${ }^{11}$ (KIPPRA 2015). Moreover, inflation and the cost of urban living are eroding urban income growth. Purchasing power is affected by natural crises-for instance provoking the growth in price of maize-as well as political crises. Thus, in the months following the post-election crisis of 2007-2008, the capital experienced a half yearly inflation rate of $25-30 \%$, a situation which is repeated with each electoral period.

Furthermore, in the 2000s, characterised by the rise of an emerging economy or at least by Kenya's ascension to the rank of middle-income country, the gap between beneficiaries and those excluded from the fallout of the growth became obvious. This differential, if not this social inequalitydescribed in budgetary as well as demographic and health surveys (DHS) through socio-economic characteristics, goods, uses, domestic equipment and the asset base of each household-is captured by the statistical measure of the income gap, estimated at 0.416 in 2018 by the Gini index. This measure, albeit high, is well below that of other southern and central African countries ${ }^{12}$ and tends to dip in the countryside, but remains high in the cities where the wealth is concentrated. In 2016 the first quintile of the population (e.g. the richest $20 \%$ ) had access to $56 \%$ of income whilst the bottom quintile (e.g. the poorest $20 \%$ ) had only $4 \%$, and in the cities the first two quintiles had access to $90 \%$ of income (data from KBS Basic Report on Well-being in Kenya).

Another measure of inequality is derived by examining paid employment or self-employment-be it formal or informal work-and wage conditions, which both reveal structural constraints and positive development, even with distortions. Due to the population growth and the inertia of these trends, the number of employees, a measure smaller than the total working population, doubles every 6 to 7 years: 1.5 million in 1986, 3 million in 1993, 6 million in 2000 and the figure reached 10 million in 2008, whilst the ratio of employees to working population (men 78\%, women $67 \%$ and young people $69 \%$ ) vary only slightly as well as the distribution by sector of activity.

11. See data in KIPPRA (2013), IEA (2010) and ADB-GoK (2013).

12. For an emerging country, Kenya, like Tanzania, is within the average. The highest index is found in South Africa. 
In addition to the weight of population growth, the sets calculated from official data (data from Republic of Kenya Economics Survey) show a dramatic turnaround. Starting from the 1990s, the formal sector dropped heavily, starting from $79 \%$ in 1986 to $19.5 \%$ in 2008 , then $17 \%$ in 2017 . The informal economy thus absorbs the growth and the subsequent effects of public policies (PAS from 1993 to 1997).

Therefore, in less than ten years, Kenya has shifted from a country of salaried employees, with a certain level of security, to a country of selfemployed or informal workers, and from a mixed regulated economy to a liberal economy. Part of the urban working classes, composed of public and private sector employees, dismissed public officials and workers-are weakened, without protection whilst their unions, impaired or controlled by the regime, fall back to defending their trades (Leitner 1973; Sandbrook 1975; Smonini 2009). The informal economy has consequently seen a sharp increase from 0.5 million in 1990 to 4.2 million in 2000, 6.1 million in 2006, 9.2 in 2011, and 13.3 million in 2017. This situation accounts for $83 \%$ of economic activity and 70\% of GDP. Yet it cuts across different situations: it comprises activities either in the process of becoming formal services or professions in certain fields, but also situations of survival and structural insecurity. Finally, youth unemployment is estimated between 17 and $58 \%$ of all the "youth," depending on how this category is defined, which is one of the highest in the region. ${ }^{13}$ Nevertheless the formal salaried economy, private as well as public, experienced a relative increase: between 2004 and 2015 it rose from 1.7 to 2.1 million, whilst during the same period, the employment share in the tertiary sector rose from $48 \%$ to $52 \%$ and that of the secondary sector stayed constant (ADB-GoK 2013).

The analysis of income redistribution through work is only possible for the formal sector, which at first glance is rather privileged compared to the informal sector: it reflects general inequalities. There is a high differential between high and median wages, in the public as well as the private sector, which is better able to acknowledge skills and qualifications, with underpaid categories in the public sector (such as the teaching and medical professions), so much so that the practice of working two jobs has become common even if public sector jobs are sought after for the security they offer. In the cities, the formal economy, as outlined by a retrospective study of urban biographies, remains the desired horizon (Bocquier 2003), but certain areas of the informal economy are the levers of growth, such as specific services, industries and urban start-ups.

This statistical and qualitative data reveals strong new trends, confirmed by the growth in financial assets (goods and services) and consumption levels among intermediate incomes. It even shows the emergence of new

13. $55 \%$ according to Awiti \& Scott (2016). 
social strata whose living standards correspond with the two top quintiles, which are "the richest" from the DHS budgetary surveys. Moreover, the statistical indicators evaluating since 2002 the social distribution of cultural capital, access to education, levels of schooling, and media access confirm the potential for meritocratic social mobility, though they are unequally distributed throughout the country. This evolution combined with population growth is both an economic and social opportunity for many. Most spectacularly is university enrolment, which is growing rapidly ${ }^{14}$ although the Kenyan economy struggles to manage this social demand. This demographic divide is fuelling an international and recently regional migration of Kenyan graduates, resulting in a significant diaspora estimated at 3 million people, a sharp increase in the last decade, (corresponding to about $9 \%$ of the population in 2014). This constitutes an important contribution for the economy and society owing to financial transfers. Such transfers are indeed the fourth largest provider of foreign exchange after tea, horticulture and tourism, as well as an asset for families thanks to support provided for schooling, health and real estate costs.

It is obvious that this macro-socio-demographic approach reveals not so much a dividing line between the cities and the modern commercial sector on one side and the countryside and the traditional subsistence sector on the other-as was the case in the decade following independence-but between two social spaces or two worlds: the rich and the poor. This reality, however, should be approached in ways that avoid the caricatured image of "the millionaires and the millions of beggars."

\section{The "Two Kenyas": Two Worlds, Two Social Spaces}

The dividing line that cuts across both the urban and the rural worlds is both a power relationship and a relation of proximity. The power relationship is characterised by the top benefiting from an abundant labour force that is both insecure and underpaid. And the relationship of proximity is evidenced by the fact that the rich were former poor or have poor relatives in their family. This divide is observable through big-picture overviews as well as through detailed observations which recent works of socio-demography, social geography and social anthropology provide, and most notably those that exploit to the fullest new research methods such as the Geographic Information System. Such close-up approaches, associated with macro-data, help to draw social landscapes, reveal social structures and bring to light social relations. They contribute to spatialising social

14. The number of students increased from 118,000 in 2007 to more than 400,000 in 2013. The government thus expected a workforce of 60,000 (or $10 \%$ of the out-of-school population) by the end of 2010-2020, a figure which was actually higher in 2016 with nearly 700,000 students (see Provini 2015). 
polarisation while revealing social nuances and new dynamics of interest to all disciplines of humanities and social science seeking to understand change and continuity. To do so, they work with various conceptual tools, like Pierre Bourdieu's "social space" or the notions of "space-time-memory" of historians and of "identity-territory space" used in social geography.

In recent years, the city has been a particularly studied area because it crystallises all inequalities but also all the hopes for initiatives, freedoms, diversity and the social rebalancing that it promises. At first glance the overall picture is not a rosy one. The capital city and the large cities display social and geographic fragmentations (Charton-Bigot \& Rodriguez-Torres 2006). They also bear witness to space injustice in terms of access to vital services (Ledant 2013), if not segregation between the upper classes gathered in their residential neighbourhoods and the populations of the slums. Unlike in the past, cities conceal the masses of street children, even families on the street, ${ }^{15}$ and at the same time host gangs like in South American cities. Yet new types of differentiation and stratification are in motion, this time in more optimistic ways. They concern even deprived neighbourhoods and the spaces that are being built at their edges, as well as slums that turn into middle class neighbourhoods. These dynamics bring to light an internal line of distinction between residents who can access mass consumption, or have just started accessing it, and those who cannotmass consumption which an increasing number of malls and shopping centres materialise as they are built in affluent neighbourhoods and in these new in-between areas. It also separates those who can and those who cannot build and secure their property, have access to water, benefit from development programs.... Thus, the new urbanised spaces, including some slums, still include informal as well as formal housing, mostly rented, but also a minority of "non-poor" owners who live above the poverty line. In Nairobi, the latter represent $27 \%$ of the slum population. A study of urban poverty carried out by Oxfam GB in 2009 helped to understand the situation of households by distinguishing the "wealthy" whose annual income varies between 200,000 and 300,000 KES per year, thus representing $10 \%$ of the population-which puts them in the middle-class bracket-and the "middle poor" with around 100,000 to 200,000 KES per year who represent $20 \%$ to $40 \%$ of the population depending on the year considered. These "middle poor" represent a median group floating on either side of the poverty threshold. ${ }^{16}$

15. There are about 200,000 street children. According to a national estimate, 100,000 of them in 2000 in Nairobi and 130,000 in 2009 were driven from downtown Nairobi to some slums.

16. The poor, who live under the poverty threshold, relate to two distinct groups: the "permanent poor" and the "very poor," who represent $40 \%$ and $10 \%$ 
Social anthropology and social demography, on the one hand, and social expertise, on the other, which poverty reduction programs call on, accurately describe these two worlds, that is, this spatial bipolarisation described above and the distinctions at play. This is the case in Nairobi, between and within the urban districts. Take for example the neighbouring districts of Muthaiga, the most residential area of the capital, and the Mathare and Pangani ghettos, which used to be slums. More generally, marginal differences appear in the slums within the different strata of settlement ${ }^{17}$ between squatters, tenants and owners, between old-timers and new comers, but also between households. Monographs reveal that in slums, which have become more and more mono-ethic ghettos following the 2007-2008 crisis, there is much demographic and economic precariousness, everyday instability and family tensions, natural and environmental vulnerabilities, prevailing insecurities and the grip of gangs and militias. They also shed light on the ways in which sociability, the economy of affection, sociocultural cohesion, the creative energy of the "little big men," and innovative or fraudulent accumulations, as Deyssi Rodriguez-Torres shows (2012), do prevail. The resilience of the slums dwellers who believe in and hope for a future of education for their children, is demonstrated in the high levels of pre-primary and primary education, both public and private, so much so that in some slums, residents nourish optimistic expectations, according to opinion polls.

The findings are the same for the countryside, even though the social situations there are not only complex but also divided. In view of this, two scenarios can be identified for the agricultural semi-urban spaces and centres. There is, on the one hand, an agrarian Kenya that stretches from Mombasa to Kisumu, and, on the other, the peripheral areas and pastoral North, from the Somali border to the Ugandan border. In the agrarian Kenya, farm workers, rural households and farm owners have to deal with a difficult process of modernisation-sometimes a complete break from and sometimes heir to the traditional model of reproductionthat is linked to the urban and international market and to cities through commuting between towns and the countryside. They simultaneously grapple with social confrontation. particularly regarding the land question (Argwings-Kodhek 2006). In this regard, the precise measure of land inequalities remains unresolved, as it raises questions about the privatisation of collective land, spoliation and redistribution, and many unknowns concerning land registrations and the legal status of land. But

respectively (Goodfellow \& Taylor 2009)

17. See Cahiers d'Afrique de l'Est/The East African Review no. 44, special issue: "Slum Upgrading Programmes in Nairobi: Challenges in Implementation." 2011. https://journals.openedition.org/eastafrica/509. 
for agriculture-oriented regions (except for pastoral zones within which the collective ownership or use of land plays an essential role, and except for the public domain where land is often labelled as heritage), data from official sources about surveyed land and from national surveys indicate blatant inequalities and large gaps over land control. Thus, in 1969, 7\% of the farm workers owned $34 \%$ of agricultural land, a figure which monographs have since confirmed. These gaps and inequalities also concern social distribution: in 2004, farmers without land, micro-owners, smallholders, and large land owners with more than 10 hectares made up respectively $26 \%, 50 \%, 25 \%$ and $5 \%$ of the total farmers. The "agrarian reforms," meaning the redistribution of land in several waves since independence, as well as the support to cooperatives and hydro-agricultural installations, have ultimately only benefited a minority of farmers from certain ethnic groups (Oucho $2002^{18}$ ). They equally benefited large established landowners who were able to buy back land put on the market. The reforms have therefore not transformed the differentials that were already in place during colonisation. ${ }^{19}$ What they did, however, is to contribute to Africanising the large land property and, in some areas of the highlands, to giving rise to small and medium-sized land owners, while confining the large former colonial properties that have invested in their farms. As a consequence, the countryside offers a mixed picture: there is a majority of young landless farmers and micro owners, partly as a result from the long-term land deprivation established during colonisation but that was not corrected by the agrarian reforms of independence; this majority rub shoulders with small or medium-sized enterprising properties that have gained from the land privatisation that started as soon as the early 1950s. This sort of properties also benefited from some subsequent booms, used economic niches (e.g. coffee, tea, cereals, horticulture), received support from economic policies, and enjoyed opportunities in local markets, in transfers with the city and the countryside, and in urban connections based upon intergenerational links. These two constituencies of farmers neighbour large estates or companies that usually depend on modern technologies and form an agrarian power as they act a politico-economic lobby and are built upon technical corporate sociability. This agrarian power has been strengthened through investment in economic areas, such as tea, cereals, horticulture and dairy products, that were more promising than the neocolonial private plantations of coffee and their public counterpart in sugar production. Their presence is prolonged and strengthened by integrating

18. See also reports on public good and their registration, notably the Ndung'u Report.

19. Forty years later we find the same differentials as in the 1950s, as observed by Kitching (1980). 
or associating with the agri-food industries in the hands of the Asians or of the former public cooperatives or companies now privatised.

This evolution contrasts with the pastoral peripheries that are still confronted with ordinary fatalities: there people struggle to feed themselves and survive. The cyclical poverty tends to become structural under the cross-effects and snowball effects of climate vulnerability, the restriction of natural resources, the high population growth, and new economic and political contexts: the tragedy of the commons is underway. It can be associated with statutory degradation (e.g. for a shepherd to lose his flock is tantamount to extinction, as it forces him to become a farmer), although historically such degradation hit a share of these communities only marginally during crises, famine or drought (Anderson \& Broch Due 1999). The capacity for resilience of these pastoralist communities, without assistance, is becoming way less effective than before and new modes of adaption are weakening the social fabric. Indeed, the marketing of pastoral resources (through cattle raiding and cattle rustling), the redistributionpartitioning of land (between ranches, reserves, and parks), and political and geopolitical instability are breaking apart the traditional means of survival in communities with high population growth and with internal and inter-regional tensions resulting from pastoral migration. In the process, groups of the newly wealthy, sometimes migrants, have taken the opportunity to monopolise the land to the detriment of local communities, playing on ethnic or regional rivalries (Grenier, Bollig \& McCabe 2011). However, these faraway or even landlocked spaces and times that are so different from the centre and have long remained the no man's land of Kenya, are now however becoming more and more connected to it: the Masai, Samburu or Turkana "young warriors" understand and speak Swahili, if not Sheng. Nevertheless, this assessment must include regional nuance. Some pastoral societies in the southern regions, including at least some of the Masai, benefit from the extension of new crops, including cereals, the meat market, or links with the big cities, such as the opening and widening of the regional tourist economy: this Westernisation, partly assimilated and controlled, that goes along with the privatisation of land and developments through ranches, farms, parks or reserves, happen at the expense of some local communities, and even more often at the expense of their own culture, resulting in a mobility of circular migration further and further away (Péron 1993; Spear \& Waller 1993). 


\section{Two, Three Kenyas Put to the Test of Reforms, Efforts for Well-Being, and the Challenges of Public Policy}

Public policies for development, social protection and investment in the public service, and more generally poverty reduction reforms and, following the Constitution, devolution and modernisation as envisaged in Vision 2030 can, or might, bring to the whole population what the market and new economic growth, based upon an abundant low-cost labour force, cannot offer by correcting Kenya's social and spatial differentials. Yet, the effects of these social-cultural policies (education) and social protection policies (which includes support to OVC, elderly people, etc.) take time, just as the multiplier effects of the major projects of Vision 2030. In addition, the assessment of these reform and the measures that accompany it as well as the rise in power of the counties have unveiled the multiple facets of territorial discrimination and increased awareness of them (Sivi 2013).

However, taking these socio-territorial inequalities into account changes how society and its various components see themselves. Poverty is no longer defined and perceived solely in monetary terms (income) and patrimony (household assets). It now includes access to services, goods, knowledge, opportunities to advance and social mobility, insisting on the notion of "well-being": such an indicator is put forward by the calculation of human development or methods of equalisation used for the equitable calculation of county budgets-somehow in the spirit of a "new Harambee." Moreover, a new measure, the poverty gap, is used to assess how far away the standard of living of the poor population at the county level is from the national poverty line. It puts in full light the full extent and acuity of the social question, in terms of developmental delay in certain counties of Kenya. Well-being and the poverty gap, once they are mapped, ${ }^{20} \mathrm{draw}$ social spaces and landscapes, less binary and more complex that the rationale of the two Kenyas: by crossing economic, patrimonial and access to services data, we rather find three Kenyas.

Firstly, there is a Kenya often described as "useful" on the MombasaKisumu axis. Undoubtedly the winner, it is characterised by an overrepresentation of the top national quintile-those who are the "richest" according to recent DHS surveys-in Nairobi (67\% of the population), in the cities (49\%), in the central region (32\%) and in coastal cities (24\%). There, the poverty line and the relative poverty gap are the lowest, while the regional indicators of human development and well-being are the highest. Additionally, for the destitute, access to services and the urban market allows hope of meritocratic advancement through school or of climbing the

20. See the maps available on the websites of SID and KPHC. 
ladder and getting rich thanks to involvement in the informal sector. The "useful" Kenya is the country's hub for consumption and employment. But these indicators decline as we move out of the cities: rural poverty is at the gates of the major cities, in their suburban peripheries, as well as in coffee producing and horticultural areas of paid employment (Kinyanjui 2007).

Secondly, and on the contrary, a Kenya made up of outskirts and territorial disparities is emerging: it includes the counties of the northern pastoral peripheries, and semi-arid spaces that form an arc of a circle with the counties of West Pokot, Turkana, Samburu, Isiolo, Mandera, Wajir, Tana river, Garissa as well as Kwale. They have the lowest socio-economic indicators (e.g. poverty line and poverty gap, incomes, high gap in the Gini index, little secured employment) and are way behind in terms of sociocultural development (access to education, water, electricity, etc.). They also have the largest number of "the poorest," making up $73 \%$ of their population, and the highest poverty intensity (for example $46 \%$ in the Tana River county versus $4 \%$ in Nairobi), whilst their communities are the most affected by climate change. Moreover, marginalisation is high, targeting the "indigenous peoples," pastoral societies, hunter-gatherer farmersoften isolated like the Ogiek and the Yaaku-, and particular ethnic groups such as Kenyan-Somalis, evidenced by many reports like the Human Rights and the Truth and Reconciliation national commission. These societies are somewhat Kenya's "Third World," as they are subordinate to both objective situations and general perceptions of their status. Last, the fact that these areas host refugee camps, for instance Kakuma and Dabaab, and have historical geopolitical border instability and recurrent dissidence, contributes to this devaluation. It also raises fears because of their higher than average population growth rate.

Finally, the third Kenya, somehow set in between, yet the most imposing demographically, is sandwiched between the two Kenyas, that is, between the useful "winner" and the peripheral "loser." It is made of the hinterlands of the useful Kenya, the coast of The Indian Ocean, the central region, the central Rift region, and the western regions, which are all overpopulated areas. They correspond to the historical and saturated population centres around Mount Kenya, in the Nyanza and Western provinces (e.g. the Kisii region), on the Swahili coast and in areas vulnerable to variation in climate near arid lands and frequently impacted by droughts. The percentages of the "poorest" and the intensity of poverty are higher here, whilst human development indicators are average. In particular educational data is above average, with the best-performing school districts: in 2016, 13 school districts out of the top 20 in the exams for accessing higher education come from this area (corresponding to the Kamba, Kikuyu, Meru, Luhya, Nandi, and Kalenjin regions), and 7 urban and semi-urban districts have a strong 
education tradition (among them Nairobi, Mumia, Kakamega, Kisumu, and Nyeri). ${ }^{21}$ This gap between the economic situation and the sociocultural indicators explains why education is a priority, if not the object of a collective strategy of promotion that includes the urban elite who send their children to these renowned schools. This divergence is also the cause of internal tensions between young people, women, the often highly educated new generations and the established elders, whose authority is increasingly contested. These spaces consequently have high levels of domestic, neighbourhood, and even political violence that testify to these internal tensions. The communities only survive through countryside-town circulations, be they permanent migrations or commuting with the centre and its cities, and thanks to intergenerational transfers. These exit options and also these efforts to keep going with rural society via income transfers are not new, going back to the colonial period, but they are reaching their limits in some areas, like in the Kisii and the Luhya regions.

The Kenya of today has thus become a case study that illustrates the interactive poverty-growth-inequality triangle inherited from the colonial time, which the crisis of the 1990s (with adjustment and liberalisation programs) have brought to light and which the growth of the 2000s and its ill-development have set in motion. The bipolarisation of the "two Kenyas"-one with its elite and one with the mass poor-is reproduced and maintained, but there are rather "three Kenyas," that is to say three social spaces increasingly distinct and visible, with diverse dynamics regarding access to modernisation, different social aspirations (advancement, emigration, rural exodus or not), and varied territorial identity, memories, and trajectories that pull towards or away from the centre. Furthermore, this triangle of growth-inequality-poverty foreshadows a future story, that of the emergence of intermediate categories, of a middle class, which hinges on redistribution by the market and at least by the state. This transformation, which owes both to emergence processes and to social advancement, may give rise to a pivotal social class, therefore raising hopes for social stabilisation in the not so distant future. Is the old developmentalist dream of social stability, of the status quo through growth becoming reality?

But in the immediate future, such bi- or tri-poled scenarios raise fears of tensions, if not social conflicts, and exacerbate social pressures given the national political and even cultural stalemates. Surprisingly and without inferring too easily a colonial legacy or at least a seduction of the Kenyan elite by the colonial elite, and in view of some commonalities in the education system and religious practices, Kenyan society could be considered somewhat "Victorian" with its triptych set against a backdrop

21. Based on the rank of the top school districts access exam results (nb: 288) (KCPE 2013). 
of wild capitalism: the first part is made of a triumphant and westernised oligarchy that includes capitalist-gentlemen but compassionate and open to charity; secondly and in contrast, we find a mass of poor people of various social and ethnic backgrounds both in urban areas and in the countryside whom young migrants constitute a lumpen proletariat, even a potentially "dangerous class"; and finally there is an increasing intermediate class that can be found both in urban areas and in some rural areas, which we can label as "middle class" or petit-bourgeois-yet with no connection to a labour aristocracy-whose main characteristics are to be somewhat anxious and frustrated by the search and learning of a safe "sweet home" in secure compounds but also because of their unmet expectations of a better life.

Today and more so than yesterday, this perspective of social divisions and their associated fear, which are the other side of this raw social deal, raise questions. On the one hand, how is it possible to overcome the deadlock in which the new educated generation are, and which the government and international organisations measure through index alerts-with a Gini index above $45 \%$ and increased levels of youth unemployment? On the other hand, and more so, how can the explosive outcome of social mobility be prevented? Politics only, as a way to bring different people together, could triumph over social dissonances. Yet, according to historian Bethwell Ogot who recently took stock of the nationalist project and of Kenyan identity, such kind of politics is missing today. Consequently, the study of social changes cannot omit a political and cultural analysis because the country is without or is in search of a national and social pact... and has actually been since independence. ${ }^{22}$

\section{Kenya without a Social or National Pact, in the Grip of Symbolic Violence}

From the first decades of independence to the transition of 1990, social divisions are present, but accepted. This social state is alive in the shape of muted acceptance which Josiah Mwangi Kariuki had condemned. The lines of separation were then still racial, neo-colonial, even regional and social. In view of this, the enrichment of national leaders and of their families, originally poor for most of them, was cast as the good fortune of the victors: it was an individual revenge rather than a social fact. These leaders neither belonged to a traditional African aristocratic elite, then non-existent, nor to the African economic elite already emerging or established, with the exception of a few. ${ }^{23}$ Thus social inequality became

22. See the latest publication on this topic: Mwangi, Opongo \& Wahome (2019).

23. Recently, scholarly biographies of nationalist leaders (e.g. Paul Ngei) and Kenya's great political families have tremendously increased, notably focusing 
Africanised, yet without the racial connotations of the colonial period, by drawing from conformist, if not unequal so-called traditional community values. This social architecture was later maintained by authoritarian political systems, the neo-patrimonial nature of the state which politicoeconomic dynasties and a managerial and business petit bourgeoisie benefited from. This elite expanded, diversified and renewed itself from the top by co-opting the newly promoted, the "big men" and those under them, such as intermediaries and officials who were often the "broker-cumclients" within such a pyramid system (Kidombo 2007). This domination and social peace suited Western partners concerned with geopolitical stability during the Cold War, especially at that time when the status quo contributed to civil peace. In effect inequalities are thus managed, ritualised, and somehow digested by imagery, rhetoric and political practices which since independence had been based on the national and moral values of sharing, solidarity, redistribution an pooling, that is, of the "all together" of Harambee-the national motto under President Kenyatta. Moreover, this nationalist political culture, confirmed and followed by the Nyayo regime (nyanyo meaning "the trace" in Swahili) of President Daniel arap Moi, resonated within the community and ethnic ethos of family and community accomplishment, success, advancement, seniority, and social conformity. Religious discourses also resounded with references to these values and contributed to the building of Kenyan identities.

In the name of this national pact, mobilising all Kenyans thus helps to symbolically and materially correct the inequalities. This happens, firstly, through community work-a model which the nationalist nations of East Africa all share-and, secondly, through exchanges, compensations and distributions that tacitly materialise the social contract, beyond the political pact. The successive regimes of Jomo Kenyatta and Daniel arap Moi instrumentalised this social "pact-contract" through political patronage and both institutionalised and ritualised it through speeches and slogans, through practices and symbols. Various very tangible gifts resulted from these in a ceremonial manner. Land was the first of these gifts, as well as commercial opportunities and profits, public amenities and social community projects, individual promotions, equipment and so on. The distribution of consumable products was the second type of gift, such as maize in times of scarcity or milk for school children. Local and territorial communities, often gendered, thus benefited from some of these exchanges, donations and takings which were sponsored and mediated by all the actors of the politico-administration. In reality patronage and clientelism were rapidly overtaking the original form of self-mobilisation, transforming

on the Kenyattas, the Mois and the Odingas. Others are about "big men," such as Charles Njonjo (Médard 2012). 
Kenyan citizens into "political beggars." Such a system reached its peak in the Moi era, a one-party regime, by integrating the periphery through the relay of local bosses, the "big men."

For a time, this redistribution-which is also a sort of politico-social evergetism-acted as a very strong social bound, despite the fact that is unequally favoured ethnic groups, allies, and partisans. It maintained links with the communities at the bottom and built an imagined national community, with the added bonus that it regulated in this way the foundations the regime in place by renewing its competing local elites. However, such a contract-pact, which also included support for the cooperatives (with 780,000 members in 1975 from a population of 13.5 million: see Kanogo 1990) and the strengthening of the public and administrative authority, the public bureaucracy and public companies, was only possible to the extent that the financial and economic margins of the ruling power was grounded upon a prosperous parastatal economy. This was the case for many reasons until the mid-1970s, until the 1980s and then 1990 when the depressive economic context giving less resources to the state, together with the authoritarian drift, poor governance, and the political transition failed this social contract-pact (Grignon \& Maupeu 1998). The ethnic-political conflicts of the transition then gained the upper hand and sowed the seeds of a "moral ethnicity," which is another type of pact.

Since then, this national and social pact, already dormant on the political level-as the political lines of the main political parties converge in an assured liberal perspective according to which redistribution is a function of the economy only-has broken down. Its rectification is still desired through a second Harambee (Equal Rights Trust \& Kenya Human Rights Commission 2012).

As such the underlying and cold violence, apparent in the regimes of poverty as well as in social inequality and to which the country seems to have become accustomed, is therefore not solely social but has also become a symbolic if not moral violence. This happened progressively as Kenya's nationalist model, which was based more on regulation than integration, which was more cultural than political, has become defective. We contend that ultimately this failing has been compensated by the recourse to ethnicity and then to religiosity.

Since the 1990s, the danger has started to show and translated into either a mass explosive social blaze owing to accumulated frustrations or a silent ethnic conflict. Both situations awaken and join up during every significant event, that is, during social conflicts, through politico-social protest movements like those which militias represent, and during political and election fever, which spreads the aspirations of the youth, the new generations, and specific age groups. The mobilisation of the youth into 
militias as well as the social dramatisation of the post-electoral crisis of 2007-08 are an illustration and a peak point of these phenomena. Lowintensity violence is also a daily experience at community level, in the streets, in families, and within household. And domestic violence is rising sharply ${ }^{24}$ as traditional, family, and community models of regulating tensions do no longer manage it as they were in the past and do no longer have the moral authority required for doing so.

What is more, it is feared that in the future the chains of social inequality might once again play on socio-political tensions-social inequality between towns and cities, between territory-defined populations and within them, between the old and the young, between men and women, and between nationals, foreigners and marginalised people, the last ones being de facto dependent on humanitarian action. Identity, ethnic, and religious answers and ways to shut from the others might also arise, which in Kenya have already been at play, or even forms of Messianism, escapism and anomy. Eventually, wandering and aimless individuals and groups might increase in number and be captured or exploited by terrorist strategies as much in cities as in the countryside.

Through these fragile social bonds and relations, it is clearly the ethnic question that dominates the social scene-or the "tribal" question if one retains the official terminology in use ("ethnic affiliations, tribes and nationalities"). At least it is the construction and uses of rigid identities that deserve to be addressed. Such identities are indeed both exclusive and violent, especially in times of open or muffled but also hopefully protective crises, yet crises that are always kept in memory. Social history therefore cannot do without a cultural and identity-aware approach.

\section{Ethnicised Social Relations: Has Ethnicity Replaced Class?}

Kenyan society appears to be more and more divided along ethnic lines, so much so that it appears that ethnicity has taken the place of class, or at least become pervasive in the understanding of social and human relations. While only $2 \%$ of Kenyans self-identify as "Kenyans," ${ }^{25}$ the declared ethnic affiliations-but is it through an exclusive sense of affiliation?-are essential even though internal social differences are growing irrespective of ethnic group. Has the ethnic struggle replaced the class struggle, as well

24. See the data in the different DHS surveys on the reality and the perception of domestic gender violence.

25. This might include, among others, naturalised Asians who do not declare themselves to be "Kenyan Asians." Since July 2017, "Asian" is politically recognised as Kenya's $44^{\text {th }}$ "tribe." 
as the racial struggle? Might imagined community equality and expected fraternity-of rank and status $-{ }^{26}$ help to accept or even erase social differences? To answer these questions, we are now turning to history and historical sociology, as ethnic groups are historical constructs.

Today the ethnic reality prevails. The 43 "ethnicities and nationalities" in place since independence (and 44 since 2017) tacitly and officially recognised this reality on a social-cultural level. Among them, some "ethnicities" are considered "central" given their demographic strength in some regions and because they are represented throughout the country (census data 2009) as follows: the Kikuyu 17\%, the Luhya 13.7\%, the Kalenjin $12.7 \%$, the Luo $10.8 \%$, the Kamba 10\%, then the Somali 6\%, the Kisii 5\%, the Mijikenda 5\%, and the Meru 4.1\%. Besides them, there are "peripheral" ethnic groups characterised as regional or even territorial minorities, which also include the "nationalities" such as the Asian Kenyans, White Kenyans, Arab Kenyans and "indigenous people." This ethnic division is undergoing internal changes due to differing population growth rates and fertility rates, as some regional groups have entered demographic transition while the pastoral communities are seeing strong growth.

This multicultural presence and ethnic diversity are part of Kenyan history and heritage. The longue durée historical perspective necessary to apprehend population settlements, the diffusion of languages (Nilotic, Bantu, Cushitic, Swahili...), techniques and material cultures, and cultural practices and exchanges, reveals differentiated constructions. Such constructions have changed because of particular demographic, pastoralist and agro-pastoralist mechanisms-impacting upon patterns of settlement, territorial expansion and growth-as well as because of social-economic, ecological, and social-cultural dynamics and due to the geopolitical context. These more or less favourable interactions stem from and have built diversity but also inequality in so-called traditional societies on the demographic, economic and geopolitical front: all of this explains the historical difference between the central ethnic groups and the peripheral ethnic groups. However, "ethnogenesis," that is, the construction of ethnic territories and identities, seems more recent. It was reinforced in the nineteenth century when the populations came into contact as a result of demographic growth, thus creating internal tension and even external conflicts, even though, at that time, ethnic borders were still fluid and interethnic exchanges frequent. ${ }^{27}$ Remarkably this construction did not result in state formations: there was no monarchy or aristocracy in Kenya except for

26. See the number of ethnic declarants who do not report their clan or subtribe.

27. All great theses of regional history by Bethwell Allan Ogot, William Ochieng, Godfrey Muriuki, Henry Mwanzi... note the porous nature of borders between tribes in the nineteenth century before colonisation. 
embryonic forms (e.g. the city-states of the coast, and the Wanga state) and for a few occasional leaders, "big men," warlords and precolonial prophets.

Secondly, colonisation administratively entrenched racial categories and ethnic identities, territorialised them and exploited them without, however, attributing more or less value, or fewer or greater privileges to certain ethnic groups to the detriment of others, unlike what happened in other neighbouring colonised areas. In the Kenyan colonial regime, the appointment of chiefs remained the responsibility of the colonial administration and was never mediated by a customary ethnic authority as seen in monarchies and chieftaincies elsewhere in Africa. For its local administration and army, the colonial power exploited local resources; for labour or clerical assistants, it drew on central ethnic groups geographically associated with colonial exploitation; and for its military force it recruited from the peripheral ethnic groups perceived more as warriors and more apt to the arms profession-a process that in some cases contributed to inventing ethnic groups, like the creation of the Nubians. Thus, while the central ethnic groups, including the Kikuyu, were the most favoured through proximity to colonial power or through new economic trends or even by the reforms of the $1950 \mathrm{~s},{ }^{28}$ they were also the most penalised by it. This style of colonial management and this proximity, this encounter between the colonial world and certain ethnic groups, is also reflected in the emergences of indigenous elites, the junior civil servants, the clergymen. They produced narratives and nationalist identity writings that blended traditions and borrowings from certain religious political conceptions of modernity (Peterson 2012). These types of "invented tradition" (Ranger 1985) and ethnic patriotism of the "small homeland" (petite patrie) compensated for the weakness of the political ethnic legacy. This local elite participated in the nationalist claim and then struggled for independence which prepositioned them to a national destiny. Upon gaining independence and although regional strife, fuelled partly by the racial question (the place of racial minorities and particularly that of the Asians), was perceptible between central ethnic groups (the Kikuyu and the Luo) and the peripheral ethnic groups or divided centres (like the Luhya, the Kalenjin, the Mijikenda), the national sentiment outshone feelings of ethnic belonging and supported a national associative project that nevertheless lacked a "national high culture," principally a national language that was then neither English nor Swahili.

Thus, in Kenya, as anywhere else-and perhaps even more so-, the proclaimed nation is even less a natural given: it is a historical contemporary

28. Including the Swynnerton plan for the privatisation and redistribution of land in 1952, the authorisation of farm plantations, indigenous trade in certain areas, recruitment of personnel with a background in industrialisation, in the aftermath of the Second World War. 
invention, a geo-economic, institutional, political construction, without long-term filiation except for the territorial, administrative and geopolitical framework inherited from colonialism. Moreover, this nation only a single objective: "nationalism," which was the history of present time as well as the collective destiny of a cultural, social and political modernisation in its beginning stage. However, at the time of independence, the national consensus was dominated by a project of "African-Kenyan Socialism" blending political democracy, well-being, a mixed economy and selfsufficiency, and the progressive Africanisation of inheritance and jobs, under which ethnic groups did not have the right to political citizenship but to cultural citizenship. Yet the latter structured daily political life and impacted the national life but in an unequal manner, because historical processes differentiated them on many levels, granting some of them intellectual, economic, geopolitical, and demographic primacy. But political actors and political parties, with their strategies of conquest and maintaining power, increasingly played this reality, pulling the strings of ethnicity under the cover of nationalist rhetoric and through authoritarian practices. This had already been the case since independence, in the construction of parties, regional alliances and then ethnic alliance (including the KANU-KADU division), then ethnocentrism as an exercise of power. Ethnic preference was used in the management of power and in access to the state, to its services and redistribution, as well as tribalism to conquer and stay in power. This tendency was reinforced even more when political life became democratic, at least competitive. From the transition of the 1990s, indeed, politics both instrumentalised the ethnic factor and was trapped by it and by its power of demographic mobilisation deployed at each election. "The tyranny of numbers" ${ }^{\prime 2}$ therefore prevailed by corrupting and playing up the "moral ethnicity" unique to each society (Berman \& Lonsdale 1992). Finally, the political disruptions and even more so, political crises-often due to identity manipulation-took root because of the litany of human and universal tragedies and the ascending collective violence they triggered, leaving in their wake painful memories and conficting identities.

The decades of independence-and even more during the transition and the democratic period-therefore contributed to the exclusive consolidation of ethnic identities, which neither the precolonial nor the colonial period had produced, or if so, perhaps only partially. Tribalism in its various forms and through authoritarian, autocratic and even democratic implementations also took part in it. For these reasons, the ethnicisation of society appears to be a top-down process that stems from strategies devised by political elites at various levels through the manipulation of ethnic identity for

29. In the words of political scientist Mutahi Ngunyi during the 2013 elections (see also Thibon, Fouéré, Ndeda \& Mwangi 2014). 
their immediate gain-be it a politico-economic or a social gain-via political client-patron networks. Thus, social differentiation, territorial discriminations, the creation of millionaires as well as the emergence of a managerial public middle class, who are sometimes perceived as the brokers of the politico-economic elite, are the direct or indirect product of ethnicisation.

However, we should not ignore a powerful bottom-up movement grounded upon the conjunction of many reasoned behaviours seeking advancement and survival, the resilience of the "ethnic groups of beggarsclients," and the many attitudes that illustrate identity tension in reaction to the often-destructive process of socio-cultural modernisation with the objective to manage the malaise suffered by family and community structures. Such a movement is all the stronger when it is relayed through writing and language, even more when modern mass media is involved. This ethnic retreat, this ethnicity from rural and urban societies weakened by modernisation clings to a tradition or lost authority. This is illustrated by the millenarian militia, the culture clashes, the masculinity crisis and the authoritarian fold around traditional authorities (age classes and the elders). We often tend to forget those who have lost everything, who do not sink collectively into social anomie but cling to "what remains when we have lost everything,": and what remains is culture, even if reinvented. Such a process is also true for the middle classes and concern both the old small managerial promoted bourgeoisie whose strategies of social meritocratic ascension are indebted to ethnic mediations, and the recent middle class that is a bit less permeable to identity-related pressures. Both resort to moral ethnicity and appropriate ethnic patriotism for security purposes or social distinction, which plunges into tribalism during time of crisis.

Thus, the ethnicisation from above has found a reactive echo in society, especially as the suffering endured during these socio-political criseswhich Kenyans experience as an intermittent civil war they are scared of-have given the people an additional memory of a sensitive nature. We would not then be facing 2 or 3 Kenyas but closer to 4 Kenyas, with the risk of seeing some leaders or local political classes play the card of decentralised ethnicity.

\section{Conclusion}

Closely observing Kenyan society in the twenty-first century and putting it into context bring to light complex dynamics that cannot easily be captured in the idea that there are "two Kenyas" based upon a binary dividing line inherited from colonisation and reproduced the decades of the independences. Rather, "three Kenyas" emerge with their own social spaces, if not their ethnic-focused spaces. This complex character becomes 
even more obvious as we take into account not only income, well-being, and politico-ethnic behaviours, but also cultural changes. Some of these changes are silent but observable in everyday practices by looking at collective behaviours and habits, the effects of education and digital booms, access to media, language usage, the demographic transition of households, and more generally modernisation and acculturation. Other changes are less visible, or even invisible, except in times of overt crisis, as they relate to perception and religious practices, collective sensitivities, gender relations and diverging identities that may be divisive. The socio-cultural differentiation at work is more complex than we first thought. It reveals silent changes that can perhaps be seen in a more optimistic light than the one we used in this chapter to depict the inevitability of social trends. Such a move requires switching from the panoramic and longitudinal approach adopted here to the analysis of social trajectories through the use of a crosssectional survey or monographic observation.

\section{Bibliography}

ADB-GoK. 2013. The State of Kenya's Private Sector. Tunis: African Development Bank Group; Nairobi: Government of Kenya. http://kenyachamber.co.ke/ wp-content/uploads/2017/02/The State of Kenya s Private Sector.pdf [archive].

Anderson, David M., and Vigdis Broch-Due (eds). 1999. The Poor Are Not Us: Poverty \& Pastoralism in Eastern Africa. Oxford: James Currey; Nairobi: East African Educational Publishing; Athens (OH): Ohio University Press.

Argwings-Kodhek, Gem. 2006. "An Inequality and Welfare Analysis of Kenya's Agricultural Sector.' In Reading on Inequality in Kenya: Sectoral Dynamics and Perspectives, 253-87. Nairobi: SID (Society for International Development).

Awiti, Alex, and Bruce Scott. 2016. "The Kenya Youth Survey Report." East African Institute. Karachi: The Aga Khan University. https://ecommons.aku.edu/eastafrica eai/17.

Berman, Bruce, and John Lonsdale. 1992. Unhappy Valley: Violence and Ethnicity. London: James Currey.

Bocquier, Philippe. 2003. "Les impacts sociaux de la crise économique à Nairobi. L'ère Moi a-t-elle eu un impact significatif ?" Politique africaine no. 90: 78-93. https://doi.org/10.3917/polaf.090.0078.

Charton-Bigot, Hélène, and Deyssi Rodriguez-Torres (eds). 2006. Nairobi contemporain. Les paradoxes d'une ville fragmentée. Collection "Hommes et sociétés." Paris: IFRA-Karthala.

Dauch, Gene. 1982. “J.M. Kariuki et l'éthique nationale du capitalisme." Politique africaine no. 8: 21-43 [archive]. 
Desgroppes, Amélie, and Sophie Taupin. 2011. "Kibera: The Biggest Slum in Africa?" Les Cahiers de l'Afrique de l'Est no. 44: 23-34.

https://journals.openedition.org/eastafrica/521.

Equal Rights Trust, and Kenya Human Rights Commission. 2012. In the Spirit of Harambee, Addressing Discrimination and Inequality in Kenya. ERT Country Report Series 1. London: The Equal Rights Trust.

Flores Fernandez, and Rosa Amelia (eds). 2011. "Slum Upgrading Programmes in Nairobi: Challenges in Implementation." Cahiers d'Afrique de l'Est, no. 44. https://journals.openedition.org/eastafrica/509.

Goodfellow, Tim, and Wendy Taylor. 2009. Urban Poverty and Vulnerability in Kenya. Kenya: Oxfam GB. https:/urbanhealthupdates.files.wordpress. com/2009/09/urban poverty and vulnerability in kenya1.pdf [archive].

Greiner, Clemens, Michael Bollig, and J. Terrence McCabe. 2011. "Notes on Land-based Conflicts in Kenya's Arid Areas." Africa Spectrum 46, no. 3: 7781. https://doi.org/10.1177/000203971104600305.

Grignon, François, and Hervé Maupeu (eds). 1998. "Introduction au thème : les aléas du contrat social kényan," numéro spécial "Le contrat social à l'abandon," Politique africaine 70: 3-22 [archive].

IEA. 2010. "The Dynamics and Trends of Employment in Kenya." IEA Research Paper, 1, Institute of Economic Affairs. https://media.africaportal.org/ documents/The-Dynamics-and-Trends-of-Employment-in-Kenya1.pdf [archive].

Kabayi,Egera. 1998. "Introduction au roman kényan.” In Le Kenya contemporain, edited by François Grignon and Gérard Prunier. Paris: IFRA-Karthala.

Kanogo, Tabutha. "Cooperatives." 1990. In Themes in Kenyan History, edited by William Ochieng, 175-86. Nairobi: Heinemann; London: James Currey; Athens (OH): Ohio University Press.

“Kenya, les cercles d'affaires des décideurs.” 2012. La Lettre de l'océan Indien Insiders, 16 November.

Kenya Private Sector Alliance (KEPSA). 2013. "List Members," Nairobi.

Kidombo, Pius K. 2007. The Architecture of Corruption in Kenya. Nairobi: Sino Printers and Publishers.

Kinyanjui, Felistus. 2007. Causes of Persistent Rural Poverty in Thika District of Kenya 1953-2000. PhD Dissertation. Grahamstown: Rhodes University. https://core.ac.uk/download/pdf/145055618.pdf.

KIPPRA. 2013. "A Comparative Study on Public-Private Sector Wage Differentials in Kenya." KIPPRA Policy Paper 5. Nairobi: Kenya Institute for Public Policy Research and Analysis.

Kitching, Gavin. 1980. Class and Economic Change in Kenya: The Making of an African Petite-Bourgeoisie. New Haven: Yale University Press.

KNBS-SID. 2013. Exploring Kenya's Inequality, Pulling Apart or Pooling Together? http://inequalities.sidint.net/kenya/wp-content/uploads/sites/3/2013/10/ SID\%20Abridged\%20Small\%20Version\%20Final\%20Download\%20Report.pdf [archive].

Kurtz, Roger J. 1998. Urban Obsessions, Urban Fears: The Postcolonial Kenyan Novel. Trenton (NJ): James Currey, Africa World Press. 
Lafargue, Jérôme. 2010. "Résistances au long cours. Narration et maniement de la mémoire insurrectionnelle à partir d'exemples des Mau Mau (Kenya)." Cahiers d'études africaines 197, no. 1: 25-50. https://doi.org/10.4000/etudesafricaines.15769.

Ledant, Martin. 2013. "Water in Nairobi: Unveiling Inequalities and Its Causes." Les Cahiers d'Outre-Mer 263, no. 3: 335-48. https://doi.org/10.4000/com.6951.

Leitner, Kerstin. 1973. Workers, Trade Unions and Peripherical Capitalism in Kenya after Independence. Frankfurt am Main, Bern \& Las Vegas: Peter Lang.

Maupeu, Hervé. 2002. "Mungiki et les élections. Les mutations politiques d'un prophétisme kikuyu (Kenya)." Politique africaine 87, no. 3: 56-77. https://doi.org/10.3917/polaf.087.0117.

Médard, Jean-François. 2012. “Charles Njonjo: A Portrait of a 'Big Man' in Kenya." In Neopatrimonialism in Africa and beyond, edited by Daniel C. Bach and Mamoudou Gazibo. London: Routledge.

Muriuki, Godfrey. 1974. A History of the Kikuyu 1500-1900. Nairobi: Oxford University Press. https://hdl.handle.net/2027/heb.02646.

Mwangi, Susan Waiyego. 2011. "The Genesis, Growth, History and Vibrancy of a Politico-Religious Movement: The Case of Mungiki in Kenya c. 19872007.” PhD Dissertation. Pau: Université de Pau et des Pays de l'Adour.

Mwangi, Susan Waiyego, Elias Omondi Opongo and Ephraim Wachira Wahome (eds). 2019. The State and Nation-Building in Kenya since Independence. Remembering the Marginalised and Forgotten Issues and Actors. Bamenda: Langaa RPCIG.

Ogot, Bethwell. 2012. Kenyans, Who Are We? Nairobi: Anyange Press.

Oucho, John Oyaro. 2002. Undercurrents of Ethnic Conflict in Kenya. Leiden: Brill Academic Publishers.

Péron, Xavier. 1993. L'occidentalisation des Maasai du Kenya. Paris: L'Harmattan.

Peterson, Derek R. 2012. Ethnic Patriotism and the East African Revival: A History of Dissent, c.1935-1972. African Studies Series. Cambridge: Cambridge University Press. https://doi.org/10.1017/CBO9781139108614.

Provini, Olivier. 2015. La circulation des réformes universitaires en Afrique de l'est, les politiques de l'enseignement supérieur au regard de la sociologie de l'action publique et de l'État. PhD Dissertation. Pau: Université de Pau et des Pays de l'Adour. https://tel.archives-ouvertes.fr/tel-01536422.

Ranger, Terence. 1983. "The Invention of Tradition in Colonial Africa." In The Invention of Tradition, edited by Eric Hobsbwam \& Terence Ranger, 211-62. Cambridge: Cambridge University Press. https://doi.org/10.1017/CBO9781107295636.006 [archive].

Rodriguez-Torres, Deyssi. 2012. Au cour du bidonville de Mathare Valley. La politique du ventre vide à Nairobi. Paris: IFRA-Karthala.

Sandbrook, Richard. 1975. Proletarians and African Capitalism: The Kenya Case, 1960-1972. New York: Cambridge University Press.

Sivi, Katindi. 2013. Exploring Kenya's Inequality: Pulling Apart or Pooling Together? Nairobi: Kenya National Bureau of Statistics \& Society for International Development. 
Smonini, Ambra. 2009. Les classes moyennes au Kenya. Les enseignants du primaire et secondaire entre syndicalisme et grève. MD Dissertation. Pessac: Institut d'études politiques de Bordeaux.

Spear, Thomas, and Richard Waller (eds). 1993. Being Maasai: Ethnicity \& Identity in East Africa. London: James Currey; Dar es Salaam: Mkuki na Nyota; Athens (OH): Ohio University Press.

Thibon, Christian, Marie-Aude Fouéré, Mildred Ndeda, and Susan Mwangi (eds). 2014. Kenya's Past as Prologue. Voters, Violence and the 2013 General Election. Nairobi: Twaweza Communications, IFRA \& Heinrich Böll.

Verdier, Isabelle. 2013. Kenya: The Top 100 People. Paris: Indigo Publications. 



\title{
Chapter 1 \\ State, Economy and Development in Kenya
}

\author{
Hervé Maupeu
}

Translated by Devon Winters, Ana de Oliveira \& Daniel Persia

Since the 1960s, Kenya has been regarded as a bastion of capitalism. Kenyan elites have been relatively consistent in their vision of development, particularly with regards to the role that the state should play; indeed, as in other African countries, the public sector has always been a key driver of development. By "state," we mean first and foremost an institutional or otherwise legal reality, which brings together within a single entity (internationally recognised) the structures of the three major powers (the executive, the legislative and the judiciary), the administration and ministries. This type of definition makes it possible to take some distance from the dominant Weberian approaches that emphasise the monopoly of the legitimate use of force over a territory and the exclusively bureaucratic characteristics of the administration. The Kenyan state has never perfectly controlled the entirety of its national space and the bureaucratic practices of administrative services coexist with neo-patrimonial dynamics. Tim Kelsall $(2013,12)$ presents the paradoxical nature of this mode of governance as such:

The system is held together by the personal distribution of material resources and perks (many of which are 'rents' in modern economic terminology) distributed and consumed as though they were the private property of the ruler and/or his staff. 'Neo-patrimonialism' refers to a political economy in which the basic authority system is combined with, or exists behind, some formal, impersonal elements of governance, such as a legal system that demarcates the public and private domain, or an administrative code with formal criteria for staff hiring and promotion.

The ways in which the state works, notably in relation to the different economic sectors, are also affected if not determined by the forms of democratisation that shape the country. Thus, in recent years, electoral democracy has been supplemented by institutions and practices characteristic of control or surveillance democracies. It means, following Pierre Rosanvallon, that the multiplication of independent authorities responsible for fighting corruption, the organisation of counter-powers between the various political institutions, and the improvement of the 
independence of the judiciary have given more legibility to the action of the state, yet without eliminating patron-client practices, as we shall see.

Under the leadership of East Africa's most elaborate-and certainly most efficient-state, Kenya's economy has changed significantly since independence. Throughout the 2000s, the economy grew at a strong and steady rate (usually above 5\% per year), and since 2015 Kenya has moved into the lower middle-income bracket (annual income between 1,046 USD and 4,125 USD). ${ }^{1}$ But the wealth produced is very unevenly distributed. Only $20 \%$ of the population makes up the middle class. ${ }^{2}$ The poverty rate (according to ILO criteria) exceeds $40 \%$ of the population. Most importantly, Kenya ranked 155th out of 188 countries in 2017 on the Human Development Index.

This chapter will explain how Kenya has put in place this type of economy by tracing the evolution of its economic policies and identifying key turning points. The Kenyan state has always been a "developmental state," in the sense that contemporary approaches give to this concept. Thus, Laura Routley (2012: 8) considers that "a developmental state has sufficient state capacity to be effective in its targeted areas and has a developmental vision such that it chooses to use this capacity to work towards economic development." ${ }^{3}$ We will present the different forms of interventionism of a state that has never fell into neither a market economy nor a marked liberalism unlike its neighbouring countries.

1. This World Bank classification is defined according to the gross national income (GNI) per capita of each country. In 2017, Kenya's GNI was 3,250 PPP USD. There are other typologies that take GDP per capita into account. In 2017, Kenya's GDP was 1,678 USD according to the IMF and 1,507 USD according to the World Bank. Tanzania's GDP per capita was 936 USD and Uganda’s GDP 604 USD.

2. According to the criteria of the African Development Bank.

3. Routley completes her definition by specifying four characteristic attributes: "1- A capable autonomous (but embedded bureaucracy); 2- A political leadership oriented towards development; 3- A close, often mutually beneficial symbiotic relationship between some state agencies and key industrial capitalists; 4Successful policy interventions which promote growth.” Maia Green $(2014,16)$ thinks that the developmental state must be distinguished from what she calls the "development state." The latter has much worse results in the economic and social fields than the first; and it is formed in close interaction with international development agencies. According to Green's criteria, the Kenyan state has characteristics of both types of state. Thus, it remains the 6th recipient of international aid in Africa (4\% of GDP in 2016). 


\section{1. "Patron-Client Capitalism" during the First Decades of Independent Kenya (1963-1992)}

In the 1960s, all the African countries gaining independence chose sides in the cleavage imposed by the Cold War. Those who were behind the United States and aimed to pursue a policy of cooperation with the former colonial power generally opted for a capitalist political and economic system. Those who preferred the Soviet or Chinese paths, or who participated in the nonaligned movement, moved instead towards a form of socialism. But what kind of capitalism and socialism are we talking about? Paul Nugent (2004) rightly speaks of "African Socialism" and "Home-Grown Capitalism." These African types of socialism and capitalism differed greatly from Western models. Some analysts even believe that in Africa, socialist and capitalist regimes functioned in a relatively similar way (with a one-party system, marked statism, personalisation of power...). We shall see that, in the 1980s, the political and economic systems of Kenya (in principle, capitalist) and neighbouring Tanzania (that followed socialism known as Ujamaa) were actually very similar. Beyond the rhetoric of those in power, these regimes can be distinguished by a series of precise criteria. Paul Nugent's frame of reference can help us characterise Kenyan capitalism during this period. He focuses on four criteria: the importance given to self-reliance; the degree to which the state is perceived as the main vehicle for economic growth; the importance given to social equality; and the degree and forms of participation of the masses in political processes (Nugent 2004, 142143). Drawing upon these elements of differentiation, one can define the particularities of the Kenyan system, which, according to Joel Barkan, constitutes a "patron-client capitalism" (Barkan 1984; 1994).

\section{Capitalism vs Socialism during the Critical Juncture of the 1960s}

Proponents of neo-institutionalism, whether economists or political scientists, emphasise the idea of "critical junctures." There would be moments in history of intense institutional change (modification of the frame of reference and ground rules) that determine the way economic, political and social structures function for the (often long) period that follows. Some call this "path dependency" (Collier \& Collier 1991). In Africa, independence represents one such critical juncture. At that time, Kenya's leaders opted for capitalism but without it seeming to be the obvious or only choice available. Jomo Kenyatta long used socialist rhetoric to justify his preference for a market economy. ${ }^{4}$ Two types of arguments have been

4. It is revealing that the manifesto of the regime of the time is entitled African Socialism and its Application to Planning in Kenya (1965). Within the dominant party, KANU (Kenya African National Union), a strong minority headed by 
used to explain how the African countries chose between the capitalist path and the socialist option. For some, the ideological preferences as well as the personality of the Heads of State made it possible to grasp these differences. ${ }^{5}$ For others, the characteristics of the national political field at the time of independence conditioned the choices available. In the case of Kenya in the 1960s, Joel Barkan emphasises three structural variables: the centrality of ethnicity in the political system; a particular colonial legacy linked to the fact that Kenya was a settlement colony; and the place of the Kenyan economy in East Africa (Barkan 1994, 1416). Thus, both political divisions and the party system were organised around ethnic identifications. Jomo Kenyatta had to constantly negotiate with regional leaders with strong legitimacy. He also had to consider the interests of a powerful white community, especially as he could not do without British military aid because of the Somali secession attempts (Shifta War) of the North-East region and the uncertainties of its army (a tentative coup d'état in 1964). Moreover, the country's economy was the most developed and diversified in the region. The Northern Corridor from Mombasa supplied the whole of Africa's Great Lakes region, and since colonial times, Nairobi has been an important hub in finance, insurance and services. Thus, Kenya has had a competitive advantage in extending its capitalist experiment.

Alongside these classical explanations, some specialists try out more general theories. This is the case of Leonardo Arriola (2013) who seeks to understand why African countries developed very different financial systems at the time of independence. Some established access to credit monopolised by state-owned banks. They often opted for a socialist regime. ${ }^{6}$ Others preferred more liberal banking systems, with a multiplicity of private banks. In this way they marked their predilection for capitalism. Arriola argues that when the Founding Father of the nation came from a constituency where the economy was based on exports, he favoured the proliferation of private banks, while those coming from a non-exporting

Oginga Odinga argued for a more egalitarian economic system and sought support from the Eastern European countries.

5. As early as the 1960 s, political scientists brought to light how much African regimes relied on the personalisation of power. Nevertheless, from one country to another, the Founding Fathers of the nations played more or less important roles. All studies on Ujamaa emphasise Julius Nyerere's role in bringing the Tanzanian political system into its socialist path and in defining its particular content (Maguire 1969; Pratt 1976; Bjerk 2016). In Kenya, Jomo Kenyatta did not have the same room for manoeuvre and his biographical analysis is less interesting than in the case of Tanzania.

6. This is not always the case (see the case of Cameroon analysed by Arriola). 
constituency insisted on the need for the state to tightly control access to credit. $^{7}$

\section{State and Capitalism during the Kenyatta Era (1963-1978)}

Kenya's initial choice of capitalism is not indicative of its particular form because, as we know, capitalism is not the same from one place to another (Fulcher 2004, chap. 4; Thelen 2012). If we take Ian Bremmer's very general definition, who considers that capitalism is "the use of wealth to create more wealth... and that, in general, in the capitalist economic system, most means of production (labour, land and capital) are owned by private actors and give rise to trade" (Bremmer 2010, 25), we can imagine how varied organisational arrangements can be. Of particular interest to us is the way in which the Kenyan state fits into economic relations and organises them (or not). In order to characterise these interactions, it is first necessary to explain some of the peculiarities of the administrative system of this country from the 1960s to the early 1980s. Over this period, the executive considered that an administration with marked Weberian characters (hierarchical system, bureaucracy, valuing merit and competence, not very corrupt...) was a major political asset in so far as it guaranteed its independence from local leaders. As soon as he came to power, Jomo Kenyatta abolished the federal-type constitutional system and imposed recentralisation based on a prefectural-type organisation. He simultaneously organised patron-client redistribution by putting notables in competition with each other to be elected in relatively free elections. In this respect, he established the basis of a representative democracy at constituency level and a rather satisfactory rule of law was guaranteed by a particularly efficient administration. In the social sciences, such a bureaucratic, autonomous and sovereign "Kenyatta state" was promoted by David Leonard (1991). His book presents the biographies of four senior officials who successfully led ministries or public enterprises. Most of them had started their careers in the colonial era and spread the spirit of British-style public service into their administration. In fact, the Africanisation of the Kenyan administration was very gradual and pragmatic (compared to Tanzania). Throughout the 1990s and 2000s,

7. This is the first element of Arriola's theory of the formation of opposition coalitions in contemporary Africa. The author thinks that political alternationcondition of a consolidated democracy-requests the constitution of multi-ethnic coalitions of the opposition forces. In political cultures where patronage prevails, these coalitions can only occur with the financial support of businessmen who engage politically only when their material interests are not directly threatened by the ruling elite. According to Arriola, this is only possible in countries where access to credit is not politically locked up by the state. These coalitions would only be found in countries where many private banks thrive. 
many senior officials of the Kenyatta time published their memoirs. Such autobiographies became a particularly popular literary genre in Kenya. They promoted the era of prosperity (and of Kikuyu dominance) that the Kenyatta period represented in retrospect, especially for those published during the economic recession of Moi's regime (1978-2002). ${ }^{8}$

It is therefore necessary to explain how this very particular state is situated in relation to economic players. To do so, some classic typologies produced by the vast field of study of forms of capitalism (or "Varieties of Capitalism" scholarship, often known as VofC scholarship) are useful. They help to clarify what Barkan means by "patron-client capitalism." In the main types of capitalism, a distinction is often main between the social model of capitalism, found mainly in Europe and Japan, and the liberal model, characteristic of English-speaking countries. It is difficult to compare the regulated market economies of Western Europe with the systems in place in postcolonial Africa. In Kenya, attempts to develop a welfare state has had limited effects. Basic health insurance quickly made it possible to cover most of wage earners with varying degrees of effectiveness. The public pension system proved to be underperforming, including for civil servants. ${ }^{10}$ Yet, the transition to a liberal system of social protection started only in the 1990s after a series of scandals regarding misappropriation of social security funds. Following Thelen's analysis (2014), the European systems differ in three crucial levels: (centralised) negotiations on working conditions, labour market policies, and (specialised) training and its links with the economic world. On the first point, Kenya from the 1940s to the 1960s had labour unions with strong national federations that had shown great capacity to organise long strikes in the workplace (Mombasa strikes) and to mobilise on political agendas, especially at the beginning of the Mau Mau crisis (Cooper 1996; Durrani 2018). The leaders of independent Kenya took it upon themselves to quickly dismantle the power of the unions and put them under the control of the single-party state. ${ }^{11}$ Since then and for the most part, working conditions have largely been negotiated at the level of each company, using local representative structures. Regarding labour market policies, the Kenyan state promoted wage employment, which explains why, up to the 1980s, Kenya, along with South Africa, had one of

8. About how the opposition to the Moi regime used the memory of the "milk and honey" era, see Maupeu (2008).

9. See notably Thelen (2014, chap. 1).

10. Munguti, Richard. 2018. "Authority Orders Posta to Pay Ex-workers Billions in Pension.” Daily Nation, 26 April. https://nation.africa/kenya/business/postato-pay-4-000-ex-staff-more-benefits-36724 [archive]; Openda, Joseph. 2018. "Retired Teachers Resume 18-year Pension Battle." Daily Nation, 27 July.

11. Only the teachers' unions have continually retained a strong influence. 
the highest wage rates in Africa. In terms of educational policies, Kenya differentiated itself from its neighbours by promoting primary education but especially secondary education. It also supported technical training supposed to meet the demands of economic actors (Cooksey, Court \& Makau 1994).

It is thus clear that, from the beginning of independent Kenya, the timid push for the development of social capitalism aborted. However, it is difficult to speak of "liberal capitalism." Of course, labour law was rather much in line with this type of economic system, but those in power were too preoccupied with controlling economic forces to really allow a "liberal" system to develop. Is it then "state capitalism" in the sense of "a system in which the state plays a leading economic role and uses the markets primarily for political gains" (Bremmer 2010, 33)? Today, the concept of "state capitalism" is associated with countries such as China or Russia, but Bremmer detects forms of state capitalism in African countries such as South Africa and Nigeria. To a lesser extent, some characteristic elements of this type of capitalism can be found in the Kenyan system of the 1960s-1970s, especially if one adds to Bremmer's definition the idea that the state uses the markets for political purposes by using patronage. This brings us back to the idea of "patron-client capitalism." At that time, the state intervened strongly in the economy, especially through three types of policies: the Africanisation of certain sectors, the redistribution of land, and the development of public enterprises.

Firstly, the Africanisation of the economy aimed at reserving certain areas for Kenyan citizens, in fact "African," and excluding economic actors from certain communities, particularly Indians, who were forced to sell some of their businesses. These measures benefited very specific clienteles. For example, many shops on Nairobi's busy River Road were sold to notables from Murang'a, the political stronghold of Dr Julius Kiano, the minister in charge of this question. The Kenya National Trading Corporation was also working to reserve certain types of imported goods to African agents. Again, businessmen of certain communities (in this case, Kikuyu and Swahili) are said to have benefited particularly from these privileges (Ochieng, 1995). Secondly, the land policy of the Kenyatta era has been a major legacy of this regime whose shock waves still carry on until this day (Onoma 2010; Joireman 2011; Boone 2014). The MillionAcre Scheme remains one of the symbols of this policy of redistribution of land in the White Highlands. During the British period, some areas of the Rift Valley were reserved for white farmers and managed directly by the state, while an indirect administration regime prevailed in other parts of the country. During the decolonisation negotiations, it was foreseen that the settlers could, if they wished, sell their land at a favourable price. 
Fifteen years later, 95\% of these farms had changed ownership. Nearly half of this land was subdivided and resold to smallholder families as part of settlement schemes. More than a third of these operations benefited the Kikuyu. ${ }^{12}$ This temporarily eased tensions within a community that was emerging from a full-blown civil war between different factions-the Mau Mau crisis had not just been an anti-colonial war. Throughout the Kenyatta era, the various organisations managing the distribution of land kept a captive clientele, in particular because no title deeds were distributed, in principle until each family had finished paying back its loans. The leaders of these groups thus became particularly powerful political entrepreneurs. The best known of them was Dixon Kihiga Kimani, the only Kenyan politician to be elected in three different constituencies (all in the Rift Valley: North Nakuru [1974-1979], West Laikipia [1992-1997], and Molo [1997-2002]). ${ }^{13}$ The Kikuyu were not the only ones to benefit from the subdivision of settlers' farms. There were also Luo, Luhya and Kisii settlement schemes, not to mention the ethnic groups that occupied these areas when the British arrived. Not surprisingly, the latter (or at least some of their dignitaries) felt that all this land had to come back to them. Jean Marie Seroney (MP of Tinderet), in particular, mobilised crowds, especially during the affirmation of the Nandi Declaration (1969), which proclaimed the exclusive right of the Nandi to these territories. ${ }^{14}$ This earned him imprisonment, ending his political career. He was not followed by the key Kalenjin leaders whom the Kenyatta regime was clever enough to include within the country's leadership team. Daniel arap Moi was appointed Vice-President and many politicians from the region were able to easily acquire large estates through loans from state-owned banks-loans that were not always repaid. Half of the settlers' farms were sold off without being subdivided, most often to people close to the regime.

Lastly, patronage was pervasive among the many public companies that were set up during this period. The public enterprise formula was intended to allow more equal access to public goods such as water or electricity. These structures were also meant to make certain sectors more attractive,

12. Leo (1984) estimates that the Kikuyu captured $40 \%$ of these territories even though they represented about $20 \%$ of the Kenya's total population.

13. Almost until his death in 2004, Dixon Kihiga Kimani was the Kikuyu patron of the Rift Valley and served as an intermediary between the Kikuyu of this province and the big men of the Central district, which is the cradle of the Kikuyu community.

14. It is during this period that the idea of a Kalenjin identity-federating several groups of the Rift Valley (in particular, the Nandi, Kipsigis, Pokot, Sebei, Sabaot, Keyo, Marakwet and Tugen)-took hold and served as a vehicle for the defence of their common interests, particularly in relation to land. See Lynch (2011). 
in particular agriculture. But very quickly, the management positions in these public companies became honorary positions to be distributed according to the political interests of those in power. The bosses of these companies often used their position to develop real patron-client machines through which they hired their dependents or those who could be useful to them. We will see later that this type of management has had economic and political effects, especially from the 1980s.

The analysis of Kenyatta-era capitalism has given rise to much discussion, notably what has been called the "Kenyan debate"-one of the great controversies of the golden age of academic Marxism. It is difficult to summarise without distorting them the dozens of books and the many articles published on this subject. At a time when the dependency paradigm was dominant in Marxist circles, these scholars asked whether economic development was financed by domestic or foreign capital. Michael Cowen and Gavin Kitching showed how some African entrepreneurs were able to generate surpluses in many agricultural sectors-surpluses they could reinvest in different other sectors. Based on research made in the national and regional archives, they described the emergence of what they called an African petite bourgeoisie (Kitching 1982; Cowen 1996 ${ }^{15}$ ). Other authors focused more on postcolonial economy. They described a highly inegalitarian development that excluded in particular the peasantry, even though the growth relied heavily on agriculture. Essentially, they believed that Kenyan entrepreneurs were rather autonomous from international capital. These entrepreneurs used the multinationals more than they depended on them, often by relying on the normative capacities of the state and the negotiation possibilities of the political elites (Leys 1975; Langdon 1987; Swainson 1987). ${ }^{16}$

At this point, and especially in desc ibing post-Kenyatta era capitalism (after 1978), it is important to refer to debates on the measurement of economic growth and its causes. In the early 1980s, talented young economists used Kenya as a ground to defend their neo-institutionalist approach. In doing

15. The major influence of Michael Cowen (1996) mostly relies on the many grey literature articles he published in the Working Papers of the Institute of Development Studies (IDS) of the University of Nairobi, in which he provided significant quantitative data on different agricultural sectors during the colonial period. The Kenyan debate developed in complement and in dialogue with the equally rich "Tanzanian debate" (Shivji 1976; Saul 1979; Hyden 1980, amongst many others).

16. The Kenyan debate continued to irrigate contemporary thinking. Dominique Connan (2014), in a non-Marxist historical perspective, studied the autonomy of current entrepreneurs compared to the autonomy of the state. Lisa Mueller (2018) believes that a new middle class-less dependent on the state than the previous bourgeoisie-is the essential vector of protest in Africa today. 
so, they opposed the neo-classics, very dominant on American campuses, which they criticise for not properly taking institutions into account and for not considering the role of politics in the functioning of economies. Robert Bates (1981) explained Kenyan prosperity by the fact that its leaders refused to give in to the "urban bias," unlike most other presidents on the continent. According to Lipton (1977), African regimes had little legitimacy and their state little capacity for action. To preserve their power, these regimes were working to meet the immediate needs of the citizens they considered the most dangerous and in particular urban dwellers. Thus, they sought to artificially lower the price of food by controlling the marketing of agricultural goods, thus buying social peace at the cost of impoverishing the countryside. Robert Bates believed that countries where elites invested heavily in agriculture refused to sacrifice the rural world to the cities. Such countries generally opted for a capitalist system. For its part, Morten Jerven (2016) advocated for more nuanced conclusions. He showed that economic growth rates had so far been relatively poorly calculated (lack of reliable data in many sectors; difficulty in comparing between countries, notably between Kenya and Tanzania because of different methodologies in public statistics...). Above all, he believed that it was difficult to measure the economic influence of political regimes. Doing so would necessitate differentiating institution by institution and sector by sector. In fact, the neo-institutionalists who studied the economic crisis of the 1980s in East Africa largely shared these concerns. Bates (1989) described how former President Moi skilfully took advantage of the famines that occurred during this period to gain control of the grain industry. This branch of agriculture struggled to recover after several decades of mismanagement and patronage. During the same period, the coffee sector, dominated by the Kikuyu, became the target of the Head of State who saw political competition there that he needed to counter (Chege 1987; Bart, Charlery de la Masselière \& Calas 1998). This is the period when the economic (and to some extent, political) situation of capitalist Kenya and socialist Tanzania were dangerously close together. In both countries, public deficits shot up as well as inflation. Overemployment was high in both states, but the quality of public services was deteriorating dramatically as a result of corruption and lack of investment. Joel Barkan's following diagnosis is sound:

In both countries politics took precedence over economics, though for different reasons. In both countries the state pursued redistributive policies and interfered with the operation of markets, resulting in a dramatic showdown of economic growth. In both countries, the ruling elite sought to monopolise political power and shackle civil society (Barkan 1994: 21).

A push of authoritarianism then dismantled many democratic gains; and international aid-so important in the public budgets of both countries- 
began to dry up. Under pressure from international donors, the two neighbours accepted (with great reluctance and lack of sincerity) structural adjustment plans and reforms aiming at democratising their regimes.

\section{Uncertain Democratisation and Kleptocracy during the Second Phase of the Moi Era (1992-2002)}

From 1992, the governing elite made concessions and adopted reforms that were characteristic of the democratisation process of this period: legalisation of multipartyism, recognition of a certain freedom of speech, especially in the media, possibility of creating civil society organisations... During this transition phase, when the regime was shifting from a type of authoritarianism that was not saying its name to a democracy not yet consolidated, the economic cost of the political control over the population increased tremendously. In order to stay in power, the ruling elite needed more material resources at a time when the state had become poorer and the national economy was in deep recession. They put in place a mode of governance that many analysts have referred to using the term "kleptocracy." This concept proves to be heuristic when we specify its components: highlevel corruption reaches unprecedented levels and diversifies; the political control of the economy is accentuated by using largely illegal methods; militias often supported by the police intervene violently and terrorise the population; structural adjustment plans and state reforms are negotiated but poorly implemented, which creates the illusion that the state operates in accordance with the modalities in force at an international level. These four dynamics make up the system.

Corruption at the highest reaches of the government is nothing new, as we have seen. It aimed to finance political life while massively enriching the elites-in short, it fuelled neopatrimonialism. Yet, democratisation opened up a period of strong uncertainties which incited the governing elite to an unprecedented gluttony. The Goldenberg case is the symbol of this practice and this period.

In addition, the political class took over many plots of land and public buildings. According to Jacqueline M. Klopp (2000), such appropriations were a means of finding resources in areas beyond the control of international bodies. However, these practices did not go unnoticed and many NGOs and other civil society organisations informed the public. Several parliamentary committees described the diversity and massive nature of these thefts. The Ndungu Land Commission (2003), in particular, highlighted that these illegal allocations of public land were made mainly in the 1990s and during election periods. It showed that the entire administrative system supposed to regulate real estate was involved. The level of corruption in 
this area was such that all property rights were weakened. Many Kenyans had the just feeling that their property title could be challenged at any time. Furthermore, banks were aware that many loans were based on fragile foundations when their clients gave, as a guarantee, land that the Parliamentary Commissions ${ }^{17}$ showed it was illegally acquired.

The privatisation of public land in a patron-client logic was linked with another characteristic of Kenya's kleptocracy: the use of extremely violent militias, especially during election periods. During the 1990s, many areas of public forest, particularly in the Mau Forest or on the slopes of Mount Elgon, were opened up for settlement for the benefit of populations close to the ruling party. At the time of the elections, communities deemed favourable to the opposition were massacred or forced to evacuate these constituencies (Klopp 2001). ${ }^{18}$ Their plots of land were often taken over by families who voted "correctly." And this happened in a context where many politicians used abundantly the rhetoric of autochthony (against supposed allochthons, or foreigners).

During this first decade of democratisation, the very high-ranked political elite stood out as essential economic actors. Thus, Moi, Biwott and several other Kalenjin politicians bought out the branches of the many multinationals that were pulling out of Kenya. They also invested in the media, transportation and the petroleum products distribution sector (Thomas 1997; 1998). They were suspected of being directly linked to more or less illegal traffic, e.g. speculation on sugar imports, especially during periods of risk of famine; cultivation and trade in drugs....

These different characteristics of the Kenyan kleptocracy are what some have called "criminalisation of the state." ${ }^{19}$ Others prefer to speak of "informalisation of political life." ${ }^{20}$ But these elements of governance were complemented by institutional reforms of the state in order to keep the

17. In addition to the Ndungu Commission, other parliamentary committees provided specific indications of misappropriation of public lands. We can think in particular of the Njonjo Land Commission (1999) and the Akiwumi Commission of Inquiry into Tribal Clashes (1999).

18. In 1992-93, these killings resulted in nearly a thousand deaths and several hundred thousand internally displaced persons' (IDPs). These ethnic cleansings mostly took place in the Rift Valley, considered the stronghold of the ruling elite of President Daniel arap Moi. In 1997-98, several hundred deaths were recorded, mostly on the Coast and on the outskirts of the Rift Valley. The lieutenants of the regime had understood that the violent technique previously tested by their bosses made it easy to win parliamentary elections.

19. See Thomas (1997) who adapts to the Kenyan situation the concept theorised by Bayart, Ellis \& Hibou (1998).

20. Branch \& Cheeseman (2010) use this concept several times but without specifying its exact content. 


\section{Box 1: The Goldenberg affair (1990-1992)}

In 1990, Kamlesh Pattni, the young heir (he was twenty-five years old) to a gold and gem trading business, met James Kanyotu, the head of the Special Branch and a very close friend of President Daniel arap Moi. He explained that Kenya could export much more gold and thus have access to more foreign currency if the state could adopt more incentive policies. Following discussions with the Head of State, it was decided that gold exports would benefit from public export compensations of 35\%. A new company, Goldenberg International Limited, co-owned by Kanyotu and Pattni, was granted a monopoly over gold and diamond exports (Hornsby, 2012). In a country that does not have any diamond reserves and hardly exploits gold, this company did not a priori have a promising future. Except that the governing elite saw in it the possibility of discreetly diverting public funds to finance the general election of 1992 . This first multi-party competition for decades was expected to be very contested and therefore very expensive.

In the beginning, Goldenberg imported gold that it re-exported by overvaluing the volumes traded, but soon it made clearing requests that did not correspond to any merchandise. Transactions were done through so-called "political" banks that dealt exclusively with the affairs of the country's ruling elite: Trade Bank, Delphis Bank, and especially the Exchange Bank created and owned by Kanyotu and Pattni. According to Pattni's statements during the official investigation in 2004, Goldenberg reportedly received nearly 170 million USD from the state. ${ }^{b}$ Part of this sum had been handed to Youth for KANU'92, the lobby group responsible for redistributing mone during the election campaign (Maupeu 2000). The entire political class were generously spoiled, including the opposition. For example, Oginga Odinga received nearly 20 million KES that was allegedly used to finance the Migori and Ndhiwa by-election (Oloo 2007, 116).

The macroeconomic effects of this financial scandal were enormous. Daniel Branch sums up the situation perfectly: "Writing in July 1993, John Githongo remarked that Goldenberg 'is shaking the very foundations of Kenya's economy'. The shilling plummeted, losing about half its value against sterling in the eighteen months leading up to the public revelations about Goldenberg in mid-1993. The increase in money in circulation drove inflation to an annual rate of over 40 percent in August 1993" (Branch 2011, 220). As early as 1993, the opposition and the media exposed the mechanisms of this gigantic corruption case. ${ }^{\mathrm{c}}$ The IMF and the World Bank called for a public inquiry into the matter. The government rejected this request but the Exchange Bank was dissolved and the head of the Central Bank of Kenya was replaced. Despite a political changeover in 2002 and an official inquiry in 2004 , most protagonists went unpunished. 
Is Goldenberg unique in the history of Kenya? Can this corruption case be compared to the scandals that were revealed in the regimes that followed? This is one of the questions that torments Michela Wrong in her study of the Anglo-Leasing Company scandal instigated by President Kibaki's close acquaintances in the early 2000s. If we compare these two cases of high-level corruption, what should first be emphasised is that the amounts embezzled are not the same at all. It is difficult to reach the heights of Goldenberg. However, Michela Wrong $(2009,166)$ estimates the cost of overbilling by the Anglo-Leasing Company at close to $5 \%$ of GNP and $16 \%$ of state expenditure for 2003-04, in a context of solid economic growth, whereas Goldenberg took place in a phase of intense economic crisis. In the case of the 1990s scandal, the mechanisms for misappropriating public money were complex. From the 2000s, the techniques of high-level corruption became much more basic (over-invoicing, rigged public procurement tenders...). The media now disclose such cases with great efficiency. Yet, parliamentary and judicial inquiries are generally conducted without leading to convictions. Since 2018, the fight against high-level corruption has seemed to be more engaged but it is still too early to diagnose a change in policy.

\section{Notes}

a. Delphis Bank belonged to Ketan Somia who had many common economic interests with the Moi family, Nicolas Biwott and Vice-President Saitoti.

b. This is just the tip of the iceberg as Kanyotu and Pattni developed multiple speculations as part of Goldengerg: it is said that the Exchange Bank speculated on currencies; and the two schemers played on multiple compensation funds (Wrong 2009, 62-63).

c. The bulk of the information came from David Munyakei, an employee of the Central Bank of Kenya. On the story of one of the most important whistle-blowers of contemporary Kenya, see Kahora (2008).

financial support of the Western powers. Since the early 1980s, Kenya has negotiated many structural adjustment plans (SAPs). It accepted the loans but did not comply with the majority of conditionalities that the IGOs sought to impose. We know that the IMF, like the World Bank, explain the "permanent crisis" (van de Walle, 2001) situation of the African economies as governance problems. The centralisation of power, the notion of imperial presidency, the alleged failure of development policy by the state are called into question in favour of policies of liberalisation of the economy (including privatisation of public enterprises, sharp staffing decreases within the civil service, autonomy of the central banks, more orthodox monetary policy...) and rationalisation of administrative work.

Kenya has regularly eluded some of the constraints of the SAPS and donors have continued to lend to the country because the political leaders have made themselves indispensable to the United Nations system, for example 
in 1991-92 when more than 400,000 refugees crossed over the border with Somalia. At other times, Kenya exploited the lack of coordination between the IMF and the World Bank. ${ }^{21}$ Thus, privatisation of public enterprises was limited (and it often benefited the Kalenjin elite) and the state structures controlling most agricultural sectors were not liberalised, particularly in the sensitive, grain sector. However, the state administration underwent severe reforms. The Civil Service Reform Program (CSRP) I of 1993 was supposed to improve the productivity of the state by injecting many techniques of the New Public Management into this heavy machine. The main objective was to massively downsize the workforce through a program of voluntary retirement and the abolition of more than 26,000 posts. The civil servant identification system was improved to combat the scourge of "ghost workers." But CSRP I did not have the expected results and the state did not become more efficient. ${ }^{22}$

The SAPs, like the administrative reforms, are commonly presented as failures. Nevertheless, can we speak of a "lost decade," because of a particularly low rate of economic growth? ${ }^{23}$ Morten Jerven (2014: 120) is more reserved: "It is not obvious that Kenya performed badly during the Moi era and it is even less obvious that it did so because of economic policy. During the Moi era, Kenya performed considerably better than the African average."

\section{In Search of a Developmental State}

With the political alternation of 2002, the economic situation improved rapidly. Investors had more confidence in the Government of National Unity that was put in place. More orthodox macroeconomic policies also allowed a return of growth which went from $1 \%$ in 2002 to $7 \%$ in 2007. The ambitious Kenya's Vision 2030 program launched in June 2008 set medium-term goals. In the words of President Mwai Kibaki, this program was "a roadmap for accelerating the transformation of our country into a rapidly industrializing middle-income nation by the year 2030" (quoted by Adam \& al. 2010, 1). The political and administrative actors and, to a lesser extent, the business community perceived it as a change of reference. They

21. On the various tactics of the Kenyan state during the negotiations with the IMF and the World Bank, see Murunga (2007).

22. According to the World Bank (2001), this failure is due to the usual wage increases that teacher unions obtain before each general election. In addition, shortly before the 2007 poll, a strong wave of recruitment of new officials called into question the effects of the reform.

23. Kempe Ronald Hope (2013) recalls in particular that growth was negative (-1\%) in 1992 and 0\% in 1993 and 1997. He uses data from the World Bank that many economists currently challenge. 
looked to Asia for their new model of development. Elsje Fourie (2015), who interviewed the designers of Vision 2030, highlights their fascination for Singapore and Malaysia as well as China. In a conception close to the modernisation theory of the 1950-1960s, they believe that a number of steps and recipes need to be followed to catch up with the Asian Tigers. Where the IMF and the World Bank recommended slimming down the state, democratising political regimes and relying primarily on private actors to develop an economy open to globalisation, the Asian model emphasises the crucial importance of the state in guiding an economy that is placed at the service of the national project-not necessarily a democratic one.

Without deluding ourselves about this doctrinal change, this episode must be situated in "the history of extraversion" (Leguil-Bayart 1999) of the state in Africa. Kenyan leaders, like those in neighbouring countries, are seeking to gain some leeway in relation to the Western powers and the United Nations system. They want to depend less on international aid since they can borrow amply from Chinese banks that do not impose political conditionalities and whose more or less transparent procedures favour the financing of certain patron-client networks. This new strategy takes the form of massive investments in large-scale projects (Fouéré \& Maupeu 2015): modernisation of the North Corridor (Mombasa-Africa of the Great Lakes) by developing highways, fully renovating the rail transport system, developing Internet cabling...; creation of a new transport corridor, LAPSSET (Lamu Port-South Sudan-Ethiopia Transport); increase in electricity production and its widespread distribution throughout the country... This also requires a strong use of public-private partnerships (PPPs). ${ }^{24}$

Vision 2030 has long made unanimity among Kenya's elites. Francis Muthaura, the head of Civil Service, at the launch of the program, explained this popularity by two factors. First, Vision 2030 was conceived during the first Kibaki presidency, when the government included the main tendencies of the political spectrum. Many leaders of the opposition participated in its genesis. In addition, this national development project closely associated all the representative groups of the private sector. ${ }^{25}$ However, since 2015, the focus of this program on "mega projects" has

24. We are only talking about the economic component of this plan. The growth thus created is meant to serve particularly ambitious social objectives: achieve the Millennium Development Goals (in the area of education, health, access to running water, sanitation facilities); develop housing for the general public; fight for true equality between the sexes... (Otieno \& Nd'ung'u 2010).

25. Mathaura, Francis. 2018. "Vision 2030 Holds the Key to a Better and More Inclusive Kenya." Saturday Nation, 9 June. https://nation.africa/kenya/blogsopinion/opinion/vision-2030-holds-the-key-to-a-better-and-more-inclusivekenya-52474 [archive] 
given rise to increasing vivid criticisms. The debate has been led by experts from the opposition. Patrick Mbataru recognises that infrastructure development promotes long-term growth, but regrets that these building projects are monopolised by large Chinese companies and do not include local companies. ${ }^{26}$ The influential analyst David Ndii warns against overindebtedness and recommends putting the focus on infrastructure that improves the lives and productivity of small-scale producers. ${ }^{27}$ This led major international financial analysis firms, such as Frost \& Sullivan, to release reports that defend the relevance of the Kenyan government's strategy. ${ }^{28}$ Yet, during the 2017 election campaign, the opposition rallied around a position hostile to the mega infrastructure projects ${ }^{29}$ that would prevent state investment in the social sector.

With ten years of hindsight, the effects of the Vision 2030 program are gradually becoming apparent. In 2018, the anniversary of the program was not widely celebrated. Undeniably, the Kenyan economy has changed but tensions remain intense. Peter Kagwanja, who was involved in the genesis of this development strategy, underlines the multiple indicators of economic growth as follows:

Kenya's economy has expanded from GDP of Sh 1.3 trillion in 2002 to Sh 7.8 trillion in 2017, with its GDP per capita expanding from Sh 27,000 to Sh 166,000. Its paved road network has expanded from 8,938 kilometers to 11,796. (...) The country's electric power has grown from 1,142 MW to 2,264 MW, increasing its capacity to power industrialisation and enabling to connect 5.9 million households to the national electricity grid, up from 0.48 million in $2002 .{ }^{30}$

Let's add that some large-scale infrastructure projects have been completed: the high-speed train between Mombasa and Nairobi; the modernisation of the port of Mombasa, which has tripled its cargo handling

26. Mbataru, Patrick. 2015. "Mega Projects Have Little Impact on the Poor." Sunday Nation, 9 August. https://nation.africa/kenya/blogs-opinion/opinion/ mega-projects-have-little-impact-on-the-poor-1118308 [archive].

27. Ndii, David. 2016. "Mega Projects and Hollow Men: What $\$ 50$ bn Can Do for a Nation." Saturday Nation, 30 January. https://nation.africa/kenya/blogs-opinion/ opinion/mega-projects-and-hollow-men-what-50-bn-can-do-to-a-nation-1165482 [archive].

28. Kariuki, James. 2015. "Big Projects Recipe for Kenya's Growth: Study." Daily Nation, 13 August.

29. Ndii, David. 2017. "Forget About Mega Projects and Address Everyday Woes." Saturday Nation, 29 July. https://nation.africa/kenya/blogs-opinion/opinion/ forget-about-mega-projects-and-address-everyday-woes-430904 [archive].

30. Kagwanja, Peter. 2018. "Kenya's Vision 2030 Caught Between the Rock and a Hard Place." Daily Nation, 17 September. https://nation.africa/kenya/blogsopinion/opinion/vision-2030-caught-between-the-rock-and-a-hard-place-87604 [archive]. 
capacity in ten years; a new deep-water port is under construction in Lamu; and the expansion of airports allows twice as many passengers as in 2002. The state budget increased considerably, as has its tax-raising capacity from 202 billion KES in 2002 to 1,365 KES in 2017. This rapid development of the economy has been accompanied by anxieties and sometimes conflicts. New patterns of inequality are emerging. This is clearly visible in the regions affected by the large-scale works policies, and therefore primarily in the vast north and the north-east of the country, the agro-pastoral areas that until then had remained on the fringes, if not totally apart. The LAPSSET project (Lapsset Corridor Development Authority) aims to integrate these areas into the nation and to connect them to neighbouring countries through a network of infrastructure.

\section{LAPSSET as a Major National Integration Policy of the North-East}

The ambitious LAPSSET program, inaugurated in 2012, is now facing external and national constraints that were not anticipated. Adrian Browne summarises the situation as follows:

In its original and most ambitious imagined form, the LAPSSET corridor project would be transformative, enormously expensive, and very invasive, linking a major new port development on Kenya's Indian Ocean coast to South Sudan and Ethiopia with an oil pipeline, railway and highway. Current circumstances make it unlikely that the pipeline will reach South Sudan or that the railway will be completed within this decade (Browne 2015, 5).

LAPSSET was designed primarily to develop an oil economy by making the best use of South Sudan's reserves, as well as of new deposits discovered in north-eastern Kenya and Uganda. Ethiopia saw it as a way to export the electricity generated by dams on the Nile. Since 2014, the fall in international oil prices has called into question the viability of the project. Above all, the geopolitics of the region have undermined the whole program. South Sudan has been locked in a long-lasting civil war and has had no short-term need for a new pipeline. In 2017, Uganda and the company Total decided to build a pipeline passing through Tanzania to the port of Tanga. This plan was less costly than the LAPSSET solution, more viable from the point of view of the safety of the areas crossed, and it could contribute to the development of a central corridor between Dar es Salaam and the Great Lakes region of Africa that would be highly desirable for better integrating regionally Burundi and Rwanda in particular. The last nail in the LAPSSET coffin came from the Horn of Africa. Reconciliation between Ethiopia and Eritrea as well as the agreements with Somaliland to develop a transport corridor between their deep-water port and Ethiopia made the port of Lamu less attractive. Finally, Ethiopia has never been 
so accessible. It cleverly negotiated multiple accesses to the sea without depending on a single country.

Thus, one can understand why LAPSSET has so far reached few achievements. Yet paradoxically, the problems come less from ongoing or finished projects than they do from more distant and nebulous projects.

Hassan H. Kochore (2016) studied the social effects of the construction of the Isiolo-Moyale road which had just been completed at the time of his research. He wanted to test the validity of the thesis commonly accepted in academic circles according to which "technologies that lead from capital cities to the regions (...) are seen to have the power to bring development, progress, national inclusion and security" (Kochore 2016, 394). On the one hand, Kochore confirms the enchanted vision of the consequences of road infrastructures. Along this road, the distribution and quality of public services improved, particularly in terms of security, a particularly sensitive problem in this part of Kenya. Strong economic growth was quickly felt (better profitability of livestock; development of trade...). Moyale and especially Marsabit experienced exponential urbanisation. All the populations of these areas felt more attached to Kenya, but have they really become Kenyan? Kochore brings a nuanced answer to this question. Like Adeline Masquelier, he believes that the roads represent "an iconic space that condenses the histories gone by" (Masquelier 2002, 830). He shows that the state penetration also produces anxieties linked to the conflictual past that these populations have had with state power since colonial times.

In fact, all along the LAPSSET route, the project and the initial construction sites it brought about became issues that easily could cause tension. In Lamu, the development of a new port led to increased land speculation and antagonisms over the influx of labour from other parts of Kenya. Since the 2013 local elections, political elites have dangerously used the ideology of autochthony and reignited tensions with the communities from the hinterland that have farmed there since the 1960s. Local cells of the Somali Al-Shabaab movement have skilfully used the frustrations of the region and multiplied the attacks in Mpeketoni, targeting exclusively the Christian families of farmers from the Kenyan highlands. On the island of Lamu itself, the project to build a coal-fired power plant has met with a lot of resistance and given rise to various types of manifestations.

In the LAPSSET project, the corridor is supposed to split at Isiolo where one route goes to Ethiopia and the other to the west to South Sudan. The construction of the city's airport in an area disputed by two counties has for years been the cause of intense armed tensions between Boran, Meru and Somali youth gangs. In the city itself, each community tries to control land (by obtaining land titles) and to ethnically homogenise the neighbourhoods where they are dominant. Relations between the local authorities and the 
LAPSSET administration are often tense because the exact routes of the corridor's roads tend to change under the pressure from different pressure groups. ${ }^{31}$ Beyond the geopolitical complexity of LAPSSET, economists opt for an optimist reading of the ambitious Kenyan policy for large-scale works, notably giving credit to the progress of the SGR project.

\section{Mombasa-Nairobi-Naivasha-Kisumu Standard Gauge Railway (SGR), the Spearhead of the Large-Scale Construction Policy}

In East Africa, large-scale infrastructure projects are usually integrated into a transport corridor system (Fouéré \& Maupeu 2015). The construction of a new railway between Mombasa and Malaba, on the Ugandan border, which is to continue towards Rwanda, DRC and South Sudan, aimed to revitalise the northern corridor, which remains the main access route to the Great Lakes. But it competes with the corridor from Dar es Salaam, on which major investments have been made and which Uganda has favoured. Uganda plans to route both its railway and its pipeline through Tanzania, as this provides shorter and easier access to the Indian Ocean. This calls into question the viability of the SGR beyond Nakuru-as illustrated by China's reluctance to fund the section between Naivasha and Kisumu. ${ }^{32}$

However, the Makadara Express that has been running between Mombasa and Nairobi since June 2017 was initially presented as an economic success that could bring to the country more than one point of annual growth. The construction of this route has been the biggest state investment since independence and President Uhuru Kenyatta saw it as the symbol of the success of his first term. In fact, this program revealed certain characteristics of the governance style of the government team in place. In 2009, Kenya rejected the low-cost option advocated by the World Bank of renovating the existing railway. A new route-diesel powered-was chosen whereas neighbouring countries such as Tanzania and Ethiopia favoured electrical systems that allow for faster travel. ${ }^{33}$ Shortly after construction began, controversies arose over the legality of the call for tender used to choose

31. Jebet, Vivian. 2018. "Isiolo Leaders Allege Diversion of Lapsset Route, Want Details of Map.” Daily Nation, 19 September.

32. Marete, Gitonga. 2018. "Questions on Viability of SGR Refuse to Go away after China Cuts Funding." Daily Nation, 17 September. https://www. businessdailyafrica.com/news/Questions-on-viability-of-SGR-refuse-to-goaway/539546-4761886-5fq1awz/index.html [archive].

33. The Kenyan system allows travellers to be transported at nearly $120 \mathrm{~km} / \mathrm{h}$ and goods at $80 \mathrm{~km} / \mathrm{h}$. This leads to substantial time savings compared to the old arrangement. Apparently, a system of electrification of the lines was planned but it was called into question (Olingo, Allan. 2018. "Kenya Halts Plans for Electric Trains." The East African, 27 January-2 February). 
the companies involved in the construction. In Parliament, two committees investigated this issue. The Public Investments Committee raised doubts regarding how the public works contract bidding was organised. Its hearings mainly disclosed a lot of information. There was no competitive bidding because the Chinese state financed the bulk of the project through a 3.23 billion USD loan. The China Road and Bridge Corporation that was chosen was apparently blacklisted by the World Bank. It was selected for both the project management and the construction, while the recommended practices encouraged dissociating the two. And the cost of the project proved to be much higher than its Ethiopian equivalent. It is said the rate of the bank loans signed were uncompetitive. ${ }^{34}$ Many elected members of the Public Investments Committee saw this as evidence of high-level corruption. Conversely, the Parliamentary Committee on Transport, Public Works and Housing considered that the procedures had been respected and that there was no reason to suspect embezzlement. ${ }^{35}$

Some political scientists interpret the different positions of the two commissions as the result of factions within the political elite. The Public Investments Committee was dominated by the camp of Vice-President William Ruto, who himself expressed reservations about the SGR tender. During the hearings, those close to him engaged in the most virulent attacks. The Transport Commission, just like the very lucrative Ministry of Transport, was run and controlled by people from the Central Province linked to the Kibaki and Kenyatta networks. This suggests that the leaders close to Ruto benefited too little from the patron-client redistribution linked to the SGR and made it known...

Two other anti-corruption agencies (the Ethics and Anti-Corruption Commission and the Public Accounts Committee) investigated the SGR construction contracts. ${ }^{36}$ Since the 2010 constitution, several Independent Administrative Authorities have specialised in the fight against corruption. The new charter also guarantees a more independent judiciary. Yet despite this institutional progress, very large public works contracts remain opaque and neither administrative actors nor parliamentary commissions can effectively control the procedures.

34. Notably, Juma, Victor. 2014. "Making of a Mega Scandal? Why Railway Figures Do Not Add up.” Sunday Nation, 26 January. https://nation.africa/kenya/ news/making-of-a-mega-scandal-why-railway-figures-do-not-add-up-942286 [archive].

35. The boss of this Commission in 2014-2015, Maina Kamanda, became the Minister of Transport.

36. Njagi, John, and John Ngirachu. 2014. "Graft Team Opens Probe on Rail Deal.” Daily Nation, 8 January. 
Yet, the Mombasa-Nairobi line was built in due time, despite tensions at the time of the purchase of the land necessary for this route ${ }^{37}$ strikes by local workforce, ${ }^{38}$ and discontent by politicians that the obligation to use local companies (for $40 \%$ of the supply) was respected. ${ }^{39}$ The management of passenger transport was entrusted to a Chinese company accused of failing to effectively train its Kenyan employees and of having racist practices. ${ }^{40}$ Freight transport began in early 2018. It was planned that at least one third of freight and in particular the heaviest containers would be transported by rail in order to avoid overloading the rapidly deteriorating roads. But the success of this policy depended and will continue to depend heavily on the competitiveness of the rail transport prices. ${ }^{41}$

\section{Water and Large-Scale Works}

In keeping with the Vision 2030 policy, the Kenyan government focused on water resources development. This involved planning the construction of many large dams on the main rivers of the country. All regions are due to benefit from these infrastructure works generally aimed at producing electricity and developing irrigated agriculture ${ }^{42}$ For example, the Thiba Dam (Kirinyaga county) is expected to double rice production in the region. And the High Grand Falls Dam on the Tana River, in Kitui and Tharaka Nithi counties, should bring nearly 250,000 hectares of irrigation to the Kitui, Garissa and Tana River counties.

At the local level, these projects are presented as vectors of general development because they are expected to have a positive impact on many areas. For example, the Thwake Multi-Purpose Dam in Makueni

37. Kairu, Pauline. 2014. "Land Owners Along Rail Route Want Fresh Valuation." Sunday Nation, 28 December.

38. Maundu, Pius. 2015. "Workers at New Railway on Strike." Daily Nation, 9 April. https://nation.africa/kenya/news/workers-at-new-railway-onstrike-1083358 [archive].

39. Karambu, Immaculate. 2015. "Uhuru Faults SGR Contractor on 40pc Procurement Quota." Daily Nation, 5 December.

40. Wafula, Paul. 2018. "Exclusive: Behind the SGR Walls." The Standard, 8 July. https://www.standardmedia.co.ke/kenya/article/2001287119/exclusive-behindthe-sgr-walls [archive].

41. In 2018, the company that manages the rail freight has lowered its prices twice in order to compete effectively with road transport. The state is encouraging importers to use the train by organising the customs clearance of goods at Embakasi, near Nairobi.

42. During Jubilee's (the President's party) election campaign in 2017, Uhuru Kenyatta promised to build 57 dams during his tenure, at least four of them being large dams (or "mega dams"). 
and Kutui counties is aimed to intensify economic and social exchanges between the two counties. Roads are to be built and economic structures (especially cooperatives) are to be promoted that will affect both counties. At the national level, the dams are due to contribute to producing more electricity but also to strengthening food security ${ }^{43}$ which, as we will see later, has been one of the main objectives of Kenyatta's second presidential term. But the management of large irrigated areas will be complicated. Thus, for decades, the rice-growing region of Mwea has been plagued by a number of setbacks that the Thiba Dam will not necessarily solve. The Galana-Kulalu Irrigation Project, officially inaugurated in early 2014, is intended to develop irrigation on more than one million acres in the Tana River and Kilifi counties, but this program is increasingly looking like a white elephant. A report from the Auditor-General noted massive misappropriation of funds. ${ }^{44}$ Many NGOs denounce the negative impact of this project on the environment and, above all, the local communities reject this structure that has been imposed upon on them. ${ }^{45}$

The many conflicts over water use illustrate Kenya's difficult management of its resources as common goods because multiple communities claim to embody the public interest. In the mountains, too much water is collected by the local populations and these water towers are drying up, threatening the survival of all the rivers in the country. ${ }^{46}$ In order to supply the capital city with drinking water, a vast system of water conveyance from the slopes of Mount Kenya is currently being built, but the governor of Murang'a county promised to stop these works if $25 \%$ of the water sale is not returned to the local authority, on the grounds that the Ndakai-ini Dam (the main water supply for Nairobi) is located in the Murang'a county ${ }^{47}$ In

43. Apollo, Silas. 2017. "Ministry Rolls out Dam Projects to Boost Food Production.” Daily Nation, 26 December. https://nation.africa/news/Govt-rollsout-57-dam-project-to-boost-food-production/1056-4242428-format-xhtmlbvfav0/index.html [archive].

44. Report of the Auditor-General on the Financial Statements of National Irrigation Board. 30 June 2016. Nairobi: Republic of Kenya.

45. Lwanga, Charles. 2018. "Kilifi MCAs Move to Push State out of Galana-Kulalu Project." Business Daily, 1 March. https://www.businessdailyafrica.com/news/ counties/Kilifi-MCAs-stop-Galana-Kulalu-project/4003142-4324908-148c21lz/ index.html [archive].

46. Komu, Nicholas. 2018. "How Greed for Water and Impunity Pushing a Community to the Brink." Daily Nation, 25 August. https://nation.africa/ kenya/news/how-greed-for-water-and-impunity-pushing-a-community-to-thebrink-80648 [archive]. The removal of forests in these water towers also helps to dry up the waterways.

47. Gachane, Ndung'u. 2018. "Now Wa Iria Slaps Nairobians with Water Levy as Revenue Row Escalates.” Daily Nation, 14 September. https://nation.africa/kenya/ 
a context where decentralisation is proving to be particularly popular, local elected representatives are called upon to best defend the interests of their communities, particularly with regard to the central state. ${ }^{48}$ The demands of Kikuyu leaders are nothing exceptional. For example, Kipsigis elected representatives are campaigning for the tea multinationals operating in their region to pay $25 \%$ of their profits to their county. The political class has obviously learned from the Turkana experience. We will see below that the Turkana obtained that $25 \%$ of the revenue from oil produced in their region go back to the population.

\section{Kenya and the Oil Economy}

In the 2000s, the main countries of East Africa moved towards becoming gas or hydrocarbon producers. Tanzania has huge gas reserves, especially in the south-east of the country. Ethiopia signed contracts to build a gas pipeline for transportation to the port of Djibouti. In 2018, it launched the first production tests of the Ogaden oil. ${ }^{49}$ Uganda has the largest oil reserves in the region. They are estimated at 6.5 billion barrels, while South Sudan is estimated to have nearly 3.5 billion barrels and Kenya has only a meagre potential of 754 million barrels. ${ }^{50}$ As the Institute of Economic Affairs points out, oil in the whole of East Africa accounts for only $0.63 \%$ of world reserves ${ }^{51}$ Apart from Uganda, no country in the region can hope to become self-sufficient in fuel. However, this sector triggers a very strong interest in many circles. Political elites see it as a great opportunity for political financing and personal enrichment. The media, many NGOs, associations and other civil society groups, not to mention pressure groups, fuel numerous debates that interest and shape public opinion. Some countries in the region are continually postponing the exploitation of their resources. This is the case of Tanzania and Uganda. Others, on the contrary, are starting small scale production. Ethiopia comes to mind, as does Kenya, a country that has been striving since 2018 to truck its first barrels to the

news/wa-iria-slaps-nairobians-with-water-levy-as-revenue-row-escalates-86672 [archive].

48. Komu, Nicholas. 2018. "Water Row: Leaders Break Ranks with Jubilee." Daily Nation, 5 October.

49. Keprop, Victor. 2018. "Ethiopia Begins Production Tests at Ogaden Oilfield." The East African, 30 June-6 July. https://www.theeastafrican.co.ke/tea/business/ ethiopia-begins-production-tests-at-ogaden-oilfield-1397200 [archive].8.

50. These are the estimates retained by the World Bank in its recent reports.

51. IEA (Institute of Economics Affairs). 2018. "How much Oil? Why East Africa's Bounty Is neither Significant nor Exceptional.” The East African, 9-15 June. https://www.theeastafrican.co.ke/tea/business/how-much-oil-why-east-africas-bounty-is-neither-significant-nor-exceptional--1395812 [archive].. 
port of Mombasa over more than $1,000 \mathrm{~km}$. In this area, political calculations count as much as economic logic.

The debates and tensions in this sector differ from one country to another. In Uganda and Tanzania, it is the Heads of State themselves who engage in an often tough dialogue with multinationals. They negotiate concessions on revenues, tax rates and calculation, infrastructure financing, and refinery development. In Kenya, oil is not the preserve of the President, especially as the main discussions are about the sharing of the income between the central state, local governments and local communities living in the production areas. In 2014, the preparatory work on the legislation to govern the sector envisaged that almost $40 \%$ would go to the counties and populations of the production area. A significant part of the revenues was also to be incorporated into an investment fund for medium and long-term investments. This idea was inspired by Norwegian practices adopted by some African producers, such as Ghana, to avoid the famous "resource curse." After an initial bill was passed by Parliament which the President refused to validate, the government agreed in 2018 to a sharing formula granting $75 \%$ to the state, $20 \%$ to the county, and $5 \%$ to the local communities. But when the state starting transporting the first barrels of oil to the coast, it was immediately blocked for several weeks as local elites were unhappy with the terms of the income sharing. These elites also demanded an improvement in the security situation and infrastructure. In early July, an agreement was signed and the first oil barrels were delivered. The government justified this early exploitation strategy by the desire to test the supply of logistics and to determine the price of this crude on the world market. ${ }^{52}$ This would also be a way of getting private investors interested in the construction of the pipeline between Turkana and Lamu.

In recent years, public policy on oil production has been structured around multiple actors with different visions. The state is trying to establish itself as the undisputed leader but so far, these tensions highlight above all the lack of transparency. Another sector of the oil economy where there are strong suspicions of corruption is transport. Transporting imported petroleum products (gasoline...) faster, cheaper and in larger quantities is becoming a vital economic issue. For ten years, domestic demand for refined oil has exploded. In neighbouring landlocked countries, economic growth is fuelling strong energy needs. Kenya has an interest in satisfying these markets. So far, gasoline has been the third most important export

52. Otuki, Neville. 2018. "Oil Billions Not Our Major Aim for Now, Says PS of Export Plan.” Daily Nation, 31 May. https://www.businessdailyafrica.com/ economy/Govt--Early-oil-export-not-a-profit-venture/3946234-4587156-12xfs2b/ index.html [archive]. 
product after tea and cut flowers ( $13 \%$ of export earnings). But here again, competition from the central corridor through Tanzania has been fierce.

The development of this sector depends on the efficiency of one public enterprise (wholly-owned by the state): the Kenya Pipeline Company (KPC). Long presented as a sleeping beauty, it has been real dynamic in recent years. The 40-year-old Mombasa-Nairobi pipeline was rebuilt at a cost of 484 million USD. It can carry over one third more oil compared to the old structure. A new pipeline between Sinendet (Nakuru County) and Kisumu was inaugurated in 2018. It complements an older facility and allows the volume being transported to be tripled. This will have positive effects on the development of the whole of Western Kenya, a region that is rapidly urbanising and has a high demand for petroleum products. In addition, it will facilitate export to Uganda.

KPC is also promoting a decentralisation strategy for the pipelines. In the short term, several structures are expected to reach seven counties in the periphery and, most importantly, it is planned to develop large fuel depots with a volume of 20 million litres in the main cities of Kenya. In a country where the price of oil is different from region to region, these investments by KPC should significantly lower the price of transport and limit seasonal speculation.

Nevertheless, KPC's policy faces resistance. First, its projects are regularly delayed because of multiple anti-corruption procedures. In a sector that handles a lot of money, and suspicions of misappropriation of funds are permanent. In addition, pressure groups hostile to these large-scale construction works use the control commissions to curb the development of the oil infrastructure. It is common knowledge that the road transport of fuel is controlled by large families of the political elite (notably the Moi clan for transport from Eldoret to Uganda) who do not appreciate the multiplication of pipelines. Finally, at the regional level, the Mombasa-Busia line should be extended across the border to Uganda and Rwanda. This project, strongly supported by the World Bank and Kenya, is met with indifference from neighbouring countries. ${ }^{53}$

The policy of large-scale construction promoted by Presidents Kibaki and Kenyatta has borne fruits. At least vital infrastructure has been built. But it is not certain that this policy of large-scale public investment will last.

53. Olingo, Allan. 2018. "No Pledges for Region's Pipeline, Open Sky Deals." The East African, 30 June-6 July. https://www.theeastafrican.co.ke/tea/business/nopledges-for-region-s-pipeline-open-sky-deals-1397178 [archive]. 


\section{Uhuru Kenyatta and the Big Four Agenda (2017-...)}

Upon his re-election at the end of 2017, President Uhuru Kenyatta announced his intention to place his second term in office under the umbrella of a new national development program, the Big Four Agenda. He aimed to focus public spending on certain areas deemed crucial: lowincome family housing, universal health insurance, guaranteed food security for all Kenyans, and increased production capacity of domestic industries. This new program was presented as a personal initiative of the Head of State to make his mark. Throughout 2018, the media resituated the promotion of the Big Four Agenda within the growing divide between the President and the Vice-President. An anti-corruption campaign was launched and particularly affected William Ruto's camp. ${ }^{54}$ The Kenyatta team was intent on presenting Ruto as the preeminent representative of the sins of the previous era and thus of rampant grand corruption. In this context, the Big Four Agenda program was supposed to restore the reputation of the Head of State... and give him room for manoeuvre in his upcoming succession. In many ways, the 2022 election campaign has already begun. It is still too early to give informed opinion on this new frame of reference for Kenyan public policy. We can only suggest a number of questions: does this program call into question the policy of large-scale works that characterised the first term in office of Uhuru Kenyatta? Is the Big Four Agenda compatible with the major decentralisation reform implemented since 2013? Should we believe in this development project or is it just a political communication exercise?

\section{End of the Large-Scale Works Policy?}

The Head of State announced that there would be no new largescale construction projects during his last term. Priority was given to completing the works already started. It is true that roads, dams and public buildings started years ago and abandoned are commonplace. However, the President's promises only engaged him because mega projects have a strong international dimension. In this area, Kenya's decisions are conditioned by a regional context from which it cannot escape. Thus, it should take into consideration Ethiopia's firm desire to develop programs of interest to both countries (Moyale Joint City and Economic Zone Project; the Lamu-Garissa-Isiolo-Moyale and Moyale-Hawassa-Addis

54. On the subject, see the analyses of one of the finest commentators of Kenyan political life, Opanga, Kwenda. 2018. "Big Four Agenda and 2022: Reasons Uhuru Is Unhappy with His Deputy." Sunday Nation, 10 June. https://nation.africa/ kenya/blogs-opinion/opinion/big-four-agenda-and-2022-reasons-uhuru-isunhappy-with-his-deputy-52754 [archive]. 
Ababa roads.....$^{55}$ Moreover, Kenya benefits greatly from its geographical position on the Northern Corridor (Mombasa-Africa of the Great Lakes) but the modernisation of this major axis requires heavy investments involving several countries. ${ }^{56}$ The development of the LAPSSET corridor implies that Kenya be responsive to the needs of its neighbours as well as their schedules. Nevertheless, Kenya has limited room for manoeuvre. It cannot easily envisage any new large-scale projects in the medium term. Chinese loans seem to be drying up. In September 2018, China refused to participate in the financing of the construction of the railway between Nairobi and the Ugandan border even though Chinese companies had developed the section between Mombasa and Nairobi. ${ }^{57}$ In fact, Kenya is the most indebted country in the region. It is seeking to reduce its dependence on Asian loans. This was the objective of using Eurobonds, but it was done at a high political cost. ${ }^{58}$

For years, the governing team argued that the policy of large-scale construction was a source of economic growth. The opposition believed

55. Olingo, Allan, and Victor Kiprop. 2018. "Ethiopia Reaches Out to Djibouti and Kenya to Partner on Mega Projects." The East African, 12 May. https://www. theeastafrican.co.ke/tea/business/ethiopia-reaches-out-to-djibouti-and-kenyato-partner-on-mega-projects--1393546 [archive].

56. The high level of public debt of all East African countries brings the risk of debt crisis, which leads these countries to limit their spending ambitions. Wanzala, Ouma. 2018. "Cash Crunch Hits EAC Integration Projects." Daily Nation, 26 June. https://nation.africa/kenya/news/cash-crunch-hits-eac-integrationprojects-59296 [archive].

57. Marete, Gitonga. 2018. "Questions on Viability of SGR Refuse to Go Away After China Cuts Funding." Daily Nation, 17 September. https://www. businessdailyafrica.com/news/Questions-on-viability-of-SGR-refuse-to-goaway/539546-4761886-5fq1awz/index.html [archive]. Since a few years, many African countries have had great difficulty repaying their loans.

58. In 2014, Kenya raised 2.8 billion USD in Eurobonds. In early 2018, it took over 2 billion USD, officially to give the country a little air to breath during the repayment of public debt. The opposition believes that some funds disappeared and would have served as a bail out with regards to the exorbitant cost of Jubilee's election campaign (the party of the President). Mwaniki, Charles. 2018. "Kenya Raises \$2bn in Fresh Eurobonds Issue.” Business Daily, 22 February. https://www. businessdailyafrica.com/markets/capital/Kenya-says-fresh--2bn-Eurobondoversubscribed-seven-times/4259442-4315350-14pr011/index.html [archive]. On the doubts held by the opposition, see the always brilliant and enlightened analyses by David Ndii: Ndii, David. 2015. "If It Looks, Quacks and Walks Like a Duck, It Is the Lies About Eurobond." Saturday Nation, 19 December. https:// www.nation.co.ke/kenya/blogs-opinion/opinion/if-it-looks-quacks-and-walkslike-a-duck-it-is-the-lies-about-eurobond-1155142 [archive].

Recently, China seemed less willing to invest in Kenya, as Kenya is getting clo- 
that, if it produced growth at all, it was unequal growth. Above all, these massive investments prevented the development of social policies, particularly in the area of social protection. Apparently, the elite in power today are now listening to these criticisms. In doing so, they are joining a certain economic orthodoxy which believes that:

genuine public assets, the transport infrastructures generate externalities, as positive as they are negative (noise, accidents, pollution, destruction of landscapes, shared uses, etc.) and do not seem to offer a short-term economic return for the sponsoring authorities. This lack of immediate economic benefits-apart from those related to the construction itself, for the state operated enterprises potentially involved-is nevertheless counterbalanced by a political benefit (Carcanague \& Hache 2017, 56-57).

Yet, this political benefit has now been much reduced. Several polls show that these large-scale construction works do not bring significant gains in popularity. Material benefits for the political elite also tend to run out: the bribes that finance political life are reaped in the preparatory phase of these large-scale works. In this context, the country leaders seem to be more open to the idea of fostering "equitable economic growth."59 In this respect, the Big Four Agenda remains true to the objectives of Kenya Vision 2030: it aims to make Kenya a middle-income country. ${ }^{60}$ Above all, it allows for a redistribution that was no longer the priority of Kenya's development policies. Several segments of civil society expressed support for this change in state priorities. Cooperatives, in particular SACCOS (Saving and Credit Cooperative Societies), indicated that they wished to participate actively in the public policies emerging from this new framework. Indeed, it seems difficult to develop social housing programs without involving SACCOS, the main providers of this type of housing. ${ }^{61}$ Kenyans in the diaspora could

ser to the US (e.g. agreements to rebuild the road infrastructure between Mombasa and Nairobi...) and the UK.

59. Warutere, Peter. 2018. "Harmonise Relevant Laws for Equitable Growth." Daily Nation, 31 May. https://nation.africa/kenya/blogs-opinion/opinion/ harmonise-relevant-laws-for-equitable-economic-growth--49308 [archive].

60. Muraya, Beth. 2018. "Will the Big Four Agenda Usher in Transformative Economic Growth?” Sunday Nation, 10 June.

61. Namlola, Juma. 2018. "Saccos Told to Cash In on Uhuru's Big Four Agenda." Daily Nation, 19 February; Ibid. 2018. "Co-operatives Key to Government's Big Four Agenda." Saturday Nation, 7 July; Mwololo, Millicent. 2018. "Sacco Turns Home Ownership Dream into Reality.” Daily Nation, 19 July. https://nation. africa/kenya/life-and-style/dn2/sacco-turns-home-ownership-dream-intoa-reality-68454 [archive]; Mwololo, Millicent. 2018. "Cooperatives to Deliver 500,000 Social Housing Units.” Daily Nation, 19 July. https://nation.africa/ lifestyle/dn2/Cooperatives-to-deliver-social-housing-units/957860-4670584format-xhtml-1051vjz/index.html [archive]. 
also fund this public policy. Their representative groups are making this known and calling for adapted tax policies. ${ }^{62}$ The Big Four Agenda also offers the prospect of new revenue for many economic agents. ${ }^{63}$

After a long career in politics, Uhuru Kenyatta has finally revealed his social streak. Yet, some analysts are sceptical and look for Kenyatta's hidden agenda.

\section{The Big Four Agenda as a Way to Recentralise?}

The constitution of 2010 attempts to bring public decision-making closer to Kenyan citizens, notably through a decentralisation reform introduced in 2013. Despite corruption scandals and frustrations caused by new local governments in counties, the vast majority of Kenyans still support this level of governance. ${ }^{64}$ Most neighbourhood policies, which fundamentally affect the daily lives of citizens, fall under their jurisdiction. The four areas of the Big Four Agenda cut across the areas entrusted to the counties. Counties inherited health management and some of them have started to implement health insurance for all those living in their territories ${ }^{65}$ Food security, which also falls under their jurisdiction, tends to become a responsibility shared with the national government. In 2016-17, during

62. Warutere, Peter. 2018. “Diaspora Remittances Can Fund 'Big 4' Affordable Housing Plan.” Daily Nation, 10 May. https://nation.africa/oped/opinion/ Diaspora-remittances-can-fund--Big-4---housing-plan-/440808-4553158-formatxhtml-jctg13z/index.html [archive]. Kenyans in the diaspora transferred nearly USD 2.5 billion to their home country in 2018 .

63. The digital industries know they will benefit from the new state program. And the President even asked them to invest in these sectors (Lang'at, Patrick. 2018. "Technology to Drive My Big Four Promises, Says Uhuru." Daily Nation, 28 February). The chemical industries specialising in agriculture sponsor Farm Clinics in several provincial universities (where farmers explain their agricultural problems and where they are offered solutions) and nowadays place them under the mentorship of the Big Four agenda (Maina, Nelson. 2018. "Farm Clinics at Heart of Big Four Agenda." Daily Nation, 7 July. https://nation.africa/ kenya/business/seeds-of-gold/farm-clinics-at-heart-of-big-four-agenda-63688 [archive]). No one is fooled, many economic actors are positioning themselves to take advantage of future state spending (Ngugi, Brian, and Neville Otuki. 2018. "Faceless Cartels Lie in Wait for the Big Four Projects." Daily Nation, 30 April).

64. Vidija, Patrick. 2018. " $84 \%$ of Kenyans Support Devolution. Ipsos." The Star, 6 April.

65. "Kiambu County to Give Free NHIF Cover to 24,000 Families." 2017. Daily Nation, 24 October; "Kisumu County Ready to Pilot Universal Healthcare." 2018. Daily Nation, 27 March; Komu, Nicholas. 2018. "Tharaka Nithi Launches TN-Care.” Daily Nation, 14 September. https://nation.africa/kenya/brand-book/ tharaka-nithi-launches-tn-care-medical-cover--111570 [archive]. 
the election campaign, a long-lasting drought affected the country, putting many people at risk. The response of the national executive was late and the counties of the semi-desert areas proved to be ineffective, forcing the central state to take over and therefore to appear as the leader in this public policy. Economic assistance is a shared competence, but all governors particularly value their role in this area. In addition, some counties have come together to form economic blocs that pool resources to have a more incisive economic policy ${ }^{66}$ In this context, the success of the Big Four Agenda depends on the establishment of strong collaborations between the national and local levels. In June 2018, the Governors' Summit declared its willingness to work with the National Executive on these issues ${ }^{67}$ Some counties negotiate directly with the Kenyan government to be involved in certain policies of the new agenda. ${ }^{68}$

For the moment, the doctrine of Kenya's leadership on the place of local governments in the implementation of the Big Four Agenda is not known. For years, both Kenyatta and Ruto have expressed their hostility towards decentralisation. Since they have been in power, they have toned down their rhetoric but they are still suspected of having dark agendas against this reform. Some go as far as to suggest that the Big Four is their Trojan horse for devitalising decentralisation... But other observers believe that the Head of State may have an interest in working with the counties. He would thus establish patron-client networks that would allow him to manage his own succession from a position of strength, particularly against his Vice-President, even if he himself cannot constitutionally stand for re-election.

66. On the Lake Region Economic Bloc, which brings together 8 counties from western Kenya, see: Luvega, Derick, et Gaitano Pessa. 2018. "Eight Governors from Lake Region to Drum Up Support for Economic Bloc.” Saturday Nation, 9 June. https://nation.africa/counties/Governors-to-drum-up-support-foreconomic-bloc/1107872-4602644-format-xhtml-byxs3c/index.html [archive].

67. Even if the majority of counties are run by elected members of Jubilee (the President's party), the Governors' Summit is led by an opponent of the regime and this body is particularly demanding if not suspicious of a national executive still suspected of not playing the game of the 2010 constitution sincerely. Oruko, Ibrahim. 2018. "State Told to Work with Counties for Big Four Success." Daily Nation, 5 June. https://nation.africa/kenya/news/politics/governors-tell-state-towork-with-counties-for-success-of-big-four-agenda-51230 [archive].

68. This is the case of Kitui. Mutua, Kitavi. 2018. "How Kitui Mineral Wealth Can Drive Uhuru's Big Four.” Daily Nation, 19 June. https://nation.africa/counties/ kitui/How-Kitui-mineral-wealth-can-drive-Uhuru-s-Big-Four/3444936-4619212mxlyqp/index.html [archive]. 
Should We Believe in the Impact of the Big Four Agenda?

There are indications that the President is serious about the success of his new development program. Thus, many ministerial departments as well as several public institutions involved in the Big Four were moved to new ministries and new senior officials were appointed. These rearrangements are generally interpreted as the executive's desire to lock down these crucial administrative services by putting them under the control of those in power. ${ }^{69}$ However, the national budget presented in mid-2018 did not clearly prioritise the four areas to be developed. Some MPs called it an "illusionist budget" in that some of the usual entries (especially in education) were labelled "Big Four Agenda enablers" to make it appear that the new budget was given a significant place to the new agenda. ${ }^{70}$ This reminds us of the technical constraints of all modern states budgets, which are subject to large amounts of expenditure and have little room for manoeuvre to change to envelopes allocated. Changes are made in the medium-term, but in a democracy, citizens must be convinced of the state's ability to change the daily lives of the country's inhabitants. Political communication must therefore persuade public opinion of the sincerity of those in power in their project of change. It is still too early to know whether the message is getting through and whether public action is going in the direction announced.

\section{Conclusion}

Since independence, Kenya has continuously experienced what has been called a developmental state. Even in times of recession, the country recorded economic growth rates above the continental average. The characteristics of its economic system have changed significantly: the majority of wealth is now produced by the service sector, agriculture is modernising and remains largely in the hands of small-scale producers... This was done under the leadership of the state but the ways in which it intervenes in the economy and in society have evolved according to external constraints, the administration capacity to be truly engaged, and the forms of governance of the successive regimes.

69. Githae, Wanjohi, et Patrick Lang'at. 2018. "Uhuru Swaps Departments as Focus Shifts to Big Four Agenda.” Sunday Nation, 18 February. https://nation. africa/kenya/news/politics/uhuru-swaps-departments-as-focus-turn-to-bigfour-agenda-14174 [archive].

70. For a detailed presentation of these false pretences in the 2018-2019 budget, Kisero, Jaindi. 2018. "Mistake: Rotich Budget Lumped 'Big Four' with Usual Spendings." Daily Nation, 20 June. https://nation.africa/blogs/Henry-RotichBudget-lumped--Big-Four--with-usual-spending/1949942-4620960-13t2pwb/ index.html [archive]. 
Until the mid-1970s, Jomo Kenyatta consolidated the strong state inherited from the colonial era, to which he added an important neopatrimonial dimension. The political and administrative elites became heavily involved in all sectors of the economy, notably agriculture. Because of genuine political pluralism, especially at the local level, the political class had to take citizens' demands into account, demands which were expressed, notably, during relatively free elections.

During the two decades of Daniel arap Moi's regime (1978-2002), those in power benefited from a narrower social base than their predecessors and came to rule the country with increasingly authoritarianism. They captured the developmental state for their own benefit and gradually established a real divorce with the economic forces and civil society.

The presidencies of Mwai Kibaki (2002-2013) and Uhuru Kenyatta took place under the seal of democratisation, despite chaotic periods-in particular, the 2007 general elections and the short three-month civil war that followed. A new social contract was established between the state and the economic forces; it expressed in particular in the Kenya Vision 2030 program. During these fifteen years, the state superstructure developed at the same pace as the economy. Its efficiency improved considerably under the effects of the New Public Management techniques to which national elites largely converted. Yet, neo-patrimonialism still rules from the national to the local level, thanks in particular to the decentralisation reforms implemented from 2013 onwards.

Under the tutelage and often the activism of the developmental state in its various facets, the economy modernised and in 2015. Kenya became a middle-income country. This undeniable success highlighted the level of inequality that persisted and which, according to some, threatened the order that had been created. Such inequality took diverse forms but two of them gave rise to controversies and public policy. Indeed, the debate focused, on the one hand, on territorial inequalities that are understood through ethnicity and, on the other hand, on inequalities between social groups.

Since the 1950s, the political system has been structured around the idea of territorial injustices that needed to be addressed. Small ethnic groups that feared being left behind joined together in a partisan structure that negotiated with larger ethnic groups deemed dominant. The democratisation of the 1990s exacerbated these tensions and strongly ethnicised political life. Following the 2007 crisis, institutional responses were adopted: a decentralisation reform gave the regions substantial material resources and real decision-making power; a special fund was created so that the poorest counties would have more money available; recruitment in the public service had to respect a certain ethnic balance, etc. Strong territorial 
inequalities persist but the political elites took stock of the frustrations of the peripheries and put in place policies that were appreciated.

Inequalities between social categories have been relatively hidden from the political debate. Of course, the opposition and some of its leaders, like Raila Odinga, present themselves as the heroes of the poor. But politics is read more though the lens of ethnicity than in terms of the social question. Anti-poverty policies have failed. The development of universal social protection is still in its infancy, and in this area, Kenya (and East Africa in general) is lagging behind Southern Africa countries. We have seen that the Big Four Agenda, which is to serve as a benchmark for Uhuru Kenyatta's last term in office, is aimed to provide solutions. For the time being, the poorest sections of the population barely appear in the public sphere, except through the multifaceted violence of the youth. The needy remain in what Kristin D. Phillips (2018) calls a "citizenship of subsistence.” They try to survive food crises (if not famines) by becoming part of patron-client networks that act as a fragile form of social security.

Since its inception, the Kenyan developmental state has been able to create economic growth but this prosperity is very unevenly distributed; it does not bring social justice, and therefore its legitimacy still remains fragile. Here again, great hopes are placed in decentralisation as it is expected to bring the state and its public services closer to the citizens. But will Kenya have the means for this ambition? Since 2018, several reports from the World Bank and the IMF have warned of the sharp increase in public debt across East Africa. In Kenya, this debt rose from 15.4 billion EUR to 42.7 billion EUR during Uhuru Kenyatta's first term in office ${ }^{71}$ in particular due to the policy of large-scale works. Thus, the state has lost much of its room for manoeuvre.

The Kenyan developmental state has many similarities with the states in neighbouring countries, although some are more interventionist (Ethiopia, Rwanda), others more focused on social justice (Tanzania), and still others more neo-patrimonialist (Uganda). It is likely that greater regional integration would be of great benefit, at least at the economic level and particularly in the development of the large-scale transport corridors. For many years, competition and suspicion have prevailed over cooperation, especially when it comes to Kenya-a country that would highly benefit from integration.

71. The share of debt in Gross Domestic Product is 58\%. See Douet, Marion. 2018. "Au Kenya, la forte augmentation de la dette publique inquiète la population." Le Monde, 13 October. 


\section{Bibliography}

Arriola, Leonardo R. 2013. Multi-Ethnic Coalitions in Africa: Business Financing of Opposition Election Campaigns. Cambridge Studies in Comparative Politics. New York: Cambridge University Press. https://doi.org/10.1017/CBO9781139108553.

Barkan, Joel D. (eds). 1984. Politics and Public Policy in Kenya and Tanzania. New York, Eastbourne: Praeger.

Barkan, Joel D. 1994. (eds). Beyond Capitalism vs. Socialism in Kenya and Tanzania. Boulder (CO) \& London: Lynne Rienner.

Bart, François, Bernard Charlery de la Masselière, and Bernard Calas (eds). 1998. Caféicultures d'Afrique orientale. Collection "Hommes et sociétés." Paris: Karthala-IFRA.

Bayart, Jean-François, Stephen Ellis, and Béatrice Hibou. 1998. La criminalisation de l'État en Afrique. Bruxelles: Éditions Complexe.

Bjerk, Paul. 2015. Building a Peaceful Nation: Julius Nyerere and the Establishment of Sovereignty in Tanzania, 1960-1964. Rochester (NY): University of Rochester Press.

Boone, Catherine. 2014. Property and Political Order in Africa: Land Rights and the Structure of Politics. Cambridge Studies in Comparative Politics. New York: Cambridge University Press. https://doi.org/10.1017/CBO9781139629256.

Branch, Daniel, and Nic Cheeseman. 2010. "Introduction: Our Turn to Eat." In Our Turn to Eat: Politics in Kenya Since 1950, edited by Daniel Branch, Nic Cheeseman \& Leigh Gardner, 1-22. Afrikanische Studien. Berlin: LIT.

Branch, Daniel. 2011. Kenya. Between Hope and Despair, 1963-2011. New Haven \& London: Yale University Press.

Bremmer, Ian. 2010. The End of the Free Market: Who Wins the War between States and Corporations? New York (NY): Portfolio.

Browne, Adrian J. 2015. LAPSSET: The History and Politics of an Eastern African Megaproject. Nairobi: Rift Valley Institute-Rift Valley Forum. http:// riftvalley.net/publication/lapsset\#.XbwFldVCc2w [archive].

Carcanague, Samuel, and Emmanuel Hache. 2017. "Les infrastructures de transport, reflet d'un monde en transition." Revue internationale et stratégique 107, no. 3: 53-60. https://doi.org/10.3917/ris.107.0053.

Connan, Dominique. 2014. "La décolonisation des clubs kényans : sociabilité exclusive et constitution morale des élites africaines dans le Kenya contemporain.” PhD Dissertation, Université Paris 1.

Cooksey, Brian, David Court, and Ben Makau. 1994. "Education for SelfReliance and Harambee." In Beyond Capitalism vs Socialism in Kenya and Tanzania, edited by Joel Barkan. Boulder (CO) \& London: Lynne Rienner.

Cooper, Frederick, David Anderson, Carolyn Brown, Christopher Clapham, and Michael Gomez. 1996. Decolonization and African Society: The Labor Question in French and British Africa. Cambridge: Cambridge University Press. https://doi.org/10.1017/CBO9780511584091. 
Durrani, Shiraz. 2018. Trade Unions in Kenya's War of Independence. Nairobi: Vita Books. https://doi.org/10.2307/j.ctvh8r4j2.

Fouéré, Marie-Aude, and Hervé Maupeu. 2015. "Une nouvelle Afrique de l'Est ? Introduction thématique." Afrique contemporaine no. 253: 13-35. https://doi.org/10.3917/afco.253.0013.

Fourie, Elsje. 2015. "L'Éthiopie et le Kenya face au 'modèle chinois' de développement." Afrique contemporaine no. 253: 87-106. https://doi.org/10.3917/afco.253.0087.

Fulcher, James. 2004. Capitalism: A Very Short Introduction. New York: Oxford University Press. https://doi.org/10.1093/actrade/9780192802187.001.0001.

Green, Maia. 2014. The Development State: Aid, Culture and Civil Society in Tanzania. Woodbridge: James Currey.

Hope, Kempe Ronald. 2011. The Political Economy of Development in Kenya. New York: Continuum.

Hornsby, Charles. 2012. Kenya: A History since Independence. London \& New York: I.B. Tauris.

Hyden, Goran.1980. Beyond Ujamaa in Tanzania: Underdevelopment and an Uncaptured Peasantry. London: Heinemann.

Jerven, Morten. 2014. Economic Growth and Measurement Reconsidered in Botswana, Kenya, Tanzania, and Zambia, 1965-1995. Oxford: Oxford University Press. http://doi.org/10.1093/acprof:oso/9780199689910.001.0001.

Joireman, Sandra. 2011. Where There is no Government. Enforcing Property Rights in Common Law Africa. Oxford: Oxford University Press. http://doi.org/10.1093/acprof:oso/9780199782482.001.0001.

Kahora, Billy. 2008. The True Story of David Munyakei: Goldenberg WhistleBlower. Nairobi: Kwani Trust

Kelsall. Tim. 2013. Business, Politics, and the State in Africa. London \& New York: Zed Books.

Klopp, Jacqueline M. 2000. "Pilfering the Public: The Problem of Land Grabbing in Contemporary Kenya." Africa Today 47, no. 1: 7-26. http://www.jstor.org/stable/4187305.

Klopp, Jacqueline M. 2001. “Ethnic Clashes' and Winning Elections: The Case of Kenya's Electoral Despotism." Canadian fournal of African Studies / Revue Canadienne des Études Africaines 35, no. 3: 473-517. https://doi.org/10.1080/00083968.2001.10751230.

Kochore, Hassan H. 2016. "The Road to Kenya? Vision, Expectations and Anxieties around New Infrastructures Development in Northern Kenya." Journal of Eastern African Studies 10, no. 3: 494-510. https://doi.org/10.1080/17531055.2016.1266198.

Langdon, Steven. 1987. "Industry and Capitalism in Kenya: Contributions to a Debate." In The African Bourgeoisie: Capitalist Development in Nigeria, Kenya, and the Ivory Coast, edited by Paul M. Lubeck. Boulder (CO): Lynne Rienner.

Leo, Christopher. 1984. Land and Class in Kenya. Toronto, Buffalo (NY) \& London: Toronto University Press. 
Leonard, David K. 1991. African Successes: Four Public Managers of Kenyan Rural Development. Berkeley: University of California Press.

Leys, Colin. 1975. Underdevelopment in Kenya: The Political Economy of Neocolonialism. London: Heinemann.

Lynch, Gabrielle. 2011. I Say to You: Ethnic Politics and the Kalenjin in Kenya. Chicago \& London: University of Chicago Press.

Maguire, G. Andrew. 1969. Towards 'Uhuru' in Tanzania: The Politics of Participation. Cambridge: Cambridge University Press.

Martz, John. 1992. "Shaping the Political Arena: Critical Junctures, the Labor Movement, and Regime Dynamics in Latin America." Studies in Comparative International Development 27, no. 1: 76-80. https://doi.org/10.1007/BF02687106.

Masquelier, A. 2002. "Road Mythographies: Space, Mobility, and the Historical Imagination in Postcolonial Niger." American Ethnologist 29, no. 4: 829-56. https://doi.org/10.1525/ae.2002.29.4.829.

Maupeu, Hervé. 2008. "Les autobiographies au Kenya. La production d'un genre littéraire." In Le statut de l'écrit. Afrique, Europe, Amérique latine, edited by Christine Albert, Abel Kouvouama \& Gisèle Prignitz, 171-89. Pau: Presses universitaires de Pau.

Maupeu, Hervé. 2000. "Vie et mort d'un groupe de pression électoral: l'exemple de Youth for Kanu'92." In Annuaire de l'Afrique orientale 2000, edited by François Grignon and Hervé Maupeu, 395-421. Paris: L'Harmattan.

Mueller, Lisa. 2018. Political Protest in Contemporary Africa. New York \& Cambridge: Cambridge University Press.

https://doi.org/10.1017/9781108529143.

Murunga, Godwin R. 2007. "Governance and the Politics of Structural Adjustment in Kenya." In Kenya. The Struggle for Democracy, edited by Godwin R. Murunga \& Shadrack W. Nasong'o, 263-300. Dakar: Codesria Books; London \& New York: Zed Books.

Nugent, Paul. 2004. Africa since Independence: A Comparative History. Basingstoke \& New York: Palgrave Macmillan.

Ochieng, William R. 1995. "Structural and Political Changes." In Decolonization and Independence in Kenya, 1940-93, edited by Bethwell A. Ogot and William R. Ochieng. London, Nairobi \& Athens (OH): James Currey.

Oloo, Adams G.R. 2007. "The Contemporary Opposition in Kenya: Between Internal Traits and State Manipulation." In Kenya. The Struggle for Democracy, edited by Godwin R. Murunga and Shadrack W. Nasong'o, 90125. Dakar: Codesria Books; London \& New York: Zed Books.

Onoma, Ato Kwamena. 2009. The Politics of Property Rights Institutions in Africa. Cambridge: Cambridge University Press. https://doi.org/10.1017/CBO9780511691942.

Otieno, R. Owino, and Njuguna S. Ndung'u. 2010. "Unlocking the Future Potential of Kenya-Vision 2030.” In Kenya. Policies for Prosperity, edited by Christopher Adam, Paul Collier \& Njuguna S. Ndung'u, 39-53. Oxford: Oxford University Press. 
Phillips, Kristin D. 2018. An Ethnography of Hunger: Politics, Subsistence, and the Unpredictable Grace of the Sun. Bloomington: Indiana University Press. https://doi.org/10.2307/j.ctv4rfqsv.

Pratt, Cranford. 1976. The Critical Phase in Tanzania 1945-1968: Nyerere and the Emergence of a Socialist Strategy. New York: Cambridge University Press.

Provini, Olivier, and Sina Schlimmer. 2018. Étude monographique : Kenya. FAPPA Livrable no. 3.

Republic of Kenya. 2016. Report of the Auditor-General on the Financial Statements of National Irrigation Board. Nairobi: Republic of Kenya.

Routley, Laura. 2012. "Developmental States: A Review of the Literature." Working Paper no. 3. Manchester: ESID. https://dx.doi.org/10.2139/ssrn.2141837.

Saul, John S. 1979. The State and Revolution in Eastern Africa. London: Heinemann.

Shivji, Issa G. 1976. Class Struggles in Tanzania. London: Heinemann.

Swainson, Nicola. 1987. "Indigenous Capitalism in Postcolonial Kenya." In The African Bourgeoisie: Capitalist Development in Nigeria, Kenya, and the Ivory Coast, edited by Paul M. Lubeck. Boulder (CO): Lynne Rienner.

Thelen, K. 2012. "Varieties of Capitalism: Trajectories of Liberalization and the New Politics of Social Solidarity." Annual Review of Political Science 15, no. 1: 137-59. https://doi.org/10.1146/annurev-polisci-070110-122959.

Thelen, K. 2014. Varieties of Liberalization and the New Politics of Social Solidarity. Cambridge \& New York: Cambridge University Press.

Thomas, Chris. 1997. "Le Kenya d'une élection à l'autre. Criminalisation de l'État et succession politique (1995-1997)." Les Cahiers du CERI, no. 35.

Thomas, Chris. 1998. "L'économie politique d'une succession annoncée." Politique africaine, no. 70: 40-53.

http://www.politique-africaine.com/numeros/pdf/070040.pdf [archive].

Van de Walle, Nicolas. 2001. African Economies and the Politics of Permanent Crisis, 1979-1999. Cambridge \& New York: Cambridge University Press.

Wrong, Michela. 2009. It's Our Turn to Eat. The Story of a Kenyan WhistleBlower. London: Fourth Estate Medias.

\section{Media}

Apollo, Silas. 2017. "Ministry Rolls out Dam Projects to Boost Food Production.” Daily Nation, 26 December. https://nation.africa/news/Govtrolls-out-57-dam-project-to-boost-food-production/1056-4242428-formatxhtml-bvfav0/index.html [archive].

Gachane, Ndung'u. 2018. "Now Wa Iria Slaps Nairobians with Water Levy as Revenue Row Escalates." Daily Nation, 14 September. https://nation.africa/ kenya/news/wa-iria-slaps-nairobians-with-water-levy-as-revenue-rowescalates-86672 [archive].

Githae, Wanjohi, and Patrick Lang'at. 2018. "Uhuru Swaps Departments as Focus Shifts to Big Four Agenda." Sunday Nation, 18 February. https:// 
nation.africa/kenya/news/politics/uhuru-swaps-departments-as-focusturn-to-big-four-agenda-14174 [archive].

IEA (Institute of Economics Affairs). 2018. "How much Oil? Why East Africa's Bounty Is neither Significant nor Exceptional.” The East African, 9-15 June. https://www.theeastafrican.co.ke/tea/business/how-much-oil-why-eastafrica-s-bounty-is-neither-significant-nor-exceptional--1395812 [archive].

Jebet, Vivian. 2018. "Isiolo Leaders Allege Diversion of Lapsset Route, Want Details of Map." Daily Nation, 19 September.

Juma, Victor. 2014. "Making of a Mega Scandal? Why Railway Figures Do not Add up." Sunday Nation, 26 January. https://nation.africa/kenya/news/ making-of-a-mega-scandal-why-railway-figures-do-not-add-up-942286 [archive].

Kagwanja, Peter. 2018. "Kenya's Vision 2030 Caught Between the Rock and a Hard Place." Daily Nation, 17 September. https://nation.africa/kenya/ blogs-opinion/opinion/vision-2030-caught-between-the-rock-and-a-hardplace-87604 [archive].

Kairu, Pauline. 2014. "Land Owners Along Rail Route Want Fresh Valuation." Sunday Nation, 28 December.

Kariuki, James. 2015. "Big Projects Recipe for Kenya’s Growth: Study.” Daily Nation, 13 August.

Karambu, Immaculate. 2015. "Uhuru Faults SGR Contractor on 40pc Procurement Quota." Daily Nation, 5 December.

Keprop, Victor. 2018. "Ethiopia Begins Production Tests at Ogaden Oilfield." The East African, 30 June-6 July. https://www.theeastafrican.co.ke/tea/ business/ethiopia-begins-production-tests-at-ogaden-oilfield-1397200 [archive].

"Kiambu County to Give Free NHIF Cover to 24,000 Families." 2017. Daily Nation, 24 October.

Kisero, Jaindi. 2018. "Mistake: Rotich Budget Lumped 'Big Four' with Usual Spendings." Daily Nation, 20 June. https://nation.africa/blogs/HenryRotich-Budget-lumped--Big-Four--with-usual-spending/1949942-462096013t2pwb/index.html [archive].

"Kisumu County Ready to Pilot Universal Healthcare." 2018. Daily Nation, 27 March.

Komu, Nicholas. 2018. "How Greed for Water and Impunity Pushing a Community to the Brink.” Daily Nation, 25 August. https://nation.africa/ kenya/news/how-greed-for-water-and-impunity-pushing-a-communityto-the-brink-80648 [archive].

Komu, Nicholas. 2018. "Tharaka Nithi Launches TN-Care." Daily Nation, 14 September. https://nation.africa/kenya/brand-book/tharaka-nithilaunches-tn-care-medical-cover--111570 [archive].

Komu, Nicholas. 2018. "Water Row: Leaders Break Ranks with Jubilee.” Daily Nation, 5 October.

Lang'at, Patrick. 2018. “Technology to Drive My Big Four Promises, Says Uhuru." Daily Nation, 28 February. 
Luvega, Derick, and Gaitano Pessa. 2018. "Eight Governors from Lake Region to Drum Up Support for Economic Bloc.” Saturday Nation, 9 June. https:// nation.africa/counties/Governors-to-drum-up-support-for-economicbloc/1107872-4602644-format-xhtml-byxs3c/index.html [archive].

Lwanga, Charles. 2018. "Kilifi MCAs Move to Push State out of Galana-Kulalu Project.” Business Daily, $1^{\text {er }}$ March. https://www.businessdailyafrica.com/ news/counties/Kilifi-MCAs-stop-Galana-Kulalu-project/4003142-4324908148c21lz/index.html [archive].

Maina, Nelson. 2018. "Farm Clinics at Heart of Big Four Agenda." Daily Nation, 7 July. https://nation.africa/kenya/business/seeds-of-gold/farm-clinics-atheart-of-big-four-agenda-63688 [archive]

Marete, Gitonga. 2018. "Questions on Viability of SGR Refuse to Go away after China Cuts Funding." Daily Nation, 17 September. https://www. businessdailyafrica.com/news/Questions-on-viability-of-SGR-refuse-togo-away/539546-4761886-5fq1awz/index.html [archive].

Mathaura, Francis. 2018. "Vision 2030 Holds the Key to a Better and More Inclusive Kenya." Saturday Nation, 9 June. https://nation.africa/kenya/ blogs-opinion/opinion/vision-2030-holds-the-key-to-a-better-and-moreinclusive-kenya-52474 [archive].

Maundu, Pius. 2015. "Workers at New Railway on Strike." Daily Nation, 9 April. https://nation.africa/kenya/news/workers-at-new-railway-onstrike-1083358 [archive].

Mbataru, Patrick. 2015. "Mega Projects Have Little Impact on the Poor." Sunday Nation, 9 August. https://nation.africa/kenya/blogs-opinion/opinion/megaprojects-have-little-impact-on-the-poor-1118308 [archive].

Munguti, Richard. 2018. "Authority Orders Posta to Pay Ex-workers Billions in Pension.” Daily Nation, 26 April. https://nation.africa/kenya/business/ posta-to-pay-4-000-ex-staff-more-benefits-36724 [archive].

Muraya, Beth. 2018. "Will the Big Four Agenda Usher in Transformative Economic Growth?” Sunday Nation, 10 June.

Mutua, Kitavi. 2018. "How Kitui Mineral Wealth Can Drive Uhuru’s Big Four." Daily Nation, 19 June. https://nation.africa/counties/kitui/How-Kituimineral-wealth-can-drive-Uhuru-s-Big-Four/3444936-4619212-mxlyqp/ index.html [archive].

Mwaniki, Charles. 2018. “Kenya Raises \$2bn in Fresh Eurobonds Issue.” Business Daily, 22 February https://www.businessdailyafrica.com/markets/capital/ Kenya-says-fresh--2bn-Eurobond-oversubscribed-seven-times/42594424315350-14pr01l/index.html [archive].

Mwololo, Millicent. 2018. "Sacco Turns Home Ownership Dream into Reality." Daily Nation, 19 July. https://nation.africa/kenya/life-and-style/dn2/saccoturns-home-ownership-dream-into-a-reality-68454 [archive].

Mwololo, Millicent. 2018. "Cooperatives to Deliver 500,000 Social Housing Units.” Daily Nation, 19 July. https://nation.africa/lifestyle/dn2/ Cooperatives-to-deliver-social-housing-units/957860-4670584-formatxhtml-1051vjz/index.html [archive]. 
Namlola, Juma. 2018. "Saccos Told to Cash In on Uhuru's Big Four Agenda." Daily Nation, 19 February.

Namlola, Juma. 2018. "Co-operatives Key to Government's Big Four Agenda." Saturday Nation, 7 July.

Ndii, David. 2015. "If It Looks, Quacks and Walks Like a Duck, It Is the Lies About Eurobond." Saturday Nation, 19 December. https://www.nation. co.ke/kenya/blogs-opinion/opinion/if-it-looks-quacks-and-walks-like-aduck-it-is-the-lies-about-eurobond-1155142 [archive].

Ndii, David. 2016. "Mega Projects and Hollow Men: What $\$ 50$ bn Can Do for a Nation." Saturday Nation, 30 January. https://nation.africa/kenya/blogsopinion/opinion/mega-projects-and-hollow-men-what-50-bn-can-do-to-anation-1165482 [archive].

Ndii, David. 2017. "Forget About Mega Projects and Address Everyday Woes." Saturday Nation, 29 July. https://nation.africa/kenya/blogs-opinion/ opinion/forget-about-mega-projects-and-address-everyday-woes-430904 [archive].

Ngugi, Brian, and Neville Otuki. 2018. "Faceless Cartels Lie in Wait for the Big Four Projects." Daily Nation, 30 April.

Njagi, John, and John Ngirachu. 2014. "Graft Team Opens Probe on Rail Deal." Daily Nation, 8 January.

Olingo, Allan. 2018. "Kenya Halts Plans for Electric Trains." The East African, 27 January-2 February.

Olingo, Allan. 2018. "No Pledges for Region's Pipeline, Open Sky Deals." The East African, 30 June-6 July. https://www.theeastafrican.co.ke/tea/business/ no-pledges-for-region-s-pipeline-open-sky-deals-1397178 [archive].

Olingo, Allan, and Victor Kiprop. 2018. "Ethiopia Reaches Out to Djibouti and Kenya to Partner on Mega Projects." The East African, 12 May. https://www. theeastafrican.co.ke/tea/business/ethiopia-reaches-out-to-djibouti-andkenya-to-partner-on-mega-projects--1393546 [archive].

Opanga, Kwenda. 2018. "Big Four Agenda and 2022: Reasons Uhuru Is Unhappy with His Deputy." Sunday Nation, 10 June. https://nation.africa/ kenya/blogs-opinion/opinion/big-four-agenda-and-2022-reasons-uhuru-isunhappy-with-his-deputy-52754 [archive].

Openda, Joseph. 2018. "Retired Teachers Resume 18-year Pension Battle." Daily Nation, 27 July.

Oruko, Ibrahim. 2018. "State Told to Work with Counties for Big Four Success." Daily Nation, 5 June. https://nation.africa/kenya/news/politics/governorstell-state-to-work-with-counties-for-success-of-big-four-agenda-51230 [archive].

Otuki, Neville. 2018. "Oil Billions Not Our Major Aim for Now, Says PS of Export Plan." Daily Nation, 31 May. https://www.businessdailyafrica.com/ economy/Govt--Early-oil-export-not-a-profit-venture/3946234-458715612xfs2b/index.html [archive].

Vidija, Patrick. 2018. "84\% of Kenyans Support Devolution. Ipsos.” The Star, 6 April. 
Wafula, Paul. 2018. "Exclusive: Behind the SGR Walls." The Standard, 8 July. https://www.standardmedia.co.ke/kenya/article/2001287119/exclusivebehind-the-sgr-walls [archive].

Wanzala, Ouma. 2018. "Cash Crunch Hits EAC Integration Projects." Daily Nation, 26 June. https://nation.africa/kenya/news/cash-crunch-hits-eacintegration-projects-59296 [archive].

Warutere, Peter. 2018. "Diaspora Remittances Can Fund 'Big 4' Affordable Housing Plan.” Daily Nation, 10 May. https://nation.africa/oped/opinion/ Diaspora-remittances-can-fund--Big-4---housing-plan-/440808-4553158format-xhtml-jctg13z/index.html [archive].

Warutere, Peter. 2018. "Harmonise Relevant Laws for Equitable Growth." Daily Nation, 31 May. https://nation.africa/kenya/blogs-opinion/opinion/ harmonise-relevant-laws-for-equitable-economic-growth--49308 [archive]. 


\title{
Focus no. 1 \\ The World of Banks \\ and Finance in Kenya
}

\author{
Adeline Pelletier
}

Translated by Morgan Carmondy

Kenya is the dominant banking centre in East Africa with 43 commercial banks (as of 2014). This sector evolved considerably over the course of the last decade with the regional expansion of African banks, along with financial innovations and regulatory banking changes. As a result, the banking industry is particularly dynamic and is characterised by the coexistence of several types of banks; local Kenyan banks (31), subsidiaries of foreign banks (including global banks in developing countries, 4), emerging banks (mostly from Asian countries, 4), and regional African banks (4).

Between 2010 and 2015, some local banks, such as Kenya Commercial Bank and Equity Bank, experienced strong growth of their assets, to the point of exceeding the subsidiaries of multinational banks, such as Barclays or Standard Chartered. ${ }^{1}$ These big domestic banks have expansion strategies in East Africa, and more generally in Sub-Saharan Africa, opening subsidiaries in Uganda and Tanzania-thereby emulating the expansion of Nigerian banks (i.e. the United Bank of Africa) and Sub-Saharan banks (i.e. Standard Bank). With new models based on technological platforms, integrated mobile payment and bank branches ${ }^{2}$ (agency banking), these banks have rapidly developed and made large profits. A fieldwork conducted at the end of 2013 in Nairobi, including interviews with senior credit and risk managers, as well as managers of subsidiaries of 26 banks, sheds light on the credit practices of these banks.

1. In 2012, Standard Chartered's total assets in Kenya were 195 billion KES, compared with 91 billion KES in 2007. For Barclays, these figures were 185 billion KES in 2012, compared with 158 billion KES in 2007. Total assets of Kenya Commercial Bank amounted to 304 billion KES in 2012, compared with 120 billion KES in 2007, while for Equity Bank, these figures were 216 billion KES in 2012, compared to 53 billion KES in 2007 (source: Banking Survey 2013, Kenya Bankers' Association).

2. Non-banking entities that provide, on behalf of a financial institution, transaction and payment services. Small businesses, pharmacies, postal agencies, etc. can play this role. 


\section{Who Do Kenyan Banks Lend to?}

The large majority of the banks surveyed lend primarily to the manufacturing, trade, construction and real estate sectors. While most bank managers interviewed highlighted the fact that there is currently a boom in the construction and real estate sector, the financing of this sector is mainly done by the domestic banks. The "global" foreign banks are more reluctant to finance it, because of a different risk appetite. The agricultural sector is largely forgotten financially by banks despite being one of Kenya's most important sectors.

Concerning the composition of the lending portfolio of banks, loans to large companies generally make up the largest share ( $42 \%$ in total for the banks surveyed) followed by loans to Small and Medium-sized Enterprises (SMEs) (35\%) and individuals (18\%). The remaining 5\% concerns loans to cooperatives (savings and credit cooperatives) or microfinance. However, domestic banks tend to offer more individual loans than the other types of banks, whereas foreign banks are more exposed to large businesses (more than $50 \%$ of loans for subsidiaries of regional African Banks, $61 \%$ for global banks, versus $36 \%$ for domestic banks). Regarding SMEs, subsidiaries of African regional banks have a level of exposure similar to domestic banksrepresenting on average, for these two groups of banks, about one third of their loan portfolio. In comparison, the share of SME loans in the portfolio of global banks' subsidiaries is about $20 \%$. It should be noted, however, that banks' definition of SMEs can vary considerably. The classification is often based on the turnover or the amount of the loans, but, depending on the bank surveyed, this amount varies between 3,000 USD and 1 million USD. Finally, it should be noted that the "business model" of some domestic banks is very focused on SMEs, as is the case for Equity Bank. Meanwhile some large foreign banks, such as Citi, do not participate in this sector, focusing instead on large companies or institutional clients.

\section{Favourable Perception of the SME Finance Sector by Banks, but Important Constraints}

Banks generally have a favourable impression of the SME segment, with $92 \%$ of respondents considering it offered good financial opportunities. However, banks face significant constraints concerning their SME lending operations, which some believe limits the growth of their loan portfolio to this sector. Among the most cited problems for banks was insufficient or lack of collateral (24\% of responses), lack of information (24\%) and managerial insufficiencies for some SMEs (29\%). Despite these obstacles, some respondents indicated that their bank had initiated a reallocation of their loan portfolio towards SMEs, due to the intense competition for loans 
to large companies, and the potentially high returns offered by the SME segment. In addition, given the banking restrictions on the concentration of loans, ${ }^{3}$ the small domestic banks do not have the capacity to offer large loans, contrary to large domestic banks, such as Kenya Commercial Bank, and the subsidiaries of foreign banks.

\section{Banking Innovations and Evolution towards Automation of Lending Practices}

The large majority of banks surveyed operate a centralised organisation for credit functions, and for $89 \%$ of them all decisions concerning loans are executed by this central office. Some of the banking managers interviewed explained that this practice increases the operational efficacy of their bank. In addition, the development of credit bureaus ${ }^{4}$ facilitates banks' screening of loan applicants.

To evaluate the demands of loans, the majority of banks concentrated on the "character" of loan applicants (through an analysis of the management of bank accounts), a criteria which could be subjective. But numerous banks have also established, or are in the process of establishing, Credit Core systems.

Generally, financing SME requires systems of screening and monitoring loans which can be expensive to set up for small banks. Equity Bank is an interesting model. Originally a mortgage bank, it became a microfinance institution before operating as a commercial bank. One of the peculiarities of Equity Bank is its Universal Banking Software, which automates the majority of decisions and helps client advisors in their lending work. Coupled with a remuneration system for their staff based on performance, this system allows for efficient evaluation and monitoring of the customers, private individuals, and SMEs.

One of the latest successful banking innovations is mobile payment. Half of the banks surveyed offer this service (100\% for African bank subsidiaries), although this may have forced banks to rethink their business model by encouraging them to establish partnerships with telecommunications companies.

3. The loan limit is set at $25 \%$ of the bank's own funds per borrower.

4. Credit Reference Bureau Africa Limited (2010) and Metropol Credit Reference Bureau Limited (2011). 


\section{A Competitive Environment Marked by Judicial Slowness but a Benevolent Regulator}

The intensity of competition and the difficulty to access customer deposits are the two challenges most cited by the banks surveyed. $80 \%$ of bank executives interviewed considered that the competition for deposits was strong or intense. The competition between banks for SME loans is equally high, with $66 \%$ of banks considering it as strong or intense. But this figure is even greater in the corporate lending sector, rising to $75 \%$ of banks surveyed. The vast majority of banks (70\%) consider that banking regulations do not constitute, or constitute a minor obstacle to their activity. However, the legal system and the slowness of tribunals are often mentioned by banks as a hurdle to their activities ( $62 \%$ of people surveyed consider it to represent an important or extreme obstacle). The judicial procedures are often long and this route is used only as a last resort because it is difficult for banks to recover collateral in this way. 


\title{
Chapter 2 \\ The Large Gaps in Development in Kenya
}

\author{
Bernard Calas
}

Translated by Geoffrey D. Hilton, Elliot Brennan \& Catherine S. Davis

The purpose of this chapter is not to re-examine each point previously discussed in 1998 in my contribution to Le Kenya Contemporain (Grignon \& Prunier 1998). First, some of the characteristics of the country have not fundamentally changed: there is no need to revisit them. This chapter rather seeks to present the major geographic changes that have taken place in Kenya-which I call "the ageing" of places-with reference to the double ageing that the novelist Georges Pérec highlighted in his Des Lieux: that of my writing, and that of my own subjectivity. This contribution will thus be marked by these three forms of ageing but will focus solely on the dynamics of Kenya's different areas. It will be less about "accounting for extreme diversity"-as was the case in 1998-but more about shedding light on the major geographic changes of the last 25 years by distinguishing two types of areas: the attractive and integrated areas, and the unattractive and marginalised ones.

Before all else, it is important to present two important factors that influence the majority of challenges in Kenya and Africa in general.

First of all, in 28 years, the Kenyan population has more than doubled, growing from 23 million inhabitants to nearly 53 million (Pison 2019)! These numbers should be considered carefully. Imagine if the population of France ${ }^{1}$ grew from its current 64 million people to 120 million in $2040 \ldots$ and, during the current migration "crisis," imagine the debates, tensions, and changes begotten by such growth. This change is the most important and must be kept in mind. Kenya is obviously not the only country to have experienced this kind of boom. Indeed, the country's growth was not the most significant in either relative or absolute terms. Neither unique nor extreme, the growth of the Kenyan population demonstrates the vitality of the African demographic transition, and this without falling into unseemly Malthusianism. Regardless from what angle we consider the country or the continent beyond, we must embrace this amasing vital dynamic that makes

1. This text was originally published in French for a French-speaking audience: this reference to France should not be seen as a sign of anachronism or ethnocentrism. 
half the population younger than 18 years old! It places the politics of men and of numbers at the centre of debates and this perspective influences the analysis of inequality and development in Kenya. Furthermore, instead of opening with a discussion on the physical base, one should better introduce the people and their most important characteristics.

Next, it must be emphasised that Kenya is still, and will remain for decades, affected by development problems more than anything else. Of course, it has developed to the point of being struck off the list of Least Developed Countries (LDC). An average annual economic growth rate over 30 years of 5-6\% per year-despite declines and slowdowns due to political, climate, and cyclical risks-made it possible for the country's GDP (67 billion USD, 68th globally) and GDP per capita (1,380 USD per capita) to rise. Nevertheless, it is still not an emerging market in the eyes of commercial banks and rating agencies. Although Kenya is no longer on the LDC list, analysts envisage it as one of the "African lions" (Mac Kinsey 2013). Its elites expect the country to emerge around 2030 (Vision 2030) and flaunt their aspiration of joining the other "tigers" and Asian "dragons." Yet the country remains fundamentally crippled by development problems. The slightest drought can lead to shortages and famines, with repercussions on the economy and society as a whole. A minor adverse El Niño-related weather event can paralyse the economy. Even if it is above the African average, Kenya's HDI (0.548 that ranked 145th in the world in 2014; 0.43 in 1990 ranked 156th) remains relatively low. Its development is extremely unequally distributed, both socially and geographically: $45 \%$ of the population still live on less than 2 USD per day and its Gini index (0.51), far from decreasing, is growing and makes it one of the most unequal societies in Africa. In total, the average Kenyan's monthly income of USD 115 places it 140th in the world.

These two introductory ideas underline the importance of the changes in the way in which the country has faced three major challenges of development: demographic transition, economic diversification, and structural transformation to end its dependence on aid, but also environmental sustainability as growing needs push productivity beyond environmental limits in a context of intensified globalisation. The challenges have brought about changes-spectacular for some, subdued for othersthat must now be discussed.

\section{First Challenge: Demographic Transition}

In the 2009 census (before the most recent one of August 2019), the Kenyan population was growing at a rate of $2.8 \%$ per year, doubling every 25 years. Since then, according to international organisations, growth has decreased to $2.3 \%$ per year (Pison 2019). The Kenyan population is therefore in the midst of a demographic transition. Growth is decelerating (3.3\% in 1990), 
under the influence of the decreased birth rate, itself correlated with the decrease in the Total Fertility Rate (6.6 in 1990, 4.7 in 2009, 3.4 in 2019). Kenyans are having fewer children than their Ugandan and Tanzanian neighbours or than their parents. According to the last Demographic and Health Survey (2014), after stagnating for a decade and even rising back to 4.6-4.9 children per woman at the end of the 1990s, the national fertility rate fell below 4 children per woman. This was the result of an increase in the uptake of contraceptive practices. At present, $60 \%$ of women older than 15 use contraceptive methods, compared with a third in 2000. This increased uptake is partially due to the introduction of free primary schooling in 2003. If the uptake of contraceptive practices continues at this rate, it may allow the country to benefit from a "population dividend." This occurred in South-East Asia fifty years ago where it lowered the dependency ratio before it raised again due to the ageing population. For Kenya, this may quickly increase GDP per capita-the central measure of development.

The growing use of contraception is combined with the slight rise in the age at marriage (20 years old), the rise of the age at first birth, and the decline of the proportion of teenage pregnancies (from 12.7\% in 1990 to $9 \%$ today), all linked to tangible women's empowerment. Infant mortality has also decreased (from 98\% in 1990 to $79 \%$ in 2009 to 35\% in 2019; see Pison 2019), improving children's chances of survival. Classically, improvement of girls' education results in a decline in women's desire to have children, and an increase of inter-birth intervals.

However, the geography of this demographic transition and the decrease in birth rates and fertility show a clear contrast between the Central Highlands and the rest of the country. In the counties of Meru and Kirinyaga, more than $70 \%$ of women have access to contraception while, in the lowlands of the north-north-east (counties of Wajir, Mandera, and Garissa) less than $7 \%$ of women use it. The Western Highlands, the Great Rift Valley, and the Coast are in the middle.

Life expectancy, after having fallen to 51 years old in 2000 due to the effects of the AIDS pandemic, has risen back to 67 years old, which marks entry in the post-AIDS period. However, some 1.6 million people still have HIV in Kenya. Large geographic inequalities in the struggle against death have appeared: in the Lake Victoria region, particularly in Luo lands, HIV prevalence remains high.

\section{Has Growth Changed the Spatial Distribution of the Kenyan Population?}

In 2009 , the average density of Kenya was 66 people per square kilometre. This is meaningless, given the large differential between, for instance, the rural density of Vihiga county with Asian-like levels of 973 people per 


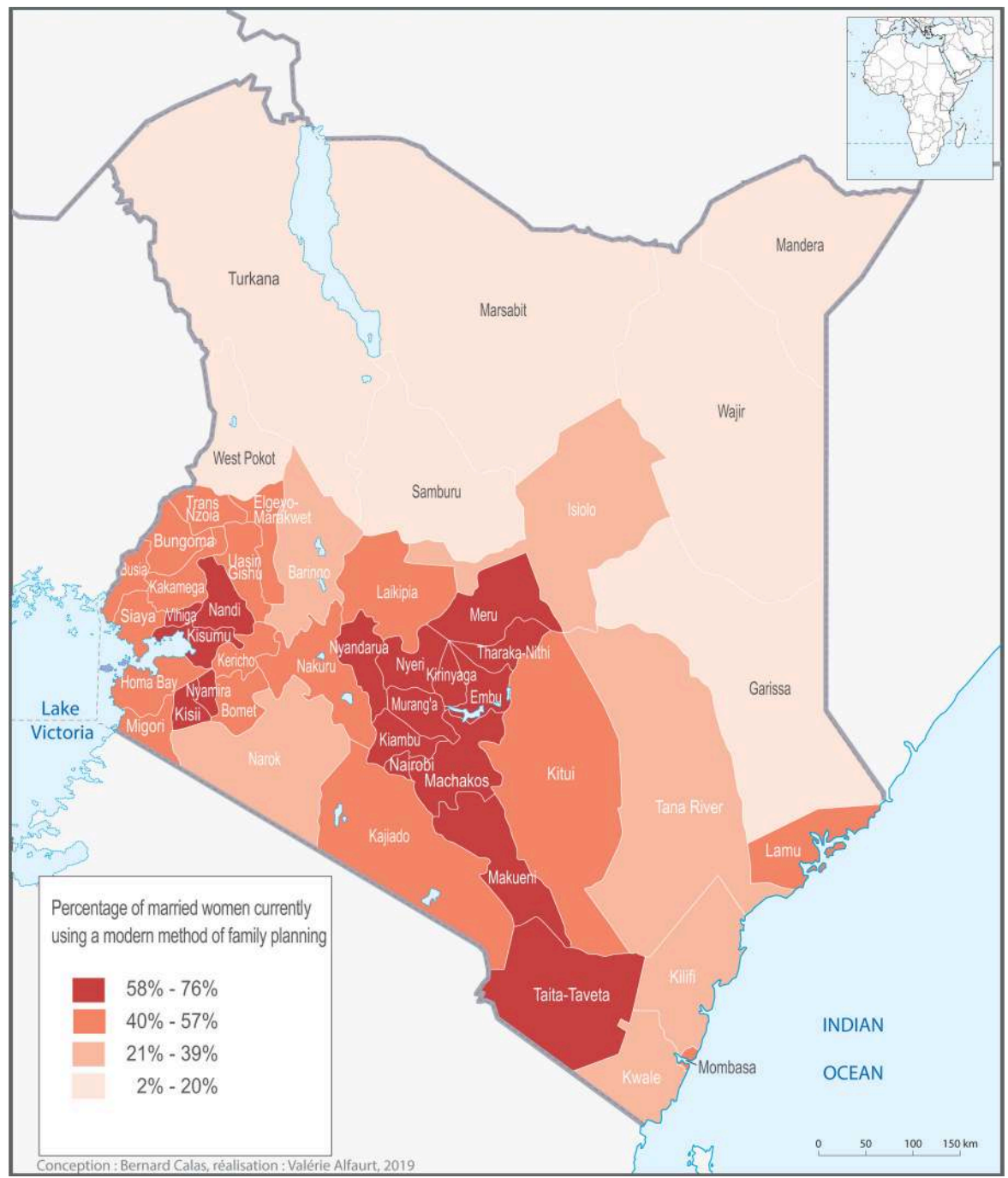

Figure 1. Usage of modern contraceptive methods Bernard Calas, Valérie Alfaurt, 2019.

square kilometre in 2009, and the quasi-Saharan levels of Marsabit with 4 people per square kilometre. High densities are centred in the highlands, particularly in the west (Kisii 877; Nyamira 659; Bungoma 452; Kakamega 546; Trans-Nzoia 324) but also in the eastern slopes of the Central Highlands (Nyeri 204; Kirinyaga 352; Muranga 366; Meru 193; Embu 180; Machakos 175; even Makueni 109). These higher densities correspond with the Luhya, Kisii, Kikuyu, and Kamba lands. The foothills and fringes of these highlands (Baringo 50; West Pokot 56; Laikipia 46; Narok 47) and the coast are in the middle (Kwale 78; Kilifi 87). The lowest densities (often less 


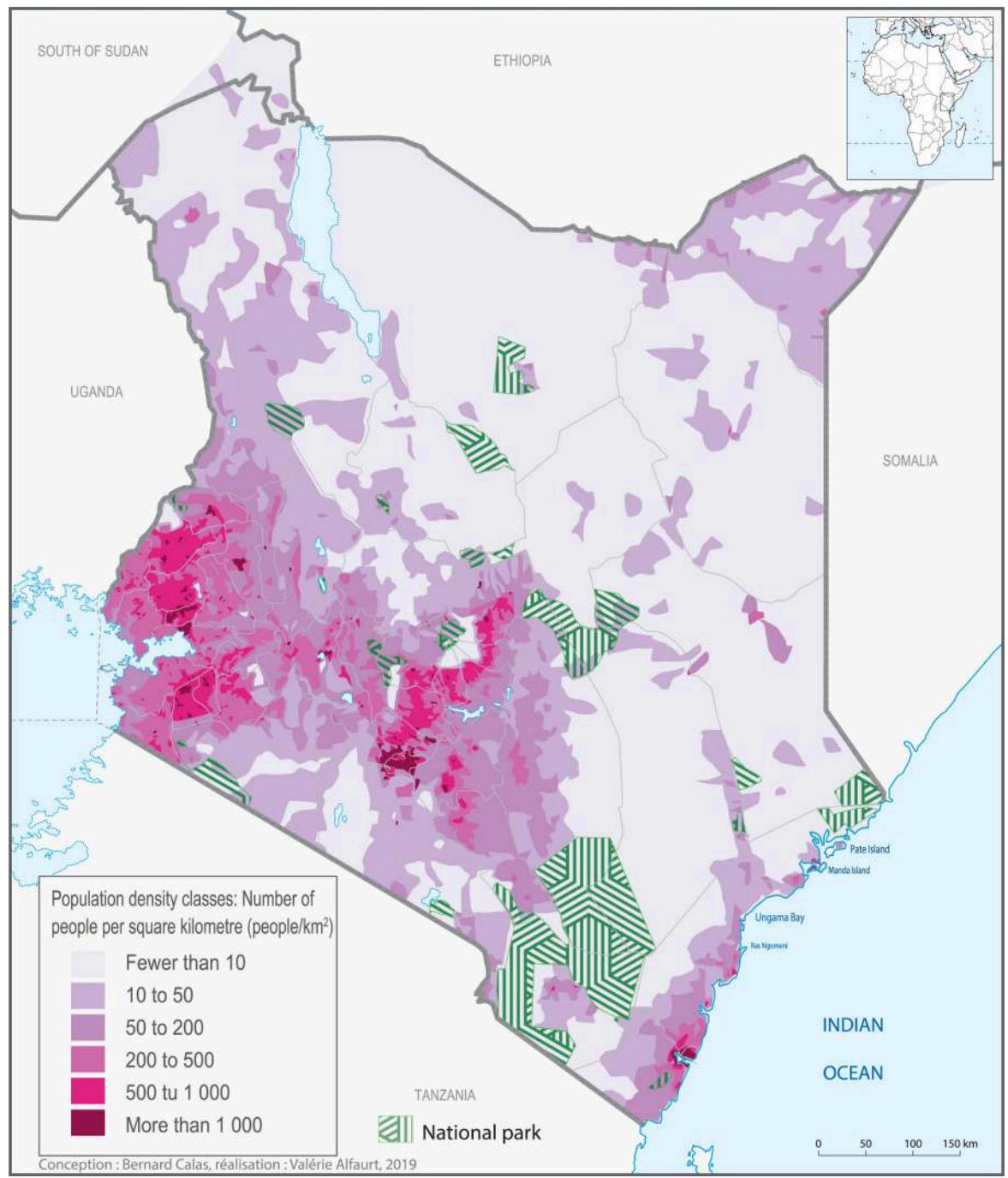

Figure 2. Map of population densities

Bernard Calas, Valérie Alfaurt, 2019.

than 10 people per square kilometre) are spread across the northeastern half of the country.

Fundamentally, the dynamics that were identified 25 years ago still hold: densification in already populated areas, pioneer fronts that are spontaneously loosening on the margins, migrations towards agrarian townsites from the old 'White Highlands', along with urbanisation through the creation of new towns, through the increasing size of existing towns, and the sprawl of suburbs and urban peripheries of the biggest cities. The Brownian motion is accentuated and polytopic ways of life have multiplied, 
facilitated by mobile telephony ( $89 \%$ of Kenyans had a mobile telephone number in 2017) and the improvement of automobile accessibility in many areas of the country. However, use of mobile phones, the Internet, the boda boda and the matatu have not radically upset the density map. The crowded highlands are becoming increasingly crowded while the arid lowlands of the north and the north-east are still relatively empty, even though the density is increasing. Two-thirds of the Kenyan population used to live above $1,500 \mathrm{~m}$. Although this has now fallen to $1,200 \mathrm{~m}$, the famous butterfly-shaped highlands remain the home of the majority of the population, together with the coastal border.

This does not mean that Kenyans are not moving, however. In 2009, $20 \%$ of Kenyans did not live in their county of birth. At the county level, mobility numbers express the different level of attractiveness of the regions. Unsurprisingly, the less attractive areas are in the arid and sometimes unsafe parts of north-eastern Kenya (Mandera, Wajir), the north (Turkana, Marsabit) and the small farms areas in semi-arid parts of the east (Kitui, and to a small extent Makueni or Tharaka on the eastern piedmont of Mt Kenya). The only exceptions in this unattractive environment are the Dadaab camps populated by Somali refugees (Meyerfeld 2016; Chkam 2016, 79-97), county seats, and border checkpoints. In contrast, the attractiveness of the Lamu-Garsen region is tied to its large harbour and agricultural projects. Uasin Gishum, Elgoyo Marakwet, Trans-Nzoia, Nyandarua, and Laikipia are also attractive counties: farmers establish there, sometimes on the White Highlands or at the expense of forests and protected lands that were delisted at the start of the 2000s, and as a result of the creation of several displaced persons camps from the 2007-08 crisis. The net migration in the cities of Nairobi, Mombasa, Kisumu, Eldoret, and Nakuru but also in the central areas around the capital (suburban countries of Kiambu and Kajiado) underline how important cities have become to Kenyans. This urban attractiveness can be found on all scales: for example, more than half of the inhabitants of Isiolo, a town set in the arid foothills to the north of Mt Kenya (Samburu and Shaba region)-generally not a particularly attractive area-were born in another county. Likewise, the migration maps of the Socio-Economic Atlas of Kenya (Wiesmann, Kiteme \& Mwango 2014, 38-39) show the attractiveness of Namanga, Oliotoktok, Kasigau, Maralal, Marsabit, or even Lodwar, and of a whole series of small and medium-sized towns (Calas 2007, 3-22).

Indeed, one of Kenya's decisive trends today is urbanisation-in the same as in the rest of Africa. It affects both men (and women) and places. The population is urbanising at a rate of $4 \%$ per year. Firstly, this is due to a daily increase in the number of people living in cities resulting from natural growth and moderate rural exodus. Secondly, urbanisation concerns areas 


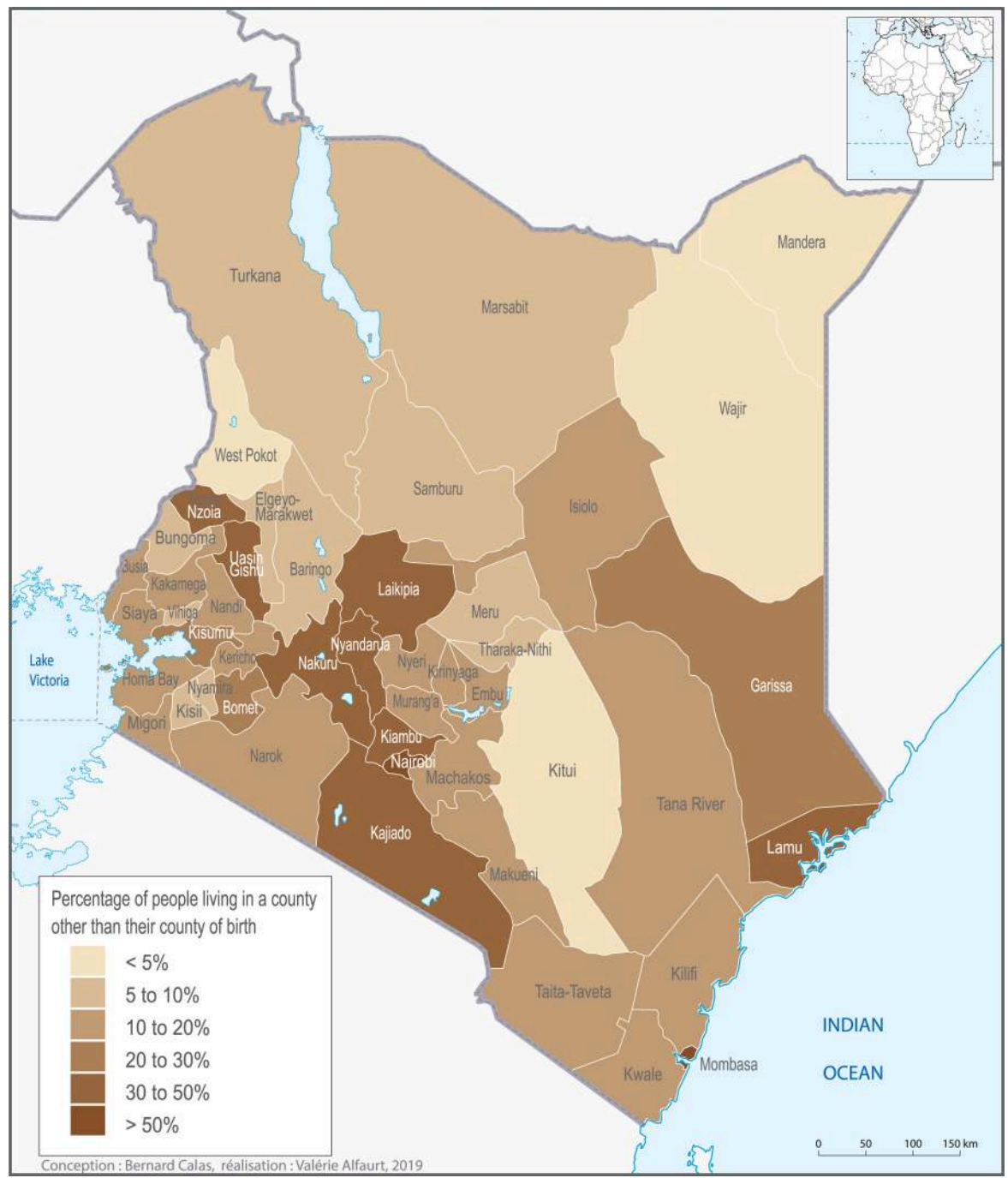

Figure 3. Map of attractive and unattractive counties Bernard Calas, Valérie Alfaurt, 2019.

where the small towns become denser: a large range of activities are taking place in locations that previously were only cross-roads, weekly markets and police stations. The population is also urbanising because of increased mobility and because the ties thus created are "rurbanising" the countryside (Racaud, Nakileza, Bart \& Charlery de la Masselière 2016)-that is, because the countryside is increasingly integrated with the urban world. As a result, the macrocephaly of the urban network is decreasing. 


\section{Second Challenge: Structural Diversification}

This second challenge relates to the analysis of economic activity which, as it is linked to the issue of development, is about the reduction of dependence on primary materials and prices through economic diversification and by moving up industrial value chains, that is to say, through what is well known as "structural transformation."

Table 1. Contributions to GNP and employment by sector and by import/export/investment in GNP

\begin{tabular}{|l|c|c|c|c|c|c|c|c|c|}
\cline { 2 - 10 } \multicolumn{1}{c|}{} & \multicolumn{2}{|c|}{ Agriculture } & \multicolumn{2}{|c|}{ Manufacturing } & \multicolumn{2}{|c|}{ Services } & \multicolumn{3}{|c|}{} \\
\cline { 2 - 10 } \multicolumn{1}{c|}{} & $\%$ GNP & $\begin{array}{c}\% \text { Man } \\
\text { power } \\
\text { (MP) }\end{array}$ & $\%$ GNP & $\%$ MP & $\%$ GNP & $\%$ MP & $\begin{array}{c}\text { Export } \\
\% \text { GNP }\end{array}$ & $\begin{array}{c}\text { Import } \\
\% \text { GNP }\end{array}$ & Investment \\
\hline KENYA 1990 & 30 & 66 & 19 & 7 & 51 & 26 & 26 & 31 & 24 \\
\hline KENYA 2016 & 36 & 61 & 19 & 9 & 45 & 30 & 15 & 23 & 17 \\
\hline
\end{tabular}

Sources: World Development Indicators Database, 3 January 2018.

The relative increase of the share of agriculture in GNP between 1990 and 2016 is surprising as it seems to contradict not only the theories of development that promote structural transformation at the expense of agriculture and profits for manufacturers or service providers, but also ideas that development should rely upon industrialisation, the expansion of the tertiary sector, and de-agrarianisation (Bryceson \& Van Der Laan 1994).

Far from declining in the production of wealth, agriculture is, in fact, progressing even though the GDP is growing by $5 \%$ per year! The concurrent relative shrinkage of agriculture's contribution to employment confirms the improvement of agricultural productivity. However, it is important to remember that in absolute terms, the number of people working in agriculture has increased substantially even though farmlands have not extended in proportion, which implies an actual increase in yields. This joint growth of productivity and agricultural yields underlines the extent to which agricultural transformation is at the heart of the dynamic of growth and development in Kenya.

Some people in the countryside are becoming big farmers and even agrobusinessmen. This transformation takes the intensification route: better crop varieties (but not GMOs yet), more extensive and careful use of inputs, and shorter crop rotations along with more frequent use of small hydropower are all part of this dynamic. This is made possible through the integration of defined areas (terroirs) in a number of national, regional, and global value chains and to the production in Kenya of products with higher added values, notably through the procurement of certificates for selected products. The rise of cash-subsistence crops for urban areas, "the 
supermarket's revolution," the emergence of East African agri-food trade (mainly legumes and grains), the multiplication of shipping contracts for fruits and vegetables to be exported fresh or packaged, frozen or tinned, and horticultural investment all determine the increased value of labour, land, water, and agricultural production. Green beans, mangetout, onions, basil, roses, milk thistle, mangos, pineapples, wheat, corn, chicken, etc. find their way to markets in major cities in Kenya, East Africa, Europe, Russia, Japan, or Arabia, thereby allowing farmers to improve their conditions. This integration has come about through the opening of the localised areas (terroirs) to traffic, contracts, credit, bank accounts, small scale irrigation equipment, cold storage rooms, and to better access to inputs. It is supported by the Kenyan government's proactive strategy to improve its network of agricultural technicians tasked to mercilessly enforce Western importers' prescriptive requirements regarding Maximum Residue Levels ${ }^{2}$ and quality in order to open new markets for export. These commercial and productive reconfigurations complicate technical farm trajectories for which diversification is becoming widespread. They accentuate rural socioeconomic contrasts while favouring the structuring of the countryside into production basins that reduce the Kenyan agricultural geography of agricultural belts. However, the rural socio-economic contrast is not totally eradicated due to the resilience of some localised areas (terroirs) that specialise in coffee production and the successful production of tea.

The time has passed when Kenya's post-colonial economy was dominated by coffee and tea: these two crops represent no more than $30 \%$ of export revenues and this decrease in overall share of production shows the extent of recent diversification and structural transformation. However, the two still play an important role in many farmers' access to cash. Despite pessimistic predictions, coffee has not disappeared, even if it is shrinking around the best-performing coffee factories that play the label card (Barjolle, Quinones-Ruiz, Bagal \& Comoé 2017, 105-119), quality label, and even prestige origin labelling. Above $1,800 \mathrm{~m}$, tea crops have progressed in profiting from high prices and the performance of Kenyan tea.

Thus, far from being homogeneous, Kenyan agriculture has various production speeds: large agricultural holdings with more than 20 ha (27\% of the value of commercial agricultural production)-which were sometimes inherited from the large colonial estates (tea, coffee) or result from recent land investment (sugar cane, market gardening, biofuel)-coexist and compete with commercial farmers often from the cooperative sector or from contract farming; and a multitude of smallholders who combine as much as they can subsistence and cash farming in varied proportions. They often diversify in

2. See European Commission, "Maximum Residue Levels": https://ec.europa.eu/ food/plant/pesticides/max residue levels en [archive]. 
an attempt to escape the hard lot of farmers or smallholders, who often live in the arid or semi-arid borderlands or the hinterlands landlocked by the coast and devoid of the resources of commercial integration such as pluriactivity. Agriculture reflects Kenyan society: fragmented and profoundly unequal. At the same time, it is the most important sector of the economy contributing $60 \%$ of export revenue, and the most important segment of society in that it provides an often poorly paid and precarious living to the majority of Kenyans. Consequently, the economic and social future of the country rests on agriculture. In light of this, agriculture should be the focus of decision-makers and development brokers. This is also why the two most important factors of agricultural production-land and waterare at the heart of Kenya's development issues.

On average, terms of trade are becoming increasingly unfavourable for agricultural products: from the index of 100 in 2001, they fell to 49 in 2016! Only the exacerbation of contrasts and inequalities, within the agricultural sector itself, can at the same time explain the growth of agriculture's contribution to the GDP and the global deterioration of the terms of trade.

Table 2. Evolution of performance of colonial commercial crops

\begin{tabular}{|c|c|c|c|c|c|}
\hline & & & 2006 & 2011 & 1016 \\
\hline Coffee & \multicolumn{2}{|c|}{$\begin{array}{c}\text { Price (KES) for a } 100 \mathrm{~kg} \\
\text { bag at the farm }\end{array}$} & 20,000 & 33,000 & 41,000 \\
\hline & \multirow{2}{*}{$\begin{array}{c}\text { Area } \\
\text { (Hectares) }\end{array}$} & Cooperatives & 128,888 & 85,000 & 88,000 \\
\hline & & Plantations & 42,000 & 25,000 & 26,000 \\
\hline & \multirow{2}{*}{$\begin{array}{c}\text { Production } \\
\text { (Tonnes) }\end{array}$} & Cooperatives & 27,000 & 27,000 & 30,000 \\
\hline & & Plantations & 21,000 & 22,000 & 15,000 \\
\hline & \multirow{2}{*}{$\begin{array}{l}\text { Yields } \\
\text { (Kg/ha) }\end{array}$} & Cooperatives & & 316 & 350 \\
\hline & & Plantations & & 900 & 600 \\
\hline \multirow[t]{7}{*}{ Tea } & \multicolumn{2}{|c|}{$\begin{array}{c}\text { Price (KES) for a } 100 \mathrm{~kg} \\
\text { bag at the farm }\end{array}$} & 14,000 & 27,000 & 24,000 \\
\hline & \multirow{2}{*}{$\begin{array}{c}\text { Area } \\
\text { (Hectares) }\end{array}$} & Cooperatives & 95,000 & 125,000 & 140,000 \\
\hline & & Plantations & 51,000 & 65,000 & 80,000 \\
\hline & \multirow{2}{*}{$\begin{array}{c}\text { Production } \\
\text { (Tonnes) }\end{array}$} & Cooperatives & 191,000 & 218,000 & 265,000 \\
\hline & & Plantations & 120,000 & 151,000 & 207,000 \\
\hline & \multirow{2}{*}{$\begin{array}{l}\text { Yields } \\
\text { (Kg/ha) }\end{array}$} & Cooperatives & 2,225 & 2,037 & 2,084 \\
\hline & & Plantations & 2,700 & 2,953 & 2,908 \\
\hline
\end{tabular}

Sources: KNBS Economic Survey 2011 and 2016. 
Table 3. Change in indices of the main agricultural types of production in quantity and value (index 100 in 2001)

\begin{tabular}{|c|c|c|c|c|c|c|c|c|}
\cline { 2 - 9 } \multicolumn{1}{c|}{} & \multicolumn{2}{c|}{2005} & \multicolumn{2}{c|}{2009} & \multicolumn{2}{c|}{20013} & \multicolumn{2}{c|}{2016} \\
\cline { 2 - 9 } \multicolumn{1}{c|}{} & Quantity & Value & Quantity & Value & Quantity & Value & Quantity & Value \\
\hline Grains & 105 & 109 & 66 & 171 & 98 & 227 & 95 & 213 \\
\hline Sugar & 123 & 95 & 139 & 132 & 146 & 167 & 172 & 169 \\
\hline Horticulture & 179 & 93 & 197 & 106 & 223 & 165 & 277 & 151 \\
\hline Tea/Coffee & 105 & 100 & 101 & 162 & 119 & 218 & 146 & 217 \\
\hline Meat/milk & 150 & 128 & 179 & 147 & 260 & 261 & 328 & 321 \\
\hline
\end{tabular}

Sources: KNBS Economic Survey 2011 and 2016.

Table 4. Exports (weight and value) of cut flowers, fruits, and vegetables

\begin{tabular}{|c|c|c|c|}
\hline \multirow{2}{*}{ Flowers } & 2005 & 2012 & 2016 \\
\cline { 2 - 4 } & $81,000 \mathrm{t}$. & 108,000 & 133,000 \\
\hline \multirow{2}{*}{ Fruits } & 23 billion & 65 billion & 71 billion \\
\cline { 2 - 4 } & $18,000 \mathrm{t}$. & $31,000 \mathrm{t}$. & $50,000 \mathrm{t}$. \\
\hline \multirow{2}{*}{ Vegetables } & 2 billion & 5 billion & 7 billion \\
\cline { 2 - 4 } & $64,000 \mathrm{t}$. & $66,000 \mathrm{t}$. & $80,000 \mathrm{t}$. \\
\hline
\end{tabular}

Sources: KNBS Economic Survey 2011 and 2016.

\section{Landscapes ${ }^{3}$}

Following the increase of human and agricultural development, natural landscapes have practically disappeared and only really exist in protected areas (15\% of Kenya's territory): or, on the decline, they are being eroded by the stubble-burning of charcoal makers in dry regions with low pastoral densities, as for example in the Nyaki desert between Mombasa and Voi, where wood charcoal is a fast, but predatory, path to profit. However, cultivated areas cover no more than $20 \%$ of the territory.

The Kikuyu, Meru, and Embu lands remain the agricultural heart of the country. The commercial orientation of this agriculture is recognised and intensification is at its height. Following the abandonment of coffee plantations, the polycultural diversification of large holdings, their opening to commercial sectors, the involvement of agricultural households in nonagricultural activities, and often polytopic multi-activity have reinforced a multitude of small commercial urban centres linked by genuine linear desakotas along the roads. On a smaller scale, these dynamics form a genuine agro-urban region centred around Nairobi (Calas, 2004): the strategies of

3. See Said, Okwi, Ndeng'e, Agatsiva \& Kilele (2007). 
sectoral or spatial overlapping related to Brownian movements integrate the terroirs into a large area harnessed to the capital city. This homogenisation impedes neither unequalisation between farmers of the same village, nor the emergence of landless farmers, nor the relative specialisation of specific productive basins in terms of physical amenities and technical solidarity.

In the West (Luhya, Luo, Teso, and Kisii lands), crop combinations are very complex and oriented towards subsistence intensification adapted to extremely high densities, to the low scale of land holdings, to the relative poverty of many farmers, and to a lesser integration if compared to the Central Province and its commercial networks. There, people strive to minimise subsistence risks and to diversify farming on smaller and smaller plots by relying on old agricultural know-how and fine-tuning farming. For example, the commonly used corn/sorghum combination allows farmers to prevent their crops from being ravaged by corn borers.

Agroforestry and bocage dominate the highland landscapes. Contrary to the widely accepted perception, trees are spreading, and this is especially true of faster-growing species (grevillea mainly, even if numerous projects expect to restore native trees).

In the lowlands, vast, parched and scrubland, attacked by the axes of charcoal producers and the buckets of diggers highly contrast with the green ribbons of irrigated lands. In between these two extremes, one finds semi-arid regions such as, for instance, in Ukambani or the Tugen region where drillings and wells allow citrus orchards and mango trees to thrive and alternate with traditional pluvial grain farming, often cultivated in terraces (Tiffen, Mortimore \& Gichuki 1994).

However, this agricultural performance does not contradict the growth of manufacturing or services. In these sectors, diversification has occurred, even if it has been partially hidden on the macroeconomic scale.

As the driving force of employment (Twining-Ward, Li, Bhammar \& Wright 2018) and an early diversified sector, tourism has also undergone diversification. The mass tourism of 1970-1980 is now combined with more distinctive kinds of tourism underpinned by a diversification of activities offered, notably Outdoor Physical Activities (Calas 2015). However, being very sensitive to political and security risks, Kenya's international image has suffered due to the Westgate Shopping Mall attack in Nairobi (2013), the attack at Garissa University College, and the Al-Shabaab attacks in the Lamu region (2014). Faced with this situation, tour operators have reoriented themselves to cater to domestic and African tourists. While not a perfect substitute for the previous tourist flows-hotel occupancy rates (6 million overnight stays with capacity for around 20 million) remain notoriously low-they allow hotels to maintain the minimum level of activity necessary 


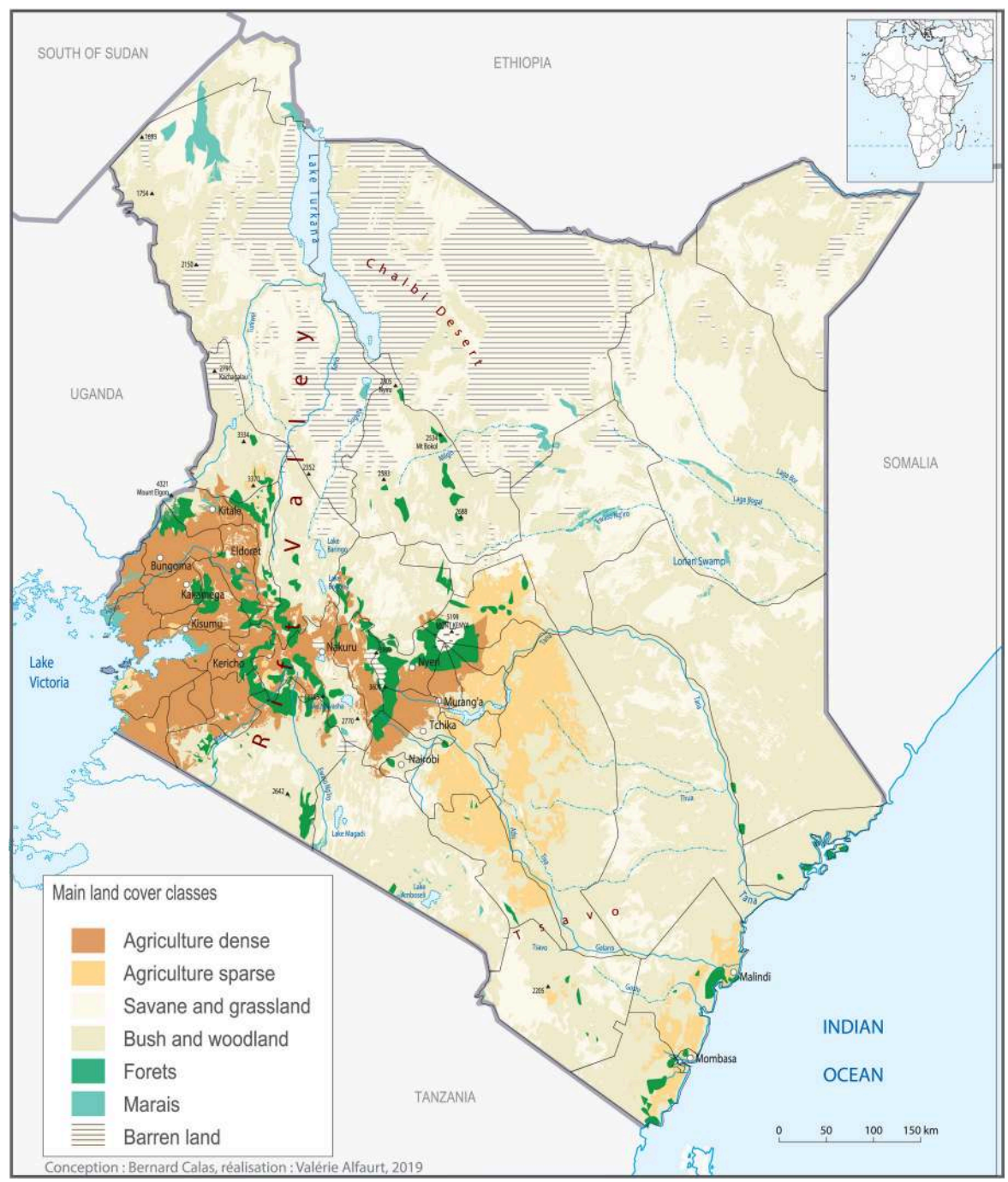

Figure 4. Land use in Kenya

Bernard Calas, Valérie Alfaurt, 2019.

to remain open all year round and maintain tourist infrastructure. However, since 2016, the international situation has slowly been improving.

In terms of the number of guests, tourism is mainly focused on the coast and its white sands, its coconut trees, its turquoise waters, its transparent lagoons, and even its nightclubs-which is typical of a tropical destination; yet, in a less expected way, the capital city is the second destination chosen by tourists. Being a national airport hub but also due to its many conferences and symposiums, Kenya's capital looms large in the country's tourist geography. National parks and animal reserves are only the third 


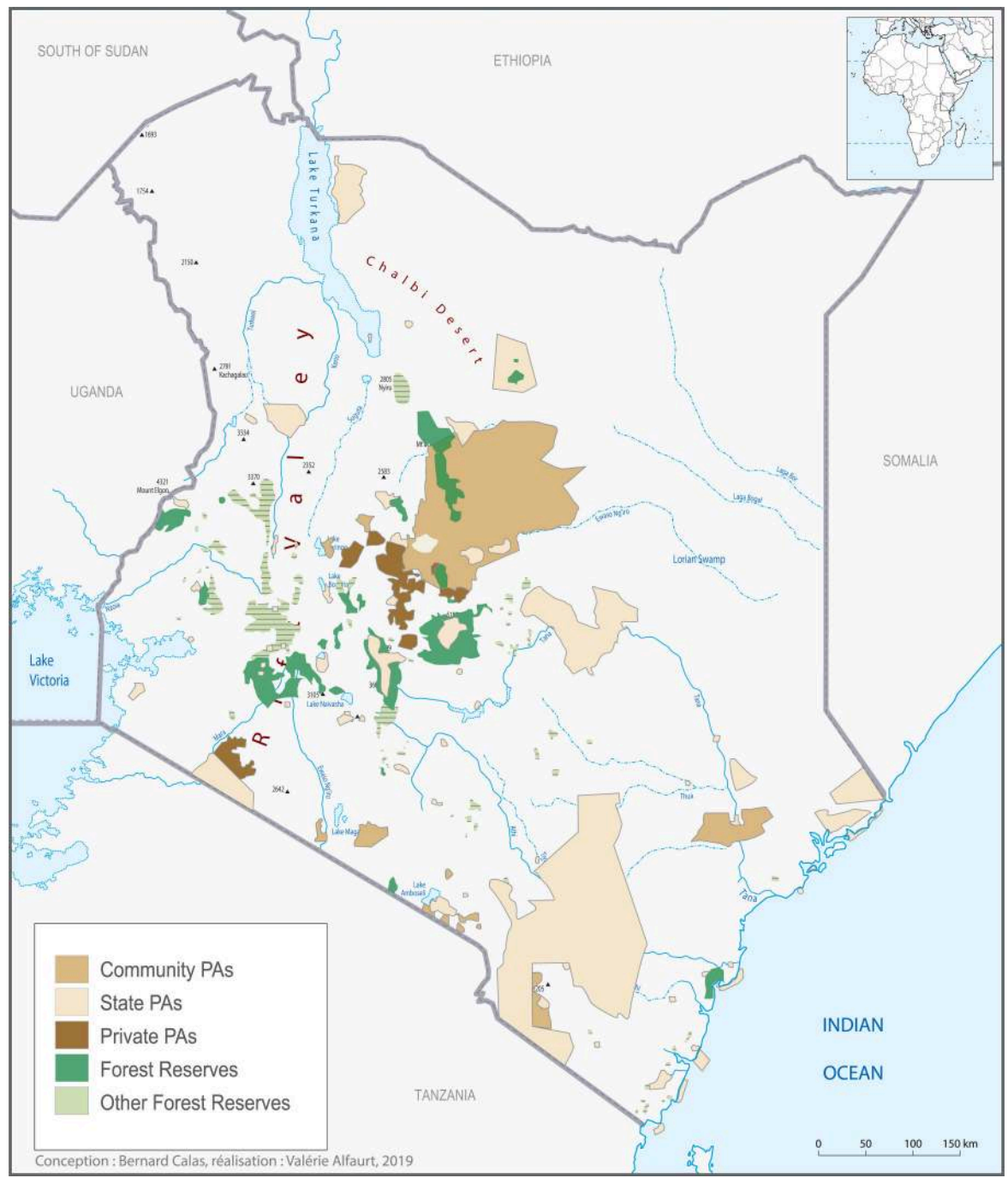

Figure 5. Protected forests and protected animal areas Bernard Calas, Valérie Alfaurt, 2019.

most important destination. Notwithstanding, fauna and nature are the emblem of Kenya as a destination in the international market: they shape tourism and, through it, the country itself.

In the cities, the growing number of malls and supermarkets, the rise in the value of manufacturing, the financialisation of the economy, the relative openness to high-tech industries, to artistic industries, and business process outsourcing, all embody the diversification of the secondary and tertiary sectors. However, they must not-in turn-conceal the informal sector, small scale street vending, handicrafts, domestic work (Lanne 2018), 
recycling, and even petty theft that provide an income to the majority of urban residents. "Coders," the "iHub" teleworking platform, the future "Silicon Savannah" (Johari 2015), French and Chinese investors amongst others, are attracted by the authorities' pro-business attitudes and by the prowess of the "start-up nation." Whilst they delight in trade forums and their employees frequent stylish bars in the city, the majority of urban residents remain concerned about poor employment opportunities, misery and the daily insecurity of "jua kali." Of course, factories have flourished and the road between Jomo Kenyatta International Airport and Nairobi city centre is no more than a succession of warehouses, factories, showrooms, conference centres, and business hotels that employ a significant portion of the population. But the day-to-day workers and subcontractors wander along the edge of the city's roads before dawn and again late in the evening, hoping to save money on public transport by walking. Nairobi appeared in the ranking of global competitive cities $\left(115^{\text {th }}\right.$ out of $120,5^{\text {th }}$ in Africa after Johannesburg, Cape Town, Durban, and Cairo according to the Economist Intelligence Unit in 2012) but many women in Nairobi stand at the roadside selling small piles of tomatoes and onions and their second-hand clothes or plastic Chinese products. In the gaps between the industrial zones, slums like Mukuru-less iconic than Mathare or Kibera, yet all the more squalidare entrenching themselves. Despite their spectacular intrusion into urban landscapes, the notably architectural landmarks of economic success do not change the sectoral power relations that pull more than $80 \%$ of the workers entering the urban labour market into the informal sector and precarious work sector. The rhetoric about the emergence of a Kenyan middle class is over-optimistic and a myth (Darbon \& Toulabor 2014). In effect, if $10 \%$ of the population earns more than 5,000 USD per year, that means that $90 \%$ earns less. A large floating population-with incomes just more than 2 USD per day-has certainly emerged from poverty, yet without reaching middle class. Is that to say that we are dealing with illusory development? How does this make up society?

Beyond the cosmopolitanism of Nairobi and other large cities, urban landscapes display in nuanced ways an increasingly complex social stratification: sheet metal slums, tenement cities of concrete and greyish basalt blocks (Hurzschmeyer 2007), housing developments of semi-detached dwellings, groups of posh buildings, towers, and gated communities are all side by side, separated by walls and railings, by bigger and bigger avenues that receive more and more traffic, urban highways, and bypasses that do not prevent traffic jams but only mitigate the delays.

The classical dynamics of a liberal metropolis govern urban extension. The cleaning of the CBD (Morange 2015, 247-269), the emergence of alternative centralities (Westlands and Upper Hill), segregated urban sprawl, and 
generalised bunkerisation, all suggest a Brazil-type metropolisation, as far as urban mega-projects are plenty (Saraswati 2014), such as the new Tatu City (built on old coffee plantations on the initiative of an investment fund) or the Two Rivers Mall that hosts a Carrefour hypermarket. The role of China in a massive 800-million-dollar real estate project bolsters this idea of Nairobi's liberal metropolisation. These urban megaprojects embody to the extreme the growing gap between the often-closed-minded visions which are occasionally realised in the form of localised enclaves, and the ordinary reality of the majority of Nairobi's inhabitants (Watson 2013, 215231; Jaglin, Didier \& Dubresson 2018).

This economic diversification goes together with a reorientation of customers and suppliers. As Europe becomes less dominant, and the countries of the sub-region and COMESA become important commercial partners, Asia, now represents half of the imports (notably petroleum products from the Gulf and manufactured goods from China and India).

Table 5. Commercial deficit and commercial balance in 2016

\begin{tabular}{|c|c|c|c|}
\hline \multicolumn{2}{|c|}{ Exports 500 billion KES } & \multicolumn{2}{c|}{ Imports 1,400 billion KES } \\
\hline Tea & 120 & Oil & $183(300$ in 2014) \\
\hline Flowers & 110 & Animal fats & 53 \\
\hline Textiles & 30 & Plastics & 60 \\
\hline Coffee & 21 & Machines & 253 \\
\hline Titanium & 11 & Vehicles & 85 \\
\hline Tobacco & 14 & & 60 \\
\hline Medications & 13 & $\begin{array}{c}\text { Pharmaceutical } \\
\text { products }\end{array}$ & 75 \\
\hline Steel & 13 & Steel & \\
\hline
\end{tabular}

Source: KNBS Economic Survey 2011 and 2016.

Table 6. Direction of Trade in Kenya

\begin{tabular}{|c|c|c|}
\hline & Exports & Imports \\
\hline Africa & $40 \%$ & $10 \%$ \\
\hline Europe & $25 \%$ & $20 \%$ \\
\hline Asia & $25 \%$ & $\begin{array}{c}66 \% \\
\text { (China 25\% of total imports) }\end{array}$ \\
\hline Other & $10 \%$ & \\
\hline
\end{tabular}

Sources KNBS Economic Survey 2011 and 2016. 


\section{Third Challenge: Environmental Sustainability in a context of Pressure on the Environment}

Combined with the growth of the population, these geoeconomic changes require the intensification and broadening of exploitation activities, even putting pressure on the environment in order to increase productivity. This concerns not only the surface but also the substrate, that is to say, the subsurface and the lower atmosphere. Productivity beyond environment limits necessitates drilling, catchments, levelling of the ground, the installation of pylons and antennas, the laying of cables and pipes, the construction of dams, of electricity grids, which are all signs of the increasing anthropisation of the environment. However, for the last thirty years, the paradigm of sustainability has been imposed on the world's development agenda, which means that increasing productivity should ideally be "eco-economic friendly." The question is therefore no longer to describe the environment as such but to focus on exploitation operations and the relationship between humans and their environment, as well as the tensions that these relationships stir up, considering also the regulations that target them.

Decision-makers, environmental lobbies and the civil society worry about deforestation and its effects, the reduction of wild fauna, the erosion of biodiversity, the increasing risks of, most notably, floods and erosion, and generally the accentuation of the negative externalities of Kenya's development. This is why, in the wake of the Brundtland report (World Commission on Environment and Development 1987), environmental requirements were imposed on development projects and programmes in Kenya like in the rest of the world. In the South, Socio-Environmental Impact Assessments (SEIA) became widespread, environmental clean-ups or at least their monstration were made obligatory to the point that the environmental concern is no longer limited to conservationist circles, but permeates the entire economy.

Of course, the common classification produced by the "tropicodevelopmentalist" ideology of the 1950s-1960s that distinguished nine agro-ecological zones by combining physical diagnostics and agricultural objectives is still relevant to understand the country. However, it must be pushed further by observing the physical potentialities and the ways these are turned into commodities, and then into resources. This trend is brought about by the increase of needs caused by the combined pressure of demographic and economic growth. The top commodities converted into resources are water, fossil fuels, renewable energy sources, biodiversity, and mineral matter. For the last 30 years, they have been-and continue to be-the central issues of Kenyan development. Today they point to its 
contradictions and tensions even more significantly-or perhaps more explicitly-than before. The result is that a certain number of places with these potential resources are becoming "eco-economic" hot spots and concentrate some of Kenya's geopolitical issues.

The whole of Kenya suffers from water scarcity as its renewable water resources amount to less than $1,000 \mathrm{~m}^{3}$ per person per year (Bates et al. 2008, 93-94). As a consequence, hydrous potentials have become important issues and hydro-political hot spots. The most important of these hot spots are the country's "water towers," that is to say, the major mountainous ranges: Mt Kenya (5,199 m), Mt Elgon (4,321 m), the Mau Forest and the Aberdares (4,000 m), and the Cherangani Hills (see also Rouillé-Kielo in this volume). These ranges where it rains more and more often than elsewhere (2,300 $\mathrm{mm}$ at 2,000 metres high on the southeast face of Mt Kenya) have bogs and forests that, like sponges, slowly release water, supporting the flows of springs and rivers that diverge from them. Deforestation and land clearing, therefore, impact the water balance of these mountains by diminishing retention efficiency, even though total rainfall may increase. As a consequence, the rivers originating from these mountains, their high and low water patterns, as well as lakes, have become a centre of attention and controversy, of debates and passionate polemics. Yet, the trend has returned to hydroelectric dams that also create irrigation reservoirs for downstream agricultural areas (Tharaka Dam) and the large flat areas that border them are coveted by large property developers (Leauthaud et al. 2013).

From the Sahara to the United States, deep fossil aquifer exploitation has also become common. How would Kenya escape this trend? The discovery of the Lotikipi basin aquifer in northern Turkana has thus been a windfall for the people in a region that is regularly threatened by droughts but also-but less publicised-by the disastrous effects of the construction of Ethiopian hydroelectric dams in the Omo valley. ${ }^{4}$ Even more discretely, it certainly serves as a windfall for the oil companies that will need large volumes of water to extract oil in the depths of Lake Turkana (see more below). ${ }^{5}$ Kenyan hydro-politics are particularly heated and conflicts around water resources are multiplying, constituting an especially pertinent part of the analysis of power relations (Rouillé, Blanchon, Calas \& TempleBoyer 2015). The conflicts about the usage of water from Lake Naivasha

4. Since 2015, hydroelectric and hydraulic initiatives in the Ethiopian Omo Valley have lowered the water level of Lake Turkana by over 1.5 metres and this will likely occur again, reducing the surface of the lake in the areas with the most fish (Human Rights Watch -14 February 2017). This could turn Lake Turkana into an African Aral Sea just as giant agricultural projects such as Give IV (the largest dam in Africa) and Give V are being built.

5. 4/5 barrels of water are needed to produce a barrel of oil. 


\section{The Large Gaps in Development in Kenya}

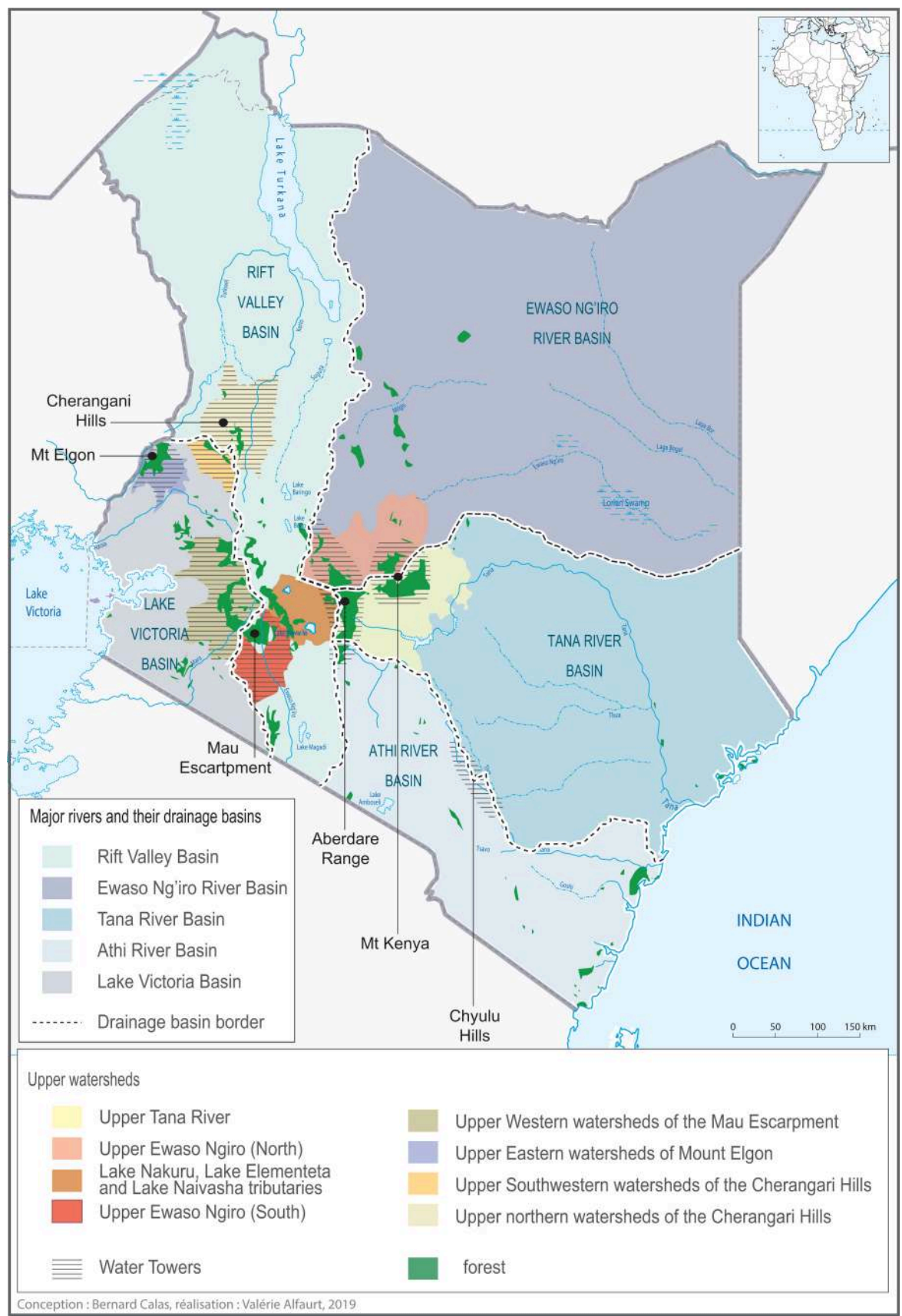

Figure 6. The physical base and its "eco-economic friendly" commodities Bernard Calas, Valérie Alfaurt, 2019. 


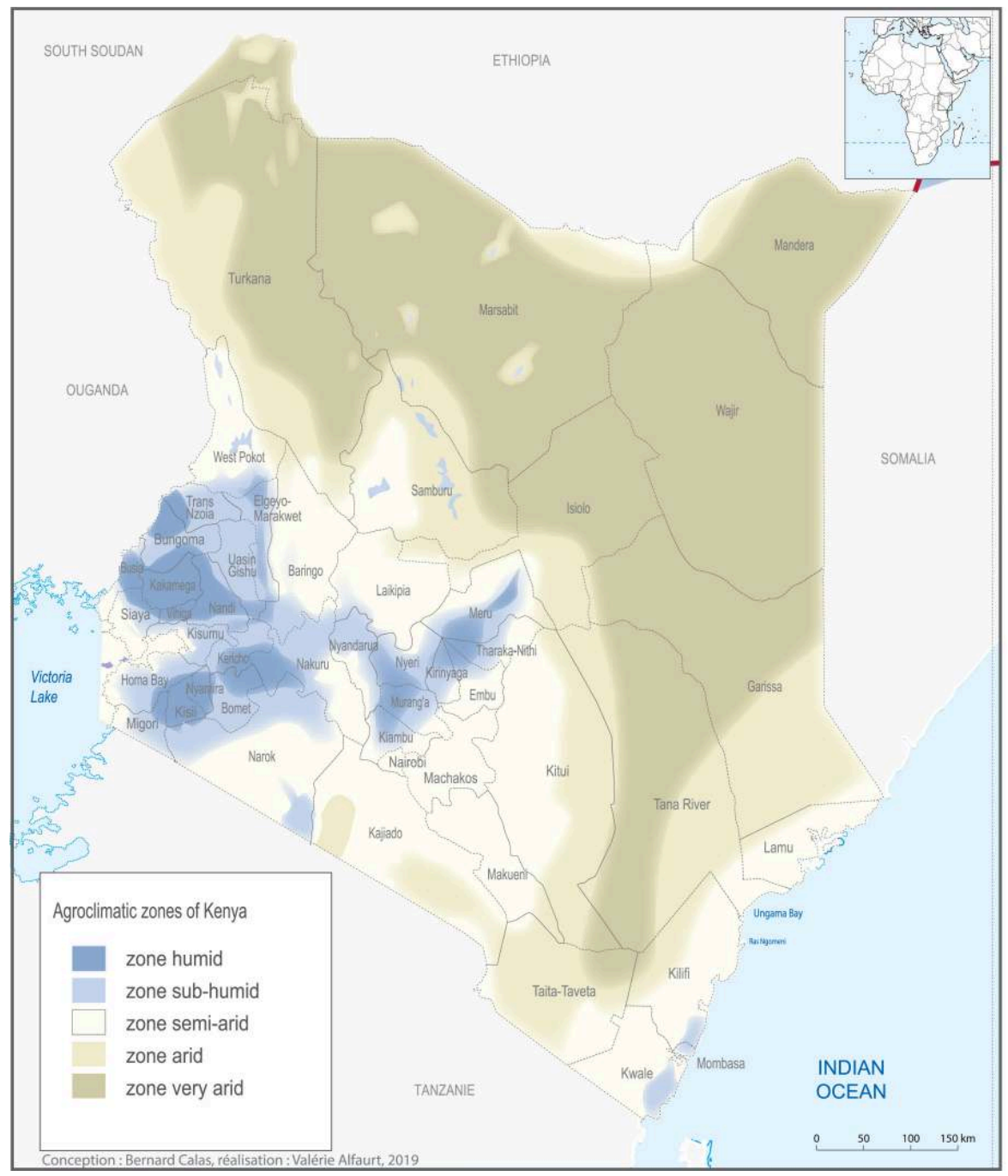

Figure 7. The agro-ecological zones

Bernard Calas, Valérie Alfaurt, 2019.

and Lake Baringo and the conflicts between residents living upstream or downstream of the Ewaso Ng'iro or Tana rivers, are textbook cases of a myriad of hydro-political conflicts.

Towards a Green Kenya? The Energy Problem and the Electricity Mix The growth of energy needs requires an increased use of energy resources that punctuate the country's geography with extraction and exploitation sites. In effect, the growing pressure of needs combined with the diversification of technical capabilities is transforming certain aspects of 
the environmental resources which a short while ago were considered to be of no interest. As with most African countries, energy is chief among the preoccupations of decision-makers such as investors. Investment experts point to the Kenyan electricity sector as a growth market, ranked $4^{\text {th }}$ on the continent (Havas Horizon 2016). The objective is to increase electrical production to 15,000 megawatts in 2030. Rivers and streams coming down from the mountains, hot gases escaping the bowels of the Rift, the consistency and regularity of trade winds and sunshine, all allow Kenya to use clean electricity, which is relatively innovative on a world scale. In effect, $80 \%$ of electricity is produced thanks to renewable sources, topped by hydroelectricity, mainly from the upper and mid Tana, that provides at least $40 \%$ of the 2,200 megawatts produced, followed by geothermal energy (30\% of the Kenyan electricity mix) (Berggren \& Österberg 2017).

Having innovating in the Hell's Gate site for more than 30 years, Kenya is now one of the world leaders in geothermal energy behind Iceland. Following the example underway in the Akira Valley near Naivasha, 14 sites are spread along the Rift Valley that must increase geothermic production to $10,000 \mathrm{MW}$.

Another path being explored is wind energy. In effect, the country has found itself with a major site for producing this kind of energy: the eastern bank of Lake Turkana. There, strong winds gust through the topographic threshold between the Kenyan highlands and the Ethiopian highlands before further accelerating thanks to the adiabatic effect of the vast heated body of water of Lake Turkana. Regular strong winds blow for years, constituting an amasing potential energy source (3,000 megawatts) in the process of being developed as a wind farm with a capacity of 310 megawatts as already been built in Loiyangalani.

The last path to increase renewable electricity production is solar. Of all energy sources, solar is the most versatile as it can combine two different approaches and technical options: large and small solar farms, and individual solar panels. When combined, these two types of production can help even out investments in energy grids by responding to the industrial and urban demand and connecting regions and even off-grid households. The state has shown that it understands the importance of this energy source when it required that all buildings that use more than 100 litres of water per day be equipped with solar water heaters. Private individuals, even in the depths of the jungle, can follow Premier League matches thanks to ingenious devices made from batteries and solar panels.

However, electricity is not synonymous with energetics and it must not be concluded from its rather virtuous energy mix that Kenya is in the process of becoming a green economy. Although it banned the export of wood charcoal in $1975,70 \%$ of households still cook over wood fires using, on average, 
between 1.4 and $2.4 \mathrm{~m} 3$ of wood charcoal per year which has contributed to accelerated stubble-burning and deforestation. Furthermore, they still largely light fires with paraffin wax which further increases greenhouse gas emissions. This nuance reveals the extreme discrepancy between, on the one hand, a modern society and economy connected, to some small extent, to globalisation and, on the other, the marginal majority of people who still make up Kenyan society and economy. Apart from such inequity, the current energetic model still has several weaknesses, notably because industrial growth and the increasing number of vehicles have caused oil imports to increase by $6 \%$ between 2004 and 2014 . Moreover, fluctuating rainfall affects the level of dams and directly weakens the electricity supply of cities and industries. The resultant recurring power outages slow investments and at any rate cause over-expenditure for entrepreneurs.

In the days of the "Anthropocene" and the " $66^{\text {th }}$ extinction," and as tourism brings in more than $20 \%$ of the country's foreign currency reserves and contributes around $12 \%$ of its GDP, the protection of biodiversity has become a common refrain, a requirement, and a major issue. This explains why there are plenty of associations, lobbies, and interest groups that, in the name of that imperative, are working towards the protection of an emblematic animal, an exceptional place or even a specific habitat. To this day, the preferred spatial arrangement to achieve this goal remains the protected area, whether it is public (50\% of Kenyan protected areas), private (25\%), or communal (25\%). The animal archipelago was formed in three phases: the colonial phase (1945-1963) and the post-colonial phase (1970s) that both created Kenya's public patrimony ( $90 \%$ of wildlife tourists and $75 \%$ of revenues), then a third phase, starting in the 1980s and especially in the 2000s, during which large landowners and pastoral communities transformed their lands into conservancies. This recent dynamic is as important in terms of biodiversity as it is in terms of territorial organisation since it has allowed for the extension of protected areas as only $35 \%$ of fauna is protected within the limits of public areas (National Parks and National Reserves).

Moreover, most of the new protected areas are located in the arid and semi-arid regions where $20 \%$ of the population (and incidentally $80 \%$ of the livestock) reside, often in poverty. Conservation, if well managed, can constitute an economic alternative for these people. In these regions, we note therefore an almost paradoxical change in the growing besiegement of protected areas, but also their extension. Emblematic of this change: the Laikipia Plateau (Evans \& Adams 2016), the surroundings of the SamburuShaba, Amboseli, the Masai Mara and the northern mountains between Maralal and Marsabit. Vast areas combine pastoral activities and wildlife tourism, but the monotony of the savannah conceals the signs of land property. 
The viability of fauna in protected areas rests on three conditions: rejuvenation of the fauna gene pools in these increasingly beleaguered areas, incentive plans for conservation targeting neighbouring populations, and the establishment of collective governance that subsumes state and institutional land fragmentation. In short, the main issue at stake is integration of wildlife isolates into a territorial archipelagic system. The emergence of a wild fauna market to transport animals from one reserve to another, the efforts to turn the large mammals migratory corridors into sanctuaries, and the scientific and political networking of the conservancies all aim to try to resolve the contradiction between the necessity of crossfertilisation to ensure the renewal of the gene pools of these areas, and the growing isolation of these areas that reduces the scope of local biodiversity. They also aim to act as a political lobby capable of influencing ad hoc local collectives, county-level institutions and the state, whose preoccupation with development sometimes contradicts the necessity for environmental conservation.

\section{A Rentier Future?}

Since the mega-cycle of raw materials of the 2000s, all over the world, multinational oil and mining corporations-often with governmental blessing-have increased the number of explorations and investments in extractive industries, leading to the exploitation of more deposits. For now, the raw materials sector remains minor in Kenya. Even if titanium from Kwale and gold from the minor deposits in Transmara are added to the salt that has long been extracted from Magadi (mostly for the Japanese optics industry), Kenya is nothing like a rentier state. However, things could change, radically, due to the 1992 discovery of oil reserves in Lokichar in South Turkana (Augé, Nkayi \& Médard 2013). The recoverable oil resources are valued at 750 million barrels and their exploitation is considered viable at 55 USD per barrel. In January 2018, after several years of diplomatic dithering, the exploitation of the Turkana reserves was relaunched. The geopolitical crises in Venezuela and Iran have increased the price per barrel back over 50 USD, Tullow has announced profits, and in April 2018, Total joined the project. This operation has accelerated the pre-exploration phase of Turkana's oil field. Furthermore, "Total has confirmed its commitment to make the Lokichar-Lamu pipeline the only method of delivery of crude oil in Kenya from Lokichar fields" (Le Point 2018). The Turkana operation should, therefore, begin production at the start of 2022, after the completion of the $700 \mathrm{~km}$ pipeline linking each production unit to the coast. Kenya could then become, for better or worse, a rentier state!

The whole of these operations produces a planting of variable sized but territorialised enclaves that, together, accentuate one of the major 
geographic characteristics of the country: its fragmentation. Yet, this is coupled with another contradictory dynamic: a dynamic of integration brought on by the need for the connection of these extractionary enclaves to meet growing globalisation.

\section{Fourth Challenge: Multiscale Integrations, Construction of the State, and National Solidarity}

It is not sufficient to produce, exploit, and extract resources. Distribution, allocation, and commercialisation are also necessary for techno-commercial networks. Yet, these are Kenya's weak points-which is typical of developing countries.

Despite appreciated progress with regards to the economic environment, investors continue to point out the recurrence of outages and load shedding as a weakness (World Bank 2019). Progress in production is not yet sufficient. As such, the wind farm already in place in Lonyangalani serves no purpose for the moment since the electrical lines that carry current to consumers have not been installed! Once again, we see a white elephant.

But beyond these setbacks, logistical integration is progressing. The road network is expanding and strengthening thanks to the East African Community along with multilateral and bilateral donors, Chinese among others. The widespread asphalting of roads, the inroad of motorway and peripheral bypasses, the construction of fly-overs and other massive roundabouts improve traffic flow, reduce congestion, and promote national integration.

Further, new technologies that Kenyans have quickly adopted (67\% regularly use the internet and $89 \%$ have a mobile phone plan) are intensifying the links between areas, promoting polytopism and contributing to integration. At the global scale, the country has innovated by experimenting, since 2007, through the M-Pesa system, with electronic transactions to the point that today, half of the GDP moves through this channel and twothirds of the population would use money kiosks to deposit and transfer money. However, even as $60 \%$ of the population has an account, at the same time, $80 \%$ does not have access to mortgage lending.

Since the 1990s, the acceleration of globalisation has reinforced integrative dynamics and a complex interdependence between the states of the world. On the East African scale, they are reinforcing Kenya's integration with its subregion. For the last 30 years already, the country's economy has relied upon transit activities, focusing on the pivotal role of the MombasaNairobi-Busia/Malaba corridor for the subregional geography (220 million people). This corridor has been strengthened: The railway has been rebuilt, the Mombasa-Kisumu pipeline is being modernised, and the Mombasa- 
Nairobi high-voltage power line has been built. The road is regularly resurfaced (Porhel \& Léon 2013) and the links between the coastline and the continental hinterlands have been considerably improved. Today, this corridor still serves as the backbone of the country and in 2012, $91 \%$ of GDP was produced within $100 \mathrm{~km}$ of it. The volume of goods that passes through Mombasa comes close to 30 million tonnes (10 million tonnes in 2003), which makes it the second largest port in sub-Saharan Africa and more than 700 lorries cross the Ugandan border at Malaba each day.

Globalisation has also tightened links between Kenya and its Ugandan and Tanzanian neighbours. For 20 years, the institution-building of the East African Community has laid the foundation for a "New East Africa" (Fouéré \& Maupeu 2015), which materialised in the construction of the NamangaTaveta border checkpoints, the largest connection with the Tanzanian and Ugandan road networks. On the regional scale, the flow of goods and peopled has been reinforced while certain tariff and customs barriers have been eliminated. Since 2005, the Machakos Protocol for peace agreements has permitted the extension of Kenyan commercial and banking networks towards Juba and South Sudan, networks that are dormant today due to the civil war, but are real, nonetheless (Calas, Racaud \& Torretti 2016). Likewise, in the north, the interconnections of electric grids and asphalt-coated road networks are integrating Kenya with the sub-region's other dominant economy: Ethiopia. Finally, since 1990, the Somali crisis and its surges have intensified Somali investment in Nairobi, the city thus becoming the "Global Somali Hub." The boom of Eastleigh-Nairobi's Little Mogadishucan be explained by the convergence of three factors on different scales: the strength of transnational Somali networks, the momentum of the Kenyan economy and housing market, and the emergence of Asia as the world's factory (Carrier 2016). Furthermore, the Somali crisis has allowed the Kenyan economy to continue to profit from humanitarian operations.

This integration is increasing towards a very dynamic and populous East African space (220 million people), the opening of the southern borders of countries of the Horn and the rise in traffic have imposed the modernisation of new infrastructure on the coast. In Mombasa, the port's capacity has been increased thanks to the construction of a new container terminal of 450,000 TEU. In the north, the digging of a new deep-water port is creating a new development corridor, from Lamu to the north-western borders and beyond, to South Sudan and Ethiopia: the famous LAPSSET (Coloma 2013; Fouéré \& Maupeu 2015; see also Maupeu in this volume). In this context, Isiolo, $400 \mathrm{~km}$ further west, is thought of as a junction between this corridor and the Nairobi-Addis road (Pan African Highway). Currently planned are 6,500 acres for a new seaside resort, a new dam on the Ewas 
Ngiro, a slaughterhouse with a capacity of 400 heads of cattle per day, and an international airport.

This infrastructure and these projects demonstrate the importance of major works and especially the large corridors of opening-up, the growth of "eco-economic" approaches harnessed to development rhetoric, and the legitimisation and funding of the elites. In 2017, President Uhuru Kenyatta and his Vice-President William Ruto campaigned on the finalisation of large infrastructure projects, such as the Nairobi-Mombasa train line. Cooperation with China was cast as a major success of Kenyatta's presidency, underlining the link between land use policy, territorialisation of the state, and electoral politics.

Integration in globalisation is noticeable in the balance of payments in a rather ambivalent way. The remittances of emigrants represent the secondlargest source of foreign currency growing from 139 million USD in 1990 to 1,700 million USD, $3 \%$ of the GDP. ${ }^{6}$ The growth of FDI to 400 million USD from 57 million USD in 1990 underlines the increasing attractiveness of the country for globalised investors. However, aid remains at a high level at 2,200 million USD (compared to 1,181 in 1990) and demonstrates how much the country still depends on aid. Likewise, as debt servicing has diminished (falling from $36 \%$ to $10 \%$ of exports), the public debt has exploded, now representing more than half of GDP and Chinese lenders now more than $3 / 4$ of the creditors.

Beyond this economic, financial, logistical, and multiscale territorial integration, the question is now how the benefits of growth are being distributed. In effect, it is through redistributive mechanisms, notably taxation, land use planning, and the sharing of powers between different administrative layers, compounded by decentralisation in 2013, that draw on contours of national solidarity as well as the effectiveness of nationbuilding thanks to the windfall of economic growth. This question is obviously an excuse for debates and intense bargaining, on different scales, between different actors.

One of these debates between foreign corporations and the government revolves around the corporate tax rate. The rate envisioned by the government, between 30 and $37.5 \%$ of capital transactions, is evidently thought to be too high and prohibitive by oil companies and generally by private corporations in all other sectors. In this way, plans to tax horticulturalists have provoked an exodus towards Ethiopia, fiscally the lowest bidder. Another debated point is the nature of taxation. Should

6. As opposed to emigrants in other African countries such as Morocco, Kenyan emigrants do not represent a significant part of the populations (500,000 people are less than $2 \%$ of the population) but their remittances are an important part of the nation's accounts. 
capital transactions or transactions in the financial market be taxed? The government favours the latter (5\% instead of 30/37\%) since corporations have an incentive to go public, which would have the collateral effect of energising Nairobi's stock exchange.

Furthermore, in the context of the stabilisation of rules surrounding the 2010 Constitution and the decentralisation of 2013, a second level of discussion pits the central government, the county governments, and productive municipalities against each other. It seems that for the moment, tax sharing is favourable enough to the intermediate level of the counties. Does this mean it will be good for citizens? Won't it be better for local notables and potentates?

More or less, these debates on the allocation of the benefits of growth also find themselves in the conservationist sphere. How do populations engage in animal conservation and how are they rewarded for their agreed efforts? Around Masai Mara, conservancies are managed on the basis of contracts between traditional landowners and tourism investors. The latter pay between 37 and 50 USD per hectare, per year, for 10 to 15 years. Even if this system solidifies the land monopolisation established by Masai elites when communal lands are subdivided, it improves local population's perception of fauna and no doubt of the sustainability of its protection and development as a tourist site. However, they now wonder about the identity of the representatives of these famous "local communities" and the borders of these "communities" themselves.

These tensions about sharing the benefits of growth and about political representation form the context in which a localised civil society is emerging. This civil society use these questions as opportunities to engage with debates that point to national and even international integration. Local elites and intermediary bodies are taking full advantage of their abilities to mobilise their zealots or external support to pressure companies and the central government in view of gaining access to the benefits of predation. Thus, in 2013, Turkana notables incited young people to pillage the Tullow oil exploration sites. Still, in 2013, it was in the forest of Arabuko-Sokoke in Kilifi county that local authorities successfully limited oil explorations by invoking their Unesco biosphere reserve. The following year, in 2014, the notables of the Kerio Valley organised protests to demand that the government hand over the communal property titles for the explored lands as a precondition for seismic exploration. This is only a common, localised process through which civil society, gathered around its notables and NGOs, is claiming a less unequal share of the fruits of exploitation. 


\section{Conclusion}

Malthus or Boserup, who will Kenya prove right? This paper illustrates few certainties as the reality of the situation offers us with as many reasons to be optimistic about the future as to make us worry. How do we reconcile Nairobi and the aridity of the North-East; how do we keep in mind Mukuru next to Muthaiga; how do we put together so disparate pieces of the Kenyan puzzle as the hyper-populated terroirs of Vihiga and the Laikipia ranches? How can we consider the decentralisation of the 47 counties and the simultaneous reinforcement of presidentialism? Kenya seems to be caught between large investments and small ventures, between devolution and recentralisation, between the myth of a middle class, even one of new millionaires ${ }^{7}$ and despite a slow decline, the persistent spectre of extreme poverty (see Thibon in this volume). How do we critically report growing territorialisation but do justice to an ever-grander aspiration for more effective spatialisation (Jaglin 2007)? Indeed, if national integration is progressing well, territorial inequalities have not disappeared, and the reverse even seems to be true.

The Coast seems to be the archetype of a more difficult region. The poverty rate there is $13 \%$ higher than the national average and only $38 \%$ of its inhabitants hold an ownership title compared to $62 \%$ for the rest of the Kenyan population. Politico-religious turmoil, economic frustrations, trafficking and mafia investments are the fertile ground for constant tensions ready to ignite at the slightest incident (see Willis and Mwakimoko in this volume). The northern coast and its hinterland (Garissa, Tana, and Lamu) have been especially impacted by incursions by Al Shabaab (Mpeketoni, 60 dead near Lamu-15 to 17 June 2014); interethnic insecurity is controlled through curfew. The Coast does not have a monopoly on tensions and interethnic violence may soon resume elsewhere, notably during elections when leaders wield identities for political ends, such as in Isiolo and Marsabit counties during the 2017 election campaign or in Laikipia, Uasin Gishu, or Elgeyo Marakwet when concurrent appetites for land collide, or shepherds and farmers confront each other. This violence especially affects the arid and semi-arid outskirts of the country that are unsafe, have been marginalised for a long time, and are subject to shifta and other cattle raids. Devolution, large projects, mining and oil prospecting, foreign investments, land allocations generally monopolised by highland residents or urban elites, and identity vexations stir resentment and can

7. With a value of 500 million USD in 2016, Kenya is the second largest luxury market in Africa behind only South Africa (2.3 billion USD) (The Wealth Report 2017, Knight Frank Johannesburg) and has the $4^{\text {th }}$ highest number of millionaires in Africa after South Africa, Egypt, and Nigeria and will attain $3^{\text {rd }}$ place in 2026 with about 17,000 millionaires. 
threaten the stability of these regions and can even impact on the stability of the whole country.

In contrast, in 2007, the World Economic Forum ranked Kenya 10th out of 29 African countries using the criteria of global competitiveness. It showed that Kenya has the characteristics of an economy in transition between an economy dependent on commodity prices and global business cycles, and an economy based on innovation thanks to a qualified labour force, an innovative financial sector, and a green energy mix. Kenya is in the process of harvesting the fruits of its former investments in higher education.

Twenty years ago, I concluded with the idea that the Kenyan development model was tired. Since then, it has shown a certain degree of longevity that demonstrates its resilience. Should we conclude today that this model is a deceptive development model or, alternatively, an emerging development model?

\section{Bibliography}

Augé, Benjamin, Rose Nakayi, Claire Médard. 2013. "Eastern Africa: A New Oil and Gas Frontier." Nairobi: FRS \& IFRA - Observatoire des Grands Lacs en Afrique. http://horizon.documentation.ird.fr/exl-doc/pleins textes/ divers14-03/010061098.pdf.

Barjolle, Dominique, Xiomara Quiñones-Ruiz, Monique Bagal, and Hermann Comoé. 2017. "The Role of the State for Geographical Indications of Coffee: Case Studies from Colombia and Kenya." World Development 98: 105-19. https://doi.org/10.1016/j.worlddev.2016.12.006.

Bates, Bryson, Zbigniew W. Kundzewicz, Shaohong Wu, and Jean Palutikof, eds. 2008. "Climate Change and Water. Technical Paper of the Intergovernmental Panel on Climate Change." Geneva: IPCC Secretariat. https://www.ipcc.ch/publication/climate-change-and-water-2/ [archive].

Berggren, Anna, and Sara Österberg. 2017. Kenya Meeting the Electricity Demand of 2030: An Assessment of How Kenya Vision 2030 and Climate Change Impact the Optimal Electricity Generation Mix. Bachelor Dissertation. Stockholm: KTH School of Industrial Engineering and Management Energy Technology Stockholm [archive].

Bryceson, Deborah Fahy, and Corina Van Der Laan. 1994. "Deagrarianization in Africa." In Proceedings of the De-agrarianization and Rural Employement, Leiden: Afrika-Studie Centrum.

https://doi.org/10.1016/0305-750X(95)00119-W.

Calas, Bernard, Sylvain Racaud, and Charlotte Torretti. 2016. "Les relations commerciales Ouganda-Soudan du Sud à l'épreuve de l'implosion du SudSoudan.” Observatoire pluriannuel des enjeux politiques et sécuritaires dans la Corne de l'Afrique, note no. 18. Pessac: Sciences Po Bordeaux-Les Afriques dans le monde. https://halshs.archives-ouvertes.fr/halshs-02386835 
Calas, Bernard. 2015. "Activating the Interactive Landscape: Diversification in Kenya's Wildlife Tourism Industry.” Dynamiques environnementales 35: 204-25. https://doi.org/10.4000/dynenviron.1211.

Calas, Bernard. 2007. "Dynamiques métropolitaines d'Afrique orientale." Cahiers d'Outre-Mer, no. 237: 3-22. https://doi.org/10.4000/com.624.

Carrier, Neil. 2016. Little Mogadishu: Eastleigh, Nairobi’s Global Somali Hub. London: Hurst Publishers.

Chkam, Hakim. 2016. "Aid and the Perpetuation of Refugee camps. The Case of Dadaab in Kenya 1991-2011.” Refugee Survey Quarterly 35, no. 2: 79-97. https://doi.org/10.1093/rsq/hdw005.

Coloma, Tristan. 2013. "En attendant le port qui doit sauver le Kenya...” Le Monde diplomatique, no. 709: 13. https://www.cairn.info/magazine-lemonde-diplomatique-2013-4-page-13.htm

Darbon, Dominique, and Comi Toulabor (eds). 2014. L'Invention des classes moyennes africaines. Enjeux politiques d'une catégorie incertaine. Collection "Hommes et sociétés." Paris: Karthala.

Evans, Lauren A. \& Adams William M., 2016. "Fencing Elephants: The Hidden Politics of Wildlife Fencing in Laikipia, Kenya." Land Use Policy 51: 215-28. https://doi.org/10.1016/j.landusepol.2015.11.008.

Fouéré, Marie-Aude, and Hervé Maupeu. 2015. "Une nouvelle Afrique de l'Est ? Introduction thématique." Afrique contemporaine no. 253: 13-35. https://doi.org/10.3917/afco.253.0013.

Grignon, François, and Gérard Prunier (eds). 1998. Le Kenya contemporain. Paris: Karthala.

Havas Horizon. 2016. Financer la croissance africaine à l'horizon 2020 : perception des investisseurs internationaux, August. https://knowledge. uclga.org/Financer-la-croissance-Africaine-a-l-horizon-2020-Perceptiondes-investisseurs.html [archive].

Hurzschmeyer, Marie. "Tenement City: The Emergence of Multi-storey Districts Through Large-scale Private Landlordism in Nairobi." International fournal of Urban and Regional Research 31: 714-32. https://doi.org/10.1111/j.1468-2427.2007.00751.x.

Jaglin, Sylvy, Sophie Didier, and Alain Dubresson. 2018. "Métropolisations en Afrique subsaharienne : au menu ou à la carte ?” Métropoles (Hors-série). https://doi.org/10.4000/metropoles.6065.

Jaglin, Sylvy. 2007. "Décentralisation et gouvernance de la diversité : les services urbains en Afrique anglophone." In Gouverner les villes d'Afrique : État, gouvernement local et acteurs privés, edited by Laurent Fourchard, 2134. Paris: Karthala-CEAN.

Johari, Amina. 2015. Kenya's Konza Techno City: Utopian Vision Meets Social Reality. Independent Study Project (ISP) Collection. https:// digitalcollections.sit.edu/cgi/viewcontent.cgi?referer=https://scholar. google.fr $/$ \&httpsredir=1\&article=3047\&context=isp collection.

Lanne, Jean-Baptiste. 2018, Des vies en veille. Géographies abandonnées des acteurs quotidiens de la sécurité à Nairobi. PhD Dissertation. Pessac: Université de Bordeaux-LAM. https://tel.archives-ouvertes.fr/tel-02117104. 
Leauthaud, Crystele, Stéphanie Duvail, Olivier Hamerlynck, Jean-Luc Paul, Hubert Cochet, Judith Nyunja, Jean Albergel, Olivier Grünberger. 2013. "Floods and Livelihoods: The Impact of Changing Water Resources on Wetland Agro-Ecological Production Systems in the Tana River Delta, Kenya." Global Environmental Change 23: 252-63.

https://doi.org/10.1016/j.gloenvcha.2012.09.003.

Archive: https://www.documentation.ird.fr/hor/PAR00010351.

Meyerfeld, Bruno. 2016. "Au Kenya, les réfugiés piégés de Dadaab." Le Monde, 16 December.

Morange, Marianne. 2015. "Street Trade, Neoliberalisation and the Control of Space: Nairobi's Central Business District in the Era of Entrepreneurial Urbanism." Fournal of Eastern African Studies 9, no. 2: 247-69. https://doi.org/10.1080/17531055.2015.1018407.

Porhel, Ronan, and Alain Léon. 2013. "L'influence des corridors dans le développement régional : le cas de l'EAC.” Nairobi: FRS \& IFRA Observatoire des Grands Lacs en Afrique.

Pison, Gilles. 2019. “Tous les pays du monde.” Population \& Sociétés, no. 569: 1-8. https://doi.org/10.3917/popsoc.569.0001.

Racaud, Sylvain, Bob Nakileza, François Bart, Bernard Charlery de la Masselière. 2016. Rural-Urban Dynamics in the East African Mountains. Dar es Salaam \& Nairobi: Mkuki na Nyota \& IFRA.

Rouillé, Gaële, David Blanchon, Bernard Calas, and Élise Temple-Boyer. 2015. "Environnement, écologisation du politique et territorialisations : les nouvelles politiques de l'eau (GIRE et PSE) au Kenya." L'Espace géographique, Tome 44: 131-46. https://doi.org/10.3917/eg.442.0131.

Said, M. Y., Okwi P., Ndeng'e G., Agatsiva J., and Kilele X. 2007. Nature Benefits in Kenya: An Atlas of Ecosystem and Human Well-Being. Nairobi: World Resource Institute, Department of Resource Surveys and Remote Sensing, Ministry of Environment and Natural Resource, Kenya Central Bureau of Statistics, Ministry of Planning and National Development, Kenya \& International Livestock Research Institute. https://hdl.handle.net/10568/1053.

Saraswati, Jyoti. 2014. "Konza City and the Kenyan Software Services Strategy: The Great Leap Backward?" Review of African Political Economy 41, Supplement no. 1: 128-37. https://doi.org/10.1080/03056244.2014.976189.

Tiffen, Mary, Michael Mortimore, and Francis Gichuki. 1994. More People, Less Erosion. Environmental Recovery in Kenya. Chichester: John Wiley \& Sons.

Twining-Ward, Louise, Wendy Li, Elisson M. Wright, and Hasita Mukeshkumar Bhammar. 2018. Supporting Sustainable Livelihoods Through Wildlife Tourism. Tourism for Development Knowledge Series. Washington (DC): World Bank Group. http://documents.worldbank.org/curated/ en/494211519848647950/Supporting-sustainable-livelihoods-throughwildlife-tourism [archive].

Watson, Vanessa. 2013 "African Urban Fantasies: Dreams or Nightmares?” Environment \& Urbanization 26, no. 1: 215-31.

https://doi.org/10.1177/0956247813513705. 
Wiesmann, Urs, Boniface Kiteme, and Zachary Mwango. 2014. Socio-Economic Atlas of Kenya: Depicting the National Population Census by County and Sub-Location, 38-39. Nairobi: Kenya National Bureau of Statistics (KNBS); Nanyuki: Centre for Training and Integrated Research in ASAL Development (CETRAD); Bern: Centre for Development and Environment (CDE).

World Bank. 2018. "Doing Business 2019: Training for Reform." 31 October. Washington (DC): The World Bank Group.

http://hdl.handle.net/10986/30438.

World Commission on Environment and Development [WCED]. 1987. Report of the World Commission on Environment and Development: Our Common Future. UN Documents. New York: United Nations.

http://www.un-documents.net/wced-ocf.htm [archive].

Book Version: The World Commission on Environment and Development. 1987. Our Common Future. Oxford: Oxford University Press. 


\section{Chapter 3 \\ Emerging Elites, Oligarchy, and the Kenyan Middle Classes}

\section{Christian Thibon}

Translated by Felix Lambrecht

The topic of emerging elites raises many questions and arouses multiple interests. What is brought to light through these elites is the significance of the ongoing economic, social and political changes as well as their historical trends and their nature. The approach adopted in this chapter extends and completes the above presentation (cf. introduction to the volume). General trends in Kenyan society are often analysed in terms of risk-tensions and following a fatalistic view of society stalled by inequality, while the changes within the elite circles are cast in a rather positive light through the lenses of renewal and opportunities. Moreover, there is a lack of statistical proofs as the question of emerging elites is mainly approached through qualitative and biographical research methods or through prosopography. These methods nevertheless benefit from a stream of academic research on social configurations, the national classes and the elites, and on the nature of economic development, all initiated in the 1960s and 1970s and still underway (Leys 1975; Van Zwanenberg 1972; Swainson 1980; Kaplinsky 1980).

\section{Capitalism, Bourgeoisie, Peasantry, and the Middle Classes in Debate}

In the 1970-80s an important academic debate left its mark on the social sciences. It involved the question of Kenya's unique brand of capitalismin comparison with that of its neighbours-and what it represented more broadly, not just in relation to the nature of economics but in terms social history. This debate borrowed from the dependency, Marxist, liberal, and developmentalist paradigms then in vogue. While it did not escape the theoretical hypotheses of the time about modes of production, it questioned and contributed knowledge about the social dimensions of development and its chaotic performances, the growth of the 1960s, and the slump of the 1970s-2000s interspersed with a few periods of growth (notably the coffee boom in 1976-77, and the years 1980-83 just before the drought of 1984). Important for our purpose, then, are the questions of accumulation, 
the existence of a national and multinational agrarian power, of a national bourgeoisie, be it comprador or not, of a petite bourgeoisie, of African or Indian bourgeoisies (Himbara 1994), and finally of the entrepreneurial spirit and capitalist ethos of certain groups. The same is true of research on the small and medium peasantry, on its rise from the colonial periodwhether this peasantry was captured or not-and on peasant-state relations (Kitching 1980; Hyden 1980).

This collective reflection continued in the years of transition, in the midst of the economic crisis, which were also a period of hope and questioning of economic policies and their state rationality. These times signalled the return to the market and privatisation, the rise of civil society and the democratic experiment, but also a succession of major politico-financial scandals. The "Kenyan malaise" (Gibbon 1995) was thus questioned. It had two sides: on the one hand, the economy was in the process of liberalisation, struggling with inherited burdens, including corruption and social predation; on the other, the resources of entrepreneurship were brought forward, including the capacities of the informal sector based on the strength of jua kali and its expected resources. ${ }^{1}$

These past and continuing scholarly debates are important for two practical reasons: they raised questions and built knowledge that are still relevant today, all the more so as the hypotheses put forward and the prospects evoked have or have not been confirmed in the course of the history of the last twenty years, which allows us to understand current events and even their evolution. The somewhat historical method used here-proceeding from the present to the past-could only meet these debates, yet requests the adoption of a double historical perspective: firstly, that of the present time dating back to the post-World War II colonial period; and secondly, that of the "immediate time," from the 1990s up to the present, and particularly of the acceleration of the last two decades.

\section{The Formation of a National Political and Economic Oligarchy?}

Understanding the nature and evolution of economic development and capitalism sheds light on the formation of a national elite and its current social embodiment-"political economic entrepreneurs"-and, beyond that, on a social class that can be characterised as more oligarchic than bourgeois. The defining feature of this social class is that economic development and modes of accumulation were intertwined through the politico-economic

1. On the debates about enterprises, see Jean Copans (1991). 
elites-a phenomena referred to as straddling that was partly inherited from colonial dependency. ${ }^{2}$

It is possible to reconstruct the history of straddling and its different times. From independence onwards, the overlap between the state, public interests and private interests, between private business and public administration-which was already in its infancy in colonial dependency-was reinforced because of the significant economic power of an interventionist state at the head of a public economy controlling the economic machinery. During the time of Daniel arap Moi, this system was reproduced through the strengthening of state power and the protection of a nascent industry. But the economic results of this economic management were mediocre and irregular. The international context (energy crisis, price of major exports) was partly to blame. The double economic predation of the state and its public servants through-depending on one's perceptioncorruption or weak governance aggravated the situation. The lack of return on investment of financial aid, public debt, and difficulties in food security were visible manifestations of this dire economic situation.

The turn of the 1990s with authoritarian decompression, democratisation of the transition, and the imposed new liberal economic order (the opening of the market, privatisation, adjustment programs...) did not change this established politico-economic system. On the contrary, the public-private link was maintained through a strategist state, admittedly advised by the international financial institutions, that pursued its own strategic interests. It then privatised a modern public sector in order to respond to national entrepreneurial owners who purchased certain public goods and public shareholdings in private companies. This was de facto a second wave of Africanisation $^{3}$ (Aseto \& Okelo 1997; Thomas 1998, 40-53).

From the 2000s-2010s, straddling became subtler, more complex and more competitive. Mirroring private-public partnerships in major projects, it adapted to new economic contexts (with the return of growth), regional transformations (with the growth of the East African Community) and international change (characterised by the rise of funding and of nonWestern partners). It also adjusted to new commercial and technological opportunities, notably in the field of communications. This showed that even if the economic situation improved, neither predation nor corruption nor bureaucratic red tape disappeared. Dirty business and scandals continued, some of them even reaching a peak, but they did not affect in

2. Presented as a form of dependency on a peripheral economy inherited from the colonial period during which the white racial minority negotiated with the government

3. The first Africanisation of services (shops) dates from the presidency of Jomo Kenyatta. 
the same way the economy, growth, financial results, and attractiveness (the public debt/GDP ratio fell below the $50 \%$ mark in the mid- 2010s). On the contrary, a steady flow of international and domestic investment was betting on the Kenyan economy as a regional economic hub, on its liberal management and on the expected payoffs they may have had in resources and domestic productions as well as in its domestic market.

The economic history of the straddling is sometimes limited by many unknowns, notably its external relays and the levels of its international dependence, and it keeps grey areas when it comes to financial exchanges. Yet, its social history can be written by looking at the experience of accumulation. From independence to the present day, successive political and economic systems have given rise to a neo-patrimonial managerial elite with both political and economic power. These "political economic entrepreneurs" have grown rich in connection with political cycles, while the circle of beneficiaries has widened with ethnic renewals or alliances at the highest level of power-first Kikuyu then Kalenjin. This circle of beneficiaries has also become more diverse since the transition and political reforms have opened up the political game. The paths to success were varied. Primitive accumulation followed different scenarios: some resulted from heroic self-made individuals-of the adventurer and "coal-merchantbecome-millionaire" types-while others were draw from historically and family predestined situations, thus benefiting the kin-heirs of political dynasties or the descendants-heirs of chiefs from the colonial period. The various economic cycles and proximity with the regime turned to their advantage. They also owed their trajectories to the allocation of real estate, public contracts, concessions, positions in international companies, and positions at the State House and in other institutions (Central Bank, Stock Exchanges, ports, transport, commercial banks, etc.) as well as to access to public funds (Simiyu 2012). Some of these success stories took on a quasidynastic form by following a diversified strategy. Others, often achieved through land accumulation, came to an end after a generation in a manner reminiscent of kleptocratic trajectories or because they were broken by family quarrels. But the majority of these political entrepreneur families have been able to overcome the pitfalls of generational change, although some have been increasingly confronted with the Buddenbrooks effect. ${ }^{4}$

The success of these "political entrepreneurs" came from their ability to take advantage of various public policies, both interventionist and liberal, of agreements with foreign companies and also of privatisations. It also lay in lucky or rational choices to invest in booms or speculative cycles, to react to various business environments, and to circumvent the political

4. In reference to Thomas Mann's novel about the decline of the third generation of families. 
setbacks while retreating into economies of affection and making use of their ethnic and regional network. Finally, as internationalisation and the financial opening of the 2000s progressed, these great fortunes discovered the resources of regional markets with sub-regional, Eastern and Middle Eastern partnerships, and with deals and investment. It was then that Dubai eclipsed London as their business destination. At the end of this evolution, the impression was that on turning "millionaires," these "political economic entrepreneurs" have become economic entrepreneurs only, and that as wealth has built up, economic interests have had more importance than political interests.

This overlap between political and economic calculation is also found in a game between closure-a nationalist temptation to Africanise and protect markets-and openness, that is, association with foreign companies, or in other words between independence and dependence. This state of mind also explains the association of these political entrepreneurs with professional entrepreneurs, whether Indian or Kenyan (mainly Kikuyu), who have been somewhat independent but competent in their field and who ensured the recognition of politicians through donations or political commitments.

Paradoxically, distance from power has been a vector of accumulation and an explanation for the success of some families. This was first the case for the Indian elites who, faced with competition from the Africanisation of trade and transport, moved in the 1960s towards the technical and industrial sectors, partly abandoning their historical model of the retail shop-the $d u k a$ system-which had allowed them to prosper. Next, this was the case for the Kikuyu elites, especially for the generation carried by the Kenyatta period but discredited during the Moi period or divided during the time of transition-democratisation. The same was true of the new circles promoted and then deposed by the successive powers, but which retained their assets and escaped the legal fallout of financial scandals. Political decline did not automatically translate into economic decline, while the learning of new techniques and new industrial, commercial and financial processes or their imitation, helped by the capacities of locally trained executives, was quickly mastered in contact with the White Kenyan large landowners, with representatives of foreign companies and with the Asian masters of industry. This interweaving and circulation of the economic and political elites can be seen in institutional networks, professional chambers and the Kenya Private Sector Alliance (KEPSA), created in 2004, or through more informal forms of sociability, such as the large national and regional agrarian events (Agriculture Shows), the promotional networks of prestigious schools, corporate associations or more exclusive associations such as clubs (Connan 2013). 
The conclusion is hardly moral, but today one could say that neopatrimonialism, after having prospered in a parasitic way on the economy, is accompanying growth and benefiting from the development of a national and regional market. This evolution, common to several emerging economies as shown by scholars (Bach \& Gazino 2012), is illustrated and confirmed by individual and collective trajectories, and accumulations and investments. Indeed, through case studies, biographies and prosopography ${ }^{5}$ and as testified in the increasing number of autobiographies (Ndegwa 2006; Wanjui 2013), one can grasp the various generations or historical cycles of accumulation, and ultimately, the pace of the formation of an oligarchic elite in Kenya.

The first cycle of accumulation was carried out under the presidency of Jomo Kenyatta. His family and the dignitaries and collaborators of the regime, from KANU and KADU, benefited from the public income. Paradoxically in this neo-colonial period, businessmen and their families, although nationalists, imitated, at least got closer in their way of life, their sociability (clubs and networks of sociability) and land accumulation, to the colonial aristocracy of "gentlemen capitalists" and agrarian landowners. In similar ways, they exploited land, financial assets, and services. The model of success that is representative of this period, apart from the Kenyatta family, is exemplified by Kikuyu dignitaries: Sir Charles Njonjo, Njenga Karume, John Michuki, Duncan Nderitu Ndegwa... and more generally by large Kikuyu owners and their associates (GEMA: Gikuyu Alliance, Embu, Meru) often referred to as "mafia," that is, a network of businessmen and politicians relying on their relatives, their clients and their dependents to negotiate with state power.

The second cycle coincided with the arrival in power of Daniel arap Moi in 1978. It marked a turning point in Kenyan political life with the coming to power of the Kalenjin and their allies, but also with a drift towards a more authoritarian and dictatorial regime. Wealth accumulation in this period followed the path of the previous cycle and developed by taking advantage of urban growth, major construction projects, the tourism boom and a partially protected private consumer goods and processing industry. Yet it expanded to include new families which, besides the Moi family, included the first circle of the faithful, often Kalenjin. In a practical way, the Moi system, as under Kenyatta but in a more systemic way, surrounded itself with allies and local potentates-"big men"-who relayed the central power to the periphery and the regions. The latter, in return for their affiliation and their political and electoral support, ensured protection in access to land and in particular urban land (Bourmaud 1988). This politico-economic context also saw the prosperity of an Asian industrial bourgeoisie that

5. This section uses Damien Thibon's data and analyses (2014). 
discovered in Kenya a haven of peace (compared with the expulsion of the Indians from Uganda in 1972) and invested in the basic industrial sectors, agribusiness and consumer goods which were then protected. Individuals from this period who represented success were, for example, Nicholas Biwott, Joshua Kulei and some large Indian families.

Paradoxically, the 1990s-characterised by the economic crisis and political instability-were the glory years of this politico-economic oligarchy. This period coincides with the second generation: those of the sons then building upon the work of the founding fathers and matriarchs (the wives of the founding fathers). Indeed, the new political and economic context presided over two noticeable changes: on the one hand the privatisation of cooperatives, public enterprises, commercial enterprises, and hotels turned to the advantage of the established great fortunes which then recovered industrial, tertiary or agribusiness tools which they later cannibalised and added value to. On the other hand, the political stakes of the time renewed the political class: there were new leaders, new opposition parties and a new generation in the image of the "young Turks of KANU." In a context of bargaining between the ruling politicians and the opposition but also of ethnic clashes, these newcomers took advantage of the prevailing instability and of the opportunity it created to access power and enrich themselves. This was the time of the big yet consensual cases of corruption, "the Goldenberg era," 6 and of many new promoted fortunes, following the example of the new barons of a regime that co-opted them. The newcomers to the powerful circle included George Saitoti, William Ruto, Ole Ntimama or former opponents like Raila Odinga.

From the 2000s, the return of growth and the economic take-off confirmed the economic reputation of these several established families. They comprised political families including allies-customers-parents (Kikuyu, Kalenjin) close to Kenyatta and Moi, and local entrepreneurs, mostly Indians and Kikuyu but also a certain number of established big men who were Kisii, Kamba, Luo, Masai, Luhya, Kikuyu ${ }^{7}$ and from the Coast. However, the novelty of this period lay in the emergence of businessmen attached to the urban market and involved in transport (matatu networks), real estate, finance and insurance, and services. They were joined by new personalities from the world of media, Internet, and new technologies. These new entrepreneurs, who for some came from the informal sector, were certainly supported and sponsored, but they were foreign to previous generations. Some of them came from the upper middle class promoted by growth. They were either skilled educated individuals who had often studied in international universities and possessed prestigious

6. See in this volume Hervé Maupeu: "State, Economy and Development in Kenya."

7. Coming from Muranga while those who preceded came from Kiambu or Nyeri. 
Kenyan school degrees, or entrepreneurs in the digital economy and the services sector, having started in their careers as senior civil servants in national agencies or as executives in foreign companies. Last, there were some scandalous trajectories of success through transit and regional or international trafficking using informal and illegal ways. The politicoeconomic oligarchy and this new generation were connected to Foreign Direct Investments (FDI) respectively through private/public partnerships and major construction projects and through investments participation in the new digital economy.

This broadening and diversification of politico-economic elites can be seen in the use they made of symbolic and cultural capital. Great families, like the "great notables," maintained their traditional symbolic capital and identity affiliations, relied on patron-client and religious networks, invested in local anchorage in their region of origin and in compassionate activities (e.g. through humanitarian associations like the Red Cross, Saint John Kenya...), and controlled large press groups-print and audio-visual media that proved to be economically very profitable (Nyanjom 2012). Contrastingly, the new notability was present in social media, radio, university spaces, civil society, and even in certain religious spaces in connection with the rise of the new Born-Again churches, Pentecostalism, etc. For some, notably those who had emerged recently, opportunism and commitment to the regime were no longer the rule.

Recently, through cross-investments or even alliances, these different generations and different political, economic and ethnic circles have been working together in business associations and consortiums, as if the class logic of a national "de place" or "réticulaire" capitalism was now prevailing! A "depoliticised" type of capitalism has emerged, which has become autonomous from the political sphere and escaped from the practices of straddling from which it was born. This trend, which only the future may confirm, is perhaps a guarantee of political stability, but it owes its success to the somewhat forgotten history of Kenyan capitalism: that of the "nonpolitical entrepreneurs."

\section{A Second Overlap: Society and Entrepreneurship}

This longer history highlights a second overlap, this time between business and society. Here, social mobility and low-intensity accumulation in an economy of affection, where sociability, often built along ethnic lines, plays just as much a role as public protection or the invisible hand of the market. The socio-historical and cultural roots of this economic history take the form of a spirit of capitalism and an individual moral achievement perceptible through various-both long and short termed-collective trajectories. 
Colonial history reveals the existence of business associations that already had a cultural dimension (Kikuyu, Luo, Kamba...) as well as of cooperatives. These two opposed types of organisations competed or entered into relations with Indian entrepreneurs, already well established, and participated in the emergence of an "economic" proto-elite and a comprador proto-bourgeoisie. As early as the 1960s, their members were running for associate-dealers or were co-opted by Western companies, and then invested in new economic sectors. The same goes for a "rural petite bourgeoisie"-often accused of loyalty during the Mau Mau insurgencythat benefited from the boom in coffee growing, land privatisation, and urban market demand. Moreover, social mobility was taking place in cities. From the 1950s, new urban categories emerged made of the educated, a working class and working aristocracy, and in the public space the Black staff of the colonial state (clerics, officials, police, military, etc.). ${ }^{8}$ From independence, these social groups-some of them somewhat marginal or out of step with the new power-were still very active because they were essential elements. A few among them were called upon for the construction of public power and the state apparatus and for economic revival. This happened at several moments throughout the period: firstly, in the 1960s, due to the Africanisation of certain economic sectors (through business licenses); then, in the 1970s, through the entry of civil servants into business (Ndegwa 1971). And finally, in the 1990s, in the mobilisation of the informal sector-jua kali-through the entrepreneurial performance or resilience of this sector in certain areas of the urban market. These micro-accumulations stumbled on technical or financial limits, yet others succeeded and testified to a creative energy. This was the case in artisanal production for tourists (Chouabi 2009), in industrial subcontracting, and in innovations in tourism services. These promotions, equally understood as ways of life and as careers, evolved between survival logics that resulted from the hazardous paths of migration and social opportunism, between meritocratic ambitions leading to successes and resourcefulness, between individual adventures and family strategies through domestic and community relays. It is therefore not surprising that some of the successes and accumulation paths of the 2010s have been grounded upon these experiences and continued to be part of such trajectories.

Moreover, to the extent that the moral economy of affection framed and normalised these industrial-commercial adventures, one may wonder whether certain inherited or acquired anthropological models shaped such an evolution by distilling a certain spirit of capitalism. The topic has given rise to stereotyped tribal analyses but it deserves to be addressed. Some

8. As shown by the latest works of social history on the colonial period, following on from Bruce Berman (1990). 
populations traditionally lived in densely populated areas and some ethnic groups fed into the groups of migrants and social dependents (cadets) who would leave, clear the land and follow a logic of expulsion and expansion. Since the colonial period, both fed professional migrations, clearing the margins of rural areas in the past and of the cities since independence. The same is true of groups who relied on family networks that were fit for dispersion and the maintenance of commercial networks, such as Kenyan Asians and Somalis. These cultural predispositions-alternatively called "ethnic ethos" or "ethnic habitus" (Droz 1999)-become important and decisive when, for geopolitical and historical reasons, some of these ethnic groups benefited from services, training, openings and employment opportunities. This first happened under colonisation with schooling-cumevangelisation, controlled mobility, then access to the state, and it continued more so with public modernisation after independence, favouring certain territories and certain ethnic groups. Such environments associated with a culture of mobility gave them an "entrepreneurial" bonus, forging modern models of social ascension and accumulation, at least social primacy. This was particularly the case for the Kikuyu, who benefited first from this.

More generally, the historical existence of a social ascension outside the oligarchic circuits-even marginal promotion with or without the umbrella of the political and economic elites in power-raises the question of grassroots opportunities, capacities and potentials. Such mobility contributed to a renewal of the economic oligarchy from below. We find this problem of upward mobility in the rise of the middle classes as will be shown now.

\section{The Emergence of the Middle Classes?}

The question of the middle classes, already at the heart of past debates, has recently resurfaced for economists particularly as well as for all those who, in marketing or commercial potentials, examine the consumer habits of these new classes and of their related sub-constituencies, like the youth, women, urban households and specific generations. This first approach takes into account and favours economic data, income and consumption levels.

To date, however, macroeconomic data and their analysis have been unsatisfactory for measuring the weight of the middle classes. While the GDP that was reached and re-evaluated in 2014 ranks the Kenyan economy within the "middle-income countries," this does not allow for a mechanical conclusion that there exists a middle-income class. The link between the GDP and the emergence of a middle class has been verified in many national contexts, yet a striking phenomenon is also at play: inequality distorts income redistribution. In addition, standards defined according to international criteria and identifying thresholds, such as that of a "global 
middle class" defined by an income of 16,800 USD to 72,000 USD per year per household, are not relevant. Relative thresholds are more informative as they estimate, depending on the country and economy considered, a floating daily consumption of between 2 USD and 20 USD per capita for emerging countries. ${ }^{9}$

Practically, definitions and sufficiently precise trend data for the recent period starting from 2005 are lacking. For instance, the KNBS sets the middle-class in the range of 23,000 KES to 199,000 KES monthly income. Such an overly broad approach cannot therefore quantify the share of the middle classes, except through a vague consensus figure of $10 \%$ to $20 \%$ of the population, depending on the source used, which is corroborated by household wealth surveys about assets and equipment targeting the first quintile of "the richest 20\%" (KIHBS and DHS). These regular national surveys make it possible to classify and better capture an improvement in household lifestyle and household wealth in the two top quintiles (from $20 \%$ to $40 \%$ of the population), but with strong regional differences. Only estimates ${ }^{10}$ based on labour income (both formal and informal) appear to be accurate. These are based on a threshold taking inflation into accountevaluated between 76,000-100,000 KES monthly in 2015-and places about 270,000 people into this category. This figure is currently growing as it is said to double every 5 years - i.e. $2 \%$ of the 15.2 million active employees in 2015-while high-income earners above 100,000 KES would correspond to $2.9 \%$, giving a total of middle and upper classes of $4.9 \%$, that is, 700,000 active employees. By extrapolating these figures into a number of households, this would represent more or less 600,000 households for a population of around 4 million. However, these data do not take undeclared income into account such as rent, real estate income, undeclared activities, and non-taxed trade.

This statistical weakness can be compensated for by using sectoral or microeconomic surveys and by studying supply, the economic, social and cultural environment and consumer practices. They reveal a process of general enrichment, distributed regionally, but do not distinguish social variations. Yet, they can help to draw a positive general context. This is the case in surveys about financial inclusion for the middle classes as well as the poor. For example, they show that the number of bank accounts increased from 4.6 million in 2005 to 33.6 million in 2014 while the number of mobile accounts rose from 1.3 million in 2007 to 25.2 million in 2014 (Gubbins 2015). Even if multiple factors-including the boom in mobile phones, access to secure transfers, the importance of exchanges on the part

9. The US poverty line is estimated at 17 USD a day.

10. See the "Middle Class Study" and its presentation by Ivory Ndekei and Kwame Owino from the Institute of Economic Affairs (2016).

https://www.ieakenya.or.ke/newsevents/iea-launches-the-middle-class-study [archive]. 
of domestic and international migrants, and the evolution of the banking system-played in favour of this take-off, this indicator of the financial environment reflects a general improvement in living conditions.

The same is true of studies that focus on the lifestyle and consumption of the middle classes, the demand for housing and construction (Arvanitis 2013), consumption patterns and consumer perceptions that give priority to quality criteria or appearance (Deloitte 2013), the level of Internet connection and use of social networks including Facebook, and the number of vehicles and imports.... even if these are goods of distinction that households only display on certain days and on special occasions. Other indicators confirm this trend. The increase in wage and employment in the tertiary economic sector and in the private sector-and particularly in national and regional commercial services-that followed on from new public policies in the fields of education, local administration, and national security testify to a growing number of intermediate socio-professional categories, among them the managerial staff even though their income is not stable.

Finally, the polling and surveys institutes ${ }^{11}$ in need of data for their sampling frames use two thresholds: a monthly income of 25,000-40,000 KES and a high income of above 40,000 KES per household, respectively $11 \%$ and $5 \%$ of the population. The former estimate corresponds to the $10 \%$ "rich" of urban surveys conducted in working class neighbourhoods. It confirms the extrapolation from employment statistics, that is, $10 \%$ and $16 \%$ of the population.

In all the cases studied, one constant emerges. The search for intermediate variables highlights two key factors: the education of heads of household, whether male or female, and urban residency (among which Nairobi stands out). The middle classes are aware of this prerequisite, which has a positive influence on social advancement and accumulation of domestic wealth. Having themselves benefited from the ambitious school policies from 2002, they in turn invest in the training of their children and in their continuing education, as well as in urban estate, at the risk of going into debt.

The aggregated and cross-tabulated quantitative data thus refute the hypothesis of a pivotal middle class, even if average intermediate incomes only provide imperfect data about the emerging middle class-and considering also that this income is relative: the majority of Kenyans are in survival while the levels of wealth accumulation are very high among the oligarchy.

As a consequence, the sociological qualitative approach can be of help in identifying social configurations. It notably helps us to distinguish and

11. See the Barometer data for May 2017, and the Ipsos Public Affairs opinion polls. 
model three situations. Firstly, there is an "upper middle class" with high monthly household incomes, owning one or more real estate properties and that is westernised in its way of life and consumer patterns. In this group there are successful small-scale entrepreneurs in the informal and service sectors, employees in certain private sectors, and high-ranking civil servants or employees of the Nairobi hub. Secondly, there is a large array of employed "managerial middle class," following on from the petite bourgeoisie of the 1980-1990s but at the limits of the poverty line as they are "neither poor nor rich." Although they are assured of income and have accumulated wealth, they are impacted by price variations and inflation, to economic conjuncture and to the instability of professional statuses. In practical terms, this second group, an erratic middle class, has access to malls, franchised restaurants, etc., but they consume little. The remaining group are "social entrepreneurs." Studies have particularly focused on them (Ontita 2015) because they exemplify the Kenyan top-down growth that takes into account the market of both the urban and the rural poor. This group, limited in size but very visible in the media, tells about Kenya's double history of the middle classes. Indeed, these economic actors are present in the services (financial, personal, production assistance...) where they implement the modernist efforts of the managerial petite bourgeoisie, of bureaucrats imbued with development ides-or at least who see development as a moral goal-but are also innovative because they master the new tools, use the new technological opportunities and walk the lines between commercial logic and moral vocations, between private interest and collective interest.

These three categories, that is, the "upper middle class," "managerial middle class" and "social entrepreneurs," share the same social model, but without all having the same means. This is confirmed by the study of the new demographic behaviours and their evolution within households. A minority of households (corresponding to the two upper quintiles) have common consumption behaviours and attitudes and refer to a typical middle-class family model valuing the nuclear household, the couple and the individual (Thibon 2015). This reading is corroborated by the more qualitative studies of sociologists, anthropologists and geographers on lifestyles. These studies reveal, among other things, the spread of new consumer patterns and of practices of social distinction and appearance geared towards branded products, new services, safe housing, but also new types of interest such as sea and national parks domestic tourism (Rieucau 2014). In all three cases, modernisation does not call into question the links with peasant and provincial kinship based upon economic exchanges (through investment, intergenerational transfers or cultural transactions during family ceremonies), yet it gradually distends them (Resnick 2015). 
These diverse and complex middle classes sharing common denominators (family model, lifestyle, etc.) reflect how much its current formation is a difficult process: the middle classes are learning to live in relative ease and are becoming urban, yet they retain their peasant character.

\section{The Middle Classes, an Ongoing Process of Formation}

Therefore, to better understand the ambiguities of the middle classes and overcome statistical and conceptual vagueness, if not a hesitant and approximate foresight, it is necessary to put this topic into historical perspective. This means, among others, reconnecting with scholarly works on the social classes and on a two-sided social structuring: one side is about the social biography of a group in formation, and the other concerns the ways in which these new classes relate to society and the regime, and the perceptions they have of these as well as of themselves.

Such history of social representations helps us to grasp continuities as well as innovations. It begins at the end of the colonial period. Its starting point is the end of the colonial period. The question of the middle classes appeared in the 1950s and since then, the public policies put in place have consistently aimed to promote the "intermediate classes," then the "national elites," and now the "middle classes" that are expected to be at the foundation of society. All these policies, from the Swynnerton Plan to Vision 2030, have also carried political projects in search of economic leaders, then political leaders who could act as intermediaries or mobilisers depending on the projects considered-colonial, nationalist mixed with African socialism, democratic, and last, liberal. In this respect, the abundance of concepts used to describe these classes is an advantage, yet it can also be risky if one uncritically makes use of the "social entities" which political or technocratic discourses designate with terms such as "executive managers," "modern sector," and "national elites" or of the sometimes ideological theoretical tools of academic works.

The contribution of the prehistory and history of the middle classes, from the 1950s to the present day, is useful to grasp the historical movement and its current effects. It can be found in different social figures-similar to ideal-types-that each period has promoted. Three figures emerge that correspond to three different moments: "the evolved," "the bureaucrat," and "the entrepreneur." In reality, the social actors combined a bit of each of these three roles depending on the historical context. Yet, their experiences and representations converged and participated, together with income and heritage, in the formation of a social class. 
Thus, colonisation, in its last decade, implemented a policy targeting the "evolved." This term is borrowed from other colonial experiences yet it is appropriate to qualify the Kenyan case-although the condition of the Asians and that of the "non-native" somehow blurred the racial colonial vision of society. This policy was coherent: it aimed to reinforce social intermediaries in rural areas through the creation of an enlightened "rural petite bourgeoisie," as Gavin Kitching observed in the 1950s-1970s when studying the social structuring of peasant property. It also aimed to supervise its auxiliaries-the African bureaucracy-in the cities as they had become essential for colonial action. Such a developmentalist and modernist project, weakened by the Mau Mau insurrection that divided the rural world between nationalists and loyalists, was pursued and defended by the supporters of Western modernisation and of a "third political path." They advocated the promotion of a meritocratic urban-rural petite bourgeoisie and the formation of intellectuals, aiming to make up for the structural constraints that had delayed the creation of national civil servants. The broader objective was the emergence of Kenyan capitalism and the creation of liberal urban elite. Such a project was part of the search for a third political path (Diouf-Kamara 1991; Charton 2000, 27-48). From independence, such a vision had its political supporters but they were contradicted by an increasingly authoritarian power in search for hegemony, with its ethnic governance and the elitist management of Kenyan universities. This does not mean that these "historical losers" disappeared: some emigrated, and the majority nestled in economic activities, including coffee production. This was the case of the average Kikuyu peasantry who invested in real estate in Nairobi (Charlery de la Masselière 1997, 7-8). They also retreated into intellectual and legal activities. They initiated internal immigration or were taken in by the regime, thus becoming its servants-clients, spokespersons and organic intellectuals.

It is in the independence context that the figure of the "bureaucrat" was foregrounded and replaced the neo-colonial image of "the evolved." The national elites in charge of an interventionist and regulatory state that promoted them and who were reinforced by the single party then fit best into the nationalist projects of President Jomo Kenyatta and even more of Daniel arap Moi. A small directorial bourgeoisie then appeared. It was quite diverse and hierarchical, and maintained (or not) links to the rural petite plantationholding bourgeoisie and the bureaucratic class of the colonial period. Its emblematic professional figures ranged from the school teachers to highranking civil servants-thus reproducing the colonial wage hierarchy. They also ranged from the askari to the district or provincial commissioners, in continuity with a colonial public order turned national order... They all benefited collectively but unequally from public employment, jobs in the 
politico-economic system or in the formal parastatal sector, and the welfare state-more precisely from the salaries that the welfare state provided as well as from some privileges in health and housing, bridges between the public and the private sector, the Africanisation of employment, and access to commercial licenses. This managerial petite bourgeoisie, endowed with intellectual capital, inherited respectability and a somehow symbolic capital of command that compensated for limited income. Yet in the 1990s, such social advancement stalled. The economic crisis and adjustment programs, followed by political and ethnic struggles, changed the situation: they weakened the managerial petite bourgeoisie, hindered its evolution and destabilised it. Confronted with reduced resources and with economic and adjustment programs, it became divided between resilience, corporatist withdrawal, and ethnic temptation. A first group, dismissed, was tempted by the promise of private enterprise and fell into informality. A second group, impoverished, downgraded by inflation and prey to general instability, protected itself as best it could according to the power of the professional unions they could rely on. And a third group supplemented their insufficient wage by resorting to related sources of income, such as public/private duplication, a return to the private sector, and corruption. Since 2002, this declining managerial petite bourgeoisie has unevenly benefited from growth while it has rubbed shoulders with the social ascents of certain private activities. Only a part of it-the high civil service, the liberal professions, and some professions in education and health-has managed to maintain its symbolic and cultural capital as well as its revenues through traditional areas that could be safeguarded (the university, the exercise of law) and through new services to business which the new economic and political contexts had enhanced.

The growth of the 2000s legitimised a new dominant figure among the middle classes, if not a whole new generation: "the small entrepreneur." The social rise of "micro-entrepreneurs," caught between survival and desire for accumulation, has played out on several levels: public and private resources, wage income, and investments in the informal sector (mechanical, electrical, computer repairs, etc.), agriculture and its new commercial productions and outcomes (e.g. foodstuffs kiosks), services (e.g. matatu), land and property return, and speculative urban and rural income. These entrepreneurs without an enterprise-who, since the 1990s, research on the informal sector has tried to understand by going beyond the image of the jua kali (handicraft and informal sector)-have taken advantage of new markets, new technologies and a high-tech D system with the intelligence of survival. They did it through new services and even through illegal activities that ensured a quick return on limited investment in an untaxed informal sector. These entrepreneurs can be found in the city where the most opportunities 
are available, including in the slums (where they play the role of "little big men") and in the countryside where petite peasant landownersfollowing the former model of peasantry or in break with it-have occupied production niches linked to the urban market (horticulture, dairy farming, khat, meat...). These post-coffee modes of exploitation are often at odds with those of the elders, so much so that these innovative rural entrepreneurs are very often young people and women. Could this be an effect of the demographic dividend? Indeed, this educated youth familiar with digital technologies has quickly adapted to new products and marketing. Or could it be an effect of the gendered dividend? However, this energy overflow is not enough. In addition to skills and domestic mobilisation, the economy of affection and relationships have become necessary to reap the benefits of new interdependencies and new jobs and opportunities (Mbataru 2009).

As spectacular as this emergence of the new middle classes may bewith its social markers and models, its car fleet, its material culture, its sociability, its modernity, and especially its role in the civil society and through the intellectuals-, they remain the minority, both in the city and even more in the countryside. Taking up Marxist phraseology, they are a "class in itself," in gestation, not a "class for itself." Certainly, the boundaries and social practices defining collective identity are gradually solidifying, but they remain porous. The new middle classes are confronted either with dangerous popular classes, at least perceived as such, or with networks of poor rural kinship, from which they come and to which they are related and often indebted. Yet the risk of overflow and downgrading still lingers, and the control of rural elders is still significant. Moreover, the new middle classes are also limited in their social ascent by the shortcomings of the Kenyan political economy, by the reserved domains of the higher political-economic elites-although some can access them-and by cyclical variations. This in-between situation and this social mobility are a source of anxiety, all the more so as the public systems and services and the liberal economy do not offer them any guarantee. Hence the cautious behaviours they develop by multiplying socio-economic, spatial and moral protections. It is noticeable that they embrace political modernity and the defence of human rights, which both serve as security for their acquired rights, but also the defects of political life such as ethnic residency, ethnicity and tribalism (Maupeu 2012). Moreover, these attitudes vary according to the power relations-of a quasi-demographic nature-that the middle classes can exert in some urban spaces. They also depend on associations with some groups, on more or less close contact with their Asian social neighbours, and on their ability to transcend ethnic divisions through inter-ethnic marriages, which enables them to become cosmopolitan and urban Nairobians and to release from family and community constraints. 


\section{Conclusion}

This reading of the social changes within the Kenyan elites-that is, within both the oligarchy and the middle classes-and of their historical trajectories completes and modifies the bipolar or tripolar analysis of an exclusive society in accordance with and inherited from the past. It reveals a society that is as unequal as in the past, with a continually high level of poverty. It is a conflictual society, but a society in motion that is constantly changing the lines of social partition and collective identities. Changes are very real within the social structures, with frequent and commonplace discrepancies ${ }^{12}$ between the rapid pace of economic and technical changes, the slower social practices experienced by societies as well as the slower trends or weight of collective representations. Such discrepancies are reflected in variations between social norms and individual and household practices, which sometimes involves authoritarian cultural constraints. They also result in cultural tensions that crystallise on social issues debated by the press but also experienced within households (the freedom of the youth, clothing...). Public opinion delights in gauging the scope of individualism's moral pitfalls, and though social mobility imperceptibly shapes and creates new opportunities for generations to come, it also imposes a debt from the fallout of such growth. The nature of economic growth, however, even if it benefits all but unequally, remains poorly integrative. It leaves to the political power and public policies the task of redistribution and the creation of national solidarity, a new political economy (Bourguignon 2004), a social protection policy ${ }^{13}$ and the maintenance of a national community bond that is hampered by identity and ethnic biases that modernisation has not yet erased.

The challenge ahead lies in the political capacity of the elites to cushion the social effects of liberal growth and to accompany the stratification or social mobility processes. Ultimately, those living in periphery societies that had long been confined to particular space-times remain in the shadow. In these societies, there has been a rapid advancement amongst the elites thanks to structural and politico-economic changes, and the numbers of university graduates are high. The question now becomes: will they come

12. According to the expression and image of the discrepancy of changes used by historian Fernand Braudel, who speaks of "the delay of culture on the social," and of "the delay of the social on the economic."

13. Sectoral policies were launched for the youth and vulnerable people based on both common type and innovative programs, including cash transfers to OVC and the elderly. 
soon on to the scene of Kenyan society, or will they conversely be tempted to break away? ${ }^{14}$

\section{Bibliography}

Arvanitis, Yannis. 2013. "African Housing Dynamics: Lessons from the Kenyan Market.” Africa Economic Brief 4, no. 3. https://www.afdb.org/en/ documents/document/economic-brief-african-housing-dynamics-lessonsfrom-the-kenyan-market-33609 [archive].

Aseto, Oyugi, and Jasper A. Okelo. 1997. Privatization in Kenya. Nairobi: Basic Books.

Bach, Daniel C., and Mamoudou Gazibo (eds). 2012. Neopatrimonialism in Africa and Beyond. London: Routledge.

Berman, Bruce. 1990. Control and Crisis in Colonial Kenya. London: James Currey.

Bourguignon, François. 2004. "Le triangle pauvreté - croissance inégalités." Afrique contemporaine 211, no. 3: 29-56. https://doi.org/10.3917/afco.211.0029.

Bourmaud, Daniel. 1988. Histoire politique du Kenya. État et pouvoir local. Paris: Karthala-CREDU.

Charlery de la Masselière, Bernard (eds). 1997. "Petits producteurs et filières agricoles au Kenya." Les Cahiers de l'IFRA, no. 7-8.

Charton, Hélène. 2000. "Les évolutions historiques de la structuration de l'élite kenyane." In The Dilemma of Post-Colonial Universities: Elite Formation and the Restructuring of Higher Education in Sub-Saharan Africa, edited by Mobolaji Ogunsanya and Yann Lebeau, 27-48. Ibadan: IFRA-Nigeria.

Chouabi, Alexis. 2009. Les relations Chine-Kenya : étude de l'artisanat. Master Dissertation. Pau: Université de Pau et des Pays de l'Adour.

Connan, Dominique. 2014. "La décolonisation des clubs kényans : Sociabilité exclusive et constitution morale des élites africaines dans le Kenya contemporain." PhD Dissertation. Paris: Paris 1 Sorbonne Université.

Copans, Jean. 1991. "De l'anthropologie des travailleurs à l'anthropologie de l'entreprise : hypothèses africanistes." Journal des anthropologues no. 43/44: 29-37. https://doi.org/10.3406/jda.1991.1587.

Deloitte. 2014. East Africa Private Equity Confidence Survey. https://www. tralac.org/images/docs/6463/2014-east-africa-private-equity-confidencesurvey.pdf.

Deloitte. 2014. The Deloitte Consumer Review. Africa: A 21st Century View. https://www2.deloitte.com/content/dam/Deloitte/ng/Documents/ consumer-business/the-deloitte-consumer-review-africa-a-21st-centuryview.pdf [archive].

14. Among them the danger of separatist claims on the Swahili coast (phrased as "Pwani Si Kenya," "the Coast is not Kenya," see Willis \& Gona 2013) or of a Greater Somalia (Kennedy Wagura 2019). 
Diouf-Kamara, Sylviane. 1991. "Les Africains aux USA : battants et intellectuels." Hommes \& migrations 1149, no. 1: 20-26.

https://doi.org/10.3406/homig.1991.2877.

Droz, Yvan. 1999. Migrations kikuyus : des pratiques sociales à l'imaginaire. Ethos, réalisation de soi et millénarisme. Neuchâtel and Paris: Institut d'ethnologie \& Maison des sciences de l'homme.

Gibbon, Peter (eds). 1995. Markets, Civil Society and Democracy in Kenya. Uppsala: Nordiska Afrikainstitutet.

Gubbins, Paul. 2015. "An Overview of Developments and Trends in Kenya's Retail Financial Landscape.” Financial Sector Deepening Kenya. https:// fsdkenya.org/an-overview-of-developmens-and-trends-in-kenyas-retailfinancial-landscape/ [archive].

Himbara, David. 1994. Kenyan Capitalists, the State and Development. Nairobi: East African Educational Publishers.

Hyden, Göran. 1980. Beyond Ujamaa in Tanzania: Underdevelopment and an Uncaptured Peasantry. London: Heinemann.

Kaplinsky, Rafael. 1980. "Capitalist Accumulation in the Periphery: The Kenyan Case Re-Examined." Review of African Political Economy 17: 83-105. https://doi.org/10.1080/03056248008703416.

Kitching, Gavin. 1980. Class and Economic Change in Kenya: The Making of an African Petite-Bourgeoisie. New Haven: Yale University Press.

Leys, Colin. 1975. Underdevelopment in Kenya: The Political Economy of Neocolonialism 1964-1971. London: James Currey.

Maupeu, Hervé. 2012. "Classe moyenne kenyane et démocratie électorale.” Afrique Contemporaine 244, no. 4: 53-68.

https://doi.org/10.3917/afco.244.0053.

Mbataru, Patrick. 2009. The Coffee Crisis. Old Interest, New Interest and Illusions of Development. Saarbrücken: Lambert Academic Publishing.

Ndegwa, Duncan. 2006. Walking in Kenyatta Struggles: My Story. Nairobi: Kenya Leadership Institute.

Ndegwa,Duncan.1971.Reportofthe Commission ofInquiry.http://kenyalaw.org/ $\mathrm{kl} /$ fileadmin/CommissionReports/Report-of-the-Commission-of-Inquiry(Public-Service-Structure-and-Remuneration-Commission)-1970\%20-1971. pdf [archive].

Nyanjom, Othieno. 2012. Factually True, Legally Untrue: Political Media Ownership in Kenya. Nairobi: Internews.

Ontita, Edward. 2015. "Catalysts in the Development Terrain: Social Entrepreneurship and Change in Nyamira County, Kenya." Les Cahiers d'Afrique de l'Est 50: 63-79. https://journals.openedition.org/eastafrica/294.

Resnick, Danielle. 2015. “The Political Economy of Africa's Emergent Middle Class: Retrospect and Prospects." Journal of International Development 27, no. 5: 573-87. https://doi.org/10.1002/jid.3110.

Rharade, Abdelhag. 1998. "La sociabilité entrepreneuriale au Kenya." Les Cahiers de l'IFRA, no. 13: 4-25.

Rieucau, Jean (eds). 2014. Le Kenya dans la $3^{e}$ révolution touristique. Au-delà du safari, Paris: L'Harmattan. 
Simiyu, Vincent. 2012. “Social Differentiation in Kenya since 1963.” In Mizizi, edited by Mwenza David Kyule \& George M. Gona. Nairobi: University of Nairobi Press.

Swainson, Nicola. 1980. The Development of Corporate Capitalism in Kenya, 1918-1977. Berkeley: University of California Press.

Thibon, Christian. 2015. "Vulnérabilité des enfants, prise en charge et violence à l'aune des changements des modèles familiaux, des modes de vie privés au Kenya." In Enfants et jeunes hors les liens en Afrique de l'Est, edited by Valérie Golaz and Christian Thibon. Paris: Karthala.

Thibon, Damien. 2014. "Principaux opérateurs économiques Kenyans et leurs réseaux d'influences." Non publié.

Thomas, Chris. 1998. "L'économie politique d'une succession annoncée." Politique africaine, no. 70: 40-53. http://www.politique-africaine.com/ numeros/pdf/070040.pdf [archive].

Van Zwanenberg, R.M.A., Anne King. 1975. An Economic History of Kenya and Uganda, 1800-1970. Atlantic Highlands (N.J.): Humanities Press.

Wagura, Kennedy. 2019. "Dynamiques démographiques de la population Samburu (Kenya) 1984-2018.” PhD Dissertation. Pau: Université de Pau et des Pays de l'Adour.

Wanjui, Joseph Barrage. 2013. The Native Son: Experiences of a Kenyan Entrepreneur. Nairobi: University of Nairobi Press.

Willis, Justin, and George Gona. 2013. "Pwani C Kenya? Memory, Documents and Secessionist Politics in Coastal Kenya." African Affairs 112, no. 446: 48-71. https://doi.org/10.1093/afraf/ads064. 

Chapter 4

\title{
Between Hopes and Disillusionment Constitutional Reforms and Decentralisation in Kenya, 2000-2020
}

\author{
Chloé Josse-Durand
}

Translated by Matteo Réveillon \& Sarah Levy Klimpke

In 2010, Kenya made a bold decision: it reformed its constitution by launching a decentralisation-also called devolution-which the World Bank referred to as "ambitious" and "unprecedented" in Africa (World Bank 2012, xi). The exceptional nature of this decentralisation lied not only in its large-scale territorial reform but also in the large number of functions delegated to new local levels of governance, called counties. Each of the new 47 counties was granted a large share of civil servants and financial and administrative means to elaborate its own local public policies and to pass laws in its parliamentary assemblies. This institutional change rekindled academic thinking on decentralised governance in Africa, inspiring new research aimed at comparing, discussing and studying this innovative governance mechanism. ${ }^{1}$ Recent academic studies have underlined the significant progress that might be made in the distribution of basic services, the reduction of economic inequalities between regions, and the appeasement of land disputes and identity claims in Kenya. ${ }^{2}$ They have, however, also emphasised the limits of this reform. Among other things, they have highlighted shortcomings in the reform's formalisation and implementation, including the conservation of a national level pre-eminence, an increase in political competition and violence, the proliferation of cronyism, and the growth of inequalities in the counties (as opposed to in the regions). ${ }^{3}$ This chapter, noting the continued relevance of the debates on the impact of

1. In the early 2005-2010, many publications analysed this original form of governance: Ghai (2008), Branch \& Cheeseman (2008), Cheeseman \& Tendi (2010), Githinji \& Homlquist (2008), Kanyinga \& Long (2012). More recently, see Burbidge (2019).

2. For some-far less numerous-optimistic prospects: Shilaho (2015), Steeves (2015), Elszasz (2016), Crawford \& Hartmann (2008), World Bank (2011; 2012; 2015), Bouka, Berry \& Kamuru (2019), Elfversson \& Sjögren (2019).

3. For some more critical perspectives: Mudida (2009), Hassan (2013), Adbille \& Abdi (2016), Cannon \& Ali (2018), Chome (2015), D’Arcy \& Cornell (2014; 2016), Githinji \& Holmquist (2012), Berman, Cottrell \& Ghai (2009), Boone et al. 
constitutional reforms and the consequences of decentralisation on Kenyan society and political system in Kenya and in the academic realm, aims to contribute to these debates. ${ }^{4}$

Debates over this reform relate to Kenya's long-term political history. Decentralisation is a political process through which-as a result their acquisition of a share of national income and the ability to raise their own funds-territorial authorities gain greater autonomy in decision making and action, as well as more financial resources. This concept has been at the heart of Kenyan political debates since the 1950s (Burbidge 2019). Until independence in 1963, these debates revolved around the issue of Majimboism, ${ }^{5}$ that is, the granting of power to regions. Between the 1960s and the 1980s, under the presidency of Jomo Kenyatta (1963-1978) and the first mandate of Daniel arap Moi (1978-2002), Majimboism vanished from political debates despite the fact that Daniel arap Moi had been a strong advocate of the Majimbo ideology during the fight for independence (Maxon 2016, 20). This disappearance was the result of both a secessionist threat (especially in the North of the country ${ }^{6}$ ) and the authoritarian regime maintained by Kenya's first two presidents (Nyong'o 1989). From 1982 onwards, Daniel arap Moi implemented pro-rural development measures, it seemed, under the pretence of deconcentrating, but not for the purpose of real decentralisation (Southall \& Wood 1996, 508-9). In the early 1990s, the political opposition, together with students and civil society, called for

(2019), Burbidge (2015), Cheeseman, Lynch \& Willis (2016), and more recently Cheeseman, Lynch \& Kanyinga (2020).

4. This chapter benefited from the sound suggestions of Marie-Emmanuelle Pommerolle, Claire Médard and Marie-Aude Fouéré, who I warmly thank, along with Paul Kembala (alias Maddo) for sharing his nuanced approach of Kenyan politics with me.

5. The Swahili word majimbo means "region." Directly after independence, these regions took the form of 8 administrative provinces, which were replaced by 47 counties from the $4^{\text {th }}$ March 2013 elections and the implementation of decentralisation.

6. Just before Kenya's independence, the 1960 independence of Somalia contributed to push the Majimbo ideology into the background during the 1960s. The Somali political elites, as well as the Kenyan political elites originally from Somalia, claimed that Kenya's Northern Frontier District belonged to the new Somali State. Two weeks before independence, President Jomo Kenyatta declared the state of emergency and deployed the army in North-East Kenya. This region immediately became one of the 8 Kenyan provinces (North-Eastern Province), which triggered a secessionist conflict at the regional level (Ethiopia, Djibouti, Somalia, Kenya). This conflict is known as the Shifta war (meaning "bandits" in Amharic) in 1963-1967. On the reformulation of these secessionist debates within the frame of decentralisation, see Brancati (2006). 
the return of multipartyism in Kenya and a radical change of its political system. They faced strong state repression (Pommerolle 2005, Ruteere 2010).

The notion of decentralisation resurfaced with the writing of a new constitution during Mwai Kibaki's 2002 presidential campaign. The 8 majimbo created after independence were divided in 47 counties. The borders of these counties correspond to the borders of some former districts which had been subdivided in the 1990s (Barkan \& Chege 1989) before being "reassembled" to form counties led by locally-elected governments. The local administration remains however highly centralised and monitored by County Commissioners. This system is somewhat reminiscent of the former provincial government (Bourmaud 1988, 217). The conjunction of a local government appointed by the central governing power (national level) with the election of a local government (which appoints a local administrative staff) highlights the combination of two distinct power structures. Note that while these power structures intertwine, they also compete with one another (Médard 2006). Nonetheless, elected local officials-including governors, senators, women's representatives, member of parliaments or members of local assemblies-enjoy flexibility in terms of governance. They play a leading role in public decision-making and, thanks to local parliaments (the County Assemblies) and the new budgets at their disposal, are capable of developing local projects. The political class is showing growth and, because of the governors' political weight and as their governments enjoy a local base, a reconfiguration of power is emerging (Cheeseman, Lynch \& Willis 2016).

For Kenyan citizens and activists, the constitutional reforms and the political openness of the early 2000s fostered some hope for the democratisation of Kenya's political and media spheres. ${ }^{7}$ In theory, such developments would ensure the improvement of governance (notably through public participation), transparency in the use of public funds, and a better redistribution of national financial resources. Hence, these reforms appear to be the long-awaited answers to both the territorialised and ethnicised resource-related tensions (including land) and the reduction of the historical inequalities and injustices that fuel these tensions. ${ }^{8}$ Because they would guarantee greater transparency and strengthen the control of public finances at the national level, the reforms could also reconciliate citizens with their elected officials. Be that as it may, this new wave of hope

7. The hopes of the Kenyan activist sphere-soon to be shattered-were transcribed in an article by Robert Press (2012) that gave voice to some activists.

8. On the question of "historical injustices" in Kenya and the entrenchment of the land issue in Kenyan power relations since the implementation of the constitutional reforms and decentralisation, see Francesca Di Matteo in this volume and D’Arcy \& Nitstotskaya (2019). 
must be put into perspective. ${ }^{9}$ While decentralisation structures political practices and representations, it does not transform them completely. Quite the opposite: it reinforces some dynamics that should be brought to light through a macro and a micro analysis of the reforms that have been implemented since the 2013 general elections.

Debates over the structure of the Kenyan state (unitary, decentralised, federalist) keep causing much violence. This violence is less the consequence of ethnic contention than of past or broken pacts between political elites at every level of authority and of the administration (Oucho 1998; Atieno Odhiambo 2004; Klopp 2002). Driven by a deep-rooted capitalist accumulation logic, these elites tend to defend their own economic and political interests through an ethnic rhetoric. This type of rhetoric succeeds in mobilising voters, but overlooks social, political and economic inequalities (Lonsdale 2004; Berman \& Lonsdale 1992, II). Changing the rules of this neo-patrimonial, paternalist and clientelist game-which underpin the interpersonal relationship between elites themselves, and between elites and citizens-is neither in the interest of elected local officials, nor in that of territorial administrators ${ }^{10}$ (Bach \& Gazibo 2012; Githinji \& Holmquist 2012; Hornsby 2013, 260-1). The governance system established through decentralisation also ensures the subsistence of political and economic agreements concluded between local and national elites; and, what is more, it guarantees the protection of their respective interests (D'Arcy \& Cornell 2014; Gadjanova 2019; Waddilove 2019). Ultimately, the effective implementation of decentralisation is restrained mostly by vicissitudes inherited from the past and the permanency of the central state's weight (Hassan 2013). Corruption, for its part, has been decentralised, or at least enhanced, at every level (Burbidge 2015a; D’Arcy \& Cornell 2016). And even if local assemblies and elected representatives (called Members of County Assemblies or MCAs) counterweigh the local executive, public participation of citizens in defining the priorities of development is not convincing (World Bank 2015; Rwigi, forthcoming).

This chapter aims to illustrate the changes initiated by these administrative and political reforms since the early 2000s. Its purpose is also to display the perceptible continuities of the political practices of Kenyan politicians. The first section offers an introductory political chronology of the elections,

9. Many academic publications aimed to nuance these flourishing hopes during that decade, for instance: Kagwanja (2003), Murunga \& Nasong'o (2006), Otieno (2005), Githinji \& Holmquist (2012), Berman, Cottrell \& Ghai (2009), Branch \& Cheeseman (2010), Kanyinga \& Long (2012).

10. On the persistence of neo-patrimonial practices in Kenyan public administration, see Cohen (1993) for the provincial administration, and Onyango (2017) for the counties' administration. 
partisan debates, and proposed reforms about Kenya's historic inequalities and political moralisation since the early 2000s. This part aims to explain how decentralisation has been implemented as a means to resolve the issues inherited from Kenya's political history-taking into consideration the fact that Kenya was built upon a strong legacy of administrative centralisation on the one hand, and major political crises on the other hand. The second section offers thoughts on the decentralisation project itself and its implementation. In particular, it questions the emphasis on local democracy and the approach of "local elected representatives." The final section sheds light on the government's development-centric vision, explains the cooperation arrangements between counties, and, on the basis of concrete examples, explores how these levels of authority interact.

\section{Decentralisation Grappled with the Turbulence of Kenya's Political Life}

Decentralisation is at the heart of Kenya's contemporary public and political debate. It is a long-standing political project whose identity and territorial dimensions have always been questioned by both Kenyan elites and citizens. In the 1960s and the 1970s, "decentralisation" denoted Majimboism (regionalism). The Swahili Majimbo and Majimboism refer to the distribution of power to the regions. A controversial political project, regionalism was championed by Jaramogi Oginga Odinga, former Prime Minister of Jomo Kenyatta having joined the opposition. Like Jomo Kenyatta's plan of unitary government, Odinga's political project proposed a territorial and ethnic definition of access to resources based on administrative regions (Médard 1999). Indeed, at the time of independence, the Kenya African National Union (KANU), the political party led by Kenyatta, played a key role in the struggle against British colonial rule. KANU promoted national unity and the advent of a centralised state based on "Kikuyu constitutionalism," which was inspired by the monarchical and imperial system established by British authorities (Kenyatta 1938, Lonsdale 2006). Representatives of ethnic minority groups, like Ronald Ngala (mijikenda), Masinde Muliro (luhya) or Daniel arap Moi (kalenjin), were opposed to this idea. With the support of the British, they proposed establishing a multi-racial governance system based on a "Majimbo Constitution." This would guarantee the interest of minorities as well as the establishment of a regional power base. ${ }^{11}$ The representatives of these ethnic minority groups first formed their own regional parties, which united behind the Kenya African Democratic Union

11. These minority groups were supported by the British (including the settlers) who saw in this project a means to oppose the Kikuyu power, see Anderson (2005). 
(KADU). In the 1960s, KADU received the support of the Rift Valley, the coastal region and the Western part of the country. The populations of these areas with little government presence favoured a federal state and the decentralisation of the public authority to the regions. The 1961 elections settled the matter: KANU won with $67,4 \%$ of the votes against $16,4 \%$ for KADU. As the KANU leaders called on those of the KADU to rally behind efforts to create a government of national unity, the "Majimbo Constitution" project came to an end and Kenya became a de facto one-party state. ${ }^{12}$

To put an end to the violence associated with the Majimbo claims in the 1960s and 1990s, the 2010 Constitution introduced and provided for the use of the more neutral Swahili terms ugatuzi $i^{13}$ (decentralisation) and usambazaji wa madaraka (responsibility sharing). These terms, which have their origins in the constitutional debates of the 1960s, were used in the official reports that followed the 2007 post-elections violence. Note that this change in terminology was less about promoting regional preference than about reforming the provincial government's system, which had resulted from colonisation and was considered inadequate. ${ }^{14}$ The districts were indeed perceived as fostering political ethnicity as they stimulated politicised ethnic disputes and entrenched local identities (Hassan 2016). Since their establishment at independence, these districts had been subjected to much political manipulation. For instance, between the 1992 and 2002 elections, Daniel arap Moi created 30 new districts in an effort to sway votes, as did Mwai Kibaki between 2002 and 2013. ${ }^{15}$ Indeed, although Moi had been a strong supporter of the Majimbo system, once he was in power (1978-2002), his promises of reform gave way to a process of power deconcentration aimed at strengthening his base in the regions through the strategic appointment of Provincial and District Commissioners, representing the central administration, and the establishment of police stations in the different provinces of the country.

12. In 1964 , less than a year after independence, the opposition was dissolved and a decree-adopted by a 2/3 majority in the House of Representatives-buried the Majimbo Constitution by amending its prerogatives.

13. On this topic, see the definition of the Swahili Oxford Living Dictionaries (2018) at the ugatuzi entry.

14. It should be made clear that the local political level has been built as a political arena since colonisation. The politicisation of the districts rests on a double dynamic: 1) the creation of new districts to fight the 1990s requests for multipartyism (Hassan 2016), but also 2) the non-reform of the provincial administration which made it possible for the central power to control the local level (Médard 2006).

15. Mathenge, Oliver. 2009. "All Constituencies now Turned into Districts." The Nation, 13 July [archive]. 
As this debate involves a long chronology of events, we should be aware of the political episodes that preceded and shaped the decentralisation project as it exists today, as well as its use in the political debates of the 2000-2020 period. In the 1990s, the KANU's strategy was mainly aimed at reviving the Majimbo ideology to win the elections in the Rift Valley and the coastal region. It put forward the ethnic argument, that is, indigenous claims, to pit the "natives" (or "self-convinced 'locals" or "new indigenes" as Gabrielle Lynch calls them, 2011) against the more recent "migrants" (Jenkins 2012), without taking any concrete steps towards decentralisation. Following the violent and biased 1992 and 1997 elections, the December 2002 elections marked a historical transition in Kenyan political history with the end of the KANU monopoly of power (which had been de facto in 1969, and de jure in 1982 and 1991) and the victory of a multi-party coalition (Throup \& Hornsby 1998, Maupeu 2003). These presidential and legislative elections took place in a peaceful context despite fears and the first terrorist attacks in the area. ${ }^{16}$ The victory of the NaRC (National Rainbow Coalition) led by Mwai Kibaki against Uhuru Kenyatta-who, in this first candidacy, had been designated as Moi's successor-was unexpected. It raised high hopes for the establishment of a social contract that the increasingly authoritarian practices of the previous regimes had torn apart (Grignon \& Maupeu 1998).

But these hopes were quickly dashed by the inertia of the first Kibaki government, which did not seem inclined to keep its promises to liberalise the political system. The work of the government agencies created to oversee the constitutional reform and transform a basic law inherited from the colonial period failed to convince the Kenyans. This was especially true in the case of the National Cohesion and Integration Commission (NCIC) whose function was to ensure the healing of ethno-political conflicts by promoting greater inclusiveness; and that of the Truth, Justice and Reconciliation Commission (TJRC) aimed at redressing the injustices of the past (Bosire \& Lynch, 2014). In 2003, the NaRc introduced the Constituency Development Fund (CDF). The CDF was intended to encourage the transfer of funds from the national level to the local level: as a result of the CDF $2.5 \%$ of the national income was allocated to Members of Parliament (MPs) for the development of their constituencies. The CDF was not so innovative in that it was an institutionalised version of harambee (literally "all together"). Collective fundraisings encouraged local leaders to initiate local development projects with the population (creation of health centres, schools, etc.), the operating costs of which would then be covered by the government. The existence of this decentralised fund-albeit highly

16. The attacks on the American embassies in Nairobi and Dar es Salaam in August 1998 left a deep impression because of their violence and death toll, in the same as the attack on a Mombasa hotel in November 2002. 
corrupt (Cheeseman 2008)-led some to describe Kenya as a country with a "high degree of decentralisation" (Ndegwa 2002) even before the 2010 Constitution had been passed. However, these measures satisfied neither the Kenyan Human Rights Commission (KHRC), nor the activists and associations, which mobilised and demanded action from the government. This move shed light on the fragility of the change in power. ${ }^{17}$ Clear objections were also perceived among the victorious (and profoundly heterogeneous) coalition (Otieno 2005), and within which the Kikuyu elite was itself divided (Branch 2010, 304).

Frustrations materialised in the creation of the "orange movement," a multi-party alliance of MPs rallied around the person of Raila Odinga, the son of Jaramogi Oginga Odinga, who opposed Kibaki's draft constitution. In November 2005, the rejection of the draft by referendum completed the break-up of the NaRc and set apart the political factions that would be part of the opposition during the December 2007 elections. As the leader his new party-the Orange Democratic Movement, ODM-, Raila Odinga pledged to carry out an ambitious program during the first 90 days of his presidency: to implement a constitutional reform (as announced in 2002) and decentralisation. He condemned the corruption of the Kibaki government, which had failed to put an end to thievery inherited from the Moi era. His program focused on setting up a more equitable redistribution of resources, strengthening the counties' capacities $(60 \%$ of public funds would go to regional and local governments), limiting the executive branch and establishing a parliamentary system. For its part, Kibaki's program was not surprising and represented a straight continuation of the promises he had made during his first term, namely: free secondary education, improved public services, and job creation.

In the aftermath of the 27 December 2007 presidential election, in which more than 14 million Kenyans came to the polls, sometimes waiting more than six hours to enter a polling station. ${ }^{18}$ The results of the elections were clear: Mwai Kibaki had been re-elected with 4,584,721 votes, while his opponent Raila Odinga had obtained 4,352,993 votes-a difference of only about 230,000 votes. Even before the official results were announced, the Raila Odinga camp actively denounced a massive fraud ordered by the incumbent government. The Electoral Commission of Kenya (ECK), a

17. While alternation was a source of optimism in Kenya and elsewhere, it was quickly put into question. See in particular the critical introduction by Godwin Murunga and Shadrack Nasong'o (2006).

18. Turnout reached an all-time high of $69 \%$, or $9,886,650$ voters. The 2013 election (the first general election under decentralisation) beat this record with a rate of $85,01 \%$ and 14,352,533 registered voters (a rate never seen before). 
supposedly independent but often denounced body, ${ }^{19}$ was seized upon the discovery of an illegal voters' list in Raila Odinga's precinct a few days before the elections, and because of internal irregularities in the system put in place: multiple registrations of the same voter or of deceased voters, circulation of false ballot papers, and suspicious movements of buses or coaches-escorted by the police or the Kikuyu militia Mungiki-which were suspected to transport full ballot boxes towards the regions which were won over to the opposition. ${ }^{20}$

On the evening of Sunday, 30 December, ECK's president Samuel Kivuitu proclaimed the final results: Mwai Kibaki had won the presidential election. Yet, the results previously announced during the counting of votes-which did not take the representativeness of the local results for the whole country into account-showed that Raila Odinga led by a considerable amount. ${ }^{21}$ Once again, political violence was used to weaken both electoral competition and democracy (Connan \& Brisset-Foucault 2008). While there was a suspicion of widespread fraud at all the levels of the presidential election (a suspicion on which the ECK did not comment), the parliamentary elections resulted in a clear victory of the ODM candidates. These events triggered demonstrations and the first acts of violence in two informal settlements of Nairobi that Raila Odinga had won over: Kibera, which was his stronghold in the Langat'a constituency, and Kawangware. In the four months following the election, from December 2007 to April 2008, nearly 1,100 Kenyans lost their lives and about 600,000 people fled the violence, becoming internal refugees (Internally Displaced People, IDP, ICG 2008). ${ }^{22}$ Fuelled by deep historical inequalities and territorial tensions over access to land (Médard 2008), the discords affecting Nairobi's poor neighbourhoods, medium-sized cities (Kisumu, Mombasa, Eldoret) and cosmopolitan regions of Kenya were reduced in unjust ways to the effects of ethnic antagonisms by political elites and the international media. Above all, these discords

19. Both for its proximity to the authorities and also for the intimidation of its representatives.

20. The Mungiki political militia is a prophetic religious movement, particularly influential in the Kikuyu diaspora of the Rift Valley and in the cities of the Central Province. It has been mobilised in times of political crises by Kikuyu elites since the late 1980s (Kagwanja 2003; Maupeu 2013).

21. The day after the vote, on the evening of December $28^{\text {th }}, 50 \%$ of the votes of the presidential poll were counted at the Kenyatta International Conference Centre by the ECK: 3.3 million votes for Odinga and 2.4 million for Kibaki. The next day, on December 29, the gap gradually narrowed to around 30,000 votes. And the day after, Kibaki was declared winner of the presidential election, with 250,000 more votes (4,584 million votes for Kibaki, 4,352 million for Odinga).

22. See the issue of Afrique contemporaine on this theme, especially the article by Christian Thibon (2013). 
were territorialised class conflicts inscribed in the trajectory of a capitalist state that had developed globalised neoliberal policies and whose neopatrimonial mechanisms structured the economy, politics and the society (see Calas as well as Maupeu in this volume). International mediations were carried out under the aegis of UN Secretary General Kofi Annan; and led to a coalition and a power-sharing agreement in April 2008. In an attempt to guarantee peace, a government of national alliance (Grand Coalition) was established. Mwai Kibaki held the position of President and worked closely with his former opponent and Prime Minister Raila Odinga to develop a set of policies aimed at reuniting the country politically and socially. Protecting the economy from the vicissitudes of politics was a priority.

Thus, Kibaki's second term was guided by a strong consensus on national development to defuse the main socio-economic gaps which had led to the 2007 crisis. This new direction led to the promotion of Kenya's Vision 2030 development plan: a set of reforms and major infrastructure projects expected to bring Kenya to the status of a middle-income country within the next 20 years. The current "Building Bridges Initiative" (BBI) is one of these projects. ${ }^{23}$ The new direction was also reflected in a complex consensus around the redefinition of the constitution which, beyond a global reform of the Kenyan system, intended to pacify the elections in Kenya. ${ }^{24}$ From 2008 onwards, the coalition government led to a process of co-writing of the 2010 Constitution (known as the Bomas Draft) by Mwai Kibaki's and Raila Odinga's political entourage and some elected officials close to them. The latest version of the draft promoted decentralisation (Kasfir 2005). In an effort to restore credit to his government, Kibaki used decentralisation as a facade while his camp's recommendations conferred a significant economic and political power to the governors. The MPs contributed to the draft Constitution by committing to decentralise power at the level of 47 counties (and not at that of the 8 existing provinces). This decision, however, went against the principle that minority groups and some opposition parties had been defending for almost 70 years. ${ }^{25}$ Indeed, the chosen political units (from the ward to the county) were generally thought to be too small to constitute a real counter-power capable of threatening the central government (see later in this section).

Following a second referendum which received a $67 \%$ "yes" vote, the adoption of the new Constitution in the summer of 2010 promised a better balance of power and mediation of land conflicts. The new text retained the

23. The BBI Initiative is an extension of the Vision 2030 project (see conclusion).

24. Indeed, the violence and their recollection profoundly influenced the campaign and the management of the election announced for March 4, 2013.

25. See the article by Justin Willis and Ngala Chome (2014), which details these expectations from the perspective of the Coastal region and elites. 
presidential system, but subjected presidential appointments (ministers, prosecutors, ambassadors) to approval by the Parliament-which could now dismiss the President. Two new bodies were also set up: the Senate, composed of 47 members elected from the new administrative districts (the counties) $;{ }^{26}$ and the Supreme Court, responsible for arbitrating disputes concerning the presidential election, as well as challenges to judgements handed down on appeal. "Traditional" civil liberties (of expression, worship, association, etc.) are guaranteed, ${ }^{27}$ and dual nationality is now possible. The land reform component was more controversial. It provided for the establishment of a National Land Commission (NLC). It also included the legal review of "historical injustices"-including "land grabbing issues"and the limitation of private ownership, in particular the duration of emphyteutic leases for foreigners. This measure challenges the illegal acquisition of land involving the highest levels of the state and its elites since independence (Boone et al. 2019). Both the National Land Policy (2009) and the 2010 Constitution adopted principles-which are not always put in practice, especially with regards to so-called "community lands"-intended to emancipate land institutions from the centralised bureaucratic system of land administration inherited from the colonial era. ${ }^{28}$ These debates show that decentralisation raises a crucial question: which level of power-local or national-is entitled to control land and legislate on land ownership as well as on past and present disputes? This question relates to the very principles of the new decentralised political system aimed at establishing local and participatory control over resources.

\section{The Principles of the New Decentralised Political System}

Consider the following sentence: "Politics in tune with community (...), building from the ground-up a participatory system of governance that stays in touch with communities by staying in communities" (Burbidge 2019, 12). It sums up the principles at the heart of the Kenyan decentralisation experience in a nutshell. It describes a participatory and inclusive system of governance anchored in public opinion and decisionmaking at the local level.

26. Also sitting in the Senate are 16 representatives designated by the political parties on the basis of their representativeness, two youth representatives and two representatives of persons with disabilities.

27. It should however be pointed out that while the new Constitution raised many hopes for freedoms (especially with the creation of various commissions), the political context hardened under Uhuru Kenyatta's presidency, between 2013 and 2017, and particularly regarding media freedoms.

28. See Di Matteo in this volume. 
The 47 counties created by the Constitution have equivalent legal and political status. Each county government has an executive branch headed by the Governor, his cabinet of ministers (the County Executive Committee) and all the County Chief Officers, namely, sub-county-, wards- and villageadministrators. The county government's legislative branch consists of the County Assembly and the county's representation at the national level (through the election of one MP per constituency and one Senator per county). The County Public Service Board recommends candidates for appointment as Ministers by the Governor, and manages human resources at the county level. The diagram below shows the relationship between the executive and legislative branches of government at the level of Kenyan county structures, and their equivalent in the national structure of power (Republic of Kenya 2014).

The Governor leads his county government, just as the President leads the national government. ${ }^{29}$ In the national government, the President appoints the Cabinet Secretaries. The Public Service Commission recommends the candidates for appointment as Principal Secretaries to the President. The civil servants of each department answer to their Principal Secretary. In the counties, the Governor appoints the County Executive Committee members (CEC or CECs). They head the local ministries, which perform the functions partially-decentralised by the central government, namely: agriculture, health services, cultural activities, trade and finance. Ministers participate in the preparation of the so-called County Planning Development Plans (five-years development plans). CECs (equivalents of ministers) and County Chief Officers (equivalents of Principal Secretaries) are recommended for appointment to the Governor by the County Public Service Board. The latter manages civil servants at the county level, just as the Public Service Commission does at the national level. These are two separate commissions in the context of which the national level cannot influence the local level (the national civil service, i.e. the state civil service, is not in a position to re-centralise its responsibilities).

To carry out the functions of the national government at the local level, a decentralised administration accountable to the central government has been maintained alongside the counties' administration. This local administration is connected to the national level and consists of Local Civil Service Administrations governed by Regional Coordinators (i.e.

29. While the president must be Kenyan, a governor is not required to be from the county he represents. Yet, in practice, and because of political ethnicity, all governors come from the counties that elected them. See the detailed results in the appendices provided by Dominic Burbidge (2019): 2013 Gubernatorial Election Results (Appendix C: 239-48) and 2017 Gubernatorial Election Results (Appendix D: 249-51), as well as governors' biographies (Appendix E and F). 


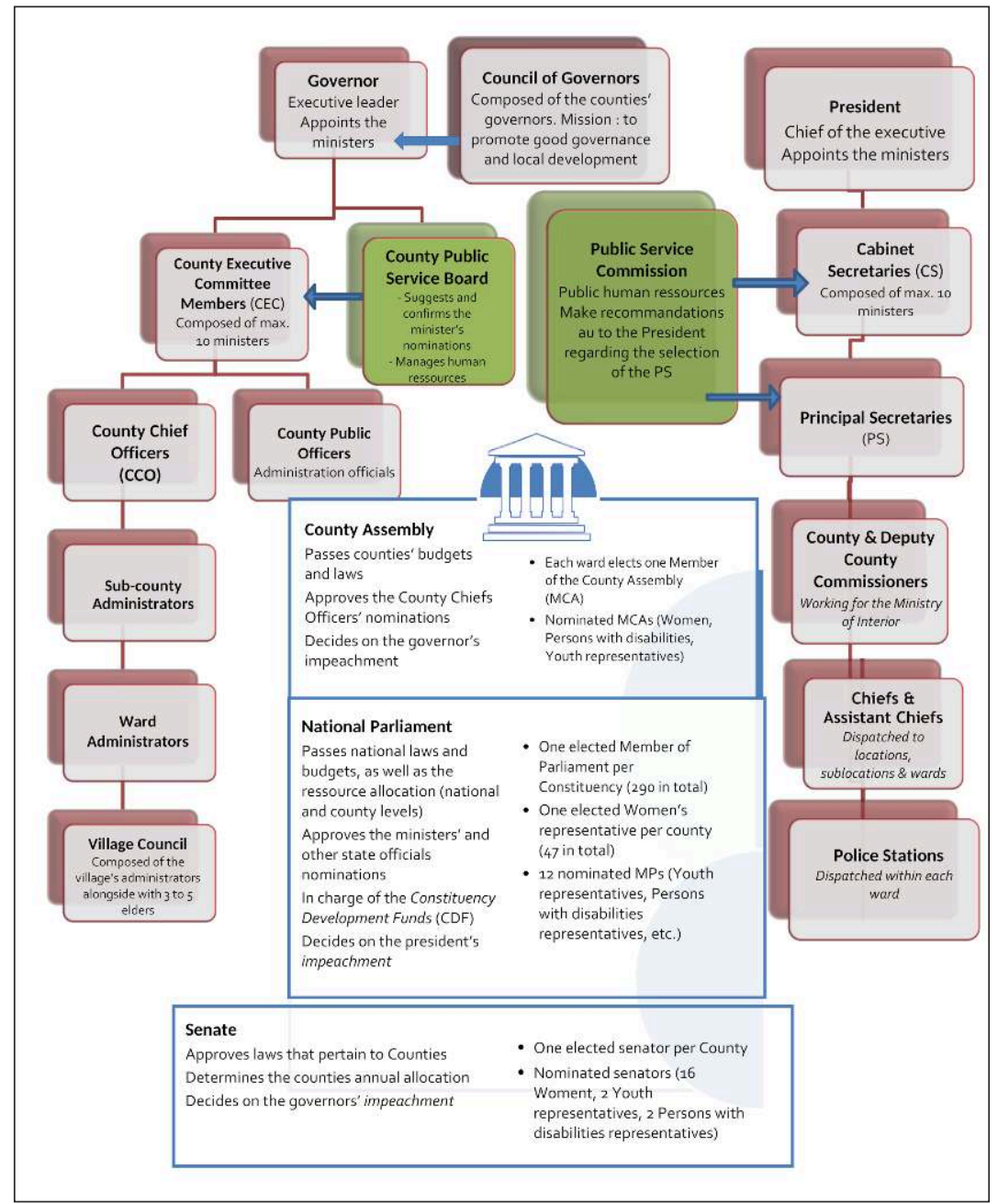

Fig. 1: Executive and legislative functions at the national and county levels

Adapted from two graphs from Burbidge (2019):

Fig. 1.1: The Executive branch of county and national governments (p. 14); and Fig. 1.2: The Legislative branch of county and national governments (p. 16).

County Commissioners), Deputy County Commissioners (at the head of sub-counties) and chiefs (at the head of wards), all of whom answer to the Ministry of the Interior. They have no say in the direction of local affairs and their missions are limited to the functions that have not been decentralised. The County Commissioners' authority places them in a role similar to those who, in the former provincial administration, were called Provincial and District Commissioners. The counties therefore have a decentralised administrative machinery to carry out their functions. This machinery has been developed at the sub-county, ward (an elected MCA) and village levels 
(with Village Administrators gathered in a village council, which is made up of a handful of "elders"). The elders are not necessarily elderly men, but they occupy a central role in the local community they represent. For each ward, the elected MCA must work closely with the chief appointed by the central government. Counties cannot negotiate constitutional changes and do not have their own sovereignty (unlike in the federalist systems, for instance).

Now turning to the legislative branch. The Parliament consists of two chambers, the National Assembly and the Senate. The National Assembly is composed of $290 \mathrm{MPs}$ who are elected in their constituencies. To promote gender parity, each county elects a woman (the Women Representative) who sits in Parliament with the MPs. Note that she represents her county rather than a particular constituency. The mission of the County Assemblies is very similar to that of the National Assembly's. They pass budgets and laws, and are both responsible for deciding on the impeachment of their respective executives. Naturally, the County Assemblies discuss and vote only on county budget and expenditures (county bills). The Senate is composed of 47 senators from the 47 counties. Their role is to pass laws that, while having a national impact, concern the counties in particular. If the MCAs request it, the Senate is also responsible for deciding on the impeachment of governors with a final vote, following [its own] investigation.

National laws regulate the distribution of national income between the central and county governments-as laid down in the Constitution. The National Assembly decides on the division of revenues between the national and county governments. It then determines how the national revenue is divided and allocated to the counties. The counties can also raise their own taxes. Note that their available sources of revenue fall into five main categories: [1] local revenues (taxes on services, property, etc.), conditional and unconditional grants (allocated to the counties by the national government for specific funding, such as "Level 5 hospitals," public hospitals previously managed by the provincial administration and that have become county referral hospitals), [2] equalisation funds (allocated to the most disadvantaged counties), [3] national equitable share (share given by the national government, corresponding to $15 \%$ of the national revenue),[4] private donors (e.g. the French Development Agency, which supported the Kisumu County Urban Renewal Plan), [5] and loans (repaid by the counties, with interests, and only with the agreement of the national government, which will pay the counties' debts if they cannot pay it). The Commission on Revenue Allocation (CRA) is in charge of administering the national equitable share, which determines the division of the national revenue of up to $15 \%$ per county each year (excluding income generated by the counties themselves) on the basis of five criteria: county population, 
basic services, poverty, land and fiscal responsibility. Note that this fund differs from the smaller equalisation fund, which is reserved for the least developed counties (CRA 2013) and intends to ensure the distribution of basic services at a level similar to that of other counties (Bosire 2017). It only represents $0.5 \%$ of the national revenue every year.

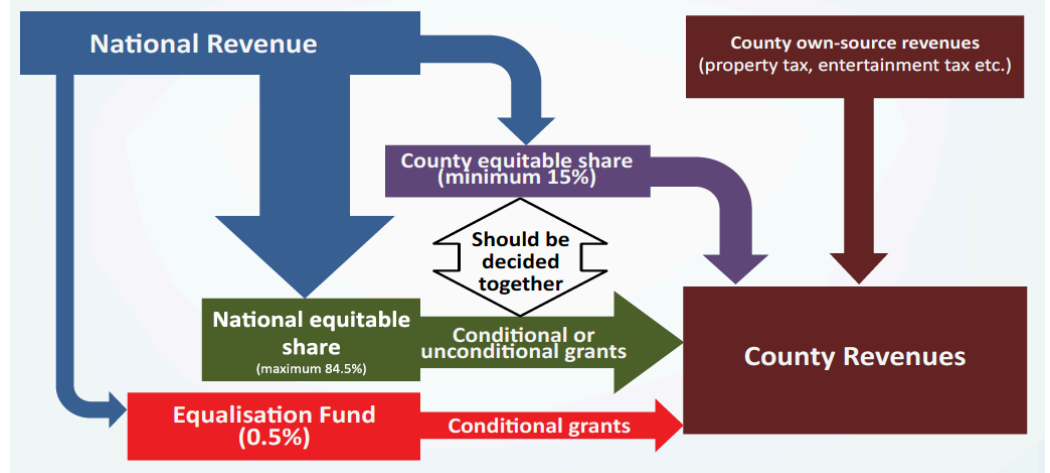

Fig. 2. Flows of revenues from different sources for county governments. Source: World Bank $(2011,42)$.

Health has been the most decentralised sector (Kimathi 2017); other sectors, such as agriculture and education, have undergone only partial decentralisation (Republic of Kenya 2014). In the field of education, for instance, some training centres-such as vocational training centres-are now managed by counties. However, school curricula are still developed at the national level. ${ }^{30}$ What is more, some sectors have not been decentralised: heritage management, still carried out by the public and research institution called the National Museums of Kenya; conservation, handled by the Kenya Wildlife Service; security has not been decentralised either. Apart from relying on the police, the national army, the NCIC and networks of national and international NGOs, the counties have little capacity to maintain peace and social cohesion at the local level (Republic of Kenya 2014). Ultimately, the absence of decentralisation in some policy areas, such as security, reflects a political and legal concern to maintain the central government's base in certain areas. This absence also has a political origin and can be explained by fear of the governors' instrumentalisation of the counties police forces; the fear that governors could have more or less organised

30. The functions carried out by the national government and which have not been decentralised are: international relations, national defence and security, labour and employment, social security, education, housing, health, agriculture, tourism, the formulation of public policies for the economy, and the currency. See Constitution of Kenya (GoK 2010), art. 186, "Respective Functions and Powers of National and County Governments." 
local armies capable of threatening the central government and, to a larger extend, the monopoly of violence held by the Kenyan state-according to the Weberian principle (Burbidge 2019, 167). However, the limitations to and the division of powers that the new constitution provided for have not yet been implemented in the local practices of the counties. Mombasa County has, for example, established its own county police as well as infrastructure (football pitches, street lighting in poor neighbourhoods such as Majengo) and activities (dance, drama) to keep young people busy after school. Recent studies conducted by political scientist Fathima Badurdeen showcase the counterpart of the unique experiment held by Mombasa County. This county has a dedicated counter-terrorism department to secure the coast, ${ }^{31}$ reduce inequalities and poverty, and alleviate the sense of marginalisation among the youth-who are readily recruited by Somali Al-Shabaab gangs and terrorists (Badurdeen, 2018). But the county police are poorly trained, have insufficient resources and therefore make up an additional layer of state repression-and are perceived as such by the youth. The county police thus exacerbate violence, conflicts and the recruitment of young people from the coast by terrorist and criminal organisations. Similarly, in the Kenyan conservation environment, land tenure tensions continue to be a source of conflict, fuelled by politicians. This is partly because conservation has mostly remained the preserve of White Kenyans. The state violently responds to these conflicts, as it did when the Kenya Defence Force was deployed to quell the invasion of private ranches in Laikipia County in April 2017. ${ }^{22}$ These two examples highlight a problematic overlap of action levels, as well as the strong interdependence between the national and local levels when it comes to managing critical issues. Beyond the adoption of a new constitution and the legal framework presented above, the overlap is most visible in the practical implementation of decentralisation.

\section{Decentralisation in Practice: Actors and Apparatus of Local Politics}

Decentralisation was part of Mwai Kibaki's political project (2002-2013), which focused on growth and the achievement of major development projects. From 2013 to 2020, Uhuru Kenyatta implemented a policy program in line with the so-called "Big 4" Agenda, a development agenda, the primary objective of which was to foster an industrial revolution in

31. Lamu, Tana River, Kilifi and Kwale counties are among the poorest in the country (KNBS \& SID 2013).

32. Ogada, Mordecai. 2019. "Decolonising Conservation: It is about the Land, Stupid!" The Elephant, 27 June. https://www.theelephant.info/culture/2019/06/27/ decolonising-conservation-it-is-about-the-land-stupid/ [archive]. 
Kenya (9.2\% of the country's GDP today against $20 \%$ of its GDP in 2022). To that extent, national issues are of concern to local elected officials. Nevertheless, it is interesting to question their relative independence and the nature of their approaches on the local political scene-a scene closely linked to that of national politics. The practical application of their approaches in relation to citizens-especially the strengthening of public participation and the representativeness of ethnic minorities and social cadets-are also being debated.

\section{Decentralised Governance,}

\section{a Political Project of a Developmentalist State and its Elites}

While inherited from the Kibaki era, the developmentalist discourse of the Vision 2030 governmental project is still relevant today. It has accompanied decentralisation: each region must join in the national effort and throw its weight behind the emergence of an economy that does no longer rely solely on its urban middle classes, but also on the wealth of the rural world and the economies of counties now presented as the touchstone of national construction. As part of the national development agenda, and in the context of an economy of public expenditure and debt, ${ }^{33}$ Uhuru Kenyatta's government (2013-2022) revaluated the Kenyan worker in his public speeches and political communications. In doing so, he played a role in the interlocking between political and development objectives (Hagmann \& Reyntjens 2016). To guarantee the peaceful environment needed for business, Kenyatta even "shook hands" with Raila Odinga. ${ }^{34}$ This symbolic handshake, which took place in March 2018, was supposed to put an end to the political crisis that ensued after the 2017 elections. The Supreme Court had overturned election results, leading to a re-run, which took place two months later and was boycotted by Raila Odinga (Pommerolle \& JosseDurand 2017).

33. "IMF Cautions over Kenya Debt Vulnerability." 2017. Business Daily, 21 November. https://www.businessdailyafrica.com/markets/marketnews/IMFcautions-over-Kenya-debt-vulnerability/3815534-4197034-mrydle/index.html [archive].

34. Despite this handshake, Raila Odinga is still running in opposition to the government's policies and more specifically to William Ruto, the current VicePresident and candidate for the 2022 election. He claims that some counties are not economically viable, advocates for constitutional changes and wants the country to be divided in 14 regions to better address the deep inequalities between counties. See Kahura, Dauti. 2019. "Building Bridges to Nowhere: Some Reflections One Year After 'The Handshake.” The Elephant, 7 March. https:// www.theelephant.info/features/2019/03/07/building-bridges-to-nowhere-somereflections-one-year-after-the-handshake/ [archive]. 
At the county level, this development policy began to take root in 2013 and is now focused on local development. In regions abandoned by the government or plundered by their elected representatives, numerous development projects (including hospitals and ambulances, water access systems, improvement of the road networks, etc.) have since been completed. The policy has also been extended to the county level. Citizens gradually seem to show as much-if not more-interest in the development projects set up by the counties and their representatives (who organise themselves in a more concrete way) as in those promoted by the President of the Republic ${ }^{35}$ (Cheeseman, Lynch \& Willis 2016; Waddilove 2019, 347). Since the implementation of decentralisation, the counties' dynamism has thus reinforced the competition between the central government and the counties, as both sides strive to be central players in Kenya's political life by emphasising their role in the development of their respective levels or fields of work (county, constituency, ward). This is particularly true in the case of productive regions resulting from colonisation (the former White Highlands), now transformed into counties (Laikipia, Trans-nzoia, Nandi, Kericho and counties of the former Central Province: Murang'a, Kirinyaga, Kiambu, Nyadarua, Nyeri). Today, these counties are working hard to develop their factories, cooperatives and export processing zones. This governmental approach to local innovation consists in capturing the added value of local products by allowing them to be manufactured locally, as in the case of coffee or fresh pasteurised milk dispensers for example (Muranga County), and by controlling export (the Chemalel Export Processing Zone in Nandi County).

This developmentalist ideology, according to which every individual and every county must play a role in the national economic effort, is now visible at all levels of the state. However, the authoritarian translation of this ideology is seen at county level; it is, in fact, reflected in the rationalisation of local development by the local and central governments. As the official slogan of the decentralised government points out-" 48 governments, 1 Nation"-, the integration of counties into globalisation will also be that of the Kenyan nation. Indeed, there is a clear overlap between the political and economic programs of the central government and those implemented by the counties despite the challenges or power games at play. The proximity of local elected officials to political and partisan networks is still relevant and continues to play a decisive role in the electoral battle. During the 2017 elections, governors who had Uhuru Kenyatta's support had an easier time winning the elections (with an average of $53 \%$ of the vote) than independent candidates who were not aligned with Kenyatta's Jubilee alliance (with

35. This is also reflected in the additional 5 million voters registered for the 2017 elections, while the 2013 elections marked a turning point in voter turnout. 
only $17 \%$ of the vote on average). This held true for the governors of Embu, Laikipia, Mandera and Meru, who won the elections by large margins despite a strong competition for their positions (Gadjanova 2019, 277). Note that, it is also a strategy on the part of some, whose credibility and legitimacy are reinforced when they criticise the central government: the MP of Nandi Constituency, Alfred Keter, was re-elected although he had been in clear opposition to Vice-President William Ruto throughout his campaign. In any case, local elected officials cannot exist independently of the national level, whether in electoral times or during the implementation of local development programs and projects-which are strongly influenced by the directives and the necessary support of the national political and economic elites.

\section{Mode of Action of Local Elected Officials:}

\section{The Members of County Assemblies (MCAs)}

The 2013 elections marked the coming into force of both the new Kenyan Constitution and decentralisation. On Monday, 4 March, voters went to the polls to elect candidates for six different positions. The competition had been particularly fierce due to a drastic increase in the number of candidates. While elections always require much "trickling-down" of national resources to the local level, the 2013 elections-which were organised at the ward, constituency and county levels-gave even more visibility to the decentralisation process. Indeed, this "trickling-down" to the county level took very concrete forms as a result of the multiplication of positions at the local level: jobs, vote buying, bribes, local or regional projects had been promised by all candidates. In addition, prior to the elections, the electoral commission had obtained international funding to organise staff training (polling station officials such as the Presiding Officer, his deputy and the clerks in particular). Note that most of the staff had been recruited locally (most of the clerks were young people from the county who had completed their primary schooling or were students). With the implementation of decentralisation, the local scene, and particularly the arena of local legislative elections, became a central arena for political participation within the (wider) Kenyan political scene. The 2013 general elections mobilised unprecedented resources. Electoral material had to be replaced: in addition to the purchase of electronic kits for biometric voting (KIEMS), ballot boxes were given their own colour. Pink represented the Women Representative (or Women Rep); and confusingly similar colours represented the MPs and MCAs (one's ballot boxes were beige and the other one's pale yellow). Moreover, before and during the campaign, many candidates made numerous requests for funding from the private sector or from local politicians who were already holding positions in the local 
or national governments. Urban centres were also overwhelmed by a wild public display of posters printed by candidates. The candidates started campaigning with pre-checked, fake ballots bearing their photograph and displaying the party symbols (a rooster, an elephant, a key, etc.), in addition to displaying the colour associated with the position they were seeking. ${ }^{36}$ For its part, the national government deployed numerous corps (military, youth, forest rangers and animal park guards ${ }^{37}$ ) to ensure the safety of the 40,883 polling stations (with two guards per station, one at the entrance and one inside). In doing so, the government underscored the attention paid to this first ballot and the ever-present suspicions of electoral fraud.

With these first general elections, came the hope that following representatives of citizens and "bottom" actors-including the "social cadets"-would enter politics: young people, women, disabled people, families and clans, squatters or migrant workers, civil servants of intermediary bodies and institutions. Prior to decentralisation, the electoral format rarely-if ever-allow these actors access to political positions. This new hope drew its strength from a deep collective belief in elective democracy and the strength of legislative institutions-an ambiguous legalism which characterises Kenya's political culture (Katende \& Kanyeihamba 1973; Warris 2013). However, while the 2013 elections initiated and put into practice this new decentralised administrative and political system for the first time, there was a clear, strong political continuity in the local elections. Thus, many "big men" as well as traditional and influential local figures-personalities who were often MPs in their region of origin before becoming ministers in the national government ${ }^{38}-$ ran for governor positions. Nevertheless, the introduction of a large number of local elected officials, the MCAs, raised the question of the political staff's renewal

36. These comments are drawn from the observation of the 2013 election
campaign in Nandi and Trans-Nzoia counties with Dominique Connan,
complemented by the author's experience as an international observer during
the 2017 elections. On the subject of vote materiality in Africa, see the special
issue of Politique africaine edited by Sandrine Perrot, Marie-Emmanuelle
Pommerolle and Justin Willis (2016): https://www.cairn.info/revue-politique-
africaine-2016-4.htm.

37. KDF, KWS, KFS, NYS, police, etc.

38. On the subject of "big men" in Kenya, see the work of Jean-François Médard (1992) and François Grignon (1997). Among the most prominent big men were Henry Kosgei, who was re-elected six times as MP for the Tinderet constituency and held eight ministerial positions between 1979 and 2013, but also Charles Njonjo (Attorney General for more than 17 years (1963-1979), MP for the Kikuyu constituency and twice minister), who was profiled in an article by Jean-François Médard (Médard 1987). The list is long and one could also name Matu Wamae, Nicholas Biwot, Kiraitu Murungi, Joseph Ole Nkaissery, etc. 
and that of the potential rapprochement between the state and citizens as a result of the implementation of decentralisation. Indeed, while the MCAs represented the smallest level of governance, they made up most of the candidates at the national level (1450 elected, 700 nominated). As of the 2013 elections and the establishment of local Assemblies, this position replaced the comparatively pale Ward Councillor position. The Constitution assigns the MCAs a dual role: the role of local legislators in County Assemblies and the role of territorial administrators, with access to the county budget for the citizens of the ward that elected them. This gives them a definite influence on the award of scholarships and local public contracts. The profiles of these elected officials have been quite atypical for Kenyan political scene: not being "professional" politicians, MCAs have seemed to be on the fringes of the traditional networks of clientelism..$^{39}$ They were often elected because they had acted on behalf of their compatriots-for example, as union representatives, local shopkeepers or businessmen, or as young graduates who had returned home to put their skills at the service of their rural communities. Their credibility was also enhanced by the possibility of impeaching the county governor, a procedure which must, however, ultimately be validated by the Senate. It seems that their appearance on the political scene encouraged voting decisions less influenced by ethnicity considerations than before. Voters based their choice on local elected officials' credibility, respectability and progress on development projects. Therefore, local elected officials had to convince voters of their deep-seated link with the community as well as their ability to act as intermediaries between voters-as is the case for MPs at the constituency level-and the state with its traditional elites. These logics of moralisation of representatives question the pre-eminence of the ethnic affiliations upon which the logics of political representation are based in Kenya (Atieno Odhiambo 2004; Berman, Cottrell \& Ghai 2009). However, generally speaking, voting on the basis of ethnic considerations remains very common, particularly in cosmopolitan constituencies-not to mention constituencies where political divisions are aligned with subidentity divisions (for instance, at the clan level) (NCIC 2014; 2016; Burbidge 2019, 91-120; Onyango 2018).

During the 2017 elections, changes in political personnel and institutional hierarchies took place. They were all the more visible at the county level, in particular at the positions of MCAs and the 47 Women Rep's (one per county). Among other things, one notes a form of power redistribution to the "social cadets," since young people and women-sometimes young

39. Waddilove, Hannah. 2017. "Kenya Voted for Change and Got it... at the Local Level.” African Arguments, 18 August. https://africanarguments.org/2017/08/18/ kenya-voted-for-change-and-got-it-at-the-local-level-elections/ [archive]. 
women-were elected; indeed, the 2017 elections saw more women entering politics thanks to the creation of a position reserved for women (Bouka, Berry \& Kamuru 2019). Several young graduate students who could not find jobs, Youth Group Leaders, young entrepreneurs, citizens from the civil society as well as-more expectedly-individuals from the trading class (especially local figures who had their own financial means and influence at the local level) were elected as MCAs. Simon Muturi, an unemployed 24-year-old candidate who campaigned on a bicycle for the Jubilee (that is, the coalition that enabled Kenyatta to be elected in 2013 and 2017) and was elected for the Muruguru-Gatitu ward, was emblematic of this "new generation." So was Cynthia Muge, a 24-year-old civil engineer and the country's youngest candidate, who was elected as an MCA for the Kilibwoni ward. As a young graduated in civil engineering, she unsuccessfully tried to get a job in Nandi County administration before deciding to run a political campaign, which she primarily envisioned as a platform to carry the voice of the youth to the county's politicians and the people in her home ward. Among other things, she proposed and introduced a technical and precise plan to renovate the deteriorated road infrastructure to the population during her campaign meetings. Note that her ward, being almost the size of a constituency (an MP being responsible for a constituency), had been divided in a peculiar way. In order to overcome the difficulty of meeting her constituents-who would have had to travel long distances to reach her office-and to take the diversity of their demands into account, she chose to set up a mobile office, moving between the different locations where she would meet them on certain days of the week..$^{40}$

However, the role of women in politics remains to be nuanced. Most of those who have reached the counties' highest positions are influential women who had already held national positions. ${ }^{41}$ This holds true in the case of the three women candidates who were elected as Kirinyaga's, Bomet's and Kitui's first female governors during the 2017 elections. $^{42}$

40. Field notes, interview with Cynthia Muge, April 2018, Hotel Eden Spring, Kapsabet, Nandi County. See also her detailed interview by the Kenyan media Daily Nation: "Cynthia Jepkosgei, 24, Speaks on her Victory as MCA.” 2017. Daily Nation, 11 August. https://www.nation.co.ke/news/politics/Nandi-MCA-elect-24beats-odds/1064-4053920-nnbwikz/index.html [archive].

41. More broadly, many local candidates are elected thanks to their inclusion in regional and national patronage networks. On the Kenyan logic of the partial renewal of local elites, see Grignon (1999) and Cornell \& D’Arcy (2014).

42. Anne Waiguru (former CS for Devolution) for Kirinyaga County, Charity Ngilu (former minister and presidential candidate) for Kitui County, and Joyce Laboso (former Vice-President of the National Assembly) for Bomet County. 
Laws on gender balance in politics and positive discrimination (according to the $2 / 3$ principle) promoted by the Constitution have not yet been passed by the Parliament which, like the rest of the Kenyan institutions and bodies, function according to a marked patriarchal habitus (Nyabola \& Pommerolle 2018). Furthermore, the role of the Women Rep remains unclear in the Constitution. The mission of these representatives is to express the specific needs and demands of Kenyan women and to be the "voice of women" in politics. The missions carried out under this new position are the subject of considerable debate. This is because they vary significantly from one profile to another. Incidentally, this new position is sometimes reduced to a springboard to access more positions deemed more prestigious and influential, in particular that of MP (ibid., 67-71). Finally, the effectiveness of administrative reforms aimed at ensuring the counties' ethnic diversification is called into question by the almost monoethnic composition of the executive, legislative and civil service of the counties. It underlines that the majority of power positions still belong to the dominant local ethnic group. ${ }^{43}$ In addition, political competition being increased by the number of candidates running, decentralisation seems to have reinforced localised violence often spurred by the political class to the detriment of citizens, who are its "foot soldiers." ${ }^{4}$

Thus, it is difficult to give a clear answer to the question whether decentralisation has brought the state and citizens closer. It is clear that this new political chessboard allows some elected officials-notably governors and senators-to position themselves in relation to national elected officials, who take up their political function to strengthen their local legitimacy, sometimes by expressing their allegiances to the central power, sometimes

43. In this regard, see the damning reports of the Auditor General (2019) on the ethnic composition of the executive and legislative branches at the county level. These reports point out that a large majority of counties do not comply with the provisions detailed in section 65 of the County Governments Act of the 2010 Constitution. The latter provides that $30 \%$ of positions must be occupied by people who are not coming from the dominant ethnic group in the county. However, the latest audit reveals that, on average, only $10 \%$ of county staff come from minority groups. Figures on the ethnic group of elected officials and civil servants in the counties' administrations are given by the NCIC (2016). See also the "Decentralisation in Kenya" section of the article by Nicholas Cheeseman, Gabrielle Lynch \& Justin Willis (2016), and Dominic Burbidge's chapter on counties described as "ethnic mini-states?" (2019, 92-101). For an analysis of the ethnic group of public servants from the 1960s to 2010, see Rebecca Simson (2017).

44. Lynch, Gabrielle. 2014. "Devolution Has Made Politics more Local and Violent than ever before." The Nation, 26 September. https://www.nation.co.ke/ oped/opinion/Majority-of-Kenyans-still-support-devolution/440808-2466284bbwxt1z/index.html [archive]. 
by criticising the government's actions in their region (Waddilove 2019; Gadjanova 2019). Nonetheless, the emergence of new levels of power and objections by the MCAs to the projects or decisions made by the governors and MPs-who used to be unquestioned leaders on their lands-indicates a kind of rapprochement between these new "local" elected officials and their voters. Increased citizen participation, which resulted from decentralisation, is supposed to strengthen this proximity between representatives and those they represent in the conduct of public affairs.

\section{Citizens' Modes of Action: The Mixed Experience of a Decentralised "Participatory Development"}

Public participation is a core element of the constitutional reform. It is up to citizens to identify local development issues (Rwigi, forthcoming), and this occurs during public forums organised by each county through the retrospective plebiscite-by show of hands-of priority development projects. This procedure-which follows the model of participatory governance created in Porto Alegre (Participatory Budgeting)-aims to tie up strategies of local development with the will of the citizens, who must actively deliberate budget orientations. The local and decentralised co-production of public policies (co-production because it brings together citizens and elected officials) is intended to enhance the managerial transparency of the counties as well as the political legitimacy of their elected officials (Fung $\&$ Wright 2001, Wampler \& Avritzer 2005). The reality is that these forums are either neglected or monopolised by supporters of the dominant party or group in local politics; or composed of citizens paid to participate or intimidated into self-censorship on the conduct of public affairs. Therefore, "participatory" democracy-as a fairer model and a system of good local governance-needs be put into perspective; as do the "democratisation" of Kenya's political space and its opening up to civil society. ${ }^{45}$

Indeed, the participatory approach has not yet proved its worth in Kenya-except, perhaps in Makueni County, which is presented as a success story. Makueni County's success is partly due to the career and technical expertise of the county governor in office since 2013, Kivutha Kibwana. Kibwana is a recognised law professor, human rights advocate and former member of the opposition. However, this specific participatory process seems to work more to the advantage of his government's political legitimacy than to improve his management. Public participation is "a structured way of consulting with persons, groups and entities before

45. For an updated and transdisciplinary analysis of these debates, see Chauveau \& Lavigne-Delville (2013). These questions also intersect with the work of French sociologist Christian Le Bart (2003) on local citizenship. 
decisions are made" (GoMC 2016). Participants must come from six different levels: Village People's Forum, Cluster People's Forum, Sub Ward People's Forum, Ward People's Forum, Sub County People's Forum and the County People's Forum. In Makueni County, citizens at each of these levels nominate eleven people of their choice to form a Development Committee (DC). The mission of each DC is to represent the interests of the citizens of the level they represent. The DCs of the first four levels negotiate and deliberate with each other on the allocation and distribution of resources for the development of the ward. At the sub-county or county level, the DCs merely reiterate their vested interests in the verification and validation of their proposals as they were validated during the public participation forums held in the 30 wards of Makueni County. Thus, in principle, public participation is supposed to help Makueni County achieve two objectives: [1] to include marginalised constituencies in public decision-making, and [2] to consolidate the government's authority over its political-administrative territory (GoMC 2016).

To some extent, this system has allowed citizens to influence spending in their ward according to their own priorities. There are, however, many participation gaps, which highlight the fact that the constituted assemblies are not always inclusive or representative. Local figures (e.g. teachers, religious leaders, activists, social workers and union representatives), particularly men, take up much of the speaking time in these meetings. Young people, for instance, often feel excluded from these forums because, in the continuity of the baraza tradition, they are usually reserved for "elders" and associated with values of respectability, maturity an honour. ${ }^{46}$ At the same time, MCAs are demanding that the government grant them their own fund (the Ward Development Fund) to carry out their projects at the grassroots. So far, they have been denied funding. According to the constitution, the ward is not intended to be a financial entity per se, and it is the county government that decides on the allocation of funds, based on the county's (that is, not the ward's) overall priorities. This situation creates deep frictions between parliamentarians and the executive. It also underscores once more the limits of citizen participation in defining local development priorities. The existence of People's Parliaments-or Bunge la Wananchi-also highlights the fact that decentralisation has not really made it possible to involve Kenyan citizens in public decision-making in satisfactory ways. These People's Parliaments offer an alternative framework for public discussion of political, social and economic affairs; and, on the basis principles close to those of "street parliaments" found

46. Baraza are community forums for public debate, often associated with or overseen by councils of elders (Haugerud 1995). 
in several African countries, they have been organised in a national and activist network. ${ }^{47}$

However, the partial renewal of the county elites between 2013 and 2017 showed that voters had not been fooled and had the means to influence the careers of elected officials. To a certain extent, by electing MCAs from their communities, citizens used the decision-making mechanisms at their disposal to restructure power relations that had hithertodisadvantaged them. They did so by mobilising the institutions and machinery of decentralisation to bring about the local reconfigurations they needed: namely, access to schooling, road construction, obtaining property titles, passing local laws to protect local labour or sectors of activities, etc. This has also been evidenced by demonstrations, petitions and increased appearances in local courts. While they are not new, these local mobilisations are becoming more effective and gaining visibility as a result of decentralisation (Lynch 2011). Employment and working conditions are central issues in the national and local political life, where corruption and co-optation are often denounced by citizens and activists who feel powerless outside election times. These grievances, directed at elected officials and the state, are relayed by the new institutions of power (the County Assemblies) and local figures (especially Senators) who question the decisions taken by national institutions and the state on their territory. To take a concrete example: a law to limit the number of machines authorised by multinational tea companies for automated tea leaf picking was passed in November 2018 by the MCAs of Nandi, a large tea-producing county. This measure allowed plantation workers to keep their jobs in spite of the mechanisation of the tea sector. ${ }^{48}$ The governor of Kericho too rallied against the multinational Finlay, which intended to dismiss its horticultural workers and close some of its tea plantations, on which the county's economy. Obviously, these elected officials were also acting to protect their own interests and secure their individual re-election (MCAs among others). They did not hesitate to go against interests of the people, when necessary to ensure the continued support of agri-food lobbies and private sector individuals who finance and support the political campaigns and local actions of governors and their ministers. ${ }^{49}$ One final note. The so-called "Councils of Elders"-the

47. See the special issue on "Public Spaces of Speech and Practices of Citizenship in Africa," of Politique africaine, edited by Richard Banégas, Florence BrissetFoucault and Armando Cutolo (2012), or Rasmussen \& Omanga (2012/3).

48. Two workers can carry this machine, where manual harvesting requires an average of 30 workers per plot.

49. Donors can indeed contribute to the counties' finances but their contribution must be declared in the budget, which is certainly not always the case (bribes, illicit financing, money laundering). 
traditional authorities in Kenya-still play a major role in guiding local policy, ${ }^{50}$ especially at the village level, where they are often appointed as administrators (see diagram).

\section{Decentralisation in Question: Political Ethnicity, Corruption and Inequality}

While decentralisation has raised high hopes, it has also caused wariness, especially of the "ethnicisation" of local governments, the potential impact of decentralisation on corrupt practices and the persistence of regional inequalities-now measured at the county level.

\section{Towards Increased Ethnicisation of Politics}

Between 2007 and 2008, fear of ethnicisation was the strongest in counties regarded as hotspots of violence. Such counties are often the scene of protracted conflicts over the control and monopolisation of resources. For example, in counties of the former North-Eastern Province like Turkana and Marsabit, lack of access to water for Turkana and Samburu pastoralist groups remains a driving force behind violent and armed conflicts (ScottVilliers 2017). In cosmopolitan counties such as Nakuru-one of the counties that hosts many IDPs in the Rift Valley-, tensions over access to and ownership of land are a source of political tensions (Boone 2013). This is also the case in counties where a majority of the population belongs to a single ethnic group. For instance, in Uasin Gishu, the Kikuyu occupation of land and ownership of trade has long been contested by Kalenjin elites, who mobilise indigenousness to maintain their political and economic base in the region (Elfversson \& Sjögren 2019, 8).

The counties' response to these fears, tensions and conflicts has been ambiguous as the initiatives of elected officials and administrators have been driven by their own interests. In the case of Nandi County, a market has been established on the western border-which Nandi County shares with Kakamega County. Land disputes and tensions over use of the forest by the two main communities of the region, the Nandi and Luhya, have long been a source of friction in the border are between Nandi County and Kakamega County. In November 2014, violent clashes erupted in the area after the arrest of three Luhya men suspected of killing a Nandi because of a land dispute. A meeting between Nandi County's governor, Cleophas Lagat (2013-2017), and the governor of Kakamega, Wycliffe Oparanya (2012-2022), ensued. The two men proposed to set up a "peace market" in Kamungei; an initiative supported and approved by the president of the

50. On the role of Councils of Elders in the conduct of local political and public affairs in Kenya, see Josse-Durand (2020) and Nyamweru \& Chidongo (2018). 
NCIC, Francis Ole Kaparo. ${ }^{51}$ With the agreement of the governors of the two counties, the NCIC decided to reinforce police patrols in the area and to allocate additional vehicles to the two counties on a temporary basis in case of conflicts. In addition, the idea of deploying the army in temporary camps along the border emerged. From 2017 onwards, on the southern border of Nandi County, Cleophas Lagat's successor-the young governor Stephen Arap Sang (2017-2022) - campaigned for the integration of eight lowland localities with Nandi names, but which belong to Kisumu County. ${ }^{52}$ The idea was to set up an Export Processing Zone, which cannot be built in Nandi County because of the pressure that intensive tea production already exerts on the arable land of the Nandi escarpment, there. A local industrial park specialised in tea manufacturing would mainly benefit Nandi County; this fact is a source of tension between not only the Luo and Nandi farmers of the area but also the Nandi inhabitants and migrant tea plantation workerswho are often of Luo, Luhya and Kisii origins. What can thus be said is that the role of the counties in conflict management has been restricted to local and small-scaled actions, which are sometimes limited to the mandate of a particular governor. Moreover, their choices and the modalities of their actions have underlined a lack of coordination with the central government and a lack of coherence in the actions carried out-in particular with the NCIC-depending on the type of issues that the conflicts give rise to.

\section{Towards Acute Corruption at the Local Level?}

Decentralisation and major development projects driven by Vision 2030 have led to the decentralisation of corruption (Burbidge 2015, D'Arcy \& Cornell 2016). Scandals are no longer just national or international, as was the case with Goldenberg or Anglo-leasing, but mainly involve the corruption of local public funds. ${ }^{53}$

51. Wekesa, Grace. 2015. "NCIC Chair Francis Kaparo Warns Nandi, Luhya Leaders against Incitement." The Standard, 25 January. https://www. standardmedia.co.ke/article/2000149182/ncic-chair-francis-kaparo-warnsnandi-luhya-leaders-against-incitement [archive]; Sirma, Evans. S.d. "Governor Lagat Commissions Amani Market to Foster Unity in Kamung'ei Border.” County Government of Nandi. https://nandicounty.go.ke/governor-lagat-commissionsamani-market-to-foster-unity-in-kamungei-border/ [archive].

52. Jelima, Rael. 2018. "Nandi County Claims Seven Towns along Border with Kisumu." The Standard, 28 May. https://www.standardmedia.co.ke/ article/2001281967/nandi-county-out-to-reclaim-seven-towns-from-kisumu [archive].

53. This corruption also concerns the CDF, managed by the MPs, as it was already the case before the implementation of devolution. The Auditor General's report on public finances for the year 2013/2014 reckons that corruption affects 270 constituencies (out of a total of 290) and is estimated at 38.5 million EUR. 
Yet, what is sometimes associated with simple corruption actually reveals tensions between county and national governments over the allocation of funds. The "wheelbarrow scandal" provides a perfect example of this phenomenon. The scandal burst forth in 2015 when the Bungoma County Ministry of Agriculture bought ten wheelbarrows at a price of 109,000 KES each (about 965 EUR) while the market price was around 5,000 KES (about 45 EUR). ${ }^{54}$ Shortly after that, seven county officials were fined 300,000 KES, the non-payment of which was punishable by imprisonment of 18 months. ${ }^{55}$ Price inflation in county budgets and the justification of expenses are also crucial issues because unspent funds are returned to the County Revenue Fund at the end of the fiscal year-which is set for 30 June-after the Budget Controller's audit. Such funds are then put back into play for the following year. ${ }^{56}$ Incidentally, while-by voting for supplementary budgets-local assemblies have enabled local governments to move money previously allocated to a budget line, project or ministry within a county, to do so is often difficult. Note that local assemblies may also occasionally clash with the executive when they wish to "settle score" with certain county officials or expose local corruption. One such tussle ensued the Assembly's refusal to transfer funds four days before the deadline for the 2019 fiscal year in Laikipia County. Because of this-and because of limited fundingthe wages of county employees were frozen for three months in a row. ${ }^{57}$ These practices, which are sometimes too quickly labelled as corrupt, highlight the challenge of spending locally and on the basis of the county's development properties and non-fungible budgets. They also underline the issue of the politicisation of budget management.

One finding bears note. Corruption has not so much been decentralisedor in the words of the Kenyans, "corruption has [not so much] been

\footnotetext{
"NEW: Billions Unaccounted For in CDF Audit." 2016. RoggKenya, 5 December. https://roggkenya.org/new-billions-unaccounted-for-in-cdf-audit/ [archive].

54. Oteba, Titus. 2015. "Uproar as Bungoma County Buys 10 Wheelbarrows at Sh1m." The Standard, 8 September. https://www.standardmedia.co.ke/ article/2000175604/uproar-as-bungoma-county-buys-10-wheelbarrows-at-sh1m [archive].
}

55. Amadala, Benson. 2018. "Seven Former Officials Sent to Jail over Wheelbarrow Scandal.” Daily Nation, 25 June. https://www.nation.co.ke/counties/ bungoma/7-sentenced-in-wheelbarrow-case/1183258-4630664-10cux86z/index. html [archive].

56. Shiundu, Alphonse. 2013. "Six Counties Fail to Spend Allocated Funds." The Standard, 14 August. https://www.standardmedia.co.ke/article/2000090917/sixcounties-fail-to-spend-allocated-funds [archive].

57. Munyi, Martin. 2019. "Laikipia Assembly Rejects Supplementary Budget." Kenya News Agency, 29 June. https://www.kenyanews.go.ke/laikipia-assemblyrejects-supplementary-budget/ [archive]. 
devolved"- as multiplied; meaning that it has multiplied due to the increase in the number of contexts that are conducive to corrupt practices. Since 2015, successive reports of the Auditor General have revealed that at least 20 counties out of 47 experience irregularities in the management of their public finances. In fact, many county governors are involved in serious corruption cases: following the disappearance of about 17 million EUR (2 billion KES), Governor Obado and several officials from Migori County have been monitored by the Ethics and Anti-corruption Authority (EACC) for "abuse of office and corruption." ${ }^{58}$ For his part, the controversial Nairobi County Governor, Mike Sonko-who was, until recently, thought to be very close to President Kenyatta [who made the fight against corruption the touchstone of his second term]-was arrested in December 2019 as he was trying to flee to Tanzania. He [and his immediate political circle] is being proceeded against for the embezzlement of public funds amounting to 3.2 million EUR. ${ }^{59}$ In 2012, an opinion poll conducted by AfriCOG highlighted that a third of the surveyed Kenyans who were against decentralisation justified their opinion by saying that the new system would lead to a "decentralisation of corruption." ${ }^{60}$ Decentralisation was, at least in theory, supposed to provide checks and balances mechanisms by affording better representation in national and local governments and institutions to minority groups, social cadets and opposition parties. In practice, however, it has also opened new windows of opportunity for corrupt practices, among other things, through the levying of local taxes and the allocation of local budgets and public contracts. ${ }^{61}$ At the same time, these practices-which are simultaneously rooted in local clientelist networks and connected to the national scene-are those of elected officials who are increasingly "close" to citizens. Thanks to their proximity to citizens, these officials are in a

58. Mbula, Ruth. 2019. "Migori County Official on Graft Charge Detained for Four Days.” Daily Nation, 9 May. https://www.nation.co.ke/counties/migori/ Court-detains-Migori-official-four-days/1183306-5097492-xcc1yrz/index.html [archive].

59. "Nairobi Governor Mike Sonko Denies Corruption Charges in Court." 2019. Al-fazeera, 9 December. https://www.aljazeera.com/news/2019/12/nairobigovernor-mike-sonko-pleads-innocent-corruption-charges-191209134806019. html [archive].

60. Two years later, a second survey showed that $33 \%$ of Kenyans believed that "all or most" of the county governors were "involved in corruption," with the figure rising to $37 \%$ for members of the county assemblies (MCAs). In 2016, the perception of corruption at the county level was even higher: $78 \%$ of Kenyans believed that the county government office "uses corruption, sometimes or systematically."

61. I warmly thank Alexia Van Riij for shedding light on my understanding of corrupt practices in Kenya. 
position to both challenge and denounce corruption; or, conversely, have a front-row seat to benefit from corruption-including in electoral times, in which bribes are commonplace.

\section{Recentralisation as a Response to the Strong Persistence of Inequalities between Counties?}

Governors have also complained about inequalities between counties; inequalities related to differing state-issued budget allowances, varying abilities to raise taxes, and the presence (or, for that matter, absence) of county-managed resources. The inequitable redistribution of resources between counties is at the heart of political debates and alliances. For example, while it is very sparsely populated-albeit very poor, much revenue is allocated to Turkana County. ${ }^{62}$ These allowances should be based on the counties' own available resources to raise funds and taxes (for example, Narok County benefits from important revenues from local tourism thanks to the presence of Masai Mara National Park, a major luxury safari destination in the East-African region). As noted above, each county receives $15 \%$ of the national revenue annually, and some counties benefit from the equalisation fund that amounts to $0.5 \%$ of the annual national income, and is earmarked for the country's poorest counties. This additional but minimal funding is not enough to "brush up" these counties, which are lagging far behind in terms of access to the most basic services. Furthermore, due to the legal and constitutional framework, which severely limits the counties' ability to obtain cash flows, the levying of local taxes leads to circumventions in counties whose economic stability depends on an unstable source of revenue (natural and cultural heritage sites, national parks) or sector of activity (tourism, agriculture, etc.). It also generates localised corruptive practices which limit the generation of revenue such as untimely taxes on public transport (matatu) between counties, levied at the entrance to cities. ${ }^{63}$ These inequalities have persisted since colonial times, and have been reinforced since then. The ghost of the former provincial administration and its functioning still hovers over the counties, whose borders are not so new, as they sometimes overlap with those of the old districts. This underlines the central state's maintained control over its peripheries, which explains the difficult and partial implementation of

62. On inequalities between counties, see the report of the Kenya National Bureau of Statistics and the Society for International Development (2013). On the political aspects of territorial inequalities in Kenya, also see Owiti (2014).

63. Owiti, Maugo. 2015. "Matatu operators decline proposal to remit tax through M-Pesa.” Hivisasa, 3 December. https://hivisasa.com/posts/------------------------------matatu-operators-decline-proposal-to-remit-tax-through-m-pesa [archive]. 
decentralisation. In the counties, structural spending reduction is also among the main challenges of decentralisation: huge amounts of resources are channelled into recurrent expenditure. And some counties spend up to $80 \%$ of their budget on wages. This is, in part, due to the fact that they inherited staff from the provincial administration (CRA 2013; Franceschi, Memusi \& Muhindi 2015).

Finally, a trend towards recentralisation-through the creation of regional economic blocs-highlights the limitations of the possibilities that decentralisation offers county governments to raise sufficient equity capital to carry out their five-year plans. A law aimed at clarifying the administrative and financial organisation of regional blocs and the potential public/private partnerships set up by counties is also under consideration. This was initiated by the Council of Governors (CoG), which is composed of the county governors who meet to promote good governance and local development. ${ }^{64}$ In September 2019, the governors voted in favour of the so-called the Ugatuzi Initiative, a constitutional reform to strengthen decentralisation. This reform provides for, among other things, the establishment of a three-tier system of government (national, county and regional) and the creation of regional governments to strengthen the devolution of responsibilities. Over the past five years, under the leadership of CoG's President Wycliffe Oparanya, governor of Kakamega County and leader of the largest regional bloc (the Lake Region Economic Bloc, which includes 14 multiparty counties), the following regional blocs have flourished and strengthened their capacities: the North Rift Economic Bloc (7 counties), the Frontier Counties Development Council (7), the Lake Region Economic Bloc (14), the Central Kenya Economic Bloc (10), the South Eastern Kenya Economic Bloc (3) and the Jumuiya ya Kaunti za Pwani (6). ${ }^{65}$ These six blocs group the counties into large economic regions independently of the partisan affiliations of the governors. The Lake Region Economic Bloc is one of the first to have formalised this economic pact between counties. It brings together 14 counties in an unprecedented combination, uniting the counties bordering Lake Victoria (which was won over by the opposition) and those of the Highlands (won over by the coalition in power since the alliance between Kenyatta and Ruto in 2013). The Lake Region Economic Bloc Investment Bank was created to serve as a joint; and, in it, each of the counties deposited an equivalent amount of money: 200 million KES per county, for a total amount of 2.8 billion KES (about 25 million EUR). The objective of these blocs is to strengthen the

64. "Ugatuzi Initiative." 2019. The Council of Governors. https://www.cog.go.ke/ component/k2/item/179-ugatuzi-initiative [archive].

65. See the map of the blocs made by the CoG (s.d.): https://cog.go.ke/regionaleconomic-blocs [archive]. 
counties' comparative advantages, optimise their economies of scale and attract regional investments-following the model of the European Union and the East African Community and with the support of the central government. In the case of the Lake Region Economic Bloc, the objective is to revive the tea, sugar, dairy and fishing sectors by: [1] providing startup capital for local entrepreneurs that are supported by their county; and [2] building regional industrial parks to create jobs in these sectors and increase the local added value.

While the policy of regional economic blocs is still topical, it lacks a legal framework; the central authorities and institutions have been slow to legislate on this issue. Thus, the governors' Ugatuzi Initiative was quickly abandoned and incorporated into the Building Bridges Initiative (BBI), a new national initiative for a general reform of the Constitution through a series of amendments. The BBI was launched in March 2018, following the symbolic handshake between Kenyatta and Odinga. A team of 14 wellknown figures appointed by the two leaders have since formed the task force at the heart of the BBI. These 14 figures-who, like the president of the commission Yusuf Haji (senator and former minister), are from the activist, political and religious spheres-are in charge of drawing up a program of reforms aimed at restoring the pact of confidence between the rulers and the ruled, and facilitating the concrete implementation of the 2010 Constitution. The taskforce issued its report on 27 November 2019, with one month's delay. The highest state dignitaries-President, VicePresident, speakers from both assemblies-and the main political leaders were present for the report's release. While this text is not legally binding, it puts forward major institutional reforms. As far as decentralisation is concerned, the proposals for improvements are many. Examples include the strongly recommended grouping of counties into "regional units." According to the report, the share of the national income allocated to the counties should be increased from the current $15 \%$ per year to a minimum of $35 \%$ per year, and should be distributed more equitably between counties by taking into account the actual population density (up to a maximum of $50 \%$ ); branches of the Auditor General's offices should be set up at the local level for greater control of public expenditures and accounts; the ward level should have greater decision-making power in access to public services; etc. The year that has elapsed since the task force began its national tour, mobilising nearly 8,000 citizens and elected officials, has been marked by criticism, hopes and rumours. ${ }^{66}$ From a political point of view, the BBI is,

66. Their activities and the preparation of the report were widely covered by the media, fuelling numerous rumours and spreading false reports. Only one member of the committee is a lawyer, and some measures remain vague, such as the range of $35 \%-50 \%$ of the budget allocated to the counties or the possibility 
above all, the expression of a rapprochement between the president and his main opponent Raila Odinga, also aimed at William Ruto and his presidential ambitions for 2022 keeping at bay. ${ }^{67}$ As a matter of fact, the main reform proposals (namely, to transition to a semi-presidential regime; strengthen anti-corruption measures, parity and inclusion in institutions; rationalise wages and the decentralised system; and introduce a Prime Minister position chosen by the President from among the parliamentary majority) are clearly reminiscent of the opposition's demands and programs at the time of the 2005 referendum.

\section{Conclusion: Decentralisation in Kenya, "Everyone's Turn to Eat"? ${ }^{68}$}

The Kenyan decentralisation experience raises the inevitable question of the consequences of the disruption of the political hierarchy on local development, corruption and political competition. In Kenya's political history, local development income has often benefited only large landowners, state-owned companies-often led by powerful elected officials or the president's entourage-and multinational corporations such as Unilever in the tea sector, owner of the Lipton brand, or Monsanto in the grain sectorand often protected by the state (Holmquist, Weaver \& Ford 1994, 76). Decentralisation has resulted in the creation of funding as well as human and institutional means of encouraging local and regional development. Yet development gains are under imminent threat of monopolisation. The taking of public action at the local level, by the ministries and county assemblies, is in fact ambiguous since it can be put sometimes at the service of citizens and sometimes at the service of the interests of elected officials and local authority representatives. Elected officials in the new local governmentsfrom the MCA to the governor and his cabinet appointees-all have taken a keen interest in the economic benefits brought and multiplied by decentralisation. Evidence shows that there are strong tensions between

that the newly reintroduced figure of the Prime Minister could be the leader of the opposition at the same time.

67. William Ruto, who aims to become President in 2022, indeed suffered from the rapprochement between the President and his former opponent Raila Odinga, which left him in the shadows. Present at the ceremony alongside the latter two, he gave his official support to the report but would suffer from a referendum campaign of which he would only be the third man.

68. According to the expression often used in reference to the "politics of the belly" (Bayart 1989) and taken up in relation to Kenya by Michela Wrong (2010), Daniel Branch, Nicholas Cheeseman \& Gardner (2010), and more recently by Michelle D’Arcy \& Agnes Cornell (2016) to refer to the corrupt practices of the new decentralised system. 
members of the local governments over access to and management of the various local budgets, not to mention the repeated scandals that illustrate the misuse of these funds-for example, when they are squandered on unjustified per diem and personal investments. At the same time, some tenuous overlaps create a strong interdependence between elected officials and the existence of a system of territorial administration deployed in the counties by the central government. These overlaps underline the persistence of the national level administrations, bodies and representatives in the conduct of local development and in the access of candidates to the positions they covet. In this respect, it seems that the establishment of a new political order, raising of national consciousness and building of unity that should have followed the collective catharsis announced in the early 2000s have not worked properly. The new decentralised structure is, as a matter of fact, still precarious in its practices, which attest to the presence of the central state and the lingering vicissitudes of the provincial era and the country's political history. The latent lack of confidence in the institutions of power and government committees, as well as the persistent distrust of the procedure of popular participation in public hearings, confirm this hypothesis (Lynch 2018).

However, it must be noted that-while they are tainted by corruptionfundings earmarked for the counties (i.e. equalisation funds and equitable share funds) and the development projects that have been implemented reflect the progress made since 2013. Decentralisation-which enjoys unwavering public and voter support-strengthens state power and, to some extent, state legitimacy. It also fuels clientelist networks, at the head of which newly elected officials take advantage of the possibilities that corruption has multiplied, at all levels. These officials blithely enjoy symbolic (career, legitimacy) and concrete (bribes, embezzlement) benefits from the redistribution and trickling down of national resources to the local level. And while some local elected officials and county servants act as counterweights in the distribution of public funds among constituencies, others become decentralised actors in a national accumulation strategy, the possibilities of which decentralisation has multiplied. The local scene is emerging as the new network of regional patronage, which is maintained by corrupt political practices and fuelled by the intimidation and/or purchase of a local electorate. To that extent, the emergence of elected officials at the county level has not resulted in a thorough renovation or transformation of the political culture of post-colonial elites (Haugerud 1995). The question then becomes whether decentralisation functions as a tool for the elites to engage in nepotistic behaviour; and we must determine to what extent local mandates are part of the debate on the colonial legacy and the formation of the post-colonial state in Kenya (Bourmaud 1988). 
The unprecedented experience of Kenyan decentralisation provides concrete answers, but also leaves open questions about the effects of decentralised governance on the transformations-and the continuitiesof the country's political culture. Future research will provide a better understanding of the consequences of decentralisation, as well as a rethinking of the political registers shaped by development issues. This will allow us to deepen and nuance the classical theories of politics in Africa, which are articulated around the notions of clientelism, nepotism and neo-patrimonialism. As the many examples and dynamics detailed in this chapter highlighted, decentralisation unites the 47 governments which make up a single nation in a complex motion. But towards which horizon? Both county governments and the central government have, on more than one occasion, claimed that "decentralisation works" or "is working." As a matter of fact, the official slogan of the Annual Decentralization Conference, where county and national officials meet, reads as follows: "Devolution is working!" Optimist slogans aside, however, we are confronted with the following question: what could the initiatives for constitutional amendments and institutional reforms bode for Kenya's future? The BBI initiative is ongoing, but it already suggests that, once again, popular participation in constitutional amendments and in shaping public and political life is partial, and will certainly, as in the past, lack concrete implementation. The restructuring of the political camps is happening in the run-up to the 2022 presidential election, in which Uhuru Kenyatta is not eligible. Many governors-such as Gideon Moi, son of Daniel arap Moi and governor of Baringo, or Ali Hassan Joho, governor of Mombasa-as well as nationallevel and government politicians, headed by the current Vice-President William Ruto, will lead a campaign that will certainly be colourful. During this campaign, the issues surrounding the reform of the constitution and the effective implementation of decentralisation-as well as the preservation of the interests of the economic and political elites and of some counties that influential elected officials playing in the foreground on the national stage represent-will be key elements of political competition at all levels.

\section{References}

Abdille, Abdullahi, and Rashid Abdi. 2016. "Kenya: Development, County Government and the Risk of 2017 Election Violence." International Crisis Group, 7 April. https://www.crisisgroup.org/africa/horn-africa/kenya/ kenya-development-county-governments-and-risk-2017-election-violence [archive].

Africa Center for Open Governance. 2012. "AfriCOG's Report on Devolution." Nairobi: Africa Centre for Open Governance. https://africog.org/reports/ africog-s-survey-report-on-devolution/ [archive]. 
Anderson, David M. 2005. "'Yours in Struggle for Majimbo.' Nationalism and the Party Politics of Decolonization in Kenya, 1954-65." Journal of Contemporary History 40, no. 3: 547-64. https://doi.org/10.1177/0022009405054571.

Atieno, Odhiambo, and Elisha Stephen. 2004. "Hegemonic Enterprises and Instrumentalities of Survival: Ethnicity \& Democracy in Kenya." In Ethnicity \& Democracy in Africa, edited by Bruce Berman, Dickson Eyoh and Will Kymlicka, 167-82. Oxford: James Currey.

Bach, Daniel, and Mamoudou Gazibo. 2012. Neopatrimonialism in Africa and beyond. London \& New York: Routledge.

Badurdeen, Fathima Azmiya. 2018. "Devolution Arguments and New Emerging Architectures of Security in Mombasa County." Presentation made during the conference Portraying Devolution in Kenya, Nairobi, IFRANairobi, 13 June.

Banégas, Richard, Florence Brisset-Foucault and Armando Cutolo. 2012. "Espaces publics de la parole et pratiques de la citoyenneté en Afrique." Politique africaine, no. 127: 5-20. https://doi.org/10.3917/polaf.127.0005.

Barkan, Joel, and Michael Chege. 1989. "Decentralising the State: District Focus and the Politics of Reallocation in Kenya." The Fournal of Modern African Studies 27, no. 3: 431-53. https://doi.org/10.1017/S0022278X00020371.

Bayart, Jean-François. 1989. L'État en Afrique. La politique du ventre. Paris: Fayard.

Berman, Bruce, Jill Cottrell and Yash Ghai. 2009. "Patrons, Clients, and Constitutions: Ethnic Politics and Political Reform in Kenya." Canadian Journal of African Studies 43, no. 3: 462-506.

https://doi.org/10.1080/00083968.2010.9707567.

Berman, Bruce, and John Lonsdale. 1992. Unhappy Valley: Conflict in Kenya \& Africa. Book 2: Violence \& Ethnicity. Eastern African Studies. Oxford: James Currey.

Boone, Catherine, Alex Dyzenhaus, Ambreena Manji, Catherine W. Gateri, Seth Ouma, James Kabugu Owino, Achiba Gargule and Jacqueline M. Klopp. 2019. "Land Law Reform in Kenya: Devolution, Veto Players, and the Limits of an Institutional Fix.” African Affairs 118, no. 471: 215-37. https:// doi.org/10.1093/afraf/ady053.

Boone, Catherine. 2013. "Land Regimes and the Structure of Politics: Patterns of Land-Related Conflict." Africa: Journal of the International Africa Institute 83: 188-203. https://doi.org/10.1017/S0001972012000770.

Bosire, Conrad M. 2017. "Interpreting the Power of the Kenyan State to Oversee National Revenue Allocated to the County Governments: Building a Constitutionally Tenable Approach." Africa fournal of Comparative Law 2: 35-66. https://journals.co.za/content/journal/10520/EJC-f51c35815.

Bosire, Lydiah Kemunto, and Gabrielle Lynch. 2014. "Kenya's Search for Truth and Justice: The Role of Civil Society." International fournal of Transitional fustice 8: 256-76. https://doi.org/10.1093/ijtj/iju002.

Bouka, Yolanda, Mary E. Berry and Marylin Muthoni Kamuru. 2019. "Women's Political Inclusion in Kenya's Devolved Political System." 
Journal of Eastern African Studies 13, no. 2: 313-33.

https://doi.org/10.1080/17531055.2019.1592294.

Bourmaud, Dominique. 1988. Histoire politique du Kenya. État et pouvoir local. Paris: Karthala-CREDU.

Brancati, Dawn. 2006. "Decentralization: Fueling the Fire or Dampening the Flames of Ethnic Conflict and Secessionism?.” International Organization 60, no. 3: 651-85. https://doi.org/10.1017/S002081830606019X.

Branch, Daniel. 2010. "The Search for the Remains of Dedan Kimathi: The Politics of Death and Memorialization in Post-Colonial Kenya." Past \& Present 206, supplement 5: 301-20. https://doi.org/10.1093/pastj/gtq022.

Branch, Daniel, Nicholas Cheeseman, and Leigh Gardner. 2010. Our Turn to Eat: Politics in Kenya since 1950. Afrikanische Studien. Berlin: LIT Verlag.

Branch, Daniel, and Nicholas Cheeseman. 2008. "Democratization, Sequencing, and State Failure in Africa: Lessons from Kenya." African Affairs 108, no. 430: 1-16. https://doi.org/10.1093/afraf/adn065.

Burbidge, Dominic. 2015. The Shadow of Kenyan Democracy: Widespread Expectations of Widespread Corruption. Surrey: Ashgate.

Burbidge, Dominic. 2019. An Experiment in Devolution: National Unity and the Deconstruction of the Kenyan State. Nairobi: Strathmore University Press.

Cannon, Brendon J., and Jacob Haji Ali. 2018. "Devolution in Kenya Four Years On: A review of Implementation and Effects in Mandera County." African Conflict and Peacebuilding Review 8, no. 1: 1-28.

https://muse.jhu.edu/article/695702.

Chauveau, Jean-Pierre and Philippe Lavigne-Delville. 2013. "Développement participatif." In Dictionnaire critique et interdisciplinaire de la participation, edited by Ilaria Casillo, Rémi Barbier, Loïc Blondiaux, Francis Chateauraynaud, Jean-Michel Fourniau, Rémi Lefebvre, Catherine Neveu and Denis Salles. Saint-Denis La Plaine: GIS Participation du public, decision, démocratie participative. https://horizon.documentation.ird.fr/ exl-doc/pleins textes/divers17-10/010071192.pdf.

Cheeseman, Nic. 2008. "Kenya since 2002: The More Things Change the More they Stay the Same." In Africa Since 2002, edited by Lindsay Whitfield and Raufa Abdul Mustapha, 94-113. London: James Currey.

Cheeseman, Nic, Gabrielle Lynch and Kanyinga Karuti. 2020. The Oxford Handbook of Kenyan Politics. Oxford: Oxford University Press.

Cheeseman, Nic, Gabrielle Lynch and Justin Willis. 2016. "Decentralisation in Kenya: The Governance of Governors." Journal of Modern African Studies 54, no. 1: 1-35. https://doi.org/10.1017/S0022278X1500097X.

Cheeseman, Nicholas, and Blessing Miles Tendi. 2010. "Power-Sharing in Comparative Perspective: The Dynamics of Unity Government in Kenya and Zimbabwe." The Journal of Modern African Studies 48, no. 2: 203-29. https://doi.org/10.1017/S0022278X10000224.

Chome, Ngala. 2015. "Devolution is only for Development? Decentralization and Elite Vulnerability on the Kenyan Coast." Critical African Studies 7, no. 3: 299-316. https://doi.org/10.1080/21681392.2015.1075750. 
Cohen, John M. 1993. "Importance of Public Service Reform: The Case of Kenya." The fournal of Modern African Studies 31, no. 3: 449-76. https://doi. org/10.1017/S0022278X00012039.

Commission on Revenue Allocation. 2013. "Policy on the Criteria for Identifying Areas and Sharing of Equalisation Fund: Financial Years 2011 to 2014." CRA/RF/VOL.I/44. Nairobi, 22 February.

Connan, Dominique, and Florence Brisset-Foucault. 2008. "L'alternance brisée et la colère politique au Kenya." Mouvements, 7 January. http://mouvements. info/lalternance-brisee-et-la-colere-politique-au-kenya/ [archive].

The Council of Governors (CoG). S.d. "Regional Economic Blocs." Nairobi: The Council of Governors. https://cog.go.ke/regional-economic-blocs [archive] Crawford, Gordon, and Christof Hartmann (eds). 2008. Decentralisation in Africa: A Pathway Out of Poverty and Conflict? Amsterdam: Amsterdam University Press.

D’Arcy, Michelle, and Marina Nitstotskaya. 2019. "Intensified Local Grievances, Enduring National Control: The Politics of Land in the 2017 Kenyan Election.” Journal of Eastern African Studies 13, no. 2: 294-312. https://doi.org/10.1080/17531055.2019.1590763.

D’Arcy, Michelle, and Agnes Cornell. 2016. "Devolution and Corruption in Kenya: Everyone's Turn to Eat?” African Affairs 115, no. 459: 246-273. https://doi.org/10.1093/afraf/adw002.

D’Arcy, Michelle, and Agnes Cornell. 2014. “'Plus ça change'? County-Level Politics in Kenya after Devolution." Journal of Eastern African Studies 8, no. 1: 173-91. https://doi.org/10.1080/17531055.2013.869073.

Elfversson, Emma, and Anders Sjögren. 2019. "Do Local Power-Sharing Deals Reduce Ethnopolitical Hostility? The Effects of 'Negotiated Democracy' in a Devolved Kenya." Ethnopolitics 19 (1): 45-63. https://doi.org/10.1080/17449057.2019.1583483.

Elszasz, Hayley. 2016. “'Devolution in Kenya: An Opportunity for Increased Public Participation, Reduced Corruption and Improved Service Delivery." BA Thesis. Williams College (Williamstown, MA, 2016).

Franceschi, Luis, Shillah Memusi and Robert Muhindi. 2015. "The Cost of Devolution in Kenya: A Cost Analysis of the New Governance Framework Introduced by the 2010 Constitution of Kenya and Its Impact on the Country's Public Finance." Africa Policy fournal 10: 28-58 [archive].

Fung, Archon, and Erik Olin Wright. 2001. "Deepening Democracy: Innovations in Empowered Participatory Governance.” Politics \& Society 29, no. 1: 5-41. https://doi.org/10.1177/0032329201029001002.

Gadjanova, Elena. 2019. “Treacherous Coattails: Gubernatorial Endorsements and the Presidential Race in Kenya's 2017 election." Journal of Eastern African Studies 1, no. 2: 272-93. https://doi.org/10.1080/17531055.2019.1592295.

Ghai, Yash.2008. "Devolution:Restructuring the KenyanState.” FournalofEastern African Studies 2, no. 2: 211-26. https://doi.org/10.1080/17531050802058336. Githinji, Mwagi Wa, and Franck Homlquist. 2008. "Kenya's Hopes and Impediments: The Anatomy of a Crisis of Exclusion.” Fournal of Eastern African Studies 2, no. 2: 344-58. https://doi.org/10.1080/17531050802058518. 
Githinji, Mwagi Wa, and Franck Homlquist. 2012. "Reform and Political Impunity in Kenya: Transparency without Accountability." African Studies Review 55, no. 1: 53-74. https://doi.org/10.1353/arw.2012.0006.

Government of Kenya [GoK]. 2010. Constitution of Kenya, 2010. Nairobi: Republic of Kenya. http://kenyalaw.org:8181/exist/kenyalex/actview. xql?actid=Const2010 [archive].

Government of Makueni County. 2016. "Public Participation Framework." Nairobi: Government of Makueni County. https://makueni.go.ke/publicparticipation-framework/ [archive].

Grignon, François. 1997. "Le politicien entrepreneur en son territoire : Paul Ngei à Kangundo (Kenya), 1945-1990.” PhD Dissertation. Bordeaux: Université Montesquieu-Bordeaux IV.

Grignon, François. 1999. "Le renouvellement paradoxal des parlementaires au Kenya (1992-1997). Une situation de 'multi-partis uniques' ?" In Le nonrenouvellement des élites en Afrique subsaharienne, edited by Jean-Pierre Dalloz, 57-75. Bordeaux: CEAN.

Grignon, François, and Hervé Maupeu. 1998. "Introduction au thème : Les aléas du contrat social kenyan.” Politique africaine, no. 70: 5-21.

http://www.politique-africaine.com/numeros/pdf/070003.pdf [archive].

Hagmann, Tobias, and Filip Reyntjens (eds). 2016. Aid and Authoritarianism in Africa. Development without Democracy. London: Zed Books.

Hassan, Mai. 2016. "A State of Change: District Creation in Kenya After the Beginning of Multi-Party Elections." Political Research Quarterly 69, no. 3: 510-21. https://doi.org/10.1177/1065912916653476.

Hassan, Mai. 2013. "Continuity despite Change: Kenya's New Constitution and Executive Power." Democratization 22, no. 4: 725-40.

https://doi.org/10.1080/13510347.2013.853174.

Haugerud, Angelique. 1995. The Culture of Politics in Modern Kenya. Cambridge: Cambridge University Press. https://doi.org/10.1017/CBO9781139166690.

Hornsby, Charles. 2013. Kenya. A History since Independence. New York: I.B. Tauris.

Holmquist, Franck, Weaver, Frederick, and Michael Ford. 1994. "The Structural Development of Kenya's Political Economy." African Studies Review 37, no. 1: 69-106. https://doi.org/10.2307/525114.

International Crisis Group. 2008. "Kenya in Crisis.” Africa Report no. 137. Nairobi, Brussels: International Crisis Group. https://www.crisisgroup.org/ africa/horn-africa/kenya/kenya-crisis [archive].

Jenkins, Sarah. 2012. "Ethnicity, Violence, and the Immigrant-Guest Metaphor in Kenya." African Affairs 111, no. 445: 576-96.

https://doi.org/10.1093/afraf/ads051.

Josse-Durand, Chloé. 2020. "How to Be Freed from a Leadership Curse? A Political 'Code of Conduct' by the Nandi Council of Elders during the 2013 Elections in Kenya." Sources. Materials \& Fieldwork in African Studies no. 1: 97-120. https://halshs.archives-ouvertes.fr/SOURCES/halshs-02864839.

Kagwanja, Peter. 2003. "Facing Mount Kenya or Facing Mecca? Mungiki, Ethnic Violence and the Politics of the Moi Succession 
in Kenya, 1987-2002." African Affairs 102: 25-49.

https://doi.org/10.1093/oxfordjournals.afraf.a138810.

Kanyinga, Karuti, and James P. Long. 2012. "The Political Economy of Reforms in Kenya: The Post-2007 Election Violence and a New Constitution." African Studies Review 55, no. 1: 31-51. https://doi.org/10.1353/arw.2012.0002.

Kasfir, Nelson. 2015. "Agency across Changing Sites: The Path to Kenya's 2010 Constitution." In The Politics of Governance, edited by Till Förster and Lucy Koechlin, 52-71. Abingdon: Routledge.

Katende, John W., and George W. Kanyeihamba. 1973. "Legalism and Politics in East Africa: The Dilemma of the Court of Appeal for East Africa." Transition, no. 43: 43-54. https://doi.org/10.2307/2935148.

Kemunto Bosire, Lydiah, and Gabrielle Lynch. 2014. "Kenya's Search for Truth and Justice: The Role of Civil Society." International fournal of Transitional Fustice 8, no. 2: 256-76. https://doi.org/10.1093/ijtj/iju002.

Kenyatta, Jomo. 1938. Facing Mont Kenya, the Tribal Life of the Gikuyu. London: Secker \& Warburg.

Kenyan National Bureau of Statistics and Society for International Development [KNBS \& SID]. 2013. "Exploring Kenya's Inequality: Pulling Apart or Pooling Together? Abridged Report." Nairobi.

Kimathi, Leah. 2017. "Challenges of the Devolved Health Sector in Kenya: Teething Problems or Systematic Contradictions?" Africa Development 42, no. 1: 55-77. https://www.ajol.info/index.php/ad/article/view/163620.

Klopp, Jacqueline. 2002. "Can Moral Ethnicity Trump Political Tribalism? The Struggle for Land and Nation in Kenya." African Studies 61, no. 2: 269-94. https://doi.org/10.1080/0002018022000032956.

Le Bart, Christian. 2003. "La citoyenneté locale." Les Cahiers français : documents d'actualité, La Documentation Française: 58-62.

Lonsdale, John. 2004. "Moral \& Political Argument in Kenya." In Ethnicity and Democracy in Africa, edited by Bruce Berman, Will Kymlicka and Dickson Eyoh, 73-95. Suffolk: Boydell \& Brewer.

Lonsdale, John. 2006. "Ornamental Constitutionalism in Africa: Kenyatta and the Two Queens." The Journal of Imperial and Commonwealth History 34, no. 1: 87-103. https://doi.org/10.1080/03086530500412132.

Lynch, Gabrielle. 2018. Performances of Injustice: The Politics of Truth, Fustice and Reconciliation in Kenya. Cambridge: Cambridge University Press. https://doi.org/10.1017/9781108575164.

Lynch, Gabrielle. 2011. "Kenya's New Indigenes: Negotiating Local Nationalisms in a Global Context." Nations and Nationalism 17, no. 1: 14867. https://doi.org/10.1111/j.1469-8129.2010.00465.x.

Maupeu, Hervé. 2003. "Kenya: les élections de la transition." Politique africaine, no. 89: 149-66. https://doi.org/10.3917/polaf.089.0149.

Maupeu, Hervé. 2013. "Élections, milices et Mungiki. Une comparaison entre 2007-2008 et 2013.” Afrique contemporaine, no. 247: 114-16. https://doi.org/10.3917/afco.247.0114.

Maxon, Robert. 2016. "The Demise and Rise of Majimbo in Independent Kenya." In Kenya After 50. African Histories and Modernities, edited by 
Kithinji Michael Mwenda, Koster Mwanzia Mickie, and Jerono P. Rotich, 19-48. Palgrave Macmillan: New York.

Médard, Claire. 2006. "La réforme de l'administration territoriale n'aura pas lieu au Kenya." L'Afrique orientale : annuaire 2005, edited by Claire Médard and Hélène Charton-Bigot, 1-10. Paris: L'Harmattan.

Médard, Claire. 2008. "Les frontières de la violence au Kenya." EchoGéo, "Sur le Vif," 12 March. http://journals.openedition.org/echogeo/2335

Médard, Claire. 1999. "Territoires de l'ethnicité : encadrement, revendications et conflits territoriaux au Kenya." PhD Dissertation. Paris: Université de Paris. https://halshs.archives-ouvertes.fr/tel-01265014.

Médard, Jean-François. 1992. “Le 'big man' en Afrique : analyse du politicien entrepreneur." Année sociologique 42: 167-92. https://www.jstor.org/stable/27890139.

Médard, Jean-François. 1987. “Charles Njongo : portrait d'un 'Big Man’ au Kenya.” In L'État contemporain en Afrique, edited by Emmanuel Terray, 49-87. Paris: L'Harmattan.

Mudida, Robert. 2009. "The Erosion of Constitutionalism and Underdevelopment: The Kenyan Experience." Eastern Africa Law Review 35-40: 1-23.

Murunga, Godwin R., and Shadrack W. Nasong'o. 2006. "Bent on SelfDestruction: The Kibaki Regime in Kenya." Journal of Contemporary African Studies 24, no. 1: 1-28. https://doi.org/10.1080/02589000500513713.

Mwathi Mati, Jacob. 2013. "Antinomies in the Struggle for the Transformation of the Kenyan Constitution (1990-2010)." Journal of Contemporary African Studies 31, no. 2: 235-54. https://doi.org/10.1080/02589001.2013.785145.

National Cohesion and Integration Commission [NCIC]. 2014. "The Status of Social Cohesion in Kenya, 2013 (Draft Report)." Nairobi. https://www. cohesion.or.ke/images/docs/Cohesion Index Status of Social Cohesion in Kenya.pdf [archive].

National Commission for the Implementation of the Constitution [NCIC]. 2014. "Assessment of the Implementation of the System of Devolved Government: From Steps to Strides.” Nairobi.

National Cohesion and Integration Commission [NCIC]. 2016. "Ethnic and Diversity Audit of the County Public Service." Nairobi. https://www. cohesion.or.ke/images/docs/Ethnic-and-Diversity-Audit-of-the-CountyPublic-Service-2016.pdf [archive].

Nyabola, Nanjala, and Marie-Emmanuelle Pommerolle (eds). 2018. Where Women Are. Gender and the 2017 Kenyan Elections. Nairobi: Twaweza, IFRANairobi, Heinrich Boll Foundation. https://ke.boell.org/en/2018/11/29/ where-women-are-gender-2017-kenyan-elections.

Ndegwa, Stephen. 2002. Decentralization in Africa: A Stocktaking Survey. Washington D.C.: The World Bank.

Nyamweru, Celia, and Tsawe-Munga Chidongo. 2018. "Elders in Modern Kenya: 'Dying Institutions' or 'Reinventing Themselves.” African Studies 77, no. 2: 240-56. https://doi.org/10.1080/00020184.2018.1452857. 
Nyong'o, Anyang'. 1989. "State and Society in Kenya: The Disintegration of the Nationalist Coalitions and the Rise of Presidential Authoritarianism 1963-78." African Affairs 88, no. 351: 229-51.

https://doi.org/10.1093/oxfordjournals.afraf.a098162.

Onyango, Gedion. 2017. "Collectivism and Reporting of Organizational Wrongdoing in Public Organizations: The Case of County Administration in Kenya." International Review of Sociology 27, no. 2: 353-72.

https://doi.org/10.1080/03906701.2017.1298429

Otieno, Gladwell. 2005. "The NARC's Anti-corruption Drive in Kenya: Somewhere Over the Rainbow?" African Security Review 14, no. 4: 69-79. https://doi.org/10.1080/10246029.2005.9627591.

Oucho, John Oyaro. 2002. Undercurrents of Ethnic Conflict in Kenya. Leiden: Brill.

Owiti, Jeremiah. 2014. "Political Drivers of Inequality in Kenya." Development 57, no. 3-4: 547-58. https://doi.org/10.1057/dev.2015.38.

Perrot, Sandrine, Marie-Emmanuelle Pommerolle, and Justin Willis. 2016. "La fabrique du vote : placer la matérialité au cœur de l'analyse." Politique africaine, no. 144: 5-26. https://doi.org/10.3917/polaf.144.0005.

Pommerolle, Marie-Emmanuelle. 2005. "À quoi servent les droits de l'homme? Action collective et changement politique au Cameroun et au Kenya." PhD Dissertation. Pessac: Institut d'études politiques de Bordeaux.

https://tel.archives-ouvertes.fr/tel-00361353/.

Pommerolle, Marie-Emmanuelle, and Chloé Josse-Durand. 2017. "Le roi est nu : crise électorale et anatomie du pouvoir au Kenya (2017)." Politique africaine no. 148: 169-81. https://doi.org/10.3917/polaf.148.0169.

Press, Robert M. 2012. "Kenya's Political 'Transition' through the Eyes of its 'Foot Soldiers' for Democracy and Human Rights (1997-2012)." Journal of Contemporary African Studies 30, no. 3: 1-20.

https://doi.org/10.1080/02589001.2012.701843.

Rasmussen, Jacob, and Duncan Omanga. 2012-2013. "Les parlements du peuple au Kenya : débat public et participation politique à Eldoret et Nairobi." Politique africaine, no. 127: 71-90. https://doi.org/10.3917/polaf.127.0071.

Republic of Kenya. 2014. Report. "Public Service Commission: Framework for Strengthening the Delivery of National Government Functions at the County Level." Nairobi: Government Printer.

Ruteere, Mutuma. 2010. "Kenya: Nouvelles formes d'activisme." Alternatives Sud 17: 61-70 [archive].

Rwigi Edwin K. (forthcoming). "Devolution and Power Redistribution: A Critical Comment on Makueni County's Participatory Budgeting Process." In Devolution in Kenya, edited by Chloé Josse-Durand.

Scott-Villiers, Alastair. 2017. "Small Wars in Marsabit County: Devolution and Political Violence in Nothern Kenya." Conflict, security \& Development 17, no. 3: 247-64. https://doi.org/10.1080/14678802.2017.1319696.

Shilaho, Westen K. 2015. "Third Time Lucky? Devolution and State Restructure under Kenya's 2010 Constitutional Dispensation.” In African State Governance: Subnational Politics and National Power, edited by Carl 
A. LeVan, Joseph Olayinka Fashagba, and Edward R. McMahon, 147-77. London: Palgrave MacMillan.

Simson, Rebecca. 2017. "(Under)privileged Bureaucrats? The Changing Fortune of Public Servants in Kenya, Tanzania and Uganda, 1960-2010.” $\mathrm{PhD}$ Dissertation. London: London School of Economics and Political Science. http://etheses.lse.ac.uk/3618/.

Southall, Roger, and Geoffrey Wood. 1996. "Local Government and the Return of Multi-Partyism in Kenya.” African Affairs 95, no. 381: 501-27.

https://doi.org/10.1093/oxfordjournals.afraf.a007766.

Steeves, Jeffrey. 2015. "Devolution in Kenya: Derailed or on Track?" Commonwealth \& Comparative Politics 53, no. 4: 457-74. https://doi.org/10.1080/14662043.2015.1089006.

Swahili Oxford Living Dictionaries. 2018. "Utaguzi." Oxford University Press. https://sw.oxforddictionaries.com/ufafanuzi/ugatuzi.

Thibon, Christian. 2013. "Élections de 2013 au Kenya. Les bégaiements de l'histoire kényane." Afrique contemporaine, no. 247: 15-32.

https://doi.org/10.3917/afco.247.0015.

Throup, David, and Charles Hornsby. 1998. Multi-Party Politics in Kenya: The Kenyatta and Moi States and the Triumph of the System in the 1992 Election. Oxford: James Currey.

Truth Justice and Reconciliation Commission [TJRC]. 2013. Report of the Truth, Fustice and Reconciliation Commission I \& II. Nairobi: Government Printer.

Waddilove, Hannah. 2019. “Support or Subvert? Assessing Devolution's Effect on Central Power during Kenya's 2017 Presidential Rerun.” fournal of Eastern African Studies 13, no. 2: 334-52.

https://doi.org/10.1080/17531055.2019.1587951.

Wampler, Brian and Leonardo Avritzer. 2005. "The Spread of Participatory Budgeting in Brazil: From Radical Democracy to Participatory Good Government.” Journal of Latin American Urban Studies 7: 37-52.

Warris, Vianni. 2013. "Doings, Non-Doings \& Mis-Doings by Kenya Chief Justices 1963-1998.” African Affairs 112, no. 446: 171-2. https://doi.org/10.1093/afraf/ads076.

Willis, Justin, and Ngala Chome. 2014. "Marginalization and Political Participation on the Kenya Coast: the 2013 Elections." Journal of Eastern African Studies 8, no. 1: 115-34.

https://doi.org/10.1080/17531055.2013.844443.

World Bank. 2011. "Navigating the Storm, Delivering the Promise with a Special Focus on Kenya's Momentous Devolution." Kenya Economic Update 5. http://hdl.handle.net/10986/26664.

World Bank. 2012. "Devolution without Disruption: Pathways to a Successful New Kenya." Nairobi, November. http://documents.worldbank.org/curated/ en/534071468272361395/pdf/NonAsciiFileName0.pdf [archive].

World Bank. 2015. "Kenya-Enhancing Decentralized Service Delivery through Participatory Project: Summary Overview. Kenya Devolution.” Washington D.C.: World Bank Group. 
Wrong, Michela. 2010. It's Our Turn to Eat: The Story of a Kenyan Whistle Blower. London: Fourth Estate.

\section{Media}

Amadala, Benson. 2018. "Seven Former Officials Sent to Jail over Wheelbarrow Scandal.” Daily Nation, 25 June. https:/www.nation.co.ke/counties/ bungoma/7-sentenced-in-wheelbarrow-case/1183258-4630664-10cux86z/ index.html [archive].

"Cynthia Jepkosgei, 24, Speaks on her Victory as MCA." 2017. Daily Nation, 11 August. https://www.nation.co.ke/news/politics/Nandi-MCA-elect-24beats-odds/1064-4053920-nnbwikz/index.html [archive].

"IMF Cautions over Kenya Debt Vulnerability." 2017. Business Daily, 21 November. https://www.businessdailyafrica.com/markets/marketnews/ IMF-cautions-over-Kenya-debt-vulnerability/3815534-4197034-mrydle/ index.html [archive].

Jelima, Rael. 2018. "Nandi County Claims Seven Towns along Border with Kisumu." The Standard, 28 May. https://www.standardmedia.co.ke/ article/2001281967/nandi-county-out-to-reclaim-seven-towns-fromkisumu [archive].

Kahura, Dauti. 2019. "Building Bridges to Nowhere: Some Reflections One Year After "The Handshake." The Elephant, 7 March. https://www.theelephant. info/features/2019/03/07/building-bridges-to-nowhere-some-reflectionsone-year-after-the-handshake/ [archive].

Lynch, Gabrielle. 2014. "Devolution Has Made Politics more Local and Violent than ever before." The Nation, 26 September. https://www.nation. co.ke/oped/opinion/Majority-of-Kenyans-still-support-devolution/4408082466284-bbwxt1z/index.html [archive].

Mathenge, Oliver. 2009. "All Constituencies now Turned into Districts." The Nation, 13 July [archive].

Mbula, Ruth. 2019. "Migori County Official on Graft Charge Detained for Four Days." Daily Nation, 9 May. https://www.nation.co.ke/counties/migori/ Court-detains-Migori-official-four-days/1183306-5097492-xcc1yrz/index. $\underline{\text { html }}$ [archive].

Munyi, Martin. 2019. "Laikipia Assembly Rejects Supplementary Budget." Kenya News Agency, 29 June. https://www.kenyanews.go.ke/laikipiaassembly-rejects-supplementary-budget/ [archive].

"Nairobi Governor Mike Sonko Denies Corruption Charges in Court." 2019. Al-fazeera, 9 December.

https://www.aljazeera.com/news/2019/12/nairobi-governor-mike-sonkopleads-innocent-corruption-charges-191209134806019.html [archive].

"NEW: Billions Unaccounted For in CDF Audit." 2016. RoggKenya, 5 December. https://roggkenya.org/new-billions-unaccounted-for-in-cdf-audit/[archive]. Ogada, Mordecai. 2019. "Decolonising Conservation:It is about the Land, Stupid!" The Elephant, 27 June. https://www.theelephant.info/culture/2019/06/27/ decolonising-conservation-it-is-about-the-land-stupid/ [archive]. 
Oteba, Titus. 2015. "Uproar as Bungoma County Buys 10 Wheelbarrows at Sh1m." The Standard, 8 September. https://www.standardmedia.co.ke/ article/2000175604/uproar-as-bungoma-county-buys-10-wheelbarrows-atsh1m [archive].

Owiti, Maugo. 2015. "Matatu operators decline proposal to remit tax through M-Pesa.” Hivisasa, 3 December. https://hivisasa.com/posts/-------------------------------matatu-operators-decline-proposal-to-remit-tax-throughm-pesa [archive].

Shiundu, Alphonse. 2013. "Six Counties Fail to Spend Allocated Funds." The Standard, 14 August. https://www.standardmedia.co.ke/article/2000090917/ six-counties-fail-to-spend-allocated-funds [archive].

Sirma, Evans. S.d. "Governor Lagat Commissions Amani Market to Foster Unity in Kamung'ei Border.” County Government of Nandi.

https://nandicounty.go.ke/governor-lagat-commissions-amani-market-tofoster-unity-in-kamungei-border/ [archive].

"Ugatuzi Initiative." 2019. The Council of Governors. https://www.cog.go.ke/component/k2/item/179-ugatuzi-initiative [archive]. Waddilove, Hannah. 2017. "Kenya Voted for Change and Got it... at the Local Level." African Arguments, 18 August. https://africanarguments. org/2017/08/18/kenya-voted-for-change-and-got-it-at-the-local-levelelections/ [archive].

Wekesa, Grace. 2015. "NCIC Chair Francis Kaparo Warns Nandi, Luhya Leaders against Incitement." The Standard, 25 January.

https://www.standardmedia.co.ke/article/2000149182/ncic-chair-franciskaparo-warns-nandi-luhya-leaders-against-incitement [archive]. 


\title{
Chapter 5 \\ Low-Cost Business in Kenya from the City to the Countryside
}

\author{
Sylvain Racaud
}

Translated by Roxane Heidrich \& Nathan Mwangi Kariuki

"Everybody knows now, everybody is a trader now, and that's the problem now," said George in April 2015 from his rudimentary stall in a Nyeri commercial street, where he sells ballet flats made in China on an almost daily basis. He represents the average response of the urban and rural populations to the obstacles of the Kenyan economy. Indeed, the formal economy is unable to absorb in a structured way the increasing share of labour force. Therefore, the sector referred to as informal is the main alternative, offering employment to more than nine out of ten businessmen and merchants (World Bank 2016). The National Bureau of Statistics estimated that, in 2014, the informal sector represented $82.7 \%$ of employment excluding the agricultural sector (ibid.). The informal sector is considered to be a shock-absorber and a crisis regulator (Charmes 1992; Hugon 2003) but George stresses that there are constraints because, according to him, the market is saturated with vendors and mainly imported goods.

Everyone is a witness to the arrival of massive amounts of low-cost goods, especially ballet flats, plastic sandals, fashion accessories, clothes, etc., which have flooded the urban commercial spaces and the rural markets. China is Kenya's primary importer with its share of total imports that grew from 12\% to 23\% between 2012 and 2014 (Sanghi \& Johnson 2016) and that remained at $23 \%$ in 2017. ${ }^{1}$ The price of commodities imported from China fell by 10\% between 2012 and 2014 (Sanghi \& Johnson 2016). Among these products, cheap junk ("pacotille" in French) ranks high. It is available, accessible, and adapted to the limited purchasing power and capital; thus, the exchange and the circulation of these goods extend the large commercial outlets up to the rural areas. In East Africa, this commercial route crosses the one of the second-hand clothing, another relatively inexpensive category of merchandise. The second-hand clothing trade sector is older and is a common driving force of informal sales.

In the context of these new combinations, how does the unprecedented circulation of vendors and cheap merchandise structure the trade route

1. UN COMTRADE, "Kenya." https://atlas.media.mit.edu/en/profile/country/ken [archive]. 
between the city and the countryside, between the formal and the informal sector, and between agriculture and commerce? How do specific regional dynamics develop? The trade route is the combination of all the actors and places that are connected by long-term commercial relations. Who are the actors engaged in these exchanges and what are their relations? What are the places where these movements take place and how are they structured? This project focuses on a specific segment of the transnational route of Chinese junk as well as its local cross-linkages with the trade route of second-hand clothing. Most of the work focuses on the visible displays of the trade route of products made in China, or in other terms, the cities with their global trade routes (Bertoncello \& Bredeloup 2007; 2009) that do not reach the rural areas (Pliez 2009). What happens to the hidden rural side at the opposite of the urban scenery? This work examines the geographic configurations of the route between Kisumu and its hinterland in Western Kenya and between Nyeri and the West side of Mount Kenya, and integrates their connections with the East-African trading posts.

The suggested hypothesis is that the development of the junk trade route generates an "in-between" resource space (Pliez 2007) located midway between the city and the countryside, between the formal and the informal sector. This space is more or less a vehicle for new opportunities and more or less suitable for those actors pursuing their goals in this in-between setting. The "in-between" is a paradoxical interstitial space which is not only between two objects but also within those objects. We can see it, for example, in the urban aspects of the countryside as well as the rural elements of the city (Brient 2007; Racaud 2006). More than a complex combination of city and countryside elements (Bonerandi et al. 2003), the in-between is a resource space between the formal and informal economy, a contradictory landscape with porous borders. Since it is both between and within objects, at times it also questions their very nature, as in the case of the formal economy when it lives from the informal. Therefore, this work focuses on the most flexible expressions, on an order of things marked by uncertainty and precariousness, and on the everyday life of the majority of the population while examining examples of self-employed businesspeople, people involved in the cycle of temporary markets, and those who sell in the streets.

The empirical data were collected during several field missions carried out in Kenya in 2015 and 2016. The data were drawn from interviews (35) mainly conducted with either sedentary or mobile vendors. Three group interviews were conducted and three life stories were recorded as well. Documenting precarious workers' testimony, also known for their economic vulnerability and their often non-recognised status, can of course present some obstacles (Steck 2006). An effort has been made to overcome 
them by adopting a comprehensive approach consisting in capturing the actors' practices and actions in their specific context.

In order to examine the regional dynamics of the trade route and the resource space of the in-between setting, this paper is organised into three sections. The first deals with the organisation of commercial spaces, the second with the accessibility of commercial networks rooted in the city and in the countryside, and the third concerns mobility and commercial linkages.

\section{Commercial Spaces}

\section{Nyeri and Kisumu:}

Two Densely Populated Agricultural Inland Cities

Nyeri, at the foot of Mount Kenya, is located 150 kilometres from Nairobi, while Kisumu, at the edge of Lake Victoria, is located 340 kilometres from Nairobi. The cities of Nyeri and Kisumu, with 119,200 and 383,000 inhabitants respectively in 2009 (KNBS 2015), are administrative and service centres and venues of social and economic interactions that play a bridging role between the city and the countryside, notably through agricultural exchanges (Rondinelli 1988). Nyeri Municipality and Kisumu City fall within an East African urbanisation marked by the densification of the urban structure (Calas 2007). These cities are witnessing increasing growth rates; $1.12 \%$ per year for Nyeri and $1.04 \%$ per year for Kisumu over the 1999-2009 decade. They are the hubs of their agricultural inland which are characterised by high rural population densities. They exceed 300 inhabitants per square kilometre on the Mount Kenya hillside (with an average of 280 inhabitants per square kilometre in Nyeri County, GROK, 2013) and count an average of 440 inhabitants per square kilometre for the old Nyanza Province. There is, therefore, a growing tension between the limited extension of the land and the size of the population.

The main part of the rural population is engaged in small-scale agricultural activities that strongly depend on the climate; it combines food crops (mainly corn and beans) with commercial crops. To the West of Mount Kenya, depending on the type of terracing, producers plant tea and coffee on the hillsides and foothills, whereas the sugar cane is the main commercial crop in the West. The commercial crops of the Central region are better connected to the market. "The economic activity of the city of Nyeri is primarily linked to agriculture" (Mitullah et al. 2006, 76) and the area produces lots of food cash crops (potatoes, market gardening products) for the cities, primarily Nairobi. In the West, the agricultural market opportunities pose a problem and the agricultural relay function for Kisumu is more reduced, notably because of the bad condition of the rural communication infrastructure and the situation in the periphery. 
With the neo-liberalisation of the economies (markets opening up, private actors increasing their influence, etc.), their intermediation functions have been renewed (Mainet \& Édouard 2013) and East African small- and medium-sized cities have become fully-fledged actors in the structuring of transnational trade routes (Mainet \& Racaud 2015). The transformation of the urban economic fabric no longer follows the pace of the population growth; for instance, these cities have not become industrial hubs. The urban economic landscape both feeds into and takes from the spatial and economic "in-between." A strong "lasting interdependence between the city and hinterland" (Mitullah et al. 2006, 76) exists, often pegged to the informal activities. In Kenya, the informal sector employs on average $53 \%$ of the urban workforce with the most significant rate being registered in Kisumu (61\%) (KNBS 2015). The urban commercial spaces and the rural markets are the privileged places of the low-cost business and the relationships between the city and the countryside and the formal and the informal sectors.

\section{The Organisation of Commercial Spaces}

Shopping districts and urban and rural markets are places of multiple intersections. They fulfil economic functions by allowing exchanges between client and merchant, city and countryside, and formal and informal economies-whether they are in the city or in the countryside. They also foster social relationships because not only the merchandise is exchanged. Information and rumours circulate, friendships are tied and broken, etc. Just like most rural markets, the regular markets of Nyeri County are mirrors to their hinterland because local agricultural productions are found there. The health of these markets depends on the health of the local economy, primarily the agricultural one. Tea, the main Kenyan export, is the most important crop on the South-Western hillside of Mount Kenya. The tea industry, like the coffee production, is structured around cooperatives that circumvent rural markets. Thus, the latter do not play any role in the gathering and the redistribution of local products. The markets of Monyu, Kiamariga, and also Kiaruhiu do not stand out as the dynamic regular markets that can be found, for example, on the Western slope of Mount Elgon, on the slopes of Uporoto in South-West Tanzania, or even in Western Cameroon. The infrastructure financed by the county notwithstanding, market days are dull: they lack the fervour of a rural market day that is supposed to be the highlight of rural life (Chaléard 1996). As a consequence, these markets play a limited role in the distribution of imported products due to the limited number of merchants that are present. Nobody comes from the cities to sell their merchandise because the rural tea trade scene is not a very flourishing one. On the contrary, in Endarasha, 
despite the absence of infrastructures, the agriculture based on food crops meant for urban markets is very active and attracts merchants from Nairobi or even from Mombasa. The rural economy, far from being rich, allows nevertheless for numerous commercial exchanges. The market attracts local customers and mobile vendors coming from Nyeri or Mweiga that sell low-cost goods. The development of the junk trade route also includes the goods that are grown in the fields.

Kisumu and Nyeri's commercial infrastructure is composed by a few small supermarkets, many boutiques in the main streets of the Central Business Districts (CBD), some daily markets, and countless makeshift vendor stalls. The latter occupy the streets with the most significant flows of passers-by, which correspond to the routes used by CBD employees heading to the bus stations. These routes are also traversed by peddlers, the most precarious type of street vendors. In Kisumu, four streets around Jomo Kenyatta Ground (a vast park between the CBD and the bus stations) are cluttered on both sides with countless stalls of various second-hand items or Chinese junk. The two sides of Otieno Oyo Street, approximately ten metres away, are also occupied by a multitude of merchants and their products. On the main street Oginga Obinda, the street vendors, stand at the entrance of and around stores and coexist with them, while in the streets of Ang'awa, Jomo Kenyatta Highway, and Ojino Okew, the right to sell is almost exclusively granted to a few hundred street vendors. The points of sale have various forms, from a display made of a cut-out bag placed on the ground, to the covered table called kibanda. Street commerce has thus various shapes, and it is hard to the observer to make distinctions within the commercial landscape of these extended markets. In any case, whether it is street vending or a market, under-equipment is the norm. The pictures below demonstrate the contradictions of street vending between some very reduced stockpile and equipment placed right next to numerous bags of second-hand items stacked indoors in an open hangar.

Despite their differences, these two types of commerce operate in spaces that were never intended for these activities; therefore, according to the legislative frameworks, they are informal and are not subject to an annual license. However, the same authorities who do not recognise their formal status, do grant them a temporary license valid for one day, averaging 30 shillings per day. For the local authorities, the criterion of "sell[ing] in a space that is not intended for that purpose" is a major criterion of the definition of informal commerce. According to the head of the Urban Planning Department of Kisumu City County, these activities "are informal in the sense that they are carried out in a space not designated for that." It is noteworthy that Kisumu's last urban plan for dates back to 1975. Therefore, at the highest level of the political rhetoric, the Kenya Vision 2030 plan 


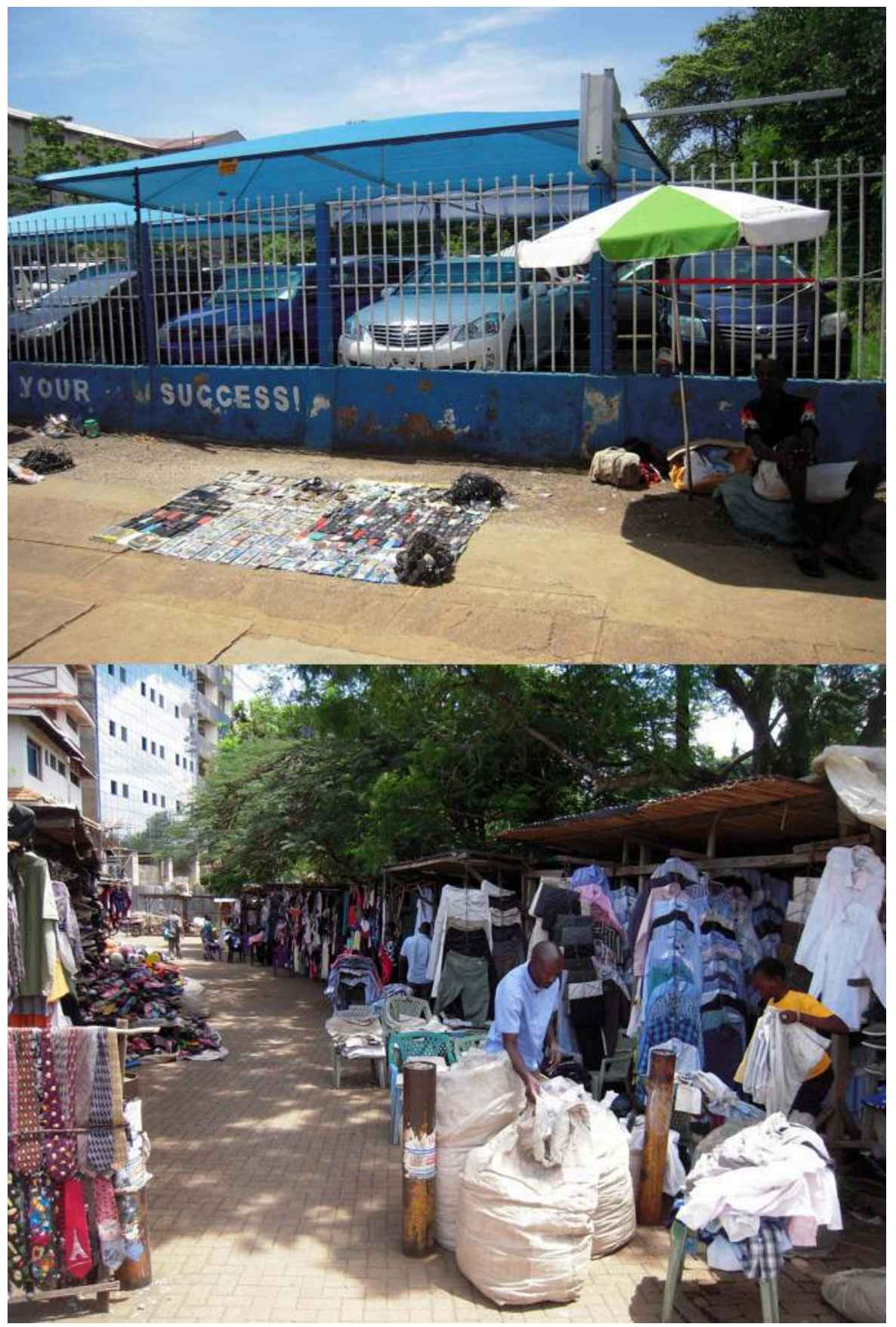

Photo 1. Diversity of sales points, JK Highway and Ojinjo Okew St Sylvain Racaud, 2016. 
articulates that "the informal sector must be supported in ways that will raise productivity and distribution and increase jobs" "to provide them [informal sector] with permanent and serviced facilities, training and access to credit and markets" (GROK 2007, 10, 14). The institutional framework presents contradictions within its different levels because the non-recognition of informal vendors by Kisumu City County, by Nyeri County, or by Nairobi City County challenges two laws: the Urban Areas and Cities Act of 2011 and the Micro and Small Enterprise Act of 2012. The latter states that "enterprise' means an undertaking or a business concern whether formal or informal engaged in production of goods or provision of services" (NCLR 2012, 7). The daily management of the informal economy resides within the national political and legislative framework and the local politics. Being placed in this in-between means, for the informal sector, being kept in its precariousness; it is also an open door to abuses such as the ongoing corruption of the officers in charge of ensuing adherence to rulings or even the political exploitation at the highest levels. For example, the Economic Strategy Action Plan of the National Rainbow Coalition political alliance, which won the 2002 presidential elections, recognised that $88 \%$ of promised jobs allegedly came from small informal business enterprises (Kamunyori 1999, 13). This temporary legitimacy, albeit renewed daily, contributes to the blurriness of the definition of informal. The common understanding of the latter refers to economic activities operating outside of state regulation whose boundaries with the formal sector are blurred (Lindel 2010).

The regulation of low-cost commerce, characterised by a strong informal component, constitutes a permanent fluctuation of powers in the local political arena. The latter is a volatile ensemble of multiple actors and various sectors (public/private, economic/political, authorities/civil society, formal/informal) with porous borders (Blundo 2002). Despite its official "informal" status, the world of street vendors is indeed organised. This bottom-up regulation is generated in the institutional in-between because this activity, although considered informal, is regulated by numerous groups registered with the Ministry of Gender, Children, and Social Development. This framework comes with requirements (daily meetings, periodic elections, record-keeping, etc.) and offers services such as savings, loans, and social assistance. These groups, called self-help groups, typically count between ten and fifty members. In Kisumu there are about forty of them and in Oginga Odinga Street, no less than eight. The most precarious vendors, i.e. those who have very limited capital, are less often members of collective organisations for a lack of trust or of capital to be converted into contributions. The price of trust and the risk of losing the little that has been accumulated curb the collective engagement. Nevertheless, the groups are an asset to the power relations between the local authorities and their 
leaders are key contacts whose favour is persistently pursued if not even bought. It is not uncommon for kiosks to be set aside for specific leaders when commercial spaces are created (Bus Park in Kisumu in 2003). These groups can be in competition among themselves (e.g. KITES and KISTA in Kisumu) and often, there are leadership problems (e.g. KASVIT in Kisumu), if not collusions between politicians and the mafia. The Apindi back lane in Kisumu is a commercial road with several dozen small shops. This project was financed in 2004 by a Constituency Development Fund generously funded by the local member of parliament at the time. The space is managed by a committee headed by two individuals that we met in a nice vehicle with tinted windows, where they were negotiating the sale of a store to a Somali merchant for the modest sum of 350,000 shillings. "We are the ones who negotiate with the County government on their behalf [vendors]," they say, in particular on the allocation and the transfer of ownership of shops. Low-cost business is an economic resource for both visible and less visible actors and it is also an electoral asset. This way, for example, businessman E. Anayo, elected Member of the County Assembly in 2013, in Kisumu, was able to reclaim to a certain extent the investment made by co-financing dozens of kiosks on a section of the JK Highway. For politicians, street vendors represent either an electoral resource or terrible grabbers of public spaces-a relationship that changes with the electoral calendar.

\section{Access to Commercial Networks Rooted in the City and the Countryside}

\section{Traders, Capital Accumulation, and Access to Commerce}

Low-cost business is flourishing because there are numerous business contenders and the number is growing. The oldest vendors have been practicing for about fifteen years but the majority of them for less than ten years. This influx of merchants also reflects that of the goods as Kenyan imports coming from China (in terms of value) increased to about $1500 \%$ from 2000 to 2010 (Patroba 2012) and about 60\% between 2010 and 2017. The trade of imported products is the main activity to the majority of young people. Showing us her market stall, Joyce, a street vendor in Kisumu, confesses that "this is where we report immediately after school"; we may rephrase "this is where we work even after completing school, since formal jobs are hard to get." There is no typical profile of a merchant and trying to sort out typologies seems far-fetched and inappropriate insofar as these actors are flexible in nature and likely to move from one category to another from one day to the next. Men, women, young people either done with their secondary studies or in the process of doing so, public service retirees, former employees enticed by the adventure of entrepreneurship, 
poor, less poor, a few rich people-in short, a wide range of individuals -engage in this world of low-cost business. It is possible to differentiate between those who chose to do this kind of a job; either those unsatisfied or perhaps fed up by their salaries in the formal/informal, agricultural, or service industry and the majority who had no other choice other than engaging in small business.

The itineraries in stages are typical for a number of those vendors who have previously experienced the life of earning salaries. In the merchant's experience, beginning with the second-hand clothing trade is a classic; access to the business of new products is already more ambitious and vendors are flexible: they adapt not only their range of products according to the seasons, but also based on opportunities and setbacks. On the other hand, street trading also known as hawking and street vending are preliminary attempts at achieving a stationery selling spot in a daily market or a shop or even selling in periodic markets. The duration of these stages depends on the success of the business venture. The circumstances of people who buy and resell goods are more or less evolving; some of them succeed at accumulating capital, others do not make any progress from the initial stage, which is often misery, a hardship experience. The lack of adequate financial capital, together with inadequate educational and social capital, limits the chances of success while the most successful merchants are those who can rely on a combination of numerous social, professional, and political networks (Walther 2015).

The starting capital is typically generated through several ways: donations (which is rare), loans (somewhat common), or accumulated capital from previous activities (in most common cases); combinations of the above is not common. Capital can be raised from savings from one or several jobs which can be combined with a loan or a donation, both of which are quite often obtained from parents or a spouse. Despite broad variations, the starting capital is typically less than 15,000 shillings and it is not uncommon for some begin with less than 5,000 shillings, sometimes even less than 1,000 shillings. Those who start with more than 20,000 , perhaps even 50,000 shillings, have, for example, been able to obtain a bank loan or a loan from a mutual-aid group. Public service retirees may begin with tens of thousands shillings of capital.

The main access to the trade route is through another vendor or through some form of apprenticeship. In both cases, access occurs through one person with whom the new vendor has a social relationship, which is quite often a family member, village, or community acquaintance. The would-be businessmen receive guidance throughout their first steps and are often accompanied in the commercial neighbourhood to be recommended to suppliers and become familiar with the urban scene, especially if the latter 
is a merchant who buys goods in a big city like Nairobi. Vendors remember this experience even after several years, like Job, who still remembers the date, ten years ago, and to be specific 2 February 2005, when for the first time he obtained his supplies in Nyeri together with his merchant friend who just like him had just set up a stall in Endarasha (3,000 residents in 2009). Cooperation can defy the market competition rules. In the biweekly Kiamariga market, a small city situated at an altitude of $1,800 \mathrm{~m}$ on the Western hillside of Mount Kenya, Florence, a merchant of clothing, layettes, plastic sandals, and small household accessories, was accompanied to Nyeri for her first procurement by her direct competitor, whose adjacent display is totally similar. She was accompanied to Nyeri by a merchant from the same market. The following photo demonstrates the proximity of the two stalls, with Florence's stall located just behind the one in the foreground. There are forms of collaborations that go beyond the simple rules of competition whereby merchants try to gain for themselves the better share of the market. Other merchants were instead guided towards Kamukunji, Nairobi's large trading post for Chinese junk.

It is not surprising that most merchants were formerly shop assistants in a family business or businesses owned in the community or perhaps a friend's business. This system links us back to the practice of placing children under apprenticeship and to the group solidarity that can be found in many African communities. This process allows beginners to gain experience, contacts, and sometimes capital. For example, despite his young age, George, a street vendor in Nyeri, got his bachelor in Information and Technology in 2015. He has been working as street trader for more than five years. He began selling on part time after his classes, while still in Form 4. George used to sell his merchandise at a lower price compared to others: "As I started my final year in High school, having lived for so long without any source of income, I tried part time business under the inspiration of my friend, he's a very good friend." It is not surprising to see high school students getting goods on credit or small capitals from close acquaintances and becoming vendors during the school holidays. Getting the experience and accessing capital are usually the fruit of close relationships, work, and solidarity. The city expands the number of possible combinations between genealogical links and extra-familial relations (Agier 1981), while the penetration of the merchant route into the countries, via the markets, also offers new possibilities of forming relationships and social networks.

\section{Activity System Based on City-Countryside Synergies}

Vendors from the countryside and numerous vendors from medium-sized cities combine the city and the country into their activity system. Synergies derived from these combinations that result in the mobility and circulation 


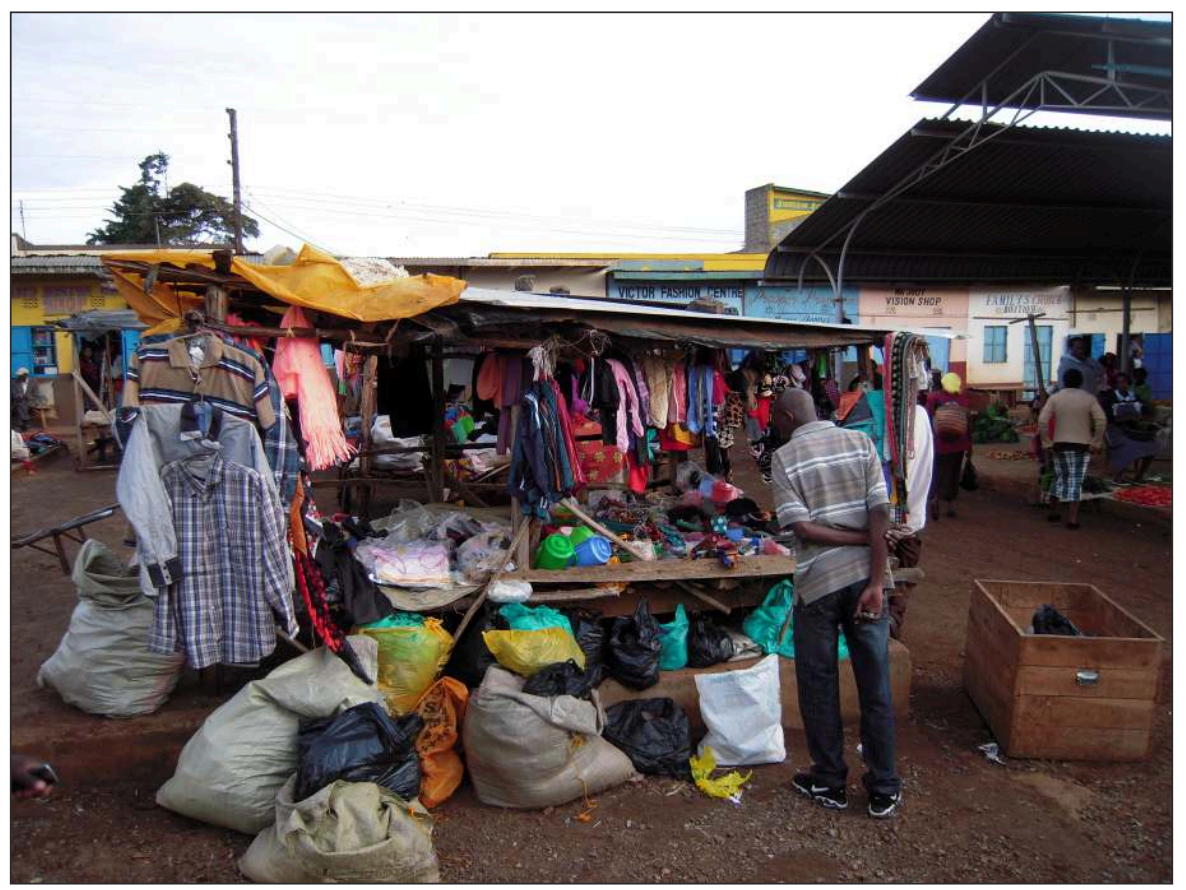

Photo 2. Stall, Kiamariga Market

Sylvain Racaud, 2015.

of resources (capital, goods in kind). The activity system is understood as the "dynamic and structured set of interacting activities implemented by a given corporate entity that mobilises the resources available in a given social and ecological environment" (Gasselin et al. 2014, 106). The permanent or periodic sale is thus often associated with agricultural work within a given household or within the personal schedule of an individual, leading to flexible arrangements that are based on agricultural and market calendars. Alfred, a small 60-year-old woman, follows the itinerary of the dynamic periodic markets for the better part of the week (Endarasha on Fridays, Nairutia on Saturdays, Mweiga on Thursdays) to sell ballet flats, plastic sandals, and slippers, cultivating her field during the rest of the week. The daily market vendors of Othaya, a small town of 5,200 residents (KNBS 2015) about 15 kilometres south of Nyeri, never arrive before ten o'clock in the morning because most are busy in the fields working from dawn. The cultivated areas in Nyeri County are moderate in size, often an acre, where corn, beans, etc., are grown, i.e. merchantable food supplemented by tea or coffee, and livestock often consisting of only one a cow under zero grazing. In the western parts of Kenya, the areas may be larger, about two acres for each household, but access to the market is more reduced. Whether it is in the western parts of Kenya or in Nyeri County, merchant-farmers 


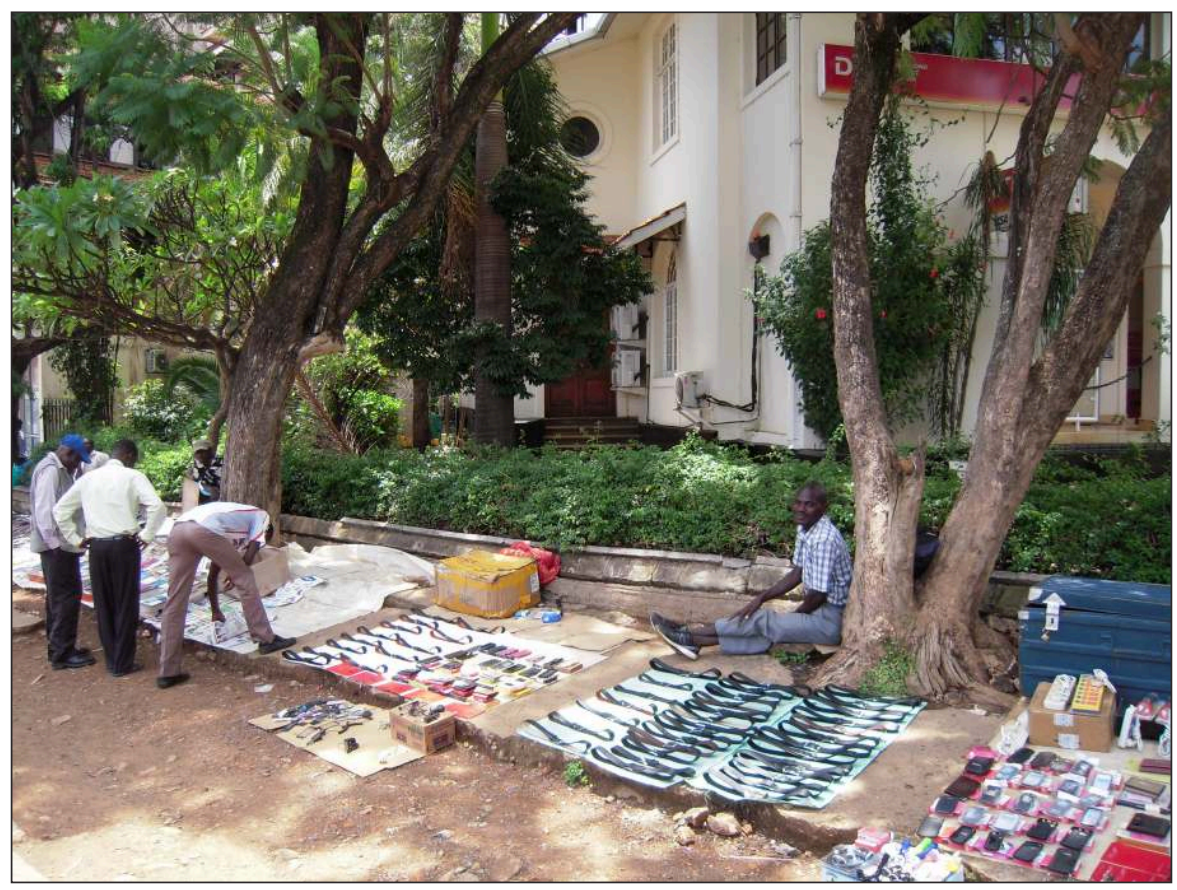

Photo 3. Street vendors, Oginga Odinga Street, Kisumu

Sylvain Racaud, 2016.

believe that agriculture does not yield sufficient revenues and that lowcost business is a cheap complementary activity. This business is strongly linked to the seasons because clients themselves derive their income in part or in full from agriculture. The harvest period is therefore the most prosperous period for merchants as money is more abundant.

Engaging in trading of cheap imported goods represents an alternative to those in rural areas who cannot engage in in agriculture due to some limitations, it could also be a means of purchasing land and investing in agriculture. Regular merchants have invested in commercial food crops destined for the urban market, like potatoes and cabbage that are sold in Nyeri, or melon sold in Kisumu. Rosemary, wholesaler of second-hand clothes who moves between Nairobi and Kisumu, no longer relies on her employment but instead uses farm workers on her land in the County of Siaya. The relative absence of merchant-farmers on their plots and investments can alter the production systems. The latter become more intensive in terms of inputs, and labour. Whether it is in Nyeri or Kisumu, vendors have been able to purchase plots in their villages thanks to the revenue generated from their business. Paul was able to buy a plot in the village after about five years; Henry, after fleeing Rift Valley, was able to build his own house in Nyeri; and Fredrick was able to extend the size of 
his inherited land by purchasing more pieces. On the other hand, nobody would envisage their retirement outside of their home villages, except perhaps the young people, who are yet to think about it, together with those who have made investments in the city. The business in town makes it possible to build a house on the inherited or purchased plot; the objective is to secure resources for the future. Investments in the village rather depend on the success of the economic activities in the city as well as the setbacks, which is particularly true for the street vendors whose work is not recognised by the authorities. This affects life in the village. This is the case, for example, when all or part of the stock is lost, sometimes even as a consequence of planned destruction by authorities as was the case during the fire evacuation of Oile Market in September 2014 in Kisumu. On the other side, for those whose origin is rural areas but living in the city, getting cash or resources such as food is a necessary in order to afford life in the city, particularly for street vendors with limited financial capital like most of those specialising in Chinese junk along Oginga Odinga Road in Kisumu.

Vendors are local vehicles of global products distribution, the grassroots links in the chains of the transnational route. The majority of vendors in medium-sized or small towns or in rural markets are of rural origin. Whether they are sedentary or mobile, permanent or seasonal, they often have one foot in the farm and the other in the market. They integrate agriculture and urban business in their activity system, which leads to specific flows of capital and goods.

\section{Mobility and Network Logic}

\section{Within East African Villages, Cities, and Trading Posts}

The expansion of the trade route, driver of economic opportunities, has led to unprecedented levels of mobility between the countryside, secondary cities, and metropoles. The movement of individuals and objects is functional to the business and takes place on several scales according to the available capital: it's all about stocking up and selling. The street vendors who follow the cycle of periodic markets can sell for up to seven days per week, like Job, a very mobile merchant. On Mondays he stocks up in Nyeri (or Nairobi, if the capital allows him) and sells in Mweiga on Tuesdays, a trading centre on Wednesdays, Mweiga on Thursdays, Endarasha on Fridays, Nairutia on Saturdays, and Kiawara on Sundays. This schedule changes based on agricultural seasons because crops differ in type and harvest time depending on the agro-ecological zones. Job's areas of mobility is within Nyeri County, even if, at times, he's able to get his supplies from Nairobi. The vendors who work in the periodic rural markets often have moderate capital, which constrains their radius of action or movement. Endarasha's periodic market 


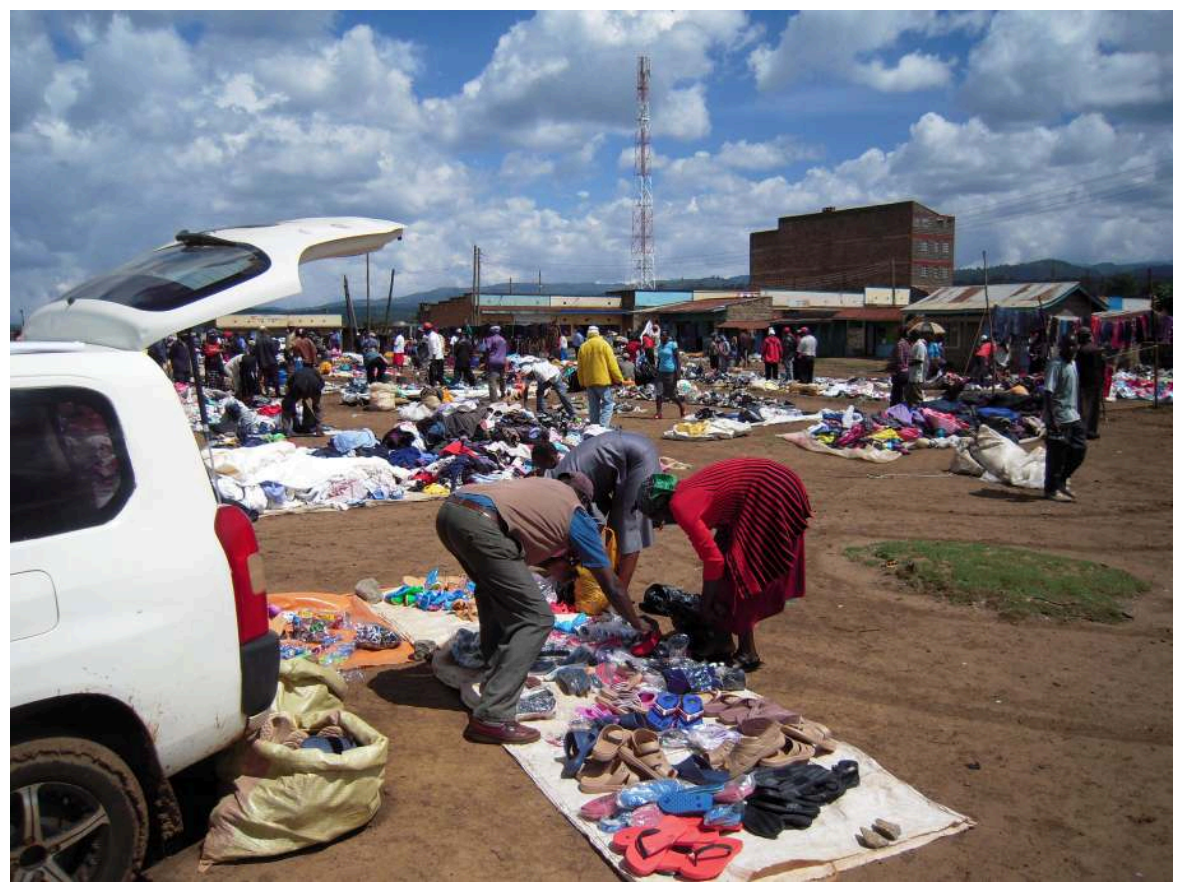

Photo 4. Endarasha's periodic market

Sylvain Racaud, May 2015.

becomes lively from eleven o'clock, once most of the merchants have set up their stalls. A large number of them comes from Nyeri, some from Mweiga (3,500 residents, KNBS, 2015), and others from Endarasha. Out of more than one hundred merchants, two thirds sell second-hand clothing, a dozen sell imported junk, and only three sell new clothes; the selection of available goods is an indicator of the local purchasing power.

When it comes to the supply of goods, the movement of goods and people from the cities to the countryside intertwines with those from the cities to the countryside or from the secondary cities to the metropoles. Limited capital leads to less movements because the reduced stock that one can purchase must often be replenished. In Nyeri County, the lowest number of trips is one per month (which is the case mostly for those who sell between one and three days per week) and the highest frequency is two trips per week to the source of supply and back. The location of the latter depends on the point of sale and the volume of the supply. Among the least dynamic markets is the South-Western side of Mount Kenya, where the economy is based on the production of tea, Karatina (8,500 residents, KNBS 2009) and Nyeri are the main trading posts. The markets located on the North-Nairobi axis from Kenya towards Ethiopia and the markets located northwest of Nyeri, where the business of commercial food crops 
generates connections with Nairobi, have easier cash exchanges. Gikomba and Kamukumji are the major trading posts for second-hand clothing and Chinese junk respectively in Kenya. These popular marketplaces are also major supply centres for Nyeri vendors. Most vendors, whether mobile or sedentary, rural or urban, engaging in the business of low cost products went less frequently to Nyeri Town and even less in Nairobi. These more recent commercial exchanges have created unprecedented fluxes, mobility areas with variable geometry, volatile "merchant territories" (Grégoire 2002) that entirely depend on the interrelations between agriculture and other economic opportunities.

On the shores of Lake Victoria, the development of the low-cost trading route has generated connections and commercial hubs on several levels. In Kisumu, Kibuye is a daily market whose peak is on Sundays since the wholesalers from Nairobi, Nakuru and Mombasa, come to redistribute their stocks of second hand clothes. Bus park, the main bus station in Kisumu, is the main regional trading post for the junk. It is here where wholesalers, retailers, and street vendors coexist or interact. The place attracts merchants who operate in the cities and towns within the region. Furthermore, a significant part of the Kisumu supply of goods made in China is ensured by numerous wholesalers and retailers who get their supplies from Kampala at a similar rate as those who get their supplies from Nairobi, meaning two to four times per month. Despite its landlocked location, Kampala is an East-African hub for imported goods. The Ugandan capital offers attractive conditions for businessmen from East Africa. This is also the case for a few merchants from the South-West of Tanzania, more than 1,300 kilometres away, who also obtain their supplies there, leaving aside Dar es Salaam. The goods that can be found in the Owino market and in the "golden triangle" (Calas 1998, 177), mainly on William Street, Kikuubo Street, and Nakivubo Street, arrive through the port of Mombasa and passes through Nairobi. However, the favourable exchange rates, the low taxes, and the less than transparent negotiations at the border between Uganda and Kenya lead to the fact that the price per unit of a sandal made in China is more cheaper in Kampala than in Nairobi. The development of the Kisumu-Kampala trade route took place at the same time when traders were forming some groups or associations, for example the Kampala Friends, created in March 2016, which has 33 members. One of the members, who had been doing his business in Kampala for 15 years, now prefers Mwanza, a NorthWestern Tanzanian metropolis; the East-African competition is keen and the network is labile.

With its goods, actors, facilitated methods of access, and places, the low-cost commerce has been generating alternative trade routes, the expansion of which results in unprecedented connections between the city 
and countryside, between medium-sized cities and metropoles, and across borders. The movement of products, capital, the layout of activities between business and agriculture, as well as the unprecedented movements are a result of new economic opportunities, which are resource spaces of the "in-between" that showcase the specific territorial dynamics integrating Western Kenyan territories, villages, and grassroots actors, with global commercial networks. These territorial dynamics represent the way "inconspicuous areas of globalisation" (Pliez \& Choplin 2015) play an active role in the system of global networks.

\section{Commercial Links Integrated into the Network Logics}

Besides the physical flow of goods, the organisation of a low-cost trade route also occurs through intangible commercial relationships. The mobility of traders exchanges is unprecedented for some of the vendors in rural markets or in the commercial areas of small towns (e.g. Othaya); by stocking up at their outlets, these merchants get used to the windows and opportunities of globalisation where they maintain more or less ongoing relationships with their suppliers. Professional merchant networks also develop. Partial credit or the granting of an advance on goods are common. They allow customers' attractions and also create the conditions for faster or easier exchanges. Maintaining long-term relationships allows for the development of trust, which can be leveraged during hard times (Berrou \& Gondard-Delcroix 2011). A supplier can "help" his client with a onetime advance on goods. Close relationships also facilitate negotiations. However, vendors are not bound to their suppliers but it is rather "the goods that lead." In most cases suppliers will call their clients to promote new goods or even to take on new potential clients who would cunningly change suppliers. Furthermore, intangible connections are facilitated by the use of smart phones equipped with the WhatsApp application and by the use of phone payments with the Mpesa system, widely used since its release in Kenya in 2007.

Due to influence of the city, the rural mobile street vendors and the urban youth from small cities sell new products that are on fashion: they are medium of fashion trends, which they actually wear themselves. The "items constitute an essential part of socialising contexts" (Kaufmann 1997, 111) and the junk contributes to the emergence of a class of small entrepreneurs of rural origin, actors that play a key role in connecting places and societies of the world. In rural communities that are opening up more and more, this relationship shaping the demand for globalised products, which represent the interconnections between the global socio-cultural factors and economic system. When people's relationship to space changes, their relationship to time changes too. The easy access to non-durable, if 
not short-lived goods, the giving rise to a sense of urgency or excitement of the gain, and unprecedented movements, all contribute to shaping the identities of the "in-between"-a social shifter (Durham 2000) in this citycountry space connected to the global. These identities, in part built through cyclical movements and increasingly individual trajectories, question the status of the territory, a collectively owned space created over time and a conveyer of identities (Charlery de la Masselière 2013). This itinerant trade therefore contributes to the unprecedented time-space relationships that shapes the city and the countryside and their complementary attributes within a resource space that is integrated on various levels in the systems of the network.

The commercial links that emerge within the low-cost route combine themselves with the daily local sociability and tie themselves around an identity soaked in entrepreneurship. The sector of low-cost merchandise is not a selective one: products are available and accessible and their sale allows for the establishment of group unity that combine social and economic systems. In the rural and urban commercial spaces, some merchants feel that what makes most sense is the social relationship rather than the trading function of this "togetherness." A group of saleswomen in Othaya admitted that the profits are small, yet business allows them to get away from the farms, out of the home, the village, and to be in town, together, and share a life between the farms and the stall on the side of the street. At the very least, this commercial activity allows to escape, if not the condition, the very image of the farmer; this is how old Wilson explains it while standing in front of his pile of old second-hand clothing spread over a piece of sheet at the Endarasha market. He proudly proclaims: "I'm a farmer and I'm a business man." The old man only sells twice per week, and, judging by the state of his stock, his prospects to expand it are uncertain. The examples of self-made men like Victor Maina or Davis Mukuha, founders of their respective supermarket chains that were initially small inherited shops, steer people's imagination in an East-African country with a neoliberal economy where entrepreneurship is strongly valued. The entrepreneurial spirit promoted through national programmes (e.g. Kenya Vision 2030) and anchored as a positive value in Kenyan society, can be found in those freelance or mobile entrepreneurs and equally as easily in the neo-liberal systems at the city level especially when it comes to urban planning practices (Morange 2013). From the field to the city, from the individual to the state, the development of the trade route in Kenya allows us to detect several geographical effects of globalisation. 


\section{Conclusion: Between the Places and the "Mobile Spaces" ${ }^{2}$ of low-Cost Business}

Leaving aside any geographic interpretation, this chapter revolved around the question of how the movement of vendors and merchandise creates a resource space that is generated by the relationships between city/country, formal/informal and agriculture/business. The space of the analysed route extends from the country to the cities. It is integrated within the systems of a porous network that combines social, professional, and political links. From the country to medium-sized cities, the majority of the actors along the route of low-cost business sells basic equipment and combines within their activity systems agricultural revenues and the retail sale of small items. Access to this business is possible with limited capitals and through social friends. The professional experience is marked by subsequent steps. Private actors, through their movements and intangible commercial connections, are the grassroots building blocks of the route that connects in an magnified way the biggest centres. The itinerant or sedentary street commerce, with its numerous and flexible forms and permeable borders, is a privileged expression of the "in-between" setting that emerges between formal and informal activities.

The "in-between" resource space demonstrates the existing geographic tension between a physical place on the one hand (a localised, named, represented, and engaged point in space) and on the other hand, a mobile space that is a relative and shifting physical reality. The commercial routes are parcels of recognised (toponymy), materialised (points of sale), and collectively owned space that have become so often after conflicts between vendors and authorities (but also between vendors themselves). Conflicts and competition over the use of space express the conflictual nature of space, which "always represents the challenge and becomes the main stake in struggles and actions that have a specific objective" (Lefebvre 1974, 471). Low-cost business associates (relatively) fixed devices with the fluidity of vendors who follow the waves of clients mainly when they leave work. In Kisumu, Nyeri, Nairobi, etc., every day at the end of the afternoon, a uninterrupted flow of potential customers populates the space between the CBD and the bus stations.

This form of resource space reminds of the "ambulantism," an opportunistic and stealthy style of selling that shapes the geography of the village in a blurry and fluid way (Monnet 2006). This human tide is synonymous with economic opportunities for the vendors that have abandoned their daily points of sales in favour of the crowded and selfappropriated sidewalks. The space, therefore, temporarily changes its

2. Rétaillé (2005). 


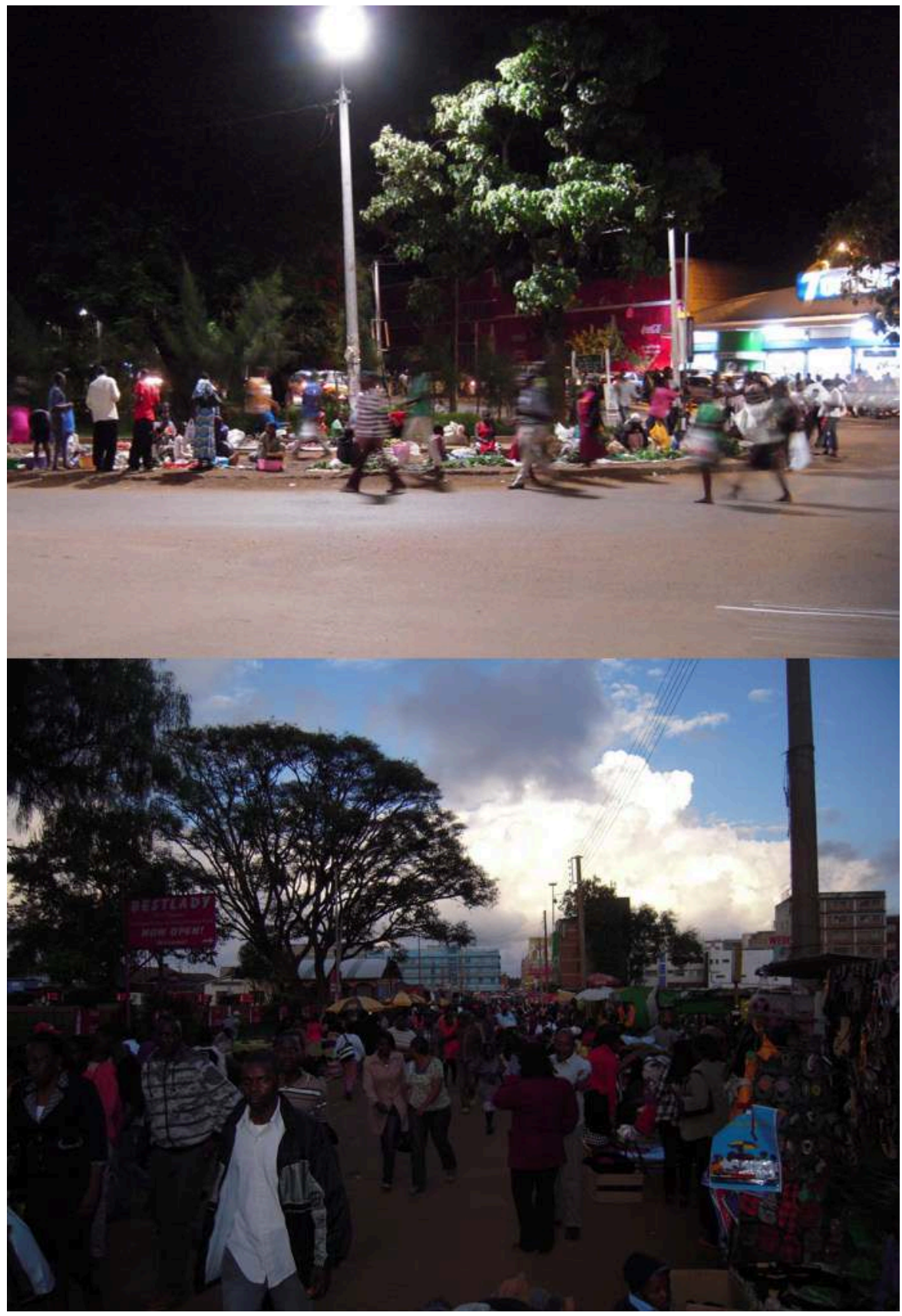

Photo 5. JK Highway Road in Kisumu (above) and Gakere Road in Nyeri (below) Racaud, 2015 and 2016. 
nature just like the CBD employee who becomes a client. Movement is the driving force of this change: traffic zones move, urban areas become merchant spaces, the form of the space changes, and so does the nature of the object in movement (Retaille 2005). In conclusion, the geography of the trade route of low-cost merchandise, through its unprecedented mobility, its unstable merchant spaces, its grassroots precarious private actors, and its unpredictable fluctuations between formal and informal, can be interpreted as the product of a precarious context affecting the largest part of the rural and urban Kenyan society and also as the product of the local connections to the global.

I express my sincere gratitude to Nathan Mwangi Kariuki for the English editing.

\section{Bibliography}

Agier, Michel. 1981. "Étrangers, logeurs et patrons: l'improvisation sociale chez les commerçants soudanais de Lomé." Cahiers d'Études africaines 21, no. 81-83: 251-65. https://doi.org/10.3406/cea.1981.2314.

Berrou, Jean-Philippe, and Claire Gondard-Delcroix. 2011. "Dynamique des réseaux sociaux et résilience socio-économique des micro-entrepreneurs informels en milieu urbain africain." Mondes en développement, no. 156: 73-88. https://doi.org/10.3917/med.156.0073.

Bertoncello, Brigitte, and Sylvie Bredeloup. 2007. "De Hong Kong à Guangzhou, de nouveaux "comptoirs" africains s'organisent." Perspectives chinoises 2007, no. 1: 98-110. http://journals.openedition.org/perspectiveschinoises/2053.

Bertoncello, Brigitte, and Sylvie Bredeloup. 2009. "Des rues globales marchandes ? Les allées du Centenaire à Dakar, Huanshi middle road à Guangzhou (Canton)." Géographie et cultures, no. 71.

https://doi.org/10.4000/gc.2001.

Blundo, Giorgio. 2002. "Éditorial. La gouvernance, entre technique de gouvernement et outil d'exploitation empirique." Bulletin de l'APAD, no. 23-24. https://apad.revues.org/129.

Bonerandi, Emmanuelle, Pierre-Antoine Landel, and Emmanuel Roux. 2003. "Les espaces intermédiaires, forme hybride: ville en campagne, campagne en ville?” Revue de géographie alpine 91, no. 4: 65-77.

https://doi.org/10.3406/rga.2003.2263.

Brient, Gaëlle. 2007. "Géographie 'ouverte' des territoires du piémont sud du Kilimandjaro (Nord - Tanzanie).” PhD Dissertation. Pessac: Université de Bordeaux III Michel Montaigne.

Calas, Bernard. 1998. Kampala, la ville et la violence. Paris: Karthala.

Calas, Bernard. 2007. "Dynamiques métropolitaines d'Afrique orientale." Les Cahiers d'Outre-Mer, no. 237: 3-22. https://doi.org/10.4000/com.624.

Chaléard, Jean-Louis, and Alain Dubresson. 1989. "Un pied dedans, un pied dehors, à propos du rural et de l'urbain en Côte d'Ivoire." In Tropiques, lieux 
et liens : florilège offert à Paul Pélissier et Gilles Sautter, edited by Françoise Pinton, 277-90. Paris: ORSTOM-CNRS-EHESS.

Chaléard, Jean-Louis. 1996. Temps des villes, temps des vivres, l'essor du vivrier marchand en Côte d'Ivoire. Paris: Karthala.

Charlery de la Masselière, Bernard. 2013. "Systèmes spatiaux, systèmes de ressources et identités : redéfinir les contextes des dynamiques territoriales." In Dynamiques rurales dans les pays du Sud, l'enjeu territorial, edited by Bernard Charlery de la Masselière, Bénédicte Thibaud, and Virginie Duvat, 9-20. Toulouse: PUM.

Charmes, Jacques. 1992. "Le secteur informel, nouvel enjeu des politiques de développement ?" L'Homme et la société no. 105-106: 63-77. https://doi.org/10.3406/homso.1992.2664.

Durham, Deborah. 2000. "Youth and the Social Imagination in Africa: Introduction to Parts 1 \& 2." Anthropological Quarterly 73, no. 3: 113-20. https://www.jstor.org/stable/3317936.

Gasselin, Pierre, Michel Vaillant, and Benjamin Bathfield. 2014. "Le système d'activité. Retour sur un concept pour étudier l'agriculture en famille." In L'agriculture en famille : travailler, réinventer, transmettre, edited by Pierre Gasselin, Jean-Philippe Choisis, Sandrine Petit, François Purseigle, Sylvie Zasser, 101-24. Paris: INRA \& EDP Sciences.

Gazel, Hervé, Dominique Harre, and François Moriconi-Ebrard. 2010. Africapolis II, L'urbanisation en Afrique centrale et orientale. Paris: Agence française de développement (AFD)-e-Geopolis [archive].

Government of Republic of Kenya. 2007. Kenya Vision 2030, the Popular Version. Nairobi: GROK.

Government of Republic of Kenya. 2013. Nyeri County Intergrated Development Plan 2013-2017. Nairobi: GROK-Department of Finance and Economic Planning.

Grégoire, Emmanuel. 2002. "Territoires marchands en Afrique subsaharienne." Historiens \& Géographes, no. 379: 133-40.

http://www.documentation.ird.fr/hor/fdi:010029301.

Hugon, Philippe. 2003. L'économie de l'Afrique. Paris: La Découverte.

Kamunyori Wanjiru, Sheila. 2007. "A Growing Space for Dialogue: The Case of Street Vending in Nairobi's CBD.” BA Dissertation. Cambridge (MA): Massachusetts Institute of Technology.

Kaufmann, Jean-Claude. "Le monde social des objets." Sociétés contemporaines, no. 27: 111-25. https://doi.org/10.3406/socco.1997.1466.

Kenya National Bureau of Statistics (KNBS). 2019. 2019 Kenya and Housing Population Census, Vol. 1: Population by County and Sub-county. Nairobi: KNBS.

Labrianidis, Lois. 2008. The Moving Frontier: The Changing Geography of Production in Labour. Aldershot: Ashgate.

Lefebvre, Henri. 1974. La production de l'espace. Paris: Anthropos.

Lindell, Ilda (eds). 2010. African Informal Workers. Collective Agency and Transnational Organizing in Urban Africa. London, New York: Zed Books; Uppsala: Nordic Africa Institute. 
Mainet, Hélène, and Jean-Charles Édouard. 2011. "Territorialités rurales et villes intermédiaires dans les montagnes d'Afrique de l'Est : vers un renouvellement des fonctions?" In Dynamiques rurales dans les pays du Sud, l'enjeu territorial, edited by Bernard Charlery de la Masselière, Bénédicte Thibaud, Virginie Duvat, 157-70. Toulouse: PUM.

Mainet, Hélène, and Sylvain Racaud. 2016. "Secondary Towns in Globalization: Challenged Position or Inconspicuous Key Role in Trade Flows?” Articulo, Journal of Urban Research, no. 12. https://doi.org/10.4000/articulo.2880.

Mitullah, Winnie, Kiura Munene, Frida Muthoni, Francis Ang'awa, Peter Ogara, and George Wagah. 2006. "Trois villes moyennes au Kenya." Les Cahiers d'Afrique de l'Est, édition supplémentaire "Les villes moyennes au Kenya : les enjeux de la gestion urbaine et les objectifs du millénaire pour le développement" edited by Samuel O. Owuor: 73-86.

Monnet, Jérôme. 2006. "Le commerce de rue, ambulant ou informel et ses rapports avec la métropolisation : une ébauche de modélisation." Autrepart, no. 39: 93-109. https://doi.org/10.3917/autr.039.0093.

Morange, Marianne. 2013. "Street Trade, Neoliberalisation and the Control of Space: Nairobi's Central Business District in the Era of Entrepreneurial Urbanism." Journal of Eastern African Studies 9, no. 2: 247-69.

https://doi.org/10.1080/17531055.2015.1018407.

National Council for Law Reporting. 2012. Micro and Small Enterprise Act. Nairobi: NCLR.

Patroba, Hilary. 2012. "China in Kenya: Addressing Counterfeit Goods and Construction Sector Imbalances." South African Institute of International Affairs (SAIIA) Occasional paper 110. Johannesburg: SAIIA.

https://saiia.org.za/research/china-in-kenya-addressing-counterfeit-goodsand-construction-sector-imbalances/ [archive].

Pliez, Olivier. 2007. "Des jeans chinois dans les rues du Caire, ou les espaces discrets de la mondialisation." Mappemonde 88, no. 4.

http://mappemonde.mgm.fr/num16/articles/art07404.html [archive].

Pliez, Olivier. 2009. "Salloum (Égypte), une bourgade bédouine sur les routes de la mondialisation.” L'Espace géographique, no. 38: 31-42.

https://doi.org/10.3917/eg.381.0031.

Pliez, Olivier, and Armelle Choplin. 2015. "The Inconspicuous Spaces of Globalization." Articulo, Journal of Urban Research 12.

https://articulo.revues.org/2905.

Racaud, Sylvain. 2006. "L'agriculture urbaine à Bafoussam, Ouest Cameroun : Aux fondements de la rurbanité." MD Dissertation. Toulouse: Université Toulouse 2 .

Retaillé, Denis. 2005. "L'espace mobile." In Le territoire est mort, vive les territoires !, edited by Benoit Antheaume, Frédéric Giraut, 175-202. Paris: IRD Éditions. https://doi.org/10.4000/books.irdeditions.3397.

Rondinelli, Dennis. "The Market Towns and Agriculture in Africa: The Role of Small Urban Centres in Economic Development." African Urban Quarterly 3, no. 1-2: 3-10. 
Sanghi, Apurva, and Dylan Johnson. 2016. "Deal or No Deal, Strictly Business for China in Kenya?" Policy Research Working Paper 7614. Washington: World Bank. https://documents.worldbank.org/en/publication/documentsreports/documentdetail/801581468195561492/deal-or-no-deal-strictlybusiness-for-china-in-kenya.

Steck, Jean-Fabien. "La rue africaine, territoire de l'informel ?" Flux no. 66-67: 73-86. https://doi.org/10.3917/flux.066.0073.

Walther, Olivier. 2015. "Business, Brokers and Borders: The Structure of West African Trade Networks." Journal of Development Studies 51, no. 2: 603-20. https://doi.org/10.1080/00220388.2015.1010152.

World Bank. 2016. Informal Enterprises in Kenya. Washington: World Bank. http://hdl.handle.net/10986/24973. 



\title{
Chapter 6 \\ The Politicisation of Land Policy Reform in Contemporary Kenya
}

\author{
Francesca Di Matteo
}

Translated by Sara Stavchansky

In Kenya, as in other African countries, the colonial experience was the foundation of a centralised and authoritarian bureaucratic institutional apparatus that continued shaping the state after independence (granted in 1963). In this former British settlement colony, state institutions, including those governing property rights, have been structured to provide territorial control, ${ }^{1}$ including through the deployment of the Provincial Administration, the branches of central state power in the Districts (Bourmaud 1988). The centralisation of state control gradually took hold in the 1970s, under the aegis of the first independent government. It gained strength in the 1980s with the second president of the Republic of Kenya, Daniel arap Moi, when the regime turned to autocracy (Nyong'o 1989). Social and political movements emerged in the 1980s and 1990s in opposition to the dictatorial state power: they called for the reshaping of the social contract through the revision of the constitution (Haugerud 1997; Klopp 2001; Murunga \& Nasong'o 2007). The democratisation of land management and administration systems has been an integral part of this overall movement calling for the restructuring of the state.

In this context in which the action of the territorial administration has allowed local political pluralism while framing and linking it to the central state through a selective redistribution of resources, i.e. a "rationalised clientelism" (Bourmaud 1988, 138), the institutions governing the land have become porous to political interference. They have thus drawn on the land resource, held de jure in trust by public authorities, to maintain clientelist networks, according to a well-known "neo-patrimonial" logic. ${ }^{2}$ This politicisation of land governance has contributed to the exacerbation of conflicting community relations in many local contexts, some of

1. The territorial nature of the colonial state (and postcolonial in its wake) in Kenya was conceptualised by Claire Médard (1999) in her doctoral thesis in Geography. She shows that the state territorialise its power through the control of both natural resources and populations.

2. For a discussion of the concept of "neopatrimonialism" applied not only to African political systems, see Bach \& Gazibo (2012). 
which, as in the Rift Valley, have resonated in the national political arena. The analysis of the conflict dimension of land issues is fundamental to understanding the triggers and vehicles of reform processes in Kenya, both constitutional reform and land governance reform. Land disputes have indeed been the basis of many institutional processes (such as the many commissions of inquiry appointed by the Kenyan presidents in the 1990s and 2000s) but also of less institutional processes (such as the constitution of a transnational network of actors) that contributed to the legal-institutional transformations of the country' systems.

From 2000 to 2010, the Constitution of Kenya Review Commission (CKRC) worked on the drafting of a new supreme law. Land reform was one of the pillars of the proposed constitutional changes. Not only were land issues incorporated into constitutional deliberations, with a chapter of the new Constitution fully dedicated to it, but a National Land Policy (NLP), was developed in parallel within the Ministry of Lands as early as 2004. The NLP had to unravel the land question and formulate general policy principles, unifying the corpus of land laws by deciding on their aims and their orientations. These two parallel reform processes were completed between 2009 and 2010. Since 2011, the legal-institutional framework proposed by these texts was progressively, albeit very slowly, put into place.

Among the salient points of land reform, the restructuring of the roles and functions of institutions governing property rights emerged, since the early 2000s, as the only policy instrument that could tackle both the colonial legacy and dysfunctional land administration (i.e. lack of efficiency and neo-patrimonial practices). Above all, it was necessary to deconcentrate and decentralise the politico-administrative power of the executive, especially limiting the hold of the president on land allocations, and thereby revising the legislative framework inherited from colonisation, now considered obsolete and plethoric. The structure of land ownership was also re-examined, including a number of principles that had remained dogmatic since independence, such as the sanctity of first registration and the inevitability of the individualisation of land tenure. ${ }^{3}$

From the beginning of the process of enactment of land reform provisions, several authors argued many actors resisted institutional change. They noted the "difficulties" in reforming institutions (Bassett 2017), as well as the existence of "counter-reform" (Klopp \& Lumumba 2017) attempts by

3. These remarks were notably expressed in the documents at the base of the reform elaboration: see Constitution of Kenya Review Commission, The People's Choice. The Report of the Constitution of Kenya Review Commission (2002), Report of the Commission of Inquiry into the Illegal / Irregular Allocation of Public Land (2004), and Sessional Paper No. 3 of 2009 on National Land Policy (2009). 
the political and bureaucratic class, namely the government of the fubilee Coalition-in power since 2013-officials of the Ministry of Lands, and, more generally, all the beneficiaries of the old regime (McAuslan 2013, 262; Manji 2014; Boone, Dyzenhaus, Ouma, et al. 2019). All these works differentiate the process of formulating land reform texts (the Constitution and the NLP) from the elaboration of laws meant to operationalise the reform provisions. Thus, the progressive impetus of the 2000s would stand in contrast to the resistance to implementation of transformative measures of the 2010s. But these analyses do not explain why the bureaucraticpolitical establishment, beneficiaries of the old regime, would initially have accepted land reform. Why would blockades and sabotage attempts have waited for the implementation of a new law radically reorganising the governance and structure of property, but have quietly allowed its formulation and promulgation?

This chapter aims to show that resistance has been a constant feature of the policy process of land reform from the early stages of its formulation to its implementation. In order to do this, it analyses precisely the process of reform starting with its setting on the government agenda and exposes the negotiations taking place before and after the promulgation of the two founding reform texts. In addition, this chapter anchors the interpretive framework of the emergence and progress of the process of land governance reform in the political history of Kenya to better understand debates and blockages. After a brief discussion of the colonial legacy and postcolonial continuity of Kenya's bureaucratic and economic-political structures, I will first show how the politico-land conflicts of the 1990s, particularly those in the Rift Valley, prompted certain stakeholders to advocate for policy change. I will then explain the reasons why the political system suddenly became more receptive to reform narratives and highlight how the international context contributed to the pro-reform movement as well as to the design of procedures for concerted decision-making. Finally, I will dwell on the political events that both obstructed and promoted the reform process. ${ }^{4}$

4. The analyses presented here are the result of doctoral research conducted in Kenya for eighteen months. I adopted several qualitative methods of data collection: semi-structured interviews with a wide range of actors (members of associations, public authorities, representatives of rural communities, etc.), press review, participatory observation in civil society and government workshops, notably through the integration of a non-governmental organisation lobbying for reform, the Kenya Land Alliance. 


\section{The "Land Question": Construction of a Dominant Narrative}

It was expected that the transfer of power from colonial authorities to indigenous elites would lead to fundamental restructuring of the legacy on land. This did not materialise and the result was a general re-entrenchment and continuity of colonial land policies, laws and administrative infrastructure. This was because the decolonisation process represented an adaptive, co-optive and pre-emptive process which gave the new power elites access to the European economy. (Republic of Kenya 2009, 5.)

This excerpt, taken from the NLP, is meant to exemplify the political aspects of what is called in Kenya the land question. ${ }^{5}$ It first associates the land question with the incompleteness of the process of decolonisation during transition to independence. The colonial legacy would thus be the first pitfall in the resolution of problems related to land management. This colonial legacy refers particularly to the "historical land injustices" caused by the expropriation of many Kenyan populations by the colonial enterprise, which have never been rectified. The establishment of a settlement colony in Kenya is indeed the result of large-scale land acquisitions, which the colonial government justified "legally" by a reversal of sovereignty. ${ }^{6}$ The lands targeted were mainly those located in areas of high agricultural potential: the Central Highlands and the Rift Valley, later known as the White Highlands. ${ }^{7}$

Although many communities in the highlands were dispossessed by the colonial enterprise, the land claims of some groups in the Rift Valley, namely Maasai and Kalenjin, have resonated most in the national and international political arenas at specific historical moments, such as during the transition to independence in the 1960 s and the return to multi-party politics in the year 1990. In order to understand the advent and regular resurgence of one of the major social cleavages structuring the partisan Kenyan system, it is important to note that until the 1940s, the colonial administration had encouraged the migration of populations deemed fit for agriculture, such as the Kikuyu of the central region, to the European farms of the Rift

5. For a discussion and definition of the "land question" in Africa, and / or in East Africa, see Okoth-Ogendo (2007), Moyo (2008) ou Manji (2013).

6. This aspect of colonial history has been largely studied by historians and jurists: see Sorrenson (1968), Péron (1995), Okoth-Ogendo (1991) and Hughes (2006).

7. They are formed in the central region, namely the Kikuyu country, named after the farmers who populate this area, and the Rift Valley, where groups who engaged in pastoralism, but also agriculture, coexisted. 
Valley. ${ }^{8}$ In the independence negotiations, these migrations were disputed by the delegations representing the Maasai and Kalenjin herders and agropastoralists who called themselves "indigenous" to the Rift Valley and feared that European farms would be handed over to the Kikuyu, who lived there as squatters. ${ }^{9}$ At the Second Constitutional Conference, held in London (Lancaster House) in 1962, the Maasai delegation demanded the return of $70 \%$ of the White Highlands (Kantai 2007, 109). The leader representing the Maasai, Justus ole Tipis, along with the representative of the Kalenjin, Daniel arap Moi (both from the same party, the Kenya African Democratic Union, KADU) and Donald Ngala, representative of some coastal communities-all three leaders from the periphery-defended the land rights of "indigenous" communities. They opposed the claims of the Kikuyu-dominated Kenya African National Union (KANU), under the leadership of Jomo Kenyatta, who emphasised the rights acquired by sedentary communities on the basis of colonial policies (TJRC 2013, 199206). The criteria used to redistribute lands occupied by the British became the bone of contention structuring power struggles between groups. The KANU won the first political elections of 1963. The political project of this organisation became then dominant and engulfed KADU, but it could not suppress the claims of the periphery, bound to resurge.

The independence land deal concluded in London was condensed in Article 75 of the 1963 Constitution protecting land rights acquired during the colonial period, regardless of the process of acquisition. This article endorsed the spoliations of the colonial period and made any land restitution impossible. To appease KADU leaders and representatives of minority groups, Kenyatta promised that the ancestral lands would not be transferred to other ethnic groups, but this promise was not kept. The Africanisation of the White Highlands followed neither the logic of restitution to the first occupants (land to the "natives") nor that of redistribution (land to the landless). The state orchestrated both sales of the old White Highlands and their financial conditions ${ }^{10}$ without any restructuring of the property system. The prevailing historical narrative argues that there was a quasi-

8. This is especially true before the outbreak of the political and military emergence known as the Mau Mau revolt, as a result of which migrations, including Kikuyu, were strictly controlled, and Africans residing on the settlers' farms "repatriated" to the reserves: (see Kanogo 1987; Berman \& Lonsdale 1992).

9. Polysemic term which, according to the historical periods and the regions of the country, can describe different socio-economic and political relations: see Kanogo (1987) for an analysis of the conditions of the Kikuyu on settler farms in the Rift Valley.

10. See the literature on settlement schemes of the 1960s: Harbeson (1973), Leys (1975), Oucho (2002). 
ethnic monopoly of land redistribution in favour of the first government's ethnic group. This narrative persisted despite the regime change at the end of the 1970s, which reoriented the neo-patrimonial strategies of land redistribution.

This moment in Kenyan history is seen as crucial because it has sown the seeds of discord among several groups, as their land claims have been neglected or even simply ignored. These claims were perpetuated and reaffirmed, in particular, by the use of the notion of historical land injustices. This notion is ambivalent and subject to successive reinterpretations according to the stakeholders and the context. ${ }^{11}$ What is important to emphasise here is that the construction of the cleavage between the Kikuyu and Kalenjin dominated and structured the national political scene, despite the salience of spoliations and injustices suffered by other groups in other parts of the country.

It follows that upon independence, the Kenyan economic structure remained intact: the role of the state remained that of "creator and protector of the great landowners" (Holmquist, Weaver \& Ford 1994, 76). Rural development policies continued to be tied to the myth of the productivity of large farmers, ${ }^{12}$ and social inequalities were fueled by neo-patrimonial management of resources, including land. ${ }^{13}$ The Ministry of Lands and the provincial administration system in particular were caught up in this system of selective redistribution of resources, putting themselves at the service of the powerful and thus impoverishing the quality of services delivered to the citizens. ${ }^{14}$ Land allocations, as well as the issuance of land titles, played a major role in such political strategies of building and maintaining clientelist networks that served political and electoral purposes, especially since the return to multi-party politics.

11. To delve more deeply into the historical-political construction of Kalenjin claims, see Médard (1999) and Lynch (2011). For a necessary detour into other regions of Kenya, see the works on the Swahili coast: Willis (1993), Cooper (1980). For northern Kenya, see also Schlee (1989) and Oba (1992).

12. For a discussion of the political economy choices, see Leys (1984).

13. Jean-François Médard $(1992,191)$ has described the phenomenon of straddling between the private and public spheres in Kenya, showing how individual enrichment is a function of access to the state. Other authors have revealed that the redistribution of resources by those in power is accomplished through regional and ethnic affiliation: Bradshaw (1990), Wrong (2010), Boone (2012). For a historical discussion of neo-patrimonial logic in Kenya, see the thesis of Jaqueline Klopp (2001).

14. See the Ndung'u Report (Republic of Kenya 2004) for a detailed description of so-called irregular and illegal land transactions of which land administration has been responsible since Kenyan early independence years. 
Indeed, coinciding with the advent of multi-party electoral competition, the question of land "restitution" to the Kalenjin dominated political debate and the rhetoric of the electoral campaigns. ${ }^{15}$ The Kalenjin claimed to be doubly dispossessed, both by the British and by the distributive policies of the Kenyatta era, a Kikuyu president who favoured his own. The Kikuyu became targets of deadly attacks in the Rift Valley throughout the 1990s and in 2007-2008, as well as elsewhere in the country.

\section{Historical and Contingent Reasons for the Land Reform Agenda}

The concept of historical land injustices is essential to understand the sensitivity of the land issue in Kenya. The national land policy defines these injustices as having arisen from the land spoliations of the colonial period, perpetuated by the independent governments (Republic of Kenya $2009,42)$. This concept became very relevant beginning with the postelection violence of 2007-2008 that threw the country into civil war for several months. In the wake of the 2008 National Reconciliation Agreement, the Truth, Justice and Reconciliation Commission, inaugurated on August 3, 2009, was established as an instrument of transitional justice. In particular, it examined the extent to which post-election violence had resulted from historic land injustices. ${ }^{16}$ The Commission report published in 2013 explains that the formulation "historical injustices" was adopted in everyday language in Kenya as part of the social mobilisations demanding the revision of the Constitution beginning in the 1980s. ${ }^{17}$

The 1990s were a turning point in the launching of constitutional reforms as well as land reforms. First, the concerted mobilisation of various sections of Kenyan civil society ${ }^{18}$ exerted considerable pressure on President Moi's

15. The term "restitution" refers to the British, but because of the intertwining of ethnic and territorial claims, it is used in everyday language in Kenya to refer to land injustices perpetrated by independent governments.

16. In December 2007, following the denunciation of electoral fraud, violence erupted notably in Nairobi and in the Rift Valley, throwing the country into deadlock for several months, causing the death of 1,200 people and displacing 500,000 (Human Rights Watch 2008). In the 1990s, this confliction associated with the electoral meetings had also affected the coastal and northern region, showing that the grievance was not localised but diffuse.

17. Through this term, the activists aimed to denounce the political and socioeconomic marginalisation of social groups and regions, whereas, more generally, this expression refers to the dispossessions and inequalities that result from the land policies implemented since colonisation: see TJRC $(2013,68)$.

18. In the 1980s and 1990s, this designation referred to the first human rights organisations, religious figures and organisations, student university unions, 
regime, pushing him to establish the CKRC in 2000. This commission was tasked with reforming the constitution. ${ }^{19}$ Then, to understand the reasons that led the president to make political concessions, it is necessary to plunge into the internal mechanics weakening the regime. Indeed, because of an increasingly predatory mode of government-notably plundering public land and redistributing resources through new clientelist channels that excluded groups previously in power-President Moi renewed and narrowed the networks shaped by his predecessor, Mzee Kenyatta (Branch \& Cheeseman 2008, 1-26).

Finally, added to the political practices spurring exclusion was the deterioration of the economic conditions of the 1970s, which led to exasperation of the regime autocratic style, while laying the foundations for the discontent of a section of society. Due to the slowdown in the economy, which resulted from, among other things, the implementation of structural adjustment plans, the nascent Kenyan middle class was unable to maintain high levels of consumption (Holmquist, Weaver \& Ford 1994, 90). Finally, an alliance between elements economically disadvantaged by the regime and international bodies were put in place. It can be said that the pro-democracy movement was well-anchored in the economic structure while also being the "product" of external forces (ibid., 96). In fact, it was through the action of the urban middle class, and not by peasant or worker organisations (largely absent from the mobilisations), that the demand for a return to a multi-party system took shape.

The advocacy movement for land reform has its roots and fed on the pro-democracy struggles of the 1980s and 1990s: it is their continuation, although metamorphosed. In the international context of the end of bipolarism, the wave of international programs of the 1990s, which funded advocacy activities, focused on human rights and pro-democracy lobbying and invested heavily in civil society organisations, designed by the aid industry as the democratising element in the face of predatory state devices. ${ }^{20}$ These aid flows led to an exponential increase in the number of non-governmental organisations (NGOs) (Kanyinga 2013).

cultural professionals (such as traveling and participatory theatre actors), as well as private sector professionals, including lawyers who actively participated in the pro-democracy struggle corporately and individually by providing pro bono legal services to political prisoners.

19. For narratives presenting a participant point of view on the momentum of these mobilisations and the struggles between the mobilised groups and state authorities, see Mutunga (1999), Mutua (2013) and Maingi (2011).

20. For a detailed reconstruction of this movement in Kenya, see Pommerolle (2005). 
In Kenya's land sector, donors were indirectly influential in the agenda setting of land reform when funding the creation of the Kenya Land Alliance (KLA). The KLA was originally conceived as a platform for NGOs dealing with land issues. It was meant to introduce new narratives and directories of commitment to these questions in order to influence the decision-making process. The KLA is a model of political participation that was promoted by Oxfam GB, ${ }^{21}$ itself funded by British cooperation, strictly in connection with Kenyan personalities with highly-internationalised profiles. ${ }^{22}$ This strategy worked well: not only did the KLA form a federation of various organisations and gain leadership, but it also managed to impose itself, in the early 2000s, as a key interlocutor of governmental and bureaucratic land institutions. This symbolic capital was built during the formulation of the land policy, the National Land Policy (NLP).

It is in this context of multiple influences that, in the wake of reports produced by the commissions inquiring into the violence of the 1990s (Kiliku Commission, 1993, Akiwumi Commission, 1998), which pointed to land claims and their ethnicisation as the cause of the conflicts (Kameri-Mbote 2008), President Moi established in November 1999 another commission of inquiry to examine the land laws in place and propose a restructuring of the legal-institutional system. The recommendations of the so-called Njonjo Commission (named after its chairman, the former Attorney General, Charles Njonjo), published in 2002, constituted a fundamental precedent for the start of the land reform process. This Commission documented the excessive (too many laws) and inefficient (lengthy and costly) nature of the legal framework governing land, while also highlighting the concentration of power within the executive branch. These land-related findings helped to justify, more broadly, a political-administrative decentralisation of public authorities in Kenya. For the first time, an official document issued from the circles of power argued for the need to reform laws and harmonise them through the development of a national land policy.

The appointment of this Commission also galvanised the transnational network (of which the KLA was part and parcel) of Kenyan and international activists, aid professionals, and consultants who had previously been waiting in the shadows of a regime, seemingly impenetrable to change, for the window of opportunity (Kingdon 1984; 2002) to convey new narratives

21. The creation of a Land Alliance is not unique to Kenya but is part of a regional or sub-continental strategy. Land Alliances have been created in Zambia, Zimbabwe, Malawi, Tanzania and Uganda, still under Oxfam GB's impetus, at the start of land reform formulation processes, to federate NGOs and thereby strengthen their advocacy capacity.

22. These are consultants, experts or academics recruited by international organisations, and / or activists operating in connection with the aid system. 
and references to the government forum to fuel the process of change. Both the Njonjo Report (Republic of Kenya 2002) and the first version of the constitutional text, a document called "The People's Choice" (CKRC 2002), were partly dependent on the contributions of the Law Professor H. W. O. Okoth-Ogendo, building stone of the transnational network. The KLA also significantly contributed to the production of these two documents. Since its founding in 1999 and during the decade of land reform law formulation, it was funded to produce research and foster the development of a policy incorporating provisions that "international standards" recognise as propoor. $^{23}$

In 2002, the electoral debacle of President Moi's heir apparent Uhuru Kenyatta, son of Jomo Kenyatta, sanctioned the first political alternation, as well as the demise of KANU, the independence party. The rise to power of the National Rainbow Coalition (NaRC), a coalition of opposition parties and KANU's dissenters, seems to have been crucial for the start of constitutional reforms as a result of the relative injection into the state machine of personalities from civil society (Anderson 2003).

At the dawn of the electoral victory of the NaRC, a group of donors ${ }^{24}$ initiated an intense collaboration with the Ministry of Lands to jointly design the methods of formulation of the NLP. ${ }^{25}$ The so-called National Land Policy Formulation Process (NLPFP) was fully funded by donors. They established a Memorandum of Understanding with the Ministry of Lands, held regular consultations with senior officials of the Ministry, and recruited consultants to manage the budget and support the conceptualisation of the land policy text.

23. It should be noted that the terms and contents of land reforms in so-called developing countries have historically been debated primarily between bilateral and multilateral donors (and only to a lesser extent with the governments concerned), who discuss the best formula for economic growth. This was true until the turn of the twenty-first century, when the focus was instead on povertyreduction strategies ideally formulated through involvement of key stakeholders (see, for example, Mosse \& Lewis 2005). In this overall framework, the KLA, like other Land Alliances in Africa, is indeed an emanation of this specific historical moment when some development aid agencies tried to formulate alternative models to the dominant dogma of privatisation and the primacy of the market (see Toulmin \& Quan 2000).

24. The Development Partners Group on Land is made up of UK Aid, Irish Aid, Swedish International Development Authority, USAID and UN-Habitat.

25. The Minister of Lands at the time, Amos Kimunya, was not a politician, but a chartered accountant who had chaired the professional organisation of accountants in Kenya and had also been a consultant for British cooperation. It was the advent of new players in high-level positions, such as Kimunya, who had some familiarity with donors, which no doubt made the start of reforms possible. 
In this context, it is instructive to put the NLPFP in perspective with the constitutional revision process. Although both processes involved to a certain extent the same actors and produced the same content, the constituent conference was fully funded by the Kenyan government and became the scene of consequential political bickering, while the NLPFP was apparently immune to conflict. The unprecedented collaboration of NGOs with the Ministry of Lands produced a document partly traversed by decolonising motives, asking, for example, for the legal recognition of local land rights of rural communities (based on the conceptualisation of the legal category of community), and the comprehensive treatment of historical injustices, thus endorsing a principle of social justice which, for some stakeholders, remained very dangerous. ${ }^{26}$ The political stakes of the NLPFP process were nonetheless highly significant, ${ }^{27}$ even if they were relatively shadowed by the strong politicisation of the constituent conference. This is explained by the fact that politicians were the main absentees of the NLPFP, while they dominated the last phase of the constituent conference. The NLPFP was led by transnational actors; only a few Ministry of Land bureaucrats were involved. The final version of the land policy was completed in 2007, but it would take two years before Kenyan government institutions endorsed it.

In this context, it is important to relativise the fall of KANU and the rise to power of the NaRC government as catalysts of change. It is true that following the political alternation of 2002, the process of formulating the NLP started, and the process of constitutional revision, which President Moi had interrupted before the December 2001 general elections, was revived. However, the reluctance of some parts of the coalition to work for change was visible as early as in 2005 , when internal disruptions stalled the reform process. The NaRC was, in effect, composed of two political forces ${ }^{28}$ that joined hands by political expediency (to get rid of Moi), though de facto remained divided. Their honeymoon was very short, and discord in the constitutional referendum of $2005^{29}$ was visible. The intra-government

26. See the report of USAID on the analysis of the NLP (USAID 2009 [2008]).

27. One need only refer to USAID's lobbying activity that tries to convince DfID to stop supporting KLA.

28. On one side, the Liberal Democratic Party (LDP) of Mwai Kibaki, former executive of KANU, who in 2002 became president; on the other side, the National Alliance Party of Kenya (NAK) of Raila Odinga, opposition leader, who had allied with KANU's dissident fringe because of the promise of creation, through the constitutional revision, of a prime minister position. A two-headed government was therefore formed, allowing the coalition to self-perpetuate.

29. Mr. Kibaki broke his promise at the Constitutional Conference by leaning towards a strong presidentialist. The constitutional draft was changed by the Attorney General, Amos Wako, just before being submitted to the popular vote (hence the name of this version of the constitutional text, the Wako draft). 
feud froze the reform process until 2007, during the presidential elections in December, which plunged the country into interethnic clashes in Nairobi, in the Rift Valley, and other places throughout the country. The peace agreement materialised from a power-sharing agreement between the two parties, who committed to the fulfillment of constitutional reforms (including land reform) in order to restore peace in the country. The NLP was adopted in December 2009 by Kenyan Cabinet and Parliament; in the same context of the end of the crisis, the new Constitutional was promulgated in August 2010 via referendum.

Both interviews and observations as well as the re-reading of historical events from 2000 to 2010 show that the entire process of land reform elaboration (six years for the NLP, and approximately ten for the Constitution) suffered the ups and downs of partisan ruptures and recompositions of the Kenyan political system. Indeed, if the reform agenda had fed on the political violence of the 1990s (Njonjo Commission appointed in the wake of commission reports investigating the causes of conflict in the 1990s), it was the brutal resurgence of conflict arising from local arenas at the centre of the national scene in 2007 (Boone 2014) that made it possible to unblock the political impasse crystallised by the 2005 referendum rejecting the Constitution. It seems that the transitional government created in 2008 had no other choice but to endorse the constitutional text in order to fulfil its commitments to restore peace in the country.

The reform of land governance was, in this sense, imposed (by concomitant internal and external forces) upon a political class that was at reluctant to reform the land administration because of the historical system of territorial control and centralised authority over land rights in place since colonisation. The initial relative enthusiasm of the incoming government (especially between 2003-2005) may have reflected an initial desire both to stand out from the past and probably also to recast political alliances through, among other things, the restructuring of land governance. Yet, the overhaul of land governance systems would prove too expensive (in political terms), especially for the bureaucratic establishment. The analysis of negotiation of norms during the formulation of land laws, meant to enact constitutional principles, corroborates this assumption, as illustrated here below.

\section{Inter-Institutional Impasse or Necessary Adjustments?}

As we have seen, the report issuing from the Njonjo Commission served as a reference for the development of the National Land Policy. The content of the land chapter of the Constitution is also inspired by the 
recommendations of this report. The commission of inquiry indicated that the concentration of decision-making power in the hands of the President and Commissioner of Lands (appointed by the President), particularly with regard to land allocations, was among the most blameworthy elements of the system of land governance. Several pages of the Njonjo Report describe this system of land administration as vulnerable to political interference. Another commission of inquiry-the Ndung'u Commission, named after its chairman, Paul Ndung' ${ }^{30}$-appointed by the NaRC government in 2002 and charged with investigating fraudulent land allocations, also unveiled the many methods of abuse of an excessively concentrated and personal power.

Indeed, by virtue of the land laws previously in force (like the Government Lands Act), the President had the right to dispose of public lands (then classified as government lands) and to delegate this power to the Commissioner of Lands. Both ignored the "public interest" clause that was to govern such measures: they allocated public land to clients of the regime. This phenomenon is commonly referred to as land grabbing in Kenya. The omnipotence of the President and his Commissioner was illustrated in the jargon of the sector by the expression "green pen." In 1997, during a parliamentary debate on the revision of the Constitution, the (then opposition) MP Prof. Anyang' Nyong'o, ${ }^{31}$ declared:

Mr. Speaker, Sir, we must, in the new Constitution, ensure that we are no more enslaved by this presidential authoritarian system. From the moment the new Constitution comes into being, no President in the Republic of Kenya should be a demi-god. No President should have the power of taking a green pen and signing a piece of paper and bequeathing to an individual thousands and thousands of acres of lands of Kenyans. (National Assembly, Official Report. The CKRC Bill, the 14th of October, 1997.)

On the basis of these findings, the recommendations of the two commissions converged on the establishment of a new institutional framework that would bring efficiency, transparency, and accountability to the land administration system, thus converging towards the establishment of an independent commission, the National Land Commission (NLC),

30. It is instructive to note that the KLA Director was also appointed a member of the Ndung'u Commission, which confirms the success of his organisation in integrating institutional forums for debate and the development of public policy solutions and tools.

31. This politician was, by the time of writing this paper, Governor of the Kisumu County, at the time of the quoted speech, a member of Ford-Kenya, the progressive wing of the NaRC, among the members of the coalition from the ranks of civil society; he was indeed a professor at the University of Nairobi then head of programs at the African Academy of Sciences in Nairobi. 
responsible for the management of the public and community land domain. ${ }^{32}$ This mandate would be included in the articles of the NLP, from 232 to 238 (Republic of Kenya 2009), thus envisaging the creation of a constitutional body, independent from the Ministry of Lands, accountable to Parliament and composed of eight commissioners ${ }^{33}$ with strong powers. The NLC was supposed to administer all public lands, establish a register of all land areas, exercise the compulsory acquisition of property, and establish and manage the National Land Trust Fund, a fund that was to finance the implementation of several reform processes, such as the resolution of historical injustices. ${ }^{34}$

Through these recommendations, the historic mandate of the Ministry of Lands was drastically reduced and even stripped of strategic functions, such as those related to land registration. However, the profound restructuring of the mandates and institutional powers proposed by the NLP had less legislative than programming value. The whole challenge of the work of the activists and members of the advocacy coalitions was to ensure that the contents of the NLP be included in the final version of the constitutional chapter on land in order to ensure its future implementation. In August 2010, following the meeting of the Parliamentary Committee on Land and Natural Resources in Naivasha to revise the constitutional text in order to resubmit it to the referendum vote, certain crucial functions attributed to the NLC were excluded from its jurisdiction. This included the clause giving the Commission the right to manage community and private lands ${ }^{35}$ as well as the clause giving it the power to co-execute (with the Ministry of Lands) the land registration program. In this respect, the final

32. Regarding (unregistered) community lands, the Njonjo Report agreed on the relevance of securing this land area through the legal recognition of customary land practices. The report also pointed to the abuses of the trusteeship model, a system whereby community lands were held in trust by local authorities, the County Councils, which eventually allocated these lands by confiscating them or giving them as concessions to private investors, while robbing the communities. Lastly, it recommended that the registration of community lands be under the jurisdiction of the decentralised bodies of the NLC.

33. The commissioners are recruited by competition, and their appointments are sanctioned by Parliament to ensure that recruitment reflects the imperatives of representation, experience and integrity: Republic of Kenya (2009); art. 232.

34. Similarly for the decentralised entities of the NLC, the County Land Management Boards, whose members were to be accountable to county parliaments. They were assigned crucial functions by the NLP in land administration, such as land use planning, land registration, record keeping of land transactions, and the issuance of titles: ibid., art. 241-246.

35. "Art. 84(2)(c) to advise the national Government and devolved governments on a policy framework for the development of selected areas of Kenya, to ensure that the development of community and private land is in accordance with the 
version of the constitutional chapter conferred on the NLC only a meagre role of advisor. ${ }^{36}$

These last-minute revisions made little contribution to an unequivocal reading of the respective mandates of land institutions. They were mainly used to trigger endless disputes over the "real" perimeter of the NLC's mandate, and by extension the Ministry's, and the formulation and enactment of laws defining in detail the functions of the Commission. The NLC Act was enacted in 2012 in conjunction with two other land laws (the Land Act and the Land Registration Act). Although the process of formulating these laws has been described by academic Ambreena Manji (2013) and other stakeholders (including NGOs) as yet another attempt by the political establishment to obstruct the reform process, these laws broadened the NLC's mandate by restoring to it some of the functions of which it had been relieved by the politicians at the Naivasha meeting. ${ }^{37}$ Some confusion nevertheless resulted from the non-repeal of laws dating from the old regime (pre-Constitution 2010) in contradiction with the new legislative provisions. ${ }^{38}$ This laid the foundation for an inter-institutional conflict fought with obstructionism, polemical statements in the press, and above all litigation to tip the scales of interpretation of norms.

Controversies related to these land laws began as soon as they were formulated. The work of the Ministry's consultant to draft the laws (a Kenyan, head of a notorious law firm in Nairobi) was harshly criticised by KLA and its members, who accused the consultant of writing the laws by "copying and pasting" Tanzanian land legislation. In addition, land laws were introduced into Parliament very late, two weeks before the constitutional deadline. The KLA and the surveyors' body, Institution of Surveyors of Kenya, then protested against the lack of public consultation during the formulation of these laws. These organisations then requested

development plan for the area." Committee of Experts on Constitutional Review. 2009. Harmonised Draft Constitution, Published on 17th November: 48.

36. "Art. 83(e) to advise the Government on, and assist in the execution of a comprehensive programme for the registration of title in land throughout Kenya (Committee of Experts on Constitutional Review 2009). We have highlighted the deleted words in the final version of the Constitution."

37. Namely: "Art. 5(2)(b) monitor the registration of all rights and interests in land; (e) manage and administer all unregistered trust land and unregistered community land on behalf of the county government" (Law of Kenya, National Land Commission Act, No. 5 of 2012). Moreover, management of land registries was conferred upon it by Articles 6 and 7 of the Land Registration Act (Law of Kenya, Land Registration Act, No. 3 of 2012).

38. For example, the Adjudication Land Act, according to which the Ministry of Lands is in charge of land registration, which differs from Art. 5(2)(b) and (e) of the NLC Act. 
and obtained a sixty-day deadline extension. Thus, debates about land laws continued within and beyond Parliament, but it seems, without inscribing in the body of laws a legal distinction between the roles and functions of land governance institutions. Indeed, in May 2012, after enactment of the laws, the President of the NLC, university professor Mohamed Swazuri, appointed a taskforce to identify provisions that were contradictory or inconsistent with other laws in order to propose amendments. ${ }^{39}$ Thus, barely enacted, the land laws were already in the process of being amended.

It was only in 2015, two years after the establishment of this taskforce, which was supposed to report on its work within three months, that the Land (Amendment) Act was published by the Ministry of Lands and not by the NLC. It is important to note that the 2013 presidential elections saw the rise of Uhuru Kenyatta, who was elected president of Kenya at the head of a coalition government (Jubilee Coalition) with William K. Ruto, leading to a fundamental transformation of the partisan opposition game. ${ }^{40}$ Unlike in the days of the $\mathrm{NaRC}$, the Jubilee government adopted a decidedly conservative approach to land management, returning to the promotion of individualised land titles as an instrument of "unblocking" economic capital. ${ }^{41}$ The Jubilee administration made the title deed into an ideological foundation, which went hand in hand with business and private enterprise incentives, typical of its neoliberal approach. It is clear that the political environment was no longer conducive to the discussion of NLP's principles of social justice, especially considering that NLP's decolonising intentions may have been detrimental to the private interests of the Kenyatta family, who were beneficiaries of the Mzee-era allocations.

From 2013 to 2016, during the elaboration of amendments to the land laws, relations between the land institutions of the old and new regime further deteriorated. Ellen Bassett (2017) described the successive developments of the tension of these relations. It would seem that as soon as the NLC's eight members were appointed in 2013, the government was reluctant to support the new institution. ${ }^{42}$ Not only did the High Court require the President to

39. Gazette Notice No.7503. 2012. The National Land Commission Act (No. 5 Of 2012) Taskforce to Develop Rules and Regulations under the National Land Commission Act, Dated the 28th May, 2013.

40. The Kalenjin and the Kikuyu became national allies, benefitting from a demographic majority due to ethno-regional alliances that were apparently decisive during elections in Kenya.

41. It is instructive to observe that in 2014-15 and again in 2015-16, the Treasury allocated 2.2 billion and 2.9 billion KES, respectively, to the Ministry of Lands for the issuance of 1 million land titles (HakiJamii 2015). See also Doyle (2016).

42. The government was also in favour of maintaining centralised administrative power within the Ministry, particularly during the enactment of Executive Order 
publish the names of commissioners in the Official Journal (prompted by a complaint filed by a KLA member), but the first budget allocation to the NLC from the Ministry of Lands was well below expectations (241 million KES, compared to 2 billion envisaged by the NLP). ${ }^{43}$

A few months before the establishment of the NLC, differences over the interpretation of the respective powers became public. The minister and the chairman of the NLC both claimed power to register land, issue land titles, and manage the resettlement processes of evicted persons. More specifically, the debate focused on the signing of land titles, symbolising authority in the land sector. ${ }^{44}$

\section{Pro-NLC Mobilisation, but Failure on the Historical Land Injustices Test}

In response to this institutional and political impasse, NGOs, including KLA, aligned with the NLC, creating an opposition front against the Ministry, and thereby the government. The Commission thus renounced its non-political character when it was defended by NGOs and by some representatives of the Council of Governors who joined the anti-old-guard front because of the reluctance of the central government to decentralise powers, as envisaged by the new Constitution. ${ }^{45}$ This is particularly true in the case of the KLA fundraising campaign from a number of donors (including USAID, but also the Ford Foundation and Swedish cooperation) for the benefit of the NLC.

NGOs were also very active in supporting the NLC requesting an advisory opinion from the Supreme Court in April 2014 (Reference No. 2 of 2014) on certain aspects of its mandate: two civil society organisations, Katiba Institute and Haki Jamii, who specialise in legal advice, declared themselves amicus curiae in favour of the NLC. The verdict, issued on December 2, 2015, clarified the roles of the two institutions, and on the thorny issue of the issuance of titles, the Court stated that, although

N.2/2013, when the Kenyan executive gave the Ministry a mandate that rendered the existence of the NLC meaningless.

43. Indeed, the budget allocation to the NLC was the prerogative of the Ministry, but only until 2015-2016, when Haki Jamii, a member of the KLA, registered a $29 \%$ increase over the previous year (with allocations of 896 million KES and 1.153 billion KES, respectively), which remained undersized but increasing (HakiJamii 2015).

44. Mutambo, Aggrey. 2014. "Confusion Mars Land Ownership Transfers." Sunday Nation, 2 February. https://nation.africa/kenya/news/confusion-marsland-ownership-transfers-944944 [archive].

45. For more details on governors' positions, see also Bassett (2014). 
the involvement of the NLC in the preliminary stages of land allocation was not under discussion, the signing and issuing of titles remained the mandate of the Ministry. ${ }^{46}$ The NLC and the Ministry then jointly set up an inter-ministerial commission so that its members could interpret and operationalise the verdict of the Court. It was therefore an interpretation of interpretation, or as the chairman of the NLC sarcastically defined it, the opinion of a "Superior Supreme Court" ${ }^{77}$ - a formulation that denounced the legalistic approach of senior Minister of Lands' officials seeking to dilute the role of the Commission.

If the civil society was convinced that the NLC was going to spearhead change, the positioning of some of these NGOs was recalibrated as of 2015 because the NLC failed the test of historical land injustices (HLI). Due to its constitutional mandate to begin investigations into injustices, the NLC formally announced on May 20,2014, the formation of a taskforce to conduct hearings and public consultations to define the scope of injustices and to propose a law systematically dealing with land grievances. Expectations were high: this working group had awakened the hopes of Kenyans. ${ }^{48}$ Nevertheless, nine months later, when the HLI bill was presented to the public, it was rejected by NGOs, including the KLA. ${ }^{49}$ The taskforce was disappointing, first, because of its composition: two members had been singled out, accused of being "beneficiaries of injustices."50 In addition, the public hearing seemed to have been conducted in a rushed manner, sometimes reduced to a brief visit to the counties, where participants sometimes lamented that they had not received any preparation regarding the questionnaires distributed during the hearings, ${ }^{51}$ on which the bill should have been based. The drafting of the bill was eventually entrusted

46. Musa, Kurian. 2015. "Supreme Court: The National Land Commission Has no Mandate to Issue Land Title Deeds.” The Standard, 2 December. https://www. standardmedia.co.ke/nairobi/article/2000184276/supreme-court-national-landcommission-has-no-mandate-to-issue-land-title-deeds [archive].

47. Interview with Mohamed Swazuri conducted on April 4, 2016.

48. Burrows, Olive. 2014. "Historical Land Injustices to Be Resolved 'Once and for All.” Capital News, 1 September. https://www.capitalfm.co.ke/news/2014/09/ historical-land-injustices-to-be-resolved-once-and-for-all/ [archive].

49. "Draft Bill Proposes Tribunal to Address Historical Injustices." 2015. Daily Nation, 6 February. https://nation.africa/news/politics/Land-Injustices-BillNational-Land-Commission-Parliament/1064-2615680-format-xhtml-hkguhkz/ index.html [archive].

50. Ibid.

51. "Taskforce on Historical Land Injustices in Marsabit." 2014. Marsabit Times, 16 October. https://marsabitimes.com/task-force-on-historical-land-injustice-inmarsabit/ [archive]. 
to a consultant who did so without taking into account the public hearings report, only compiled a posteriori because of the criticism. Moreover, the bill merely established an ad hoc tribunal expected to tackle the cases of historical injustices. This amounted to relieving the NLC of its constitutional mandate by delegating it to another entity whose establishment would have called into question the relevance of the NLC.

Because of all these criticisms, the bill was shelved. To fulfil the constitutional mandate of the NLC, a shortcut was to be found: as part of the amendments to the 2016 land laws, the NLC was conferred the power to investigate and deal directly, on a case-by-case basis, with the complaints and historical grievances, without however a comprehensive legal framework to which refer to. All the amendments to the 2012 land laws were enacted on August 4, 2016. Ultimately, the NLC found itself deprived of its decentralised bodies, while the most strategic functions were attributed to the Ministry, such as the management of all land transactions as well as the registration of so-called community lands. ${ }^{52}$

\section{Conclusion}

The reform of the land system would not have been put on the Kenyan agenda in the early 2000s if different dynamics, both domestic and international, had not converged fortuitously at the very moment when policy entrepreneurs (Kingdon 1984), operating within the framework of transnational networks, were able to seize the "window of opportunity" that was offered to them. The analysis of these accidentally-convergent dynamics helps to unlock the black box of decision-making to comprehend institutional change as itinerant, contradictory, and decidedly hybrid.

The case of the Kenyan land reform highlights the fact that the "window of opportunity" is contingent and does not last long, as shown by the political vicissitudes in 2005 and 2007, as well as the successive changes made to the texts of the land reform. Secondly, the political economy of the decisionmaking process revealed the multi-scale power dynamics in which the decision-making machine is embedded, in Kenya as elsewhere. The legalinstitutional processes of policy-making have been put into perspective with political contingencies to show their intertwining: partisan power struggles, the weight of personalities, and individual interests participated in the negotiation of norms and of the political-legal status of the actors of the reform process.

52. For an empirical discussion of the reform of land tenure categories, namely the attempts to instigate a paradigm shift, moving from the land trust model introduced at the time of colonisation to the recognition of a "community" legal personality, see Di Matteo (2017). 
Policy and politics are very closely linked, as the process of developing land reform in Kenya has been the source of intense political activity resulting in alliances, ruptures, and many re-compositions. This case study challenges a conceptualisation of the decision-making process as eminently technocratic, depoliticised or extroverted, especially in an African country under aid-regime. The stalling of contemporary land reform in Kenya must be understood in a historical perspective so to account for the multidimensional politicisation processes of issues, procedures, and actors themselves. The in-depth analysis of the multiple processes and power struggles leads to relativise the concept of "resistance" and to consider the complexity of the "land question" from its historicity and its entrenchment in the power dynamics structuring the Kenyan state and polity. If, on the one hand, it appears that political and land institutions are strongly defined by habitus and neo-patrimonial practices, we can see, on the other hand, that the institutionalisation of change and democratic practices is not a clearly linear process, which is reflected in particular in the reluctance of some NLC commissioners to confront the spectres of corruption and historic land grievances.

This chapter has benefited from the advice of many researchers whom I would like to acknowledge: Claire Médard, who reviewed and commented on several versions of this article, as well as Philippe Lavigne Delville, Catherine Boone and the editors of this book, notably Marie-Emmanuelle Pommerolle and Marie-Aude Fouéré, who offered valuable advice. Omissions and inaccuracies are my responsibility.

\section{Bibliography}

Anderson, David M. 2003. "Briefing: Kenya's Elections 2002: The Dawning of a New Era?” African Affairs 102, no. 407: 331-42. https://doi.org/10.1093/afraf/adg007.

Bach, Daniel, and Mamoudou Gazibo. 2012. Neopatrimonialism in Africa and Beyond. London \& New York: Routledge.

Bassett Ellen M. 2017. "The Challenge of Reforming Land Governance in Kenya the 2010 Constitution." The Journal of Modern African Studies 55, no. 4: 537-66. https://doi.org/10.1017/S0022278X17000441.

Berman Bruce, and John Lonsdale. 1992. Unhappy Valley: Conflict in Kenya \& Africa, London: James Currey.

Boone, Catherine. 2012. "Land Conflict and Distributive Politics in Kenya." African Studies Review 55, no. 1: 75-103.

https://doi.org/10.1353/arw.2012.0010.

Boone, Catherine. 2014. Property and Political Order in Africa: Land Rights and the Structure of Politics. New York: Cambridge University Press.

https://doi.org/10.1017/CBO9781139629256. 
Boone, Catherine, Alex Dyzenhaus, Seth Ouma, et al. 2019. "Land Law Reform in Kenya: Devolution, Veto Players and the Limits of an Institutional Fix." African Affairs 118, no. 471: 215-37. https://doi.org/10.1093/afraf/ady053.

Bourmaud, Daniel. 1988. Histoire politique du Kenya : État et pouvoir local. Paris: Karthala.

Bradshaw, York W. 1990. "Perpetuating Underdevelopment in Kenya: The Link between Agriculture, Class, and State." African Studies Review 33, no. 1: 1-28. https://doi.org/10.2307/524625.

Branch, Daniel, and Nick Cheeseman. 2008. "Democratization, Sequencing, and State Failure in Africa: Lessons from Kenya." African Affairs 108, no. 43: 1-26. https://doi.org/10.1093/afraf/adn065.

Committee of Experts on Constitutional Review. 2009. Harmonised Draft Constitution, 17 November.

Constitution of Kenya Review Commission. 2002. "The People's Choice. The Report of the Constitution of Kenya Review Commission. Short Version." Nairobi: Constitution of Kenya Review Commission.

Cooper, Frederick. 1980. From Slaves to Squatters: Plantation Labor and Agriculture in Zanzibar and Coastal Kenya, 1890-1925. New Haven: Yale University Press.

De Soto, Hernando. 2000. The Mystery of Capital: Why Capitalism Triumphs in the West and Fails Everywhere Else. New York: Basic Books.

Di Matteo, Francesca. 2017. "Community Land in Kenya: Policy-making, Social Mobilization, and Struggle over Land Entitlement.” LSE Working Paper, 17-185 [archive].

Doyle, Kevin. 2016. "Customary Land Rights in Kenya in the Context of History: From Colonial through Independence, from Jomo Kenyatta to Uhuru Kenyatta.” In Breaking the Mould. Lessons from Implementing Community Land Rights in Kenya, edited by Collins Odote and Patricia Kameri-Mbote. Nairobi: Strathmore University Press.

Harbeson, John Willis. 1973. Nation-Building in Kenya: The Role of Land Reform, Evanston: Northwestern University Press.

Haugerud, Angelique. 1997. The Culture of Politics in Modern Kenya. New York: Cambridge University Press.

Holmquist, Frank W., Frederick S. Weaver, and Michael D. Ford. 1994. "The Structural Development of Kenya's Political Economy." African Studies Review 37, no. 1: 69-106. https://doi.org/10.2307/525114.

Hughes, Lotte. 2006. Moving the Maasai: A Colonial Misadventure. Basingstoke: Palgrave Macmillan.

Human Rights Watch. 2008. "Ballots to Bullets: Organized Political Violence and Kenya's Crisis of Governance," March. https://www.hrw.org/ report/2008/03/16/ballots-bullets/organized-political-violence-and-kenyascrisis-governance [archive].

Kameri-Mbote Patricia, and Kithure Kindiki. 2008. “Trouble in Eden: How and Why Unresolved Land Issues Landed 'Peaceful Kenya' in Trouble in 2008?” Forum for Development Studies 35, no. 2: 167-93.

https://doi.org/10.1080/08039410.2008.9666408. 
Kanogo, Tabitha. 1987. Squatters and the Roots of Mau Mau, 1905-63. Nairobi: East African Publishers.

Kantai, Parselelo. 2007. "In the Grip of the Vampire State: Maasai Land Struggles in Kenyan Politics.” Journal of Eastern African Studies 1, no. 1: 107-22. https://doi.org/10.1080/17531050701218890.

Karuti, Kanyinga. 2013. "Contradictions of Neoliberalism: Donors, Human Rights NGOs, and Governance in Kenya." In Human Rights NGOs in East Africa: Political and Normative Tensions, edited by Makau Mutua. Philadelphia: University of Pennsylvania Press.

Kingdon, John W. 1984. Agendas, Alternatives, and Public Policies. Boston: Little Brown.

Klopp, Jaqueline. 2001. "Electoral Despotism in Kenya: Land Patronage and Resistance in the Multi-Party Context." PhD Dissertation. Montreal: McGill University. https://escholarship.mcgill.ca/concern/theses/q524jq43q.

Klopp, Jacqueline M., and Odenda Lumumba. 2017. "Reform and CounterReform in Kenya's Land Governance." Review of African Political Economy 14, no. 44: 577-94. https://doi.org/10.1080/03056244.2017.1367919.

Law of Kenya. 2012. Land Registration Act, no. 3.

Law of Kenya. 2012. National Land Commission Act, no. 5.

Leo, Christopher. 1984. Land and Class in Kenya. Buffalo: University of Toronto Press.

Leys, Colin. 1975. Underdevelopment in Kenya: The Political Economy of NeoColonialism, 1964-1971. Berkeley and Los Angeles: University of California Press.

Lynch, Gabrielle. 2011. I Say to You: Ethnic Politics and the Kalenjin in Kenya, Chicago and London: University of Chicago Press.

Maingi, Grace. 2011. "The Kenyan Constitutional Reform Process: A Case Study on the Work of FIDA in Securing Women's Rights.” Feminist Africa 15 (Special Issue). http://www.agi.ac.za/sites/default/files/image tool/ images/429/feminist africa journals/archive/15/fa 15 case study grace maingi.pdf [archive].

Manji, Ambreena. 2013. The Politics of Land Reform in Africa: From Communal Tenure to Free Markets. London: Zed Books.

Manji, Ambreena. 2014. "The Politics of Land Reform in Kenya 2012." African Studies Review 57, no. 1: 115-30. https://doi.org/10.1017/asr.2014.8.

McAuslan, Patrick. 2013. Land Law Reform in Eastern Africa. Traditional or Transformative?London: Routledge. https://doi.org/10.4324/9780203491867.

Médard, Claire. 1999. "Territoires de l'ethnicité : encadrement, revendications et conflits territoriaux au Kenya." PhD Dissertation. Paris: Université de Paris 1. https://halshs.archives-ouvertes.fr/tel-01265014.

Médard, Jean-François. 1992. “Le 'big man' en Afrique : analyse du politicien entrepreneur." Année sociologique 42: 167-92. https://www.jstor.org/stable/27890139.

Mosse, David and Lewis David. 2005. The Aid Effect: Giving and Governing in International Development. London: Pluto Press. 
Moyo, Sam. 2008. African Land Questions, Agrarian Transitions and the State: Contradictions of Neo-Liberal Land Reforms. Dakar: CODESRIA.

Mungai, Wandaka Lewis, Eric Kanyi, Odindo Opiata. 2015. Citizen Participation in the Budget Process. Towards Linking the Budget Process to Specific Needs of the People. Nairobi: Economic and Social Rights Centre (Hakijamii) [archive].

Murunga, Godwin R., and Shadrack W. Nasong'o. 2007. Kenya: The Struggle for Democracy. New York and London: Zed Books.

Mutua, Makau. 2013. Human Rights NGOs in East Africa: Political and Normative Tensions. Philadelphia: University of Pennsylvania Press.

Mutunga, Willy. 1999. Constitution-Making from the Middle: Civil Society and Transition Politics in Kenya, 1992-1997. Nairobi \& Harare: Sareat and MWENGO.

Nyong'o, Anyang'. 1989. "State and Society in Kenya: The Disintegration of the Nationalist Coalitions and the Rise of Presidential Authoritarianism 1963-78." African Affairs 88, no. 351: 229-51. https://doi.org/10.1093/oxfordjournals.afraf.a098162.

Oba, Gufu. 1992. "Ecological Factors in Land Use Conflicts, Land Administration and Food Insecurity in Turkana, Kenya." Overseas Development Institute. https://www.odi.org/sites/odi.org.uk/files/odi-assets/publications-opinionfiles/5389.pdf [archive].

Okoth-Ogendo, Hastings Wiston. 1991. Tenants of the Crown: Evolution of Agrarian Law and Institutions in Kenya. Nairobi: African Centre for Technology Studies Press.

Okoth-Ogendo, Hastings Wiston. 2007. "The Last Colonial Question: An Essay in the Pathology of Land Administration Systems in Africa." Présentation au Workshop on Norwegian Land Tools Relevant to Africa. Oslo, 3-4 May. Oucho, John O. 2002. Undercurrents of Ethnic Conflicts in Kenya. Leiden: Brill. Péron, Xavier. 1995. L'occidentalisation des Maasaï du Kenya : Privatisation foncière et déstructuration sociale chez les Maasaï du Kenya. Tome I. Paris: L'Harmattan.

Pommerolle, Marie-Emmanuelle. 2005. "À quoi servent les droits de l'homme? Action collective et changement politique au Cameroun et au Kenya.” PhD Dissertation: Pessac: Institut d'études politiques de Bordeaux.

Republic of Kenya. 2002. Report of the Commission of Inquiry into the Land Law System of Kenya on Principles of a National Land Policy Framework, Constitutional Position of Land and New Institutional Framework for Land Administration. Nairobi: Government Printer.

Republic of Kenya. 2004. Report of the Commission of Inquiry into the Illegal/ Irregular Allocation of Public Land. Nairobi: Government Printer.

Republic of Kenya, Ministry of Lands. 2009. Sessional Paper No. 3 of 2009 on National Land Policy. Nairobi: Government Printer.

Republic of Kenya. 2013. Gazette Notice No. 7503. "The National Land Commission Act (No. 5 Of 2012) Taskforce to Develop Rules and Regulations under the National Land Commission Act," 28 May. http://www. landcommission.go.ke/media/erp/upload/nationallandcommission5of2012. pdf [archive]. 
Schlee, Günther. 1989. Identities on the Move: Clanship and Pastoralism in Northern Kenya. Manchester: Manchester University Press.

Sorrenson, M.P.K. 1968. Origins of European Settlement in Kenya. New York: Oxford University Press.

Toulmin, Camilla, and Julian Quan (eds). 2000. Evolving Land Rights, Policy, and Tenure in Africa. London: DFID/IIED/NRI.

Truth, Justice and Reconciliation Commission [TJRC]. 2013. Report of the Truth, Fustice and Reconciliation Commission I. Nairobi: Government Printer.

Truth, Justice and Reconciliation Commission [TJRC]. 2013. Report of the Truth, Justice and Reconciliation Commission IIB. Nairobi: Government Printer.

USAID. 2009 (2008). Kenya Land Policy: Analysis and Recommendations.

Willis, Justin. 1993. Mombasa, the Swahili, and the Making of the Mijikenda. Oxford: Clarendon Press.

Wrong, Michela. 2010. It's Our Turn to Eat: The Story of a Kenyan Whistle Blower. London: Harper Collins UK.

\section{Media}

Burrows, Olive. 2014. "Historical Land Injustices to Be Resolved 'Once and for All."' Capital News, 1 September. https://www.capitalfm.co.ke/ news/2014/09/historical-land-injustices-to-be-resolved-once-and-for-all/ [archive].

"Draft Bill Proposes Tribunal to Address Historical Injustices." 2015. Daily Nation, 6 February. https://nation.africa/news/politics/Land-InjusticesBill-National-Land-Commission-Parliament/1064-2615680-format-xhtmlhkguhkz/index.html [archive].

Musa, Kurian. 2015. "Supreme Court: The National Land Commission Has no Mandate to Issue Land Title Deeds.” The Standard, 2 December. https://www. standardmedia.co.ke/nairobi/article/2000184276/supreme-court-nationalland-commission-has-no-mandate-to-issue-land-title-deeds [archive].

Mutambo, Aggrey. 2014. "Confusion Mars Land Ownership Transfers." Sunday Nation, 2 February. https://nation.africa/kenya/news/confusion-mars-landownership-transfers-944944 [archive].

"Taskforce on Historical Land Injustices in Marsabit." 2014. Marsabit Times, 16 October.

https://marsabitimes.com/task-force-on-historical-land-injustice-inmarsabit/ [archive]. 
Chapter 7

\title{
Natural Resources Management in Kenya (Water and Forest) Centralised Policies, Between Exclusion and Participation of the Local Population
}

\author{
Gaële Rouillé-Kielo
}

Translated by Gordana Petrovska Dojchinovska \& Alex Lyons

\section{Introduction}

In the eyes of the world, and especially in the West, Kenya is largely associated with its vast savannah landscape and its exceptional, but endangered fauna. The country also regularly attracts the attention of the international media because of extreme weather events, such as the particularly long and intense drought of 2017. In a country already exposed to significant water stress, ${ }^{1}$ the effects of global warming raise concerns about the potential enhanced frequency and intensity of such events. On the regional and international stage, Kenya occupies a special place in the field of environment protection. Its capital city, Nairobi, is the seat of several regional and international organisations, which are highly influential in the field, such as the United Nations Environment Program (UNEP), established there in 1972.

From the twentieth century, the protection of natural resources in Kenya has been predominantly characterised by the creation of protected areas subjected to more or less strict protection measures, depending on their status. Today, these protected areas cover $12.7 \%$ of the total area of the country. ${ }^{2}$ However, the presence of economic activities and infrastructures

1. As per the Falkenmark indicator (1989), a country is considered to be experiencing "water stress" when the amount of available water is less than 1,000 cubic metres per person per year. In 2009, the available water per person per year in Kenya was estimated at 647 cubic metres (RoK, WRMA, 2009). However, this number is constantly evolving, depending on demographic changes, as well as the changes of known available water and water reserves. The discovery of two giant aquifers in the county of Turkana in 2013 largely modified the estimation of the global volume of water resources that may potentially be mobilised on the national territory.

2. Kenya has 348 protected areas, covering a surface of $75237 \mathrm{~km}^{2}$ (KWTA 2016, 11). Around $8 \%$ of the country's surface area is covered by reserves and national 
in the vicinity of, or even sometimes inside national parks, ${ }^{3}$ regularly sparks tensions between, on one side, the proponents of strict conservation measures and, on the other, those who support a more flexible approach of natural resources use to enable the economic development of the country.

In a chapter of the last edition of Contemporary Kenya (1998), entitled "Conservation of natural resources. From exclusion to community involvement," Jean-Luc Ville presented the evolution of the methods used for the protection of natural resources and pointed to the beginnings of participation of the local populations. In the 1990s indeed, several initiatives supported by the Kenya Wildlife Service (KWS) emerged in order to allow communities living nearby national parks to participate in the development of eco-tourism (Nelson \& Agrawal 2008).

The new mantra for "integrated management" of natural resources promoted for several decades on the international scene, which notably encourages involvement of the resource users, has found some favourable echo in Kenya like in many other countries worldwide. The prevailing "integration paradigm" on the international scale along decision-makers and actors of the environment sphere (especially after the publication of the World Conservation Strategy in 1982 by IUCN, UNEP and WWF) corresponds to a "broadening of the objectives for environmental protection towards considerations that are not ecological but more broadly social" (Depraz 2008, 1094). The management models that draw inspiration from this vision encourage participation of local population in conservation projects and favour the delegation of some central government prerogatives to local stakeholders so that decision-making is performed through a bottom-up approach (Rodary \& Castellanet 2003). This different approach does not only concern large environmental organisations, but also inspires changes in the national legislative frameworks of countries-Kenya being one of them.

On the national level, the issue of encouraging stronger involvement of populations in natural resources management was also subject to increasing politicisation in the 1990s as state monopolistic control was being challenged by Kenyan "civil society." This context also served as a background to the reforms implemented in the 2000s, which were characterised by the willingness to delegate to lower governing levels some prerogatives of the central government with regards to natural resources management.

parks run by the Kenya Wildlife Service.

3. We can point out as an example the Olkaria geothermal station inside the Hell's Gate park in Naivasha, or the new Standard Gauge Railway (SGR) fast rail line, linking Mombasa to Nairobi and passing through Nairobi's National Park.

4. Translations from French are made by the author. 
In order to explore the new orientations in environmental policies in Kenya from the beginning of the 2000s, this chapter will look into the cases of forest and water resources in particular. These are regularly portrayed as endangered resources due to various pressures linked to demographic growth and hunger for land, as well as to inadequate governance. It will mainly rely on a literature review relating to these questions, as well as on empirical data, which were primarily collected in the region of Naivasha ${ }^{5}$ and to which reference will occasionally be made. Some information is also drawn from interviews with members of associations and staff members of public institutions. After presenting the evolution of the water and forest resources protection issue, which is strongly linked to political issues, we will question the effects of the reforms in the management policies of these natural resources, and in particular the introduction of water and forest users' associations.

\section{New Political and Ecological Concerns in the Protection of Kenya's Forests}

The forest areas classified as "reserves" are primarily located in the Kenyan highlands, at the heart of the "agriculturally useful Kenya" (Raison 1994), i.e. the area located "between 1,500 and 2,500 metres of altitude [which forms] an ecologically optimal setting for human settlement" (Calas 1998, 17, translated by the author). The forest reserves are therefore in direct proximity to the more densely populated areas of the country since they are among the most watered and fertile areas. These forests, primarily composed of endemic tree species, are qualified as indigenous forests ${ }^{6}$ (Wass 1995). The usage of resources there is limited to dead wood collection and livestock grazing. Cutting down trees and cultivation are completely prohibited. The management of these areas has become a major ecological and political challenge for Kenya over the last decade, especially after the implementation of the "rehabilitation" programmes for highland forests, often referred to as "water towers." These programmes are part of the national effort to increase tree cover nationwide.

\section{Putting into Question the Control of the Central Government over the Forests}

After the colonial era, many forest reserves were degazetted in order to authorise the settlement of private individuals or public institutions

5. 10 months of fieldwork between March 2014 and December 2016.

6. Defined by the authorities as "a forest which has come about by natural regeneration of trees primarily native to Kenya, and includes mangrove and bamboo forests" (RoK 2005). 
(schools, hospitals, etc.). Degazettement was done by central governments that took office successively (Boone 2012), but was particularly prevalent under Daniel arap Moi's mandate (1978-2002). The publication of the Report of the Commission of the Inquiry into the Illegal/Irregular Allocation of Public Land, better known under the name of "The Ndung'u Report" (in reference to the name of its lead author) in 2004, allowed for the magnitude of this phenomena and the direct implication of the ruling class and the central administration to be uncovered (Southall 2005). While the national parks were spared, the forest reserves were subjected to high levels of misappropriation. The report also revealed that the classified forest areas covered only $1.7 \%$ of the national territory at the time of the study, compared to $3 \%$ in the aftermath of independence. The illegal allocation of forest reserves was especially intense during the 1990s, under Moi, when a period of political liberalisation was beginning (Klopp 2012). The interventionist and predatory attitude of the central government in matters relating to natural resources management is considered to have led to the uncontrolled and unreasonable exploitation of the public forest areas (Constantin 2000; Kariuki 2006; 2007). The denunciation of these irregularities by civil society movements and some influential public figures (such as Wangari Maathai), became a major reason for political mobilisation during the 1990s. Greater transparency was being claimed in the management of these forests, which were increasingly considered as an integral part of the national natural heritage.

\section{A New Environmental Challenge: \\ The "Rehabilitation" of Kenya's Water Towers}

Since the end of the 1990s, the degradation of forest areas has been highlighted in several reports. Rehabilitating ${ }^{7}$ them has been part of the main national projects adopted in the field of environment protection for several years now. ${ }^{8}$ The measures taken to evict people settled in these forests gave this environmental issue a strong political dimension.

For over a decade, the main mountain forests in Kenya have commonly been qualified as "water towers" and presented by the authorities as "the fountains of life and lungs of the country" (KWTA 2015, 1). Eighteen forests were gazetted in 2012 and now bear this status (map 1). It is expected

7. This terminology seems to indicate that the protection activities undertaken in these areas reference a previous state (Rouillé-Kielo 2020). However, neither the documents on the subject, nor the responses obtained during the interviews specify any specific timeframe of reference.

8. For example, the Kenyatta government declassified around 6,100 hectares of forest reserves in the Aberdare Mountains in 1970 by (UNEP, KWS, Rhino Ark \& KFWG 2003). 


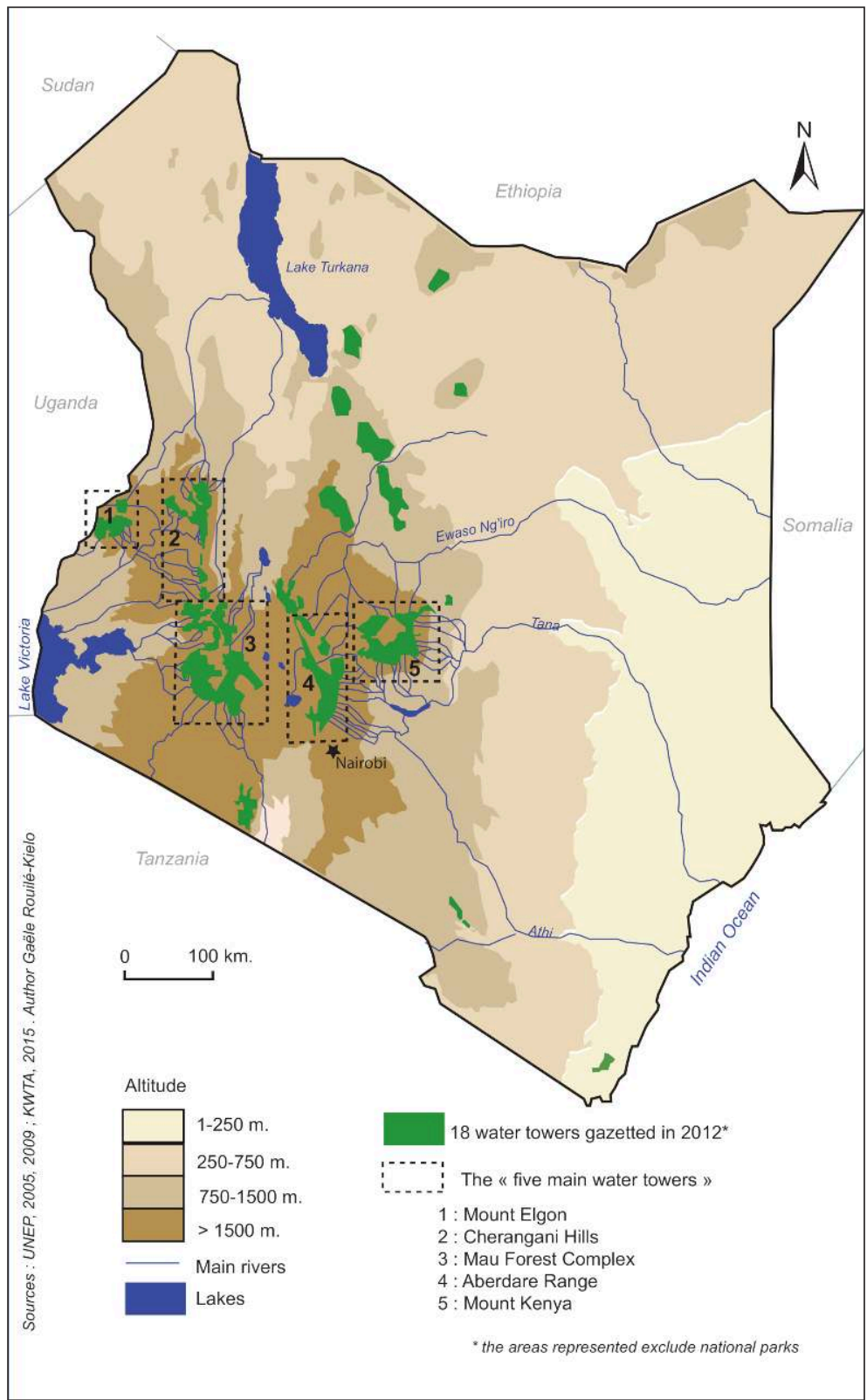

Map 1. The main Kenya's water towers

Source: UNEP (2005; 2009); KWTA (2015). Author: Gaële Rouillé-Kielo.

that the same will be done for seventy others in the near future. Mount Kenya, the Aberdare Range, the Mau forest Complex, Mount Elgon and the Cherangani Hills are considered to be the five main water towers of the country. These "Water Mountains" [montagnes d'eau] (Bart 2006) are 
presented by the authorities and by UNEP as providing considerable support to the economy for water supply in the agricultural, industry and energy sectors ( $70 \%$ of which is of hydraulic origin). The economic losses related to their deforestation are estimated to be around 6 billion KES per year, i.e. over 50 million EUR (UNEP 2012). Moreover, these forests are described as reserves for biodiversity. For several years now, with the development of the policies for combatting global warming, they are also described as "carbon sinks" because they absorb and sequester CO2 (UNEP 2009).

Works led by UNEP then in association with other stakeholders such as the Kenya Forest Working Group (KFWG) have relied on the diachronic analysis of aerial or satellite images for analysing the evolution of the forest cover and measuring the type and scope of the human activities that have posed a threat since the end of the 1990s9 (UNEP 1999; UNEP KWS, Rhino Ark \& KFWG 2003; KFWG 2004; 2006). Despite the (acknowledged) lack of precision of some of the data gathered, the authors of the most recent report concluded that the Mau forest Complex (considered to be the largest water tower in the country in terms of surface area and because of the number of rivers originating from it) was far from being the most endangered forested area nationwide; they consequently urge the authorities to take immediate action (KFWG 2006). In 2008, the office of the Acting Prime Minister (Raila Odinga) appointed a working group comprised of several national institutions (the KFS, the KWS, the Water Resource Management Authority and the relevant ministerial offices) to address the question. Their report, published the next year, reveals that 107,000 hectares were cleared in fifteen years, which represents $25 \%$ of the total surface area of the forest complex. The "rehabilitation" of the Mau Forest entailed the eviction of the people living in the forest blocks, a measure for which accusations were made that it primarily targeted groups already marginalised (in particular, the Ogiek people). The "Mau question" represents a fundamental step in the agenda setting of the protection of water towers-made a a national issueas well as of the protection of water towers. The decision of evicting forest residents seems to prefigure the modus operandi endorsed in other areas.

In April 2012, the creation of a new institution, the Kenya Water Towers Agency (KWTA), in order to supervise the conservation measures taken for preserving these areas reflects the importance attached to the issue of "rehabilitating" Kenyan water towers. One of its official objectives is for Kenya to no longer be considered as a country suffering from water stress, despite its strong demographic growth. ${ }^{10}$ Following the failure of the

9. Such as coal production, marijuana growing, and exploitation of timber.

10. By counting on the increase of the forest cover over the water towers and its beneficial effects on the rainfall and water flow regulation. See Bernard Calas' chapter in this book for more information on demographic trends in Kenya. 
project to merge different parastatal agencies responsible for environmental management in Kenya (presented in image 1), ${ }^{11}$ the delimitation of KWTA's areas of jurisdiction and prerogatives may compete with the mandates of the Kenya Forest Service (KFS) and the Kenya Wildlife Service (KWS). In fact, these two agencies are among the oldest and the most powerful in the country and may not be so keen on sharing the management of the areas for which they have traditionally been in charge.

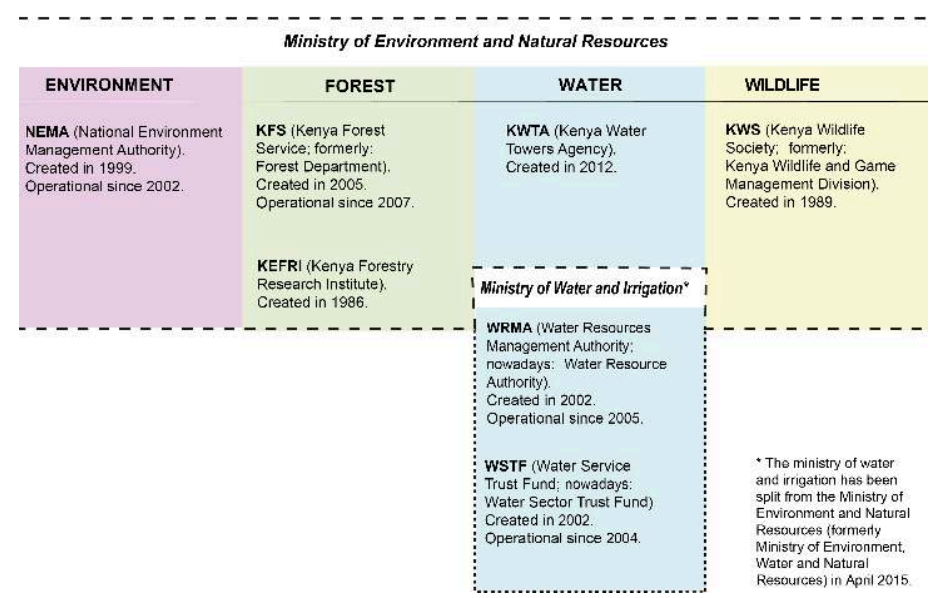

Image 1. Parastatal agencies involved in environmental management and their respective responsible ministries in Kenya

Source: Websites of Kenyan ministries and parastatal agencies.

Author: Gaële Rouillé-Kielo.

The measures supported by the public authorities for the protection of water towers in Kenya have led to greater restrictions on the use of these areas. In this sense, two main types of actions have been carried out. The first, highly controversial, has been based on operations to evict populations living in certain forest reserves. These operations have mainly taken place in the Mau forest complex and in the Cherangani Hills over the past few years ${ }^{12}$ and until very recently, and have involved several tens of thousands

11. The Kenya Forestry and Wildlife Service is supposed to bring together the KWS, KFS, KWTA and the Nyayo Tea Zone. Donors, in particular those supporting the KWS, were strongly opposed to the reform, the goal of which was to create budgetary savings. See in particular Ndii, David. 2015. "Why Uhuru's Parastatal Reform Was Doomed to Fail." Daily Nation, 8 May. https://nation. africa/kenya/blogs-opinion/opinion/why-uhuru-s-parastatal-reform-wasdoomed-to-fail-1092180 [archive]; Kemei, Kipchumba. 2014. "KWS-KFS Merger Opposed, Says CS." The Standard, 5 April. https://www.standardmedia.co.ke/ kenya/article/2000108630/kws-kfs-merger-opposed-says-cs [archive]).

12. Vidal, John. 2014. "Kenyan Families Flee Embobut Forest to Avoid Forced Evictions by Police." The Guardian, 7 January. https://www.theguardian.com/ 
of people. ${ }^{13}$ On several occasions, international human rights NGOs denounced the operations carried out in the Mau and the Embobut forest in the Cherangani Hills (Amnesty International 2018). After the death of a high-profile Sengwer leader ${ }^{14}$ the European Union, which had endowed the Cherangani Hills rehabilitation programme with 31 million EUR, decided to suspend its aid in April 2018. ${ }^{15}$

The erection of electric fences around forest reserves is another type of measure developed in recent years for the protection of water towers. After the construction of a 400-kilometre fence around the Aberdare Mountains, which took place from the late 1980s to 2009, the Rhino Ark organisation was entrusted with the construction of the fence around the Eburru Forest, which is part of the Mau Forest Complex (2012-2014), and the Mount Kenya Forest Reserves (since 2012). This non-governmental organisation, which for a long time focused on the protection of black rhinos and on a single

global-development/2014/jan/07/kenya-embobut-forest-forced-evictions-police [archive]; Kitelo, Peter. 2016. "Does Burning Homes Save the Water Towers? Quite the Opposite." The Star, 12 July. Published in Katiba Institute: http:// katibainstitute.org/does-burning-homes-save-the-water-towers-quite-theopposite/ [archive].

13. In autumn 2019, the authorities announced plans to evict around 60,000 people from land within the forest reserve north of Narok (Sayagie, George. 2019. "60,000 Families Targeted in Second Mau Forest Eviction." Daily Nation, 2 September. https://nation.africa/kenya/counties/narok/60-000-familiestargeted-in-second-mau-forest-eviction-199852 [archive]). According to Human Rights Watch, 50,000 people have been driven out of the Mau Forest since 2018, and nine people have been killed during the operations ("Kenya: Mau Forest Evictees' Plight Intensifies.” 2020. Human Rights Watch, 23 July. https://www.hrw. org/news/2020/07/23/kenya-mau-forest-evictees-plight-intensifies [archive]). See also the following press articles: Mwale, Anne. 2019. "Looming Mau Phase Two Evictions Elicit Mixed Reactions." Kenya News Agency, 6 September. https://www. kenyanews.go.ke/looming-mau-phase-two-evictions-elicit-mixed-reactions/ [archive]; "Mau Evictions Should Be Done Humanely." 2019. The Standard, 7 October. https://www.standardmedia.co.ke/editorial/article/2001344617/mauevictions-should-be-done-humanely [archive].

14. Robert Kirotich, considered to be one of the last representatives of a huntergatherer community, the Sengwer, was reportedly killed during an eviction order by agents of the Kenya Forest Service (Watts, Jonathan. 2018. "Kenya Forest Death: Activities Blame EU for Ignoring Human Rights Warnings." The Guardian, 19 January. https://www.theguardian.com/environment/2018/jan/19/ kenya-forest-death-activists-blame-eu-for-ignoring-human-rights-warnings [archive]).

15. See on the European Parliament's website the text referring to the question E-000557/2018 dated 19 April 2018 (https://www.europarl.europa.eu/doceo/ document/E-8-2018-000557 EN.html [archive]). 
geographical area-the Aberdares ${ }^{16}$-has gradually integrated other issues such as the protection of water towers as part of the expansion of its area of action. ${ }^{17}$ While the activities of this organisation were for a long time financed exclusively through fundraising by individuals and companies within the framework of the Rhino Charge, ${ }^{18}$ it has been receiving public funds since 2012 within the framework of the implementation of a public-private partnership. ${ }^{19}$ This has doubled the organisation's budget, which exceeded 2 million USD in 2012 when the construction of fences was launched around Mount Eburru (43 kilometres), one of the blocks of the Mau forest complex, and Mount Kenya (450 kilometres of fences, still in progress). The electric fences are either in contact with the KFS forest plantation areas or directly with the cultivation and housing areas. Although they can still be crossed by local residents, who are allowed to collect firewood or graze their livestock, they are only accessible through gates 3 to 4 kilometres apart, which is a constraint for the population.

\section{An Ambitious National Objective: Reaching over 10\% Tree Cover}

The protection of Kenyan water towers is part of a new national effort to increase the country's tree cover. The Vision 2030 national development plan and the Constitution of 2010 set as an objective to attain and maintain a minimum of $10 \%$ tree cover on the national territory, thus following the international recommendation of the United Nations on the horizon of 2030. However, official Kenyan texts do not specify what is understood by the expression "tree cover." ${ }^{20}$ Recently, a 2022 deadline was mentioned in a governmental document providing details about the national strategy to fulfil this objective (RoK 2019).

16. In their typology of environmental organisations active in sub-Saharan Africa, Brockington and Scholfield (2010) classified this organisation as falling into two common categories: "Charismatic animal-orientated NGOs" and "Single protected area NGOs."

17. This is reflected in the activity reports of the Rhino Ark ("Arkives") published every two years, which can be consulted on the organisation's website (http://rhinoark.org/).

18. It is a competition between $4 \times 4$ vehicles in steep areas. It brings in about 100 million KES per year (about 1 million USD).

19. Interview, 2 December 2016, Rhino Ark Manager, Nyeri.

20. Most of the reports and articles refer to the forest cover surface area, even if its definition differs from one organisation to another. According to the FAO, whose data we use, a "forest" is a "land spanning more than 0,5 hectares with trees higher than 5 metres and a canopy cover of more than 10 percent (...)" (FAO 2012). 


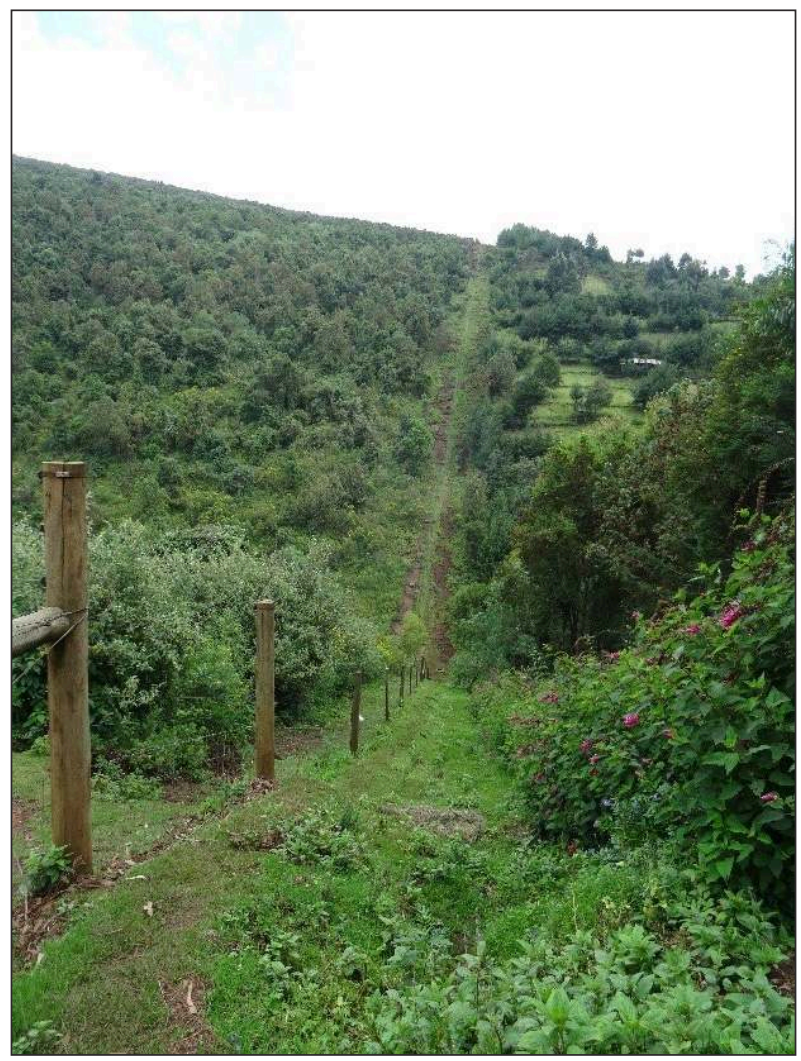

Photo 1. The electric enclosure located east from Mount Kipiriri This section was completed in 2009, finalising the encirclement project of the Aberdare Range. The fences stretch along the forest reserves and allow the migration of the elephants between Mount Kipiriri and the Aberdare Range along a $4 \mathrm{~km}$ corridor. The fence delimits the forest from the agricultural area, in this case the settlement scheme of Mikaro created on former forest reserves in 1969.

Photo credits: Gaële Rouillé-Kielo, 23 January 2016.

The afforestation measures (i.e. the planting of trees on non-forested areas) in the country can build on a dense and old network of tree nurseries, managed by individuals, community groups and associations. This willingness to increase the tree cover in Kenya has been encouraged for several decades now, especially by the Green Belt Movement, created in 1977. The tree planting measure was presented by Wangari Maathai's association as a means of combatting the supposed desertification of the country-which was a great political concern in the 1970s-and to improve the living conditions of rural populations (and especially of women) who could find the resources necessary for their domestic conditions directly on their land before, without having to go to the forest (Maathai 2005). 
Today, measures favouring the increase of the country's tree cover are also justified by the issues related to water supply on a national level and the fight against global warming on an international level.

Since the areas classified as "forest reserves" account for only $3.5 \%$ of the total surface area of the country and are mostly forested, the ordinary, non-classified areas, and the private property areas are also important for the goal of increasing tree cover. Farmers are therefore encouraged by the authorities to dedicate $10 \%$ of their land to tree planting. It is notably in this aim that agroforestry is promoted. ${ }^{21}$ In fact, as noted in the region of Naivasha, the national authorities and environmental organisations present in Kenya insist on giving priority to indigenous trees instead of the more exotic fast-growing trees, such as the cypress and especially the eucalyptus, that are nevertheless favoured by many farmers. The reasons behind this are ecological (increasing the local biodiversity), hydrological (local tree species consume less water) and agronomical (enriching the soil) in nature.

In order to encourage the increase of tree cover, including in the productive areas, and prevent its destruction in other areas, for several years now projects of "payment for environmental services" (PES) are being developed in Kenya-a compensation mechanism consisting of monetary or in-kind incentives for the purposes of encouraging the adoption of environmentally-friendly practices. Kenya is one of the first East African countries to have initiated "payments for watershed services" programmes ${ }^{22}$ (Bennett \& Caroll 2014) in the region of Naivasha. This is the only programme of its kind in Kenya that has gone beyond the study phase and in which financial transactions, albeit modest, have taken place so far between the actors involved upstream and downstream (Rouillé et al. 2015; Rouillé-Kielo 2019a). ${ }^{23}$ Several REDD+ projects (Reduced Emissions from Deforestation and Forest Degradation) have also been implemented in the country (Kariuki et al. 2018).

21. Especially by the World Agroforestry Centre (ICRAF), which also has a regional office in Nairobi.

22. Several "payments for watershed services" projects were studied and/or piloted in Kenya over the last fifteen years (around the Sasumua dam, in the Upper-Tana, and in the Upper-Mara).

23. It is worth noting that several "payments for watershed services" projects have been developed in Kenya, mainly in the highlands, to improve water supply to large cities or key sectors of the economy. However, the lack of "buyers" for these watershed services has prevented the achievement of these projects. The Nairobi Water Funds project currently being developed by The Nature Conservancy, if it comes to fruition, could be the first African "Water fund" (there are several in Latin America). 
According to a report published by the FAO in 2015, measures to increase tree cover has already produced positive effects. The surface of the territory covered in forests is constantly increasing: from 3.5 million hectares in 2000 , it reached over 4 million in 2005, and up to 4.2 million in 2010, to finally reach 4.4 million hectares in $2015 .{ }^{24}$ However, this monitoring of the tree cover percentage encountered significant difficulties in its evaluation. At the moment, the forest cover of the country is officially around 7\% (KFS 2015). This rapid increase since the year 2000 (25\% in fifteen years) cannot be solely attributed to the reforestation and afforestation efforts of the country, but also to the usage of more efficient remote sensing software or to the use of tdifferent definition criteria of a "forest." It should also be noted that there are strong regional disparities, with 15 counties having a lower cover than the national average, especially in the area around Lake Victoria $(0.44 \%$ in Kisumu county) and in the North of the country, but there are also 17 counties that have already surpassed the threshold of $10 \%$, especially in the old central province (38.03\% in Nyeri county) (KWTA 2015, 31).

\section{Despite the Reforms, Users' Involvement Is still Limited}

Following the lively critiques directed to the extremely centralised character of natural resources management in Kenya, and the injunctions expressed on an international level for a transition towards a more participative and decentralised management of these resources, the sectorial laws promulgated at the beginning of the 2000s (Water Act 2002; Forest Act 2005), under president Mwai Kibaki's mandate (2002-2013), have seemed to represent a historic turning point regarding governance. The creation of users' associations could be seen as a demonstration of the willingness of the central government to delegate part of its prerogatives to the local level. However, according to recent studies on this subject, the global trend is towards the strong inertia of previous functioning modes, with the decision-making power still remaining largely in the hands of the state and the parastatal agencies maintaining the state's control locally.

\section{Water and Forest Reforms in Kenya}

The content of the Water Act adopted in 2002 embraces the main principles of the Integrated Water Resource Management (IWRM) (monetisation of usage, river basin management approach and users' participation), which were initially stated during the Conference on Water and the Environment in

24. These figures relate only to forests such as they were previously defined in note 16 and not to smaller and less dense vegetation patches. 
Dublin in 1992 (Rouillé-Kielo 2019b). One of the major changes ${ }^{25}$ introduced by the Water Act consists of delegating part of the central government's powers to lower levels (Mumma 2007). New management areas were also created to correspond to those of the drainage areas of the country's major rivers. ${ }^{26}$ On a regional level, six catchment areas $^{27}$ were defined. Each one is managed from a regional office of the parastatal institution created for the reform, the Water Resource Management Authority (WRMA). Basin committees for each of these have also been established. Finally, the territory was also subdivided in sub-catchments (in 2016 their number stood at $\left.1,237^{28}\right)$. Each of these sub-catchments is supposed to be represented by one Water Resource Users Association (WRUA). In June 2014, only 30\% of the country's potential WRUAs were established, with considerable inequalities among regions. In 2016, established WRUAs would have reached 50\% (Rouillé-Kielo 2019b).

Another reform in the forest sector was undertaken with the adoption of the 2005 Forest Act, which came into force in 2007. It was inspired by the principles of Participatory Forest Management, a management model that calls upon central powers to delegate the management of forest resources to local institutions. The forest sector reform thus introduced two major changes. The first was the creation of the parastatal agency Kenya Forest Service (KFS) as a replacement to the Forest Department, whose actions were highly criticised in the past. The KFS was to take over the management of all state forests. The second was the establishment of community-based organisations, called Community Forest Associations (CFAs), as well as the possibility for the existing associations to have their rights for participating in public forest management activities recognised before the KFS. Given that there can be only one CFA per forest block, their possible total number in the entire country reaches over 400 . A vast majority of them had been created already by the late 2000s (Hübertz 2009). As is the case of water users associations, the definition of the potential members of a CFA is both

25. The others consist of a separation, which is now clear, between the institutions responsible for water management and the water supply services, a separation of the policy design with daily administration and daily regulations; the involvement of non-government entities in both the water resource management and the water supply services (Mumma 2007: 160).

26. The division was made with respect to a critical size (in terms of surface area-150 to $200 \mathrm{~km}^{2}$ per WRUA (Richards \& Syallow 2018) and representation of population), with the limits of the catchment areas not being necessarily taken into account.

27. Lake Victoria North, Lake Victoria South, Rift Valley, Ewaso Ng'iro North, Tana, Athi.

28. Interview, 16 September 2016, Assistant Technical Coordination Manager, Community Development, WRMA. 
vague and potentially very large, since it does not stipulate the maximum distance from the forest where the potential members of these associations are to be living and the decision on that matter is ultimately left to the discretion of each association.

\section{Persistent Centralism}

Despite the declared willingness to put a stop to the concentration of power in the hands of the central government, the newly created parastatal agencies, KFS and WRMA, responsible for representing the state locally, have preponderant power.

In the forest sector, the creation of a CFA must be approved by the KFS after examination of the association's statute and management plan. The KFS also has control over the resources and the rules related to their usage. Ultimately, the CFA members are responsible only for ensuring the monitoring of the state of the resources and the control over the rights of use. It is therefore more of a so-called "Join Forest Management" model between the authorities and the users than a real participatory management placing the users at the heart of the decision-making process and regarding them not only as simple users, but also as owners of the resources (Witcomb \& Dorward 2009; Mogoi et al. 2012). More specifically, the main advantage gained from being a member of a CFA is the ability to access the possibility of cultivating the plantations managed by the KFS. ${ }^{29}$ Regarding this last point, the establishment of the Plantation Establishment and Livelihood Improvement Schemes (PELIS) can be regarded as a return to the shamba system. Introduced by the British in 1910, this system consisted of jointly planting tree seedlings and food crops in the plantation areas managed by the Forest Department. The farmers involved were responsible for making sure that both the tree seedlings and their food crops would grow well. After about three years, when the tree seedlings were creating too much shadow over the food crops, a new section of the forest inside the plantations was cleared. Prohibited in 1988 before being re-established in 1994 (under a non-residential form), the system was again halted in 2003 before it was reintroduced in 2007, this time under the acronym "PELIS" (Witcomb \& Dorward 2009). This change was however only a facade since the functioning globally remained the same. The Kenya Forestry Research Institute (KEFRI) evaluated the surface of the plantation managed by the PELIS system at 10,000 hectares ${ }^{30}$ in 2013 (KEFRI 2014).

29. The users rights attached to public forests (such as the right to collect dead wood, honey or medicinal herbs and graze livestock) do not depend on the CFA membership.

30. As a first step, only 24 plantations in the country are affected. 
In the case of water reform, the decision-making power also remains very centralised (Mumma 2007). Regionally, it is the government authorities that prepare the management plans (the catchment areas management strategy plans). As observed in the Naivasha region, the management and water resource protection rules, which are supposedly formulated by the WRUAs, are not very adjusted to the local contexts and coincide very much with the rules established by law and WRMA recommendations or from other organisations that work with the WRMA locally. It is noteworthy that these associations have no sanctioning power and must settle for reporting any irregularities observed to the WRMA, with the WRMA not necessarily following up on the requests made to it, due to a lack of time and resources. Their creation was encouraged by meetings organised by WRMA in collaboration with representatives of local authorities, or by NGOs or cooperation agencies with a local base. The members of these associations are mainly mobilised for activities related to protection of catchment areas, and especially for maintaining and restoring riparian woodlands (or riverside forests) by planting local tree species cast as water-friendly trees. In rural areas, they are also called upon to approach riparian land owners (many of which are farmers) in order to raise their "awareness" of issues related to the protection of water resources.

The scarcity of resources available to the users is described in the literature as a major obstacle to economic development. The KFS retains control over revenues from the exploitation of forest resources while WRMA controls the royalties on water consumption. The annual contributions of their members are the only fixed revenue base the associations can count on. When these are provided by individuals, they are usually of little value (about a few euros). The associations can however apply for one-off grants as community groups with the Community Development Trust Fund (CDTF). In the water sector, the WSTF (the Water Service Trust Fund), which is supposed to finance the activities of WRUAs' subcatchment management plans, now applies a logic by county for the distribution of funds to the WRUAs. ${ }^{31}$ In order to resolve this rather precarious financial situation, the WRUAs and CFAs located in non-selected counties are encouraged to develop strategies for differentiating their sources of revenue, especially by responding to grants offered by environmental organisations.

31. Within the framework of the ASAL program (arid and semi-arid land), led by the Danish cooperation agency Danida and the European Union, only six counties were selected. Today, with many new projects emerging, around 17 counties and a little under 100 WRUAs should be able to receive support by the WSTF in the years to come (interview, 16 September 2016, two WSTF agents). 


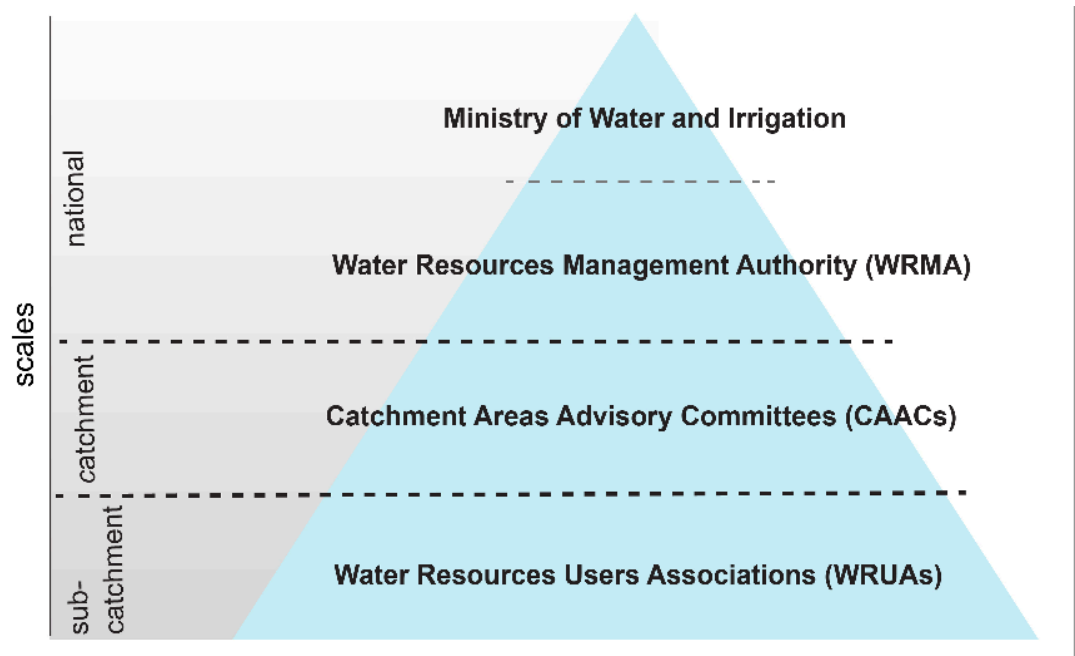

Image 2. Institutional organisation of the water sector after the adoption of the Water Act of 2002

Source: Kenyan Ministry of Water. Author: Gaële Rouillé-Kielo.

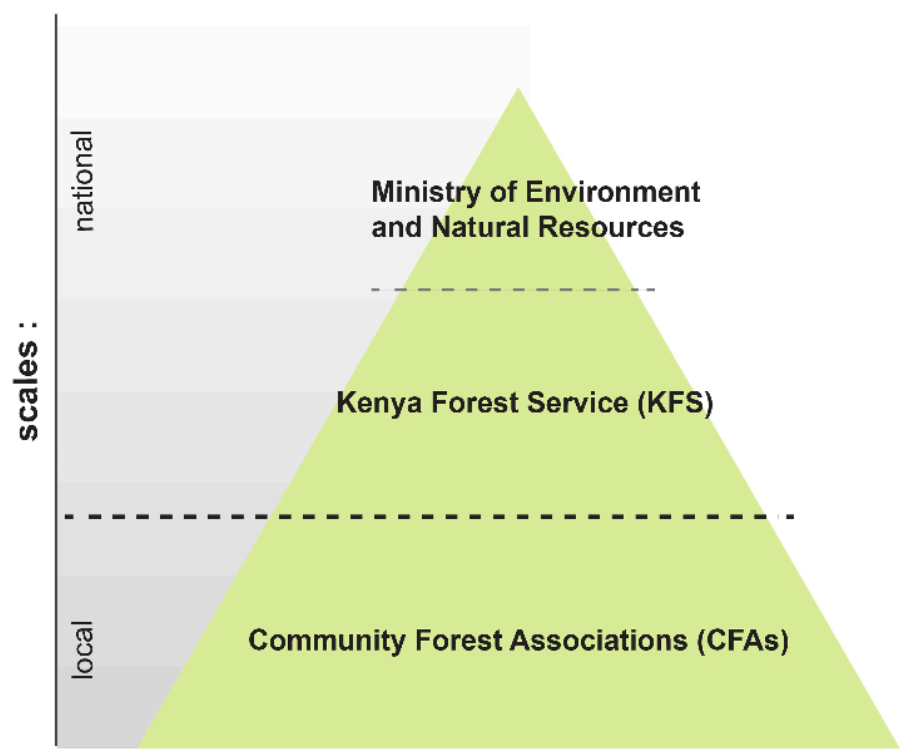

Image 3. Institutional organisation of the forest sector after the adoption of the 2005 Forest Act

Source: Kenyan Ministry of Environment and Natural Resources. Author: Gaële Rouillé-Kielo. 
Who Is "Involved"?

Participation in users' associations is voluntary by nature and subjected to a payment of a membership fee, usually paid annually. Most of the users' associations have a corporate membership system and represent different groups of stakeholders (tree nursery growers, beekeepers, etc.). In the regions with such associations, it is in fact common that these are both members of the local CFA and WRUA. While the composition of the associations, and especially of their office, is supposed to be (as encouraged by the authorities) representative of the different elements of the local "community" in question (gender parity criterion, representation of young people and different cultural groups, representation of the different areas from upstream to downstream of the sub-catchments for the WRUAs), studies addressing the issue have reported a more contrasted reality. Works dedicated to CFAs underline the marginalisation of the poorest population, which can be attributed to the membership fee system, seen as an economic barrier to participation (Hübertz 2009). In fact, the prominent positions of the association's offices (president and secretary) are largely occupied by men, while women are relegated to more time-consuming and less gratifying tasks (Mogoi et al 2012). Furthermore, in the CFA of the forest Ngare Ndare near Mount Kenya, Chomba et al. (2015) report monopolisation of the power by several members in an area marked by strong socio-economic and land-ownership discrepancies. ${ }^{32}$ However, this situation is not necessarily reported elsewhere. For instance, in the eastern part of the Mau forest complex (i.e. in the Sururu and Eburu forests) the corporate membership system is presented as a safeguard against confiscation of power by the wealthiest users (Mutune, Wahome \& Mungai 2015). Most of these remarks also apply to the WRUAs. For example, the twelve associations in Lake Naivasha water basin were all managed by men in 2016. The requirement to fluently know how to read and write in Swahili and in English in order to be considered for the position of secretary or president of an association can prevent less educated people from accessing these positions.

32. The major landowners, who are for the most part of European origin and own ranches or conservancies which can be of over 10,000 hectares, managed to influence the budgetary orientations of the CFA in their favour, and did so at the expense of the small landowners who are Kikuyu, Maasai and Meru and 91\% of which own less than 2 hectares of land (Chomba et al. 2015). 


\section{New Challenges Related to Natural Resources Management within the Framework of the Devolution}

In 2010, Kenya adopted a new constitution introducing a major change with the creation of 47 counties, each having its own government. The harmonisation of the content of the water and forest acts with the constitutional provisions entailed the delegation of some of the central government's prerogatives to the counties. However, the issue of the devolution of natural resources management created tensions.

\section{Constitutional Provisions concerning Natural Resources Management}

Section 69 of the Constitution of 2010 specifies the obligation of the state regarding natural resources and environmental management. The state is committed to ensuring the exploitation, usage, management, and sustainable protection of the environment and its natural resources, as well as a fair distribution of the revenues that may be generated from the same (KLR 2010, 69, 1, a). The state shall also encourage involvement in the management and protection of the environment (KLR 2010, 69, 1, d).

Schedule 4 of the constitution lays out the respective functions of the central government and the counties within the framework of the devolution process but does not allow however to clearly identify who will be in charge of natural resources management. This ambiguity gave way to multiple interpretations and discussions during the examination of the water and forest laws. The text (Schedule 4,22) states that the national government is responsible for ensuring the protection of the environment and its natural resources for the purpose of establishing a sustainable development process. However, according to this same text (Schedule 4, 10), the counties' mission in terms of natural resources management is also very broad: counties are responsible for implementing the government policies for protection of the natural resources and the environment, which also includes, as is specified in the text, the protection of the soil and the water resources, as well as the management of the forests. They are responsible for the forests previously managed by the local authorities, while the public forests (which are much larger) remain under the management of the Kenya Forest Service.

\section{Natural Resources Management, a Coveted Financial Issue}

Since the creation of the counties, and in the period during which legislation frameworks were being revised and adapted to the constitutional provisions, intense discussions were ongoing. Disputes between counties 
were echoed in the press several times ${ }^{33}$ following the expressed intention by the governors of counties such as Nyandarua and Murang'a, where the waterway sources supplying notably Nairobi are located, to request financial compensation from the counties situated downstream. During the revision period of the framework law on forests, the issue of sharing revenues was highly debated. With the provisions of the new law, KFS retains discretionary power over the issuing of licenses for exploitation of public plantation forests, and with it, control over the related revenues (evaluated at 1 billion KES per year, which is equivalent to 8.6 million EUR). Furthermore, the exploitation of mature trees from the forests with local species or the selling of carbon credits as part of the possible implementation of the REDD+ programs could provide important revenues rising great interest among counties' governors. During the discussions preceding the adoption of the law, the National Alliance of Community Forest Associations (NACOFA), responsible for representing the CFAs on a national level, also started negotiations with the central government for allowing users associations to benefit from a part of the revenues generated by the exploitation of the public forests they co-managed. A priori, these claims were to remain unsatisfied.

The Water Act (RoK 2016) and the Forest conservation and management Act (RoK 2016) were finally adopted in September 2016, i.e. respectively two years and one year following their drafting. These laws partially clarify the conditions for participation of counties in natural resources management issues. As for water resources, the counties' representatives shall be appointed in the new basin committees, the Basin Water Resources Committees (BWRC), which have an expanded mandate and are created as a replacement to the old CAACs, which had only a very limited and exclusively advisory role. The assertion of decision-making power at the national level marked in the Water Act 2016 was challenged by county representatives as soon as the text was adopted, claiming that it was unconstitutional. ${ }^{34}$ Since then, there have been press reports of county governors' continued willingness to take possession of water from dams

33. See in particular, Munyeki, James. 2013. "Central Nakuru, Nairobi Counties Have Vowed not to Pay for Water." The Standard, 9 August. https://www. standardmedia.co.ke/central/article/2000090485/uproar-over-countys-plan-tocharge-for-water [archive].

34. Several press articles were published in the months following the adoption of the text, in particular to report an appeal to the Court of Justice by the Council of Governors, representing the county governors (Kadida, Jillo. 2016. "Counties in Court to Block Enforcement of Water Act, Say it Takes away their Roles." The Star, 15 December; Kadida, Jillo. 2017. "Citizen Sues to Stop Implementation of New Water Act." The Star, 6 February [archive]; Kakah, Maureen. 2016. "Governors Challenge Implementation of Water Act in Kenya.” Daily Nation, 14 December. 
for riverine communities ${ }^{35}$ or to impose taxes on water supplies to other counties. ${ }^{36}$ In 2019, Nairobi County committed itself to compensating the counties where rivers that contribute to the city's water supply are located by adopting the Water and Sanitation Services Policy. ${ }^{37}$

Apart from these new acts of parliament, that followed the adoption of the constitution in 2010, several initiatives for developing discussion between the different key stakeholders for natural resources protection on the county level emerged. The county natural resources forums were intended to be set up to unite all representatives of the local government, the county, the private sector, the civil society and the "indigenous communities." By 2016 only six forums would have been created. ${ }^{38}$ In the case of water towers, many of which stretch over several counties (the one in Mount Kenya, for example, is shared between five counties), KWTA has encouraged the development of inter-county management plans by adopting a landscape approach so as to allow natural resources management to be organised in line with the ecosystem limits rather than the administrative boundaries (KWTA 2015, 32).

\section{Conclusion}

The changes initiated with the adoption of the Water and Forest Acts adopted in the early 2000s, which have been revised recently, reflect the "integration" paradigm in natural resources management, with a greater involvement of the local levels in "governance." However, after several years of implementation and in spite of the small revisions recently made as part of the devolution, participation primarily concerns the management of natural resources that can be described as "productive" (for example, KFS's plantations with the "PELIS" system, or riparian agricultural holdings), and do not pertain to areas under stricter protection. In the "productive" areas, the central government retains control over the rules for the use of

https://nation.africa/kenya/news/governors-challenge-implementation-ofwater-act-337874 [archive]).

35. Gachane, Ndungu. 2019. "Wa Iria Threatens Lawsuit for Murang'a to Get Ndakaini Water." Daily Nation, 8 September. https://nation.africa/kenya/ counties/muranga/wa-iria-threatens-lawsuit-for-murang-a-to-get-ndakainiwater-201678 [archive].

36. Maina, Waikwa. 2018. "Nyandarua Leaders Want 14 Counties to Pay for Water Supply." Business Daily.

37. The county of Nairobi is the first in the country to have adopted a law in this area. The amount of funds earmarked for compensation to other counties was not reported in the sources consulted.

38. Interview from 25 September 2016, Kenya Working Forest Group (KFWG), national coordinator. 
resources, as well as over the revenues generated by this use. It seems that the water and forest users' associations "participate" in the management activities primarily as auxiliaries to the central government, in order to help achieve the objectives set on a national level, in particular that of a $10 \%$ tree cover up to 2022 .

Recently, the challenge of protecting water towers allowed for the justification of a stricter protection of the forest reserves. The valorisation of the forests described as "indigenous" is part of the process of making the Kenyan water towers sanctuaries of the national "natural" heritage and presenting them as guarantors to the emerging economic prosperity of the country. Protection of these forests is implemented through materialisation (with electric fences) of their borders and through regular eviction of the groups of people residing there. The selective nature of the movement for recalling the former forest reserves raises the question of the way the authorities decide whose presence in these areas is legitimate or not. The modalities of protecting these forests, particularly the evictions measures, raise human rights concerns. The ongoing preparation of a Bill regarding the management of water towers (whose first draft was released in 2019) will potentially clarify the strategy of the national authorities on how to restore these areas.

\section{Bibliography}

Amnesty International. 2018. Families Torn apart. Forced Eviction of Indigenous People in Embobut Forest, Kenya. London: Amnesty International. https:// www.amnesty.org/en/documents/afr32/8340/2018/en/ [archive].

Amnesty International. 2007 Nowhere to Go: Forced Evictions in Mau Forest. London: Amnesty International. https://www.amnesty.org/en/documents/afr32/006/2007/en/ [archive].

Bart, François. 2006. "La montagne au cœur de l'Afrique orientale." Les Cahiers d'Outre-Mer no. 235: 307-22. https://www.doi.org/10.4000/com.126.

Bennett, Genevieve, and Nathaniel Caroll. Gaining Depth: State of Watershed Investment 2014. Washington: Forest Trends.

https://www.forest-trends.org/publications/gaining-depth-2/ [archive].

Benjaminsen, Tor A., and Hanne Svarstad. 2012. "Discours et pratiques de conservation en Afrique." In Environnement, discours et pouvoir. L'approche Political ecology, Denis Gautier, and Tor A. Benjaminsen (eds), 111-33. Versailles: Quae. https://doi.org/10.3917/quae.gaut.2012.01.0111.

Boone, Catherine. 2012. "Land Conflict and Distributive Politics in Kenya." African Studies Review 55, no. 1: 75-103. https://doi.org/10.1353/arw.2012.0010.

Brockington, Dan. 2002. Fortress Conservation: The Preservation of the Mkomazi Game Reserve, Tanzania. Oxford: James Currey. 
Brockington, Dan, and Katherine Scholfield. 2010 "The Work of Conservation Organisations in Sub-Saharan Africa." The fournal of Modern African Studies 48, no. 1: 1-33. https://doi.org/10.1017/S0022278X09990206.

Calas, Bernard. 1998. "Des contrastes spatiaux aux inégalités territoriales." In Le Kenya contemporain, edited by François Grignon and Gérard Prunier, 13-51. Paris: IFRA-Karthala.

Chomba, Susan W., Nathan Iben, Peter A. Minang and Fergus Sinclair. 2015. "Illusions of Empowerment? Questioning Policy and Practice of Community Forestry in Kenya." Ecology and Society 20, no. 3. https://doi.org/10.5751/ES-07741-200302.

Constantin, François. 2000. "Kenya : forêts violées.” In L'Afrique orientale. Annuaire 2000, edited by François Grignon and Hervé Maupeu, 237-68. Paris: L'Harmattan.

Depraz, Samuel. 2008. Géographie des espaces naturels protégés. Paris: Armand Colin.

European Union External Action. 2018. "EU Suspends its Support for Water Towers in View of Reported Human Rights Abuses." Delegation of the European Union to Kenya, 17 January. https://eeas.europa.eu/delegations/ kenya/38343/eu-suspends-its-support-water-towers-view-reportedhuman-rights-abuses en [archive].

Evans, Lauren A., and William M. Adams. 2016. "Fencing Elephants: The Hidden Politics of Wildlife Fencing in Laikipia, Kenya." Land Use Policy 51: 215-28. https://doi.org/10.1016/j.landusepol.2015.11.008.

Falkenmark, Malin. 1989. "The Massive Water Scarcity now Threatening Africa: Why Isn't it Being Addressed?” Ambio 18, no. 2: 112-18.

FAO. 2015. Global Forest Resources Assessment (FRA). Country Report. http://www.fao.org/3/a-i4808e.pdf [archive].

Government of Kenya (GoK). 2002. Water Act 2002. Nairobi: Government Press. http://extwprlegs1.fao.org/docs/pdf/ken37553.pdf [archive].

Government of Kenya (GoK). 2005. Forest Act 2005. Nairobi: Government Press. https://www.fankenya.org/downloads/ForestsAct2005.pdf [archive].

Government of Kenya (GoK). 2007. Vision 2030, The Popular Version. Nairobi: Government Press. https://vision2030.go.ke/publication/kenya-vision-2030popular-version/ [archive].

Hubertz, Hanne. 2009. Empowering and Strengthening Civil Society for Participatory Forest Management in East Africa (EMPAFORM Programme), Final Evaluation Report. https://www.yumpu.com/en/ document/read/49167414/empaform-final-evaluation-report-2009-careinternationals- [archive].

Kariuki, Joseph. 2006. "Common Heritage, Diverse Interests: Deforestation and Conservation Alternatives for Mount Kenya." Les Cahiers d'Outre-Mer 235, no. 3: 347-70. https://doi.org/10.4000/com.112.

Kariuki, Joseph. 2007. "Vested Interests and Natural Resource Governance in Kenya." In L'Afrique orientale. Annuaire 2005, edited by Hélène Charton and Claire Médard. Paris: L'Harmattan. 
Kariuki, Jane, Regina Birner, and Susan Chomba. 2018. "Exploring Institutional Factors Influencing Equity in Two Payments for Ecosystem Service Schemes." Conservation and Society 16, no. 3: 320-37.

http://doi.org/10.4103/cs.cs 1627.

Kenya Forests Working Group (KFWG). 2006. Changes in Forest Cover in Kenya's Five "Water Towers" 2003-2005. Nairobi: United Nation Environment Programme (UNEP). http://hdl.handle.net/20.500.11822/8695.

Kenya Law Reports (KLR). 2010. The Constitution of Kenya, 2010. https://www.wipo.int/edocs/lexdocs/laws/en/ke/ke019en.pdf [archive].

Klopp, Jacqueline M. 2012. "Deforestation and Democratization: Patronage, Politics and Forests in Kenya." Journal of Eastern African Studies 6, no. 2: 351-70. https://doi.org/10.1080/17531055.2012.669577.

KWTA. 2015. Kenya Water Towers Status Report. Narok: Kenya Water Towers Agency.

KWTA. 2016. Strategic Plan 2016-2020. Narok: Kenya Water Towers Agency.

Maathai, Wangari. 2005. Pour l'amour des arbres. Paris: L'Archipel.

Mogoi, Jephine, Emily Obonyo, Paul Ongugo, et al. 2012. "Communities, Property Rights and Forest Decentralization in Kenya: Early Lessons from Participatory Forest Management." Conservation and Society 10, no. 2: 18294. http://doi.org/10.4103/0972-4923.97490.

Mumma, Albert. 2007. "Kenya's New Water Law: An Analysis of the Implications of Kenya's Water Act 2002 for the Rural Poor." In Communitybased Water Law and Water Resource Management Reform in Developing Countries, edited by Barbara Van Koppen, Mark Giordano, John Butterworth, 158-73. Oxford: CAB International.

Mutune, Jane M., Raphael G. Wahome, David N. Mungai. 2015. "Local Participation in Community Forest Associations: A Case Study of Sururu and Eburu Forests, Kenya." International fournal of African and Asian Studies 13: 84-94. http://erepository.uonbi.ac.ke/handle/11295/96088.

Nelson, Fred, and Arun Agrawal. 2008. "Patronage or Participation? Community-based Natural Resource Management Reform in Sub-Saharan Africa." Development and Change 39, no. 4: 557-85. https://doi.org/10.1111/j.1467-7660.2008.00496.x.

NEMA. 2011. State of the Environment and Outlook 2010. Nairobi: National Environment Management Authority. https://na.unep.net/siouxfalls/publications/Kenya SDM.pdf [archive].

PNUE, KWS, RHINO ARK \& KFWG. 2003. Aerial Survey of the Destruction of the Aberdare Range Forests. Nairobi: United Nation Environment Programme (UNEP). http://hdl.handle.net/20.500.11822/8576.

PNUE. 2009. Kenya, Atlas of Our Changing Environment. Nairobi: United Nation Environment Programme (UNEP). http://hdl.handle.net/20.500.11822/7837. PNUE. 2012. The Role and Contribution of Montane Forests and Related Ecosystem Services to the Kenyan Economy. Nairobi: United Nation Environment Programme (UNEP). http://hdl.handle.net/20.500.11822/29024.

Raison, Jean-Pierre. 1994. "Le Kenya, fragile vitrine." In Géographie universelle : Les Afriques au Sud du Sahara, edited by Roger Brunet, Alain Dubresson, 
Jean-Yves Marchal, Jean-Pierre Raison, 330-42. Paris: Belin; Montpellier: Reclus.

Republic of Kenya (RoK), Water Resources Management Authority (WRMA). 2009. Integrated Water Resources Management and Water Efficiency Plan for Kenya. Nairobi: Republic of Kenya.

Republic of Kenya (RoK). 2014. Kenya Gazette Supplement 116.

Republic of Kenya (RoK). 2016. The Forests Act. Kenya Gazette Supplement 88, no. 7.

Republic of Kenya (RoK). 2016. The Forest Conservation and Management Act. Kenya Gazette Supplement 155, no. 34.

Republic of Kenya (RoK). 2016. The Water Act 2016. Kenya Gazette Supplement 164, no. 43.

Rodary, Estienne, and Christian Castellanet. 2003. "Les trois temps de la conservation." In Conservation de la nature et développement, L'intégration impossible ?, edited by Estienne Rodary, Christian Castellanet and Georges Rossi, 5-44. Paris: GRET-Karthala.

Rouillé, Gaële, David Blanchon, Bernard Calas, and Élise Temple-Boyer. 2015. "Environnement, écologisation du politique et territorialisation : nouvelles politiques de l'eau (GIRE, PSE) et processus de territorialisations." L'Espace Géographique Tome 44: 131-46. https://doi.org/10.3917/eg.442.0131.

Rouillé-Kielo, Gaële. 2019. "La Gestion Intégrée des Ressources en Eau (GIRE) au Kenya : Une mise en œuvre inachevée et inégale sur le territoire national.” In L'accès à l'eau en Afrique: Vers de nouveaux paradigmes? Vulnérabilités, exclusions, résiliences et nouvelles solidarités, espace et justice, edited by David Blanchon and Barbara Casciarri. Nanterre: Presses universitaires de Paris Nanterre.

Rouillé-Kielo, Gaële. 2019. "Distributing Responsibilities in an Agricultural Ecosystem. Insights from the Lake Naivasha Water Basin in Kenya." Nature and Culture, vol. 14, no. 3: 251-70. https://doi.org/10.3167/nc.2019.140303.

Rouillé-Kielo, Gaële. 2020. "Traduction du concept de Paiements pour services hydriques, politiques de l'eau et processus de territorialisation au Kenya." PhD Dissertation. Nanterre: Université Paris Nanterre.

Southall, Roger. 2005. "The Ndungu Report: Land \& Graft in Kenya." Review of African Political Economy 32, no. 103: 142-51.

http://www.jstor.org/stable/4006915.

Ville, Jean-Luc. 1998. "La conservation des ressources naturelles. De l'exclusion à la participation communautaire." In Le Kenya contemporain, edited by François Grignon and Gérard Prunier, 231-43. Paris: IFRA-Karthala.

Wass, Peter (eds). 1995. Kenya's Indigenous Forest: Status, Management and Conservation. Gland \& Cambridge: IUCN Forest Conservation Programme. https://www.iucn.org/fr/content/kenyas-indigenous-forests-statusmanagement-and-conservation [archive].

Witcomb, Mark, Peter Dorward. 2009. "An Assessment of the Benefits and Limitations of the Shamba Agroforestry System in Kenya and of Management and Policy Requirements for Its Successful and Sustainable 
Reintroduction.” Agroforestry Systems 75, no. 3: 261-74.

https://doi.org/10.1007/s10457-008-9200-z.

WRMA. 2015. WRMA Performance Report 4, A Report to the Public from the Water Resources Management Authority. https:/wra.go.ke/wp-content/ uploads/2019/05/WRMA Performance Report 4.pdf [archive].

\section{Media}

Gachane, Ndungu. 2019. "Wa Iria Threatens Lawsuit for Murang'a to Get Ndakaini Water.” Daily Nation, 8 September. https://nation.africa/kenya/ counties/muranga/wa-iria-threatens-lawsuit-for-murang-a-to-getndakaini-water-201678 [archive].

Kadida, Jillo. 2016. "Counties in Court to Block Enforcement of Water Act, Say it Takes away their Roles." The Star, 15 December.

Kadida, Jillo. 2017. "Citizen Sues to Stop Implementation of New Water Act." The Star, 6 February [archive].

Kakah, Maureen. 2016. "Governors Challenge Implementation of Water Act in Kenya.” Daily Nation, 14 December. https://nation.africa/kenya/news/ governors-challenge-implementation-of-water-act-337874 [archive].

Kemei, Kipchumba. 2014. "KWS-KFS Merger Opposed, Says CS.” The Standard, 5 April. https://www.standardmedia.co.ke/kenya/article/2000108630/kwskfs-merger-opposed-says-cs [archive].

"Kenya: Abusive Evictions in Mau Forest." 2019. Human Rights Watch, 20 September. https://www.hrw.org/news/2019/09/20/kenya-abusiveevictions-mau-forest [archive].

“Kenya: Mau Forest Evictees' Plight Intensifies." 2020. Human Rights Watch, 23 July. https://www.hrw.org/news/2020/07/23/kenya-mau-forest-evicteesplight-intensifies [archive].

Kitelo, Peter. 2016. "Does Burning Homes Save the Water Towers? Quite the Opposite." The Star, 12 July. Published in Katiba Institute: http:// katibainstitute.org/does-burning-homes-save-the-water-towers-quite-theopposite/ [archive].

Maina, Waikwa. 2018 "Nyandarua Leaders Want 14 Counties to Pay for Water Supply." Business Daily.

"Mau Evictions Should Be Done Humanely." 2019. The Standard, 7 October. https://www.standardmedia.co.ke/editorial/article/2001344617/mauevictions-should-be-done-humanely [archive].

Munyeki, James. 2013. "Central Nakuru, Nairobi Counties Have Vowed not to Pay for Water." The Standard, 9 August. https://www.standardmedia.co.ke/ central/article/2000090485/uproar-over-countys-plan-to-charge-for-water [archive].

Mwale, Anne. 2019. "Looming Mau Phase Two Evictions Elicit Mixed Reactions." Kenya News Agency, 6 September. https://www.kenyanews. go.ke/looming-mau-phase-two-evictions-elicit-mixed-reactions/ [archive]. 
Ndii, David. 2015. "Why Uhuru's Parastatal Reform Was Doomed to Fail." Daily Nation, 8 May. https://nation.africa/kenya/blogs-opinion/opinion/ why-uhuru-s-parastatal-reform-was-doomed-to-fail-1092180 [archive].

Sayagie, George. 2019. "60,000 Families Targeted in Second Mau Forest Eviction.” Daily Nation, 2 September. https://nation.africa/kenya/counties/narok/60000-families-targeted-in-second-mau-forest-eviction-199852 [archive].

Vidal, John. 2014. "Kenyan Families Flee Embobut Forest to Avoid Forced Evictions by Police." The Guardian, 7 January. https://www.theguardian. com/global-development/2014/jan/07/kenya-embobut-forest-forcedevictions-police [archive].

Watts, Jonathan. 2018. "Kenya Forest Death: Activities Blame EU for Ignoring Human Rights Warnings.” The Guardian, 19 January. https://www. theguardian.com/environment/2018/jan/19/kenya-forest-death-activistsblame-eu-for-ignoring-human-rights-warnings [archive]. 


\section{Chapter 8 \\ Securing Everyday Nairobi \\ Challenges and Tactics of Private Security \\ Guards in the Fragmented City}

Jean-Baptiste Lanne

Translated by Sadie 7. Mobley

In 2016, private security services made up the largest sector of Kenya's salaried labor force. In 2015-2016, this fast-growing market generated an average of 265 million EUR in annual turnover and employed 300,000 to 350,000 workers in 2018. ${ }^{1}$ Roughly $70 \%$ of these workers are concentrated in Nairobi. Beyond statistics, the importance of the private security market in Kenya's capital city stands out immediately in the urban landscape. For locals, seeing an askari-originally meaning "soldier" in Swahiliopening doors and checking visitors at the gates of private compounds or shopping malls is an everyday experience. For an outside observer, the direct experience of military urbanism (high walls, barbed wire, electronic locks, and cameras) gives the impression of encountering an "anxious city" (Bernard \& Segaud 2011).

Yet, the scope of urban threats remains difficult to grasp. Police reports are the only documents available to map out a statistical portrait of crime in Nairobi, though they are highly unreliable. On the one hand, many residents choose not to report crimes because of widespread mistrust of the police. On the other, statistics are limited to "cases" filtered by the administration and exclude minor offenses and situations involving police misconduct (Ruteere, Mutahi, Mitchell et al. 2013). Empirical evidence identifies four main types of fear emanating from different social groups: fear of "the poor," generally associated with juvenile delinquency; mass political violence, such as riots, lynching and murders; police violence; and terrorism, pervasive for over twenty years and which the attacks of Westgate (2013) and Garissa (2015) revived. $^{2}$

1. Source: Kenya Security Industry Association (2018). The lack of market regulation explains the inaccuracy of statistics.

2. Kenya was hit by a series of attacks claimed by the al-Shabaab Islamist group in response to Kenya's military action in southern Somalia. Two large-scale attacks were especially traumatic: the attack on the upscale shopping centre "Westgate" in Nairobi on 24 September 2013, and another at the University 
Faced with these difficulties, it seems necessary to move beyond questions about effectiveness of security systems. Relying on a recent epistemological renewal, ${ }^{3}$ this chapter proposes to diverge from Frédéric Gros' objectivist definition of security as "an objective situation characterised by the absence of danger" (Gros 2012, 74), and rather open onto a more performative approach. Security, then, refers to a performance whose main objective is to stimulate, guide and manage the peace of mind of given population. This approach consequently draws the focus to actors who literally embody security on the ground: guards posted at the gates of private residences or large public facilities. It allows to identify two main axes of research. The first one is about examining the strict disciplinary constraints weighing on the guards: physical education, inculcation of corporate codes, mandatory wearing of the uniform, and GPS tracking of any movement. Over time, the guards nevertheless develop tactical routines to evade the constant supervision and recreate spaces of freedom. The security performance is secondly to be studied as a powerful mechanism of social distinctioncreating a sense of belonging at the heart of residential neighbourhoods, that is, a sense of home and community. This last matter has repercussions on the ambiguous role held by guards-while they come to protect an "inside" (the safe place, the microcosm), they are often, in fact, physically and symbolically relegated outside the social space they consecrate.

\section{Creating the Immobile Human ${ }^{4}$}

For formal neighbourhoods in Nairobi, there are three prominent types of security service supply. The first brings together some thirty national-scale (BM Security, Securex, Lavington, Security) or international security firms (KK Security, G4S). These are structured by a strong chain of command: managers, team officers, supervisors, and senior security guards. These companies are in charge of the most critical infrastructures (airports, embassies, public buildings, shopping centres) as well as of residences in the wealthiest parts of the city. The second type includes around 1900 "small" companies (50 to 500 employees) allotted to lower infrastructures: supermarkets, shops, and service stations, as well as middle class residences. These companies are characterised by working methods borrowing both from the official register (uniforms, vehicles, acronyms, corporate

of Garissa in the eastern part of the country on 2 April 2015, carried out in a similar manner (terrorist commando storming the building and slaughtering a large number of hostages).

3. See especially Schneier (1999), Pain \& Smith (2008), and Barnett (2015).

4. "One of our goals is to create immobile human beings... As long as they don't move, nothing can happen. They have to report anything they witness." (Director of operations at Lavington Security Ltd, interview, 9 February 2016). 
headquarters, and registration with the Capital Markets Authority) and the informal sector (bribes, absence of employment contracts and social contributions). Finally, the third type of supply, by far the largest in terms of clients, is made up entirely of individually contracted untrained guards, directly hired by owners or owners' associations. It is the one contracted by the vast majority of the middle-class in Nairobi.

When hired, guards are divided into three segments based on two criteria: the level of education and physical skills. Men or women who can substantiate an "O-level" (12 years of schooling) and meet certain size and strength requirements, seek employment with formal or semiformal enterprises. Those ones provide them significantly higher salaries $\left(\sim 12,000 \mathrm{KES}\right.$ per month, expenses deducted $\left.{ }^{5}\right)$ and possibly a contribution to the national social security fund (NSSF) or health insurance programs (NHIF). Workers who do not meet these criteria find a job in the informal sector, earning from 6,000 to 8,000 KES per month. Beyond these main distinctions, guard profiles are relatively homogeneous. Among the sixty guards surveyed, most are newcomers to Nairobi with less than five years in the city. Most of them are young, and just starting their family life. The lack of economic opportunities in the countryside, combined with rising financial needs (dependent children, tuition fees), pushes them to leave their home towns to try their luck in Nairobi, often on the advice of a relative. When they left, none of them ever imagined becoming an askari. Mr Safala, ${ }^{6}$ a marketing manager for Securex Ltd, is conscious of the low motivation of his employees: "You don't grow up wishing to become a security guard. In Kenya, mothers tell to their children: if you don't work hard enough, you will finish like those askaris!” (interview 6. April 2016).

In the formal sector, training askaris is an attempt to compensate for the lack of prestige in the profession. The issue is twofold: avoiding early demotivation, while instilling guards with enough morale to faithfully showcase corporate values. This strategy is characteristic of an "emotional labour" where emotions expressed by workers, especially through their body language, are an integral part of the professional performance. Every day at his post, the security guard must visibly express values of seriousness, commitment, courtesy, prestige and professionalism. By doing so, he contributes in augmenting the standing of the place. In practice,

5. The figures given are averages, because of the great variability of wages, especially in the informal sector. Government recommendations as of June 26, 2015 are respectively 10,954 KES per month and 12,221 KES per month for day and night guards Source: Kenya Gazette Supplement no. 91: 587.

6. Names have been changed to protect anonymity.

7. On the notion of "emotional labour," see Leidner (1999), Mac Dowell (2009), and Wharton (2009). 
training remains short: they last from a week to a month depending on the company. It basically consists of two main components: physical training and an introduction to public relations. The physical component closely resembles paramilitary training; new recruits learn how to march in formation and perform a proper salute (arm along the body, joined ankles, military salute). The development of physical discipline is a core exercise, even more than the teaching of basic defense techniques. Purely protective performance is relegated to the background. As Nandini Gooptu (2013) points out in her study of urban sentinels in India, "public relation" training allows one to learn the full lexicon of subordination. In class, new recruits are taught how to use expressions such as "Good morning, sir/ madam, how can I help you? What can I do for you today?," "Yes, sir," and "Yes, madam." They must ask clients how they wish to be addressed in order to satisfy their needs. Although rarely put into practice, the military salute is theoretically required. Finally, communication techniques are taught in order to mitigate and resolve conflicts. Faced with a belligerent or aggressive client, the guard must remain firm yet calm. Guards must not challenge clients, but should rather intensify expressions of politeness: "Sir, I understand your point, but...," "This is not in my power to allow you to..." As the tone rises, guards are advised not to take initiative, and to leave management of the incident to the proper chain of command.

According to a manager, the main purpose of training is to create "immobile human beings." This control over bodies and attitudes requires a two-fold immobility from the askari: a physical one, first-being able to stand for hours at the gate of compounds; a social one, then-i.e. agreeing to stay at his/her place, a social notch below the residents.

\section{What Security for Those who Secure?}

\section{Holding a Job Somewhere...}

After training, security guards are assigned to a position. Those from the informal sector usually work in their employer's home. In the two survey districts, Kileleshwa (Nairobi West) and Buruburu (Nairobi East), guards express recurrent concerns Workdays are long (12-hour shifts starting or ending from 6 A.M. to 6 P.M.) and often described as boring due to the monotonous nature of the work: opening and closing the door for incoming or outgoing vehicles. Hunger is also frequently mentioned. Most of the guards have tea in the morning, eating only once a day for dinner. Eating during a shift is indeed difficult, as cooking at the workplace is mostly prohibited ("it makes the place dirty," a tenant of Kileleshwa says). Respondents also evoke physical suffering: standing fatigue, headacheinducing heat, sickness brought on by the rain and cold, or mosquito bites 
in the evening or early morning. More specific to night watchmen, feelings of loneliness and fear characterise the watching experience. More, the interactions with customers seem to be at the heart of the work's difficulty. For residents or customers, guards may even appear as daily obstacles. Customers have an array of names at their disposal, depending on whether they want to be polite or rude. "Soldier!" and "Askari!" are relatively benevolent terms, while "Watchman"! (referring to the passive function of one who only watches), or "Maasai!" (locally and professionally perceived as "primitive" in popular representations) are intentionally humiliating. If an incident upsets a passer-by, he or she can play on the register of social distinction, putting the guardian back in his (lower) place: "You are useless!," "Open the gate, stupid!", or "You are so primitive!" Such verbal abuse contributes to weaken the guards' psychological condition, as most of them felt reached in their dignity. Nelson A., 31, working in a residence in Kileleshwa, describes this interiorised condition: "I open your gate, I wait at your gate... I'm waiting for you like your dog...!" (Interview 11 February 2016). Alfred G., 46, guard in a Kileleshwa compound, explicitly recognises the process of alienation that he is undergoing:

[>Interviewer]: And are you ready if someone attacks you?

[>Alfred]: Yeah. I'm ready because we still have the material. We are just trained to use the material...

[>Int.]: What kind of material are you talking about?

[>Alfred]: Material... I have this one [he shows me his baton], and then myself.

[>Int.]: And then yourself?

[>Alfred]: Mmhhh. I just leave myself to you.

(Interview 3 February 2016.)

Alfred's words seem to rehearse the rhetoric assimilated during training. The technical term "material" he uses to refer to his own body is quite significant in that sense. Likewise, the expressed value of total commitment to the customers ("I just leave myself to you"), mirroring the idea of sacrifice in the army, is typical of ideological conditioning. Thus, fear, loneliness, poor self-esteem and a feeling of alienation all by turns create a sense of identity and psychological insecurity among the guards.

\section{... and Being Absent Elsewhere}

Guards assignments to a fixed position for a dozen hours a day directly explain their weak integration in their neighbourhoods. In a vast majority, they live in informal settlements in Nairobi-the only urban areas where rents are available-but work in better-off neighbourhoods. For example, guards working in Kileleshwa usually live in Kawangware, Kibera, or Kangemi, all slums in the western part of the city. Guards in Buruburu reside in the slums east of the city, like Mathare, Kiambui, Korogocho, or 
Dandora. In these neighbourhoods, self-preservation is rooted in profound and sustained social interactions. ${ }^{8}$ Safety is built daily through nods and greetings in passing, offering a cigarette, advancing a small sum of money, in short, maintaining good neighbourhood relations. These relationships may be useful in case of harm (theft, assault, landlord litigation, etc.), especially in urban areas where police intervention is often perceived as ineffective. As newcomers to the city, guards do not benefit from this social capital and struggle to build it. Leaving at 5 A.M. and returning at nearly 7 P.M., they live as strangers in their own places of residence. During interviews, many mention that they do not trust their neighbours. Some fear that because of their daily absences, their landlords will rent their place to other tenants. Others describe the lack of material investment in their place for fear of being stolen during the day. The inside is then reduced to bare necessity (no TV or even radio). Josphat M., 25, a guard in Kileleshwa and resident of Kawangware, talks about his daily absence that makes him a potential target for neighbourhood youth: "When you are not around... obviously they know that you have gone searching for money. So, when you come back... they look at you in a certain way... they think that you are making a lot. When you are not around, and they know you are going for work... they know you are making [money]... the more you are lost, the more you are making [money]... So, you have to look for your security very well" (Interview, 15 February 2016).

The perceived dangers are not limited to the neighbourhood. From a sample of 57 guards surveyed, 32 admit being victims of assault on their way to work, most often for racketeering purposes. Certain factors increase the odds. The first concerns the times of the trips: around 5 A.M. and around 7 P.M. for day guards. These times are higher risk because of the darkness (the night guards are a little favoured because they start at 5 P.M. and return at 7 A.M.). Another factor is the route used for commuting: at least part of the trip is made through the slums on unlit roads. Guards newly-arrived in the city have little knowledge of the hotspots for danger and sometimes unknowingly take routes known for frequent muggings (e.g. Jamhuri estate when leaving Kibera, or Dandora Bridge, on the path to Dandora). Finally, the regularity of the commute constitutes an additional risk factor. Adding to the racket, the potentiality of police aggression is real (brutal interrogation, threats, arrest). A lone man, ${ }^{9}$ walking from or to a slum at an early or late hour, is automatically suspect. The guards, among others, are the first victims of the criminalisation of the poor in Nairobi. One might ask why the guardians do not simply wear their uniforms in

8. These findings come from a multi-month ethnographic work in Kibera, a large slum in Nairobi West, conducted between February 2015 and April 2017.

9. The guards surveyed did not report any such police aggression. 
transit. Yet the same attire that might protect them from police violence, makes them a walking target to youth gangs in the slum.

Could these workers, subjected daily to uncertain and harmful conditions, then be described as an "urban precariat" (Standing 2011)? Guy Standing's theoretical effort to define a new category of workers-neo-victims of the neoliberal city-seems partly relevant, provided that the term "precariat" is not necessarily to be understood in terms of "class." Standing defines precariat as a social group characterised by its vulnerability to multiple uncertainties: job-insecurity due to the interchangeable nature of the worker (without bringing valued skills to the table); social insecurity in the absence of trade unions and social protection systems; uncertainty of times and places of work in the name of flexible economic activity; and finally representational insecurity, as dispersed workers have no place for a collective voice to emerge. In the cities of the Global North, representations of the precariat are increasingly embodied by deliverymen, janitors, maintenance workers, and dry cleaners. It is important to remember that such a precariat also exists in Global South cities, operating through the same mechanisms of subjection. In Nairobi, the guards also undergo a form of poly-insecurity, visible at several levels: physical, psychological, social, relational and political.

\section{Living in the Place of the Other: What Tactics for which Lifestyle?}

Askaris carry many burdens every day. Those are mostly due to the fact that guards actually live in the place of the other. This last expression describes a generally enclosed place where a person or a group of persons (a tenant, a group of tenants, or a chain of command) have the power to impose their own life rules. As a result, guards are daily subjected to a series of small injunctions specific to their workplace (and life): being told how to stand, what one has the right to do or not do, with whom one has the right to interact, how objects should be arranged, and for what uses, etc. This emblematic type of place finds local variations in Nairobi: the "compound" (enclosed luxury buildings divided in apartments) in wealthy areas like Kileleshwa, Kilimani or Lavington; the "court" (small single houses distributed around a privatised street) in the middle-class neighbourhoods of Buruburu, Ngumo, or South C. These places are by definition familial, leading to a blurring of family and professional relationships, as Staci Strobl illustrated through the example of housemaids in Bahrain (Strobl 2009). Domestic workers are kept in an indistinct status oscillating between temporary family-members (they are given presents for Christmas for example, or second-hand clothes for their kids) and fundamentally undesirable figures (outsiders coming 
to disturb the family's privacy). Their work is desired, and yet, they must know how to become invisible when the situation requires it. Faced with this ambiguity, the guards develop "tactical" behaviours (Certeau 1991, 46) consisting of trickery, playing with conventions, diverting the uses of micro-places and objects to pursue their own interests. In this very specific case, a comparison between Kileleshwa's compounds and Buruburu's courts makes it possible to grasp the importance of spatial configuration in the development of individualised tactics.

\section{In Kileleshwa, Number as Resource}

In Kileleshwa, a wealthy neighbourhood west of Nairobi, residential buildings are mostly composed by private compounds. The specific type of housing consists of several buildings divided into apartments, usually organised around a car park and often equipped with shared facilities (gardens, games for children, gym, swimming pool) depending on the standing. It is usually surrounded by a wall, most often equipped with an electric fence. Several characteristics emerge here. Firstly, the compound is inhabited by wealthy populations, who typically employ domestic staff. Secondly, the habitat density-due to the apartment complex styleexplains the daily proximity of employees. Guards, caretakers, gardeners, garbage collectors and domestic helpers all work together in a relatively small space. Finally, residents most often rely on private security firms from the formal sector. Such firms exercise strict control over the guardsparticularly regarding safety protocols-via supervisors or team officers on motorcycles. For the most secure compounds, high technology further reinforces this control (real-time geolocation of guards, push buttons to operate at regular intervals, etc.).

In this context, can guards find some spaces of freedom? The number of people working in the compound, combined with the limited space, creates the conditions for a community of mutual aid. It is common, for example, for domestic helpers to bring leftovers from the family dinner to the askaris quarters. Gardeners share the fruits they have harvested in the gardens. In hotels, launderers run laundry for everyone. As for the guards, they are deliberately less careful about the entry and exit of domestic helpers during the day. This community of workers does not end, however, with a series of good deed exchanges. It branches out to provide psychological support as well-especially when facing domestic violence-but also through the simple pleasure of social gathering. The spatial configuration of the compound makes it all possible. With a number of hidden spaces, workers can find respite from tenants' constant surveillance. Staircases, flat roofs where laundry is suspended, car parks, swimming-pool areas: all these spaces, relatively quiet at certain times of the day, become interstitial life 
places where people converse, exchange tips, eat together, or braid hair. Day by day, the development of such sociability can be directly understood in regards to the workers' difficulties in producing social cohesion in their places of residence. Kept away from their neighbourhoods during the day, they recreate neighbourly relationships (mutual favours, daily conversations, invitation to their respective "corners" ${ }^{10}$ ) in adapting to the monitoring and local constraints. Finally, contracting with a formal security company seemingly produces, a certain disempowerment of tenants vis-à-vis the security protocol. As the company's supervisors take care of discipline, it is not up to tenants to worry about the behaviour of any particular askari. As a result, some tenants are more lenient with the small economic businesses of the guards: newspaper sales, car washes, small commissions at the neighbouring store, etc. As they benefit these extra services for themselves, they even defend, if necessary, their employees against the managers.

\section{In Buruburu, Fluidity of Spaces... and Social Positions}

In Buruburu, a middle-class residential neighbourhood east of Nairobi, the socio-spatial structure of the environment offers varied possibilities. The general neighbourhood consists of five estates built successively from the 1960s (Phase I to Phase V), with each subdivided into "courts." A court is a group of small houses distributed around a cul-de-sac street, enclosed by a gate. The airy setting, detached houses with gardens, semi-private streets and the location a retreat from the hustle and bustle of the city centre make it an ideal place for family life. The population is mainly composed of civil servants, business workers, and employees-forming a much wealthier fringe than that of the surrounding neighbourhoods like in Umoja, Kariobangi, Kayole, or Jericho.

Buruburu's singular space can be understood as a "continuum of publicity" (Staeheli \& Mitchell 2008). In other words, there is a gradient of publicity from the domestic space to the main street, understood as the centre of public life (commercial activities, bars, lively animation, traffic). Between these two poles fit at least two spaces representing varying degrees of enclosure. The common areas of the court, enclosed by a gate, come just after the domestic space: they constitute a relatively private space shared between neighbours, where children are free to play. Beyond this space, intermediate streets connecting several courts to the main street

10. While doing my observations, I noticed that domestic workers tend to create a place of their own within the compound: a partially limited or withdrawn place, equipped with a few personal belongings, generally corresponding with their different workstations (sentry box, garden, swimming pool facilities, stairwells, rooftop terraces for the cleaning staff). This is how they are able to receive visitors and develop a neighbourhood social life. 
are vitalised by some shops. If these streets are not closed in the literal sense of the term, they remain a semi-exclusive space, insofar as they only give access to private spaces. This continuum of spaces allows a more fluid mobility for the guards. It is not uncommon for instance to see a Buruburu askari leaving his court to talk with a colleague across the way, or to buy a soda at the small grocery on the street. The either public or private character of the streets is ambiguous enough to offer the guards a certain flexibility in their movements. Following the same logic, the gate of the court does not need to be systematically closed, which allows the askari to be absent for a short period of time.

Buruburu guards mostly come from the informal sector. They are individually recruited by the association of residents managing the court. As a result, the compliance with the security protocol is far much looser. Guards have no training, little to no equipment, few wear uniforms, and they do not fall under the supervision of a team officer. To some extent, this increases their flexibility. An observation in the neighbourhood confirms it. At Buruburu Phase II, two courts face each other: Fatia Court and Lomilio Court. In March 2016, while finishing an interview with Paul S., a Fatia Court guard, one of the guards from Lomilio, Jackson, came to interrupt our conversation. Jackson was employed by a formal company, 247 Security Ltd, unlike Paul. Two years before indeed, the inhabitants of Lomilio Court preferred to use the services of a formal security company following cases of vandalism within the court. Jackson came to Paul to propose him an agreement: if the latter agreed to come to Lomilio Court to wash resident cars, they would share the profits. Jackson could not do it himself, because his uniform forbid him. The inhabitants of Lomilio Court, in opting for a formal company, put a subsequent end to the guard's polyactivity. At Lomilio Court, they had to focus exclusively on surveillance. But the relative mobility of Jackson allowed him to outsource his extra work to Paul-a guard without uniform and foreign to the court, who would discretely do the job. This example is representative of the different tactics at work in Buruburu. Guards can play on their visibilities (uniforms or absence of uniforms), on their worker status (informal guards or formal guards controlled by team officers), as well as on their differentiated mobility, linked to the relative fluidity between different closed spaces.

\section{Conclusion}

In Nairobi, the security performance is not to be only understood as a response to identified threats. It is also, and perhaps even above all, a powerful force for social distinction. Contracting with a security company is a sign of standing, both for real estate developers and residents. Socioeconomic hierarchies are explicitly displayed through the type of security services contracted: 
international companies using high technologies for the wealthiest; local, sometimes semi-formal enterprises for the upper and middle classes; askari recruited informally for the small middle class; and protection by youth groups for the poorest populations. ${ }^{11}$ This literally distinctive value, in Bourdieu's sense of the term "distinction," does not only apply to spaces and social groups that employ security services. It logically leads to the subjection of security workers themselves, and in particular the guards. The security performance can be read as a system of representations in which the guard is, in a way, reduced to the role of a stooge. For the tenant, he-like all domestic staff-is presented as the subordinate, the inferior, the one who lacks education and whose ways (of speaking, standing, working) call back to a certain "primitiveness" (this term often comes up in interviews). For the visitor, for the customer of the mall, he must rather be a living marker of the prestige of the place. The cleanliness of the uniform, the politeness, the qualities of communication, as well as a quasi-mechanical compliancy in the exercise of the protocol are determinants in the construction of a standing. Therein lies an observable paradox of the everyday security performance: the material and symbolic construction of a peer group leads to the creation of a "zone of indistinctness" (Agamben 1997, 46) at its margins-a space that lets neither inside nor outside those who, by their own bodies, contribute to secure the community.

Finally, guards are assigned to places-gates, parking lots, entrances areas of shopping malls-that they do not choose, and from which they can be removed at any time. These places are generally located far from their place of residence, out of their fields of action, and inserted into social configurations offering them few opportunities to develop a professional sociability. As a result, some form of social immobility is added to spatial immobility. A current representation of social achievement in urban areas is based on the mobility of the individual: to be able to move, to go to work by car, to access various leisure areas, to leave for the weekend on holidays, etc. In Nairobi, in order for a small - and certainly growing - number to safely access such mobility, a large number finds itself consequently immobilised, assigned to a place or moved arbitrarily. This last remark makes it possible, in essence, to turn away from an objectivist conception of security. Observing the daily challenges and tactics of guards in Nairobi shows that the goal of security-if there is one-is never so much oriented towards a person or a property, but rather towards a "social arrangement"(Dalby 1997, 9): the collective acceptance of a given situation to the detriment of another.

11. Security mechanisms in Nairobi's slums are not covered in this chapter, which focuses exclusively on the figure of the askari posted at the entrance of privatised spaces. Security in slum is nevertheless very subtly organised. For an overview, see Rodriguez-Torres (2014). 


\section{Bibliography}

Agamben, Giorgio. 1997. Homo Sacer I. Le pouvoir souverain et la vie nue. Paris: Seuil.

Barnett, Clive. 2015. "On the Milieu of Security. Situating the Emergence of New Spaces of Public Action.” Dialogues in Human Geography 5, no. 3: 25770. https://doi.org/10.1177/2043820615607758.

Bernard, Yvonne, and Marion Segaud. 2011. La ville inquiète. Habitat et sentiment d'insécurité. La Garenne-Colombes: L’Espace européen.

Certeau (de), Michel. 1991. L'invention du quotidien I. Arts de faire. Paris: Gallimard.

Dalby, Simon. 1997. "Contesting an Essential Concept: Reading the Dilemmas in Contemporay Security Discourses." In Critical Security Studies. Concepts and Cases, edited by Keith Krause and Michael Williams, 3-32. London: University College London Press.

Gooptu, Nandini. 2013. "Servile Sentinels of the City: Private Security Guards, Organized Informality, and Labour in Interactive Services in Globalized India." International Review of Social History 58, no. 1: 9-38. https://doi. org/10.1017/S0020859012000788.

Gros, Frédéric. 2012. Le principe sécurité. Paris: Gallimard.

Leidner, Robin. 1999. "Emotional Labour in Service Work." Annals of the American Academy of Political and Social Sciences 561, no. 1: 81-95. https://doi.org/10.1177/000271629956100106.

Mac Dowell, Linda. 2009. Working Bodies: Interactive Service Employment and Workplace Identities. Malden (MA): Wiley-Blackwell.

Pain, Rachel, and Susan Smith. 2008. Fear: Critical Geopolitics and Everyday Life. Aldershot: Ashgate.

Rodriguez-Torres, Deyssi. 2014. Au cœur du bidonville de Mathare Valley. Paris-Nairobi: IFRA-Karthala.

Ruteere, Mutuma, Patrick Mutahi, Becky Mitchell et al. 2013. Missing the Point: Violence Reduction and Policy Misadventures in Nairobi's Poor Neighbourhoods. Nairobi: IDS-CHRIPS.

Schneier, Bruce. 2003. Beyond Fear: Thinking Sensibly about Security in an Uncertain World. New York: Copernicus Books.

Staeheli, Lynn, and Don Mitchell. 2008. The People's Property? Power, Politics and the Public. London: Routledge.

Standing, Guy. 2011. The Precariat: The New Dangerous Class. London: Bloomsbury.

Strobl, Staci. 2009. "Policing Housemaids: The Criminalization of Domestic Workers in Bahrain." The British fournal of Criminology 49, no. 2: 165-83. http://dx.doi.org/10.1093/bjc/azn071.

Wharton, Amy. 2009. "The Sociology of Emotional Labour." Annual Review of Sociology 35, no. 1: 147-65.

https://doi.org/10.1146/annurev-soc-070308-115944. 


\title{
Chapter 9 \\ What Education for All in Kenya? The School of Inequalities
}

\author{
Hélène Charton
}

Translated by Clare Rainey \& Hannah Stauch

Education occupies a central position in Kenya's social and political landscape, as evident in the number of schools and academic institutions throughout the territory. Key measures have been implemented over the last 10 years to democratise education by making schools accessible to everyone, particularly the poorest in society. These measures included the introduction of free primary education in 2003, followed by the abolition of secondary education fees five years later. These decisions have strengthened public debate on education issues and have featured prominently in newspaper columns.

In 2012, with official net enrolment rates of $81.8 \%$ in primary and $50 \%$ in secondary education, as well as 11 years of school life expectancy and a survival rate in primary education of $90.7 \%$, Kenya was at the forefront of the educational rankings in sub-Saharan Africa, according to data compiled by the Unesco ${ }^{1}$ Institute for Statistics. The country was then spending approximately $30 \%$ of its budget and $6.7 \%$ of its GDP on education. However acceptable this may seem, these figures, produced and compiled by the institute, were notable in what they did not reveal in terms of regional, socio-economic and gender inequalities and as such this must be borne in mind. In 2009, Kenya had more than one million children out of school. This phenomenon had been on the rise after a sharp decline in 2007 and, as in many other African countries, it has affected the poorest and most marginalised populations. In $2008,55 \%$ of girls from the poorest households in the North-Eastern region had not attended school. The quality of education provided in schools also raises many questions. According to the annual Unesco Education for All monitoring report, 6\% of young men between the ages of 15 and 29 who had left after 6 years of schooling were considered illiterate and $26 \%$ semi-literate. These figures were even more alarming for young women, with $9 \%$ considered illiterate and $30 \%$ semiliterate (Unesco 2012). With only $4 \%$ of students enrolled in universities,

1. Unesco Institute for Statistics. http://www.uis.unesco.org/DataCentre/Pages/ countryprofile. aspx ?code $=$ KEN\&regioncode $=40540$ (Unavailable, retrieved 20 August 2014). 
access to higher education remained problematic in Kenya: only $30 \%$ of qualified baccalaureate graduates were then admitted at university.

This outcome must be viewed in the context of the global standards for educational reforms implemented worldwide since 2000 in the framework of the Millennium Development Goals (MDGs), a result of the approach to education undertaken in Kenya since its independence in 1963. Some elements of this approach date as far back as the colonial period. With only $4 \%$ of its resources coming from international aid, education in Kenya is essentially a national affair, as is highlighted by the close ties between educational reform and the country's political and electoral agenda.

This chapter aims to highlight the historical dynamics that have helped shape education in present-day Kenya. First, we will address the nature and expression of the social demand for education. Then, we will examine the way in which education has been extensively invested in by the successive political regimes. This dual dynamic has been a key element in driving forward education, yet it has also been at the root of the deep geographical and economic inequalities that characterise Kenya's educational system.

\section{The Desire to Go to School}

At the beginning of the January 2003 academic year, over one million new pupils attended Kenya's government primary schools, declared as being "free of charge." The confusion generated by the implementation of the election promise made by the then new President of the Republic, Mwai Kibaki, was widely covered in the press. Coverage focused on the chaos in schools and described long queues in front of the most popular schools. ${ }^{2}$ By the end of that month, 500,000 new entrants joined schools that were often already full. ${ }^{3}$ For the sake of clarity, these figures must be put into perspective. Almost 5\% of these new entrants dropped out of school in their first year (Unesco 2005). A number of them had actually been enrolled in schools that were not recognised by the government and found in the poorest neighbourhoods, to which a few pupils returned after a while.

This phenomenon was brought to light in the poorly integrated Kibera district of Nairobi during a study carried out by the John Templeton Foundation between April 2003 and December 2005 on the existence of private educational provision for the poorest populations in Africa and Asia. It helped emphasise the importance of social demand for education in the most disadvantaged areas. Seventy-six formal private schools (not registered by the government) were identified in Kibera, which had a population of about 600,000 at that time (Tooley, Dixon \& Stanfield

2. "Admission Chaos Hits Schools." 2003. Daily Nation, 8 January.

3. “Free Education: Kenya's School Overwhelmed." 2003. Daily Nation, 20 January. 
2008, 451). This finding was made in October 2003, 10 months after the introduction of the Free Primary Education program (FPE) and included the $57 \%$ enrolment increase in the five public schools in the neighbourhood (compared to the $43 \%$ increase in Nairobi), partly at the expense of private schools. The scale of enrolment in these private primary schools, which in November 2003 had 12,132 pupils compared to 9,126 in public schools, revealed the constant demand for fee-paying education among the poorest populations. Interviews held with parents and the administrators of these schools confirmed this demand. They gave two main reasons: the cost and the quality of education. All these schools, with the exception of two run by religious congregations, received tuition fees ranging from 50 to 500 KES per month. These fees were tailored to individual situations, ranging from discounts to exemptions for large families or orphans. However, these fees are lower than the hidden fees in public schools that are non-negotiable and involve compulsory purchases, such as acquiring two sets of uniforms (compared to one in the private sector) or various other contributions (activity or construction fees). The total amount can be prohibitive for the poorest households. Teaching conditions and conditions in general are also perceived as more favourable in the private sector. Private schools are generally smaller than public schools, which accommodate up to 2,000 pupils. They also benefit from a higher teacher-pupil ratio, on average 21 pupils for every one teacher compared 60 or even 67 pupils to one teacher in public schools. These facts are crucial to the perception of what constitutes a quality education, one which even the poorest are willing to pay for. As one parent put it, "If you go to the market and are given free fruit and vegetables, they are probably rotten. If you want fresh fruit and vegetables, you have to pay for them" (Tooley, Dixon \& Stanfield 2008, 462).

As this study shows, the way in which the poor relate to education (although the inhabitants of Kibera are not all poor to the same extent) demonstrates the importance of school investment for the people of Kenya whose long-standing history is inseparable from the shortcomings of the educational provisions implemented by its successive governments.

In a colonial context marked by severe racial segregation, the educational system for the Africans, entrusted mainly to missionaries, was aimed primarily at providing for the colony's labour needs. It was in response to this narrow perspective of education that the first African initiatives for education were launched.

From their creation in 1924, the Local Native Councils, established by the colonial power to provide an avenue of legal expression for African communities, made educational development one of their priorities through the creation of mission-free schools. Mission schools were accused of foregoing their pedagogic duties in favour of evangelising. In 1926, LNCs 
spent an average of $20 \%$ of their budget on education (Mutua 1975, 152-153). The Western and Central provinces which were both the most populated and most exposed to European colonisation were at the top of this list (Charton 1997). The colonial government, anxious to avoid disrupting the fragile treaty established with the missions, never authorised the LNCs to open their own schools, as they had requested. It simply channelled the funds raised from local communities in the form of taxes to finance its own institutions (Government African schools) outside the sphere of missionary influence. In Kenya's Central Province, however, LNCs found another outlet for their education-centred mobilisation by funding independent Kikuyu schools, created following the circumcision crisis and the shutdown of many schools whose teachers had been dismissed. ${ }^{4}$ In 1935, there were 34 independent schools with 2,500 students. Ten years later, these schools, which were constantly threatened with closure by the colonial authorities, had 13,500 students enrolled. At that time, $12.5 \%$ of the African population had access to education but at primary level it was $97 \%$. The colony then had only one secondary school, Alliance High School in Kikuyu, built in 1926. The only post-secondary option was Makerere College in Uganda, which trained African administrative assistants in education, agriculture, veterinary sciences and medicine for the whole of East Africa.

The creation of the African Teachers College in Githunguri in 1939 to train teachers for independent schools and to address gaps in secondary and post-secondary education had strengthened this network, partly thanks to the investment of Chief Koinange wa Mbiyu and his eldest son, Peter Mbiyu. On his return from the United States in 1938, where he had gone to study in 1927 with the support of the Phelps-Stokes Foundation, Peter Koinange was the most educated African in the colony. Declining all job offers in the administration, he then took over the leadership of Githunguri College, which he named Teachers College, in reference to Columbia where he had obtained his master's degree. On the eve of its closure, following the declaration of a state of emergency in November 1952, nearly $30 \%$ of students in Kiambu and Fort Hall districts attended the college.

The education level of the African people tripled over the course of the decade following the Second World War, as a result of the policies of "colonial modernisation" initiated by metropolitan authorities that

4. Kikuyu independent churches were born in 1929 with the refusal of a number of worshippers to comply with the injunctions of Reverend Arthur (Church of Scotland Mission of Kiambu, Central Province) asking them to renounce traditional practices such as clitoridectomy. The dissident Christians, many of whom were teachers or catechists, founded their own network of churches and schools. 
stimulated people's investment in their children's education, as shown in the following graph:

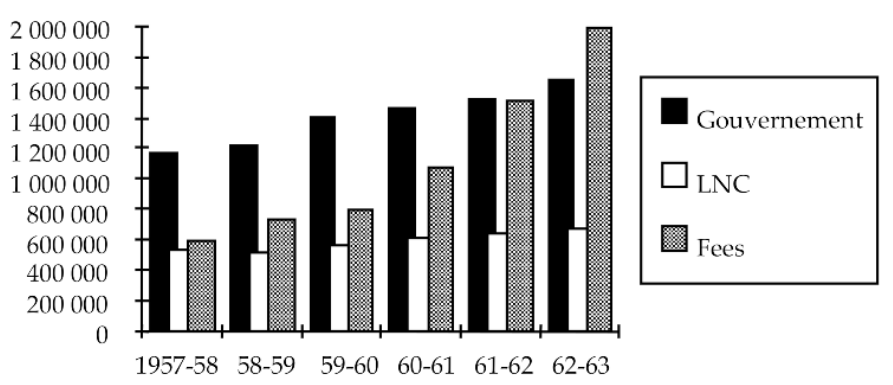

Figure 1. Education funding between 1957 and 1962 Sources: Colony and Protectorate, Education Department Triennial Surveys 1958-1960 and 1961-1963.

It was precisely these dynamics that led to an explosion in the number of schools that marked the country's transition to independence in 1963. At the beginning of the 1964 school year, primary schools welcomed over a million students, twice the number welcomed in 1957 and four times more than in 1948 (Bogonko 1992, 112). Expectations of school were then commensurate with the frustrations of the colonial era. During independence, education was officially identified as a lever for the country's economic and social development, in which all populations were invited to participate within the framework of the Harambee state philosophy.

In ten years, the number of primary schools doubled and the number of secondary schools increased tenfold. This was due to the combined efforts of the government, whose budget share for education increased from 11.9\% to $24.7 \%$ between 1963 and 1973 (Bogonko 1992, 112). The population directly contributed as part of Harambee fundraising campaigns for school construction and teacher recruitment. Harambee schools, which in 1973 accounted for $60 \%$ of secondary schools built since independence, charged high tuition fees for poor quality education compared to national and regional schools, which had limited capacity (Amutabi 2003, 130).

These institutions were created by communities to overcome the shortage of secondary education provided by the government, thus placing its educational responsibilities on local communities (as in the case of LNCs during the colonial era). Several politicians, such as Tom Mboya, spoke out against a system that reinforced social and regional inequalities as regards access to education, but without any real success apart from increased inspections and some additional resources. However, most Harambee schools were integrated into the national system in 1974, but in an unequal manner, since it was the central province that benefited most from these 
takeovers, strengthening an already dense network of schools in the region (Hornsby 2013, 138-140).

These different stages in the long history of education in Kenya highlight the scale of the demand for schools and the extent of people's commitment to education (Charton 2011, 219-237). The way in which this desire for education has been used politically is a second characteristic feature of the history of education in Kenya. While it can also be traced back to colonial times, it actually took effect in 1973 when free primary education was first introduced. The 2003 presidential decree included nothing new. It simply reiterated, in a very different political, economic and international context, one of the key measures by the Father of the Nation, Jomo Kenyatta. This was implemented on the country's tenth year of independence and was approved by his successor, Daniel arap Moi, upon his arrival to power in 1978. The history of education is closely linked to the country's political history. It can also be claimed that education has been a major instrument of political legitimisation for the various governments that have succeeded each other since independence.

\section{School as an Instrument of Political Legitimacy}

In 2003, as well as in 2008, the withdrawal of school fees from primary and, later, secondary schools, was in line with the election promises made by then candidate Kibaki. These latter measures benefitted from an international climate favourable to their implementation within the context of the MDGs and Education for All programmes supported by international benefactors. However, like the two previous experiences of free primary education, they occurred at significant moments in Kenya's political life. A major political legacy driven by strong social demand, universal education was brandished by each of Kenya's three presidents during periods of transition and political fragility in order to restore the social bond between society and its government.

Initially driven by African nationalist movements in the 1940s, universal education has always been at the centre of Kenya's political agenda. Present in the memorandum sent by the representatives of the Kenya African Union (the first national political association) to the Colonial Office in 1945, universal education remained a social ideal enshrined in the 1960 KANU (Kenya African National Union) manifesto, which was the heir to nationalist struggles. When Kenyatta became Prime Minister on 1 June 1963, he identified education as a national priority on which all the efforts of the Kenyan people should be focused (Kenyatta 1965). On the tenth year of independence, the 1973 Presidential Decree which established free primary education for the first four stages and capped enrolment fees at 60 KES (8.5 USD) for the other three stages was in line with this 


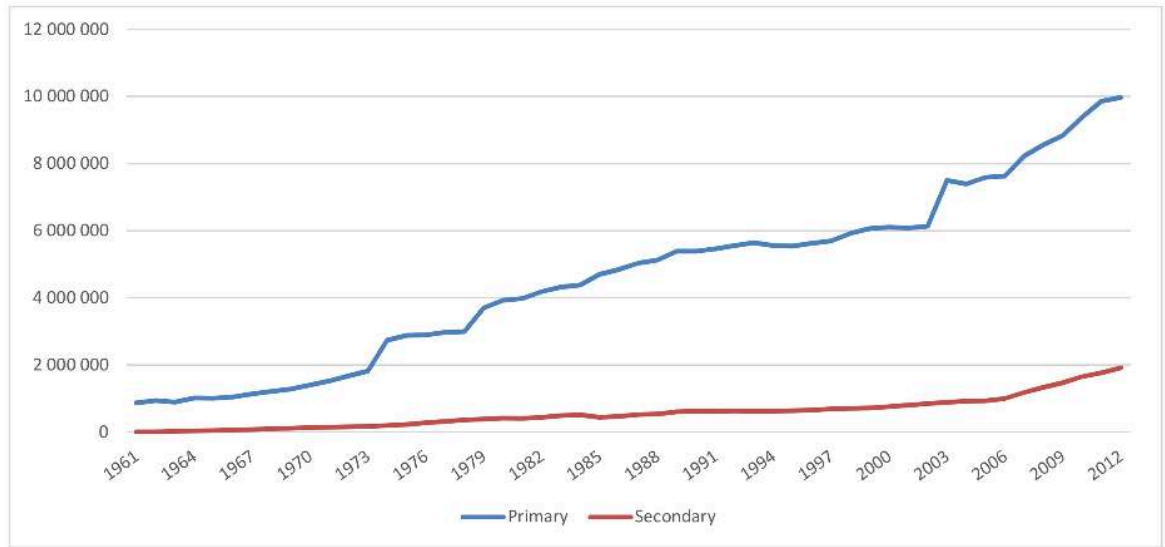

Figure 2. Primary and secondary school enrolment 1961-2012 Source: Ministry of Planning and National Development. Statistical Abstract (1960 to 2012). Nairobi: Government Printer.

tradition. The President's "gift" to the Nation was a concrete reaffirmation of KANU's commitment to universal education while rewarding the efforts and sacrifices made by the population for educational development. The effects of this measure were immediate and saw the arrival of 1.8 million additional students and a $152 \%$ increase in first-year enrolment. Despite large drop-outs in the first few years $(54.7 \%$ of students who entered the system in 1973 had left the system four years later) first-year enrolment stabilised at a high level $(600,000$ new students) and drop-out rates were "normalised" (20\% of drop-outs after three years in the 1976 study: Somerset 2007, 10-11). To cope with this influx of students, the government undertook a massive recruitment drive for unqualified teachers. Their numbers rose from $22 \%$ to 37\% between 1973 and 1976, thus maintaining the teacher-pupil ratio at a relatively low level (one teacher per 32 pupils: ibid., 14-15). But welcoming new entrants required additional classrooms to be built at the expense of schools and, therefore, families. Numerous rises in compulsory contributions for buildings, activities and even security (Abreu 1982) began to arise. As these schools were not governed by any legislation, there were significant disparities between schools, some charging fees ten times more than the tuition fees that existed prior to 1974 (Somerset 2007, 11). By 1978, primary education everywhere had become more expensive than it had been in 1973 (Charton 2005).

It is within this context that Daniel arap Moi, who succeeded Kenyatta in 1978, kicked off his presidency by abolishing all contributions at all primary stages. The 1978 decree provided the new president, from a minority ethnic group, with an opportunity to assert his political legitimacy by following in the footsteps and actions of his predecessor, while endorsing KANU's legacy. As in 1973, the implementation of the presidential decree 
in January 1979 led to a new influx of pupils into primary schools with 970,000 new enrolments in the first year. Enrolment rates remained high in the years following the adoption of the measure (900,000 pupils) but equally drop-out rates remained very high with $45.5 \%$ of pupils who entered school in 1979 still in school five years later and only $32.2 \%$ at the end of the seven-year primary cycle. Due to a lack of recruitment, the teacher-pupil ratio had increased significantly to 1:39 (Somerset 2007, 1415). As in 1973, covert school fees soon reappeared, making free schooling obsolete. The comprehensive " $8-4-4$ " 5 reform of the education system, which came into effect in 1985, placed a heavy burden on households. The extension of the primary cycle by one year, from 7 to 8 years, required the construction of new classes $(13,370)$ and additional equipment for technical and agricultural disciplines (laboratories, workshops, etc.). These costs were largely borne by parents through the reappearance of additional fees and the proliferation of Harambee for the construction of new buildings. Since 1983, school supplies had no longer been provided by schools and parents were officially responsible for equipping classrooms. The emphasis on basic education (with a specific ministry from 1979) at the expense of other educational stages has corresponded to the liberal shift taken by international organisations and the emergence of the first structural adjustment plans (applied in Kenya in the 1990s) to try to recover economies in crisis. While population growth continued at a sustained pace, weighing heavily on the education system, Kenya's economic growth slowed with a decline in GDP from 6.5\% to 3.7\% between 1964 and 1984 (Ogot \& Ochieng' 1995, 151-153). School adjustment policies were defined in a 1988 World Bank report entitled Education in Sub-Saharan Africa: Policies for Adjustment, Revitalization and Expansion. In a context where resources are scarce, priority should be given to sectors where the social return on public investment is most significant. According to calculations by World Bank economists, this was the primary stage (Heyneman 2005).

At secondary and higher levels, where education was considered a personal investment due to its direct employment benefits, cost-sharing with beneficiaries was advocated. These recommendations were endorsed in Sessional Paper No. 6 of 1988, which introduced the principle of "Cost sharing with beneficiaries." This was applied in Kenya from 1991, with the cost of boarding school fees for public secondary schools transferred to parents and the introduction, for the first time, of higher education fees initially set at 6,000 KES (100 USD) before being increased to 50,000 KES (833 USD) in 1998. Despite the existence of scholarships and, more especially, loans granted by the Higher Education Loans Board (HELB) to the

5. Schooling is now divided into a 8-year primary cycle, followed by a secondary cycle and a higher cycle of 4 years each. 
majority of students, these measures contributed to preventing the poorest populations from accessing university (Klopp \& Orina 2002, 60). As in most African countries, students, who were almost guaranteed employment in public services and parastatal companies, hitherto enjoyed privileged conditions (free education and pensions and an allowance known as the "boom": Eshiwani 1993, 46 \& 51). This policy proved to be disastrous at all levels. In a context of increasing extreme poverty, school had never been more expensive. Between 1994 and 1997, the average annual burden for the families of a primary school pupil increased from 843 KES to 1,200 KES (12 USD to 22 USD), covering contributions for classroom construction, examination fees, the purchase of books, equipment, uniforms, cutlery and mattresses in boarding schools, etc. This excluded the most economically vulnerable populations (Koech 2000, 75). For those who managed to complete primary education, opportunities to pursue secondary education continued to decline with transition rates falling from $49 \%$ to $40 \%$ between 1992 and 1999 (ibid., 94). The crisis in the education system that began in the 1990s resulted in an unprecedented erosion of gross enrolment rates to $89 \%$ in 1998 , from $105 \%$ in 1989.

For the first time in Kenya's history, some populations were shying away from school, hence disrupting the school dynamics established since independence. The government attempted to address the school crisis, which showed similarities with the social and political crisis the country was experiencing at the time. They appointed an inquiry commission on the eve of the 1997 general elections, in a climate of extreme political tension and violence, which was to carry out a thorough reform of the education system. The announced school reforms were supposed to ease the political and social climate but President Moi quickly buried these promises as soon as he was re-elected. The Koech Commission report was published three years later, in 2000, and despite strong protests and strikes by 50 schools (including the prestigious Alliance Girls High School) the government limited itself to flashy measures, such as shortening the curriculum, instead of remodeling the system as a whole by moving from the 8-4-4 structure to a 12-year basic cycle, as recommended in the report (Charton 2003).

It is in this climate of crisis and breakdown of dialogue between state and society that the theme of universal education resurfaced at the heart of the electoral platform of the opposition coalition led by Mwai Kibaki (NARC 2002). As a key measure of the National Rainbow Coalition's (NarRC) programme, free primary education was not only the President's "gift" to his people, as in 1973, but the pledge of a new social agreement that the new democratically elected government intended to establish. The guarantee of equal access to education for all citizens refers to the principles of justice and equity. This forms the basis of the Nation's rebuilding to which the 
new President and his team have committed themselves. ${ }^{6}$ After ten years of major crisis, this measure had a very strong symbolic significance in that it marked a break with the practices and excesses of the previous regime while continuing the legacy of Kenyatta. The context in which free education was restored in primary schools in January 2003 was, however, very different from that of 1973. At an international conference held in Jomtien, Thailand in 1990, and more so at another international conference held in Dakar in 2000, the international community and donors committed themselves to universal primary education by 2015. This is the second "Millennium Development Goal." Free education programmes, introduced in Malawi in 1994 and Uganda in 1997, subsequently became more widespread, thanks to the support of international donors. As in the 1973 and 1978 experiments, the abolition of school fees generated a significant influx of new pupils, whose numbers remained high. Kenya's primary schools recorded a 32\% increase in enrolment in the first year at the beginning of the 2003 school year (Oketch \& Somerset 2010). The state was able to meet the direct cost of the Free Primary Education program, estimated at 62 million USD, thanks to the release of 69.5 million USD ${ }^{7}$ (a one-quarter increase in the education budget) to pay schools the allocations calculated in proportion to the number of enrolled students. However, the success and sustainability of the reform depended on the new team's ability to attract external funding by restoring donor-confidence, shaken over the last ten years of the Moi era. The ERS (Economic Recovery Strategy for wealth and employment creation), endorsed by international donors in 2004 and backed by the education sector strategy, had established priorities for action in terms of economic and financial governance. The national consultation, which brought together 800 participants in November 2003, made it possible to define the orientations of the sectoral education strategy, adopted on 25 July 2005 under the title, Kenya Education Sector Support Programme 20052010-Delivering quality education and training to all Kenyans (KESSP). KESSP, which was $89 \%$ government-funded, received support from donors through the Education Donor Coordination Group (EDCG), including 80 million USD from the World Bank in 2006 and 121 million USD from the Fast Track Initiative.

Building on these successes, Mwai Kibaki promised to withdraw school fees in secondary public day schools if he were re-elected in December 2007. However, this policy, implemented in January 2008 during a climate of high tension following the violence that followed the disputed election results, did not keep all its promises. However, the extension of free education

6. Inaugural speech of the 3rd President of Kenya, Mwai Kibaki, on 30 December 2002, Nairobi.

7. Daily Nation, 30 April 2003. 
to secondary schools made it possible, as the FPE did, to bring back to secondary schools the children of those economically weakened by the crisis, without affecting the poorest.

Yet the main effect of the high volume of pupils accessing primary education, and to a lesser extent secondary education, was the reinforcement of the hierarchies and differentiation strategies of schools and families, hence an increase in the already glaring social and geographical inequalities. In Kenya, the poor had never been to school in such numbers, yet the schools they were attending were schools for the poor.

\section{What Type of Universal Education in Kenya?}

Historically, with nearly ten million children enrolled in primary school compared to one million at the time of independence and a net enrolment rate of $82 \%$ in primary schools and $50 \%$ in secondary schools in 2012, according to Unesco statistics, ${ }^{8}$ the measures taken over the past 40 years to promote universal education seemed to have yielded some results. However, despite these proactive measures promoting access to education, poor and marginalised populations continued to be excluded from school.

Social and geographical inequalities in access to education have been, in fact, another characteristic feature of Kenya's education system, the origins of which are old and have worsened rather than been rectified over time. Policies to increase access to education have automatically led to an increase in supply which has diversified in response to the remodeling of high social demand. The privatisation of education at all levels (from preschool to university) has portrayed, until today, both the persistent desire for education that is still strong yet not satisfied by the public authorities and the role that schools play in the process of differentiation and social stratification.

Since the colonial period, education provision has been developed locally, depending on the mobilising capacity of communities (LNC, Harambee) and the degree of investment by local political leaders, who have sometimes endowed their districts with institutions bearing their names as in the "Kenyatta High" or "Moi Girls" model (Amutabi 2003, 131). Initiatives by political elites to promote access to school capital for their citizens have further enhanced these inequalities, projecting the ethnic difficulties that structure contemporary Kenyan politics into the school setting. Thus, in 1984, President Daniel arap Moi decided to increase the quota of places reserved for primary school pupils in the region's prestigious high schools

8. Unesco Institute for Statistics. http://www.uis.unesco.org/DataCentre/Pages/ countryprofile.aspx?code $=K E N \&$ regioncode $=40540$. (Unavailable, retrieved le 20 August 2014). 
from $60 \%$ to $85 \%$. This policy, in addition to strengthening the "ethnicisation" of society, enabled the Rift Valley (President Moi's region of origin) to catch up with the level of secondary education in the central province. When Mwai Kibaki came to power in 2003, he was quick to restore the quotas to their original proportions (Hornsbt 2013, 649).

Such features produced strong regional disparities. In 1969, the central province had gross primary school enrolment rates of $102 \%$, while only $56 \%$ and $43 \%$ of children in Nyanza and Rift Valley provinces were enrolled (ibid., 267). Some districts, such as Nyeri, had almost achieved universal education by 2003 , when the net primary school enrolment rate was only 40\% in the North East region in 2010 (Oketch \& Somerset 2010, 10). Regions with high school capitals were those that best resisted the 1990 crisis, further increasing geographical inequalities not yet tackled by free education programmes (apart from specific actions in arid and semi-arid areas), nor have they made it possible to solve the social inequality problem reproduced by schools.

Admittedly, free education has increased access to schools for the poor but perhaps not for the poorest because school has never been completely free. In a broad context, the hidden costs of education have made it possible to maintain distinct hierarchies between schools by practising convoluted forms of selectivity. A survey conducted between 2007 and 2008 among 17 schools (14 public and three private) in four districts (Nairobi, Nyeri, Kajiado and Kisii) revealed the differential effects of the EPF on access to education. Some public schools continued to select their students by charging twice as much as anywhere else. In Kisasa (Nairobi), for example, the total amount of contributions that replaced traditional school fees reached an annual total of 143 USD, one year after the introduction of the EPF. In Kazi (Nyeri), where additional contributions were abolished, first-year places were reserved for students in the private kindergarten section (16 USD per month). These schools have thus bypassed the EPF by screening their pupil recruitment, in order maintain the reputation and level of their schools. In 2006, Kazi was ranked sixth in Nyeri District for its results on the Kenya Certificate of Primary Education (KCPE) exam which determines access to secondary education (Oketch \& Somerset 2010, 10).

Despite the scholarships introduced by the government in 1994, the poorest populations remained less likely to continue on to secondary education. The distribution of students according to family income level shows that, in 2012, $10 \%$ of the lower echelon had access to this level of education compared to $55 \%$ of boys and $42 \%$ of girls in the higher echelon (Muriithi Muhindi 2012,34). Despite the abolition of school fees in 2008, it was not possible to address these inequalities. A study conducted in the Nyeri region in 2009 with 33 secondary schools, showed that the government's 


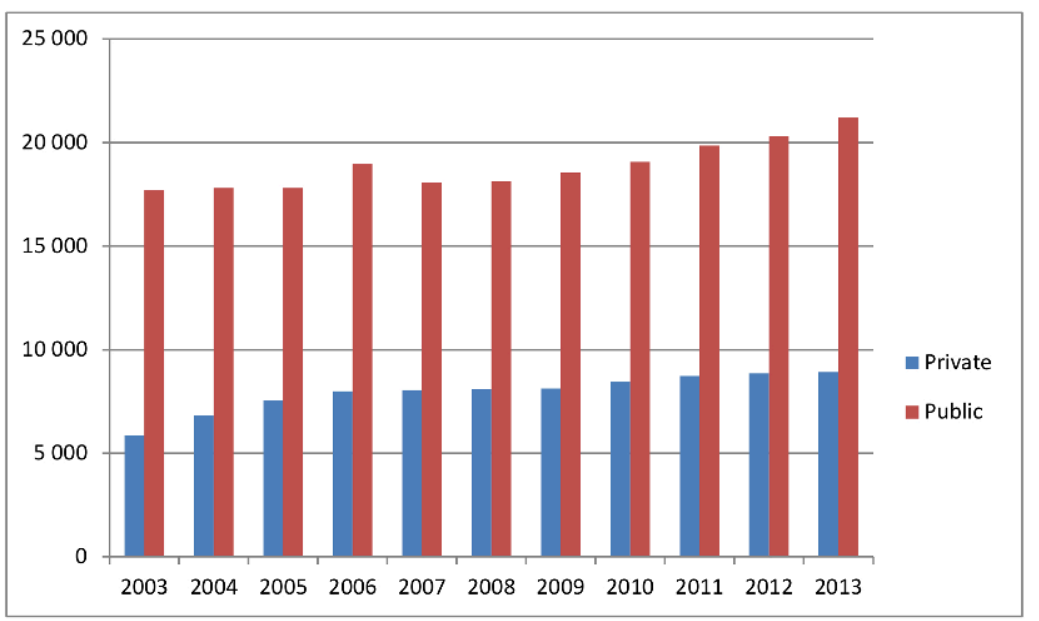

Figure 3. Number of private and public primary schools from 2003 to 2013 Sources: Government of Kenya. 2004. Economic Survey. Nairobi: Government Printer.

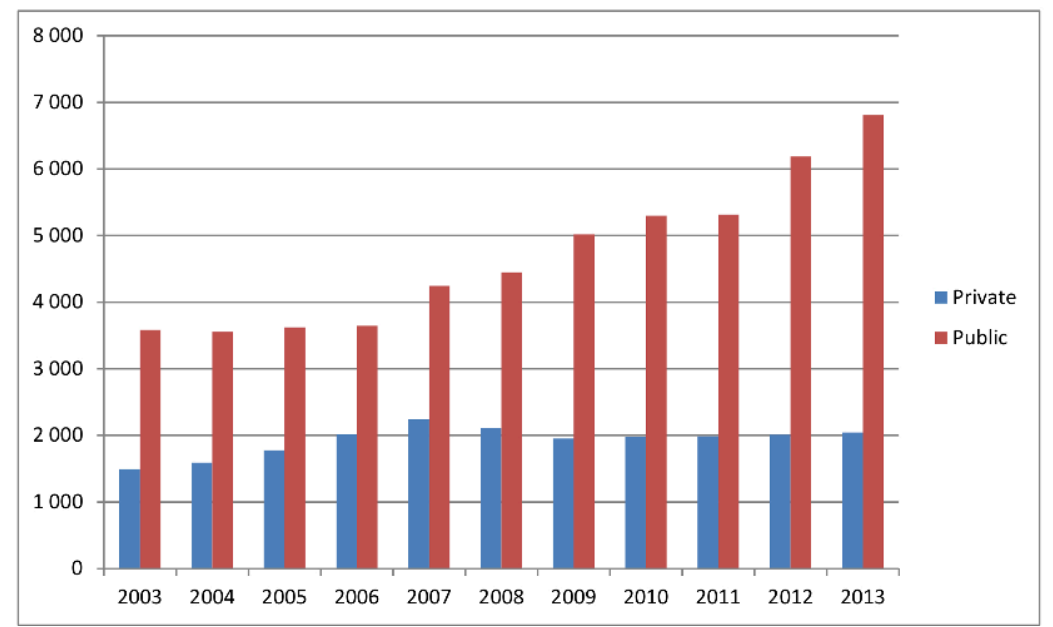

Figure 4. Number of private and public secondary schools from 2003 to 2013 Sources: Government of Kenya. 2004. Economic Survey. Nairobi: Government Printer.

allocation to secondary schools of 10,625 KES per enrolled student was not sufficient to cover their actual needs, estimated at 24,590 KES by the school principals who were interviewed. Above all, however, the total cost of mandatory purchases was estimated at 9,230 KES (uniforms, dictionaries, atlases, etc.) to which was added 3,200 KES for the purchase of additional equipment required by most schools (school bags, sports equipment, school T-shirts, etc.). These additional costs remain an exclusion factor for certain population groups (ibid., 51). As with scholarships, the reduction in secondary school tuition fees has mostly affected children who are already in school. 
All in all, the abolition of (partial) school fees in primary and secondary education has improved access to education for a greater number of children without changing the hierarchies and selection methods still occurring in some schools. Expanding this basis has automatically led to increased selectivity towards higher education, one of the consequences of which has been the development of private education and new forms of "privatisation" of public education.

Private primary education developed during the crisis in the 1990s to fill the gaps left by public education provision. At that time, Kenya had 290 private primary schools, mainly located in urban areas, but ten years later, 1,236 schools, and 7\% of the school population, were registered. Free programmes have led to an increase in this trend, as shown in the following graphs. The proportion of pupils enrolled in private schools increased from $10 \%$ to $15 \%$ between 2004 and 2011 .

From the 1990s, most private schools began to position themselves in the high-performance education niche, as shown by the results obtained in the national end-of-primary (KCPE) and secondary (KCSE-Kenya Certificate of Secondary Education) examinations. With only 1\% of candidates in 1996, private schools had won the top ten positions at KCPE. Five years later, in 2001, 27 of the top 30 scoring schools were private schools. In Nairobi and Nyeri district, private schools occupied the top 57 and 45 places in the KCPE ranking in 2007 (Oketch \& Somerset 2010, 24).

The results obtained in this examination are crucial because they determine the orientation of students towards the different types of secondary schools that do not offer the same conditions of study and opportunities for university access. The 18 national institutions, which are schools dating back to the colonial period, recruit the best primary school students (1\%) and obtain the best results in the KCSE, whose grades determine access to university. Next come provincial schools $(20 \%)$, which developed in the 1960s under a system of regional quotas. The vast majority are oriented towards district schools, most of which are former Harambee schools, "free" since 2008 (they are day schools, unlike the other two categories: Oketch \& Somerset 2010, 24). This prioritisation of educational provision determines the school strategies of families who strive, when they have the means, to choose the most efficient primary (or even nursery) schools and employ private tutoring so that their children succeed in entering a national or provincial secondary school where students are most likely to go to university. Such a system helps promote social inequalities in access to education. These actions were denounced by the 1998 Koech report, whose recommendations proposed the abolition of the KCPE and the classification of primary schools (Koech 2000). The report found that the deterioration in pupil reception conditions in public 


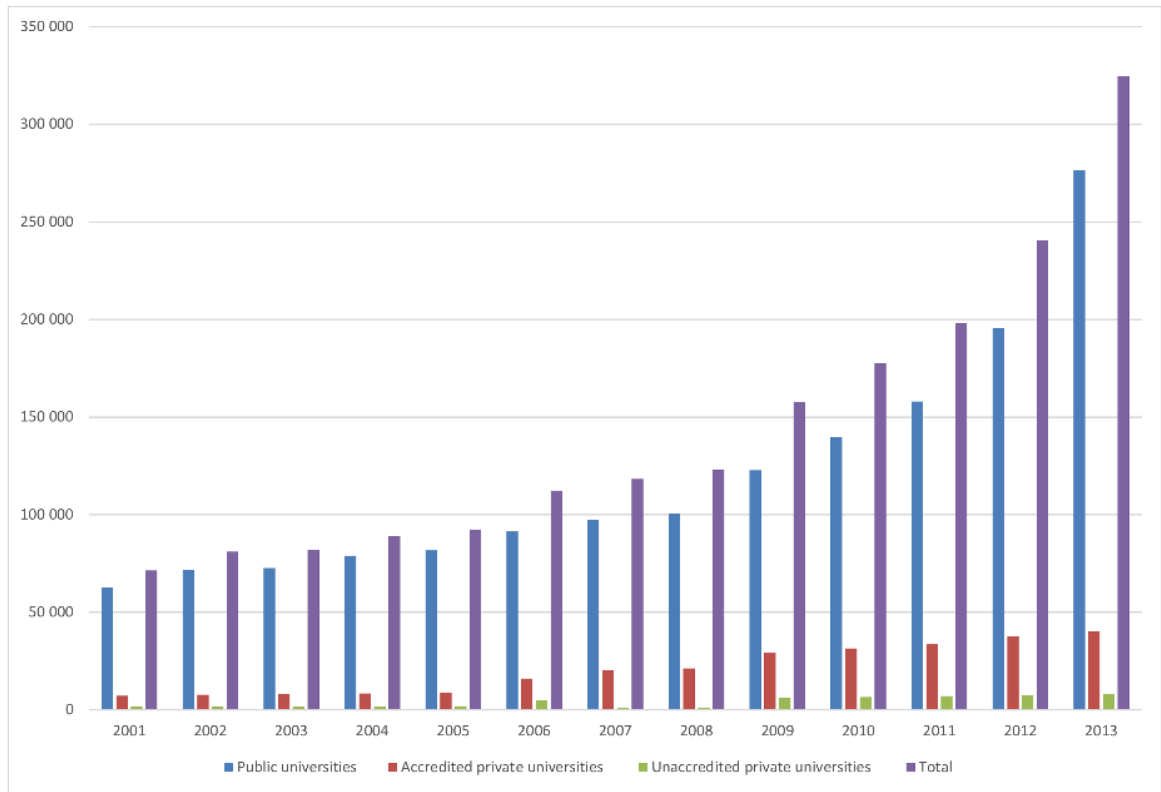

Figure 5. University enrolment from 2001 to 2012

Sources: Ministry of Planning and National Development, Statistical abstracts, Nairobi Government printer.

schools since the introduction of free education programmes had further increased the divisions between schools and widened the inequality gap in access to education, also found at higher education levels.

The total number of students enrolled in university increased fivefold, from 44,000 to 240,000 between 1996 and 2012. Public and private provisions increased considerably during this period, after the creation of five new higher education institutions from 1984, bringing the total number of public universities to seven. ${ }^{9}$ After the opening of the Baraton University of East Africa in 1991, the Commission for University Education (CUE) increased the number of accredited private universities from 18 to 30 between 2005 and 2012 (and enrolment from 8,800 to 37,600 during the same period: Mwiria 2007, 21). To meet the ever-increasing demand for higher education, public universities started to offer private courses from 2006. Known as "parallel courses," their annual cost varied between 120,000 KES for an Arts student

9. Sources: Commission for University Education, http://www.cue.or.ke [archive], list updated in 2014. After the creation of Moi University in Eldoret in 1984 (President Moi's home region), three higher education institutions were granted university status (Kenyatta University, Egerton University, and Jomo Kenyatta University of Agriculture and Technology) and two new universities were created, Maseno University in 2001 and Masinde Muliro University of Sciences and Technology, in Kakamega (Western Province) in 2006. 
and 450,000 KES for a medical student (excluding boarding fees), while the average enrolment fee for regular courses was $28,500 \mathrm{KES}$ in $2008 .{ }^{10}$

Like private universities, these courses welcome baccalaureate graduates who qualified to enter university but whose KCSE grades were not enough to enter regular training. In 2006, 10,600 of the 47,000 qualified high school students had obtained a place in public education ${ }^{11}$ and by 2012 it was still less than one third of the initial amount. The teaching conditions on parallel courses, whose numbers exceed those of regular courses, also attract students who can prepare the same diplomas without facing the threat of strikes and administrative bottle-necks that lengthen the duration of studies (Charton 2012). Frequently denounced as a hindrance to the quality of education and a source of inequality, the merging of these courses with regular training, recommended by a report by the Public University Inspection Board, has been constantly postponed, as the public university finds itself unable to welcome all the graduates. ${ }^{12}$ In the meantime, the Higher Education Loans Board is offering loans to students on parallel courses and endorsing the privatisation process.

\section{Conclusion}

The educational landscape of present-day Kenya is the end result of a long process of structuring, whose roots date back to colonial times. The importance of the school experience, which has been reflected in the different forms and degrees of investment by the population throughout the country's history, has made it a major political subject and a central point for agreement on the bond between state and society. Since independence, successive governments, aware of the challenges related to education have systematically used educational issues to assert their legitimacy in times of political tension or fragility. This dual dynamic of a social and political nature has enabled education to reach unprecedented heights over the past half-century without, however, questioning the elitist and selective nature of the education system inherited from the colonial period and reflected in strong social and regional inequalities. The latest measures taken to promote universal education in the context of educational liberalisation is a far cry from addressing these trends. Instead, it has heightened them

10. "Move to Abolish Parallel Programmes in Kenyan Universities." 2009. The Standard, 30 March. http://africanewsonline.blogspot.com/2009/03/move-toabolish-parallel-degree.html [archive].

11. The Standard, 26 June 2006.

12. Ngare, Peter, and Benjamin Muindi. 2008. "Parallel Degree Programmes Blamed for Declining Quality of Education.” Daily Nation, 24 August. https:// nation.africa/kenya/news/parallel-degree-programme-blamed-for-decliningquality-of-education--555980 [archive]. 
by confirming the existence of second-class schooling for the poorest. In this we can conclude that the education system reflects and crystallises the social, regional economic and political divisions of present-day Kenya.

\section{Bibliography}

Abreu, Elsa. 1982. The Role of Self-help in the Development of Education in Kenya: 1900-1973. Nairobi: Kenya Literature Bureau.

Amutabi, Maurice. 2003. "Political Interference in the Running of Education in Post-Independence Kenya: A Critical Retrospection." International fournal of Educational Development 23, no. 2: 127-44. https://doi.org/10.1016/S0738-0593(01)00055-4.

Bogonko, Sorobea. 1992. A History of Modern Education in Kenya (1895-1991). Nairobi: Evans Brothers.

Charton, Hélène. 1997. Le désir d'écoles, les initiatives africaines dans l'éducation au Kenya. Paris: Publications de l'Université Paris 7-Denis Diderot.

Charton, Hélène. 2003. "La débâcle éducative du Kenya. Éléments d'analyse historique." Cahiers d'Études africaines 169-70, no. 13: 189-208. https://doi.org/10.4000/etudesafricaines.196.

Charton, Hélène. 2005. "L'école primaire gratuite : chimère politique ou idéal social ?" In L'Annuaire de l'Afrique de l'Est 2004, edited by Hélène Charton and Claire Médard, 239-78. Paris: L'Harmattan.

Charton, Hélène. 2011. "Réformes éducatives et légitimation politique au Kenya." Cahiers de la recherche sur l'éducation et les savoirs 10: 219-37. https://journals.openedition.org/cres/322.

Charton, Hélène. 2012. "La place des universités africaines dans le nouveau paradigme scientifique mondial: le cas du Kenya." In Universités, universitaires en Afrique de l'Est, edited by Nicodème Bugwabari, Alain Cazenave-Piarrot, Olivier Provini and Christian Thibon (eds), 237-55. Paris: Karthala.

Eshiwani, Georges. 1993. Education in Kenya since Independence. Nairobi: East African Education Publishers.

Heyneman, Stephen. 2003. "The History and Problems in the Making of Education Policy at the World Bank 1960-2000." International fournal of Educational Development 23: 315-37.

https://doi.org/10.1016/S0738-0593(02)00053-6.

Hornsby, Charles. 2013. Kenya: A History since Independence. London: IB Tauris.

Kenyatta, Jomo. 1965. Harambee! The Prime Minister of Kenya's Speeches, 1963-64: From the Attainment of Internal Self-government to the Threshold of the Kenya Republic. Nairobi: Oxford University Press.

Klopp, Jaqueline, and Janai Orina. 2002. "University Crisis, Student Activism, and the Contemporary Struggle for Democracy in Kenya." African Studies Review 45, no. 1: 43-76. https://doi.org/10.2307/1515007. 
Koech, Davy. 2000. Totally Integrated Quality Education and Training TIQUET: Report of the Commission of Inquiry into the Education System of Kenya. Nairobi: Government Press.

MEST (Ministry of Education, Science and Technology). 2005. Sessional Paper no. 1 of 2005 on Policy Framework for Education Training and Research: Meeting the Challenges of Education, Training and Research in Kenya in the $21^{\text {st }}$ Century. Nairobi: Government Printer.

MEST (Ministry of Education, Science and Technology). 2005. Kenya Education Sector Support Programme: Delivering Quality Education and Training to All Kenyans. Nairobi: Government Printer.

Muriithi Muhindi, Dedan. 2012. "Challenge Facing the Implementation of Free Day Secondary Education: A Case Study from Nyeri South District, Nyeri County in Kenya." MD Dissertation. Nairobi: Kenyatta University. http:// ir-library.ku.ac.ke/handle/123456789/6425.

Mutua, Rosalind. 1975. Development of Education in Kenya. Nairobi: East African Literature Bureau.

Mwiria, Kilemi, et al. 2007. Public \& Private Universities in Kenya: New Challenges, Issues \& Achievements. Nairobi: James Currey.

NARC. 2002. Democracy and Empowerment. Manifesto for the National Rainbow Coalition. Nairobi: Nairobi Rainbow Coalition.

Ogot, Betwell, and William Ochieng'. 1995. Decolonization and Independence in Kenya (1940-1993). Nairobi: East African Education Publishers.

Oketch, Moses, and Anthony Somerset. 2010. "Free Primary Education and After in Kenya: Enrolment Impact, Quality Effects, and the Transition to Secondary School." CREATE Pathways to Access Research Monograph 37: University of Sussex Centre for International Education \& University of London.

Somerset, Anthony. 2007. "A Preliminary Note on Kenya Primary School Enrolment Trends Over Four Decades." CREATE Pathways to Access Research Monograph 9: University of Sussex Centre for International Education.

Tooley, James. Pauline Dixon and James Stanfield. 2008. "Impact of Free Primary Education in Kenya: A Case Study of Private Schools in Kibera." Educational Management Administration \& Leadership 36: 449. https://doi.org/10.1177/1741143208095788.

Unesco. 2005. Implementing Free Primary Education in Kenya: Assessment Report. Paris, Unesco.

Unesco. 2012. Education For All Global Monitoring Report. Education in Kenya. Fact Sheet. Paris, Unesco. http://www.unesco.org/new/fileadmin/ MULTIMEDIA/HQ/ED/pdf/EDUCATION IN KENYA A FACT SHEET. pdf [archive]

World Bank. 1998. Education in Sub-Saharian Africa: Policies for Adjustment, Revitalization and Expansion. Washington: World Bank.

https://documents.worldbank.org/en/publication/documents-reports/ documentdetail/276651468193498631/education-policies-for-sub-saharanafrica-adjustment-revitalization-and-expansion [archive]. 


\section{Media}

"Admission Chaos Hits Schools." 2003. Daily Nation, 8 January.

"Free Education: Kenya's School Overwhelmed." 2003. Daily Nation, 20 January.

"Move to Abolish Parallel Programmes in Kenyan Universities." 2009. The Standard, 30 March. http://africanewsonline.blogspot.com/2009/03/moveto-abolish-parallel-degree.html [archive].

Ngare, Peter, and Benjamin Muindi. 2008. "Parallel Degree Programmes Blamed for Declining Quality of Education.” Daily Nation, 24 August. https://nation.africa/kenya/news/parallel-degree-programme-blamed-fordeclining-quality-of-education--555980 [archive]. 

Focus no. 2

\title{
The Regionalisation of University Systems: An Empty Shell?
}

\author{
Olivier Provini
}

Translated by I.f. Walker

In 2006, the Inter-university Council of East Africa (IUCEA) and the German Academic Exchange Service (DAAD) established a partnership to promote quality assurance programs within public and private universities in East Africa. Between 2006 and 2012 the DAAD invested 1.4 million EUR for this large scale project for the sector. This cooperation programme has, among other things, enabled staff from various universities to undertake management training in Germany and to draft framework documents that set benchmarks and regional standards for public and private institutions' quality assurance procedures. This collaboration between the IUCEA and DAAD is part of a policy of harmonisation of certain activities in higher education institutions within the framework of the East African Community (EAC) and based on the European integration model (the European Union and the Bologna Process).

This inter-university council is an organisational structure of the EAC, the inception of which dates back to 1970, following the dismantling of the University of East Africa. Indeed, the formation of the IUCEA has been supported by the legacies of the universities of Nairobi (Kenya), Makerere (Uganda), and Dar es Salaam (Tanzania), all of which share a singular history and common anglophone academic practices as they formed, between 1963 and 1970, the University of East Africa, an independent college of the University of London. Because of this, the IUCEA's official mission has been to coordinate and pilot regional university policies with higher education national commissions from each member country, the sector being thought of as a driving force for regional integration. IUCEA's principal objectives are therefore to facilitate contact between leaders of East African universities, to provide an arena for discussion for higher education stakeholders, and to establish comparable academic standards. The IUCEA is therefore a space that encourages a priori the sharing of technical expertise, while disseminating a specific vision of what it is, what it must be and what it means to be a university. Since the end of the 1990s and the beginning of the 2000s, IUCEA's successive executive secretaries, notably Tanzania's Mayunga H.H. Nkunya and Rwanda's 
Alexandre Lyanmabje, have indicated their willingness to strengthen the standardisation of the regional space, in particular on the basis of this quality assurance policy.

One of the central changes adopted by higher education institutions in the region, that is however overlooked in the scientific literature, resides in very transformations of the governance of public and private universities by the advent of this regional quality assurance policy. The apparent necessity of establishing these new procedures has been legitimised by the IUCEA regarding the challenge encountered by since the end of the 1990s: the massification of higher education. With the flourishing of public and private universities, one has witnessed the advent of a substantial regional higher education market. For example, Kenya currently has 25 public universities and 68 private ones; Uganda has 11 public and 33 private; Tanzania has 11 and 29. The decaying state of public institutions has freed up space in the higher education market due to the rise in demand. The private university has therefore positioned itself as a credible alternative to public higher education. This massification of higher education commits political leaders and universities to respond to the increase in the number of students. Kenya, for example, went from having 62,677 students enrolled in higher education in 2002 to 194,528 in 2013, an increase of around 210\% in just over ten years. Yet, the increase in staff numbers brings into question the quality of outputs in private institutions as well as public. The IUCEA, within the framework of the EAC's framework, has therefore positioned itself as an institution that hopes to improve and harmonise the functioning of universities in the region.

By taking a position on sensitive policy subjects such as regional harmonisation of university tuition fees, the IUCEA shows that it has significant ambitions to oversee further reforms, whether these are in national policies or more local strategies. However, the IUCEA and the EAC do not yet possess the restrictive legislative framework to directly manage university policies in the region and to establish a harmonisation of university structures. Notably, the IUCEA does not yet own the budgetary or human resources for its ambitions and so must form numerous partnerships with foreign founders to lead these regional programmes. At first sight the IUCEA appears to be an empty shell, where historic public universities such as those of Nairobi, Makerere and Dar es Salaam are poorly represented. The IUCEA is instead co-opted by new universities, both private and public, that find visibility for themselves there. The semiregular conferences that the IUCEA organises are not decisive spaces for public higher education policy where future transformations of institutions are discussed and played out-these meetings and seminars are, rather, 
spaces for socialisation that allow political and administrative actors to meet each other, to exchange views, and to establish new partnerships.

The activities of the IUCEA, within the framework of the EAC, thus question the regionalisation of public higher education policies in East Africa. Regional integration promotes the dissemination of dominant theories on the reforms to be undertaken, a dynamic that is facilitated by the IUCEA's activities and by the movement of academics. However, harmonisation and regularisation of university systems in East Africa is still difficult to achieve. The case of quality assurance programmes that proliferate in the region is the exception. The most discussed example that illustrates the difficulty of implementing regional policy in the sector is, without any doubt, that of institutional economic models. Kenya, Uganda and Rwanda have public and private universities that have been marketised, where the majority of students pay tuition fees, whereas Tanzania and Burundi already have university systems largely subsidised by their governments. These set-ups are the results of policies and reforms inherited from different governments since these countries gained their independence. East African universities, under the guise of convergence-for example in new modes of governancehave nevertheless their own singularities, histories, and memories. There exists significant differences between public and private universities, to the extent that one can question the formation of a homogeneous East African university space, in particular on the very politicised issue of tuition fees. However, the regional space of the East African Community seems to be a coherent structure that is able to respond to the challenges of higher education. It is particularly the case that universities have become strategic institutions in the economic development of the region. This is evidenced by national programmes (Vision 2030 in Kenya and Vision 2045 in Uganda, for example) that allow universities to train qualified staff and to develop research capacities in strategic sectors (science, energy, management, etc.). This will involve a strengthening of the binding legal capacities of the IUCEA and the EAC and a budget consistent with their missions. These transformations can not be achieved without the common and shared willingness of all the different political leaders in the region. 



\title{
Chapter 10 \\ Christian Forms of Religion in Kenya
}

\author{
Yvan Droz \& Yonatan N. Gez
}

Translated by Ellen Kibble, Francesca I. Kleine \& Claire Hefty

\section{Introduction}

Although Kenya is often considered a Christian country, a Kenyan journalist asserted in 2013 that, "if an opinion poll was conducted to establish how many citizens regularly go to places of worship, the results would frighten the clergy to death. If the researchers were to probe deeper, it might emerge that going to heaven is hardly the reason the few who visit places of worship (to ogle at gorgeous choir members) go there in the first place." Despite these cynical remarks, several surveys underline the importance of religion for Kenyans. One study by Afrobarometer indicates that $88 \%$ of the country's citizens ( $85 \%$ of men and $90 \%$ of women) consider religion to be very important in their lives (Afrobarometer 2011'). Another survey shows that $80 \%$ claim to attend church at least once a week, while $64 \%$ participate in religious groups every week (Pew Research Center 2006). In both studies, Kenyans' religiosity ranked highest among the ten countries surveyed. ${ }^{2}$

This chapter opens with a historical overview of Christianity in Kenya. ${ }^{3}$ It then discusses recent transformations in the field of religion, before examining the political role of churches in Kenya. Finally, we describe certain religious practices and show that they are not confined to single religious institutions but instead involve butinage or "church hopping." Such practices are present in various religious forms, and are as much part of Kenyans' everyday life as they are of their lifelong religious trajectories.

1. The question asked was, "How important is religion in your life?" (question 98B), and possible options included: "Not at all important"; "Not very important"; "Somewhat important"; "Very important"; and "Refused to answer."

2. The countries that participated in the second survey were the United States, Brazil, Chile, Guatemala, Kenya, Nigeria, South Africa, parts of India, the Philippines, and South Korea.

3. We have limited our scope to Christianity. According to the 2009 census, Christianity accounts for $82.6 \%$ of the population. Historian John Lonsdale claims, evoking "educated 'guesstimates'," that $80 \%$ of Kenyans were Christian, 7.3\% Muslim, and 11.55\% "traditionalists" (Lonsdale 2009, 63). For consideration of Islam in Kenya, read Michel Adam's chapter in this volume, as well as Adam (2010) and Herzig (2006). 


\section{Christian Religions in Kenya}

Three branches of Christianity have played an important role in the evangelisation of central Kenya: Catholicism, Protestantism, and Anglicanism. ${ }^{4}$ Though this division into three branches poses little problem for the Catholics and the Anglicans-the latter being united under the Church of the Province of Kenya $(\mathrm{CPK})^{5}$-the considerable diversity encompassed under the label of "Protestant" makes things less straightforward for the third branch.

Likely the "most important institution" in the country, the Catholic Church remains a significant power in Kenya. The Church's social engagement-such as parish activities, teaching, and especially healthcarehas contributed greatly to the Church's success in Kenya. This appeal continues to this day, even though Catholic schools were not considered to be among the best in the country during the colonial period. Additionally, the Church Fathers' nationalities (French and Italian) allowed them to adopt a position relatively independent from the British colonial government while forcing them to take extreme political caution. This particular feature of Catholicism stood in stark contrast to the stance taken by Protestants and Anglicans, who were tempted by political compromise and were always suspected of supporting the colonisers. The almost marginal political position of Catholicism within a colony of Anglican obedience did not go unnoticed by future converts, who were often more eager to embrace the "religion of the 'more powerful,' of those who call the shots, who control the situation and thereby demonstrate their superior strength" (Neckebrouck 1978, 472-473). Today, Catholicism seems to resist the significant loss of followers suffered by other religious groups following the meteoric rise of Pentecostalism. ${ }^{6}$ The explanation for this stability lies not only in the prudent restraint and relative lack of scandals embroiling the Catholic hierarchy, but also in the involvement of Catholic missionaries on the ground,-as well as papal prestige. Protestant puritanism influenced by the East African Revival (which we shall discuss later), however, regards Catholicism as a superficial religion, and suspects it of compromising with traditional religious practices. Some even consider Catholicism to be a cover for "satanic" activities.

4. We were inspired here by Droz (2004), which we have thoroughly revised and updated.

5. Since renamed the Anglican Church of Kenya (ACK).

6. According to the 2009 national census, the Kenyan Catholic Church has close to 10 million followers. 
A former church of the British state, the Church of the Province of Kenya $\left(\mathrm{CPK}^{7}\right)$ was long seen as the church of the colonisers, and was suspected of complicity with the colonial administration. It is true that the role held by this branch of Christianity throughout the Mau Mau War (1952-1956) left painful scars. Indeed, the Anglican and the Evangelical Churches supported the British army in the "rehabilitation" of the Mau Mau prisoners. ${ }^{8}$ Today, the $\mathrm{CPK}$ remains associated with conservative currents, even though it adopts-together with the Presbyterian Church, PCEA-a very critical outlook on Kenyan politics. ${ }^{9}$

Other historic Protestant churches make up nearly a third of Christians in Kenya. The largest among them remains the Presbyterian Church of East Africa (PCEA). Unlike Anglicans and Catholics, and despite some exceptions, Presbyterians consider the consumption of tobacco and alcohol as sinful. This prohibition demonstrates the strictness of faith taught by the Presbyterian Church-and, as we will see, by the Pentecostalists as well-and explains why these denominations perceive Catholicism as a lax religion.

\section{The Independent African Churches in the Wave of Pentecostalism}

As in the rest of sub-Saharan Africa, missionary churches-particularly Anglican churches, and especially Protestant ones-were subject to schisms that led to the establishment of independent churches. In Kenya, this resulted from clashes concerning clitoridectomy and the quality of education (192838), ${ }^{10}$ in which the Anglican and Catholic churches supported a moderate position. The diverse movement towards religious independence, equally

7. According to some estimations, the Anglican Church represented almost $10.6 \%$ of the population in 2007 (Kagema 2008). This is a significant increase, as statistics presented by David Barrett from the early 1980s indicate that only $7.2 \%$ of the population followed this denomination (Barrett 1982). In the latest censuses $(2009,2019)$, the Anglican Church was integrated into the larger category of "Protestants."

8. The British put into place an anti-insurrectional strategy inspired by their then-recent experience in Malaysia in order to "bring back" and "rehabilitate" the Mau Mau prisoners. The prisoners passed through a series of camps where Protestant preachers would play an infamous role (Elkin 2005; Maloba 1993).

9. Benson $(1995,195)$; for a detailed account of Anglicanism in Kenya, see Bowen (2016).

10. The attempt to forbid clitoridectomy in Kikuyu territory was met with fierce resistance that inspired Kikuyus to found the independent schools movement as well as numerous independent Christian churches (Murray 1974; Sandgren 1989; Strayer 1978). 
motivated by colonial racism and political activism, coincided with the East African Revival (1936-38), which originated in Rwanda. ${ }^{11}$ Terence Ranger interprets the emergence of the East African Revival as a reaction from missionary churches which experienced a considerable loss of followers who left to join the independent churches (Ranger 1986, 35). This is true for central Kenya, where the East African Revival offered an alternative to the independent churches. Pentecostalism and independent churches were therefore two sides of the same coin, with both taking a new perspective on conversion and, more generally, on social mobility with a view to achieve personal fulfilment (Droz 1999).

Indeed, the commonalities between these two religious traditions are not confined to the motivations people have for converting to them, but can also be found in numerous doctrinal similarities, and in the emphasis placed on an expression of faith, both emotionally and institutionally (congregationalism). Even if certain "pagan" aspects seem to characterise independent churches, they often follow the same organisational framework, such as with regard to parish independence or the active participation of the congregation in religious services. ${ }^{12}$ Moreover, these factions were historically developed in unison until the country's independence. In the 1920s and 1930s, Pentecostalism was confined to restricted social circles, often composed of settlers. That Pentecostalism emerged from (first wave) "white" North American fundamentalist groups, and was distinguishable from (second wave) "black" American Pentecostalism (Hollenweger 1999). With the arrival of the East African Revival, the Pentecostal movement took off:

"placing an emphasis more on the experience of converting than on religious instruction, [the East African Revival] made itself more accessible to illiterate or poorly educated believers. In addition, its hymns [...] gained great popularity and are often integrated into the ceremonies of other Churches. The third factor in its success is due to the fact that the East African Revival took a decisive stance on lay people (and notably on women), who are freely elected to lead the group. This denomination soon developed affinities with the Pentecostals [...]" (Maupeu 1998).

A second period in the development of Kenyan Pentecostalism can be distinguished, beginning in the 1960s, when the independent churches seemed to experience an equally significant growth following the end of the Mau Mau War. This phase was characterised by the arrival of foreign preachers, most of whom came from North and South America. As demonstrated by the flourishing of the Assemblies of God, these groups

11. The East African Revival was a movement of Protestant revivalism that grew rapidly in neighbouring countries (Peterson 2012).

12. Personal correspondence by Hervé Maupeu, 24 December 1999. 
found Kenya to be a fertile ground. During this time, the number of Pentecostal churches in Kenya exploded, as did the number of Protestant missionaries, many of whom were Pentecostal or Evangelical. More recently, the wave of conversion to neo-Pentecostalism ${ }^{13}$ reached Kenya, along with the rest of Africa. The first conversions took place in the early 1980s, and the numbers have been rising ever since. This third wave of Pentecostalism constitutes an important sociological phenomenon that is transforming religious affinities. ${ }^{14}$ It came at a time when Kenya faced major political and social upheavals-marked by the democratisation and the liberalisation of the political, economic, and religious markets. The process of registering a new denomination has been greatly simplified, thereby eliciting an explosion in the number of recognised churches..$^{15}$

The new Pentecostal missionaries have profoundly transformed Christianity in Kenya. ${ }^{16}$ They offer a charismatic liturgy that underlines the importance of being "born again,"17 and they often emphasise the theology of prosperity. It is important to note that the Born-Again conversion process should not be understood as a phenomenon implicating the entirety of one's beliefs, but rather as a social practice involved in the construction of multiple identities which prevail in Kenya (Droz 2002). Usually, the new converts would keep their previous religious affiliation after becoming born again, adding a new layer to their multifaceted identity (ethnic, religious, political, socio-economic, etc.) as they reposition themselves within new social networks. Conversions reinforce the social fabric of Pentecostalists, as "Jesus is the object of one's commitment, but the commitment only

13. For a description of neo-Pentecostalism, see Rey (2018) and Anderson (2004). (Neo-)Pentecostalism is an umbrella term for a number of movements that are so different that it is difficult to categorise them under any sort of common label (Anderson 2010).

14. At the end of the twentieth century, there were 126 million Pentecostalists in Africa, making up nearly $11 \%$ of the population of the continent. The majority converted after 1980 (Barrett 2001, 287).

15. In 2007, the Attorney General of Kenya, Amos Wako, asserted that there were 8,520 recognised churches in Kenya and 6,740 requests for recognition, with around 60 arriving each month (Ndegwa, Alex. 2007. "Over 6,000 Churches Awaiting Registration." The Standard, 4 September).

16. As John Lonsdale has stressed: "in the 1990s Kenya had 1,300 of them [Evangelical missionaries], an astounding figure, twice as many as any other African country, and a second missionisation none would have foretold in 1963" (Lonsdale 2002, 184). According to Paul Gifford, the number of foreign missionaries in Kenya was even higher (Gifford 1994, 519). In 1989, there were 1,225 American protestant missionaries; in 1993, they were 1,337 (out of a total 1,150 missionaries of all nationalities in 1978, 1,850 in 1986, and 2,321 in 1993).

17. Born again are Christians who have accepted a second baptism by immersion. 
becomes apparent in social relationships" (Englund 2007, 485). Nevertheless, a person's conversion can also weaken their prior social relations, as some converts break former solidarities, or give up on participating in family ceremonies henceforth considered as "pagan."

Today we are seeing a rapprochement between Pentecostalism and Evangelical Protestantism, a shift that has enabled a certain fluidity between independent and Pentecostal churches. Followers are able to alternate between events organised by different denominations with relative ease, as we will see below. At the same time, multiple denominations may come together to collaborate around public Christian "crusades." Some international evangelists draw enormous crowds to their Pentecostal rallies at Nairobi's Uhuru Park, and these performances that showcase masterful technical skills (Gifford 1987; 1992; Samita 2004). In addition, American televangelists such as Joel Osteen, Joyce Meyer, and T.D. Jakes attract numerous followers who watch their television programmes or read their books. ${ }^{18}$ Some of them are accused of "stealing" congregants from small independent churches or of subverting their structures in order to "prove" the value of their own evangelist work to their believers in Europe, South Africa, Nigeria, and especially North America. This frenzied quest for followers is further reinforcing the divisions inherent in Pentecostal and independent churches. ${ }^{19}$ Ever so often, minor leaders in one church allow themselves to be tempted by the seductive prospect of founding a new denomination, thereby seeing their name inscribed into the annals of Christianity.

These preachers proselytise in the markets, and announce the end of the world, or the imminence of the reign of God, or sometimes the Second Coming..$^{20}$ They testify to the imminent power of God, promise healings or economic successes, and urge the audience to offer public confessions, so

18. The commitment of these famous evangelists and their congregations in Kenya is not limited to the dissemination of sermons and the occasional crusade, and many Kenyans are regular beneficiaries of evangelistic and development programs funded and led by them. That said, their self-assessment of their work in Kenya is sometimes exaggerated, as we saw in 2013, when the North American evangelist T.D. Jakes was forced to apologise after overestimating the extent of the donations made by his church. He said, "the natives all over Kenya drink water because of this ministry. And the hospital in Nairobi survives because of this ministry." Karanja, Antony. 2013. "US Pastor TD Jakes Apologises over Kenya Comments." Daily Nation Online, 18 October. https://nation.africa/kenya/ news/us-pastor-td-jakes-apologises-over-kenya-comments-905700 [archive].

19. We recall that these fissures are not new, and that they have studded the history of Christianity in Kenya, and elsewhere (Neckebrouck 1983).

20. An era promised to the Righteous, after the second coming of Christ, according to the Apocalypse (20: 16). 
that they may be to be "saved" by receiving baptism by the Holy Spirit. Like pre-colonial African prophets, some predict future events or "explain"armed with biblical passages-extraordinary accidents or natural disasters.

Additionally, many of these Pentecostal preachers seek to carry out all of the signs indicated in the Bible to hasten the Second Coming of the Messiah (Droz 2001). This atmosphere of exalted expectation of the Second Coming is equally expressed in the numerous Pentecostal publications sold in the streets, outside the religious services of many provocatively named Pentecostal churches: Maximum Miracle Centre, Universal Church of the Kingdom of God, Jesus Is Alive Ministries, Glory of Christ Ministry, Power of Jesus Around the World, and so on. These publications announce upcoming "crusades" and peddle signs for the end of times: The Antichrist lives among us and tempts the faithful by the means of false prophets; the "Y2K bug" proved that the power of God remains superior to the miraculous technologies of Man; the Mark of the Beast is concealed in barcodes, revealed to those who inspect closely and, through numerological calculations, identify the infamous 666; dead children are revived after the laying on of hands by valiant preachers; the 1998 attack on the American embassy in Nairobi was an attempt by Satan's supporters to weaken the soldiers of Christ; the inauguration of a Hindu temple in Nairobi is a worrying sign of the power of idolaters (Séraphin 2003). In short, there are many Kenyans who live in a world re-enchanted by the apocalyptic teachings of Pentecostal movements.

The certainty of bearing witness to the millennium quickly leads to performative social practices, as they can be akin to self-fulfilling prophecies. The millennium thus takes a prosaic form, with the faithful hoping to see non-believers punished so that they themselves might enjoy the very concrete fruits promised to the faithful disciples of this exacting faith. In other words, such Pentecostals live in a (re-)enchanted world where the hand of God (as well as that of Satan) is omnipresent and where miracles and sinful temptations co-exist in daily life. They believe that the times they are living correspond to the early days described in the Bible, those following the birth of Christ, and when the effusion of the Holy Spirit embraced the apostles.

In recent years, we have seen these spiritual ideas give way to ambitious plans to transform Kenyan society. Many Pentecostal movements have abandoned their reticence of "worldliness," and openly engage in politics to promote a programme that some have qualified as "politics of the spirit" (Marshall 2009; Steigenga 2001; Villafañe 1996; Yong 2010). They maintain that their religious ideals could surpass earthly woes and promote a moralisation of political life, such as through the rejection of corruption, adherence to Christian values, etc. This new political involvement, which 
is informed by a clear division between good and evil, could be considered as a form of pentecostalisation of the public sphere, which would clean up Kenyan politics and to bring morals back to political life (Parsitau 2008).

Despite such ambitions for society in general, a large part of Pentecostal entrepreneurship manifests itself in the opening of small denominations (often micro-denominations) that start off with grandiose ambitions, but ultimately remain active only locally. As Paul Gifford notes, Pentecostalism has seen the emergence of a "new class of religious professionals, that is to say the founders/owners/religious leaders" (Gifford 2009, 154; Gez \& Droz 2021). Unlike the priests of historic churches, these entrepreneurs do not enjoy the support of a recognised church platform, nor do they possess formal theological training. As Ruth Marshall points out with regards to Nigerian Pentecostalism, "While various forms of institutionalised accreditation exist, pastoral authority is represented as inhering in a personal call from God; anybody with a vision can start a church, a fellowship, or a mission, and they do" (Marshall 2009, 12; see also Corten \& Marshall-Fratani 2001, 5). In Kenya, Pentecostal churches are so numerous that the national office cannot keep up with the rate of applications, even as the majority of churches probably do not seek official registration.

The arrival on the religious scene of these new entrepreneurs with no theological training has thrown into question the separation between social, political, economic and religious aspects of life; so much so that it is often said that "religion has become just like a business." Founding a religious movement is therefore often considered to be a means of building up a political clientele and satisfying preachers' thirst for power. ${ }^{21}$ In the eyes of many, Kenyan Pentecostals have lost their moral credentials in recent years due to repeated financial and sexual scandals (Gez \& Droz 2015). Some people feel that the political projects of the Pentecostal movement do not represent a viable alternative to the current political system, but are simply a means for leaders to insert themselves into it. Consequently, Pentecostals are considered to be "among the most enterprising entrepreneurs of the

21. The case of the Pentecostal bishop Margaret Wanjiru of the Jesus is Alive Ministries (JIAM) is edifying. She was elected to Parliament in 2007 for the ODM in the Starehe Constituency, but then lost her seat in 2013. Despite largely mobilising her followers through her sermons, the scandals which had enveloped her proved to be fatal. Though her claims that almost 20,000 voters in Starehe were from her flock are no doubt exaggerated, they underline her church followers' role in her 2007 success (Kareithi, Amos. 2006. "Bishop Wanjiru Hopes to Be President.” The Standard, 5 November. http://allafrica.com/ stories/200611060988.html). In January 2013, shortly before the election, she said from the pulpit that, "if you do not know who to vote for, call the numbers on the screen and we will tell you who to vote for" (JIAM morning service, 13 January 2013). See Gez \& Alvis (2015). 
religious world" (Anderson 2004, 280), and the absence of any centralised institutional structure further heightens the appeal of individual initiatives. Today, it is common to hear the inhabitants of Nairobi make remarks such as, "to become a pastor nowadays, all you need is a Bible and a suit." Under such conditions, it is not surprising that Pentecostalism's social and political long-term impact remains uncertain.

\section{Churches and the Pluralist Elections}

Since the return of a multi-party political system in 1991, each of the six general elections that have been held have revealed a different state of Kenyan civil society (Droz \& Maupeu 2013; Maupeu 1998). In the late 1980s, a number of civil society actors criticised the repression of Moi's dictatorial regime and its totalitarian inclinations: tight control of the corps intermédiaires (political parties, trade unions, employers, etc.), rising numbers of political prisoners, political persecution, and surveillance. In the elections of 1988, a new voting process that required voters to line up behind their candidate, and the marginalisation of certain ethnic groups, shocked many high-profile civil society leaders. Some ministers stood up against these trends and criticised the voting system. In close collaboration with human rights lawyers, they backed the politicians persecuted for demanding free, multi-party elections. Following intense international pressure, President Moi-who threatened that ethnic unrest would befall the country following the abandonment of the single-party system-authorised new political parties, which were created under the patronage of the main Churches. During this period, the opposition party utilised religious establishments and disseminated its messages through Christian networks. But the political class quickly sought to free itself of this religious tutelage, and during the electoral campaign of 1992, the clergy was ostensibly left aside. Despite its divisions, the opposition was confident about winning the elections. However, the re-election of President Moi and the decisive victory of his party forced the opposition politicians to reconsider their strategy, and their means for expanding their electoral base.

In 1992 and 1993, the main churches worked to accommodate almost one hundred thousand refugees fleeing massacres in the Rift Valley. These ethnic cleansings were denied by the authorities, who were complicit in (if not the actual authors of) the killings (Maupeu 1997). The state and the ruling elite ignored the dramatic situation in the Rift Valley, while the administration hindered the relief efforts of Christian organisations. During this humanitarian crisis, the opposition unconvincingly denounced the massacres, creating a rupture between the political class, religious forces, and human rights NGOs. Five years later, human rights associations dictated the agenda and the themes of the electoral campaign of 1997. 
As early as 1996, some activists mobilised a diverse public to propose a reform of the Constitution. Many Protestant and Catholic opinion leaders supported the constitutional reform from the ground up. Nevertheless, these attempts were unsuccessful and only superficial modifications were introduced to the Constitution, tailor-made to favour President Moi's reelection in 1997.

The same year, the opposition organised huge demonstrations in order to demand a change to the Constitution before the elections. Convinced by the success of these mobilisations, an ailing opposition attempted to recapture some of the momentum that had been generated. Once again, politicians joined the opposition party, working with the Catholic and Protestant Churches. However, six months before the vote, the demonstrations escalated due to increased police persecution, and demonstrators were beaten inside the Anglican Cathedral in Nairobi. Faced with the number of casualties and the risk of anarchy, the clergy and several opposition leaders negotiated with the authorities, further marginalising the leaders of the social movement. As a result, Christian organisations have long alienated human rights NGOs and many lawyers (Maupeu 2001).

In 2002, the Churches hardly appeared in the national electoral campaign. Most of them supported the opposition, but their commitment was mostly felt at the local level, where they organised the primary round of voting for certain parties and endorsed their candidates at religious ceremonies. Thus, with the exception of the $\mathrm{AIC}^{22}$ and some Pentecostal movements, the Christians strongly supported Mr Kibaki and his party, whose victory was also theirs. The new regime cleverly appointed several high-ranking clergy members to committees which were essentially well-paid sinecures. Hence, these leaders did not look for a reason to criticise the new governmental team (Maupeu, Musambayi \& Mitullah 2005).

In the 2005 constitutional referendum, the churches uncritically defended the modification of the country's constitution, which were swept away by the voters. In the 2007 elections, the Catholic elite ostensibly supported the re-election of Mwai Kibaki. The National Council of Churches of Kenya (NCCK), which acts as the umbrella organisation for the country's Protestant Churches, seemed to lose its neutrality when its leader ran in the legislative elections under the banner of the President's party. Furthermore, many religious leaders, particularly among the Pentecostals, decided to enter the race for a seat in Parliament, encouraged by the rejection of the 2005 draft of the Constitution (Cheeseman 2008; Kavulla 2008; Gez \& Alvis 2015; Gifford 2009; Droz \& Maupeu 2013). Thus, the 2007-as well as the 2013-elections saw a tidal wave of Pentecostal candidates, many of whom

22. The African Inland Church broke away from an evangelical mission originated in the East Coast of the United States. 
came from neo-Pentecostal currents, which preach involvement in world affairs and advocate entrepreneurship through their theology of prosperity. In 2010, a new version of the Constitution was submitted for referendum and was eventually accepted. However, heated debates on the religious issues addressed in the Constitution draft-like the legalisation of abortion and the autonomous status of the Khadi Courts for the Muslims of Kenyaunderlined the influence of the Christian lobby (Osur 2011).

The elections of 2013 raised fears of a recurrence of the 2008 postelectoral violence that had inflamed the whole country and left more than 1,500 dead. Back then, some religious leaders had played incendiary roles by violently supporting their own candidate and fuelling tensions between different communities, showing that the churches had grievously failed to play their role as peacemaker. Having largely learned from these tragic events, they developed programmes to promote national unity and to successfully prevent future violence. For example, many ecumenical prayer meetings were organised and widely reported in the media. In an interfaith meeting broadcast on television, Bishop David Oginde of the Nairobi Pentecostal Church (NPC) pointed out that the use of churches as electoral stepping-stones by politicians had been sharply curtailed: "If you compare this year with the 2007 [elections] for example, you hardly notice any church group or any church leader that are praying for, endorsing any particular candidates. [...] We had a meeting and we agreed [that] we pray generally for the elections to be peaceful, we pray for our members who are campaigning that God may go before them, but that is [a] general prayer" (Citizen TV, 16 February 2013). Nevertheless, the effectiveness of these measures is still open to question, given that the forum of Muslim chiefs supported the candidacy of Raila Odinga, while Uhuru Kenyatta was backed by the association of Muslim organisations. ${ }^{23}$

The latest elections in 2017, which saw Uhuru Kenyatta's victory in the first round of voting, did not give rise to much public intervention from the churches, contrary to what we have seen in previous elections. ${ }^{24}$

\section{Religious Butinage in Kenya}

We met Charles in August 2014, near Kisumu on the shores of Lake Victoria in Western Kenya. At thirty years old, he was living with his wife, and their three children. His parents, both members of Legio Maria (Kustenbauder

23. Alongside the commitment of the historic churches in electoral politics, other religious forces played an influential role, such as neo-traditionalist religious movements.

24. Perhaps we can see here the results of the ecumenism created by religious butinage. See Droz \& Gez (2019). 
2009)-his mother, a born catholic, had to convert in order to marry her husband-brought him to Kisumu at a young age. His birth was difficult and considered as a miracle brought about by the prayers of the members of Legio Maria. His mother was admonished that Charles "at all times should be in Legio, should not walk out of Legio." He remained in this denomination for many years, becoming a devout "mass child." However, as the demands of his church his church precluded him from studying, he left it in secondary school. But his life was not easy-he passed from odd job to odd job, and his house was burgled. For his family, all these troubles were the result of him leaving Legio Maria, in contravention of the prophecy of his birth. They attempted in vain to convince Charles to return to their church. But his woes did not end there. Charles suffered several accidents before meeting a young Luo man in a park in Mombasa, who invited him to join his small Pentecostal church. Although he really enjoyed this church for a while, Charles became exasperated by the political turn the sermons took before the 2007 elections. He left this church and returned to Kisumu.

He then approached another church, Deliverance Church, but soon left it following institutional quarrels (the central leadership accused its Kisumu branch of siphoning off money from the tithe) in order to join another Pentecostal denomination led by a white reverend. However, the reverend asked him to testify on his behalf before the police, which irritated Charles: "I'm sorry for this, [but] one of my objectives of coming to church was to pray, not to do [court] cases. I'm sorry, I'm not coming to that." After some time, the institutional quarrel was resolved, and Charles' wife, as well as his children, returned to Deliverance Church where they remain today.

Thinking of the succession of misfortunes that had befallen him, Charles admits that he sometimes believed that he was cursed by members of his family. In fact, Charles dreaded returning to his home village for fear of witchcraft. He explained that he would never go to consult a witchdoctor for help, but he admitted to having asked a preacher to pray for him, in order to protect him from spells, with little success. He complained of false preachers, of the many preachers who divert money from the Church or who take advantage of their congregation. Nevertheless, he insisted that "back in the day," the members of Legio Maria were truly animated by the Holy Spirit: "We the people, we've walked away from God. People [today] want to do their things, there is despair, desperate, we want money, and the people who know God's matter, people who are eloquent, who understand God's word, they also seem to take advantage of the same, just to extort money from the people." Charles feels demoralised by the attitudes of today's pastors and admits to not having attended church in more than a year. Before that, he visited several denominations, including the Jehovah's Witnesses, without remaining at any for long. He now says he is drawn to 
Catholicism, having enjoyed the Catholic services he attended in Mombasa with his maternal uncle. However, he has clashed with his wife over this, as she remains deeply committed to Deliverance Church. Having recently bought a television set, he spends his Sunday mornings "church zapping"that is, channel-hopping from one religious station to another.

How can we understand a story like Charles', so varied and yet not unfamiliar to the people of Kenya? Statistics tell us a part of the story. According to the most recent census data from 2019, Kenya's population of 47.6 million consists of 85.5\% Christian (33.5\% Protestant, 20.6\% Catholic and $20.4 \%$ Evangelical) and $11 \%$ Muslims. The census respondents had to choose a single response out of the eight provided, though we observe that it is common for many people to participate in the services of several denominations. Of course, the census did not consider the degree of involvement in religious services either: is it a formal and recognised affiliation, a constant participation in a religious service without formal affiliation, an episodic participation, or an occasional visit? Finally, knowing that in Kenya it is frowned upon not to declare a religious affiliation, it is highly possible that respondents claimed an affiliation even if it is barely, if at all, practised. In this respect, it is noteworthy that almost a million Kenyans still affirm an absence of religion affiliation.

Nevertheless, though religious identity is strongly influenced by religious institutions, it is not limited to them. Religious identities in Kenya are polymorphous and highly variable. Social science researchers have demonstrated-by evoking the concept of "lived religion" (Hall 1997; McGuire 2008; Roof 2001)-that religious practices transcend institutional boundaries. For their part, Kenyans often declare that "God is one" and that religious practices depend on personal preferences or pragmatic and contextual considerations, insofar as they keep to the realm of Christianity. In her master's thesis, Elisabeth Wafula (2003, 106-107), a Kenyan, states:

Previously, people attended a Church because of their loyalty to the congregation. Even if the Church was not ministering to their needs, they remained because of their sense of duty. Nowadays, people hop from Church to Church depending on their particular needs and available programs within the Church which minister to their needs. Their identity within the Church is nolonger [sic] based upon the past, but upon the contributions the Church makes on their lives and families. This has indeed brought pressure upon most Churches to develop multiple ministries resulting into inter-denomination [sic] mobility. ${ }^{25}$

25. Wafula's thesis relies on the results of the study done by the Nairobi Urban Integration Research Project. The data were collected in the early 2000s from 1,535 people in Nairobi. 457 among them (30\%) claimed to have changed religious denomination at least once since birth. 
A more refined approach to religious identities in Kenya, such as Charles', therefore requires acknowledging a relative fluidity of participation in religious services, as well as a significant mobility of affiliations, both at present, as Wafula indicates, and likely also in the past (Neckebrouck 1978; 1983; Peterson 1996; 2000; Chanson, Droz, Gez \& Soares 2014). Kenyans can adopt a denomination that they consider to be the core of their affiliation, while maintaining more "peripheral" links to other religious forms, and can equally participate in circular religious mobility, or go back and forth between churches.

It is therefore possible in Kenya to distinguish between "visits" to religious services and affiliation to a church. This distinction highlights the possibility of combining simultaneous engagement in different forms of participation in religious services with the existence of a hierarchical difference between them. The affiliation remains at the heart of belonging to a faith, both declared and experienced, while visits represent a "secondary," often exploratory, form of participation. They are generally institutionalised and often follow an established protocol (Gez \& Droz 2017). Nevertheless, such mobility can turn into "church hopping," a notion describing a person's lack of stable affiliation as a solid primary affiliation is not maintained. An individual may be suspected of changing affiliation to create dissension or to seek financial or sexual interests. Some, like Charles, prudently limit their participation in religious services and stay at home to watch the ceremonies of various Christian television programmes, or to follow the virtual "crusades" of the televangelists, and consequently are less involved in "church hopping" than they are in "church zapping." For example, a Kenyan journalist presents the story of a lady called Christine Ndegwa, "a Christian who prefers watching sermons on television to attending church." Ndegwa explains her preferences by alluding to discontent with contemporary pastors, who she sees as living a lavish, immoral lifestyle, while their congregations languish in poverty. During our research in Nairobi, we heard several people give similar examples. In Kenya, there are many religious television channels such as Family TV, and international religious stations are equally available. Some religious programmes also broadcast on private channels. While "church zapping" could come from disillusionment with today's preachers, it could also be a means of coping with the demands of wage employment, as waiters or receptionists who work on Sundays can also "participate" in religious services, just like taxis drivers who listen to these radio programmes while on the road. ${ }^{26}$

26. Okeyo, Verah. 2013. "Preaching to the Converted: The Rise of Atheism in Modern Kenya." Daily Nation-DN2, 3 July: 2-3. https://nation.africa/kenya/lifeand-style/dn2/the-rise-of-atheism-in-modern-kenya-872868 [archive]. 
Such observations emphasise that taking religious practices into account requires us to go beyond the "theological" notion of a singular religious affiliation, which suggests a strict adherence to explicit institutional prescriptions. Rather, the concept of "religious butinage" (named after the French term for the foraging movement of bees while gathering pollen) makes it possible for us to account for these fluid and varied religious practices. To discuss religious butinage is also to examine the social practices and the "manières de faire" ("ways of doing," de Certeau 1980) within the religious field, and to thus document religious practices that too often go unnoticed: switching from one denomination to another, participating in several churches at once without formally adhering to any one, partaking in prayer circles that bring together practitioners of various denominations, channel-hopping between televised sermons, etc. The Abrahamic religions offer a representation of the religious and of religious practices that favours the dichotomy between believers and unbelievers. Any view to the contrary is perceived as a deviation from orthodoxy. However, religious butinage's manière de faire acknowledges the everyday mobility of the practitioner as irreducible to institutional prescriptions.

The practice of religious butinage takes religion into account as a practice of (re)production of social relations (neighbourhood, friendships, etc.) but also of meaning. The practice of butinage may thus be interpreted as allowing Kenyans to accumulate religious resources that offer them certain securities in the face of the ever-changing field of religion-in which schisms, collapses, and fusions of religious movements are frequent, as are suspicions of abuse of power by religious dignitaries (Droz 1997; Gez \& Droz 2015). Religious butinage, or multiple practices, allows for diverse ways of worship to be preserved in case one's primary, or initial, denomination descends into political or financial scandal, or an individual's religious identity transforms in light of lived experience such as geographic mobility. Religious identity is in a constant process of renegotiation.

Speaking of religious butinage also takes into account the entanglement of the religious world with the secular one (Soares 2009; Soares, Droz \& Gez 2012; Droz, Soares \& Oro 2014; Droz, Soares, Gez \& Rey 2016; Droz \& Gez 2019). Consequently, in order to avoid seeing their followers stray into the sins of popular entertainment (alcohol, sex, disco, cinema, etc.), the Christian churches offer religious services that are sometimes akin to a "show" with musical and theatrical production values on par with those of professional performers.

Emphasising the blending of the secular and the religious allows us to show that the latter is not only a place of spiritual engagement, but also a place of socialisation, recreation, and pleasure (Bayart 2014). Many of our interlocutors remarked that the Sunday religious services are very engaging 
and that they take pleasure in going because the church is "where things happen." Additionally, for the many inhabitants of Nairobi with limited financial resources, the leisure activities offered by the capital remain inaccessible, meaning that religious services are also seen as an affordable entertainment and a way to "pass the time."

\section{Conclusion}

Since colonisation, Christian churches in Kenya have helped to make sense of a world in constant upheaval by offering opportunities for social advancement, through education or politics, and by achieving (at least partially) some of their promises of development (Droz 2016). This chapter has highlighted the range of perspectives taken by established religious denominations, first in the face of British powers and later under independent rule. The country's religious leadership played sometimescontradictory roles confronting the ruling power, before engaging in the game of representative democracy during the 2007 and 2013 elections at the risk of losing their independence.

This commitment to secular politics was further reinforced by the establishment of numerous Pentecostal churches. New religious movements (whether they represent independent African churches emerging out of missionary churches or Pentecostal movements) have profoundly transformed the religious landscape of Kenya. In recent years, the wave of neo-Pentecostalism and missionary work (mostly by American preachers) has further intensified this process. So much so that, according to a Kenyan journalist, "From the 1970s to date, what was and what is are now worlds apart." ${ }^{27}$ These changes can be seen in the "Pentecostalisation" of Kenyan Christianity, to the extent that Pentecostal teachings are today shared by many established churches.

But outside the institutional confines of Kenyan religious forms, it appears that the "faithful" are much more than that: their religious commitments, whether visiting other churches or their primary religious affiliation, transcend institutionalised identities and practices. Kenyans like Charles move freely within the religious landscape to build their oftenpolymorphic and composite religious identities. The study of religious denominations should therefore not be limited to institutional dynamics such as the political actions of the church and their official discourses. Research should equally take into account the social norms and actual practices of the congregants, who oscillate between their primary religious

27. Oduor, Peter. 2013. "The Kenyan Church and the Gospel of Prosperity." Daily Nation-DN2, 13 February: 2-3. https://nation.africa/kenya/life-and-style/dn2/ the-kenyan-church-and-the-gospel-of-prosperity--847652 [archive]. 
affiliation and multiple visits, not to mention the practice of "religious butinage" or "church zapping" on television. The dynamics of these practices go beyond the institutional prescriptions and offer a new research horizon for analysing religious practices in Kenya and elsewhere.

If we attempt to predict the future of these institutional, personal, and political religious dynamics, one might evoke the relatively recent emergence of questions about the possibility of no longer affiliating with any single church, or recognise the absence of commitment to a religion. Even if statistics are not very reliable, Kenyans have a sense that "the number of families who have no affiliation with any religion is growing." ${ }^{28}$ Some have argued that this tendency could be explained by the appearance of a middle class, whose higher rates of education promotes a "scientific" representation of the world and a critical spirit, reinforced by access to new means of electronic communication..$^{29}$ Moreover, this trend might equally be associated with the numerous scandals that affected multiple religious leaders and their churches. This caused a certain disillusionment affecting church leaders and self-proclaimed prophets, who are overly preoccupied by very secular things: money, sex and power. Whatever this trend means and wherever its supposed causes may lie, it underlines the intense mobility - of religion, politics, or identity-within the religious landscape of Kenya, and its members.

\section{Bibliography}

Adam Michel (eds). 2015. Indian Africa. Minorities of Indian-Pakistani Origin in Eastern Africa. Dar es Salaam: Mkuki na Noyta [Originally Adam, Michel. 2010. L'Afrique indienne : les minorités d'origine indo-pakistanaise en Afrique orientale. Collection "Hommes et sociétés." Paris: Karthala].

Afrobarometer. 2011. Round 5 Afrobarometer: Survey in Kenya. Institute for Development Studies (IDS), University of Nairobi \& Michigan State University (MSU). http://afrobarometer.org/fr/publications/kenya-round-5summary-results-2011 [archive].

Anderson, Allan. 2004. An Introduction to Pentecostalism: Global Charismatic Christianity. Cambridge: Cambridge University Press.

Anderson, Allan. 2010. "Varieties, Taxonomies, and Definitions." In Studying Global Pentecostalism: Theories and Methods, edited by Allan Anderson, Michael Bergunder, Andre Droogers and Cornelis van der Leer, 13-29. Berkeley (CA): University of California Press.

28. Wangeri, Perpetua. 2014. "Give Me That Old Time Religion." The PeopleFusion, 18 May: 30-31.

29. Ibid.; Okeyo, Verah. 2013. "Preaching to the Converted: The Rise of Atheism in Modern Kenya." Daily Nation-DN2, 3 July. https://nation.africa/kenya/lifeand-style/dn2/the-rise-of-atheism-in-modern-kenya-872868 [archive]. 
Barrett, David Brian (eds). 1982. World Christian Encyclopaedia: A Comparative Survey of Churches and Religions in the Modern World A.D. 1900-2000. Nairobi: Oxford University Press.

Barrett, David Brian, George Thomas Kurian and Todd M. Johnson. 2001. World Christian Encyclopaedia: A Comparative Survey of Churches and Religions in the Modern World A.D. 1900-2000. Vol. III. New York: Oxford University Press.

Bayart, Jean-François. 2014. “À nouvelles pratiques religieuses, nouveaux instruments d'analyse ? L'écriture abiographique des plans de foi." In Mobilité religieuse. Retours croisés des Afriques aux Amériques, edited by Philippe Chanson, Yvan Droz, Yonatan N. Gez and Edio Soares, 39-52. Paris: Karthala.

Benson, Georges P. 1995. "Ideological Politics versus Biblical Hermeneutics: Kenya's Protestant Churches and the Nyayo State." In Religion and Politics in East Africa: The Period since Independence, edited by Holger Bernt Hansen and Michael Twaddle, 177-99. London: James Currey; Nairobi: EAEP; Kampala: Fountain Publisher; Athens $(\mathrm{OH})$ : Ohio University Press.

Bowen, Kurt. 2016. Anglicans in Postcolonial Africa: The Kenyan Experience. Tellwell: Kurt Bowen.

Certeau (de), Michel. 1984: The Practice of Everyday Life. University of California Press, Berkeley [Originally Certeau (de), Michel. 1980. L'invention du quotidien. Arts de faire. Paris: UGE].

Chanson, Philippe, Yvan Droz, Yonatan N. Gez and Edio Soares (eds). 2014. Mobilité religieuse. Retours croisés des Afriques aux Amériques. Paris: Karthala.

Cheeseman, Nic. 2008. "The Kenyan Elections of 2007: An Introduction." Journal of Eastern African Studies 2, no. 2: 166-84. https://doi.org/10.1080/17531050802058286.

Corten, André and Ruth Marshall-Fratani (eds). 2001. Between Babel and Pentecost: Transnational Pentecostalism in Africa and Latin America. London: Hurst \& Company.

Droz, Yvan. 1997. "Si Dieu veut... ou Suppôts de Satan? Incertitudes, millénarisme et sorcellerie parmi des migrants kikuyus." Cahiers d'études africaines 37, no. 145: 85-117. https://doi.org/10.3406/cea.1997.1989.

Droz, Yvan. 1999. Migrations kikuyus. Des pratiques sociales à l'imaginaire. Ethos, réalisation de soi et millénarisme. Neuchâtel and Paris: Institut d'ethnologie \& Maison des sciences de l'homme.

Droz, Yvan. 2001. "Les formes du millénarisme en pays kikuyu." In Millenarian Movements in Africa and the Diaspora, edited by Jan-Lodewijk Grootaers, 97-112. Bruxelles: Académie Royale des Sciences d'Outre-Mer \& Association belge des Africanistes.

Droz, Yvan. 2002. "Esquisse d'une anthropologie de la conversion. Pratiques religieuses et organisation sociale en pays kikuyu." In Convocations thérapeutiques du sacré, edited by Raymond Massé and Jean Benoist, 81103. Paris: Karthala. 
Droz, Yvan. 2004. "Retour au Mont des Oliviers. Les formes du pentecôtisme kényan.” In L'effervescence religieuse en Afrique, edited by Gilles Séraphin, 17-42. Paris: Karthala.

Droz, Yvan. 2016. "Les métamorphoses de la mobilité: du schème migratoire au butinage religieux." In Religion, guérison et forces occultes en Afrique. Le regard du jésuite Éric de Rosny, edited by Gilles Séraphin, 113-26. Paris: Karthala.

Droz, Yvan and Yonatan N. Gez. 2019. "Pentecôtisation du christianisme et butinage religieux au Kenya: entre fondamentalisme et mode populaire d'action politico-religieuse." Canadian fournal of African Studies/Revue canadienne des études africaines 53, no. 2: 317-35. https://doi.org/10.1080/00083968.2019.1577146.

Droz, Yvan, and Hervé Maupeu. 2013. "Christianismes et démocratisation au Kenya." Social Compass 60, no. 1: 79-96.

http://doi.org/10.1177/0037768612471771.

Droz, Yvan, Edio Soares, Yonatan N. Gez and Jeanne Rey. 2016. "La mobilité en religion à l'aune du butinage religieux.” Social Compass 63, no. 2: 251-67. https://doi.org/10.1177/0037768616629305.

Droz, Yvan, Edio Soares and Ari Pedro Oro. 2014. "Le butinage religieux : regard anthropologique sur les pratiques religieuses." In Mobilité religieuse. Retours croisés des Afriques aux Amériques, edited by Philippe Chanson, Yvan Droz, Yonatan Gez and Edio Soares, 17-37. Paris: Karthala.

Elkins, Caroline. 2005. Imperial Reckoning: The Untold Story of Britain's Gulag in Kenya. New York: Henry Holt and Company.

Englund, Harri. 2007. "Pentecostalism beyond Belief: Trust and Democracy in a Malawian Township." Africa: Journal of the International African Institute 77, no. 4: 477-99. https://doi.org/10.3366/afr.2007.77.4.477.

Gez, Yonatan N. and Tanya Alvis. 2015. "Bishop Margaret Wanjiru and the 2013 Kenyan Elections: Between Politics of the Spirit and Expanding Entrepreneurship." In Kenya's Past as Prologue: Voters, Violence and the 2013 General Election, edited by Christian Thibon, Marie-Aude Fouéré, Mildred Ndeda, and Susan Mwangi. Nairobi: Twaweza, IFRA \& Heinrich Böll.

Gez, Yonatan N. and Yvan Droz. 2015. "Negotiation and Erosion of Born Again Prestige in Nairobi." Nova Religio: The Journal of Alternative and Emergent Religions 17, no. 3: 18-37. https://doi.org/10.1525/nr.2015.18.3.18.

Gez, Yonatan N. and Yvan Droz. 2017. "The Sheep Stealing Dilemma: The Ambiguities of Church Visits in Kenya." Journal of Religion in Africa 47, no. 2: 163-89. https://doi.org/10.1163/15700666-12340103.

Gez, Yonatan N., and Yvan Droz. 2021 "Breakthroughs, Blockages, and The Path to Self-Accomplishment: The Case of Pentecostal Church Founders in Kenya" Africa Today vol. 67 (forthcoming).

Gez, Yonatan N., Yvan Droz, Jeanne Rey, and Edio Soares. 2021. Butinage: The Art of Religious Practices. Toronto: University of Toronto Press.

Gifford, Paul. 1987. “'Africa Shall be Saved.' An Appraisal of Reinhard Bonnke’s Pan-African Crusade.” Journal of Religion in Africa 17, no. 1: 63-92. https://doi.org/10.1163/157006687X00055. 
Gifford, Paul. 1992. "Reinhard Bonnke's Mission to Africa, and His 1991 Nairobi Crusade." In New Dimension in African Christianity, edited by Paul Gifford, 157-82. Nairobi: All African Conference of Churches.

Gifford, Paul. 1994. "Some Recent Developments in African Christianity." African Affairs 93, no. 373: 513-34. https://doi.org/10.1093/oxfordjournals.afraf.a098757.

Gifford, Paul. 2009. Christianity, Politics and Public Life in Kenya. London: Hurst Publishers.

Hall, David D. 1997. Lived Religion in America: Toward a History of Practice. Princeton (NJ): Princeton University Press.

Herzig, Pascale. 2006. South Asians in Kenya: Gender, Generation and Changing Identities in Diaspora. Münster: LIT Verlag.

Hollenweger, Walter J. 1999. “The Black Roots of Pentecostalism.” In Pentecostals After a Century: Global Perspectives on a Movement in Transition, edited by Alan H. Anderson, 12-20. Sheffield: Sheffield Academic Press.

Kagema, Dickson Nkonge. 2008. "Leadership Training for Mission in the Anglican Church of Kenya." PhD Dissertation. Pretoria: University of South Africa. http://hdl.handle.net/10500/3252.

Kavulla, Travis R. 2008. “'Our Enemies are God's Enemies': The Religion and Politics of Bishop Margaret Wanjiru, MP.” Journal of Eastern African Studies 2, no. 2: 254-63. https://doi.org/10.1080/17531050802058369.

Kustenbauder, M. 2009. "Believing in the Black Messiah: The Legio Maria Church in an African Christian Landscape." Nova Religio 13, no. 1: 11-40. https://doi.org/10.1525/nr.2009.13.1.11.

Lonsdale, John. 2002. "Kikuyu Christianities: A History of Intimate Diversity." In Christianity and the African Imagination: Essays in Honour of Adrian Hastings, edited by David Maxwell and Ingrid Lawrie, 157-97. Leiden, Boston \& Cologne: Brill.

Maloba, Wunyabari O. 1993. Mau Mau and Kenya: An Analysis of a Peasant Revolt. Bloomington (IN): Indiana University Press; London: James Currey.

Marshall, Ruth. 2009. Political Spiritualities: The Pentecostal Revolution in Nigeria. Chicago: The University of Chicago Press.

Maupeu, Hervé. 1997. "Les Églises chrétiennes au Kenya: des influences contradictoires." In Religion et transition démocratique en Afrique, edited by François Constantin and Christian Coulon, 81-113. Paris: Karthala.

Maupeu, Hervé. 1998. "Églises et société." In Le Kenya contemporain, edited by François Grignon and Gérard Prunier, 143-67. Paris: IFRA-Karthala.

Maupeu, Hervé. 1998. "Organisations pentecôtistes, espace public et sujet politique: l'exemple du Kenya." Présenté au colloque Laïcités, religions et démocratie : perspectives comparatistes, Paris, 7-8 December.

Maupeu, Hervé. 2001. "The Churches and the Polls." In Out for the Count, the 1997 General Elections and Prospects for Democracy in Kenya, edited by Marcel Rutten, Alamin Mazrui and François Grignon, 50-71. Kampala: Fountain Publishers.

Maupeu, Hervé, Katumanga Musambayi and Winnie Mitullah (eds). 2005. The Moi Succession: Elections 2002. Nairobi: Transafrica Press. 
McGuire, Meredith B. 2008. Lived Religion: Faith and Practice in Everyday Life. New York (NY): Oxford University Press.

http://doi.org/10.1093/acprof:oso/9780195172621.001.0001.

Murray, Jocelyn. 1974. "The Kikuyu Female Circumcision Controversy: With Special Reference to the Church Missionary Society's 'Sphere of Influence.” University of South Africa. Berkeley: University of California.

Neckebrouck, Valeer. 1978. "Le onzième commandement. Étiologie d'une église indépendante au pied du mont Kenya." Immensée : Nouvelle revue de science missionnaire XVII, 472-73.

Neckebrouck, Valeer. 1983. "Le peuple affligé: les déterminants de la fissiparité dans un mouvement religieux au Kenya central." Immensée : Nouvelle revue de science missionnaire, 92-96.

Osur, Joachim. 2011. The Great Controversy: A Story of Abortion, the Church, and Constitution-making in Kenya. Nairobi: J. Osur.

Parsitau, Damaris Seleina. 2008. "From the Fringes to the Centre: Rethinking the Role of Religion in the Public Sphere in Kenya." Pronounced at CODESRIA: $12^{\mathrm{e}}$ Assemblée générale de Governing the African Public Sphere, Yaoundé, Cameroun, 7-11 December.

Peterson, Derek R. 1996. "Dancing and Schooling: Missionaries, Athomi and the Outschool in Late Colonial Kenya." MA Dissertation. Minneapolis: University of Minnesota.

Peterson, Derek R. 2000. "Writing Gikuyu; Christian Literacy and Ethnic Debate in Northern Central Kenya, 1908-1952." PhD Dissertation. Minneapolis: University of Minnesota. https://halshs.archives-ouvertes.fr/tel-01256147.

Peterson, Derek R. 2012. Ethnic Patriotism and the East African Revival: A History of Dissent, c.1935-1972. African Studies Series. Cambridge: Cambridge University Press. https://doi.org/10.1017/CBO9781139108614.

Pew Research Center. 2006. Spirit and Power: A 10-Country Survey of Pentecostals. Washington (DC): The Pew Forum on Religion \& Public Life.

Ranger, Terence O. 1986. "Religious Movements and Politics in Sub-Saharan Africa." African Studies Review29, no. 2:1-69. https://doi.org/10.2307/523964.

Rey, Jeanne. 2018. Espaces pentecôtistes de la migration africaine en Suisse. Logiques transnationales et dispositifs rituels. Paris: Karthala.

Roof, Wade Clark. 2001. Spiritual Marketplace: Baby Boomers and the Remaking of American Religion. Princeton (NJ): Princeton University Press.

Samita, Zacharia Wanakacha. 2004. "Christian Evangelistic Crusades and their Contributions to the Growth of the Church in Kenya with Reference to Nairobi." PhD Dissertation. Nairobi: Kenyatta University.

Sandgren, David P. 1989. Christianity and the Kikuyu: Religious Divisions and Social Conflict. Bern, New York, Frankfurt am Main, Paris: Peter Lang.

Séraphin, Gilles. 2003. "La presse chrétienne de Nairobi: Des combats politiques et idéologiques dévoilés." In Annuaire de l'Afrique orientale 2003, edited by Hervé Maupeu, 131-65. Paris \& Nairobi: IFRA-Karthala. 
Soares, Edio. 2009. Le butinage religieux : pratiques et pratiquants au Brésil. Geneva \& Paris: Institut de hautes études internationales et du développement-Karthala.

Soares, Edio, Yvan Droz and Yonatan N. Gez. 2012. "Butinagem religiosa: a importância da metáfora para pensar o religioso.” In A religião no espaço publico, edited by Ari Pedro Oro, Carlos Alberto Steil, Roberto Cipriani and Emerson Giumbelli, 111-37. São Paolo: Terceiro Nome.

Steigenga, Timothy J. 2001. Politics of the Spirit: The Political Implications of Pentecostalized Religion in Costa Rica and Guatemala. Lanham (MD): Lexington Books.

Strayer, R.W. 1978. The Making of Mission Communities in East Africa: Anglicans and Africans in Colonial Kenya, 1875-1935. London: Heinemann.

Villafañe, Eldin. 1996. "The Politics of the Spirit: Reflections on a Theology of Social Transformation for the Twenty-First Century." Pneuma: The fournal of the Society for Pentecostal Studies 18, no. 2: 161-70.

Wafula, Elizabeth Were. 2003. "Inter-Denominational Mobility of the Faithful among Churches in Nairobi." MD Dissertation. Nairobi: University of Nairobi. http://hdl.handle.net/11295/63783.

Yong, Amos. 2010. In the Days of Caesar: Pentecostalism and Political Theology. Grand Rapids (MI): Eerdmans.

\section{Media}

Karanja, Antony. 2013. "US Pastor TD Jakes Apologises over Kenya Comments.” Daily Nation Online, 18 October. https://nation.africa/kenya/news/uspastor-td-jakes-apologises-over-kenya-comments-905700 [archive].

Kareithi, Amos. 2006. "Bishop Wanjiru Hopes to Be President." The Standard, 5 November. http://allafrica.com/stories/200611060988.html.

Malanda, Ted. 2013. "The Key Opinion Polls We never Carry out." The Standard, 8 April. https://www.standardmedia.co.ke/crazy-world/article/2000081073/ the-key-opinion-polls-we-never-carry-out [archive].

Ndegwa, Alex. 2007. "Over 6,000 Churches Awaiting Registration." The Standard, 4 September.

Oduor, Peter. 2013. "The Kenyan Church and the Gospel of Prosperity." Daily Nation-DN2, 13 February. https://nation.africa/kenya/life-and-style/dn2/ the-kenyan-church-and-the-gospel-of-prosperity--847652 [archive].

Okeyo, Verah. 2013. "Preaching to the Converted: The Rise of Atheism in Modern Kenya." Daily Nation-DN2, 3 July. https://nation.africa/kenya/lifeand-style/dn2/the-rise-of-atheism-in-modern-kenya-872868 [archive].

Wangeri, Perpetua. 2014. "Give Me That Old Time Religion." The People Fusion, 18 May. 
Focus no. 3

\title{
The Church as a Provider of Material Support: An Inner/Outer Circles Perspective
}

\author{
Yonatan N. Gez
}

In this brief text, ${ }^{1}$ I discuss independent Pentecostal churches in Kenya as facilitators of material support for their members, and illustrate some of the dilemmas that these churches face concerning the allocation of limited resources in assisting members in need. I argue that, in order to understand such practices, we must take into account congregations' internal diversity, including socio-economic disparity and varying degrees of commitment. While such divisions might be expected in large congregations, I evoke the example of The Sanctuary Mission (pseudonym), an independent Pentecostal church of about 40-50 members located in Kisumu, to show how even small and quite tightly knit congregations contain such internal diversity. Using the distinction between inner- and outer circle members, I suggest that churches' behaviour in response to members' material needs is largely influenced by the tension between repelling and drawing in lessercommitted members.

Scholars often emphasise the role of religion in maintaining spiritual, social, and material benefits as a key for understanding its particular appeal in the Global South. For instance, Pippa Norris and Ronald Inglehart hold the view whereby societies' drift away from religion, especially in the Global North, can be tied to "existential security-that is, the feeling that survival is secure enough that it can be taken for granted" (Norris \& Inglehart $2004,4)$. This is clearly not the case with fast-urbanising Kenya, where the relevance of religion appears to coincide with volatility and precarious living circumstances, above all for the low and floating classes. Already as far back as 1977, Andrew Hake suggested that migration to Nairobi can generate a thirst for religion, which in turn offers a sense of security "particularly when traditional beliefs and groupings are threatened with

1. This text was written within the context of the project "Structures anthropologiques du religieux: butinage et voisinage," financed by the Swiss National Science Foundation (2010-2013; prolonged for 2013-2014). Fieldwork at The Sanctuary Mission was carried out between May and July 2014. Some of the ideas hereby presented were developed in conversation with Lena Kroeker of the University of Bayreuth. 
break-up" (Hake 1977, 234). More recently, with regard to Kenya's thriving Pentecostal movement, Damaris S. Parsitau, and Philomena N. Mwaura $(2010,16)$ argued along similar lines that "Pentecostalism provides a place of spiritual security and personal community to people who find Kenya's rapid social change to be both unsettling and frightening."

One of the ways through which religious communities can serve as a haven of stability is by providing material support to its members in their hour of need. Informed by a sense of camaraderie and Christian values, as well as by a missionary zeal, churches tend to acknowledge a certain obligation towards the wellbeing of their members. As examples throughout the history of Christianity show, this sense of material obligation tends to be intertwined with an ultimate preoccupation with spiritual salvation. ${ }^{2}$ Wherever their motivation for assistance may lie, Kenyan churches are often perceived as islands of solidarity within a general climate of institutional mistrust. ${ }^{3}$ But while mainline churches may afford to finance special ministries dedicated to assisting members in need, independent Pentecostal churches have less room for manoeuvre. These churches, which have emerged since the 1980s-1990s, struggle with intense competition. With their small and mainly lower classes congregations, and little to no overseas partnership and financial backing, many of them barely manage to keep themselves afloat.

While these new churches might not have a designated department or fund for assisting members in need, they may offer congregational assistance on an ad hoc basis, for example by using the church platform to hold fundraising called harambee. ${ }^{4}$ Yet such interventions tend to be quite rare, and are limited to what one Sanctuary Mission member termed "overwhelming problems," such as death in the family and outstanding hospital bills. Intervening in cases of everyday challenges, such as school fees arrears or need for travel fare, risks attracting disgruntlement and bitterness from other members, who feel that they too are struggling, and can lead to accusations of nepotism. As one lay leader at The Sanctuary Mission explained, "you cannot say in front of the church [that you need school fees]. You know, sometimes, if we say [that] we have a fundraising

2. One leader at The Sanctuary Mission evoked the image of the New Testament story of the wedding at Cana, whereby Jesus' miraculous provision of wine made the wedding participants attentive to his words. As my interviewee concluded, "some people, if we go the extra mile to show we care for them, for their needs, they will be motivated to sit down more and listen to what we are teaching them."

3. This being said, there appears to be indications that religious trust in Kenya is eroding (Gez \& Droz 2015).

4. Such collections may take place on Sunday after the main service. 
for someone, there is somebody on the other side who will be in need for school fees too."

More can be said once we draw a distinction between The Sanctuary Mission's inner- and outer membership circles. The church's inner circle, which amounts to about 15 individuals, consists of the church committee, which includes the clergy and lay members engaged in various institutional departments. This inner-circle congregational commitment appears to have significant correspondence to the congregation's income and educational elite. Overall, members of the inner group hold more prestigious, middle class jobs (e.g. accountant, teacher, businessman) compared to less committed congregants. Thus, for instance, the five partners in The Sanctuary Mission's lucrative car hire business, which requires substantial initial capital through the ownership of at least one vehicle, are all members of the church committee. The wider Sunday assembly, by contrast, includes a majority of lesser-committed, low-income individuals, many of whom are youth.

This association between socio-economic advantage and assuming church roles is probably not coincidental. In my research, I often noticed that better-educated and better-paid individuals tend to gravitate towards church leadership. While this might be because such individuals see themselves, and are perceived by others, as natural leaders, they may also be coaxed into such positions in attempt to ensure access to their talents and means, and to ensure their long-standing institutional commitment in an environment of high institutional turnover (Gez and Droz 2017). Indeed, placing a member in a position of institutional responsibility involves a tacit expectation of him or her to be committed to the success of that particular ministry-among other things, through pledging economic contributions. By contrast, it appears that, by and large, lesser educated and lesser paid Kenyans are more prone to religious mobility. This tendency might be linked to precarious living and pragmatic outlook, as well as to greater reliance on religion as a provider of such services as healing (Gez 2018; Gifford 2009, 125-33).

In a highly competitive religious market, the church is particularly preoccupied with drawing members of the outer circles towards greater commitment, for instance by inviting them to join one of countless church departments. ${ }^{5}$ When it comes to members' material needs, while being

5. Thus, for instance, despite its small size, The Sanctuary Mission has a complex institutional structure, which can be understood as one way of binding members towards greater institutional commitment. The church's ministries appear to include the following: women, men, and youth ministries; Sunday school; church development; instruments; praise and worship; intercession; ushering; and discipleship. 
assisted by the church may help to bind a non-committed outer circle member, it may simultaneously repel other members, who already feel burdened by Pentecostal churches' reputation as emphasising economic contributions. As one church leader explained, "when we say, "next week we have fundraising, we need money to assist somebody's school fees, we hope to do like this"-we realised that when they reach that day, other members are not coming-[namely,] the non-committed ones."

Understanding this distinction between inner and outer circles and the risk of disaffiliation on the part of outer circle members offers insights into the considerations surrounding members' assistance at The Sanctuary Mission. All formal requests for assistance must pass through the church committee, which then deliberates and decides whether to pass the request on to the congregation and to organise a formal fundraiser. While the committee may reject requests or approve them, cases that are less than "overwhelming" are most likely to be resolved within the committee itself. One of my interviewees explained this procedure using the following, hypothetical example: "[if a member needs money for] transport to go and see someone who is sick in Nairobi [...] and we announce that in churchwe cannot [do that]. They need transport, so we come and sit [in the church committee], [...] the pastor gives 500 , I give 500, so-and-so gives 500 , that money is enough." While resolving members' needs within the committee level might be economically strenuous for those inner circle members, such a course of action may offer an effective response to a number of challenges. As the committee is predominantly comprised of the church's socio-economic elite, providing solutions within the committee may obey a redistributive logic, whereby those who are in need-who are most likely to be from among the fragile outer circle-are assisted directly by the higher earners from among the inner circle. Moreover, resolving individual challenges on that level can mitigate the discomfort of excessive demands from the church's lower-class lay members through the Sunday assembly, thus reducing the risk that appealing for assistance might drive outer-circle members out of the church. Indeed, the better-resourced members of the inner circle might hope that, by assuming the costs of assisting outer-circle members in their hour of need, they would be able to draw them towards greater commitment.

One more advantage to such strategy of action is discreteness. From the assistance seeker's perspective, resolving challenges within the church committee replaces the need to face the entire congregation and announce one's economic fragility and dependence publicly. This discreetness might also be preferred by the institution, for the inconspicuousness of such appeals saves the church from the risk of incurring an influx of additional requests. The Sanctuary Mission already had such a negative experience 
when, some years back, it experimented with issuing membership cards, yet soon had to abandon the idea, after it has seemingly given members a sense of entitlement to material assistance. As the church's pastor explained to me, the issuance of cards attracted a stream of requests, including from uncommitted-and even former-members, who re-emerged, waving their membership card as proof of the church's obligation towards them. Indeed, in a setting where basic material lack is high, the church must consider how its moves might open the floodgate to unrealizable demands and overwhelm the rest of the congregation.

It remains to be seen to what extent what was observed in the case of The Sanctuary Mission-and especially, the rough association between degrees of membership commitment and social class-can be generalised as a common trend in Kenya, or even beyond. Patterns may vary between small, medium and large congregations, as well as across socio-economic levels and degree of congregational disparity, and between urban and rural churches.

\section{References}

Gez, Yonatan N. 2018. Traditional Churches, Born Again Christianity, and Pentecostalism: Religious Mobility and Religious Repertoires in Urban Kenya. Cham (Switzerland): Palgrave Macmillan.

Gez, Yonatan N., and Yvan Droz. 2015. "Negotiation and Erosion of Born Again Prestige in Nairobi." Nova Religio 18, no. 3: 18-37. https://www.doi.org/10.1525/nr.2015.18.3.18.

Gez, Yonatan N., and Yvan Droz. 2017. "The Sheep-Stealing Dilemma: The Ambiguities of Church Visits in Kenyaa." Journal of Religion in Africa 47, no. 2: $163-89$.

Gifford, Paul. 2009. Christianity, Politics and Public Life in Kenya. London: Hurst.

Hake, Andrew. 1977. African Metropolis: Nairobi's Self-help City. London: Sussex University Press.

Norris, Pippa, and Ronald Inglehart. 2004. Sacred and Secular: Religion and Politics Worldwide. Cambridge: Cambridge University Press. https://doi.org/10.1017/CBO9780511791017.

Parsitau, Damaris Seleina, and Philomena Njeri Mwaura. 2010. "God in the City: Pentecostalism as an Urban Phenomenon in Kenya." Studia Historiae Ecclesiasticae 36, no. 2: 95-112. http://hdl.handle.net/10500/4631. 



\title{
Chapter 11 \\ Minorities of Indo-Pakistani Origin
}

\author{
Michel Adam
}

Translated by Shruti Singhal

At the beginning of the twenty-first century, the population of Kenya includes minorities of Indian or Pakistani origin whose number (approximately 100,000 people, or $0.3 \%$ of the total population) is unrelated to their economic, social and cultural importance (Nowik 2010, 132-33).

At the crossroads of several cultural and linguistic areas (Bantu, Nilotic, Cushitic, Arab-Swahili), Kenya is an ethnically composite country, populated by successive waves of migration over the past centuries. If most of the country's ethnic groups are of African descent, other groups-despite the fact that they may have established in Kenya long ago in historywere coming from more distant territories, in any case outside of the African continent. This is the situation of the Arab and Persian minorities, established on the coast of the Indian Ocean since the beginning of the Middle Ages, or of the populations from the Indian subcontinent discussed in this chapter. ${ }^{1}$

Compared to its western coast, which is facing the desolate expanses of the Atlantic Ocean, the eastern coast of the African continent opens onto an inland sea dotted with islands. From Yemen to the south of India, it is bordered by lands which were once populous and prosperous, and by means of a regular regime of trade winds, lend themselves to important human and commercial exchanges. Navigating at high speeds, big dhows coming from the coast of India could-and can still today-reach unhindered the coasts of Africa and Madagascar from the beginning of the winter monsoon (October to March) and return during the summer monsoon to their home ports in favour of the inversion of the trade winds. Closely associated with the African settlements of the Arabs and Persians since the sixteenth century, various Indian traders from the regions of Gujarat and Sindh did not fail, as the Portuguese navigators testified, to arm ships coming from India and the Persian Gulf, occasionally financing cargo caravans within

1. The curious reader will find much more complete information on the subject in the book that the author published in French (Adam 2010), and its English translation (Adam 2016). Other sources of information include Adam (2004; 2006). The English translation of the 2006 text, published in 2010, is seriously flawed ("A Microcosmic Minority: The Indo-Kenyans of Nairobi," in Nairobi Today: The Paradox of a Fragmented City, see: http://doi.org/10.2307/j.ctvk3gmfc.11). 
the African continent and engaging in local trade activities in Zanzibar, Pemba, Mombasa and as far as in the northern parts of Kenya's coast.

If the presence of Indians on the Kenyan coast is ancient, their settlement in the interior of the country is comparatively recent: it dates from the late nineteenth century and corresponds to the establishment of British colonies in Eastern Africa.

From the beginnings of British colonisation, the British East Africa Protectorate, a sparsely populated territory and climatically welcoming to European immigration, became, in the eyes of the colonial authorities, a sort of extension of the Indian empire geographically quite close and easy for marine access. While the use of the Indian rupee as an instrument of exchange became dominant in the country, the small staff of the African colony (clerics, domestic, policemen and soldiers) were recruited on a voluntary basis in the northern and western provinces of the sub-continent (Baluchistan, Punjab, Gujarat, Kerala). In order to ensure the rapid construction of a railway linking Mombasa to the protectorate of Buganda and because they were anxious to distinguish the professional qualities of an already trained workforce, the British called on 35,000 skilled Indian workers (masons, blacksmiths, carpenters, surveyors, drivers, mechanics, etc.) to work in Kenya. After most of these contract workers were returned to their country at the completion of the railway, several waves of voluntary immigrants succeeded in the first quarter of the twentieth century. Almost all of these migrants were from intermediate castes (craftsmen and technicians, skilled workers, traders, employees) who came to make a fortune in the country. By settling in the cities but also in the intermediate villages and in the proximity of the peasant populations, these newcomers understood very quickly that the African population, which the British incited to enroll in a monetary economy, represented a very vast market (Gregory 1993, 11).

Like in South Africa, Indian immigration to Kenya-and to East Africa in general-was encouraged by the colonial authorities. Following the expansionist and imperialist aims of Cecil Rhodes, the British had in mind that a vast Indo-African confederation could be ruled from India. In this imperial context characterised by large demographic disparities and significant inequalities in technical development, the purpose of population movements was to ensure a better distribution of the human resources, necessary for the development of each province. In Kenya, a territory of a great future already promised to an important European settlement but devoid of resources of intermediate level manpower (e.g. technicians, tradesmen, administrative staff), the colonial power strove to gather the human means susceptible to work on what was called at the time "development" (mise en valeur), even sketching the idea (yet abandoned 
before the 1920s) of a massive installation of Hindu Patel small farmers ${ }^{2}$ in the distant hinterland of the port of Mombasa and around Kisumu. In the period between the two wars, Indians quickly exceeded Europeans. From 44,000 individuals in 1931, the number of Indians reached 177,000 in 1962, or $2 \%$ of the total population, and almost $20 \%$ of the urban population.

Like in other imperial spaces where the logic of colonial confinement ruled, the socio-economic and socio-cultural model of the ethnic division of labor was applied even without being establishing institutionally. This system of territorial exploitation followed two regulatory principles:

- First principle. The colonial society was made up of three specialised and hierarchical community groups:

-the Europeans, about 30,000 people at the end of the colonial period, who, after seizing the best lands, reserved for themselves the very remunerative functions of agro-export exploitation (tea, coffee, cotton, etc.), general administration and command;

-Africans, confined to reserves, were dedicated to food production; under the control of the British administration, some of them were mobilised for subordinate services (domesticity, forced labor) and to serve as auxiliaries to large export agriculture;

-Indians were assigned to economically and socially intermediate tasks, which were themselves divided according to the community specialisations related to the caste system. They were appointed with trusted administrative responsibilities (state employees, health personnel, police officers, postal and railway staff), or were wholesale and retail traders, qualified technicians, service providers, small industrial contractors. Overtime, they encroached, as far as possible, on the privileges of Europeans, gradually controlling a growing share of industry, banking and insurance, gaining access to many liberal profession positions thank to their first-class university degrees, thus becoming lawyers, architects, doctors, pharmacists, etc.

- Second principle. The three production and community entities were deemed complementary, not in competition. Enclosed in specific and largely exclusive activities, these communities exchanged goods and services but were not (or only marginally) competing economically. Thus, Indians were (legally) excluded from agricultural activities while Africans were banned from export farming and removed (de facto) from trade and industry.

These three communities remained physically and socially separated in accordance with the principles of colonial apartheid, which was not a legal but a de facto partition in force until the threshold of the 1960s, and materialised through the system of African "reserves," residential

2. Patel: caste of peasants and traders from north-western India. 
segregation in the city, segregation at school, in hospital and in society, strict endogamy, etc. Without endorsing the apartheid principles of which they were also the victims, the Indians made do with-and in some respects profited from-the tripartite division of labour and communal separation which reflected the division of castes still in force in India.

As secondary actors in the anti-colonial struggle, and being unpopular among the African population, East African Indians suffered from xenophobic reactions in the aftermath of African independence with partial expulsion and massacres in Zanzibar, mass expulsion in Uganda (Prunier 1990), and discriminatory measures in Kenya. At the end of a period of uncertainty corresponding to a strong demographic regression, they nevertheless preserved over the years their social and cultural characteristics while consolidating their economic power over the country.

\section{Main Characteristics of the Indian Diaspora in Kenya}

Also present in the other countries of Eastern and Southern Africa (Tanzania, Uganda, Malawi, Zimbabwe, Botswana, South Africa), minorities of Indian origin in Kenya mainly live in major cities (Nairobi, Mombasa, Kisumu, etc.) Some of them also reside in secondary urban centres, including the most remote rural villages. Since the first years of independence, the significant reduction in their demographic importance has been accentuated by the considerable increase in African population, and even more in the urban population. From $2 \%$ of the total population in 1962, their numbers fell to $0.7 \%$ in 2010 and to $1.5 \%$ of the urban population instead of $20 \%$.

The diaspora of Indian origin has, for two or three decades, been partially renewed by the more or less clandestine influx of migrants from India. The latter are often eager, at the end of a first professional experience in Africa, for a migratory rebound towards a Western country. Typically recruited from the Internet and from the middle class, this recent wave is mostly made up of young single graduates, facing unemployment in their home country, as a result of positive discrimination measures in favour of "low castes" and "disadvantaged classes," also called "scheduled casts" or "backward classes" respectively (Jaffrelot 2002). These new expatriates are attested in several branches of industry, banking, import export and international hotels. Equipped with a high level of qualification (especially in IT, commerce and management), low wage requirements and poorly welcomed by most Africans, these new expatriates are nicknamed rockets ("rockets"). Evaluating their numbers is all the more difficult as many of these young workers are undocumented and have obtained residency status through bribery (Adam 2010, 29-30; see also Prunier 1998). 
On its side, the Indo-Kenyan population of older stock maintains over generations the geographic dispersion of some of its members, both in East Africa and in a limited number of English-speaking countries, from the United Kingdom to North America to Australia. In their eyes, this propensity for mobility shows the capacity for reconversion associated with the family geographical break-up, but without calling into question-as will be seen below-the claim for the status of autochthones which people of Indian origin living in Africa frequently make.

Originally, in the great majority of the north-west of the subcontinent (Gujarat, Punjab, Maharawra, secondarily Kerala, and Pakistani Sindh), the Indian diaspora in Kenya has no less form a sort of cultural concentrate of India or apart from the political dimension, like "India in reduction." Almost all the social and religious communities in India are represented, but in different proportions than in the former metropolis: more Muslims (35 to $40 \%$ instead of $14 \%$ ), and among these, a significant proportion of Shiites ( $40 \%$ instead of 13\%, including a large proportion of Ismailis); more "classes" or "castes" averages, and very few low or very low castes, among which the untouchables are absent. Finally, among Hindus, representatives of schismatic organisations form very large minorities (15\% of Jains instead of $0.3 \%$ in India, $8 \%$ of Sikhs instead of $1.8 \%$ ). Other minorities which are tiny in India, such as Christians or Pârsis, are also over-represented in Kenya (10\% Christians instead of 3\%, 0.05\% Pârsis instead of $0.01 \%$ ). This prevalence of religious minorities maintains highly tolerant behaviour among all communities (Adam 2010, 32-33).

The Indians are grouped into 100 community associations formed by reference of the following three criteria of belonging: denominational membership, caste (or, for Muslims and Sikhs, the professional corporation that stand for it), and the region of origin. Community associations are instances of sociability and cultural and ceremonial animation, mutual aid and cooperation, and legal protection. They own their religious buildings, their recreation centres, their clubs, and wherever possible, their schools, hospitals, credit societies, radio-TV stations, and so on. In the case of certain communities (Ismailis and, to a lesser extent, Bohra), the association leaders possess as delegates supranational religious authorities and have quasi-sovereign powers: they raise taxes, control the allocation of credit, register acts of civil status, manage health and social services, administer sanctions, etc.

Although divided religiously and statutorily, the Indo-Kenyans are nonetheless united by the feeling of a common belonging as well as, for the most part, by the same geographical origin and by the existence of a widely shared cultural heritage: language (Gujarati or Hindi), etiquette, 
social, dress and culinary usages, secular rituals (almost all of Hindu origin, but commonly observed by Muslims and Christians).

The feeling of unity, which is reactivated in situations of xenophobic pressure, is further reinforced by the fact that in the diaspora situation, IndoKenyans are generally perceived by Africans (who are often ill-informed of the complex differences that separate the different communities) as belonging to a single socio-cultural entity. Sometimes neglected-or even decried-in inter-community relations, the community of belonging feeds on the external gaze or even more on threats made by others.

\section{The Place of the Indians in Multi-Ethnic Kenyan Society}

In the aftermath of independence, when called to choose between departure and integration into a new socio-political group, the Kenyan Indians chose a middle way: they preferred to establish in the country but refused full integration as they were invited to do by the new authorities. Successive Kenyan governments accepted this compromise-concerned, for their part, not to jeopardise sectors of activity considered vital for the prosperity of the country-and respected a kind of self-segregation among Indian communities contrary to the principles of diversity advocated by the paladins of independence. The new situation that had thus just been created was in several times detrimental to the immigrant communities, yet it was to continue until today. Its characteristics can be described as follows:

1. Partial survival of the community and statutory division of labour;

2. Displayed willingness to preserve the culture of the origins;

3. Low social and political integration.

1) Despite the denial by the independent Kenyan state of the formalised framework of the old ethnic division of labour (statutory barriers, corporatist protections, social segregation, etc.) and the competition of Indians with Africans concerned about promotion economic and social, the Indians have maintained and greatly expanded their hold on trade and industry activities in many ways. Having acceded to the British ownership of the main means of production, they now control about $80 \%$ of industrial branches (agri-food, textile, metallurgy, pharmacy, plastics, paper and packaging, chemistry, etc.), a growing share of agribusiness (fruit and vegetables), tourism and hospitality, $50 \%$ of banks and insurance, the bulk of retail, wholesale and retail of the press and advertising agencies which is a very important fraction of real estate activities and liberal professions (Adam 2010: 45-52). In Indian-controlled enterprises, recruitment takes 
place on family and community bases, with African staff being, with some exceptions, maintained in low professional positions.

The professional compartmentalisation associated with the caste has lost its binding character nowadays, yet the division of professions specific to each community still corresponds, to a certain extent, to ancient corporatist traditions: leatherworking, goldsmithing, laundry, metallurgy, textiles, bank, etc. Due in large part to the inertia of acquired situations (transmission of knowledge and capital), these technico-professional continuums-which are frequently modernised and brought up to date-do contribute to an Indian stranglehold on certain branches of activity.

In the current distribution of professions, we observe interesting symbolic transpositions that are quite similar to those encountered in Europe in the history of the old corporations. This is how Soni (jewelers) are today jewelers and watchmakers, but also sellers of curios; Dhobi (whiteners) have the monopoly of Dry Cleanings while Mochi (shoemakers) are industrial and shoe merchants; Wanza Darji (tailors) are industrial and clothing traders; the Nayee (barbers) are frequently doctors and surgeons; the Sutar (carpenters) are building contractors, etc.

2) Socially, Indians remain very weakly integrated into African society. The old segregation imposed by the colonial tutelage has been replaced by an informal self-regulation that leaves little room for a social and cultural mix: separate residential neighbourhoods, denominational schools, community hospitals, social and sports clubs, etc.

One of the first reasons for this social isolation, stemming from very ancient prescriptions of the Hindu culture, resides, according to the Indians themselves, in the repulsion with regard to natural and organic mattersearth, blood, bodily substances-commonly manipulated by Africans and generally placed by their counterparts in the symbolic register of the impure. Attached to the chtonian rites, consumers of alcohol, beef and animal blood, operators of the human body (on the occasion of the initiation ceremonies), the Africans are opposed in all, by their religious and daily practices, to these canonical preventions, as they are in any case displayed by orthodoxy. One of the consequences of this opposition is the almost total absence of commensality between Indians and Africans as expressed in the register of food and inter-corporal contact.

Secondly, community endogamy, which was inherited from religious and statutory prescriptions, resists the temptations of mixed marriage, even within the diaspora itself. While religious endogamy (still very strict) itself contributes to limiting inter-marriages between Indians and Africans to a small minority of Sunni Muslims (Shiism having practically no followers in East Africa), ethnic endogamy, in the broad sense, represents, in the eyes of the Indians, only an enlarged form of caste endogamy. At the same time, it 
seems to be self-evident as caste endogamy, for most of the part, has retained its dissuasive force. Thus, there are very few Indo-African marriages, but low percentages are nonetheless on the growth, especially among young people with higher education from a foreign country. Moreover, these marriages, when they exist, are always limited to the union of a man of Indian origin and of an African woman, a formula which inevitably leads-because of the patrilineal rule-to the absorption of wife and children by the husband's family. It thus excludes the opposite hypothesis of the insertion of a woman of Indian descent and her descent into African culture.

The logic of community confinement has two complementary effects: it limits the impregnation of African cultures among representatives of the diaspora-except for the use of the Swahili language generally adopted by all Indians; and it contributes greatly to the preservation of the Indian culture of origin (religion, language, clothing, food, social code, aesthetics, etc.), a culture that remains foreign and frequently indecipherable to Africans.

3) The weak involvement of the Indian diaspora in the political life of their host countries is another aspect of community juxtaposition with East Africa. Indians form informal pressure groups, sometimes very intricate in circles of power. Yet, with some exceptions, they do not participate in public political debates, show little partisan commitment and despite the political alliance attempts initiated after independence, they delegate very few representatives in the local or national deliberative instances.

\section{Identity Issues and the Future of Indians in Kenya}

In many respects, however, the situation of the Indians does not correspond to the caricature of xenophobic slogans which make them foreigners in Kenya and emissaries of rival interests. Kenyan Indians, like all East African Indians, have largely broken their ties with the homeland of their ancestors. Although India remains a place of occasional pilgrimage and an unsurpassed reference to revitalise the culture of origins (music, dance, literature, cinema, etc.), it has become a foreign land, socially, economically and politically speaking as well as in terms of family connections, and is in no case represents a possible reverse migratory appeal. For most of them, the Indians of Kenya have been settled in Africa for several generations and a majority hold Kenyan citizenship, so much so that they can as just be considered as Africans of Indian origin, being Indo-Africans or AsianAfricans as they name themselves.

In ways similar to the South African Indians but distinct from the West Indians and the Indonesians, the identity situation of the Kenyan Indians is original and, in some respect, hitherto unseen. Interlocked identities, in the first place, are remarkable. Born in Kenya, an Indian from the diaspora engages, successively or simultaneously, half a dozen identity references: 
his family, the geographical and social environment of his childhood, his vernacular language, his religious community, his caste (or what stands for it), his two vehicular languages (Swahili and English) and the cultural environment of its insertion his modern life (school, profession, social environment, etc.), and his citizenship (Kenyan). Moreover, and in a complementary way, as certain religious denominations are minorities-a dominant pattern in East Africa, with the Ismailis, the Bohra, the Jain, the Pârsis, etc.-, transnational community attachment has become the privileged protective reference, beyond the nation-states. As mentioned earlier, this is how the Ismailis, for example, find in the Aga Khan institutions quasi-state services (e.g. bank, judiciary, hospital, education, etc.). Such transnational ties facilitate the establishment of industrial, commercial and financial networks. The frequent dispersion of the families-a phenomenon that is independent from economic expansion-continuously maintains the link with other regions of the world and cosmopolitan references. Already influenced by several cultures (Indian, Anglo-American, African) and multiple identities (Indo-community, national-African), many families of the diaspora are disseminated across the globe due to the contingencies of academic curricula (children enrolled in Anglo-Saxon universities) or to secondary emigration (other African countries, North America, Europe, Australia, etc.). National identity, which Africans reproach Indians for not being attached to-though they are themselves not always attached to it more than to another regional or clan identity-is not, however, negligible value for the Indians. But it connects to other identity referents that compose complex individual trajectories, and in some ways always unique. The problem of the Indians is then no longer to choose between several trajectories situated both within and outside their person; it is rather to discover the way to make these multiple components coexist whilst respecting their duties as citizens and the laws of their host country.

The array of cultural characteristics specific to Indo-Africans in general evokes the description by Arjun Appadurai (2001) of the "postmodern diasporas" as well as the notion of the "end of the territories" used by Bertrand Badie (1995). In many ways, these scattered minorities are the illustrations of globalisation on the move across the globe. Without exclusive territorial ties, they deploy their activities on a transcontinental scale and communicate easily with their distant correspondents in a world without borders. However, they have not given up their identity ties. The reference to largely reconstructed or imagined cultural resources-for example, in the territorial references of ancient castes in the distant and abstract pastrevives Benedict Anderson's "imagined communities" and the mobilisation of their respective "ethnoscapes" (Anderson 1996). 
Are they citizens of their countries and citizens of the world? It is almost in these terms that in East Africa a minority of political activists pleading for integration present themselves against the conception of the "isomorphism of the extremes" between territory, origin and religion. Without partisan belonging and political ties, they plead the cause of citizen integration (national preference in economic matters, fiscal citizenship, opening of companies to African leaders, etc.), without denying the diversity of their cultural references or their cosmopolitan attachments. Represented by lawyers, teachers, doctors, and tradesmen, these activists display that their links with Africans and sometimes give the example of social mix through marriage. Despite the support of the liberal press (Nairobi's Daily Nation, for example), their commitments, however, are currently largely unheard of by the public.

\section{Conclusion}

As a conclusion, let us to return to a debate that has stirred the African and Indo-African intellectual circles for a number of years and briefly above mentioned.

As Kenyan citizens, the question arises-once again-whether Kenya's Indians can be considered "Africans," that is, indigenous or autochthones in this country, or not? In other words, at what point does one stop being a foreigner or allochthone, knowing of course that in all countries of the world, most but if not all autochthones are former allochthones. To define autochthony is apparently, therefore, about assessing how long ago establishment in a particular place happened. It goes without saying that an answer in terms of temporal depth calls other questions of a socio-cultural nature. Indeed time is not a condition in itself here, but a simple factor of one of the way more fundamental attributes of the identity of "native," namely, not so much the erasure as such of the previous origins but the irreversibility of immigration defined as the impossibility of a return to that origin.

Considering this important clarification, we can call "autochthone," in the general sense of the term, any person who can not avail themselves of other family ties as well as social and socio-cultural ties than in the country of their birth. To put it differently, it defines a person who cannot envisage, even as a possibility, a return to the country of their forebears, even in the hypothesis that such a country could be identified.

Just like the Maasai-who arrived in the country just 250 years ago-, the Indo-Kenyans are at home in Kenya. The curious walker can discover on the shores of the Indian Ocean, a few kilometres north of Mombasa but at some distance from any human settlement, a Hindu temple set in a marine cave, partially covered by the waves at high tide. This temple is still very 
popular with the faithful of the neighbourhood and can be dated more than 200 years, and it is not impossible that it is much older. No African has ever thought of questioning the legitimacy of Indians to hold this temple on the African soil of their ancestors.

\section{Bibliography}

Adam, Michel (ed.). 2010. L'Afrique indienne. Les minorités d'origine indopakistanaise en Afrique orientale. Collection "Hommes et sociétés." Paris: Karthala-IFRA.

Adam, Michel (ed.). 2016. Indian Africa. Minorities of Indian-Pakistani Origin in Eastern Africa. Dar es Salaam: Mkuki na Nyota; Nairobi: IFRA.

Adam, Michel. 2004. "Qui sont les populations d'origine indienne au Kenya?" Les Cahiers d'Afrique de l'Est 24: 2-49 [archive].

Adam, Michel. 2006. "Une minorité microcosmique : les Indo-Kényans de Nairobi." In Nairobi contemporain. Les paradoxes d'une ville fragmentée, edited by Hélène Charton-Bigot and Deyssi Rodriguez-Torres, 286-58. Collection "Hommes et sociétés." Paris, Nairobi: Karthala, IFRA.

Anderson, Benedict. 1996 (1983). L'Imaginaire national. Réflexions sur l'origine et l'essor du nationalisme (traduction française). Paris: La Découverte.

Appadurai, Arjun. 1996. Modernity at Large: Cultural Dimensions of Globalization. Minneapolis: University of Minnesota Press.

Badie, Bertrand. 1995. La Fin des territoires. Paris: Fayard.

Gregory, Robert G. 1993. Quest for Equality: Asian Politics in East Africa, 19001967. New Delhi: Orient Longman.

Jaffrelot, Christophe. 2002. "Inde : l'avènement politique de la caste." Critique internationale 4, no. 17: 131-44. https://doi.org/10.3917/crii.017.0131.

Nowik, Laurent. 2010. "Les Indiens d'Afrique de l'Est. Combien sontils ?" In L'Afrique indienne. Les minorités d'origine indo-pakistanaise en Afrique orientale, edited by Michel Adam, 109-90. Collection "Hommes et sociétés." Paris, Nairobi: Karthala, IFRA.

https://halshs.archives-ouvertes.fr/halshs-00866103/document.

Prunier, Gérard. 1990. L’Ouganda et la question indienne. Paris: Éditions Recherche sur les Civilisations (ERC).

Prunier, Gérard. 1998. "Les communautés indiennes." In Le Kenya contemporain, édité par François Grignon and Gérard Prunier, 191-207. Collection "Hommes et sociétés." Paris, Nairobi: Karthala, IFRA.

Salvadori, Cynthia. 1989 (1983). Through Open Doors. A View of Asian Cultures in Kenya. Nairobi: Kenway Publications. 



\title{
Chapter 12 \\ Kenya's Coast: Religion, Race, Ethnicity and the Elusive Nature of Political Community
}

\author{
fustin Willis \& Hassan Mwakimako
}

In January 2019, Kenya's already crowded political landscape was joined by another new party. The Umoja Summit Political Party was, avowedly, a party for the coast "formed on the basis of bringing back the elusive unity of the region," as its founder declared. ${ }^{1}$ Observers might have been forgiven for regarding this initiative with scepticism. Following the general elections of 2013 there had been a series of meetings amongst a slightly shifting cast of politicians from the six counties which had-until the implementation of the 2010 constitution-made up Kenya's Coast Province. Those meetings too had announced the formation of a new party to embody coastal unity. ${ }^{2}$ Even then, the idea was one with a long and inglorious history. There had been several avowedly "coast" parties in the brief initial phase of party politics in the late 1950s and early 1960s-the Coast People's Party, the Coast African People's Union, the Kenya Protectorate National Party (Salim 1973). The idea that the coast should have its own party had been revived in the 1990s, with a succession of parties laying claim to this role: Shirikisho and the Kenya African Democratic Union-Asili are the most obvious examples (Gona 2008). Again and again, it has been argued that a distinct political constituency of wapwani ("coast people") or (as some put it) "coastarians" requires united political representation. ${ }^{3}$

The idea of such a party reflects Kenya's wider politics which, while they have been described as ethnic or "ethno-nationalist," may more usefully be called "ethno-regional"-since the grievances that lie behind ethnic mobilisation are a long-term product of regional inequalities (Muigai 2004; Branch \& Cheeseman 2009, 3). Regional big men seek to mobilise

1. Baya, Samuel. 2019. "New Coast Party Out to Woo Hassan Joho, Amason Kingi.” Daily Nation, 27 January. https://www.nation.co.ke/news/politics/USPPthe-new-party-in-the-Coast/1064-4953386-8hvi3kz/index.html [archive].

2. "Coast Region to Form One Political Party." 2014. The Star, 6 January.

3. "Coast MPs to Quit ODM for New Party." 2014. The Star, 1 April; "Coast Leaders to Discuss Political Future." 2014, The Star, 13 November; "MPs Form Group for Unity, Economic Clout." 2015. The Star, 17 November. 
and maintain political constituencies which are defined both by ethnicity and locality, amid a popular sense that government is unpredictable and responsive only to claims made through the affective ties of kinship, ethnicity and locality. The core term of this politics is marginalisation. It is a term that expresses a salient historical truth-that the centralised nature of the post-independence constitution allowed incumbent presidents to channel the spoils of power to their own home regions. It is also a term that has become something of a cliché; now every act of political claimsmaking tends to be prefaced by the assertion that a particular community and region has been marginalised. Yet those who claim to speak for the coast will readily agree that the region has been especially subject to marginalisation under British rule and subsequently; grievances over land, education and employment are keenly felt.

Despite their unanimity on that core issue, however, those who claim to represent the coast have never actually created a distinctive coast party with general support, nor is there likely to be one in the near future. Though a succession of politicians from the coast have risen to brief prominence, all have struggled to mobilise widespread support at the coast itself. The idea of a coast party has been encouraged by the sense that since 2007 there has been a strong vote at the coast for Raila Odinga's Orange Democratic Movement. But as this chapter will suggest, the coast has not been, and still is not, a single political community. There are multiple divisions among the people who live in the six counties of the former Coast Province; like other ethno-regional identities, the coast is in practice deeply contested. Raila Odinga's apparent popularity in a succession of elections and referenda rested on a shared sense that the coast has been disadvantaged by central government-but was possible partly because he is not from the coast, and so cannot be readily identified with any particular one of the groups who vie to embody the coast. While "the coast" can be imagined as a singularitythe antithesis of "up-country" Kenya-there are in truth are many coasts, and they exist in tension with one another.

\section{Where is the Coast?}

A campaign for secession flourished briefly on the coast just before Kenya's independence in the early 1960s, and has been revived in the early twentyfirst century in the context of debates over Kenya's constitution (Willis \& Gona 2013). The campaign has always been driven by fears of political and economic domination by people from other parts of Kenya, but it was partly predicated on a historical distinction. The initial establishment of British authority at the coast, in the 1880s, had rested on the legal basis of the 1886 Anglo-German treaty, which had declared a ten-mile strip, running south along the coast from the mouth of the Tana River, to be the 
territory of the Sultan of Zanzibar. The Sultan leased this to the British East Africa Company in 1887. In 1895 the British government took direct control of the strip as part of the larger British East Africa Protectorate. When, in 1920, the rest of that Protectorate became Kenya Colony, the strip remained, formally, the territory of the Sultan-hence the title "Colony and Protectorate of Kenya." So it was that as independence neared in the early 1960s, some argued that "Mwambao," as they called it, should either be returned to Zanzibari rule or become independent by itself (Brennan 2008; Prestholdt 2014). Those arguments were echoed some fifty years later by the supporters of the nebulous Mombasa Republican Council (MRC), which again called for independence for the coast. The MRC insistedquite without evidence-that the 1963 agreement by which the Sultan had renounced all claims to sovereignty in the coast was subject to a time limit, and expired in 2013. Those campaigners for secession, in the early $1960 \mathrm{~s}$ and in the early twenty-first century, were deliberately vague in their use of the term "coast." Sometimes this focussed on the shoreline, but sometimes it effectively embraced the whole of Coast Province, which stretched far inland to the Taita hills, and included a long finger of land along the Tana River, roughly following the area inhabited by Pokomo people. The claim that this larger coast could-or should-form a political community was driven by the idea that the "original" inhabitants of the province were threatened by an "up-country" monopoly on wealth and power; here, as elsewhere in Kenya, the claims of autochthony have been strengthened since the 1990s by the international efflorescence of a language of indigeneity (Hughes 2005; Geschiere 2009; Lynch 2011). This "coast" was very much largerand more clearly defined on the map-than the "ten-mile strip," which had never been marked out by administrative boundaries (Willis \& Gona 2013).

Both "ten-mile strip" and "Coast Province" were, of course, in some measure arbitrary: the first a useful legal device in the partition of Africa; the second a colonial and post-colonial administrative convenience. Yet the difference between these two definitions of the coast expresses two quite different imaginaries of the coast as a physical territory, as well as a human society-on the one hand, as a thin fringe of shoreline, looking out to the Indian Ocean for its commerce and cultural inspiration; on the other hand, as a wider landscape, across which people move and trade continually, combining shoreline with a hinterland which embraces both the relatively well-watered agricultural land of the coastal ridge and the Taita hills, and a swathe of semi-arid land long used by pastoralists. These contending imaginaries are both shaped by-and shape-everyday life in the very varied territory embraced by what are now the six "coast" counties; and these differing territorial visions are overlaid on religious, ethnic and racial divides, sometimes cross-cutting and sometimes coinciding. All of 
these categories are, of course, social constructs: yet they are powerful forces in shaping people's experience and their ideas of personal and collective interests.

\section{The Muslim Coast?}

For many Kenyans-including many at the coast-the coast and Islam are somehow synonymous. Islam has a long history at the coast; both archaeological remains and the current architecture and public culture of most shoreline towns reveal the powerful presence of Islam as a daily part of many people's lives over more than a thousand years. But in terms of population, the six counties of the coast are by no means overwhelmingly Muslim. According to the 2019 census, there are significantly more Christians (2.4 million) than Muslims (1.6 million) in the six counties of the coast. Muslims are in a majority only in Kwale, Lamu and Tana River (Kenya National Bureau of Statistics 2019, 422). While the population of the towns and smaller settlements of the shoreline have historically been Muslim, the people of the hinterland have not. South of Mombasa, and along the Tana River, there was a relatively swift process of Islamisation in the late nineteenth and twentieth centuries; but in the quite densely settled hinterland immediately north of Mombasa, Islam spread more slowly (Holway 1970). While Christianity too was slow to win converts at the coast in the colonial period, it spread more swiftly from the 1960s (Deacon et al. 2017). Even more significant, however, has been the movement to the coast of people from elsewhere in Kenya- "up-country" people, or wabara, as coast people call them-a large proportion of whom are Christians (Sperling 2000). This migration to the coast was already apparent in colonial Kenya, as Mombasa in particular drew in workers from many miles away. Since independence, this in-migration has continued, and over time it has come to affect many areas of the coast. It has been particularly apparent in the main towns and centres of the tourist industry along the shoreline, but is also a feature of some settlement schemes (Kanyinga 2000).

Relations between Christians and Muslims have often been tense. As David Sperling (2000) has argued, there has been a history of religious plurality at the coast. Both in the rural hinterland and in some urban settlements, a family may have members who are Christian, Muslim, or who follow neither faith, living close together and routinely involved in each other's daily lives; everywhere, Muslims and Christians live as neighbours, and there is no religious "zoning," though some areas may have particular concentrations of one faith or another. But this plurality has come under strain (Mwakimako 2007). Over the last three decades, a narrative of collective Muslim marginalisation has become increasingly powerful. This identifies individuals' quotidian experiences of inequality 
and discrimination as aspects of a global marginalisation of Muslims as a community. While this narrative of marginalisation is by no means the only way in which Muslims at the coast talk about their political interests or identity, it is nevertheless powerful, and it has inspired a whole range of political involvements, from a peaceful activism focussing on constitutional change and human rights, to a violent radicalism which entirely rejects the state (Chome 2019; Thordsen 2009). At the same time, the identification of Christianity with political and economic power in Kenya has become ever more apparent (Wandera 2008-9). This is, moreover, a Christianity which is increasingly Pentecostal and often overtly hostile to Islam (Gifford 1994). The sense that Christianity and Islam are in conflict is readily aroused (Chome 2019, 17-18). Suspicion that Christians receive favoured treatment from the state merges with resentment against people who have moved to the coast from other parts of Kenya, many of whom are Christian.

This sense of exclusion in Kenya has become entwined with debates on the position of Muslims internationally, which have become ever more intense in recent years, enabled by new technologies and driven by events in Palestine and elsewhere in the Middle East, and by the complex conflict in Somalia. One consequence of this has been the emergence of a violent radicalism in Kenya, particularly amongst Muslim youth (Shinn 2007). The terrorist bombings of US embassies in Nairobi and Dar es Salaam in 1998 were largely externally planned, but between 2001 and 2014 there was a steady increase in the frequency of attacks, and considerable local recruitment of men who committed themselves to a violent jihad, largely at the coast, but also elsewhere in Kenya. Such recruitment built on the argument that local experiences-of poverty, poor education, landlessness, and misgovernment-are simply manifestations of a wider pattern of discrimination against Muslims globally, and that the only effective way to counter them is the violent overthrow of the state, and of the wider international system. The Kenya military intervention in Somalia in 2011 lent strength to this argument, and led to increased violence. Alongside occasional major terrorist attacks-one of which, at Mkepetoni, targeted a major centre of up-country settlement at the coast in a clear attempt to appeal to Muslim grievances-there was from 2012 to 2015 a bitter little war of assassination and counter-assassination, mostly in and around Mombasa, between the security forces, suspected radicals and suspected informers (Mwakimako and Willis, 2014). The often-brutal and extra-legal campaign of "counter-terrorism" at the coast increased tensions (Prestholdt 2011; Open Society Justice Initiative/MUHURI 2013). In 2012 and 2013, when radical preachers died in targeted assassinations which were widely blamed on the security forces, there were riots in Mombasa in which churches became the target of angry Muslim protesters; Christian pastors were also 
attacked in several incidents. The ambiguous position of Christianity at the coast was evident in the debates around the nature of the MRC. Those who claimed to be the leaders of the MRC were Muslims; and MRC slogans appeared spray-painted on urban walls alongside the slogans of radical Islam, apparently by the same hands. Yet some MRC supporters insisted that this was a movement for all "coast" people, not just for Muslims (Willis \& Gona 2013; Deacon et al. 2017).

A similar uncertainty characterises the debate over a "Coast party"; must the coast be represented by a Muslim leader? The most prominent politicians from the coast in the 1960s were Christians: Ronald Ngala was a Christian; so too was well-known politician of the early 2000s, Karisa Maitha (despite his earlier association with the United Muslims of Africa, an organisation founded with government backing in the 1990s to confront anti-government Muslim activists on the streets of Mombasa). But Maitha, who died in 2005, was not ostentatious about his Christianity; nor was Ngala. In the current national political climate, in which church services and fund-raisings are routinely used as political platforms, and political events blur uncertainly into prayer meetings, it would be difficult for a Christian national politician to avoid very public displays of faith; which, in turn, would make problematic any claims to leadership of "the coast." In recent years, those who sought national status as leaders of the coastNajib Balala, Chirau Mwakwere, and most recently Hassan Joho-have been Muslims; though, as will be explained below, ideas of ethnicity and race have undermined their ambitions.

If the divide between Muslims and Christians on the coast has become more evident in recent years, so too have divisions among Muslims. The perceived contest between "African Islam" and "Islam in Africa" has become a near-dominant analytical paradigm for understanding tensions amongst Muslims in Africa (Cruise O’Brien 1981; Rosander 1997). The neatness of that paradigm may misrepresent a reality in which individuals live across the two categories (Otayek and Soares 2007); but clearly Islam on Kenya's coast has long been shaped by debates over what it means to live properly as a Muslim (Chome 2019). Generations of Muslim reformers have sought to change established local practices and beliefs. Though the process is often dated to the 1970s, in Kenya it was first apparent in the 1930s, in the work of Shaykh Al-Amin Mazrui, and gained energy from the 1960s, notably through the work of scholars on the northern island of Faza, who were inspired by Egyptian teachers (Pouwels 1981; Swaleh 2012). External finance, and the intellectual influence of Islamic institutions of higher education outside Kenya, have played a part in these debates. From the 1960s, a growing range of governments and international bodies offered scholarships for religious studies, and provided funds for the building of 
mosques and madrassa, and for the salaries of imams. Young men from the coast went to study in Saudi Arabia, Yemen or Sudan, and latterly also in Uganda; they returned with belief both that Islam should be spread to nonbelievers, and that "innovations"-the Arabic word bid'a is routinely used in Swahili to describe these-which had crept into orthodox Islam should be removed, as part of a process of religious and social reform and renewal (the Arabic words, islah and tajdid, are routinely used in Swahili and English text and speech for "reform" and "renewal"). South Asian movements such as the Tabligh Jamaat also became active participants in a rural campaign of proselytisation. Empowered by their education-which gave them the allimportant ability to pursue theological debates in Arabic-and by the funds which supported them and allowed them to run minor local education and welfare projects, these men steadily shifted the terms of debate, and the bounds of permissible practice (Kresse 2007). The result has been tension over the propriety of some long-established practices: some funeral prayers; the offering of prayers at the tombs of renowned holy men; the playing of music in mosques as part of the celebration of the Prophet's birthday (the mawlid). Physical confrontations over these issues, became less common by around 2010, but debates remained lively, and occasionally divisive. After 2010, some practices-such as the celebration of mawlid-which had vanished for a time under the influence of the reformers have begun to reappear.

The debate over "innovation," on the Kenya coast as elsewhere in Africa, is often cast as a contest between a moderate form of established practiceusually described as Sufi-socially tolerant, and politically uninvolved as well as syncretic in ritual, and an intrusive reformism which is strict in its view of religious practice, intolerant of diversity and is inherently political. The reformist work of Salafists-as most now prefer to be called, shunning the Wahhabist label which some still apply to them-has come to be seen as linked with radical projects of political Islam and with violence and acts of terrorism (Haynes 2005; Rosenau 2005; Loimeier 2011). The narrative of Salafists using Saudi money or training to displace a tolerant local Islam is not wholly misleading (Ndzovu 2018). Yet it requires some nuancing. "Sufism" takes a particular form at the Kenya coast: practices associated with Sufism have been common in Islam at the coast. But, while mosques in which these practices are common may consider themselves as "tariqa mosques," Sufi brotherhoods (tariqa) actually have little significance. The widespread networks of spiritual patronage-and therefore of social power-which characterise Sufism in, for example, Senegal, are much less significant on the Kenyan coast. More importantly, the simple association of Salafism with "Islamism"-that is, with the quest for a political system run along Islamic principles-may underestimate the growing political engagement of all Muslims, which is both a wider Kenyan and international 
phenomenon (Thordsen 2009). In Kenya, and on the coast in particular, the politics of multi-partyism and the constitutional debates which have dominated public life for the last two decades have involved Muslims from the outset (Bakari 1995; Haynes 2006). In the early 1990s the Islamic Party of Kenya (IPK) was for a time one of the most prominent organisations calling for political change (Cruise O'Brien 2003; Oded 1996). While it came to be dominated by a radical preacher who had studied in the Middle East, IPK's agenda was to challenge despotism, and mainly focussed on opening up political space for Muslim youth through multi-partyism and electoral participation. Since then, multiple Muslim organisations have been closely involved in constitutional debates, both because of the perceived threat to the position of "Kadhi courts" (which provided justice to Muslims in matters of personal law) and because constitutional reform was seen as a way to overcome the political and economic marginalisation of Muslims. In both 2005 and 2010, Muslim organisations took very clear stands in constitutional referenda, and Muslims everywhere in Kenya-whatever their views on bid'a-were encouraged to think of themselves as Muslims, with a shared political interest.

Radical preachers who combined Salafist views on religious practice with an explicit support for violent jihad have undoubtedly encouraged recruitment to al-Shabaab on the Kenya coast. But not all those attracted to the idea of violent jihad-who are almost all young men-have any particular interest in debates over practice. The young men who flocked to an advertised "jihad training" event at Masjid Musa-a mosque in the Majengo area of Mombasa-in early 2014 were not all Salafists, or regular worshippers at mosques where Salafists preach. The sense that Muslims are marginalised, and that this is an international condition, is not restricted to those who call themselves Salafists; it is an idea articulated, in different ways, by many preachers in many mosques, as well as on the internet (Chome 2019; Mwakimako \& Willis 2014). It is by no means always advanced as a justification for violence-there are many prominent Muslims at the coast whose views on religious practice might be viewed as Salafist, but who nonetheless encourage peaceful political engagement through the constitution and through elections. That encouragement tends to be conditional-based not on the belief that liberal democracy is a good thing, but rather on the argument that it is the best way to pursue the interests of the Muslim community in current circumstances (Mwakimako \& Willis 2016). It is, however, the corollary of a substantial engagement in electoral politics; while a small number of Muslim youths at the coast have become involved in radical violence and denounce the very idea of democracy, it seems clear that large number of Muslims registered and voted in both 2013 and 2017 elections. 
There was not, however, any "Muslim vote" in either of those sets of elections. In 2013 this was despite-or perhaps because of-attempts by various Muslim organisations to orchestrate a community consensus; in 2017, little effort was made to mobilise Muslims collectively. The rivalrous multiplication of leadership bodies has been a feature of Islam in Kenya since the 1990s, and there have been repeated disputes over which, if any, organisation has the right to endorse particular candidates or policies (Constantin 1993; Ndzovu 2012). The rivalry sometimes sets coast Muslims against Somali or "up-country" Muslims, but there are rivalries for leadership amongst Muslims on the coast (Kresse 2009). Debates over practice can drive such rivalries. So, for example, the Kenya Assembly of Ulama and Imams (KAULI) - which despite its name, was really focussed on the coast-was created specifically to represent imams of "tariqa mosques," who felt that they were inadequately represented by other bodies, notably the Council of Imams and Preachers of Kenya (CIPK), which was also very largely a coast organisation. Both have become rather inactive since 2013. The proliferation of Muslim representative organisations was been fuelled by personal rivalries, and perhaps by the availability of "anti-radicalisation" funds from the US and its allies, some of which have been channelled through such bodies. But doctrinal differences and external funding aside, there are other dividing lines among Muslims at the coast, which were perhaps most clearly evident in the distinction between CIPK and another organisation, the Kenya Muslim National Advisory Council (KEMNAC). Like CIPK, KEMNAC has been based at the coast, despite its name-and is, in fact, very largely restricted to Mombasa. The difference between these two organisations was not doctrinal, and has nothing to do with the debate over bid'a. It was, quite simply, based on ideas of racial category. CIPK was led by men who-whatever they may call themselves-would be called Swahili or Arabs by many coast people who view themselves as Africans. KEMNAC, on the other hand, has been led by a man who has assertively argued the claims of-as he puts it-Africans (Ndzovu 2012, 34).

\section{Who Are the Wapwani?}

This sense of racial difference is a powerful force on the coast. Its influence is felt well beyond the rivalries of Muslim leadership organisations. It is also, of course, deeply problematic. Many of those who claim some distant Yemeni or Omani ancestry would nonetheless insist that they are Africans, as well as Arabs; and one of the many ways in which the ethnonym Swahili has been used is to capture a sense of an identity which is both African and coastal, looking out to the Indian Ocean but also rooted in the continent (Constantin 1989; Topan 2004). Arab and African, some would say, are entirely compatible kinds of identity. Yet there are many others who simply 
do not accept this, and who resent what they see as a long-standing social and economic dominance of coast society by people who they categorise as Arabs. Undoubtedly, this sense of racial difference is partly the result of British colonial policy, which linked these categories to distinct sets of rights, privileges and obligations-so that, for example, Arabs could own land, and vote, and Africans could not. Arabs were citizens and Africans were natives (Salim 1973, 183-246; Willis 1993). But as Glassman (2011) has argued of Zanzibar, racial thinking is not simply a colonial imposition; it draws on local understandings of identity in which a sense of indigeneity is a powerful force.

Whatever its origins, this idea of "race" continues to divide Muslims at the coast, and the population of the coast more generally, as Janet McIntosh's work (2009; also Ndzovu 2012) has shown. African Muslims believe that they are subject to discrimination and exclusion by their Arab co-religionists, and readily locate this contemporary condition to a history of slavery which is seen (not entirely accurately) as a history of Arab oppression of Africans. Landlessness is a constant source of friction at the coast, especially along the coast and its near hinterland north of Mombasa, where the legacy of nineteenth-century slavery and Omani rule, of British colonial policy, and of post-colonial rule is that tens of thousands of people live as squatters on the land of large landowners (Kanyinga 1998). For decades, this friction has been understood, and expressed, in racial terms, as conflict between Arabs and Africans-although that, again, is a considerable simplification. While some accuse "up-country" people-and especially, Kikuyu-of grabbing land at the coast, there are many squatters who prefer to blame "the Arabs" for their plight. In talking of land, in particular, people play with an uncertain categorical distinction between what might be called "race" and "ethnicity," which turns on an idea of autochthony. Up-country Kenyans are Africans-a term explicitly used-though they belong to other tribes; but "Arabs" are allegedly not. Public statements on racial difference have become less common in the face of threatened prosecutions by the National Cohesion and Integration Commission-but private language still routinely evokes race, in way that allows an allusive public style in which categories of racial difference are not mentioned, yet are ubiquitous.

The depth of this divide made itself apparent in the secessionist agitation associated with the MRC. The supporters of the MRC described themselves as wapwani. Yet there were uncertainties over who these wapwani were. The Facebook page of the MRC evoked a vision of the coast whose epitome was Mombasa's Old Town: Arab or Swahili in culture. The chosen symbols of the movement, which echoed the (largely Arab and Swahili) Coast People's Party of the 1960s, emphasised this link; in contrast, one self-defined African politician who was publicly critical of the MRC (though evidently 
mindful of its potential to mobilise coast grievances), Chirau Mwakwere, suggested that the very name "Mombasa Republican Council" revealed how unrepresentative the movement was-a characteristically elliptical way of raising the issue of racial difference. Meanwhile, some of the written material circulating under the name of the MRC offered an inclusive, cosmopolitan vision of the coast; while other "MRC" literature pointedly excluded Arabs from membership of the community of wapwani (Willis \& Gona 2013). These contradictions may to some degree reflect unresolved tensions in people's own sense of their identity; but they evidently also reflect the way in which the "MRC" as a brand could be appropriated by different groups, who had very different ideas of what "the coast" was.

Neither are the "Africans" of the coast united. Since the 1940s, the term Mijikenda has come into use to express an idea of political community amongst "nine tribes" on the southern coast: the nine being usually listed as Digo, Duruma, Giryama, Rabai, Ribe, Kambe, Jibana, Chonyi and Kauma. There are considerable cultural and linguistic continuities among the people of these groups (though also some differences); their slightly halting emergence as a "super-tribe" was roughly contemporaneous with a similar process among the groups who became the Kalenjin. A product of the late-colonial period, and particularly of the frenzied politics around independence, Mijikenda identity reflected the power of the idea of a collective voice which was both African and distinctively of the coast (Willis \& Gona 2013). Uncertain attempts to fold other ethnic groupsnotably the Taita and the Pokomo-into this wider identity have had little success, both because cultural and historical differences mean that there is little emotional power to this, and because members of those groups have seen little advantage in adopting this identity. If categorised as a single group, the Mijikenda form a clear majority of the population in the six counties of the coast: 1.9 million of a total coast population of 3.3 million, according to the 2009 census. Yet their sense of shared identity is fragile. Most Digo are Muslim, unlike other Mijikenda; not all Mijikenda languages are readily inter-comprehensible; and while multiple ties of migration and marriage bind Mijikenda, there are also bitter local disputes over land which can be expressed in terms of rivalries between Chonyi and Kauma, or Jibana and Giryama. At the same time, to be Mijikenda is not always so incompatible with being Swahili: ties of marriage and descent blur a boundary that appears very clear in rhetoric (Parkin 1989; Peake 1989). It is not, of course, unusual for identities to be multiple, and for larger groups to be internally fragmented. Yet it is striking that the mobilising and disciplining force of the idea of "being Mijikenda" seems so limitedperhaps because these divisions have been exacerbated by an engagement with national politics which sees aspiring Mijikenda leaders evoking these 
differences in attempts to undermine one another's claims to leadership, and allows national politicians to playing on such divisions to keep the upper hand over their Mijikenda "point men."

Repeated attempts by individuals to establish a national position as "coast" leaders have been confounded by ethnic and racial division. Ronald Ngala was engaged in a constant struggle-waged often along racial linesto assert his status (Stren 1974). Sharif Nassir became a powerful politician in Mombasa, but could never establish himself as a wider coast leader, because he was seen as a Yemeni Arab. Karisa Maitha, sometime protégé of Shariff Nassir (who used him to try and reach a Mijikenda constituency), became vocal in his denunciations of Arabs and achieved a degree of prominence, but at the cost of alienating his former patron. Rivalry for position in Kenya's politics of ethno-regionalism is not unusual, but the coast has seen a particularly high turnover of politicians, particularly since the return of multi-partyism (Gona 2008). Najib Balala, who more than one national politician has hopefully sponsored as a potential coast leader, has never been able to reach a wider constituency because he is seen as an Arab-his "Republican Congress" party was a spectacular failure in the 2013 elections. Chirau Mwakwere, who aspired to be the coast "point man" for national politicians, was unable to build any sort of reputation outside his own Digo community, even among other Mijikenda. In 2013, the competition for the position of governor of Mombasa revealed very clearly the nature of racial and ethnic politics: the two leading candidates, widely seen as Arab or Arab/Swahili, each took care to ensure that they had a Mijikenda running mate. Between them, these partnerships took $88 \%$ of the vote. The successful candidate in that election, Ali Hassan Joho, has become the most influential individual in coast politics, and has achieved a national prominence.

Between 2014 and 2017, Joho apparently courted confrontation with Uhuru Kenyatta, presenting himself as the champion of coastal interests against central government. The gambit paid off; despite criticism of his performance as Mombasa's governor, Joho won that position again in 2017 with a substantial majority. But neither this prominence nor his unconcealed ambition to run for the presidency have made him the unquestioned leader of the coast; there have been repeated attempts by Mijikenda politicians to form groups or parties that specifically exclude him. ${ }^{4}$ In the run-up to the 2017 election one Mijikenda politician forecast that Joho would lose as

4. Oketch, Willis. 2016. "Governor Hassan Joho Says He Will Be First President from the Coast Come 2022.” Standard Digital, 21 March. http://www. standardmedia.co.ke/article/2000195586/governor-hassan-joho-says-he-willbe-first-president-from-coast-come-2022. For one example of plans for coastal unity which exclude Joho, and are Mijikenda focussed, see Gari, Alphonce. 2016. 
he lacked the support of the "indigenous communities"-which turned out be quite wrong, but was a reminder of the persistence of that racialised language. ${ }^{5}$ The aftermath of the 2017 elections was revealing. Joho, together with the governor of Kilifi County Amason Kingi (a Mijikenda) made bold statements threatening coast secession as a response to the debacle of the presidential poll. ${ }^{6}$ Both men then stepped back from that confrontational line, and were quick to welcome the "handshake" that reconciled Kenyatta and Odinga in March 2018. Since then, Kingi has apparently become more distant from Joho; one of his reported public statements simultaneously asserted and denounced divisions: "The importance of the Mijikenda must be recognised, as well as the unity of the coast people."

Joho's presidential ambitions rest on the idea that he might become the regional big man for the coast. That hope is inspired by what looks like a pattern of voting, yet it may be misplaced. In the elections of 1992 and 1997, Coast Province-with the exception of Mombasa-was considered something of a "KANU zone," and Moi received $63 \%$ of the presidential votes at the coast in 1992 and 67\% in 1997. At that time, however, the ruling party's dominance relied on a patchwork of local leaders playing to local constituencies, not on a single key "coast" intermediary. The coast vote looked more like a real phenomenon in the series of polls since 2005 that gave a consistent majority for Raila Odinga, or for causes supported by him, with an overall rise in participation levels.

"Movement to Unite Counties for 2017 Poll." The Star, 29 April. http://www.thestar.co.ke/news/2016/04/29/movement-to-unite-counties-for-2017-poll c1341235.

5. Mwaboza, Anania. 2017. "Why Joho Will Lose on August $8^{\text {th }}$." The Star, 27 June.

6. Ahmed, Mohamed. 2017. "Hassan Joho, Amason Kingi Call for Breakaway of Coast." Daily Nation, 3 November. https://www.nation.co.ke/news/Hassan-JohoAmason-Kingi-call-for-breakaway-of-Coast-from-Kenya/1056-4172150-2rxmh2z/ index.html.

7. Reported in Lwanga, Charles. 2018. "New Bid for Mijikenda Unity Announced at Cultural Festival." Daily Nation, 12 September. https://www.nation. co.ke/counties/kilifi/New-bid-for-Mijikenda-unity-announced-at-culturalfestival/1183282-4752918-fq0qlxz/index.html. 
Table 1. Voting figures on the coast from 2005 to 2017, with participation rates and percentages of votes for Raila Odinga

\begin{tabular}{|c|c|c|c|c|c|}
\hline Year & Nature of vote & $\begin{array}{c}\text { Registered } \\
\text { voters, } \\
\text { Coast } \\
\text { Province }\end{array}$ & Turnout (\%) & $\begin{array}{c}\text { Votes for } \\
\text { Odinga (\%) }\end{array}$ & $\begin{array}{c}\text { Votes for cause } \\
\text { supported by } \\
\text { Odinga }\end{array}$ \\
\hline 2005 & $\begin{array}{c}\text { Constitutional } \\
\text { referendum }\end{array}$ & 967,518 & $334,08734 \%$ & & $\begin{array}{c}269,855 \text { ("No" } \\
\text { votes) } 81 \%\end{array}$ \\
\hline 2007 & $\begin{array}{c}\text { Presidential } \\
\text { election }\end{array}$ & $1,178,537$ & $601,20151 \%$ & $353,73359 \%$ & \\
\hline 2010 & $\begin{array}{c}\text { Constitutional } \\
\text { referendum }\end{array}$ & 997,080 & $537,15854 \%$ & & $\begin{array}{c}425,626 \text { ("Yes" } \\
\text { votes) } 79 \%\end{array}$ \\
\hline 2017 & $\begin{array}{c}\text { Presidential } \\
\text { election }\end{array}$ & $1,164,803$ & $817,20970 \%$ & $612,05775 \%$ & \\
\hline & $\begin{array}{c}\text { Presidential } \\
\text { election } \\
\text { (August) }\end{array}$ & $1,714,096$ & $1,112,865$ & $801,03172 \%$ & \\
\hline
\end{tabular}

Sources: figures released by ECK and IEBC.

This does suggest that voters at the coast see themselves as very much a part of Kenyan politics, whatever the talk of secessionism. It also suggests that the determined efforts by Uhuru Kenyatta and William Ruto to shift public opinion at the coast in advance of the 2017 elections-notably through some limited but high profile interventions over the chronic problem of land-were not very successful. ${ }^{8}$ But to interpret this pattern as evidence that the coast as a whole supports Raila, or is an "ODM" zone, or that Joho could count on this vote in his own presidential bid, would not be safe. In the August 2017 poll, as previously, the vote for Odinga was concentrated very much in the southern half of the coast (where the bulk of the population is); Lamu and Tana River counties saw considerable support for Kenyatta. Despite Joho's national prominence, the turnoutand the vote for Odinga-in his Mombasa County was weaker than any other southern part of the coast (a 59\% turnout, and a 70\% vote for Odinga; by contrast, Kilifi saw a $65 \%$ turnout and an $84 \%$ poll for Odinga). It would seem safer to say that voting patterns have indicated a broad preference for devolution, and a suspicion of central government, in the southern counties of what was once Coast Province; since Odinga has been an advocate

8. Tsuma Nyassi, Daniel, Kalume Kazungu, and PSCU. 2016. "Uhuru to Visit Lamu and Issue Title Deeds to Waitiki Land Owners.” Daily Nation, 6 January. http:// www.nation.co.ke/news/politics/Uhuru-to-visit-Lamu-and-give-title-deeds-toWaitiki-land-owners/1064-3022564-xwncc6/index.html [archive]. "Uhuru, Ruto, Start Coast Tour Full of Goodies.” 2016. Daily Nation, 3 September. https://nation. africa/news/politics/Uhuru-Ruto--start-Coast-tour-full-of-goodies/31263903367774-15csglwz/index.html [archive]. 
for devolution, and the avowed enemy of centralised government, this favoured him. Were Joho to stand for the presidency, that support would not necessarily transfer to him.

\section{Conclusion}

The multiple divisions of the "coast" mean that no politician has ever been fully able to claim to represent this contested entity. Odinga's popularity was itself anomalous in a context where the most prominent "national" politician in any region is usually a person from that area-it seemed to contradict the logic of ethno-regionalism. His role as coast champion was the consequence of his status as an outsider, but also an outsider who is not connected with the coast's history of marginalisation: neither his family, nor his ethnic group are seen as land-grabbers at the coast. Coast politicians are irretrievably marked by their religious identity, by their ethnicity andmost of all-by the imagined but immensely powerful categories of race which shape and divide the coast. Odinga benefitted for a time by standing apart from those divisions and at the same time supporting devolution, which commanded widespread support.

Yet while "devolution" may be popular in principle, there are significant differences in how people understand the term, which expose the multiple divisions among the imagined "wapwani": will it offer Muslims relief from the apparently arbitrary violence of the security forces? Will it give land title to squatters? Will it allow Digo to monopolise employment in Kwale, or Giryama to do so in Kilifi? These divisions have been amplified, not resolved, by the debate over the Building Bridges Initiative. Rival politicians from the coast continue to seek support for their own ambitions-and rewards for their particular religious, ethnic or racial community-by offering themselves as intermediaries to national politicians. Despite the constant rhetoric of coast unity, the coast remains profoundly divided: what devolution should mean, and which "coast" people should benefit from it, remain very much open to debate.

\section{Bibliography}

Bakari, Mohamed. 1995. "Muslims and the Politics of Change in Kenya." In Islam in Kenya: Proceedings of the National Seminar on Contemporary Islam in Kenya, edited by Mohamed Bakari and Saad Yahya, 234-51. Nairobi: MEWA Publications.

Branch, Daniel, and Nic Cheeseman. 2009. "Democratization, Sequencing, and State Failure in Africa: Lessons from Kenya." African Affairs 108, no. 43: 1-26. https://www.doi.org/10.1093/afraf/adn065. 
Brennan, James R. 2008. "Lowering the Sultan's Flag: Sovereignty and Decolonization in Coastal Kenya." Comparative Studies in Society and History 50, no. 4: 831-61. https://doi.org/10.1017/S0010417508000364.

Chome, Ngala. 2019. "From Islamic Reform to Muslim Activism: The Evolution of an Islamist Ideology in Kenya." African Affairs 118, no. 472: 531-52. https://doi.org/10.1093/afraf/adz003.

Constantin, François. 1993. "Leadership, Muslim Identities and East African Politics: Tradition, Bureaucratization and Communication." In Muslim Identity and Social Change in Sub-Saharan Africa, edited by Louis Brenner, 36-58. Bloomington (IN): Indiana University Press.

Constantin, François. 1989. "Social Stratification on the Swahili Coast: From Race to Class?” Africa 59, no. 2: 145-60. https://doi.org/10.2307/1160484.

Cruise O’Brien, Donal. 1981. "La filière musulmane : confréries soufies et politique en Afrique noire." Politique Africaine no. 4: 7-30.

http:/www.politique-africaine.com/numeros/pdf/004007.pdf [archive].

Cruise O’Brien, Donal. 2003. Symbolic Confrontations: Muslims Imagining the State in Africa. London: Hurst.

Deacon, Gregory, and Gabrielle Lynch. 2013. "Allowing Satan in? Moving toward a political economy of neo-Pentecostalism in Kenya." Journal of Religion in Africa 43, no. 2: 108-30.

https://doi.org/10.1163/15700666-12341247.

Deacon, Gregory, George Gona, Hassan Mwakimako, and Justin Willis. 2017. "Preaching Politics: Islam and Christianity on the Kenya Coast." fournal of Contemporary African Studies 35, no. 2: 148-67.

https://doi.org/10.1080/02589001.2017.1287345.

Geschiere, Peter. 2009. The Perils of Belonging: Autochthony, Citizenship, and Exclusion in Africa and Europe. Chicago: University of Chicago Press.

Gifford, Paul. 1994. "Some Recent Developments in African Christianity." African Affairs 93, no. 373: 513-34.

https://doi.org/10.1093/oxfordjournals.afraf.a098757.

Glassman, Jonathon. 2011. War of Words, War of Stones: Racial Thought and Violence in Colonial Zanzibar. Bloomington (IN): Indiana University Press.

Gona, George. 2008. "Changing Political Faces on Kenya's Coast, 1992-2007." Journal of Eastern African Studies 2, no. 2: 242-53. https://doi.org/10.1080/17531050802058351.

Haynes, Jeffrey. 2005. “Islamic Militancy in East Africa." Third World Quarterly 26, no. 8: 1321-39. https://doi.org/10.1080/01436590500336807.

Haynes, Jeffrey. 2006. "Islam and Democracy in East Africa." Democratization 13, no. 3: 490-507. https://doi.org/10.1080/13510340600579433.

Holway, James D. 1970. "The Religious Composition of the Population of the Coast Province of Kenya." Journal of Religion in Africa 3, no. 2: 228-39. https://doi.org/10.2307/1594687.

Kanyinga, Karuti. 1998. "Politics and Struggles for Access to Land: "Grants from Above" and "Squatters" in Coastal Kenya." European fournal of Development Research 10, no. 2: 50-69. https://doi.org/10.1080/09578819808426716. 
Kanyinga, Karuti. 2000. Re-distribution From Above: The Politics of Land Rights and Squatting in Coastal Kenya. Uppsala: Nordic Africa Institute.

Kenya National Bureau of Statistics [KNBS]. 2019. "Kenya Population and Housing Census. Volume IV: Distribution of Population by SocioEconomic Characteristics." Nairobi: Republic of Kenya. https://www.knbs. or.ke/?wpdmpro=2019-kenya-population-and-housing-census-volume-ivdistribution-of-population-by-socio-economic-characteristics.

Kramon, Eric, and Daniel N. Posner. 2011. "Kenya's New Constitution." Journal of Democracy 22, no. 2: 89-103.

https://www.journalofdemocracy.org/articles/kenyas-new-constitution/.

Kresse, Kai. 2007. "The Uses of History." In Struggling with History: Islam and Cosmopolitanism in the Western Indian Ocean, edited by Edward Simpson and Kai Kresse, 223-60. London: Hurst.

Kresse, Kai. 2009. "Muslim Politics in Post-colonial Kenya: Negotiating Knowledge on the Double-Periphery." In Islam, Politics, Anthropology, edited by Filippo Osella and Benjamin Soares, 576-94. London: The Journal of the Royal Anthropological Institute Special Issue Book Series. https://doi.org/10.1002/9781444324402.ch5.

Loimeier, Roman. 2011. "Zanzibar's Geography of Evil: The Moral Discourse of the Ansar al-sunna in Contemporary Zanzibar." Fournal for Islamic Studies 31, no. 1: 4-28. https://hdl.handle.net/10520/EJC48364.

Lynch, Gabrielle. 2011. "The Wars of Who Belongs Where: The Unstable Politics of Autochthony on Kenya's Mt Elgon.” Ethnopolitics 10, no. 3-4: 391-410. https://doi.org/10.1080/17449057.2011.596671.

McIntosh, Janet. 2009. The Edge of Islam. Power, Personhood and EthnoReligious Boundaries on the Kenya Coast. Durham (NC) and London: Duke University Press.

Muigai, Githu. 2004. "Jomo Kenyatta \& the Rise of the Ethno-Nationalist State in Kenya." In Ethnicity and Democracy in Africa, edited by Bruce Berman, Dickson Eyoh and Will Kymlicka, 200-17. Oxford: James Currey; Athens $(\mathrm{OH})$ : Ohio University Press.

Mwakimako, Hassan. 2007. "Christian-Muslim Relations in Kenya: A Catalogue of Events and Meanings." Islam-Christian Muslim Relations 18, no. 2: 287-307. https://doi.org/10.1080/09596410701214266.

Mwakimako, Hassan, and Justin Willis. 2014. "Islam, Politics and Violence on the Kenya Coast." Observatoire des enjeux politiques et sécuritaires dans la Corne de l'Afrique, Note no. 4.

https://halshs.archives-ouvertes.fr/halshs-02465228.

Mwakimako, Hassan, and Justin Willis. 2016. "Islam and Democracy: Debating Electoral Involvement on the Kenya Coast.” Islamic Africa 7, no. 1: 19-43. http://dx.doi.org/10.1163/21540993-00701001.

Ndzovu, Hassan Juma. 2012. "The Politicization of Muslim Organizations and the Future of Islamic-Oriented Politics in Kenya." Islamic Africa 3, no. 1: 25-53. https://doi.org/10.5192/21540993030125.

Ndzovu, Hassan Jum. 2018. "Kenya's Jihadi Clerics: Formulation of a "Liberation Theology" and the Challenge to Secular Power." Journal of 
Muslim Minority Affairs 38, no. 3: 360-71.

https://doi.org/10.1080/13602004.2018.1523359.

Oded, Arye. 1996. "Islamic Extremism in Kenya: The Rise and Fall of Sheikh Khalid Balala." Journal of Religion in Africa 26, no. 4: 406-15. https://doi.org/10.1163/157006696X00181.

Oded, Arye. 2000. Islam and Politics in Kenya. London \& Boulder (CO): Lynne Rienner.

Open Society Justice Initiative/Muslims for Human Rights. 2013. We are Tired of Taking You to Court: Human Rights Abuses by Kenya's Anti-Terrorism Police Unit. New York: Open Society Foundations.

Otayek, René, and Benjamin F. Soares. 2007. "Introduction: Islam and Muslim Politics in Africa." In Islam and Muslim Politics in Africa, edited by Benjamin Soares and René Otayek, 1-24. New York: Palgrave Macmillan.

Parkin, David. 1989. "Swahili Mijikenda: Facing Both Ways in Kenya." Africa 59, no. 2: 161-75. https://doi.org/10.2307/1160485.

Peake, Robert. 1989. "Swahili Stratification and Tourism in Malindi Old Town, Kenya.” Africa 59, no. 2: 209-20. https://doi.org/10.2307/1160489.

Prestholdt, Jeremy. 2011. "Kenya, the United States, and Counterterrorism." Africa Today 57, no. 4: 3-27.

Prestholdt, Jeremy. 2014. "Politics of the Soil: Separatism, Autochthony and Decolonization at the Kenyan Coast." Journal of African History 55: 249-70. https://doi.org/10.1017/S0021853714000322.

Pouwels, Randhall L. 1981. "Sh. Al-Amin B. Ali Mazrui and Islamic Modernism in East Africa, 1875-1947." International fournal of Middle Eastern Studies 13, no. 3: 329-45. https://doi.org/10.1017/S0020743800053459.

Rosander, Eva Evers. 1997. "Introduction: the Islamization of 'Tradition' and 'Modernity." In African Islam and Islam in Africa: Encounters Between Sufis and Islamists, edited by Eva Evers Rosander and David Westerlund, 1-27. London: Hurst.

Rosenau, William. 2005. "Al Qaida Recruitment Trends in Kenya and Tanzania." Studies in Conflict \& Terrorism 28, no. 1: 1-10. https://www.doi.org/10.1080/10576100590524357.

Salim, Ahmed Idha. 1973. The Swahili-speaking Peoples of Kenya's Coast, 18951965. Nairobi: East African Publishing House.

Shinn, David H. 2007. "Al-Qaeda in East Africa and the Horn." Journal of Conflict Studies 27, no. 1: 47-75.

https://journals.lib.unb.ca/index.php/jcs/article/view/5655/6658.

Sperling, David. 2000. "Religion and Society." In The Kenya Coast Handbook. Culture, Resources and Development in the East African Littoral, edited by Jan Hoorweg, Dick Foeken and R.A. Obudho, 157-71. Hambourg: LIT Verlag.

Swaleh, Kadara. 2012. "Islamic Proselytising Between Lamu and Mozambique: The Case of Kizingitini Village.” Social Dynamics 38, no. 3: 398-418. https://doi.org/10.1080/02533952.2012.752240.

Thordsen, Sara Normann. 2009. New Muslim Activism in Kenya. Copenhague: Institut for Statskundskab. 
Topan, Farouk. 2004. Swahili Modernities: Culture, Politics and Identity on the East Coast of Africa. Trenton (NJ): Africa World Press.

Wandera, Joseph. 2008-2009. "Muslims, Christians and State: The Contest for Public Space in Kenya." Annual Review of Islam in Africa 10: 17-22. http://www.cci.uct.ac.za/usr/cci/news/Joseph Wandera.pdf [archive].

Willis, Justin, and George Gona. 2013. "Pwani C Kenya? Memory, Documents and Secessionist Politics in Coastal Kenya." African Affairs 112, no. 446: 48-71. https://doi.org/10.1093/afraf/ads064.

Willis, Justin and George Gona. 2013. "Tradition, Tribe, and State in Kenya: The Mijikenda Union, 1945-1980." Comparative Studies in Society and History 55, no. 2: 448-73. https://www.jstor.org/stable/pdf/23526388.pdf.

Willis, Justin, and Ngala Chome. 2014. "Marginalization and Participation on the Kenya Coast: The 2013 Elections.” Journal of Eastern African Studies 8, no. 1: 115-34. https://doi.org/10.1080/17531055.2013.844443.

Wolf, Thomas. 2000. "Contemporary Politics." In Kenya Coast Handbook: Culture, Resources and Development in the East African Littoral, edited by Jan Hoorweg, Dick Foeken and Ray Obudho, 129-55. Hambourg: LIT Verlag.

\section{Media}

Ahmed, Mohamed. 2017. "Hassan Joho, Amason Kingi Call for Breakaway of Coast." Daily Nation, 3 November. https://www.nation.co.ke/news/HassanJoho-Amason-Kingi-call-for-breakaway-of-Coast-from-Kenya/10564172150-2rxmh2z/index.html.

"Ambassador Bellamy Visits Coast Province." 2006. Wikileaks, $1^{\mathrm{er}}$ March. http://www.wikileaks.org/plusd/cables/06NAIROBI919 a.html.

Baya, Samuel. 2019. "New Coast Party Out to Woo Hassan Joho, Amason Kingi." Daily Nation, 27 January. https://www.nation.co.ke/news/politics/ USPP-the-new-party-in-the-Coast/1064-4953386-8hvi3kz/index.html [archive].

"Coast Leaders to Discuss Political Future." 2014, The Star, 13 November.

"Coast MPs to Quit ODM for New Party." 2014. The Star, $1^{\mathrm{er}}$ April.

"Coast Region to Form One Political Party." 2014. The Star, 6 January.

Gari, Alphonce. 2016. "Movement to Unite Counties for 2017 Poll." The Star, 29 April. http://www.the-star.co.ke/news/2016/04/29/movement-to-unitecounties-for-2017-poll c1341235.

Lwanga, Charles. 2018. "New Bid for Mijikenda Unity Announced at Cultural Festival." Daily Nation, 12 September. https://www.nation.co.ke/ counties/kilifi/New-bid-for-Mijikenda-unity-announced-at-culturalfestival/1183282-4752918-fq0qlxz/index.html.

Mwaboza, Anania. 2017. "Why Joho Will Lose on August $8^{\text {th }}$." The Star, 27 June. "MPs Form Group for Unity, Economic Clout." 2015. The Star, 17 November.

Oketch, Willis. 2016. "Governor Hassan Joho says he will be first president from the coast come 2022." Standard Digital, 21 March. http://www. standardmedia.co.ke/article/2000195586/governor-hassan-joho-says-hewill-be-first-president-from-coast-come-2022. 
Tsuma Nyassi, Daniel, Kalume Kazungu and PSCU. 2016. "Uhuru to Visit Lamu and Issue Title Deeds to Waitiki Land Owners." Daily Nation, 6 January. http://www.nation.co.ke/news/politics/Uhuru-to-visit-Lamuand-give-title-deeds-to-Waitiki-land-owners/1064-3022564-xwncc6/index. html [archive].

"Uhuru, Ruto, Start Coast Tour Full of Goodies." 2016. Daily Nation, 3 September. https://nation.africa/news/politics/Uhuru-Ruto--start-Coasttour-full-of-goodies/3126390-3367774-15csglwz/index.html [archive]. 
Focus no. 4

\title{
History, Memory, and the Heritage of Slavery on the Kenyan Coast The Witu and Shimoni Cases
}

\author{
Patrick O. Abungu \& Clélia Coret
}

Translated by Stephanie Horsford

Despite their different trajectories, the Witu and Shimoni cases are interesting to compare as they provide a contrasting perspective on the history of slavery and trafficking on the Swahili coast, as well as on the way this past has been variously understood by the contemporary coastal society and by the Kenyan state and its institutions. Today's Witu and Shimoni are two villages: one is situated to the north of the coast, on the mainland facing the Lamu archipelago, and the other is seventy-five kilometres to the south of Mombasa. The history of these two places is linked to slave trafficking at its height in East Africa in the nineteenth century.

Many runaway slaves (watoro in kiswahili) settled in the Witu region in the middle of the nineteenth century, after having, for many of them, escaped from plantations in Lamu. Their settlement around Witu can be explained, in part, by the formation of alliances with the Aweer huntergatherer populations. It can also be explained by the presence (from 1862) of a Nabahani rebel chief-sultan Ahmed Simba ${ }^{1}$-whose influence enabled him to oppose masters seeking to recover their slaves. These watoro are estimated to be around several thousand in the second half of the nineteenth century. Some lived in the villages surrounding Witu and negotiated patron-client relationships with the sultan, but others, further from the town and more autonomous, recreated their kinship and alliance networks with non-Swahili populations.

The Shimoni site has a different history: it was a major step in the slave trade. The freshly captured slaves were held there before being put on the Zanzibar market. In kiswahili, the term shimoni means "a place in the hole" or "inside the hole," which accurately conveys the use that was made of the caves in that area. Naturally created by the tides, these caves extended over

1. The dynastic Nabahani clan was in power in Pate from around the end of the seventeenth century until the beginning of the nineteenth century. At that time, they suffered political pressure from the Omani imam (who became the sultan of Zanzibar in the 1840s) and from his allies in Lamu. Part of the Nabahani family fled to the mainland and re-established a city-state in Witu. 
almost five kilometres and were divided into multiple tunnels. Oral sources indicate that they were used to hide the slaves when British ships, looking to break up the trafficking networks, attempted to intercept boats in the Indian Ocean that were transporting human cargoes.

By crossing the available written documentation (especially the German and British archives) and the oral sources, it is possible to sketch an approximative map of the watoro villages around Witu. Many villages no longer exist and their population was displaced following violence in the region, particularly during the Somalian shifta raids in the 1970s. Furthermore, the ethnonyms used at the end of the nineteenth century to define these watoro groups (such as Wadoe, Wazigua and Watu wa Witu) are no longer in use today. It seems that, amongst the descendants of the escaped slaves, there is no pride in having ancestors who rebelled against their masters by fleeing and founding new villages. Thus, it is extremely difficult to study the memory of the former slaves' arrival, especially since research is still to be done to determine where the history of marronage and slavery situates in local memories-unlike the Shimoni case where oral investigations could be carried out thanks to the heritage making of the site.

In Shimoni, archaeological excavations contributed to demonstrating that the caves were used as warehouses to keep the slaves. Interviews have revealed differences in memory interpretation about the historic usage of the caves. While certain testimonies refer to a warehouse for slaves departing to Zanzibar, others speak of a place used to secretly hide the local slaves in order for them to serve on the coastal plantations after the closure of the Zanzibar market (in 1873). Moreover, those whose ancestors were involved in slave trade deny the existence of any slavery practices, whereas the families of the victims of slavery confirm its historical existence, although it is still rare to admit to a servile ancestry. Thus, unlike other regions affected by trafficking and slavery, these themes are discussed in Shimoni, in different versions, which gives a particularly illuminating example of the way in which these societies "tinker" with memory to construct their heritage and their identity.

Yet, Kenyan institutions have not initiated much heritage initiatives about the history of slavery and marronage on the coast. In the case of Witu and of Lamu region, the heritage-making of the Swahili "civilisation" and its history largely ignores slavery. The history of slavery does not yet have its place in heritage development, which is linked to the tourism industry that generates the highest income for the archipelago. The history and culture of the coast are at the heart of the heritage initiatives, to the extent that the Lamu archipelago is generally considered to be one of the birthplaces of the Swahili "civilisation." The Swahili House Museum as 
well as the exhibitions at the fort and at the Lamu museum unambiguously reflect the prominence given to certain aspects the coastal history-its trade culture, dhows, Islam, city-states, etc.-while they neglect the long-term contacts that the coastal cities maintained with the non-Swahili mainland populations through trade, patron-client relations, migrations between the coast and the mainland, etc. The same partial perception of history is found in the way heritage is showcased in the rest of the archipelago (e.g. the ruins of the ancient city-state in Pate) and at the mouth of the Tana river (in Ungwana for example), where archaeological excavations have been carried out since the 1960 s.

However, in Shimoni, actions towards a better visibility of the history of slavery have been taken for many years. Protected under the Museums and Heritage Act of Parliament of 2006, the gazetted Shimoni heritage landscape covers over fourteen hectares of land, and the slave cave was opened for tourism in 2001 as a place of memories of slave trade and slavery. The caves were used earlier by the local inhabitants to hide from raids by hostile communities, then as a warehouse for holding slaves by the traffickers, and later a local shrine by the local community. In general, Shimoni heritage landscape is place of multiple memories, and apart from the slave caves, also hosts some colonial buildings and a cemetery where a British soldier, Captain Frederick Lawrence, was buried after he was killed while leading an antislavery expedition around Gazi, near Shimoni. In 2014, a museum entirely dedicated to the issue of slavery was inaugurated in one of the colonial buildings, making the Shimoni Slavery Museum one of a kind in Kenya. This place of memory for trafficking and slavery has made it possible to generate income which is used locally for social ends.

Despite differences in the history of slavery in Witu and Shimoni, these two regions have both been marked by major constraints on mobility which still have an impact on the coastal societies of contemporary Kenya. Moreover, the heritage development of these sites is unequal: while Shimoni, through the 2000s, has become a place of memory for slavery, the regions of the Lamu archipelago and Witu have not, for the time being, prompted any such initiatives from the state. Yet, the involvement of state institutions in these sensitive historical and memory questions cannot be achieved without a profound reflection on the impact of their actions on the populations concerned by the heritage of slavery. 


\section{Bibliography}

Abungu, Patrick O. 2013. "Heritage, Communities and Opportunities: Shimoni Slave Cave and Wasimi Island Heritage Sites (Kenya).” The Uganda fournal 53: 202-21.

Coret, Clélia. 2016. "La refondation d'une cité swahili à Witu. Écriture de l'histoire et légitimation du pouvoir au nord de la côte est-africaine (18121895)." PhD Diss., Université Paris 1-Panthéon Sorbonne.

Kiriama, Herman. 2009. "Memory and Heritage: The Shimoni Slave Caves in Southern Kenya.” PhD Diss., Deakin University.

Morton, Fred. 1990. Children of Ham: Freed Slaves and Fugitives Slaves on the Kenya Coast, 1873 to 1907. Boulder: Westview Press.

Romero-Curtin, Patricia. 1983. "Laboratory for the Oral History of Slavery: The Island of Lamu on the Kenya Coast.” The American Historical Review 88, no. 4: 858-82. https://doi.org/10.1086/ahr/88.4.858.

Ylvisaker, Marguerite. 1979. Lamu in the Nineteenth Century: Land, Trade and Politics. Boston: Boston University. 


\title{
Chapter 13 \\ Beyond its Whitewashed Past, the Unique Peoples of Precolonial Kenya
}

\author{
Anne-Marie Peatrik
}

Translated by fane Womack \& Sara Doel

Twenty years have elapsed since the first edition of Kenya contemporain (Grignon \& Prunier 1998), even more if we refer to the point at which the authors wrote their respective contributions. The last chapter of the edited volume (Grignon 1998) on the "democratic invention," for instance, was an attempt at determining what the effects of the fall of the Berlin Wall and the new multi-party system were on political life. Obviously, since then, Kenya, like the rest of the world, has changed in this area, as in many others.

Taking stock of change is not as simple with regard to the topic to which we are paying particular attention here, namely the peoples and cultures or civilisations before the conquest of what was to become Kenya, as well as the advances in knowledge pertaining to them during those two decades. In this regard, the chapter on "Les sociétés anciennes et leur héritage" ("Ancient Societies and their Heritage") drafted by myself (Peatrik 1998) stands up reasonably well but the idea of "heritage" which underpinned a number of developments needs revisiting. "Heritage," defined as the implicit or deliberate transmission and reception of ways of acting and thinking which leave their mark on contemporary practices, is no longer understood in the same way in Kenya: the quite different notion of "heritagisation" (or "heritage-making") of culture has taken its place. This reappraisal of the status of the peoples and of their "customs," and the new anthropological theory on which it is based, is arguably the real intellectual innovation which came from those decades. Before getting to the heart of our topic, it is important to highlight these shifts as they shape the way in which knowledge of the populations under discussion is presented and disseminated, and more immediately, the content of this article.

\section{How Current Events Affect Knowledge}

The move towards freedom of speech and the freedom to broach a wide range of topics within everyday conversation and across various media, magnified by the availability of digital technologies, has undoubtedly led to introduce questions about "culture" within the public debate which would have been previously impossible or unthinkable to address in Kenya. 
One must remember the reticence and self-censorship that existed in the shadow of a culture of informing, which restricted exchanges and conversations under Daniel arap Moi's presidency (1978-2002) until the early 1990s. Customs, music and "traditional" clothing, which are in many ways harmless practices, were no exception: it was impossible to refer to them, let alone reclaim them at the risk of being labelled anti-modern, backward and even unpatriotic. The author of this text, who carried out research among the Meru from 1986 to 1993 on their ancient (and highly original) traditional political system, well remembers the initial disapproval, refusal to speak or even disbelief of the people she spoke to. Kenyans were educated, modern, properly dressed, they said, adding that all these customs of yesteryear were long gone and only pastoralists from the semi-desert regions and their herds would cling on to these retrograde practices. The popularity of the Maasai was then at its height among tourists (foreigners, needless to say) and many incredulous Kenyans questioned what image these warriors with their braided hair, bodies covered in ochre and armed with spears were conveying about their country. The only belated concession to the tradition and to the Africanness it represented was made by Moi, who, ready to make concessions in order to counter claims of multi-partyism, began extolling the virtues of committees of elders, whether revived, or self-appointed without foundation, since they had been brushed aside for so long. The "reinvented tradition" (Ranger 1983) was thus reimagined for the purposes of political control: few were fooled by the U-turn performed by the skilful tyrant, but the move delighted certain local baronets for whom it was too good an opportunity to miss. ${ }^{1}$

A quarter of a century later, the shift is evident. There is no city, no village anywhere in Kenya where you cannot find at least one "cultural dance" group, approved, if possible, by the County committee ${ }^{2}$; no market where you cannot find signs promoting local plants and medicines or a little

1. At the very beginning of the 1990s, the Njuri Ncheke, at that time in decline, re-emerged among the Meru (Peatrik 1999: 455-470, 2020 [2019]: 372384): President Moi saw them as a model council of elders and encouraged that such councils be (re)instated elsewhere in Kenya. Within the framework of the Organisation of African Unity, until 2011 these councils were financed by Muammar Gaddafi, the "King of Kings," who considered them to be better suited to managing populations than Western-inspired structures. This period in which traditional councils were manipulated to thwart multi-partyism, and which resumed the practices of the colonial administration under a different guise, is still in need of specialist research. Some elements can be found in Nyamweru \& Chidongo (2018).

2. Since the reform of 2010 , the county has replaced the district (an administrative division equivalent to the French department) and is governed locally by a county assembly which is elected by universal suffrage. 
private museum that an elderly person will be delighted to show you around. During public meetings, the governing elites break into isukuti steps-a very popular dance originating from the West of Kenya (Kiiru 2014)-to break up the meeting, casually don shirts with "African" designs on, and their wives no longer think twice about draping themselves in billowing brown dresses decorated with braids, reminiscent of the clothes of their ancestors, made from tanned and softened hides, adorned with pearls and cowry shells. Could it be the fallout from the years of policies encouraging cultural diversity to stave off fratricidal ethnic rivalries, particularly the post-election violence of 2007-2008?

Or could it be the intensive heritagisation programmes funded by Unesco and relayed through local campaigns and NGOs who see it as a resource for tourism and potential development? And what about the YouTube videos and countless websites promoting one "ethnic group" or another, and the use of local languages? Never before has cultural diversity and the ethnic brand associated with it been as promoted or lauded as it is in Kenya today. To the extent that the ethnographer must now contend with interviewees who are too keen to allow their culture to be studied and mirrored back to them.

How are we to understand it when Kenyans now speak of "culture," that is, as an understatement or euphemism for what they used to call customs or traditions? Are they praising the idea of returning to a frugal, ecological way of life which nonetheless incorporates cars, mobile phones, electricity and running water? Are they championing the values of respect and solidarity even though they are now being divorced from the practices which instilled them, such as gruelling initiations, public male and female circumcision, or even restrictive rules like the "bride price" ${ }^{3}$ " that was paid to secure marriages and determine the parents of children yet to be born? Do they want a return to the funerals of the past, during which, so as to not pollute the soils, the remains of the deceased were left in the bush for the hyenas and vultures, and grief was relieved through ritual coitus, for fear that the stain of death would otherwise endure? What should we say about "pagan" ceremonies (to use the missionaries' term), which are a far cry from various festivities that exist today where just a few animals are sacrificed? And about cultural dances whose choreography draws freely

3. "Bride price" or "bride wealth" was paid in kind and/or in cash by the future husband (usually with help from his family) to guarantee the status of any future children by the woman, his future wife, who would leave her family of origin to set up home with their husband and start their own family. This transaction and social contract are often confused in both French and English with the "dowry" which refers to the material goods that a woman brings with her to her new family. The two transactions can co-exist but do not in any way follow the same logic. 
from those rituals, with the sequences which seem inappropriate or out of place removed? As for witchcraft, that paragon of past customs, what should we make of the fact that the way in which it spreads and feeds rumours turns out to be closely linked with modernity (Middleton 1963; Luongo 2011)?

It appears that in Kenya, culture, customs and traditions cover a broad spectrum of meanings, ranging from the quest for identity in a post-colonial context to membership of clientelist networks or self-defence groups; from an imaginative space from which creative inspiration can be drawn, to stereotypes which can promote folklore-influenced brands or breed ethnic violence; or even knowledge and straightforward skills passed down by a parent to implicit ways of categorising which are conveyed through use of the mother tongue. We must not overlook geographical patterns, ways of roaming the land, the fact of staying in certain sites more than others, ways of perceiving the landscape, and associated land and property claims. ${ }^{4}$

To illustrate this abundance of meanings, conducive as it is to syncretism and a mish-mash of ideology, let us consider the astonishing movement called, "The Multitude" or Mûngiki (from the verb kwonga, meaning to multiply). This is the name of a generation of reinvented traditionalists, among them a small number of young Kikuyu who joined in the 1980s at the time of the first ethnic conflict and formed self-defence groups. Aimed at young men faced with unemployment and low achievement, these Mûngiki activists, who also called themselves heirs of the Mau Mau uprising (which, we must remember, led to independence in 1963), advocated a return to family "traditions" and to the ancient practice of passing official powers down through traditional generations. ${ }^{5}$ This young Multitude, in search of neo-patriarchal models and practices (Maupeu 2003; Lafargue 2010), even if they failed to rally anyone beyond their accomplices, still managed to frighten the middle classes, both Kikuyu and Kenyan, and those within powerful circles.

Yet all of this is a very long way from what the ante-colonial populations referred to using the ethnonym kikuyu, or by any other ethnonym. More than a century has passed since the military conquest, longer than that if we

4. In short, a civilisational process which anthropological scholars have incorporated into the notions of ethos or habitus, and have set about deconstructing across many analytical fields such as kinship, powers, modes of production, rites and religion, beliefs and knowledge... The collection recently published under the direction of Hughes \& Lamont (2018) which addresses the way in which 2010 constitution promoted culture to the status of "cultural rights" puts forward interesting avenues.

5. The subject of traditional generational classes is explained in the section 4, p. 363. 
refer to the arrival of missionaries in the middle of the nineteenth century. This has been a century and a half of major transformation across Africa and the world, over the course of which traditional institutions and ancestral practices, themselves shaped by a unique history, have been continuously put to the test.

Whilst in recent years, knowledge of the history of contemporary Africa has grown considerably, supported by an increasing number of written sources which are at last available-consider for example the reappraisal of the Mau Mau uprising (Ogot 2005; Charton 2011) or research into writing in African languages in Kenya (Peterson 2004; MacArthur 2016)-, knowledge of the societies and cultures that really existed prior to the conquests has progressed very little, with a few exceptions. The crisis affecting Kenyan national museums is proof of this. The prestigious site is now a sad thing to behold, after the reform of 2006 which resulted in the ethnographic galleries at the Nairobi National Museum being closed ${ }^{6}$-they were judged to be "colonialist" but were a mine of information about ancient societies and customs-and in devolved responsibilities to counties who were supposed to revive the national museums locally. Apart from a few wellequipped rooms, one wanders past mostly empty, dusty display cabinets, with a few photos and several plaques which make up the temporary exhibitions that are always there. And the groups of schoolchildren who go for extracurricular visits hardly make up for the sluggish visitor numbers. A new national museum of ethnography and history of peoples and past civilisations is still looking for its creators in Kenya, as is also the case in other African countries.

Unravelling Africa's distant past presents a number of methodological difficulties (Spear 1981; Sutton 1990). Written sources remain limited and oral traditions have a specific relevance but their analysis requires precaution. Regarding the history of languages, it is difficult to come up with reference points that are easy to use. Ethnographical data is poorly mobilised and historiography lacks reflexivity. As for archaeological digs, they are insufficient: they are costly and seen as less prestigious than research into hominisation and early man by the academic world and by financers, thus attracting fewer researchers even though there are many sites listed. In Kenya, according to the accounts of researchers at the national museum,

6. The superb Kikuyu hut which demonstrated the skill of traditional builders and was located outside was also destroyed, on the pretext that it perpetuated the confusion between national identity and Kikuyu identity... At the same time, the open-air Bomas of Kenya museum on the edge of the Nairobi National Park, where the national dance company is based and habitats ("bomas") which represent national diversity have been built, has not undergone any specific renovation even though its more national character would make this highly worthwhile. 
working on 1,000,000 year old history potentially offers more prestige and credibility than that which dates back $10,000,5,000$ or 1,000 years BP. And yet it is during these last millennia that key elements of the historical framework of today's East Africans have fallen into place (Lane 2016). Very recently, a few studies have been carried out on the history of ecosystems linked to the climate crisis and the question of preserving natural heritage. Similarly, progress has been made in settlement history thanks to the rise of population genetics but the major socio-human frameworks are still rarely questioned. Highland societies are still considered to be limited in their historical richness. This is of course contrary to the cities of the Swahili Corridor which left behind "traces" and accounts that are more in keeping with the conventional tools of historical and archaeological research.

In the absence of debate around these areas, while the cultural heritage craze is in full swing, the gap between the knowledge of contemporary East Africa and the East Africa of the past is widening. One must, supported by specific knowledge, be increasingly imaginative in avoiding anachronisms and capturing the unique spaces and peoples of East Africa. How long will it take for intellectuals and the educated elite to realise that the institutions and practices which underpin "customs" are born of a history that is social, political, religious, aesthetic, demographic, which pertains to heterogeneous timescales (emic and etic) and which should be investigated? This is the way things happen in science and knowledge production. As soon as there is evidence of a social and political expectation regarding these questions, coming from the new generation, the academic momentum and stewardship will follow.

The overview presented below is based on field research and monographs carried out in the twentieth century, at a time when witnesses and participants from before the conquest were still able to provide first-hand information. Ethnographic in its content, this broad portrait aims to draw out the original characters from unique worlds, which have undergone profound change but whose influence can be found in a number of ways in the present-day reality.?

\section{A Unique Geography and Economy}

Who and which peoples from the time before colonial borders were created are we talking about? In what became Kenya, the smallest populations and groupings, wherever they were located, were often identified by proper names which are rarely used and are not well known today. According

7. It is impossible to detail the countless references which support this overview. At the end of the article, the selected biography suggests further reading and provides links to further references. 
to whether these peoples named themselves or other people named them, they had changing ethnonyms. And many contemporary names, which seem to carry the hallmark of antiquity, are as much the product of tenuous transcriptions and opposing representations as they are of the improvised way the colonial administration was implemented.

The Meru ethnonym was coined in 1908 by the conqueror and first administrator of the area, derived from a Maasai name, which also appears to echo a toponym of the place where the first administrative and military post was established. In reality, at least five groups came under the label "Meru": the Igembe, Mwiko jwa Ngaa (still called Tigania), Imenti, Chuka, Tharaka. The "Kikuyu" ethnonym was reappropriated in the 1930s to embrace all the people living between the northeast and southwest, and west of Mount Kenya-Meru, Embu, Mbeere, Gichugu, Ndia, Gaki, Metume, Karura-all of whom came under the single "Kikuyu Land Unit" by the colonial administration.

The Samburu, herders from North Kenya, known by this name of Bantu and/or Maasai origin, call themselves Lokop, an ethnonym that only they use. Further west towards Mount Elgon and Nyanza, the name (Aba-)Luyia incorporates, in simple terms, the Vugusu, Hayo, Marach, Wanga, Nyala, Tsotso, Marama, Holo, Isuxa, Idaxo, Kisa, Nyole, Logoli, Tiriki. Returning to the hinterland of the coast of the Indian Ocean, we find the Mijikenda (literally "the nine settlements"), an ethnonym that was coined in the 1930s to distinguish it from the Swahili (also an exogenous ethnonym) and to replace their unflattering naming as "bushmen" (wanyika), bringing together nine different groups: Giriama, Jibana, Chonyi, Ribe, Kambe, Kauma, Rabai, Digo, Duruma.

The list is long. An interactive, multi-scalar map would best accommodate these ancient and contemporary onomastics. This would be a very solid introduction to the relativity and historicity of designations, which would look good in the entrance hall of a renovated and reinvented Kenyan national museum of ethnography and history, something which it is pleasing to imagine in this text. However, this does not mean these labile or arbitrary designations should be seen to reflect vague, ill-defined and unstructured communities, in line with another idea conceived in the minds of the first conquerors and administrators of these groups. Behind these names, or within them, there lie memberships and affiliations, rights and bans, solidarity and conflict, and also several limits-in sum, institutions, all without the use of writing or state bureaucracy, which it fell to anthropology and ethnography to decipher. Briefly, and without going into too much detail, the notion of "people" used here refers to the effectiveness of marking out political units which have been formed within or by the generational system (or traditional generations) and initiations- 
we will explain these two institutions later in the text. Otherwise, we are referring to more modest human groupings, which are expected over time either to expand or to merge or join together with more powerful neighbouring groups, or even disappear.

The highlands and lowlands of Kenya, like those of the border regions of neighbouring countries, are part of a unique environment made up of long, mostly gentle slopes, which are exposed to seasonal winds mainly coming from the Indian Ocean, bringing maritime influences and with them, rain. With the slopes acting as a shield against the humid winds, clouds form and rainfall increases in intensity in line with altitude as the temperature cools. And because these air masses come and go twice in the year, they trigger two rainy seasons (bimodal rainfall pattern) which allows for the possibility of two harvests, continuous lactation of herds and the regular production of beehives. The layering of ecosystems is another characteristic and additional benefit. Thermal gradient and humidity combine to produce environments that are versatile, according to altitude: lower down it is drier and suited to cereals and peas; at altitude it is cooler and more humid and suitable for roots, tubers, sugar cane, beans and bananas. Land at around 1700 metres has (or had) many advantages conducive to human settlements: in an intermediate position and at a reasonable distance from those mentioned above, land at this altitude which is comparatively cool without being too cold, was unaffected by the anopheles (carriers of malaria) or by diseases that spread in hot and humid environments (lower morbidity).

However, this natural potential is limited by irregular rainfall. Such irregularity owes to the contrast between the well-watered slopes and the dryer leeward slopes, but also to the irregular rains from year to year, whether these are short rains in autumn or long rains in spring which can be insufficient, excessive, late or early. Current changes in the climate are, for the moment, only exacerbating this irregularity. There are a number of responses that people, over centuries and millennia, have learned to identify, to protect themselves and make the best use of this potential. The most sustainable of these was to have sufficiently large and varied land available and to practice a range of economic activities. Taking the opportunity to open gardens, graze a herd, hunt and forage for food in places where the rain is more abundant and moving to another slope or altitude without having to negotiate the move or the land's ownership is the most appropriate response. The political drivers behind such a territorial arrangement are examined below.

Carrying out multiple economic activities in these spaces does not fit well with the portrayed image of the Maasai herdsmen, whose pastoral specialisation would have been a quintessential aspect of the traditional East African economy. Again, we must correct the stereotype that the 
Maasai themselves often employ. This problematic and exceptional specialisation was probably a late decision in the history of these peoples, and the Maasai, although highly visible, are not very representative. The other peoples combined, to varying degrees and made up in many different ways, foraging and hunting, breeding (large and small ruminants, bees), agriculture (cereals, legumes, tubers, bananas, sugar cane), handmade items and bartering.

A wide range of items were made by hand, from the construction of various buildings (varying in size, life span and purpose) to the tanning of skins for clothing and bedding, as well as jewellery, ropemaking and containers: decorated gourds, wooden buckets sewn with leather, earthenware pots made by women during the cool and dry season, a period of plenty, conducive to feasts and rituals. Only the manufacturing of iron tools was carried out by specialists. Blacksmiths, who used pits for ore reduction, were craftsmen who were both feared and despised. These people and their activities were avoided and were subject to prohibitions. For example, they were not allowed to marry non-blacksmiths and a blacksmith's wife could not practice farming, with the exception of small gardens within the family homestead. Blacksmith's wives traded iron tools for agricultural goods, sometimes by means of force. Blacksmiths often owned large herds which had been amassed in exchange for their products, in particular essential weapons with which to equip the warrior classes.

The idea of "caste," however, is inappropriate since these societies were non-hierarchical, egalitarian and by no means imbued with the ideology of purity. For both pragmatic and symbolic reasons, blacksmiths were considered to be abusive and ill-mannered. Since people could not do without them, it was best to protect oneself from them. But their Oolitic iron deposits were kept secret and guarded by warriors, as were some clay pits which were reserved for female potters, and salt deposits which were essential for health of herds and people. Medical knowledge was widely shared to such an extent that the same pharmacopoeia was used to treat herds of animals and human beings. The diviner-healer was a little unusual: a healer who was visited by the sick or victims of repeated misfortune, he was also the diviner that warriors would consult before embarking on a raid. These skills did not overly set him apart; as he was obviously paid for his consultations the traditional diviner-healer tended simply to be richer than average.

Tasks were distributed according to limits of age, generation and gender which in turn helped to maintain those limits. Again, one should not view this division as inflexible and its limits as insurmountable: within the sphere of economic activity, practical reason and the demands of everyday life took precedence. Beekeeping (and mead) and hunting were reserved 
for men, while pottery and making beer were reserved for women. The domestic economy relied largely on the contributions of children and young people. And when they grew older, leaving the family homestead to become warriors and join the warrior class, or to marry into another homestead, was delayed for as long as possible. Adults worked in the gardens and with the herd for as long as they had the strength. The most common mix of activities was agriculture and animal husbandry, to varying degrees depending on time and space. Some non-farmers combined blacksmithing, breeding and foraging. Everyone, including those who had a small number of herds or no longer had any, loved and idealised cattle, which were seen as the very best way to conduct contractual relations between humans, as well as offerings and sacrifices to the deity: called by different names according to the language, this principle, around which the world would come to be based, was universally recognised by these peoples.

One final aspect relating to exchange and movement deserves further explanation. The idea that these peoples were isolated and inward-looking, that they were self-sufficient, in line with the stereotype that has been so prevalent in relation to these "primitive" precolonial people, is not appropriate. People moved around East African areas quite freely with almost no insurmountable obstacles, with only a need to know routes and take precautions. Over the centuries, networks were created, undone and rebuilt. Bartering was in operation across short or long distances: it was practised within domestic markets by people living short distances away, between producers of goods grown on higher and lower ground (cereals in exchange for bananas, roots and beans, and agricultural products for small cattle or iron objects). It was also practised between neighbouring people: women would go on trading expeditions under the protection of warriors, carrying bags of various goods-grains and cereals-on their backs, which they would trade for skins which were abundant among pastoralists. Conversely, pastoralists went up to markets at high altitudes in search of agricultural products, iron objects etc, which they traded for cattle.

There was no money, in the strict sense of the term, hence the concept of barter, but exchange values existed, which were determined from place to place and according to the seasons. A plausible value attributed to cattle was used as a focal point which varied according to the quality of the animals. A certain number of bags of grain were traded for iron tools; herds of small cattle for bananas or even large cattle, cows, heifers, calves, bulls, oxen, both fat and scrawny; and salt cakes for bags of yams. Blue or cowry shell pearls were given in exchange for cereals or herds of cattle... These transactions took place alongside other forms of trade and debt such as cattle contracts, marriage contracts and child fostering. These oral contracts, sealed in various ways (animal sacrifices and blood pacts together with the 
threat of curses and retaliation in cases of non-compliance) were based on interpersonal relationships and mutually recognised contacts. Thus, the names of categories relating to generation and age, by means of comparing lists specific to each group of people, very often made it possible for people to locate any given person they had met in passing. Here, as elsewhere, people could break their word, or break a contract but these interactions would involve nearby or distant communities. Trading networks of widely varied kinds interconnected these peoples and communities. Distances beyond the reach of a trumpet call were given a value according to the number of days of walking, for the warriors in particular, one of whose main functions was to survey the country-theirs and others'-sometimes with hostile intentions. It was usually women who would carry things over shorter distances. Processions of men would cross each other while travelling longer distances. The tsetse fly limited the use of donkeys almost everywhere; and dromedaries roamed the more arid Northern regions.

These areas had relatively gentle terrain and were outward-looking. Various products were introduced: cowry shells, coloured pearls, blue Persian pearls in particular, new species and varieties to farm, which were adopted and adapted according to soil cultivation, transforming and improving them: American or South Asian species (beans, bananas, taro, sugar cane...) that arrived via the Nile basin and the coasts, which facilitated the development of more elevated land and allowed for new economic combinations and an increase in population. Products were transported to the coast of the Indian Ocean where coastal societies had been formed, long before the so-called Swahili cities appeared, this time in collaboration with well-established Arab-Muslim traders. For a long time products from highland blacksmiths were exported. Cattle were also brought to the coast. Valuable goods such as rhinoceros horns and elephant tusks arrived through the Kamba and other people too, who had established themselves as essential intermediaries. Lastly, contrary to what happened in the hinterland of what was to become Tanzania, Swahili and Arab merchants' caravans did not penetrate, or not to a large degree, the continent in the hinterland of today's Kenya. The people who lived there had a reputation for being "savage" and barbaric and for being protected by cruel warriors, a reputation that the Kamba were careful not to dispute, all the more so since the fate that met Swahili or Somali caravans that never returned confirmed this.

In this ancient economy, being rich and accumulating wealth were by no means held in contempt. The rich man, one who was successful in his various occupations, was an important person who was constantly called upon: he was "the one who makes people happy," according to the literal meaning of one of the local names for these "big men." He became 
someone who provided benefits and was a resource for his citizens. $\mathrm{He}$ could not avoid the demands that were made of him as they went along with his reputation and position, which were determined by the number of "dependants" and by his ability to widen his networks. After a while, however, the accumulation and transfer of wealth were doomed to fail. Despite people's proven expertise in conservation, any potential surplus from harvests could not easily be stored for long periods. Herds, despite being spread out across different areas, just as people lived in scattered settlements, remained exposed to epidemics or raids.

In short, the primitive accumulation of capital, so dear to economists, was not possible. It was the accumulation of people that mattered. The ability to overcome food or political crises, or increased mortality, was what set apart groups or individuals: this is one of the merits of having a range of activities, along with the possibility of having a sufficiently large and versatile area of land. Raids also made it possible to quickly recover what was needed to survive and start again: raids were carried out to seize cattle, or take captive-women and children who were taken and integrated to replenish the workforce. But it was important not to set off a cycle of retaliatory attacks. The use of raids had to be contained, otherwise widespread war would set in, something which had obviously happened in the past ${ }^{8}$ but not to the point of causing lasting depopulation. We must adopt another point of view in order to understand that these peoples and their modes of organisation created the possibility of another form of accumulation, one which resulted in increased population density.

\section{Peoples and Speakers}

These versatile highlands were conducive to human settlements, provided the settlers were equipped to benefit from them and enjoyed a lower prevalence of disease. The varied economic activity mentioned above is the result of a complex process spanning centuries and millennia. Unlike many underpopulated or depopulated areas of pre-colonial Africa, these regions appeared to the conquerors to be "bastions of population" (or densely populated highlands) according to the classical expression used by French geographers: high undulating plateaus of the lacustrine kingdoms to the west, highlands and peaks towards the Indian Ocean, Mount Elgon, Mount Kenya; in Tanzania, Mount Meru and Kilimanjaro and other regions with

8. The least well-known example is that of the internal Maasai wars which devastated these peoples at the end of the nineteenth century after their herds were destroyed by rinderpest (not to mention the drought and small pox epidemic which affected all populations in these regions), which again puts into question the risk they would have taken and the choice they would have made to undertake only one kind of activity. 
bimodal rainfall; to the north, beyond the semi-arid Turkana Basin, uplands which spring up again in Ethiopia.

Various peoples slowly moved into these areas, in search of hunting ground and places to fish, seeking new pastures to keep pace with new crops and slow but definite demographic growth. The existence of three major linguistic families-Cushitic, Bantu and Nilotic-in the present day attests to this, even if it is difficult to piece together the history of how they spread and mixed together. ${ }^{9}$ Whilst some can be seen to predominate, the mixing of populations is nonetheless active and dates back a long time. A number of terms pertaining to ancient political institutions are commonly used, demonstrating the melting-pot effect that some of them had and points to them having been actively used in the past. Some Bantu speakers gradually mixed with proto-Nilotic speakers and/or proto-Cushitic speakers, which, little by little, were "Bantu-ised," a mixture which is probably at the root of so-called oriental Bantu languages (around Kenya's Central Province) and differs from other branches of Bantu speakers. In the same way, Nilotic speakers-aside from the very staggered arrivals from South Sudan-can be separated into southern Nilotic speakers who arrived long ago and whose language borrows considerably from Cushitic languages (Nandi, Kipsisgis, Tugen, Pokot, Okiek...), eastern Nilotic speakers who arrived more recently (Samburu, Maasai, Turkana) and most recently, western Nilotic speakers (Luo). All groups, however, mixed with other pre-existing groups.

Beyond the differences in languages or their division into different dialects, the modes of existence of the various families of speakers remained very similar. Human settlements became permanent, and attracted and integrated other migrants. The warmer, lower areas which were suitable for grazing and cereal but exposed to recurrent droughts could be easily abandoned simply by moving to higher ground and settling on higher and better resourced slopes. Over the centuries, many territorial communities organised themselves according to slopes by combining diverse soils and grasslands on higher and lower ground. If groups differed from each other, due to distances that were too far to travel, close ties were forged between highland and lowland societies, which were sanctioned by various rituals. In the west of Kenya, we can refer to the famous case of the Luo, Nilotic speakers and agropastoralist fisherman who came from South Sudan as their herds were displaced and they mixed with pre-existing populations; by settling on the eastern shores of Lake Nyanza-Victoria, an area rich in resources, they forged strong links with the Gusii, communities of farmers and breeders who were established on the hills to the east. The Gusii, Bantu

9. All the more so since the current speakers are the last recorded; their presence in no way rules out other families of speakers having existed and then disappeared without leaving easily detectable traces (Philippson 2009). 
speakers who had lived on these highlands for many years, were themselves a product of mixing with proto-Nilotic speakers who long preceded them.

This settlement process was made all the more likely to happen when a significant resource made the area at the bottom of the slopes an initial focal point, which led to a pioneer front heading upstream: salt deposits, surface iron, quality clay and wells that were easy to dig. Long-term settlement at the water's edge was avoided due to exposure to the tsetse fly. Ithanga, a clay deposit at the southern foot of Mount Kenya, was probably the basis for a settlement of people that became long after the Kikuyu. Blacksmiths in what became Mbeere set up permanent populations, then expanded to higher ground, eventually becoming the Embu. To the northeast of the Nyambene Hills, Ngombe-a crater lake rich in salt and minerals and a source of vitality for humans and herds-agglomerated, in association with sites controlled by blacksmiths, one of the centres of populations that much later became the Igembe and Tigania (Meru). In southwest Kenya, beneath the Loita Hills, farmers and breeders settled around foothill springs, and became known as the Loita Maasai; these people married within groups of farmers, the most well-known example being the Kikuyu, among whom mothers and fathers are of Maasai descent and two traditions of initiation co-existed (the Maasai tradition and Kikuyu tradition).

More widely, any eminence that provided two rainy seasons and a defensive ridge was able to attract permanent populations: the Taita settled on the mountains of the same name, behind the Swahili coast; to the northwest, if it benefitted them to roam the dry lowlands, the Kamba would often settle on any of the hills that were dotted around towards Mount Kenya and make them their territory. As a counterexample, the people who eventually became the Turkana worthy of note. They had very good reasons for leaving the highlands of the Karimojong peoples from the sixteenth century onwards and scattering across the semi-desert foothills. In short, the exception that proves the rule is that settling on higher ground while taking control of lower slopes and foothills is the winning combination. And tracing the movements of ancient populations and human settlements requires detailed knowledge of the geographical frameworks and ecological potential of the areas concerned, which are themselves unstable.

One final subject deserves clarification: the scattered settlements that characterise these regions and go far beyond Kenya. This is something which is difficult to explain. The "villagisation" imposed on the Kikuyu and on some of the Embu and Meru during the 1950s under the state of emergency and anti-Mau Mau repression conversely reveals how prevalent this custom was. It is reminiscent of the contrast between bocage (a French word designating a landscape of hedges and settlements scattered across 
hamlets) and open field (settlements grouped together in villages) which have long been observed in the West, along with the stream of analysis it elicited; or closer to the world of Africa, in Cameroon, the enduring controversy around the Bamileke bocage and its scattered settlements. The scattering of settlements as a way of meeting the need to develop diverse ecosystems, within secure areas, is the simplest explanation that can be provided within the scope of this article. Especially since as family settlements appeared along the slopes and on the preferred land situated at 1,700 metres (roughly), there was a custom of congregating for various purposes: the promotion of warriors who were placed in kind of warriors barracks in strategic places; processions of novices and newly initiated members travelled across the land reasserting its boundaries; occasional meetings in public grounds, barter markets, assemblies for Fathers of the Country and at a different location, assemblies of women. When the time came, these localities, often used day to day as communal pastureland, were transformed into dedicated or sacred areas by means of sacrifices and suitable invocations, which brings us straight on to political and religious structures.

\section{East African Government and Politics of the Past}

The highlands of today's Kenya, like those of the border regions of neighbouring states, were known for an original form of social and political organisation, a kind of polity based on class systems relating to generation and age. ${ }^{10}$ Within the polities in question, each put in place by its own traditional generational class system and identifiable through a specific list of names, the population, primarily the males, were included in generational classes of people who exercised power in turn. If a man was in class "A," his sons would be in class "B," his grandsons in class "C," etc. When there was a transfer of power from an aging generation to the successive younger generation, the other classes would also change position. In this often antagonistic phase of reordering positions (particularly in connection to the variable number of individuals who were born too early or too late relative to the time when their class came into power), names which were provisional then permanent were collectively chosen for the newly promoted classes. Another characteristic was that the manner in which power was transferred varied considerably from one polity to another: partial transfers occurred every eight years (Borana), every 15 to 20 years (Meru, Samburu, Maasai, Nandi, Kipsigis, Pokot, Gabbra, Dassanatch...), or

10. "Polity" in the sense of a political entity characterised by individual sociopolitical institutions: here there are generational systems, elsewhere there could be chiefdoms, kingdoms, empires, city-states, the latter of which can be found on the so-called Swahili coast, and there are as many different kinds of polity. However, some of their characteristics can be combined to a certain extent. 
the transfer took place every 30 to 40 years (Kikuyu, Karimojong peoples, Giriama..... ${ }^{11}$

These variations reflect tensions relating to reproduction within traditional generations and to the specific methods by which classes were recruited, such as by organising rituals, by controlling, mostly successfully, the time at which people married or through the practice of polygamy; but the methods and ethos through which power was exercised were very similar. The ruling class of men, or Fathers of the Country, had authority through assemblies which would meet in public grounds: the fathers debated public affairs, judged the cases put before them, modified traditions if necessary, such as altering the "bride price" (see note 3) when it tended towards increasing too much. It was their particular responsibility to keep control of the class of young men from which their own sons were often recruited, and who made up the official warrior class. When the warriors came of age and expressed the desire to establish themselves as fathers of families, then a new group of warriors had to be promoted, even if it meant putting pressure on Fathers of the Country who were ageing but reluctant to accept being replaced by new fathers of the Country.

Life was often broken up into clearly defined stages, i.e. age grades or age status, in which rights and responsibilities were set out, and which had to be reached either on a personal basis or, more often, together with one's own age and/or generation class. The initiation process to become a warrior was a crucial step for men. Warriors-the Maasai morans provide an example made popular by tourism-carried out offensive or defensive raids, bringing back herds taken from enemies; we have also mentioned that women and children were taken captive and integrated through initiations to boost the numbers among populations which were deemed insufficient; there was no slave trading or slave status. However, the Fathers of the Country took care to reign in the warriors' aggressive zeal. They feared retaliation from neighbouring polities, who could very often put together armies of warriors who were capable of similar attacks. This allows us to understand the importance of the link between warriors, territory and Fathers of the Country which was the foundation of each polity: it is not inappropriate to talk in terms of "territorial sovereignty" and, in the case of the fathers,

11. On this huge topic of social and political anthropology, see, among others: Baxter \& Almagor 1978; Bernardi 1985; Legesse 2006; Marmone 2017; Muriuki 1974; Peatrik 1995, 1999, 2003, 2004, 2019; Tornay 1995, 2001; Spencer 1973; Stewart 1977. These political organisations have presented particular challenges in terms of description and analysis. The overview being offered is a (condensed) response to the key question the purpose of these forms of society which have become prevalent in these regions of East Africa, and the twofold question of their historicity or historical depth, and their historical bearing on East Africa. 
of "collective sovereign." Even when travelling, or indeed migrating, each person belonging to an age or generation class remained a member of that class and a citizen of that polity, even if they did not live there. That is unless people left, in cases of a crisis or a disagreement with their fathers and along with fellow dissenters. They would leave to try to create their own polity under the pretext of seeking new pastures, often taking groups of girls with them as accomplices.

Over the centuries, some polities disappeared and others were formed, bringing together the populations of defunct polities. This simple and effective form of government which was self-referential or even selfestablished but not free of intrinsic tensions and reproductive crises, was based around it being possible to quickly get institutions moving again after the inevitable disasters which leave their mark on human societies: human and animal epidemics, environmental problems, small-scale wars that descend into full-scale conflict, for example, as previously mentioned in note 8, the conflicts and disasters that struck East Africa at the end of the nineteenth century and helped pave the way for the colonial conquest by justifying it. By putting a group of self-appointed Fathers of the Country on one side and their sons who were in charge of defence on the other, a territory was established and social life could get back to being less chaotic; later, initiation sessions and ritual processions would strengthen the collectives and reinforce ties to the newly established territory. There was no chief here, no dynasty descending from a founding hero. Rather there were groups of men who shared the same traditional ethos, remarkable individuals who were also able to influence others, who were determined to work together to set up their own society.

These political systems, with their collective authority and shared power, were egalitarian. These societies were not very hierarchical and fostered an individualism which was unconnected to modernity and drew upon a farming ethos and pastoralist practices. There was little hierarchy because all young people, who at one time were subordinate, were called upon to become Fathers of the Country. The order of birth was almost unimportant in these matters, and the idea of differential roles and status depending on who is first born, second born... or last born, as is typically seen in the lineage societies well-known within African Studies, have no real relevance. We are looking at a different African paradigm. Everyone, provided they lived long enough, would cross the age thresholds along with their class and take on various roles relating to family, politics and ritual. With everyone potentially in the same boat, this system valued the achievements of each person, creating and also legitimising the idea that some people (men and woman) were more successful than others. 
These democracies of yesteryear were also capable of amalgamating relatively large populations through generation and age classes: it can be estimated that the numbers ranged from 20,000 to 90,000 inhabitants. Under 20,000 , it was no longer possible to line up sufficient numbers of warriors and a polity whose existence was under threat risked having to merge with its neighbours. Above 90,000, the distances needing to be crossed became too long but sometimes neighbouring polities would join together on the basis of jointly organised initiations. These grand rituals were a focus for the populations and enemies were sometimes tempted to attack groups while they were busy recruiting a new class of warriors. Historicalmythical accounts explain this clearly and help us understand how, step by step, territorial sections grouped together in larger areas which were made peaceful through co-initiation. We discover the capacity of collective rites of passage to integrate, as well as their importance in governance, forming assemblies and controlling peace and war in any given territory. In this way, these polities were able to control sufficiently large territories within which anyone considered a member of the polity, or even as its ally, could move around. The adaptive advantage these territories displayed has already been mentioned. These polities were not defined by borders in the Western sense of the term, but by boundary areas which were identified by different notable ground features, very often considered "consecrated" sites where sacrifices were made during initiation processions which crossed the length of the territory. Lastly, the citizens of each of the polities could be identified through a common list of class names (relating to generation and age). This identification was a preliminary part of meetings and meant that everyone could find their bearings and move around far from their respective bases.

Without going into too much detail, it should be noted that women were included in the system through classes of wives who were named and associated with their husbands' generation classes; they usually had their own councils and deliberated matters that concerned them, and remarkable women emerged from this. Rules of kinship, in terms of children and marriage, as well as how quickly people married and prohibitions within marriage, were often regulated by the system of generational and age classes. A man could not have sexual relations with a woman who was the daughter of a man of the same generation as him, or even marry that woman. That would amount to him marrying his own daughter, and for a girl to accept the advances of a man considered as her father was taboo and a form of incest, in this case generational, in addition to the more well know taboo of family incest.

In these polities there was therefore no chiefdom or dynasty; the principle of hereditary succession in a lineage within a predominant clan could even be said to contradict the principle of replacing a class of aging fathers with 
the consecutive class of sons. The colonial administration, in the beginning, evidently concluded that these populations devoid of centralised power had no government-"anarchic" was the word used to describe these "archaic" indigenous people-until the most astute among them, including district commissioner Harold E. Lambert, realised the complexity of the traditional systems, their capacity for integration and the principles of devolving authority. These principles-elicited by Jomo Kenyatta (1938) in his pioneering monograph on the Kikuyu-were at the root of the resistance fought by Africans, who then became colonial subjects, even after their generation class system had been disrupted by the conquest.

It is telling that in terms of regional distribution, these political regimes disappear in places where, for reasons relating to geography and historical heritage, other regimes asserted themselves. If you head west towards the Great Lakes region, you find kingdoms that deeply fascinated the British such as the Baganda and their kabaka which was not dissimilar to their own monarch. This affirmation of dynasty goes hand in hand with the increasing importance of lineage based on proven filiation and the ancestralisation of some of the deceased. To the south, towards what is today Tanzania, chiefdoms were formed when chiefs managed, to the detriment of the Fathers of the Country, to sustainably manage the process of initiating and training the warrior class which they would use to their own advantage (Chagga, Rwa). To the north, towards Ethiopia, peoples with a generational class system like the famous Oromo gadaa system, after having conquered the southern half of the Ethiopian plateaus, became principalities before later being absorbed into Menelik II's empire at the end of the nineteenth century. Towards the coast of the Indian Ocean, there is good reason to think that the Swahili cities are the result of the transformation of local societies probably organised in the remote past according to classes of generation and age, similar to the system which remains in the Comoros archipelago. Generation and age systems of East African origin, as evidenced by a common vocabulary and principles continued to exist there while they were transformed by the influence of traders, then by Arab-Muslim principalities. This situation is indicative of ancient links between the continent and the archipelago which have recently been picked up by historians.

\section{The Religion of Initiation}

East African peoples, with their generation and age-based systems, had little interest in stories about the origins of the world, cosmogony or the genesis of the beings who came to populate it. A different conceptual and symbolic framework prevailed and other themes informed the stories and legends that they liked to tell. The world was considered to be originated from an 
abstract power seen as working continuously for its self-maintenance. This abstract, energising power was regarded as a kind of deity called Ngaï, Murungu, Akuj, Waaka... depending on the language. It could be felt in the air people and animals breathed, in the wind that makes the leaves rustle and the water ripple; and also in reproductive substances, in the seminal reproductive forces of men and bulls, forces of germination seen in harvests and the fertilising forces of saliva mixed with mead. The world's ills and misfortunes were a result of human misconduct which disturbed exchange and balance; and rituals, prayers and sacrifices to the deity or higher power aimed to redress this balance and restore proper flow and exchanges.

Ritual activities were of great importance in the life of these populations. The household economy, besides everyday food provision, was a way for the head of the family and his wives to fulfil their ritual obligations in a dignified manner by providing what was needed in order for them to take place, and by feeding the largest possible number of spectators. Paul Baxter, ethnographer of the Boran, even maintained that these populations lived in a sea of rituals and blessings, also implying that it was difficult to separate activities that could be classed as rituals from those that were part of everyday life.

In order to really characterise the religion of these East African worlds, we have to talk of a religion of initiation, and relate it to the link between the initiator and the initiated, as with the worship of ancestors, which relates to lineage-and has long been identified by religious studies-or, more recently, outside of Africa, the principle of the shaman and the shamanic journey to the spirit world. Nowhere else, in fact, have initiation and rites of passage, biographical and political, taken on such importance: rites of passage that mark a person's life from birth until death, and the collective rite of passage when a new class of fathers comes to power, causing all the other classes to change position. The organisation of rituals legitimised the political; and generally speaking the effect of a rite was not only symbolic or magical, it had a practical effect that changed people in concrete ways, reconfiguring social ties and social precedence. Some rites were modest procedures, almost surreptitious but no less significant, such as the first shaving of a child's hair which was carried out long after they were born, within the family homestead, at a time when it was sure that they would survive. The child would then receive a name, the first of several during his existence, which would be that of a grandparent of the same sex. This grand-parent, through the gift of his or her name and the principle of the identity of the alternating generations, was thus granted a kind of longevity. Other rituals such as the initiation to promote someone to warrior status-some involved circumcision but many other initiatory ritual procedures existed-could take place over the course of a year. Various groups of the population would 
perform as part of a true spectacle with the initiation process starting only when the granaries were full, the herds were well fed and there had been peace for a sufficiently long time; these ritual gatherings or co-initiations helped to incorporate groups into larger collectives, as mentioned above.

In accordance with the egalitarianism of the political and social system, no religious leader was responsible for conducting the rituals but some dignitaries sometimes worked in conjunction with the Fathers and the "Accomplished." A person's intangible and spiritual capacity to influence the course of life depended firstly on having the power to bless, and also to curse. Every person potentially had this gift but the effectiveness of their power depended on the person's age status and reputation as an individual. The blessings of those who had reached the last age grade were particularly effective and sought after: having succeeded in overcoming all the crises of existence, these "Accomplished" men and women were considered to be closest to the Deity, if not as part of it. In some polities, certain figures were known for having a particular aptitude for giving blessings, such as the mûgwe among the Meru, whose blessings using the left hand were beneficial and sought after. Outside the setting of rituals, nothing really distinguished them from their fellow citizens. These specific dignitaries simply honed their particular skills which it was useful to draw upon during times of excessive or insufficient rain, among other examples, in an eclipse or even when an epidemic indicated a disturbance in the cycles of rain and sun (Bernardi 1959; Legesse 1979; Waller 1995; Wood 1999).

The requests for protection that these figures or the Accomplished persons would address to the Deity, their benevolent words interspersed with jets of saliva mixed with mead, the rubbing of clay or fat on to certain parts of the body-all their actions were very effective and the presence of the Accomplished men and women was essential during the many rituals that marked age-grading and the progress of generation classes. The opposite and complementary practice of cursing, in which menacing words were publicly declared interspersed with saliva projected from the top teeth, was available to everyone; but again, its effectiveness corresponded to the age of the speaker, and cursing was a powerful instrument of social control not be used lightly. Among certain peoples, a curse was irreversible (the Maasai for example) while for others, it was possible for it to be lifted after a certain length of time, when the speaker of the curse had come to accept the request put forward by the person being cursed. Reconciliation took place through a ritual based around the sacrifice of a particular animal followed by the sharing of the carcass which was eaten immediately. Blessings and curses forged links between the living and, in some cases, the recently deceased whose word had not been respected and who people tried to appease through sharing a sacrificed animal (Peatrik 1991). 
Since they were publicly announced, blessings and curses were known to everyone, and were everyone's responsibility, unlike attacks through witchcraft which were thought to be secret acts by certain wicked people who spoke evil words to themselves, buried certain objects that were considered dangerous in specific places and slipped poison into the food of those they wanted to harm. A source of fear and anxiety, rumours of witchcraft constituted a serious disruption to public order. The individuals accused were judged by councils of fathers and subjected to ordeals, and the guilty were condemned to death and executed, only after being subjected to torture and enduring "exemplary" suffering. The work of the assembly of fathers was broader as they decided on the ritual procedures to be performed when misfortune and hardship repeatedly struck the polity: excess water or drought, epidemic and increased mortality... there was a complete sacrificial process which included the dignitaries mentioned above and aimed to restore balance to the cycles of rain and sun. Sometimes even disturbances in the atmosphere indicated that the time had come to renew the social and political body, to urge the older generation to depart and bring in a new class of Fathers of the Country. Ideally, aging and rejuvenation would be a part of the way in which institutions kept going: individuals would come and go but the polity, distinguished by its list of names of generations, would remain.

It fell to the diviner-healer to deal with individual and family troubles and find the causes (Fratkin 2011). He would examine the entrails of a goat which was sacrificed for this purpose or the diagrams drawn by the tiny objects projecting from his divination gourd. There was a wide range of causes of unhappiness which could involve family or community networks. Misfortune or illness could result from accidentally or deliberately committing a forbidden act considered particularly improper, from insufficient blessings or intentional curses, or from witchcraft. Again, making amends meant sacrificing an animal from the herd, with the procedures varying according to the type of animal: its age, sex, the colour of its coat, the method of killing and the way the carcass was used, whether it was shared or completely destroyed. Other methods of treating diseases existed such as herbal medicine and initiation into therapeutic associations, but the use and the sacrifice of animals from the herd, even if it was only a few goats' heads, remained the quintessential way of carrying out acts of reparation.

Funeral rituals were strictly a family matter, involving no public display, and differed according to the age of the deceased. This was in accordance with an indifference to the idea of individual post-mortem existence besides grandchildren, but not to a collective existence after death since bringing back the names of old generational classes made sure of this. 
Everything was thought to take place during a person's lifetime which accounts for the high value placed on initiations and the final stage of accomplishment. Protocols were similar from group to group, with some variations. Therefore, the deaths of people who died before this stage had been completed were considered tragic and their remains were left in the bush for predators; in contrast, the remains of the Accomplished which sometimes dried out quickly due to fires that were kept going day and night, were buried and considered beneficial to the ground in the pit where the herd's droppings were collected. And as is logical, if one looks outside the area where systems relating to age and generation predominate, one comes across ways of worshipping ancestors, well-formed lineages, rules of inheritance for widows, recognisable funeral rites-in short, all the workings of other ritual-social societies, for example of the Luo or the Luyia. However, social hierarchies, despite having different features, were not expressed and were characterised by the same high value placed on the herd and the same central importance of cows.

In light of this picture of East African and Kenyan worlds before they were transformed by the colonial conquest, then by decolonisation, there is clearly food for thought and a case for imagining a new national museum of Kenyan ethnography and history, which could make use of multimedia collections and resources in ways not seen before. The emphasis could be on processes and dynamics-technological, organisational, ritual-, on variations of scale which highlight specific geographical and historical features, on biographies, not of kings but of figures who have left a wealth of material in collections of oral sources, which could make up a highly original gallery of portraits. The historical depth of these phenomenaeven if we only partially know about it-, could be enhanced and conveyed through synoptic tables displaying the different methods-those used by archaeologists differing from those of linguists for example-and separating likely or plausible dates from proven dates, with this being modified as and when there are advances in knowledge. The display would also need to show the mixture of both what is permanent and the profound changes that makes up the real Kenya: a variety of languages but a homogeneity in terms of economic conditions; environmental contrasts and conflict relating to land use but also ancient trading systems and the active circulation of goods; societies with collective power, forms of territorial sovereignty, forms of individualism, not without their parallels with contemporary political processes. Age-grading and learning through initiations echo the schooling which Kenyans have championed, as well as the readiness for hard work and the value placed on individual achievement which, in the early days, fuelled for example the energy of Kenyan runners... Beyond the undeniable rupture that the colonial conquest represented, now that 
a sufficient number of years have passed since decolonisation, we have a better sense of the way in which Kenya is a product of these legacies. In a nation that sometimes doubts itself, we can allow ourselves to think that perhaps becoming (re)acquainted with a shared past, with all its rough edges and differences and not just made "heritage," would allow for a clearer look ahead to a shared future; perhaps the use of critical and reflexive knowledge of the past and identities is not incompatible with nation building, in fact quite the opposite.

\section{Conclusion}

Broadly speaking, the subject of Kenya as presented in this article is an invitation to further research which will be set out by way of a conclusion. When considered alongside other situations in Africa and elsewhere, it could provide the basis for a comparison incorporating two starting points: the status of customs and nation-building. Thus, in analysing the "folklorisation" process that popular customs underwent following the French Revolution, which accompanied the advent of the industrial world and modern nation-states, it is revealed that customs were subject to a double transformation at the very moment that they were destined to disappear. They were regionalised and folkorised, even inspiring regionalist literature and became knowledge objects for the first methodical ethnographic surveys which were designed to rescue them before they died out (Fabre 1996; Thiesse 1999).

African states, beyond some common dysfunction analysed by political scientists, display great diversity. Concerning East Africa only, how can we keep thinking of the institutions of Kenya, Ethiopia, Uganda and Tanzania as fitting into the same mould, as if the distinctive features of their antecolonial circumstances have had no effect on their modes of existence? Kenya, with its unique configuration, appears to be permanently influenced by the generational polities which once prevailed across a large part of its territory. However, these old political systems-still partly in existence in the northern counties of Kenya-as well as inviting us to look beyond the idea that a state-based society and a stateless society are opposed to one another, ${ }^{12}$ have to do with the practical values and methods that have permeated the various emancipation movements and remained within contemporary practices. Thus, there exists a continuity, one which is often underestimated and misunderstood, between territorial sovereignty (Mbembe 2005) and the ethos of these ancient democracies, on the one

12. This opposition seen in the first major study of African political systems (Fortes and Evans-Pritchard 1940) should not be jettisoned but rather qualified, amended or built upon, drawing upon the great number of monographs which have been produced in different regions of Africa since this pioneering work. 
hand, and modern democracies, on the other. The current situation of cultures in Kenya is best clarified in a different way. The "heritagisation" in progress could be less indicative of a whitewashed past, instead displaying an awareness of a past which is in the process of becoming the past, and of customs disappearing. In a kind of dialectic movement being passed down through successive generations, the folklorisation called for in most Kenyan counties could serve as a prelude to distancing from the societies and cultures of yesteryear, and to the sustainable ${ }^{13}$ development of systematic knowledge, this being the task that lies ahead for the future of history in tomorrow's Kenya.

\section{Bibliography}

Adam, Michel. 2018. Un deuxième monde. La nuit des Kikuyu du Kenya. Collection "Anthropologie de la nuit." Nanterre: Société d'ethnologie.

Adamson, Joy. 1967 [2003]. The Peoples of Kenya. London \& Nairobi: Collins \& Harvill Press-Elsa Conservation Trust.

Ambler, Charles. 1988. Kenyan Communities in the Age of Imperialism: The Central Region in the Late Nineteenth Century. New Haven \& London: Yale University Press.

Baxter, Paul, and Uri Almagor (eds). 1978. Age, Generation and Time: Some Features of East African Age Organisations. London: Hurst.

Bernardi, Bernardo. 1959. The Mûgwe, a Failing Prophet: A Study of a Religious and Public Dignitary of the Meru of Kenya. London \& New York: Oxford University Press.

Bernardi, Bernardo. 1985. Age Class Systems: Social Institutions and Polities Based on Age. Cambridge: Cambridge University Press.

Blanchy, Sophie. 2004. "Cités, citoyenneté et territorialité dans l'île de Ngazidja (Comores)." Journal des africanistes 74, no. 1-2: 341-80.

http://journals.openedition.org/africanistes/460.

Boucheron, Patrick, and François Hartog. 2018. L'histoire à venir. Paris: Anacharsis.

Brown, Jean. 1995. Traditional Metalworking in Kenya. Oxford: Oxbow Book. Charton, Hélène. 2011. "Acteurs, victimes et témoins de la violence dans l'histoire. L'exemple mau mau (Kenya)." Cahiers d'études africaines no. 201: 169-82. https://doi.org/10.4000/etudesafricaines.16615.

13. Sustainable because in the decade that followed independence until the end of the 1970s, the desire to "know" and to objectify the past informed a number of methodical works carried out by Kenyan students and academics (Kipkorir 1973; Muriuki 1974; Ogot \& Ehret 1976; Peatrik 2014). These movement subsequently came to a halt. Could this be an effect of the succession of historical generations and their different relationships to the past and present? Generations who lived through independence were certain to embody an emancipatory sense of modernity. This feeling later declined, leading to a newly defined status attached to customs and therefore to the fabric of the past. 
Droz, Yvan. 2015. "Jeunesse et âge adulte en pays kikuyu. Des éthos précoloniaux aux nouveaux mouvements politico-religieux." Cahiers d'études africaines no. 218: 213-30. https://doi.org/10.4000/etudesafricaines.18094.

Fabre, Daniel. 1996. "L'ethnologue et les nations." In L'Europe entre cultures et nations, edited by Daniel Fabre, 99-120. Mission du Patrimoine ethnologique (cahier 10). Paris: Éditions de la Maison des sciences de l'homme.

https://doi.org/10.4000/books.editionsmsh.3919.

Fiquet, Eloi. 2003. "Dynamiques générationnelles et expansion des Oromo en Éthiopie au Xvi ${ }^{\mathrm{e}}$ siècle." L'Homme, no. 167-68: 235-51.

https://doi.org/10.4000/lhomme.21527.

Forde, Daryll (ed.). 1952-1968. Ethnographic Survey of Africa: East-Central Africa, North Eastern Africa. 5 volumes. London: International African Institute.

Fortes, Meyer, and Edward Evans-Pritchard (eds). 1940 [1978]. African Political Systems. Oxford: Oxford University Press.

Fratkin, Elliot. 2011. Laibon: An Anthropologist's fourney with Samburu Diviners in Kenya. Lanham (MD): Altamira Press.

Galaty, John G. 2009. "Les sociétés d'éleveurs du Rift." In Le Rift est-africain, une singularité plurielle, edited by Bertrand Hirsch and Bernard Roussel, 38998. Marseille: IRD Éditions. https://doi.org/10.4000/books.irdeditions.1704.

Glazier, Jack. 1985. Land and the Uses of Tradition Among the Mbeere of Kenya. Lanham: University Press of America.

Grignon, François. 1998. "L'invention démocratique et le multipartisme en question (1992-1996)." In Le Kenya contemporain, edited by François Grignon and Gérard Prunier, 364-82. Paris: IFRA-Karthala.

Grignon, François, and Gérard Prunier (eds). 1998. Le Kenya contemporain. Paris: IFRA-Karthala.

Grillo, Katherine M.2014. "PastoralismandPotteryUse:AnEthnoarchaeological Study in Samburu, Kenya." African Archeology Review 31, no. 2: 105-30. https://doi.org/10.1007/s10437-014-9147-6.

Haugerud, Angelique. 1995. The Culture of Politics in Modern Kenya. Cambridge: Cambridge University Press. https://doi.or!g/10.1017/CBO9781139166690.

Hillewaert, Sarah. 2016. "Whoever Leaves Their Traditions Is a Slave': Contemporary Notions of Servitude in an East African Town." Africa 86, no. 3: 425-46. https://doi.org/10.1017/s0001972016000322.

Hughes, Lotte, and Mark Lamont (eds). 2018. "Cultural Rights and Constitutional Change.” African Studies 77, no. 2: 159-70.

https://doi.org/10.1080/00020184.2018.1452852.

Josse-Durand, Chloé. 2018. "The Political Role of 'Cultural Entrepreneurs' in Kenya: Claiming Recognition Through the Memorialisation of Koitalel Samoei and Nandi Heritage." African Studies 77, no. 2: 257-73.

https://doi.org/10.1080/00020184.2018.1452859.

Kenyatta, Jomo. 1938. Facing Mount Kenya: The Traditional Life of the Gikuyu. London: Secker \& Warburg. [There are many reissues.] 
Kiiru, Kahithe. 2014. "Bomas of Kenya: Local Dances Put to the Test of the National Stage." Mambo! 12, no. 1.

https://hal.archives-ouvertes.fr/halshs-01206441.

Kiiru, Kahithe, and Maina wa Mutonya (eds). 2018. Music and Dance in Eastern Africa. Current Research in Humanities and Social Sciences. Nairobi: Twaweza Communications.

Kipkorir, Benjamin E. 1973 [2008]. The Marakwet of Kenya: A Preliminary Study. Nairobi: East African Educational Publishers.

Kratz, Corinne A. 1994 [2010]. Affecting Performance: Meaning, Movement, and Experience in Okiek Women's Initiation. Tucson (AZ): Wheatmark.

Lafargue, Jérôme. 2010. "Résistances au long cours. Narration et maniement de la mémoire insurrectionnelle à partir d'exemples des Mau Mau (Kenya)." Cahiers d'Études africaines, no. 197: 25-50.

https://doi.org/10.4000/etudesafricaines.15769.

Lambert, Harold. 1956. Kikuyu Social and Political Institutions. London: Routledge. https://doi.org/10.4324/9780429488214.

Lamphear, John. 1991. The Scattering Time: Turkana Responses to Colonial Rule. Oxford: Oxford University Press.

Lane, Paul J. 2016. "New Directions for Historical Archaeology in Eastern Africa?" The Journal of African History 57, no. 2: 173-81. https://doi.org/10.1017/S0021853716000049.

Legesse, Asmaron. 1979. "La mort du soleil : signes naturels, tabous et autorité politique." In Soleil est mort. L'éclipse totale du soleil du 30 juin 1973, edited by Gérard Francillon and Patrick Menget, 245-76. Nanterre: Laboratoire d'Ethnologie et de Sociologie comparative.

Legesse, Asmaron. 2006. Oromo Democracy. An Indigenous African Political System. Trenton (NJ): The Red Sea Press.

Le Guennec-Coppens, Françoise, and Sophie Mery. 2002. "Les Swahili : une singularité anthropologique en Afrique de l'Est.” Journal des africanistes 72, no. 2: 55-70. https://doi.org/10.3406/jafr.2002.1306.

Lindblom, Gerhard. 1920. The Akamba in British East Africa: An Ethnological Monograph. Uppsala: Appelberg.

Luongo, Catherine. 2011. Witchcraft and Colonial Rule in Kenya, 1900-1950. Cambridge: Cambridge University Press, 2011.

MacArthur, Julie. 2016. Cartography and the Political Imagination: Mapping Community in Colonial Kenya. Athens (GA): Ohio University Press. [Consacré aux Aba-Luyia.]

Marmone, Giordano. 2017. Danser et chanter un système d'âge. Anthropologie musicale des Samburu (Kenya). PhD Dissertation. Nanterre: Université Paris Nanterre.

Maupeu, Hervé. 2002. "Mungiki et les élections. Les mutations politiques d'un prophétisme kikuyu (Kenya)." Politique africaine, no. 87: 56-77. https://doi.org/10.3917/polaf.087.0117.

Mbembe, Achille. 2005. "À la lisière du monde. Frontière, territorialité et souveraineté en Afrique." In Le territoire est mort : vive les territoires ! Une (re)fabrication au nom du développement, edited by Benoît Antheaume \& 
Frédéric Giraut, 47-77. Paris: IRD Éditions.

https://doi.org/10.4000/books.irdeditions.3385.

Middleton, John (ed.). 1963. Witchcraft and Sorcery in East Africa. London: Routledge. https://doi.org/10.4324/9781315018041.

Muriuki, Godfrey. 1974. A History of the Kikuyu 1500-1900. Nairobi: Oxford University Press.

Nyamweru, Celia, and Tsawe-Munga Chidongo. 2018. "Elders in Modern Kenya: 'Dying Institutions' or 'Reinventing Themselves.” African Studies 77: 240-55. https://doi.org/10.1080/00020184.2018.1452857.

Ogot, Bethwell A. 2005. "Review: Britain's Gulag." The fournal of African History 46, no. 3: 493-505. https://doi.org/10.1017/S0021853705000939.

Ogot, Bethwell, and Christopher Ehret (eds). 1976. Kenya Before 1900. Eight Regional Studies. Nairobi: East African Publishing House.

Parkin, David. 1991. Sacred Void: Spatial Image of Work and Rituals among the Giriama of Kenya. Cambridge: Cambridge University Press.

Peatrik, Anne-Marie. 1991. "Le Chant des hyènes tristes. Essai sur les rites funéraires des Meru du Kenya et des peuples apparentés." Systèmes de pensée en Afrique noire, cahier 11: 103-30. https://doi.org/10.4000/span.1258.

Peatrik, Anne-Marie. 1995. "La Règle et le nombre : les systèmes d'âge et de génération d'Afrique orientale." L'Homme, no. 134: 13-49. https://doi. org/10.3406/hom.1995.369906.

Peatrik, Anne-Marie. 1998. "Les sociétés anciennes et leur héritage. Éclairage anthropologique.” In Le Kenya contemporain, edited by François Grignon \& Gérard Prunier, 53-76. Paris: IFRA-Karthala.

Peatrik, Anne-Marie. 1999. La Vie à pas contés. Génération, âge et société dans les hautes terres du Kenya (Meru Tigania-Igembe, Kénya). Nanterre: Société d'ethnologie.

Peatrik, Anne-Marie. 2003. "Un paradigme africain.” L'Homme, no. 167-68: 271-84. https://doi.org/10.4000/lhomme.21540.

Peatrik, Anne-Marie. 2003. "Arrangements générationnels : le cas inattendu des Gusii (Kenya)." L'Homme, no. 167-68: 209-34.

https://doi.org/10.4000/lhomme.21521.

Peatrik, Anne-Marie. 2004. "Une Sparte africaine. Initiation, classes d'âge et souveraineté chez les Meru Tigania-Igembe (Kenya).” Journal des africanistes 74, no. 1-2: 315-40. http://journals.openedition.org/africanistes/228.

Peatrik, Anne-Marie. 2013. "Kill to Engender. Agencies of Lifelong Constructed Masculinities (East Africa)." Cahiers d'études africaines no. 209-210: 217-45.

Peatrik, Anne-Marie. 2014. "Le singulier destin de Facing Mount Kenya. The Traditional Life of the Gikuyu (1938) de Jomo Kenyatta. Une contribution à l'anthropologie des savoirs.' L'Homme, no. 212: 71-108.

https://doi.org/10.4000/lhomme.23737.

Peatrik, Anne-Marie. 2020 [2019]. A Complex Polity. Generations, Initiation, and Territory, among the Old Meru of Kenya. Nanterre: Société d'ethnologie ; Nairobi: Twaweza Communications-Institut français de recherche en Afrique. [Publié originellement au format ebook par la Société d'ethnologie en 2019.] 
Peterson, Derek P. 2004. Creative Writing. Translation, Bookkeeping and the Work of Imagination in Colonial Kenya. Portsmouth: Heinemann.

Philippson, Gérard. 2009. "Langues et histoire dans le Rift." In Le Rift est-africain, une singularité plurielle, edited by Bertrand Hirsch \& Bernard Roussel, 367-77. Marseille, IRD Éditions. https://doi.org/10.4000/books.irdeditions.1790.

Ranger, Terence. 1983. "The Invention of Tradition in Colonial Africa." In The Invention of Tradition, edited by Eric Hobsbwam \& Terence Ranger, 211-62. Cambridge: Cambridge University Press. https://doi.org/10.1017/CBO9781107295636.006 [archive].

Sangree, Walter. 1966. Age, Prayers, and Politics in Tiriki, Kenya. London: Oxford University Press.

Schlee, Gunther. 1994. Identities on the Move. Clanship and Pastoralism in Northern Kenya. Nairobi: Gideon Were Press.

Shipton, Parker. 2007. The Nature of Entrustment: Intimacy, Exchange, and the Sacred in Africa. New Haven: Yale University Press.

Spear, Thomas. 1981. Kenya's Past. An Introduction to Historical Method in Africa. London: Longman.

Spear, Thomas, and Richard Waller. 1993. Being Maasai. Ethnicity and Identity in East Africa. London: James Currey.

Spencer, Paul. 1973. Nomads in Alliance: Symbiosis and Growth among the Rendille and Samburu of Kenya. London: Oxford University Press.

Stewart, Franck. 1977. Fundamentals of Age-Group Systems. New York: Academic Press.

Sutton, John E. 1990. A Thousand Years of East Africa. Nairobi: British Institute in Eastern Africa.

Tablino, Paul. 1999. The Gabra. Camel Nomads of Northern Kenya. Marsabit (Kenya): Paulines Publications Africa.

Thiesse, Anne-Marie. 1999. La création des identités nationales. Europe, XVIII $X X^{e}$ siècles. Collection "L'Univers historique." Paris: Seuil.

Tornay, Serge. 1995. "Structure et événement : le système générationnel des peuples du cercle karimojong." L'Homme, no. 134: 51-80. https://doi.org/10.3406/hom.1995.369907.

Tornay, Serge. 2001. Les Fusils jaunes. Générations et politique en pays Nyangatom (Ethiopie). Nanterre: Société d'ethnologie.

Ville, Jean-Luc, and Abajila Guyo. 2004. Le dernier éléphant. Histoire d'un chasseur kenyan. Paris: Autrement.

Waller, Richard D. 1995. "Kidongoi's Kin: Prophecy \& Power in Maasailand." In Revealing Prophets. Prophecy in Eastern African History, dirigé David M. Anderson and Douglas H. Johnson, 28-64. London: James Currey.

Willis, Justin. 1993. Mombasa, the Swahili, and the Making of the Mijikenda. Oxford: Clarendon Press.

Wood, John Colman. 1999. When Men are Women: Manhood among the Gabra Nomads of East Africa. Madison: University of Wisconsin Press. 

Focus no. 5

\title{
The Aravai Peoples, the Site of Rabai and its Sacred Forests on the Kenyan Coast
}

\author{
Marie Pierre Ballarin
}

Translated by Keenya Hofmaier

Social science research on the Kenyan coast has largely emphasised Swahili culture-for which there exists a vast amount of academic literature-but has paid little attention to the Mijikenda. The Mijikenda, linguistically related to the Bantu populations, include the following subgroups: Agiriama, Akambe, Aribe, Aravai, Achhonyi, Adigo, Aduruma, Adzihana and Akauma. According to oral tradition, they came from a mythical territory called Singwaya (in the southern part of present-day Somalia) and settled in hilltop villages that were "fortified" by very dense vegetation, known as the kayas (Kiriama 2013). ${ }^{1}$ The Mijikenda formed a group of intermediaries between the coast and the hinterland, and they were very early on included in the economic and political exchange systems conducted by the Swahili (Thomas 1978; Brantley 1981). According to the historian Justin Willis (1993), the name "Mijikenda" does not identify a unified ethnic group but rather was created under British colonisation to designate the two demographically dominant coastal groups under the guise of a land access policy based on ethno-racial differences. From an anthropological viewpoint, research carried out in the 1970s by David Parkin on the Giriama, as well as more recent research by Linda Giles and Monica Udvardy (Udvardy 1992; Udvardy, Giles \& Mitsanze 2004), made it possible to show the complexity of the Giriama's social and ritual organisation in the broader context of Mijikenda culture (Giles \& Gearhart 2014). ${ }^{2}$ Since the 1990s and 2000s, a team from the National Museums of Kenya undertook archaeological and historical research on some of the primary sites formerly occupied by the

1. Archaeological research recently conducted by the National Museums of Kenya showed that occupation of the kayas dates back even further to the beginning of the second millennium. See notably Kiriama (2013).

2. The recent introduction of Cynthia Brantley in the collective work edited by Linda Giles and Rebecca Gearhart, Contesting Identities (2014), appropriately places the Mijikenda studies in their historical and academic context since the 1970s. This book is a recent synthesis about the Mijikenda and relies on fieldwork conducted mainly with the Giriama people. 
Mijikenda people. This research was part of a governmental policy aimed at the valorisation and protection of sacred forests. The scope of much of the research focused on the Aravai, the site of Rabai and its sacred forests; all of which will be presented in this paper.

Origin myths begin with the establishment of the Aravai in the kayas and, as Thomas Spear described, the creation of the nine ethnic groups that formed the Mijikenda identity. It is also widely accepted that in the nineteenth century, following the territory's pacification and due to demographic pressure, the Mijikenda began to settle outside their forest lands. The original settlements were maintained as sacred places and burial grounds, reinforcing the territorialisation of the group. The elders from these lineages formed a council with the intention of preserving these places. At the same time, strict rules were put in place to guarantee the sanctity of the forests: the cutting of wood and vegetation was prohibited, a particular dress code was required, various taboos were to be respected, access was reserved for elders-especially in places of high magical value where the community's protective talismans (fingos) are buried-and finally, specific paths of circulation were created within the kaya enclosure. The boundary between land for human use and sacred land was therefore reinforced. Today, the kayas are still central to ceremonies such as social harmony rituals and rain rituals held under the elders' authority. These elders play a dominate role regarding social regulations and control and organise weekly meetings designed to resolve community problems. In this regard, these forests are "by the ritual acts that occur there, a place within the village where the social and territorial ties from various social groups of diverse origins are created" (Liberski-Bagnoud, Fournier \& Nignan 2010).

In Rabai, resorting to a longue durée approach makes it possible to understand the evolution of Mijikenda groups and their guardianship over the kayas until today. Rabai is an extremely rich site of varying facets, and its study is part of a broader reflection on the role of history and memory in the process of valorisation of heritage resources. It raises questions about the preservation and sustainable management of heritage sites by the communities concerned, all while the sacred forests of Rabai are being threatened by reckless deforestation.

The 5 kayas of Rabai are: Mudzimuvya, Bomu, Fimboni, Mudzi Mwiru and Mzizima. They form a block of forest composed of small wooded hills that constitute a prominent feature of the landscape bordering large coconut plantations. Rabai has one of the highest concentrations of coconuts on the coast and their exploitation plays a significant role in the local economy (notably through the production of palm wine). These plantations are under the responsibility of the elders who are divided into two main clans: 
the Amwezi and the Achiza. The plantations can be accessed by following a path leading to two to three entrances.

Just before the first entrance, depending on the kaya, one can see the tombs (makaburini) of individuals who died outside the site. These individuals were buried on both sides of the path in accordance with their cause of death and/or their clan membership. Not far away is the cherani, or area where the body is exposed before a decision is made about its final burial place. The elders and the most renowned prophets are buried inside the kaya. For example, the kaya elder named Jindwa is buried in Mudzi Muvya. In the mid-nineteenth century, Jindwa welcomed Johannes Krapf, the Anglican missionary who founded the Rabai mission, thus making it the starting point for the expansion of Christianity in Kenya.

The last entrance leads to the historically occupied site. The elders bury their wooden sticks (ndata) in the ground before entering the kaya and retrieve them once they have finished their activities. These sticks symbolise their authority as well as hierarchy within the group. In a secret location of high sacred value, one finds the buried fingo, a talisman brought from Singwaya which is associated with the myth of their arrival. The parliament (moro), originally located in the middle of the kaya, is now located in the village. There, the elders manage everyday life within the community and decide on ritual activities. Sessions are organised to deliberate on the various problems faced by the village's inhabitants (family issues, land conflict, societal offences, etc.).

The ceremonies and cultual locations are diverse, and each kaya has a specific role. In Rabai, there is an annual ritual cycle related to community preservation and kaya maintenance. It is marked by various rituals and organised according to the circumstance, such as the reparation of an offence, the initiation of an elder to a higher rank, or other specific requests. For example, in 2008, a ritual honouring a Mijikenda prophetess was modified with the addition of a special prayer to obtain the ancestors' consent to open the Mudzi Muvya kaya to ecotourism. This ritual also sought authorisation to undertake archaeological research in Mudzi Mwiru, the oldest kaya in terms of occupancy, and the most important in terms of rituals.

The current affirmation of Mijikenda identity through a cultural revival marked by festivals, the creation of ecomuseums and ritual effervescence is part of a larger search for legitimisation and social recognition. This affirmation aims to cope with external pressures: solicitation by political movements, pression on land access and resources, and other requests related to tourism development. The 2009 public opening of the Mudzi Muvya kaya, funded by the French Embassy in Kenya, is indicative of the diversity of interests and issues involved, whether local (the Rabai group 
of elders, villagers, elders of the surrounding kayas, local authorities, etc.), national (governmental authorities, National Museums of Kenya, political parties, etc.) or international (Unesco, NGOs and research institutions). In 2013, this project was self-directed with real investment from the groups involved. But the tensions between its members are constant, both within the elders' councils and between the elders and the women's groups who challenge the power of the latter-who are always men-and demand a more equitable share of the benefits. On the other hand, the site does not receive enough visitors, and to overcome this problem, some members of the association approach Mombasa hotels with a significant international clientele. Thus, on July 13, 2013, a delegation of tourism professionals visited Rabai where a new portion of forest was being prepared as a tourist village to promote the site. Dances and songs from different villages were abound, and ceremonial practices and daily activities were presented. Yet, one of the new members of the association had invited some political leaders from the opposition party, and the day ended up becoming a political meeting... In fact, questions arise concerning the different levels of power and the scale game at play which the situation of heritage-making in Rabai reveals. Today's Mijikenda society is caught up in these contradictions and the elders of the Aravai and Giriama kayas are at the heart of the socio-political issues encompassing the whole of contemporary Kenyan society.

\section{Bibliography}

Ballarin, Marie Pierre, and Sophie Blanchy (eds). 2016. "Revalorisation patrimoniale des sites naturels sacrés (Kenya, Ouganda, Madagascar) : enjeux locaux, nationaux et internationaux." Dossier. fournal des Africanistes 86, no. 1. https://journals.openedition.org/africanistes/4723.

Brantley, Cynthia. 1981. The Giriama and Colonial Resistance in Kenya, 18001920. Berkeley: University of California Press.

Gearhart, Rebecca, and Giles Linda. 2014. Contesting Identities. The Mijikenda and their Neighbors in Kenyan Coastal Society. Trenton: Africa World Press.

Kiriama, Herman. 2013. "Intangible Heritage, Identity and Archaeology at kaya Mudzi Mwiru (Kenya)." The Uganda fournal, no. 53 (Special issue: "Sacred Natural Sites and Cultural Heritage in East Africa," edited by Marie Pierre Ballarin, Herman Kiriama, and Cecilia Pennacini): 187-200.

Liberski-Bagnoud, Danouta, Anne Fournier and Saibou Nignan. 2010. "Les 'bois sacrés', faits et illusions : à propos des sanctuaires boisés des Kasena (Burkina Faso).” In Forêts sacrées et sanctuaires boisés. Des créations culturelles et biologiques (Burkina Faso, Togo et Bénin), edited by Dominique Juhé-Beaulaton, 59-90. Paris: Karthala.

Spear, Thomas. 1978. The kaya Complex: A History of the Mijikenda Peoples of the Kenya Coast to 1900. Nairobi: Kenya Literature Bureau. 
Udvardy, Monica. 1992. "The Fertility of the Post-Fertile. Concepts of Gender, Aging and Reproductive Health among the Giriama of Kenya." Journal of Cross-Cultural Gerontology 7, no. 4: 289-307. https://doi.org/10.1007/BF01848696.

Udvardy, Monica, Linda L. Giles, and John B. Mitsanze. 2004. "Cultural Property as Global Commodities. The Case of Mijikenda Memorial Statues." Cultural Survival Quarterly 27, no. 4 ("Indigenous Education and the Prospects for Cultural Survival”): 8-82. https://www.culturalsurvival.org/publications/ cultural-survival-quarterly/cultural-property-global-commodities-casemijikenda [archive].

Willis, Justin. 1993. Mombasa, the Swahili and the Making of the Mijikendas. Oxford: Clarendon Press. 



\title{
Chapter 14 \\ Stage Dynamics \\ Presentation and Representation \\ in the Nairobi Art Market
}

\author{
Danielle de Lame
}

Translation revised by the author

\section{Introduction}

The history of the development of visual art-and other art forms-in Nairobi reflects and condenses the history of networks between the city and the world through personal interactions. In general, art objects give us a specific material representation of the insertion of goods in the international chain of commodities. In Nairobi, the creation of graphic artwhich is the subject of this article-is rooted in the local social dynamics operating in synergy with various markets and in connection with the knowledge of international artistic trends, past and present. It could be argued that in Nairobi as elsewhere the quest for sponsors and access to markets exerts a multiform influence on artistic content and form. If the insertion of artists in these circuits is a necessary pathway to secure their access to market, the modalities of their insertion result from a synergy between the transnational and the local perspectives. In Kenya, the social ethos of mutual support has for a long time been, and to a certain extent continues to be, the source of a creative blossoming from which great individuals emerge. The transformation of the capital city over time and the mobility of its areas of insecurity and of transit zones have shifted its traditional points of contact. The emergence of online trading in art has disrupted the more conventional gallery and studio networks. Some of these networks continue to operate from shantytowns that remain attractive to a certain public. However, most galleries today attract an audience of "connoisseurs"-and collectors-even though consecration by the pundits of "African Art" remains largely dependent on chance encounters. A recent trend tends to circumvent traditional channels and give more value to peer recognition at the international level. 


\section{The Flower-Power Years}

I will recount the journey of some artists and their works as the capital city of Nairobi, now a great metropolis, got increasingly inserted into the world-system. I do not intend to theorise, but simply to provide some ideas that could encourage an accurate collect of facts, which further studies could push forward, hopefully free of exoticism. The blooming of visual arts during the "golden sixties" in Kenya, and more specifically in Nairobi, is partially anchored in local cultures and in the colonial training belatedly initiated by the Kenya Art Association. The extraordinary coifs and jewels worn by different groups, the Kisii soapstone sculptures, the engraving of calabashes, etc., all demonstrate, if needed, the deep-seated aesthetic sensibility and cleverness in the use of materials. An informal ${ }^{1}$ trade for tourists existed, especially for sculptures. In addition, beyond a rudimentary school training (Robarts 1981), the splendid "ethnic" representations by the Austrian Joy Adamson materialise a form of contact-characteristic of that era-between worlds that claimed to be so different: the world of the those who represent and that of the represented. For some Kenyan observers, these pictures may have constituted an incentive to a documentary selfrepresentation, which is found in the early times of the local pictorial production in bars, for instance, where oral traditions can be have been put in painting, as I have observed in Ngecha. ${ }^{2}$ The use of commercial signs, ${ }^{3}$ which were a source of income that made it possible for artists to develop a more elaborate art, may have allowed for the emergence of creativity which the educational system did not favour (Robarts 1981). Finally, as elsewhere in Africa, a new trend emerged that was tied both to, on the one hand, the local effects of the independences and the pride and enthusiasm they generated, and, on the other, the American Pan-Africanist, Black Power and "Flower Power" movements, themselves growing within the more general movements of liberation from social constraints and antiVietnam war protests.

1. Equating the entire informal Kenyan art market with the informal sector, locally called jua kali, as done by Margaretta Swigert (2011), does not seem to capture the reality. Her work provides interesting information- sometime in need of cross-checking-about this first period of artistic development in Nairobi. Margaretta Swigert, under the name Margaretta WaGacheru, publishes an art column in two Kenyan newspapers belonging to the same group, The Daily Nation and The Business Daily. Her often-partisan articles contain a lot of interesting information, though.

2. Kiambu County, 30 minutes from Nairobi. See below.

3. See the magnificent book by Steve Bloom (2009). Today's signs differ from those created earlier, which belonged to the art of graffiti that can be seen on the well-known matatu vans. 
Art education opened to Africans, as shown by the case of Francis Kahuri, a Kenyan artist trained by Dora Betts at the $\mathrm{KAS}^{4}$ (Swigert 2011, 65), who joined other East African artists, notably Kenyans, trained at Makerere University (Uganda) by Margaret Trowell (ibid., 66). At the beginning of the seventies, a dynamic scene emerged where several artists crossed paths, such as Elimo Njau, a Tanzanian artist who had arrived in Kenya in 1958 and was commissioned by the Anglican Church to design murals at Fort Hall, ${ }^{5}$ as well as avant-garde poets and writers, such as Ngugiwa Thiong'o. Elimo Njau, who had a solo exhibition in London in 1961 (ibid., 69) and travelled to Europe, founded the first African art centre in Nairobi in 1966, PaayaPaa; it was an art gallery as well as an international art centre, ${ }^{6}$ a refuge for artists from African countries experiencing social and political unrest, especially those from the African East Coast. Kenya also attracted American artists; among them, one finds the three founders of Watatu Galery ${ }^{7}$ in 1969, Yoni Waite, Robin Anderson, and David Hart. These three prestigious artists created, according to Swigert, what was perceived to be an artistic universe for expatriates (ibid., 72). Other initiatives left their marks on today's Nairobi artistic scene, such as the establishment of jewelry workshops in the slums. Two Americans, including Alan Donovan, ${ }^{8}$ who had a significant role in the Nairobi arts market, were behind these activities (ibid., 75).

This is the period (1977) when the Alliance Française, locally known as the "French Cultural Centre" set up a first important exhibition, displaying Ancent Soi (Michael Soi's father), the Ugandan artist Jak Katarikawe and other artists during the "Wildlife Awareness Week" (ibid., 74), which presented mainly pieces exalting nature.

4. The Kenya Art Society was linked to the East African Women's League, which still exists; it holds weekly meetings and intends to be "multiracial."

5. Fort Hall was the name of the city of Murang'a during colonial times. The paintings are known as "the Murang'a murals" and their creation was linked to a commemoration of the victims of the Mau Mau anti-colonialist attacks reprimanded by expeditions launched from Fort Hall. It seems ironic that a personality like Elimo Njau, the first artists to have promoted the arts in Kenya, could be linked to this controversial work. See also Miller, 2014.

6. PaayaPaa and its activities remain in the memory of those who were present in Nairobi at the time (John Lonsdale, personal communication, Paris, February 2015.)

7. For a detailed history of the Watatu Gallery, critically read Margaretta WaGacheru: WaGacheru, Margaretta. 2013. "Nairobi's Upmarket Red Hill Opens a New Gallery." Business Daily, 16 September. http://www.businessdailyafrica. com/Nairobi-upmarket-Red-Hill-opens-a-new-gallery/-/1248928/1498086/16k5jqc/-/index.html [archive].

8. Alan Donovan promoted not only painting and jewelry making; he organised "afro" fashion shows and still exhibits an interesting collection of paintings in his "Heritage House" not far from Nairobi National Park. 
During the 1980s, the Watatu Gallery, which welcomed all types of artists, changed hands as the three founding artists prioritised their artistic activities rather than the management of the gallery. ${ }^{9}$ After a brief period of management under Rhodia Mann and Sherri Saittoti, the American Ruth Schaffner ${ }^{10}$ became the owner of the gallery and orientated it towards the promotion of African artists. It is hard nowadays to form an opinion on Ruth Schaffner's personality as she was both vilified and glorified. She had created a familial atmosphere around the Watatu Gallery, took charges on school fees and made loans to artists in exchange for absolute loyalty, exclusivity, and... a 50\% commission as from the 1990s (Littlefield Kasfir 1999, 79) - an unusually high rate in Africa and never required again in Kenya. As the owner of two galleries in Los Angeles, she had a significant influence on the artistic development in and around Nairobi. With her, anyway, the field of painting grew along with the opportunities she was offering by establishing contacts between artists during workshops and encouraging certain shapes (even certain hues) which connected artists from the village to the American market, expatriates and tourists. The existing galleries-Watatu, PaayaPaa, the Stanley Hotel gallery, and later the Donovan "African Heritage" Gallery-were located in the heart of Nairobi, a place insuring a cosmopolitan clientele at a time when the downtown, alive with activity, was safe, where the cafes were welcoming passers-by. This city centre is hard to imagine today, described by the cliché phrase of the time: "the green city under the sun," with a postcard optimism that dropped the mask during the 1982 riots, the beginning of the spread of crime from the slums to the city centre (Grignon 1997; de Lame 2006).

Just like the jewelry artisans from the Mathare Valley slums who worked for Donovan, the up-and-coming painters had experience making small earnings in the art of advertisement and in the often-mediocre works sold in small curio shops. While Donovan created many jobs in the "hybrid" (Swigert 2011, 75) jewelry field, but also, later, in the textile and fashion industries, thanks to Ruth Schaffner, the painters who tried to earn a living in a field where they developed their talents, real or imagined, were able to emerge, create their style, and adapt to a market they, themselves, influenced. Wanyu Brush, who is settled on the green hills of Kiambu County in Ngecha, and who was taught painting at the YMCA Art Center, took with him Sane Wadu, Chain Muhandi, Sebastian Kiarie, Alan Githuka, and many others. The Ngecha Artist Association was born. It provided many

9. Y. Waite, personal communication.

10. "the formidable German-born Californian who'd long given up her social life in America for Africa's savanna and a sixth husband twenty years her junior" "Wanyu Brush." S.d. Art Nanadede [archive]. For more biographical data, see Littlefield Kasfir (1999, 78-84). 
young artists-a number of them still active-with training-and attracted other artists like Shine Tani. ${ }^{11}$ Ruth Schaffner supported this movement: in addition to advice, she provided the necessary supplies, organised monthly workshops and bought the works of artists to resell them to the Watatu Gallery or to galleries in the United States. ${ }^{12}$ She emphasised on the autodidact nature of these artists (according to Yoni Waite, there were not many others), in tune with a naïve form of "African Art" as she wanted to sell it. ${ }^{13}$ WaGacheru insists on the pioneering aspect of Schaffner at the commercial level: she has supposedly been the first to perceive the value of Kenyan art on the international market. ${ }^{14}$ Painting became a feature of local culture in the village of Ngecha, as the organisation of an annual festival demonstrates. As early as 1993, the Banana Hill Art Studio, founded by Shine Tani, ten kilometres away from Nairobi, welcomed and exhibited local artists' works,$^{15}$ including those from Ngecha. As nowadays, it offered training to the youth, a typical and persistent feature of the life of many Nairobi painters. The Banana Hill Art Studio and the One Off Gallery, founded in the same year by Carol Lees, ${ }^{16}$ started two different yet interconnected orientations of the market, at a time when Ruth Schaffner

11. Shine abandoned his bread and butter as an acrobat downtown after he discovered painting in a hotel and touched base with R. Schaffner (personal communication).

12. On the topic of prices, see WaGacheru, Margaretta. 2013. "Good Old Gallery Watatu in Limbo.” Daily Nation, 5 August. https://nation.africa/kenya/ life-and-style/dn2/good-old-gallery-watatu-in-limbo-880584 [archive]; details also received from Shine Tani (one of WaGacheru's informants), personal communication.

13. Lucki Mutebi interviewed by Margaretta WaGacheru: "Tani didn't like the way she bought Kenyan art for very little then sold it at much higher prices. He felt she was not benefiting the artists." WaGacheru, Margaretta. 2012. "Artist of Two Worlds Finally Traces His Way back to Kenya.” Business Daily, 22 March. https:// www.businessdailyafrica.com/lifestyle/society/Artist-of-two-worlds-finallytraces-his-way-back-to-Kenya/3405664-1371484-q8467p/index.html [archive].

14. International ignorance of the art produced in Kenya lasted until a decade ago: see below.

15. Here is a list of the pioneer artists as it was communicated to me by James Mbuthia: Shine Tani, Kamuyu Martin, Kamondia, Livingstone Miringu, Jim Gay, Lucky Mutebi, late Alex Mbugua, late George Thairu, Joseph Cartoon, Anthony Muya, Daniel Kinyanjui, Jeff Wambugu, Peter Kibunja, John Silver, Jonathan Mbugua, Julius Kimenia, Sebastian Kiarie, Hosea Muchugu (Giko), Shade Kamau, Baba, Willie Wamuti, Mary Ngugi, Rachael Wangari, Rahab Shine, Mwura. Personal communication on March 14, 2014.

16. The gallery, located as it is today "off Limuru Road," on Carol Lees' property, is halfway between the CBD and Banana Hill and Ngecha. Carol Lees, just like Yoni Waite and Mary Collis, are Kenyans. 
was redesigning her action in order to strengthen artists' training; she did it together with her assistant Rob Burnett, who gave it a decisive momentum and transformed the artistic scene in Nairobi.

Some sociological aspects of that time are worth noting, such as the habit of artists to work with one another, to train the youth, often for free, and to represent social and political events in diverse pictorial styles, going from the descriptive to the satirical or even typical daily life scenes. In this first phase, the influence of galleries was stronger than that of sponsors, who, other than providing exhibit space, were quasi absent. These exhibits and the work of some gallery managers transformed the Nairobi artistic scene, starting in 1996 when the Kuona Trust was founded. The artists connected to the Ngecha Artists Association and the Banana Hill Art Studio have pursued their work until today, in their own styles that they had developed from the early days. According to Sidney Littlefield Kasfir (1999), these artists embody Kenyan contemporary painting, adding Kivuthi Mbuno, an artist who was notably published in La Revue Noire. ${ }^{17}$ Littlefield Kasfir's choice, in the Schaffter and Watatu Gallery exoticising line, can explain why Okwui Enwezor, the Pope of modern African art, ${ }^{18}$ did not include Kenya in his piece on contemporary African painters (Enwezor \& Okeke-Agulu 2009). This world of critics, centered on the Atlantic coast from Nigeria to Congo to South Africa, and the festivals of francophone Western Africa, does not mix with an immerging artistic scene such as Kenya, ${ }^{19}$ For Kenyan artists to be connected to a wider world, which galleries had failed to do up to this point, required the interest of important sponsors, persuaded of the social benefits of training artists in the field, and willing to provide them with common workshops and with means allowing them to develop their creative freedom.

The galleries, located in Nairobi's city centre when the owners could afford it, were connecting the works and the buyers, but not the artists. Restaurants and hotels also exhibited Kenyan and more generally East African painters. As much as they can afford it, galleries are located where the potential clients are, which varies depending on urban development.

17. Revue Noire. 1994 (March-April-May): 13. Kivuthi is present in numerous collections including the Pigozzi collection. Its theme-the proximity, see the equal value of men to animals-is also present with other painters, notably Richard Kimathi. Kivuthi is very particular in his technique of pencil drawing.

18. See Azimi, Roxana. 2015. "L'homme de l'art." M Le magazine du Monde, 24 January: 29-35. Enwezor was commissioner of the Dokumenta 2011 in Kassel and at the Venice Biennale in 2015.

19. In an article published in Le Monde on July 27, 2016, André Magnin gives a description of his work as collector at the service of Pigozzi, illustrating the interaction of coincidences, research, and exhibits in the creation of collections, but also of markets. 
During this first period, the city centre was attractive. ${ }^{20}$ The less wealthy galleries were located in Ngecha and Banana Hill and exploited-and still exploit-the appeal of an authentic village-like Africa to attract potential buyers. With the same goal, others bet on the fascination for slums where artists set up their studios serving as galleries. ${ }^{21}$ The artists, at that time, had very little direct contact with the artistic world abroad.

\section{The Era of Sponsors}

The Ngecha Artist Association looked for sponsors ${ }^{22}$ through rather usual means while Shine Tani and his group benefitted from the help, among other sponsors, of a Mennonite couple, Bob and Betty Baumann. They organised the exhibition "New Art from Nairobi" in Philadelphia (USA) that gave Shine Tani the opportunity to participate in many workshops in Europe (Swigert 2011, 93). Yet, with the creation of the Kuona Trust situated next to the National Museum, the search for sponsors became more professional. This creation caused a chiasmus between the two types of activities of the Watatu Gallery: on the one hand, sale, and on the other, artists' development. This schism coincided not only with the creation of the Kuona Trust in $1996,{ }^{23}$ but also with the passing of Ruth Schaffner.

The systematic search for sponsors and the connecting of artists to international workshops, gave the painters the means to display their work internationally, which was a necessary step to the construction of a resume that was previously left to chance encounters. The Kuona Trust was twoyears-old when I met there numerous artists now in vogue. The location within the National Museum was ideal in a climate of growing insecurity that made the city centre unsafe (de Lame 2006). Lead by Rob Burnet, the

20. The city centre has recently been the object of a new interest, as shown by the establishment of artists' studios near the Railway Museum, the GoDown installation and its studios in the industrial area, as well as the "Naini who" initiatives aiming to make Nairobi known thanks to the organisation of events in different urban locations, or even the project of a modern art museum at the heart of old Nairobi, not far from the National Archives.

21. Certain artists continue to aim for this goal, such as the Msaï Mbili group combining the line of exoticism of misery with the more recent form of "installations." One should note that the "two Masaï," Otieno Gomba and Otieno Kota are not Masaï but decided to label themselves as members of the ethnic group favoured by tourists (personal communication with Otieno Gomba). Their success-supported by the Goethe Institute-is linked to personal relations, today with the artist Sam Hopkins.

22. See the magazine Caravan, 2001, where the painter King Dodge expresses his desires to create an artistic centre in Ngecha and where this pacifist militant magazine launched a fundraising plan to fund the project.

23. For details that I was not able to verify, see Swigert (2011, 94-104). 
centre was managed with dynamism by Judy Ogana ${ }^{24}$ and included a music workshop and storytellers, in addition to a space shared by a dozen of preselected painters. Among those painters were, as I recall, Michael Soi, Patrick Mukabi, Peterson Kamwathi, ${ }^{25}$ Peter Elungat, Richard Kimathi, Simon Muriithi, Jimnah Kimani, Justus Kyalo, and Beatrice (Wanjiku) Njoroge. Many of them had benefitted from artistic training before their arrival to the Kuona Trust, ${ }^{26}$ for example at the Creative Arts Center, such as Patrick Mukabi who obtained his certificate in 1988. Since the selection was based on the promising character of the candidates, a previous training was an advantage. This training could come from a family environment, as it was the case for Michael Soi or John Kamicha, ${ }^{27}$ or from more formal centres. The Buruburu Institute of Fine Arts (BIFA) was founded in 1993, next to the Creative Arts Center in Nairobi. Initially, it intended to give youths from the popular area of Buruburu, an artistic training that was aimed towards their entry into the profession. In addition to a three-year curriculum, courses lasting a month to a year focused on skills as varied as ceramics, technical drawing, floral arrangements, event management, and... graffiti. Even in this field, the emphasis is put on access to employment but creativity is successfully promoted. Beatrice (Wanjiku) Njoroge, an internationally renowned painter, completed her training there and, henceforth, the BIFA attracts youths from all over the country. These painters of the Kuona Trust were often labeled as the "second generation," ${ }^{28}$ somewhat strangely, since, on the first hand, the first generation had not been clearly defined, and on the other hand, the tendencies of styles and themes of the early days are still seen in many painters, notably in Ngecha and Banana Hill.

24. See the interview of Judy Ogana by Zaidi in Msanii no. 10, 2004: "Art as a Statement of where People Are at." The content of the interview completes in a structured (and contrasted) way the allegations communicated without critique by Swigert (2011, 108 and following).

25. The biography of Peterson Kamwathi by Olivier Marcel (2012) and the interview by Sam Hopkins (2011) complement each other. Otherwise, David Kaiza (Hopkins 2011) brings to light the social insertion of art in Nairobi through the life trajectory of Kamwathi-an artist whose "Series" convey a political message. See "Contact Zones NRB": https://www.contemporaryand.com/fr/ publication/contact-zones-nrb-a-book-series-of-the-goethe-institut-kenya-andnative-intelligence/ [archive].

26. This preliminary artistic training is shown in the biographical notes given by the artists themselves in the "Kenya Arts Diary" calendars published annually as from 2011.

27. John Kamicha is the son of Zachariah Mbutha, artist at Banana Hill.

28. The "young guns" launched this year by Circle Art Agency (see below) might form a new generation and we will have to see how it distinguishes itself from the previous ones. 
Insecurity, the oppressive political climate to which an opposition, cautious in its verbal expression, responded, ${ }^{29}$ and the increase in both economic and retributive crimes influenced the themes adopted by artists, but also the themes that defined the search of sponsors. The artists felt they were the privileged interpreters of a silenced majority "since the police officers didn't take painters seriously" ${ }^{\text {"30; }}$ painters, above all, made themselves the intermediates in the expression of grief and popular irony. Additionally, they responded to the buyer's interests in the expression of social problems and the opposition to the dictatorship. Besides, all means were to be used to "cleanse" the city of its "street children." The issue of urban poverty was a powerful engine to mobilise funds. While the slums, violence, and corruption became common themes for the Ngecha artists and others, the potential of art as a means of employment was-and is-used, as much to attract buyers in the slums as to encourage the generosity of donors and the youths searching for employment and training. The prospect of seeing the end of the Moi era sparked fervor for a Kenya that would have an optimistic and prosperous future and encouraged the generosity of donors.

Rob Burnet proved to be an extraordinarily efficient lobbyist. On the one hand, he was able to obtain funds from the Ford Foundation and numerous donors within the framework of development and cultural policies; on the other hand, by entering the Triangle Network, ${ }^{31}$ he put Kenya on the map of international artistic networks. When he was hired by the Ford Foundation in 2000, he subsidised many Kenyan organisations, among which were the Wasanii workshops, Kuona Trust, and RaMoMa. The move of Kuona Trust to the industrial zone of the city centre, in the heart of the much vaster GoDown complex, allowed to, not only shelter artists' workshops, but also to host a performance hall. At the time when Kuona Trust was moving again, this time towards Hurlingham, the GoDown opened training workshops in fields as diverse as computer science, dance, classical music, graphic design, etc. while maintaining a few artists' studios, notably those of Michael Soi, and, until recently, Patrick Mukabi. ${ }^{32}$ The creation,

29. We remember, for example, in the weekly editorial signed by Wahome Jutahi "Whispers"; on Wahome Mutahi, see Maupeu \& Mutahi (2005).

30. Personal Communication, Chain Muhandi, 2000.

31. Officially known as the Triangle Arts Trust, the organisation was launched, in 1982, by Robern Loder and Anthony Caro, with the goal of creating links between visual artists, organisations, and independent creative workshops held by artists; it is now present in 30 countries. See: https://en.wikipedia.org/wiki/ Triangle Arts Trust.

32. In 2015, Patrick Mukabi, who introduced numerous young students to painting, founded the Dust Depo Art Studio, located in the studios next to the Railway Museum, downtown. 
and later management and multiple moves of Kuona Trust, resulted in a diversification of the location of artists. Numerous artists present during the early days of Kuona Trust left for areas where they found themselves close to one another, such as Kitengela, where is located the workshop of artistic glass creation of Nani Croze, an artist of German origin and an important player in the Nairobi art scene, and organiser of many training workshops in the art of glass. Next to the daily emulation created by the proximity, the more formal workshops, ${ }^{33}$ such as the Wasanii Workshops organised annually at Naivasha, Lamu, etc. gave artists connections beyond borders. From the beginning of Kuona Trust, the opportunity was given to artists, active on site, to visit workshops abroad and stay there in residence, in Africa as well as in Europe and the United States. The artists thus found themselves in contact with other cultures while also building a reputation and creating opportunities for exhibits abroad. The notion of an autodidact artist, dear to Ruth Schaffner, became a differentiating criterion-and also became partly obsolete-compared to a majority of artists who had been trained in one way or another ${ }^{34}$ and who advertised this training and their participation in workshops, artist residence, or exhibitions abroad.

Another sign of the times in the search for sponsors is the contrast between the engagement of private donors and the search for official or commercial sponsors. Thus, the PaayaPaa gallery, destroyed by a fire in 1998, was reopened on a distant ${ }^{35}$ site thanks to the aid of an individual donor and through harambee fundraising, organised by leaders in the world of art. As for RaMoMa, founded by Mary Collis and Carol Lees, while the gallery benefitted from Ford Foundation grants, it gradually became sponsored by for-profit firms (Dormans, Safaricom...), and received donations from diplomatic offices, such as the High Commission of Canada to Kenya ${ }^{36}$ RaMoMa, located in the wealthy area of the Upper Hill,,${ }^{37}$ under Carol Lees' leadership, immediately symbolised an evolution that continues

33. For a list of the workshops over the course of the years, see also Gerschultz (2013). Informal workshops where artists train young students are added to the list. Yet, we are far from the "hundreds" of artists mentioned by Gerschultz. Another reservation: Gerschultz underestimates the role of two Kenyan women, Mary Collis and Carol Lees, signaling that "a few expats" appear on the scene. Both are Kenyan.

34. The University of Nairobi offers a "Masters in Fine Arts."

35. PaayaPaa Arts Center, Ridgways Road, off Kiambu Road.

36. See, for example, the Msanii magazine, no. 14, March 2006, p. 2: "News."

37. The location of administrative buildings and the Hotel Fairview, in the Rahimtullah Tower property of a Kenyan family (hence the name of the gallery which also alludes to the New York MoMa) near offices, avoided downtown neighbourhoods. 
today at the GoDown Arts Center and Kuona Trust. In harmony with the actors of the city's art scene, RaMoMa was able to offer, in addition to workshops, beautiful exhibition and sale spaces; it attracted an educated public through the organisation of cultural activities involving foreign African artists from other horizons: concerts, modern dance, etc. Each exhibit premiere, along with other artistic Kenyan events, was recorded in a quarterly magazine from 2002, Msanii. ${ }^{38}$ This magazine, dedicated to the manifestation of visual arts in Nairobi, was a first in establishing a continuous contact between the public and the artists. The now well-known photographer, James Muriuki, designed the graphics of the magazine while the painter James Mbuthia ${ }^{39}$ participated in the organisation of workshops. The freedom left to the artists by Carol Lees facilitated the Ngecha and Banana Hill autodidact artist's participation who were intimidated by the criteria required to be part of Kuona Trust.

At the Watatu Gallery (where the activities were now limited to sale), the Ngecha and Banana Hill studios had been added, as well various art centres such as RaMoMa and Kuona Trust. Art was also spreading through the city, whether in form of graffiti, notably by a team of the National Museum on the bridge that leads to its buildings or, in an omnipresent way, in hotels, restaurants-The Rustic, that no longer exists today, is a good example-and the Coffee Houses. Original paintings by Jimnah Kimani ${ }^{40}$ still decorate all the "Java House" cafes that have been designated as interior design models. The Sankara Hotel (Westlands) possesses one of the best collections in the country ${ }^{41}$ : the works are exhibited in public areas, as well as in the rooms and a proper gallery attracts a posh clientele accordingly.

The cultural centres and embassies had offered exhibit spaces to Nairobi's artists as well as all Kenyan artists, and, occasionally, to artists from all over East Africa-as early as 1977 when it comes to Alliance française. Harsita Waters' constant presence, responsible for Cultural Affairs and Communication at the Alliance française for over twenty years, contributed to the institution's solid cultural policy, founded on the knowledge of the

38. The last edition holds no. 25, November 2008-January 2009, little before the closing of RaMoMa.

39. James Mbuthia, of Banana Hill, was supposed to launch workshops for sick children at the Nairobi hospital. This activity, which he is still pursuing, illustrates the frequent social engagement of artists.

40. "With their signature Jimnah Kimani artwork, brick red and cream walls grounded wood and wrought iron..." Awori, Jordan. 2016. "Restaurant Inspiration: Java House Inspiration.” The Interior Decorator, 16 March. https:// www.jordanawori.com/?p=253 [archive].

41. Mark van Rampelberg, already present at the Watatu Gallery where he had designed the furniture, is the curator. 
Kenyan and East African art scenes, ${ }^{42}$ and, more generally, on the social issues that often gave their themes to the exhibitions. The situation is slightly different at the Goethe Institute, which for a long time had been a partner on the Nairobi art scene, but where the successive directors managed the cultural policies. The visitor can thus pass, with a few years' interval, through an exhibit of expertly painted wooden birds (1999) or through an avant-garde exhibit whose authors, members of the Masaï Mbili group, were little experienced. Johannes Hossfeld, the director of the Goethe Institute from 2009 to 2013, clearly favoured fashionable artistic forms: installations, performances. He was at the source of the financing of "HalfLife Nairobi," a highly successful movie, remarkable for its social realism, and of the publications of artist monographs. His choices influenced the way Kenyan artists were represented abroad, as can be seen in the Afropolis volume where the Masaï Mbili group artists, based in the slums of Kibera, appear. In this volume, distributed internationally, the section dedicated to Nairobi focuses on the slums. The chosen groups rely on the personal networks of the Goethe Institute's director at the time. Hossfeld had clear opinions when it came to which artists to promote: painting and sculpture that he considered "outdated" had to be replaced with installations (Sam Hopkins, Miriam Siowia Kambu), and performances (Ato Malinda), video clips, cinema (notably "Half-life Nairobi" ${ }^{43}$ ) and street art, specifically the famous matatu, yet relatively sober at the time of the Afropolis edition. ${ }^{44}$ Paradoxically, while the Masaï Mbili group of the slums appears in Afropolis as a typical group, Hossfeld considered "good manners" to be a prerequisite for the international scene, next to high quality art. Embassies also organised exhibitions, following the individual artistic interests of their ambassador. This was the case, for example, during the two terms of Belgian Ambassador Bart Ouvry. Finally yet importantly, the National Museums of Kenya, that had for a long time a rather jumbled sales gallery, opened itself to contemporary art following its renovation.

42. The Alliance française in Nairobi possesses a collection of paintings, recently digitised, constructed over the course of exhibits. The artists only have one obligation when they are exhibited and that is to leave one work.

43. Personal communication.

44. From 2005 to 2015, the Kenyan Government prohibited paintings on the usual minibuses, VW type, the matatu. This is an aspect of the laws that affects them, and in addition limits the number of passengers and imposes various security norms. To respond to the limitation of the number of passengers, the owners focus on buying larger vehicles which escape the white and yellow striped colors that had become the mandatory and uniform design of the traditional vehicles. The current president has lifted the ban regarding the decoration of vehicles, reestablishing a dialogue between the styles of art visible to the public, the matatu being the most obvious example. 


\section{The Buzz Years}

On the extremely dynamic Nairobi art scene, every withdrawal has sparked momentum. The move of the Kuona Trust to the industrial area, still under the management of Judy Ogana, allowed for the opening of GoDown in 2003 and a diversification of the artistic activities offered. Kuona Trust separated itself after Judy Ogana's short absence and settled in Hurlingham, under the management of Danda Jaroljmek, an artist member of the Triangle Network. The two institutions, now very different, experienced continuous expansion. Today, in the industrial area of the city, near a slum, the GoDown, managed by Judy Ogana and Joy Mboya, attracts a young crowd by various means: varied and popular training programs-break dancing, for example-but also now almost weekly "live" concerts, the organisation of annual exhibits with specific themes, "Manjano," taking place in the chic and popular area of "Village Market," and encourages young talents by connecting them to current social themes. The opening of GoDown was a major social event (given the "trendy" location) where were artists from all walks of life could meet and during which Thelatini, the first reference publication on Kenyan painters and sculptors, was launched. The selection of artists, probably more difficult during that time than today, was conducted with an emphasis on impartiality by a double committee of artists, gallery owners, and collectors (Kuona Trust 2003, 8). In 2017, Susan Wakhungu Githuku published a less selective and much more voluminous piece, which was, as a result, much more representative of the variety of pictorial production since the seventies (Waghungu Githuku 2018).

The ambitious move of RaMoMa to a safe and attractive location in Parklands radically transformed its activities by installing many galleries and exhibit spaces, workshops for children, a restaurant, a major monthly exhibition, the creation of a collection, etc. Carol Lees was its curator. The Msanii journal kept on publishing the artists and was even sold in kiosks. Swigert ${ }^{45}$ suggests a collusion, "a cartel" of subsidised centres producing for sale in the RaMoMa galleries. The reality is different: on the one hand, artists were free; on the other hand, in order to deny this allegation, it would be enough to consult the program of exhibitions and to recall the origin of each artist exhibited. The second version of RaMoMa offered a unique space for interaction where one could find, just like in the Kuona and GoDown workshops, artists from Ngecha and Banana Hill. ${ }^{46}$ These different locales, by the various people they attracted, allowed artists to

45. Swigert $(2011,118)$ speaks of a "cartel."

46. It was at this time that the Banana Hill Art Studio, after a crisis, stopped being a cooperative and became the property of Shine Tani. 
evolve out of the ghetto of naif art, a movement that was accentuated by the progression of the Kuona artists as well as the increasing individualism of the artists. These years coincided with a certain dormancy of the Nairobi Museum, which was being renovated. Its reopening, in 2008, was a national event marked by the addition of a new exposition space, "the old PC's office building, ${ }^{37}$ where temporary exhibitions ${ }^{48}$ are being held in the heart of the city centre. The renovated museum also included the works of local artists, notably Miriam Syowia Kyambi, ${ }^{49}$ whose exhibit retraced the political Kenyan history.

The year of 2008 (who would not remember it?) was the beginning of a major economic crisis resulting in a drastic decrease of subsidies. For Kenya, it was also the beginning of a year marked by post electoral violence and the successive displacement of dozens of thousands people. These two events, one could argue, had important repercussions on the development of the Nairobi art scene as we know it today.

The decrease of donations from sponsors hindered the personal initiatives and created a need for more visibility. In particular, the government's attention to the economic potential of artistic activities was drawn on multiple occasions, notably by the GoDown team. ${ }^{50}$ This team, with the support of the Ford Foundation, took control of the coverage of the post electoral violence conducted by nine talented photographers, to lead a campaign and spread awareness in various cities in the country. The photo collection "Kenya Burning" was even sold in supermarkets. Favouring raising awareness, the spread of these terrible images also allowed for the realisation of the power of images that would be demonstrated again in the years to come, notably through a pre-electoral graffiti campaign. The name of the photographer Boniface Mwangi is linked to the two events ${ }^{51}$ : that of

47. Located in the city centre, at the intersection of Kenyatta Avenue and Uhuru Highway.

48. I was able to visit an exhibition of photographs taken by young artists from Eastleigh in the context of a competition organised by the National Museum: this testifies to the social engagement of art.

49. Laureate (second) in a UNESCO artistic competition in 2004, Miriam SyowiaKyambi graduated from the School of the Art Institute of Chicago. In 2016, the artist chose to no longer use her European first name and now goes by Syowia Kyambi.

50. Personal communication of Judy Ogana: many meetings and a lot of research was organised.

51. See also Meyerfeld, Bruno. 2016. "L’hyperactiviste." M Le Magazine du Monde, 23 January, 38-40: "Une 'guérilla artistique' menée sans illusions." A few elements of the interview seem to have not been verified by the author. 
the artistic centre Pawa254 (that he manages) is linked to the second. ${ }^{52}$ The events of 2007-2008 and the camps set up for the displaced people served as inspiration for many painters and became themes for workshops as a rather common representation of social and political facts..$^{53}$

The years 2008 and 2009 were transitional years for the Nairobi arts scene. These years were the beginning of personal initiatives, as much from galleries as from artists: it became necessary to multiply events, make yourself visible, and create a "buzz." Media and internet became omnipresent and essential means of communication for those interested in the field. Many events mark this period: the closing of RaMoMa (2009) and the reopening of its own gallery by Carol Lees (One Off) ${ }^{54}$ in 2010; Danda Jaroljmek's arrival to the scene, first in 2009 as director of Kuona Trust, and later in 2012 as director of the Circle Art Agency (or Gallery); the unwavering dynamism of GoDown, which, in 2018 initiates a crowd funding for a renovation of its buildings $\mathrm{s}^{55}$; the remarkable persistence of the Banana Hill studio under Shine Tani's management; the opening of Red Hill Gallery, a new gallery concerned with the whole East Africa, by a German couple, coincide with the new dynamic of the Nairobi Museum where a contemporary art curator, Lydia Gatundu Galavu is working and progressively deploys temporary exhibitions, as she resorts to experienced curators in specific domains; the project "Amnesia," which explored multiculturalism and post colonialism was led by Siman $\mathrm{Njami}^{56}$ and was

52. Ni Chonghaile, Clar. 2012. "Kenyan Graffiti Artists Step up Battle against 'Vulture' Politicians: Protesters Want Voters at Next Election to Kick out MPs Accused of Corruption.” The Guardian, 21 March. https://www.theguardian. com/world/2012/mar/21/kenya-graffiti-artists-politicians-vultures [archive].

53. Well before these events, numerous painters had used the abuse of power, corruption, and police violence as themes... An exhibit on these themes was organised at Kuona Trust2 under the title "The Eyes have it," which is also the title of a work by Kimathi. Among the painters who used these themes, we cite S. Kiarie-at their beginnings-P. Kamwathi, R. Kimathi, Bertiers, Michael Soi, J. Mbuthia, J. Kamisha, A. Githuka... See also Whalley, Frank. 2010. "Thin Line between Arts and Politics." The East African, 26 July.

54. Located on her personal property, the gallery is an original architecture created by Dominic Martin and like to "create the buzz." Group visits are frequent.

55. On the GoDown Arts Centre site (http://www.godowntransforms.org [archive]), a reader interested in the history of GoDown will be able to hear from its director, Joy Mboya, outlining it and, above all, the philosophy.

56. The presence of Simon Njami in Nairobi promises a disembarkation of Kenyan artists. Co-founder of Revue Noire, artist and critic, Simon Njami can make artists known by an informed public. The project was also presented in Brussels by Africalia. Another sign of opening up is the intervention of artists 
presented there in 2009. All the other places are engaged in the regular and frequent creation of events, widely publicised on the internet; some, in fact, exist only on the web. It is crucial, for artists, to be very present online and to distinguish themselves by style, quality, and the presentation itself.

In addition to the annual events, such as the Manjano competition organised by the GoDown and the exhibition organised by the art centre at the International School of Kenya, we find the monthly openings of the exhibitions at One Off, and the slightly less frequent ones at Red Hill Gallery and Banana Hill Arts Studio, as well as, recently, the initiative of Circle Art Agency. The artists regularly find themselves at the One Off exhibition openings, a place of conviviality and continuity with a history that they share with Carol Lees, a place where they converse with art amateurs or young talents who are seeking recognition. This proximity with the artists, in an informal way also present at Banana Hill, is typical of One Off where Carol Lees uses her knowledge and her networks to help the artists she represents and immediately pass on their success to those in her mailing list. Since 2012, one can also find these artists, and in a more sensational way, in the events created by Circle Art Agency. ${ }^{57}$ Led by Danda Jaroljmek, Circle Art Agency mostly functions around punctual events that, during several years, were organised through three-day sales in various places and, until today, by organising auctions. Recently (in 2017), the openings in this gallery and the launch of little-known ${ }^{58}$ young artists shook the Nairobi art scene once again. The first auction had taken place in November 2013, displaying mostly Kenyan painters put in perspective thanks to the works of other East African artists. It followed the most "buzzing" event of the year, the controversial auction sponsored by the Watatu Gallery when it permanently closed. ${ }^{59}$ Interestingly, the news of the Circle Art auction of $2017^{60}$ presented works of Kenyan artists from the seventies and eighties:

linked to the group "White Cube" (see below) to put Nairobi on the international scene.

57. Contrary to what is written on its website, Circle Art is not, the reader realises, the first "independent agency" in Kenya.

58. The "Young Guns" exposition was opened at the Circle Art Gallery on June 7, 2017, presenting the works of 26 artists "especially young men, who have lots of energy and talent, and are becoming successful." Some of their works are proof of the innovation of techniques, such as those of Mwini Mutuku, who works digitally and with lasers.

59. See WaGacheru, Margaretta. 2013. "Good Old Gallery Watatu in Limbo." Daily Nation, 5 August. https://nation.africa/kenya/life-and-style/dn2/good-oldgallery-watatu-in-limbo-880584 [archive].

60. On February 27, 2017, in a big hotel in the centre of Nairobi, this sale auctioned a few ancient works sold at very high prices in the typical emulation of the circumstance, at the pleasure of a few artists who were present. The 
now individualised, these artists of the early days should take their own place in the market... and their collections become more valuable.$^{61}$ Indeed, such collections do exist, as they have been patiently constituted by art connoisseurs for three decades or more, whether they were shown ${ }^{62}$ to the public or not. Any success abroad gives value to African artists... as do all artists that find themselves "in the right place." For a long time, Carol Lees has used her contacts to make works travel, notably to London where she has gone annually since the first edition of the Contemporary African Art Fair where, in 2018, Circle Art and ArtLabAfrica were also represented. From her Karen house, ArtLabAfrica's director LaviniaCalza plays a systematic role in the diffusion of Kenyan artists to places as prestigious as London and New York. Born in Nairobi, based in London, producing works clearly inspired by Kenya, the artist Michael Armitage, thanks to the "White Cube" network to which he belongs, put Kenya on the map by organising a threeday seminar with the title "Art, Space and the City," bringing together about fifty artists and personalities of the "cultural world," coming from sixteen different countries. The last day, "The Gathering," was open to a wide Nairobi public, with a bus allowing anyone to travel for free from Nairobi to Naivasha, where the seminar was taking place. ${ }^{63}$ The presentation of the artist Theaster Gates, based in Chicago, made it an unforgettable day and, without being closed, elitist, in a way that called on emotion as much as on analysis to promote the implantation of an urban art giving beauty to its environment, as poor as it may be.

The promotion of public urban art also appears as an efficient way to stimulate an artistic sensibility and familiarise the public with art and artists: this is the explicit goal of the installation of a monumental and tactile work by Peter Ngugi at the "Hub," the commercial mall in Karen.

Classically, two journalists systematically report artistic events in the press. One, Margaretta (Swigert) waGacheru, ${ }^{64}$ has long been present through

attraction for works produced in the seventies and eighties was obvious, despite the small number of works presented, while current artists proposed one or another of their works at the auction: sign of the slowing down of this type of sale requiring a search for works or artists' attempts to raise their prices? They are not mutually exclusive.

61. As for big auction houses, only Bonham's sold works by Kenyan artists.

62. Hotel Sankara, Alan Donovan's African Heritage House, Red Hill Art Gallery...

63. More precisely, from February 17 to 19, 2017, at Great Rift Valley Lodge.

64. WaGacheru, Margaretta. 2012. "Nairobi’s Upmarket Red Hill Opens a New Gallery." Business Daily, 16 September. http://www.businessdailyafrica.com/ Nairobi-upmarket-Red-Hill-opens-a-new-gallery/-/1248928/1498086/-/6k5jqc/-/ index.html [archive]. 
her columns in the Daily Nation and Business Daily. In 2008, a more informed critic, Frank Whalley "evaluates the quality of works offered in the public and private galleries by placing them in national and international context both in the present and past..." ${ }^{65}$ each week in The East African. His desire to educate his readers is clear. ${ }^{66}$ Finally, starting in 2010, at the request of the glass-artist of German origin, Nani Croze, the "Kenya Arts Diary" calendar, presenting mostly Kenyan artists, was published; its annual launching is an opportunity to honour an artist of which the most recently honoured was... Elimo Njau, the now octogenarian ${ }^{67}$ "father" of the artistic scene with his PaayaPaa gallery. Nani Croze attempts to individualise the artists and, by the sale of a luxurious and artistic diary, make them known abroad-thanks to the travels of expatriates-by showing their works, their biography, and their contact. Her contribution accompanies the desire of Kenyan artists to be, simply, artists, with a name, a style, a personality expressed in their works and universal themes: whether one buys a Sane Wadu (for example), and not a Kenyan or African painting. Whalley immediately echoes the successes of artists in his weekly art column, as he did, for example, for Paul Onditi ${ }^{8}$ or Beatrice Wanjiku, the latter declared, in 2016, best artist of the Contemporary African Arts Fair in New York. ${ }^{69}$

\section{Conclusion: In the Big Leagues}

The considerations of specialists of contemporary art apply to Kenyan art, matured since its beginnings, immune to the "empty period" of contemporary art deplored by Azimi and Bellet ${ }^{70}$ : there is still enthusiasm

65. Whalley, personal communication on July 13, 2016.

66. See, a.o. Whalley, Frank. 2014. "From Kenya to the US with Love." The East African, 22 August [archive]. Paul Onditi, a Kenyan artist, lived ten years in Germany where he received a thorough artistic training. His works, created with materials resulting from personal research, testify to societal concerns that far exceed the context of Kenya. Following the election of Donald Trump, he created a series of paintings expressing the anxiety of many of us facing the drastic change of a world that he glimpses without optimism.

67. "The Kenya Arts Diary Launch and Arts Exhibition 2015." 2014. Heinrich Böll Stiftung Nairobi, 6 November. https://ke.boell.org/2014/11/06/kenya-artsdiary-launch-and-arts-exhibition-2015 [archive].

68. Whalley, Frank. 2015. "Smokey Leads the Charge at International Arts Fair." The East African, 9 October [archive].

69. Whalley, Frank, 2016. "Wanjiku Featured No 1 in New York's African Art Fair." The East African, 14 May [archive].

70. Azimi, Roxana, and Harry Bellet. 2015. "Désespérance de l'art contemporain." Le Monde, Cahier $\mathrm{n}^{\circ}$ 21976, 12 September. https://www.lemonde.fr/culture/ article/2015/09/13/desesperance-de-l-art-contemporain 4751360 3246.html. 
in Kenya. More than ever, the Kenyan capital best embodies the description by these two authors: "Contemporary art is now part of the urban or media landscape (ibid.)." Nairobi is one of the greatest examples of omnipresent art, in the events that take place, as well as in everyday billboards, innumerable and magnificent graffiti, and the matatu that President Uhuru Kenyatta has returned to their colourful flow. This street art is taught and has become the subject of competition launched very recently by the Alliance française. The events that celebrated art-such as the Oscar awarded to the actress Lupita Nyong'o for her role in the film "Twelve Years a Slave," result in as much national pride as the successes of athletes. In contrast, the lack of appreciation for arts by the authorities continues to be lamented, but everything is done to inform, put the Kenyan elites at ease, and create a market on the national scene. ${ }^{71}$ The intervention of the authorities in the context of financial support for the job market sometimes results in the sponsoring of groups, which at first glance, would not have access to the international market, which is still confusing.

Kenyan painters arrived on a scene already structured by festivals and by the-still rare-publications dedicated to modern works realised by Africans. Some have succeeded in circumventing these circuits and putting themselves on the forefront of more open stages. Often, the connection between works and stereotypes of naïve and primitive African art alleviates the ignorance of emerging networks, whether in Kenya or abroad. As shown recently by a public exhibit of a work by Peter Ngugi, the success of Paul Onditi, the consecration of Beatrice Wanjiku or that of Peterson Kamwathi, who has, among other successes, a work exhibited at the British Museum, the artist emerges alone if he escapes the clichés and if $\mathrm{s} / \mathrm{he}$ embodies universal themes on the international art scene which s/he reaches through intermediaries ${ }^{72}$ Freed from the clichés of exoticism, $\mathrm{s} /$ he no longer needs the faded laurels of a conventional biannual exhibit. ${ }^{73}$ International art

71. Thus, on July 22, 2017, the First Lady of Kenya, Margaret Kenyatta, was present at the launching of the Visual Voices book by S. Wakhungu Githuku.

72. The crucial role of intermediaries and collectors in the promotion of artists is not unique to Kenya or Africa. A striking example is the role that Peggy Guggenheim played in the emergence of Western abstract artists. Lavinia Calza, with ArtLabAfrica, presents African artists at the International Contemporary Art Fair in London (Somerset House, in the heart of London) and in New York.

73. The Kenyan Pavilion of the 2013 Biennal presented 11 artists of which 9 were Chinese, that of 2015, 8 Chinese artists and two Kenyans. This is self-explanatory and it is most fortunate that Kenyan artists and intellectuals reacted with force. See Serubiri, Moses. 2015. "The Double Life of Kenya at Venice. Serubiri Moses about the Kenyan Pavilion at this year's Venice Biennale." Contemporary\&, 6 April. http://contemporaryand.com/magazines/the-double-life-of-kenya-atvenice/ [archive]. 
fairs, such as the Contemporary Arts Fair in New York and London, bring new Kenyan works to the attention of the public each year. Computing technology plays a remarkable role in the international diffusion of Kenyan art and the creation of events that make the city vibrate and attract its elite and middle class. The purchase of works by Kenyans has become increasingly common, particularly if they have a cosmopolitan background. The media certainly helps the diffusion and the education of artistic judgement. Numerous artists are standing out, as much through style-as they intend to define their own artistic criteria-as through their means of access to the market. When they can, they install home studios and create a website, some going to greater lengths and creating their own network of representation without using an intermediary.

The galleries mostly (but not only) present Kenyan artists; the diversity of the origins of the works creates a context for the Kenyan works.

Long linked to sponsors, to their own objectives and their perception of the sociopolitical situation and possible solutions, the Kenyan art scene has partially emerged in the wake of the success of great individualities. It is characterised now, in Nairobi, by the diversification of the production and of the markets, as much as by a diversification of the means of diffusion and the mobility of major artists. The art sometimes finds itself at the service of social issues, for example workshops dedicated to children in hospitals or AIDS patients, as done by the group Art2Be, or at the service of issues of national unity-the role of artists as social mediators was remarkable during the attack of the American embassy in Nairobi,${ }^{74}$ by the Al-Shaabab group in 1998, or during the post-electoral violence when the government itself encouraged the artists to favour "the good governance," a manipulation that testifies to aesthetic ignorance as well as economic benevolence. Recently, the lifting of the ban on decorating the matatu, the most democratic vehicles of graffiti art, was an opportunity to highlight the role of art on the local job market. For potential buyers, a demand remains for the remaining of pictorial, colourful, and naive works evoking the countryside, the slums, or everyday poverty, sometimes on a humorous model. But how can one talk about the extraversion of Kenyan art while this type of work, corresponding to clichés, is specifically awarded by international art fairs, notably in Dakar, while the best artists have followed different tracks?

74. On August 7, 1998, Kenya suffered from its first terrorist attack in a still unfinished series: this one targeted the American Embassy. The Kenyan victims, including 300 deaths, were numerous. Several painters, notably Patrick Mukabi who reported this to me, laid out large canvases in the streets adjacent to the incident to paint the suggestions of passersby and help them express their emotions in this way. See also Azimi, Roxana. 2015. "L'homme de l'art." M Le Magazine du Monde, 24 January: 29-35. 
These artists access the international market through the universality of their message and the quality of their works. The Kenyan Pavilion of the 2017 Venice Biennale resets a quality standard absent in previous editions of the Biennale and presents five Kenyan artists under the leadership of Kiprop Lagat, a commissioner linked to the National Museums of Kenya.

The art scene in Nairobi, even if one limits it to graphic art as I do in this case, appears to be essentially multifaceted with its overlapping practices and subjects, conventions, and freedoms. It is also an exciting scene because, despite its international dimension, it remains a hotbed of clearly identifiable social networks and illuminates the more general development and operation of the art market. The (cyber) gallery operators and knowledgeable collectors could spark a surprise... unless that is already the case. The Kenyan art market is reflective of its imbrication in a city of tentacular growth engulfing galleries such as One Off, not so long ago on the outskirts, and-whilst now urban in its own right-is "popping up" in the new Riviera Mall, or even in Red Hill, to which the city is gradually getting closer.

\section{Acknowledgement}

For their welcome and the exchanges that made me discover a vibrant universe of creativity, all my gratitude goes to Alan Donovan, Peter Elungat, Hadija Ernst, Alan Githuka, Otieno Gomba, Johannes Hossfeld, Danda Jaroljnek, Cartoon Joseph, Sebastian Kiarie, Richard Kimathi, Peterson Kamwathi, Ivan Korsak, Otieno Kota, Carol Lees, Dominic Martin, James Mbuthia, Chain Muhandi, Patrick Mukabi, James Muriuki, Jesse Nganga, Judy Ogana, Thom Ogonga, Paul Onditi, Samantha Ripa di Meana, Rahab Shine, Miriam Syowia Kiambu, Michael Soi, Shine Tani, Chelenge van Rampelbergh, Mark van Rampelbergh, Xavier Verhoest, Sane Wadu, Margaretta (Swigert) wa Gacheru, Yoni Waite, Harsita Waters and Frank Whalley.

A spare of thought for Deissy Rodriguez-Torrès who introduced me to Nairobi in 1998 as part of her project "Contemporary Nairobi." I also express my gratitude to the successive directors of IFRA and of the Royal Museum of Central Africa to which my visits to Nairobi were linked before my stays were accommodated thanks to the generosity of my friends and the passion that I have for the city and its diversity.

\section{Post-scriptum}

This contribution was revised several times and completed in November 2019. Since then, the Covid-19 pandemic has hit the art world hard, in Kenya and elsewhere. In Nairobi, the art market has declined considerably, despite the 
tremendous efforts of a few galleries also affected by the situation. As soon as the confinement was lifted, which roughly coincided with the summer holidays (2020), the wealthy left the city, already largely abandoned by expatriates; as a consequence, a large proportion of the art buyers were absent. At the time of writing, at the end of September 2020, a slight upturn was starting off but, as elsewhere in the world, the fear for a downturn in the Nairobi art market is there, which raises questions about when and how the extraordinary dynamism of the Kenyan art scene will pick up again. But it will!

\section{Bibliography}

Bloom, Steve. 2009. Trading Places: The Merchants of Nairobi. London: Thames \& Hudson.

Donovan, Alan. 2004. My fourney through African Heritage. Nairobi: East African Publishers.

Enwezor, Okwui, and Chika Okeke-Agulu. 2009. Contemporary African Art since 1980. Bologne: Damiani.

Gerschultz, Jessica. 2013. "Navigating Nairobi: Artists in a Workshop System, Kenya." In African Art and Agency in the Workshop, edited by Sidney Littlefield and Till Forster, 207-29. Bloomington (IN): Indiana University Press.

Grignon, François. 1997. "Les pierrots du bidonville. Peintres de matatu à Nairobi, Kenya." Autrepart 1: 151-60. https://www.documentation.ird.fr/hor/fdi:010012709.

Hossfeld, Johannes, and Ulf Vierke (eds). 2011. Contact Zones NRB, vol. 3: Peterson Kamwathi. Nairobi: Goethe Institüt, Iwalewahaus \& Verlag für Moderne Kunst.

Hossfeld, Johannes, and Ulf Vierke (eds). 2011. Contact Zones NRB, vol. 4: Ato Malinda. Nairobi: Goethe Institüt, Iwalewahaus \& Verlag für Moderne Kunst.

Kahora, Billy, Yasuyoshi Chiba, and Boniface Mwangi. 2009. Kenya Burning: Mgogoro baada ya Uchaguzi 2007/8. Nairobi: GoDownArts Centre \& Kwani Trust.

Kasbarian, Jean-Michel. 2002. L'art de vivre la maison / Artistic Perceptions of Home. Nairobi: Maison française de la Culture \& Findakly.

Kenya Arts Diary. 2011 and following years.

King, Kenneth. 1996. Jua Kali Kenya: Change and Development in an Informal Economy, 1970-1995. Ohio: Ohio University Press.

Kuona Trust. 2003. Thelatini. Thirty Faces and Facets of Contemporary Art in Kenya. Nairobi: Kuona Trust.

Lame (de), Danielle. 2006. "Gris Nairobi. Esquisses de sociabilités urbaines." In Nairobi contemporain, les paradoxes d'une ville fragmentée, edited by Hélène Charton and Deyssi Rodriguez-Torres, 221-83. Paris: IFRA-Karthala. 
Lame (de), Danielle. 2012. "The Arts and the City." International Conference Norms in the Margin and Margins of the Norm. The Social Construction of Inequality. Tervuren, 25-27 October.

Littlefield Kasfir, Sidney. 1999. Contemporary African Art. London: Thames \& Hudson.

Marcel, Olivier. 2012. "De la 'ferme' au 'marché'. Trajectoire et mobilités de Peterson Kamwathi, artiste nairobien." Transcontinentales, no. 12/13. http://journals.openedition.org/transcontinentales/1372.

Maupeu, Hervé, and Patrick Mutahi. 2005. Wahome Mutahi's World. Nairobi: Transafrica Press.

Miller, Harold F. (ed.). 2014. The Murang'a Murals. Nairobi: CreateSpace Independent Publishing Platform.

Ogonga, Jimmy. 2011. Amnesia. Imagining Afrika Without the Crisis of Historical and Cultural Memory. Nairobi: Nairobi Arts Trust.

Pinther, Kerstin, Larissa Forster, and Christian Hanussek. 2010. Afropolis: Stadt, Medien, Kunst: Kairo, Lagos, Nairobi, Kinshasa, Johannesburg, Köln. Cologne: Verlag der Buchhandlung Walther König.

Robarts, Geraldine Sally. 1981. "Curriculum Planning for Art Education for Schools and Colleges in Kenya." PhD Dissertation. Nairobi: University of Nairobi. http://erepository.uonbi.ac.ke/handle/11295/25968.

Swigert, Margaretta. 2011. "Globalizing Kenyan Culture: Jua Kali and the Transformation of Contemporary Kenyan Art: 19602010.” PhD Dissertation. Chicago: Loyola University. https://ecommons.luc.edu/luc diss/265/.

Swigert-Gacheru, Margaretta. 2013. Creating Contemporary African Art: Art Networks in Urban Kenya. Saarbrücken: Lambert Academic Publishing.

Wakhungu-Githuku, Susan. 2017. Visual Voices: The Work of Over 50 Contemporary Artists in Kenya. Nairobi: Footprint Press.

WaMungai, Mbugua. 2010. "Dynamics of Popular Transgression: The Speed Culture of Nairobi Matatu." In Popular Snapshots and Tracks to the Past: Cape Town, Nairobi, Lubumbashi, edited by Danielle de Lame and Ciraj Rassool, 117-40. Tervuren: Musée royal de l'Afrique centrale.

\section{Media}

"Art as a Statement of Where People Are at." 2004. Msanii: The Magazine for the Arts from Rahimtulla Museum of Modern Art, no. 10.

Awori, Jordan. 2016. "Restaurant Inspiration: Java House Inspiration." The Interior Decorator, 16 March. https://www.jordanawori.com/?p=253 [archive].

Azimi, Roxana. 2015. “L'homme de l'art." M Le Magazine du Monde, 24 January: 29-35.

Azimi, Roxana, and Harry Bellet. 2015. "Désespérance de l'art contemporain." Le Monde, Cahier no. 21976, 12 September. https://www.lemonde.fr/culture/ article/2015/09/13/desesperance-de-l-art-contemporain 47513603246. $\underline{\mathrm{html}}$. 
"Matatu Graffiti Art." 2015. African Slum fournal, 27 February. http://www. africanslumjournal.com/matatu-graffiti-art-in-nairobi/ [archive].

Meyerfeld, Bruno. 2016. "L’hyperactiviste." M Le Magazine du Monde, 38-40, 23 January.

"News." 2006. Msanii: The Magazine for the Arts from Rahimtulla Museum of Modern Art, no. 14: 2.

Ni Chonghaile, Clar. 2012. "Kenyan Graffiti Artists Step up Battle Against 'Vulture' Politicians: Protesters Want Voters at Next Election to Kick Out MPs Accused of Corruption." The Guardian, 21 March. https://www. theguardian.com/world/2012/mar/21/kenya-graffiti-artists-politiciansvultures [archive].

Remy, Jean-Philippe. 2015. “À Nairobi, j'ai vu un monde mourir." M Le Magazine $d u$ Monde, 52-54, 21 November. https:/www.lemonde.fr/m-le-mag/ article/2015/11/20/a-nairobi-j-ai-vu-un-monde-mourir 48144724500055. html [archive].

Serubiri, Moses. 2015. "The Double Life of Kenya at Venice. Serubiri Moses about the Kenyan Pavilion at this year's Venice Biennale." Contemporary\&, 6 April. www.contemporaryand.com/magazines/the-double-life-of-kenyaat-venice/ [archive].

“The Kenya Arts Diary Launch and Arts Exhibition 2015." 2014. Heinrich Böll Stiftung Nairobi, 6 November. https://ke.boell.org/2014/11/06/kenya-artsdiary-launch-and-arts-exhibition-2015 [archive].

WaGacheru, Margaretta. 2012. "Artist of Two Worlds Finally Traces His Way Back to Kenya." Business Daily, 22 March. https://www.businessdailyafrica. com/lifestyle/society/Artist-of-two-worlds-finally-traces-his-way-back-toKenya/3405664-1371484-q8467p/index.html [archive].

WaGacheru, Margaretta. 2012. "Nairobi’s Upmarket Red Hill Opens a New Gallery." Business Daily, 16 September. http://www.businessdailyafrica. com/Nairobi-upmarket-Red-Hill-opens-a-new-gallery/-/1248928/1498086/16k5jqc/-/index.html [archive].

WaGacheru, Margaretta. 2013. "Good Old Gallery Watatu in Limbo." Daily Nation, 5 August 2013. https://nation.africa/kenya/life-and-style/dn2/goodold-gallery-watatu-in-limbo-880584 [archive].

"Wanyu Brush." S.d. Art Nanadede [archive].

Whalley, Frank. 2010. "Thin Line between Arts and Politics." The East African, 26 July [archive].

Whalley, Frank. 2014. "From Kenya to the US with Love." The East African, 22 August. [archive].

Whalley, Frank. 2015. "Smokey Leads the Charge at International Arts Fair." The East African, 9 October. [archive].

Whalley, Frank, 2016. "Wanjiku Featured No 1 in New York's African Art Fair." The East African, 14 May [archive]. 
Focus no. 6

\section{Into a "Global Encounter" from the Art Scene in Nairobi}

\section{Olivier Marcel}

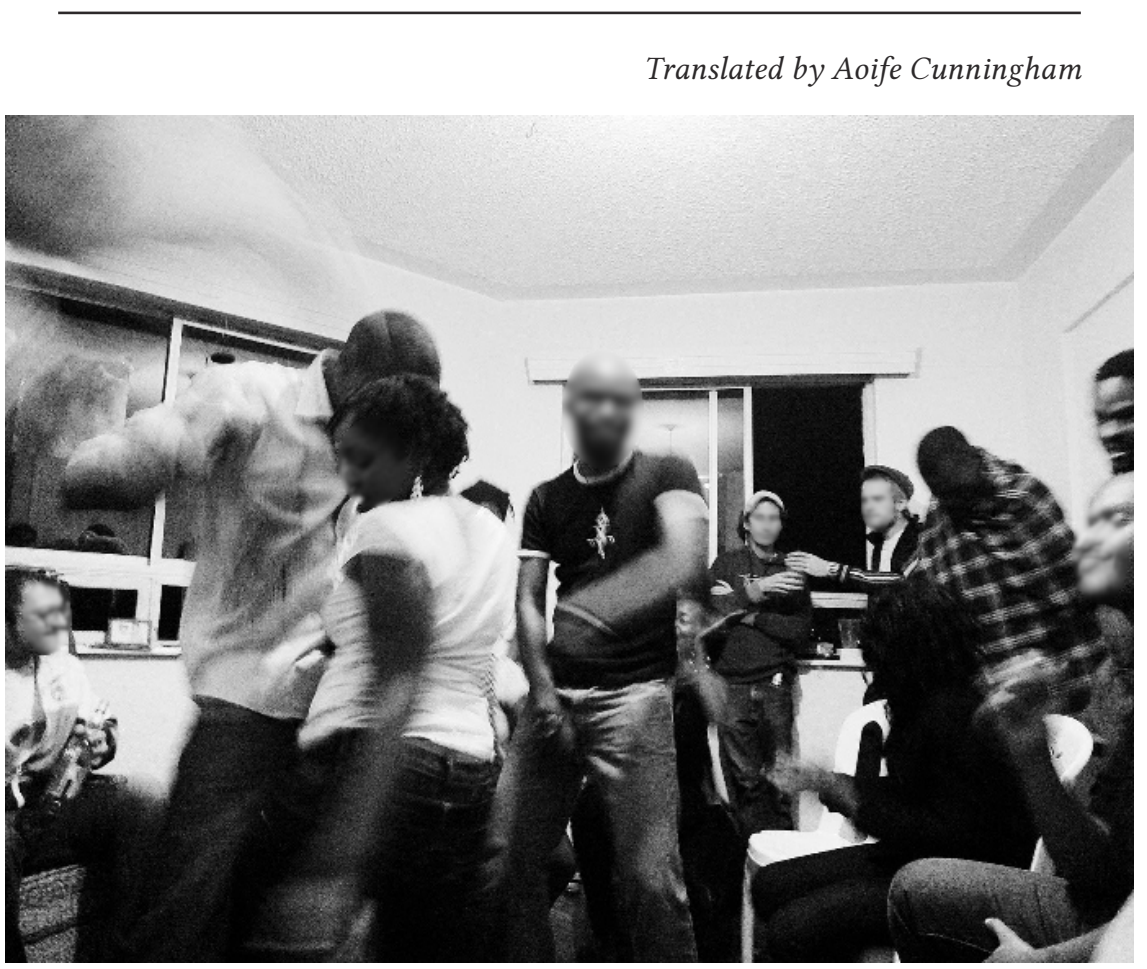

A private house party in an apartment in Valley Arcade, March 2011 Image: Olivier Marcel.

This photograph shows a house party, that is, a selective and secure type of sociability typical of affluent residential neighbourhoods in Nairobi. ${ }^{1}$ Held in the shared house of a Kenyan performance artist just back from her time abroad, this party brought together many significant public figures from the contemporary art scene of the city. One can see, for example, an Italian filmmaker and cultural activist, an Ivorian photographer in residence, an Anglo-Kenyan visual artist, a German intern from the Goethe-Institut as well as many members of Maasai Mbili, a collective of Kenyan artists who are emblematic of the Kenyan slum of Kibera. There is a mutual gravitation

1. This text is derived from my $\mathrm{PhD}$ research (Marcel 2014). 
to each other here despite their differing career paths. This scene portrays one type of performance that anthropologist Bob White $(2011,6)$ called a "global encounter" ${ }^{2}$ of which the composition reflects Nairobi's position in the global contemporary art scene.

Despite the restrictive design of the places where such encounters happen-the green and electrified fences of the apartment complexes being the vivid expression and harsh metonymy of it-, the access to the switch of artist camaraderie does not result from the "crystallisation of a hypothetical urban identity." It reflects rather the "fluidity of social, political, cultural and economic relations; the difficulty in clearly distinguishing between country and city dwellers, the elite and the common people, the formal and the informal" (Fourchard \& Goerg 2009, 40, translated). This fluidity makes it a privileged ground for the merging of interests between the figures of the "cosmopolitan" and of the "local" (Hannerz 1990, 237-251). In a game where spatial hierarchies and tactics subtly play out, the "cosmopolitan" seeks to place their legitimacy on the "local". These "locals," who succeeded in overcoming the obstacles of a fragmented city, display their repertoire of auto-exoticism in order to obtain the resources needed for their mobility. Such encounters go along with the projects and careers of the artists and constitute for them a social resource. It is in these fringes of Nairobi's cultural life that, among other things, collectives get formed. Through them, the ideological, aesthetic and curatorial lines of the projects that are emerging in the East African metropolis are stimulated and affirmed. The horizon of accomplishment of Kenyan artists is therefore partly played out in the connections they establish in Nairobi with a population in transit and mostly expatriates. Thus, at the end of the house party at Valley Arcade, new collaborations grew and led to a series of artistic events on memory, archives, "Afrofuturism" or the "ghetto culture," which were notably hosted by the German cultural centre, acting both as a go-between and a director of this globalisation of art.

Nairobi maximises the opportunities for global encounters such as these because of its position as an East African hub for both tourism and humanitarian action, making the city an interface for North-South relations. Today however, cultural exchanges on one side only are no longer the rule because art centres and artistic communities from Africa's large cities choose to network. Between 2011 and 2012, Kuona Trust, one of the region's most active centres for visual arts, showcased the work of 256 artists. The national identity of these artists, as shown in the reports that the institution

2. The notion of "global encounter" "refers to situations in which individuals from radically different traditions or worldviews come into contact and interact with one another based on limited information about one's another values, resources, and intentions." 
produced for its Western sponsors, showed that half of them came from international exchanges: 27\% came from other African countries, $14 \%$ from Europe and North America, and 8\% from the "South" (Marcel 2013). It is through these circulations that contemporary art practices in the "South" expand and, conversely, that Kenya's participation in the globalised world of contemporary art needs to be considered.

\section{Bibliography}

Fourchard, Laurent, and Odile Goerg. 2009. "Vivre la sociabilité dans les villes en Afrique." In Lieux de sociabilité urbaine en Afrique, edited by Laurent Fourchard, Odile Goerg, and Muriel Gomez-Perez. Paris: L'Harmattan.

Hannerz,Ulf. 1990. "CosmopolitansandLocalsin WorldCulture." Theory, Culture and Society 7, no. 2-3: 237-251. https://doi.org/10.1177/026327690007002014.

Marcel, Olivier. 2014. "Des horizons à la trace. Géographie des mobilités de l'art à Nairobi." PhD Dissertation. Bordeaux: Université Bordeaux Montaigne.

Marcel, Olivier. 2013. "Filling the Blank Space of Global Art Peripheries: Measurements of Art Mobility and their Ambivalence in Nairobi, Kenya." Artl@s 2, no. 2: “Do Maps Lie?” https://docs.lib.purdue.edu/artlas/vol2/ iss2/6/ [archive].

White, Bob. 2011. Music and Globalization: Critical Encounters. Bloomington: Indiana University Press. 



\section{The Authors}

Patrick O. Abungu, Fort Jesus Museum, National Museums of Kenya. Mombasa, Kenya.

Michel Adam, Université François-Rabelais. Tours, France.

Marie Pierre Ballarin, Unité de recherche Migrations et société (URMIS), Institut de recherche pour le développement. Nice, France.

Bernard Calas, Les Afriques dans le monde, Université Bordeaux Montaigne. Pessac, France.

Hélène Charton, Les Afriques dans le monde, CNRS. Pessac, France.

Clélia Coret, LabEx HASTEC (ANR-10-LABX-85) - Centre AlexandreKoyré, École des hautes études en sciences sociales. Paris, France.

Francesca Di Matteo, Gouvernance, Risque, Environnement, Développement (GRED), École des hautes études en sciences sociales. Marseille, France.

Yvan Droz, The Graduate Institute of International and Development Studies. Geneva, Switzerland.

Marie-Aude Fouéré, Institut français de recherche à Nairobi (IFRANairobi), USR Afrique au sud du Sahara. Nairobi, Kenya ; Institut des mondes africains (IMAF), École des hautes études en sciences sociales. Paris, France.

Yonatan N. Gez, Arnold Bergstraesser Institute (ABI). Fribourg, Allemagne; The Graduate Institute of International and Development Studies. Geneva, Switzerland.

Chloé Josse-Durand, Institut français de recherche à Nairobi (IFRANairobi) - USR Afrique au sud du Sahara. Nairobi, Kenya.

Danielle de Lame, AfricaMuseum-Musée royal de l'Afrique centrale. Tervuren, Belgium.

Jean-Baptiste Lanne, Centre d'études en sciences sociales sur les mondes africains, américains et asiatiques (CESSMA), Université de Paris. Paris, France.

Olivier Marcel, Les Afriques dans le monde, Université Bordeaux Montaigne (2010-2014). Pessac, France.

Hervé Maupeu, Université de Pau et des Pays de l'Adour. Pau, France. 
Hassan Mwakimako, Department of Philosophy and Religious Studies, Pwani University. Kilifi, Kenya.

Anne-Marie Peatrik, Laboratoire d'ethnologie et de sociologie comparative (LESC), Centre national de la recherche scientifique. Nanterre, France.

Adeline Pelletier, Institute of Management Studies, GoldsmithsUniversity of London. London, United Kingdom.

Marie-Emmanuelle Pommerolle, Institut des mondes africains (IMAF), Université Paris 1 Panthéon-Sorbonne. Paris, France.

Olivier Provini, Centre de recherche juridique, Université de la Réunion. Saint-Denis de La Réunion, France.

Sylvain Racaud, Les Afriques dans le monde, Université Bordeaux Montaigne. Pessac, France.

Gaële Rouillé-Kielo, Laboratoire architecture, ville, urbanisme, environnement (LAVUE), Université Paris Nanterre. Nanterre, France ; Laboratoire interdisciplinaire Sciences Innovations Sociétés (LISIS), Institut national de recherche pour l'agriculture, l'alimentation et l'environnement (INRAE). Noisy-le-Grand, France.

Christian Thibon, Les Afriques dans le monde, Université de Pau et des Pays de l'Adour. Pau, France.

Justin Willis, Department of History, Durham University. Durham, United Kingdom. 